Käsissänne on ensimmäinen politiikan ja talouden tutkimuksen laitoksen julkaisuja -sarjan kirja. Se on kirjoitettu ja toimitettu valtiotieteelliseksi oppikirjaksi suomalaisesta poliittisesta järjestelmästä. Artikkelikokoelmalla on selkeä pedagoginen tavoite avata valtio-opin ja yhteiskuntatieteiden opiskelijoille ja pohtijoille yhteiskunnallista ja poliittista kulttuuria ja sen historiallisia murroksia. Samalla haluttiin rekrytoida kirjan kirjoittajaryhmään tutkimuskentän parhaita suomalaisia tuntijoita ja pohtijoita, jotka myös tuntevat toistensa tulkintoja ja haluavat keskustella keskenään.

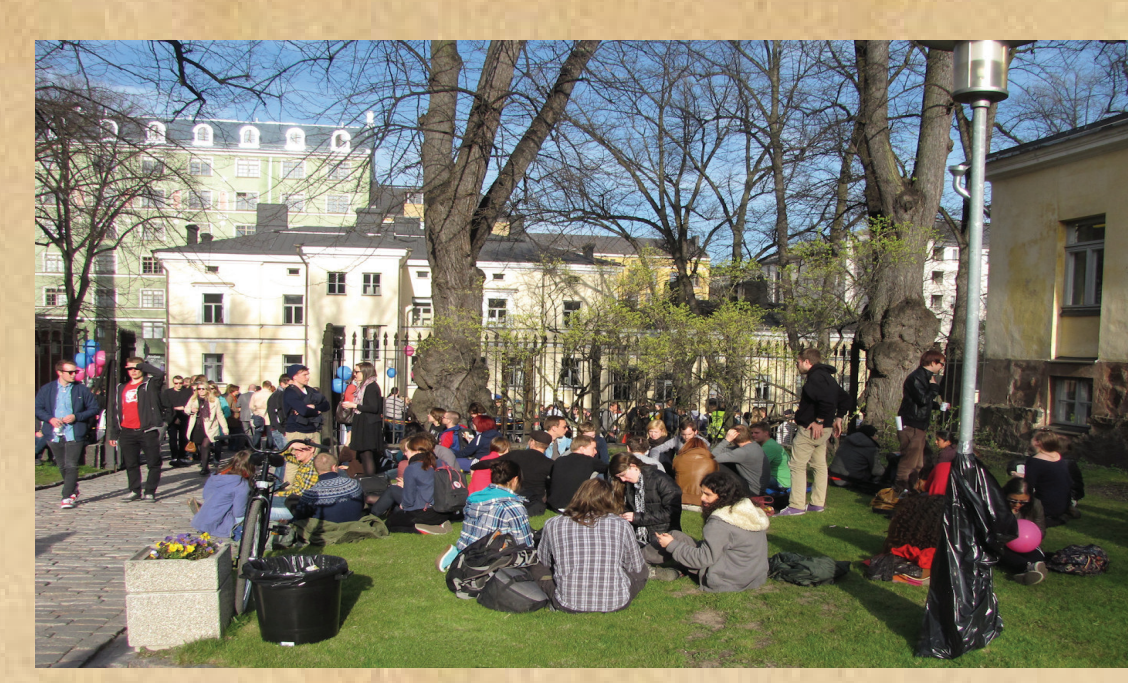

Kari Paakkunainen (toim.)

\title{
Suomalaisen politiikan murroksia ja muutoksia
}


Suomalaisen politiikan murroksia ja muutoksia 

Kari Paakkunainen (toim.)

\section{Suomalaisen politiikan murroksia ja muutoksia}

Helsingin yliopisto

Politiikan ja talouden tutkimuksen laitos 2012 
Politiikan ja talouden tutkimuksen laitoksen julkaisuja 2012:1

Yleinen valtio-oppi

(C) Toimittaja ja kirjoittajat

Taitto: Raimo Parikka

Kannen kuva: Eveliina Kotilainen

Painettua julkaisua myy ja välittää:

Unigrafian kirjamyynti

http://kirjakauppa.unigrafia.fi/

books@unigrafia.fi

PL 4 (Vuorikatu 3 A) 00014 Helsingin yliopisto

ISSN-L 2243-3635

ISSN 2243-3635 (Painettu)

ISSN 2243-3643 (Verkkojulkaisu)

ISBN 978-952-10-8196-5 (nid.)

ISBN 978-952-10-8197-2 (PDF)

Unigrafia, Helsinki 2012 


\section{Sisällys}

Juri Mykkänen - Eeva-Liisa Nisula - Jussi Pakkasvirta

Esipuhe:Uuden yhteistyön ja avoimen julkisuuden oppikirja ................... 7

Kari Paakkunainen

Johdantoa: Isänmaan järjestyksestä ja hyvinvointimobilisaatiosta

eurooppalaisiin vääntöihin

Pasi Saukkonen

Suomalaisen yhteiskunnan poliittinen kulttuuri

Sami Suodenjoki

Kansalaisyhteiskunnan ja Suomen ideat, liikkeet ja julkisuudet

ennen vuotta 1917

Pauli Kettunen

Kansallinen toimijuus suomalaisessa politiikassa .

Rauli Mickelsson

Suomalaiset puolueet kertomuksina

Jan Sundberg

Puolueet yhteiskunnan ohjaajina ja ohjattuina

Pentti Puoskari

Suomen talouspolitiikan ja työmarkkinamallin murrokset

sotakorvauksista kilpailuyhteiskuntaan

Eija Nurminen

Sosiaalipolitiikan muutos Suomessa 1960-luvulta

tälle vuosituhannella

Juha Herkman

Politiikan mediajulkisuus Kekkosen jälkeen

Pertti Abonen

Suomen julkisen hallinnon ja julkisen sektorin muutoksesta institutionalistisesta tutkimusnäkökulmasta 
Arto Lindholm

Kansalaisten vaikutusmahdollisuudet ympäristöpolitiikkaan

243

Raimo Väyrynen

Suomen pitkä linja: politiikka, talous ja globalisaatio

261

Henri Vogt

Suomen ulkopolitiikka: monensuuntaista eurooppalaistumista?

295

Marjaana Jaubola

Tasa-arvosta Suomen vientituote?

Suomalainen tasa-arvopuhe erojen tuottajana

Kari Paakunainen

Omaperäinen parlamentarismi järjestyksen ja ulkoisten

tehtävien puristuksessa

377

Artikkelien kirjoittajat

391 
Juri Mykkänen - Eeva-Liisa Nisula - Jussi Pakkasvirta

\section{Esipuhe: Uuden yhteistyön ja avoimen julkisuuden oppikirja}

Käsissänne on ensimmäinen politiikan ja talouden tutkimuksen laitoksen julkaisuja -sarjan kirja. Se on kirjoitettu ja toimitettu valtiotieteelliseksi oppikirjaksi suomalaisesta poliittisesta järjestelmästä. Artikkelikokoelmalla on selkeä pedagoginen tavoite avata valtio-opin ja yhteiskuntatieteiden opiskelijoille ja pohtijoille yhteiskunnallista ja poliittista kulttuuria ja sen historiallisia murroksia. Samalla haluttiin rekrytoida kirjan kirjoittajaryhmään tutkimuskentän parhaita suomalaisia tuntijoita ja pohtijoita, jotka myös tuntevat toistensa tulkintoja ja haluavat keskustella keskenään. Nämä tavoitteet olivat mukana jo kesällä 2011 Avoimen yliopiston suositussa vierailuluentosarjassa "Miten suomalainen yhteiskunta ja politiikka ovat rakentuneet?". Monitieteisen kurssin jälkeen reetorit ovat istuneet kirjoittamaan esseitään oppiaineissa sukkuloineen kurssin koordinaattorina ja kirjan toimittajana häärineen Avoimen yliopiston yliopisto-opettajan kanssa.

Oppikirja onkin lähellä politiikan ja talouden tutkimuksen laitoksen tehtävää oppiaineiden yhteisen tutkimustoiminnan ja opetuksen kehittämiseksi. Se perustuu vain tieteelliseen perustutkimukseen ja reflektioon, missä kohdataan yhteiskunnallisen ja poliittisen järjestelmämme solmukohdat, erityiset piirteet sekä kansalaisten aktiivisuus yksimielisyyspaineiden ja globaalien kohtalonyhteyksien maailmassa. Laitos voi kirjan turvin hyvin katsoa myös yhteiskuntaan. Teoksessa on kiteytetty sitä kulttuuri- 
pääomaa, jota Valtiotieteellisellä tiedekunnalla ja sen tiedon yhdistäjillä on populaarienkin yleisöjen edessä. Aiemmista perusopuksista tiedämme sen, että myös verkossa julkaistava oppikirja saa tuhansia ja taas tuhansia lukijoita myös yliopiston ulkopuolella - lukioista kentän lukupiireihin. Emme usko enää valtiotieteen modernin klassikkogurun professori Yrjö Ruudun ajatuksiin valtiotieteellisestä valistuskirjallisuudesta tai tiedekunnastamme (1945) panoksina, jotka aina suoraan nostavat myös maamme politiikan tasoa. Mutta tiedämme, että perustulkintamme voi liikauttaa ihmisiä, nuoria ja ammattilaisia kaiken pirstaleisen ja ristiriitaisen asiantuntija- ja nettitiedon keskellä ja saada heidät harkitsemaan ja kokeilemaan valtiotieteiden käsitteitä ja tulkintamalleja.

Yliopiston strategia eri laitosten ja kumppaneiden yhteistoiminnasta ja synergiasta saattaa joskus jäädä juhlavaksi ja epäselväksi. Käsillä oleva kirja manifestoi osaltaan sitä, että osaamme puurtaa laadukkaasti myös yhdessä ja piristää tutkimuskenttää ja sen julkisuutta. Avoin yliopisto on koko sisällön ja kirjan työstämisen ajan ollut päävastuussa hankkeessa ja saanut heti alussa valtio-opin oppiaineen ja politiikan ja talouden tutkimuksen laitoksen mukaan tiiviiseen kumppanuuteen. Mietimme jo uusia askeleita yhteistyössä.

Helsingin yliopistossa, kesäkuun 1. pnä 2012

Juri Mykkänen

professori, yleisen valtio-opin oppiainevastaava

Eeva-Liisa Nisula

koulutuspäällikkö, Avoin yliopisto (HY),

Jussi Pakkasvirta

professori, politiikan ja talouden tutkimuksen laitoksen johtaja 


\section{Johdantoa: \\ Isänmaan järjestyksestä ja hyvinvointi- mobilisaatiosta eurooppalaisiin vääntöihin}

\section{"Maailma muuttuu ja politiikan uusi epävarmuus jää - Eskoseni"}

Tarve uudistaa politiikan tutkimuksen oppikirjoja on elämän merkki. Jopa instituutiot ja perustuslait muuttuvat epävirallisemmista poliittisista valtakeskuksista, tiedosta ja liikkeistä puhumattakaan. Entistä enemmän pohdimme, mikä kehystää tai vie poliittista järjestelmäämme: eurooppalainen, kansallinen vai markkinajärjestelmä - vai kaikkien voimien ristiveto, yritykset surffailla eri voimien välillä vai monensuuntainen poliittinen harkinta? Poliittisen järjestelmän ja kulttuurin jäsentäminen ja pedagoginen esittäminen ovatkin poliittisia ja dynaamisia ja haasteita. Perusjuristiikka ja lukiohenkinen poliittisten toimijoiden ja instituutioiden harmiton määrittely eivät riitä muuttuvan ja kiistanalaisen politiikan realistisen sykkeen ymmärtämiseksi. Tavoittaakseen valtio-opillisen näkemyksellisyyden politiikan oppikirjan on tavoitettava olennainen (epä) virallinen valtapeli. Mutta samalla on liikautettava lukijaa ja jätettävä hänet poliittisen epävarmuuden ja kiistanalaisten etujen, valtasuhteiden, arvojen ja instituutioiden äärelle. Viime kädessä on kyse myös poliittisen kansalaisen pelastamisesta, puolustamisesta kaikenlaisen maailmaa koskevan tosiasia- ja välttämättömyysmäärittelyn ja talous- ja ammattilaistiedon keskellä - median fakta-anarkiasta puhumattakaan. 


\section{Kari Paakkunainen}

Silti tarvitaan perustavaa tietoa suomalaisille relevanteista poliittista 'järjestystä koskevista normeista, toimijoista ja ideoista. Tämän kokoelman artikkelit ovat kuitenkin tyylissään ja tulkinnoissaan vaativia ja usein tutkimuksellisia. Ilman perussivistystä Suomen ja Euroopan historiasta ne eivät helposti avaudu. Yliopisto-oppikirjana sitä edeltävätkin valtio-opin johdantokurssien tiedot ja peruskirjat. Esseekokoelman kunnianhimoinen oppi-intressi näkyy myös artikkeleiden yhteisessä pyrkimyksessä purkaa suomalaisen poliittisen järjestelmän puhtoisuuden ja itsenäisyyden myyttejä. Pikkuvaltio on aina hiukan polvet taipuneina, ja se ennakoi suurvaltojen liikkeitä ja muutoksia pyrkien käyttämään niitä hyväksi oman edun ja (toivon mukaan) paremman maailman puolesta? Kirja turvaa paljon historiallisiin tarkasteluihin ja murrosanalyyseihin, koska halutaan hakea myöhäismodernin netti- ja mediasirpaletiedon sijaan olennaisia ja murrostilanteissa kiteytyneitä olennaisia suomalaisia valintoja ja niiden taustaolettamuksia. Näin ei uskota mihinkään alkuperäiseen tai itsenäisen aseman saavuttaneeseen Suomeen. Suomi on poliittisten (voima)valintojen tulosta, sen mobilisoinnin ja selviämisen perustelut ovat aina olleet epävarmoja ja poliittisia - usein myös eliitin (väistämättömiksi) tekemiä, kansan (edustuksen) antamaa oikeutta toistavia, epäselviä tai tarkoituksella monimielisiä.

Paradoksaalisesti monet suomalaisen politiikan pesämunat olivat olemassa paljon ennen muodollista itsenäistymistä jo ruotsinvallan oikeuksissa, Venäjän emä-valtion suojaisissa varjoissa ja talousratkaisujen logiikassa. Myös itsenäinen ja demokraattinen Suomi on monessa kuvitteellinen ideaali. Kirjassa analysoidaan aukinaisesti ja monilla tavoin suomalaisten välttämättömyyksien - suurvaltojen voimasuhteet, kansallisen yksimielisyyden luomisen tavat, kilpailukyky ja globalisaatio - kautta rakennettua selviytymispolitiikkaa. Tällaisen politiikan poljennossa pikku-valtiollinenkin järki on ollut hyvin paineinen ja liikkuva. Samaa poliittista perustuslakia luettiin eri tavoin 1920-luvulta 1980-luvulle, kun oman maan ja maailman muuttuvat voimasuhteet sitä vaativat ja antoivat tilaisuuden. Voimme puhutella poliittista järjestelmäämme suomettumisen ja eliittis-korporatiivisen kilpailukykypolitiikan termein tai ihmetellä välttämättömyyspolitiikan ja kilpailuvaltion taidonnäytteitä, kykyä ahtaissakin väleissä antisipoida konsensuksen ja innovaatioiden hengessä maailman mahtien ja talouden voimasuhdemuutoksia. Mutta 
eri näkökulmatkaan eivät peitä parlamentaaristen periaatteiden, kansalaismobilisaation, julkisuuden ja demokraattisen vastuunalaisuuden erilaisia ja omintakeisia rajoituksia ja pakkosovelluksia eri vaiheissa itsenäiseksi julistautuneen Suomen historiassa.

Oma lukunsa aikamme politiikan ja demokratian pohdinnoissa on globaalien riskien ja eurooppalaisen integraatiopolitiikan tuskat. Uskottavat demokraattiseen valintaan perustuvat poliittiset instituutiot horjuvat tai puuttuvat maailmanpoliittisella areenalla. Euroopan unioni on valinkauhassa: harvinainen kontinentaali demokraattinen viritelmä odottaa kärsimättömänä toimia joko "enemmän Euroopan" poliittisen liiton tai kansallisvaltioiden (blokkien) suunnassa hajautuvan ja kiristyvän kilpailun suunnassa. Tässä kokoelmassa ei nosteta Euroopan unionia poliittisen järjestelmämme tarkastelun keskiöön, vaan se jätetään muiden (uusien) oppikirjojen varaan. Silti Suomen poliittisen järjestelmän syvällinen kulttuurinen, taloudellinen ja turvallisuuspoliittinen orientaatiomuutos eurooppalaiseksi ja monissa suhteissa globaaliksikin toimijaksi 1990-luvulla on osa esseiden tarkastelua.

Tässäkin suhteessa artikkelikokoelma on kunnianhimoinen ja nostaa esiin eurooppalaisen poliittisen järjestelmän vajavaisuudet, keskeneräisyyden ja ristiriitaiset toimijuudet. Euroopasta ja sen unionista käydään monenlaista kamppailua, suomalaiset ovat monin kekseliäinkin tavoin mukana uudenlaisten globaalisti vastuullisten ratkaisujen ajamisessa monissa poliittisissa instansseissa - valtiollinenkin ulkopolitiikka on osa arkista eu-puurtamista, sen yhteistä ulkopolitiikkaa ja sekaantumista monensuuntaisiin maailman projekteihin. Kansallisesta poliittisesta edusta ja järjestelmästä puhuminen alkaa kuulostaa jo yksinkertaiselta tai populistiselta - siksi monimutkaiset ovat globaalit kohtalonyhteydet ja poliittiset tarttumapinnat juuri Euroopassa. Yllättävän monet toimijat jaksavat ylläpitää poliittisen kansalaisdemokratian tuntoja ja ideaaleja sekä tavoitella kosmopoliittisia politiikkoja - globaali-hikisestä ilmanalasta ja kilpailuvaltiokamppailuista huolimatta.

Juuri suomalaisten poliittisen osallistumisen, tiedon/kommunikaation ja järjestelmän kansainvälistyminen ja markkinariippuvuuden kasvu olivat yhdessä Suomen omien perustuslakimuutosten lisäksi seikka, joka muutama vuosi sitten inspiroi tämän oppikirjan kokoamiseen ja julkaisemiseen. Dosentti Pasi Saukkosen vuonna 2003 toimittaman "Suomen 


\section{Kari Paakkunainen}

poliittinen järjestelmä -verkkokirjan” (http://blogs.helsinki.fi/vol-spj/ (viitattu 1.8.2012)) ja sen asiantuntija-artikkeleihin perustuvan kirjajulkaisun "Paikkana politiikka: tietoa ja tulkintoja Suomen poliittisesta järjestelmästä" (2003) oivallinen anti täydentyi aluksi verkkokirjan editoinnilla ja sen uusilla esseillä. Monet ajankohtaiset tiedot ja verkkolinkit kuitenkin muokkaantuivat hektisesti uusiksi ja Helsingin yliopiston valtio-opin oppiaineessa, Politiikan ja talouden tutkimuksen laitoksella ja Avoimessa yliopistossa päädyttiin yhteishankkeeseen toimittaa tämä käsillä oleva artikkelikokoelma. Oma kohta kolmekymmentä vuotta jatkunut Helsingin yliopiston valtio-opin perusteiden opetus Avoimessa yliopistossa ja oppinaineessa oli varmaankin seikka, minkä vuoksi sain toimitettavaksi tämän kirjan ja hyvin itsenäisesti valita ja motivoida kentän parhaita professoreita ja tutkijoita mukaan. Kaikki mukaan tulleet innostuivat pohtimaan, kuinka esittää tutkimuksellisesti relevantteja juuria, rajoja ja tulkintoja suomalaisesta ja eurooppalaisesta poliittisesta kulttuurista ja herättää ja säilyttää samalla lukijoiden ja opiskelijoiden viritys ja motivaatio syvenevään tietoon.

\section{Kansalaisyhteiskunnan mobilisaatiosta ja kansallisesta toimijuudesta maailmanpolitiikan ja -talouden keskelle}

Sami Suodenjoki kokoaa hienosti suomalaisen poliittisen mobilisaation kehitysaineksia ja dialektiikkaa esseessään "Kansalaisyhteiskunnan ja Suomen ideat, liikkeet ja julkisuudet ennen vuotta 1917”. Huolimatta emävaltioriippuvuudestaan ja agraarisuudestaan Suomella oli paikalliset perinteensä ja oikeutensa, kansallista ja poliittista sivistysprosessia kunnioitettiin eri ryhmissä; eliitti ja rahvaan nousevat liikkeet yhdessä väittelivät kansan edustamisen periaatteista. Työväenliike kuitenkin politisoi torppariosattomuuden, ankeat työolot ja äänioikeuden. Työväenliikkeelle oli Suodenjoen mukaan mahdollista vahvasti artikuloida samassa poliittisessa liikkeessä sekä valistusinto että yhteiskunnallisen vihan ainekset. Kapina 1918 olikin enemmän poliittisen pettymyksen kuin luokkavihan tulosta. Pauli Kettunen laajentaa nykypäivään saakka tätä kansan, kansakunnan ja kansallisvaltion eheyden ja ristiriitaisuuden sekä konfliktien tunnustamisen pohdintaa artikkelissaan "Kansallinen toimi- 
juus suomalaisessa politiikassa”. Suomessa ristiriitojenkin tunnustaminen perustellaan ulkoisilla ja kehitysvälttämättömyyksillä. Sävyttyneessä ja ladatussa esseessä perustellaan sitä, miten Suomessa on varsinkin ulkoja talouspolitiikassa toteutettu sisäisen kansallisen toimijuustahdon voimalla asioita, välttämättömyyksiä sekä legitimoitu tämä selviämishistorialla, politiikan hallinnollistamisella ja määrittelemällä se valtiolliseksi yhteisten asioiden hoidoksi tai (kilpailu)valtion toiminnaksi. Kun kriisit ja "seinän edessä”-tilanteet piirretään esiin, tarvitaan kansallisia talkoita tai talvisodan henkeä.

Kettunen osoittaa intellektuellin ja historiallisen jäljittäjän keinoin ajankohtaisessakin kontekstissa, kuinka konsensus voi yhtä aikaa sekä peittää että paljastaa ristiriitoja. Jotkut arkisen kilpailukykynationalismin kuten puhtaan ympäristön, tasa-arvon ja hyvinvointivaltion arvot eivät kestäkään, kaikkien ihmisryhmien intressit eivät taivukaan kilpailukykyyhteisön projektiin; samaan aikaan nähdään, ettei pelkkä tiukka kilpailuvaltio takaa talousjärjestelmien elinkelpoisuutta. Samalla kansalliset toimeenpanovallan eliitit joutuvat sopeutumaan eurooppalaisen finanssipolitiikan markkinaehtoisiin kompromisseihin ja saavat vastaansa monia kansalaisten protesteja. Toisaalla vaaditaan radikaalimpia puna-vihreitä projekteja, jotka yhdistävät paikallisia ja kansallisia aloitteita ja verkostoja globaaleihin hankkeisiin ja trans-nationalistiseen politiikkaan: tulee nousta kilpailukyky-, hyvinvointi- ja muukalaispelkoisen nationalismin yläpuolelle. Toisaalla populistinen uhkakuvapolitiikka ja revanssin haku kaiken epävarmuuden ja oikeudettomuuskokemuksen keskellä ruokkivat juuri muukalaispelkoista nationalismia ja Perussuomalaisten kaltaisia populistisia liikkeitä.

Marjaana Jauholan feministisestä politisointistrategiasta ja maailmanpolitiikan tutkimuksesta inspiroituneessa esseessä "Tasa-arvosta Suomen vientituote? Suomalainen tasa-arvopuhe erojen tuottajana" osoitetaan Kettusen teesi tasa-arvo- ja hyvinvointinationalismin rajoista relevantiksi. Esseessä puretaan Suomen Un Women -järjestön ja Väestöliiton 'tasa-arvosta Suomen vientituote' -tiedotemoton (2011) absurdiutta. Maailmanpolitiikan, naisasialiikkeen ja kehitys- ja tasa-arvopolitiikan kustannustehokkuuden ja markkinarationaalisuuden arvostelulla ryyditetyssä esseessä irrotetaan tasa-arvo Mallimaa-Suomen normatiivisesta poliittisesta puheesta ja pohjoismaisesta idealisoidusta kertomuksesta. 


\section{Kari Paakkunainen}

Viimeksi mainittu malli palvelee tehokkaasti koulutukseen, ansiotyöhön, heteroparisuhteeseen ja -äitiyteen sitoutuvia naisia. Esiin nousee myös esimerkkejä, jolloin kansainvälinen lainsäädäntö on pakottanut Suomea kehittämään omia sanktioitaan esimerkiksi naisten kokeman väkivallan suhteen. Samalla osoitetaan muodikkaiden "sosiaalisten (tyttö- tai marginaaliryhmä)investointien" mukaisen policyn ohuus. Tasa-arvon tuotteistaminen on myös sokea naisten luokka- ja etnisille asemille ja sukua 1980-lukulaiselle "developmentalismille", missä kansallinen elinkeinoelämä on keskeinen kehitysyhteistyön toimija ja hyötyjä.

Raimo Väyrynen piirtää tarkkaa ja solidia kaksisataavuotista kuvaa esseessään "Suomen pitkä linja: politiikka, talous ja globalisaatio". Maamme on kehittynyt murrosten ja kriisien kautta. Kriiseissä ovat yhdistyneet geopolitiikan ja talouden murrokset sekä toisaalta jatkuvuus. Yleensä geopolitiikka on kulkenut Suomen historiassa "kylki edellä" ja talous on saanut sopeutua poliittisiin muutoksiin. Globalisaatioaaltojen tarkastelussa pitkän linjan esseisti Väyrynen korostaa (geo)poliittista keskiötä ja (taloudellista) luovuutta otsikon kolmen toimijuuden ja kehityskulun välillä Kettusta enemmän, ainakin eri termein. Vuoden 1809 murros merkitsi lähinnä maan kansainvälisen aseman muutosta, välivyöhykkeen "Talousvaltio-Suomen" hidasta kehkeytymistä; näin Väyrynen kiteyttääkin keskeiset drastiset murrokset, joissa maan talouden tuotantotapa, poliittinen järjestelmä ja kansainvälinen asema ovat yhdessä tai erikseen muuttuneet, kolmeen vaiheeseen. Ensimmäinen murros - vuosien1860-1917 (1939) välillä - liittyy kansalaisyhteiskunnan poliittiseen mobilisaatioon, puoluejärjestelmän syntyyn ja teollisen kasvun alkuun.

Toisen maailmansodan jälkeen toisessa murroksessa politiikan ja talouden rakenteet ja sisällöt muokkaantuivat uusiksi. Valtion talousvalta, uudet poliittiset voimat ja epävakaat hallitusrintamat kuvaavat muutosta. Jos 1930-luvun lama muokkasi tietä kasvuhakuisen punamultakoalition suuntaan (Cajander 1936-), niin 1980-luvun keskiluokkaistuvan Suomen talouden rakennemuutos - kolmantena murroksena - pihtisynnytettiin sitten 1990-luvun lamasuhteissa. Näin siirryttiin myös vakaiden, mutta vaihtuvien, hallituskoalitioiden aikaan - joiden myötä poliittinen ohjaus yhteiskunnassa ja taloudessa paradoksaalisesti väheni ja kilpailuvaltion rooli oli taloutta ja vientiä "peesaava" ja tukeva. Talouden avautuminen globaaliin maailmaan sisälsi taloudellista tuskaa, Holkerin "hallittu ra- 
kennemuutos" ei hillinnytkään kasinotaloutta vaan aluksi ajauduttiin kriisipolitiikkaan.

Periferian geopolitiikka yhdistyy talouden ja viennin murrosvaiheisiin, toimettomiin ja vitaalisiin kausiin sekä taloudellisen eliitin vaihtuviin poliittisiin alliansseihin ja poliittisten voimien 'politiikan talouteen' (luokkien lisäksi sektorit, vientitalous). Maailman(voima)politiikan ja -kapitalismin sääntelyn jäsennykset muodostavat johdonmukaisen kontekstin Väyryselle jättäen varan periferian paradokseille, uusille sosiaalisille jaoille ja politiikan mutanteille ratkaisuille. Maailmanjärjestelmätermein olemme kulkeneet periferiasta semiperiferian kautta järjestelmän ytimeen. Näin on käynyt, vaikka 2000-luvun logistisesti ongelmallisen Suomen integraatioaskeleet eivät ole aina olleet hallittuja, ja nykyinen EU-sidos rajoittaakin poliittista suvereenisuutta. Paljolti historiamuistiinsa ja toisen käden tutkimuksiin nojautuen hän luo uniikkejakin suhdannekuvia talouden ja politiikan suhteista - esimerkiksi Kekkosen hegemonisesta eliittipaktista 1970-luvulla. Samoin emeritusprofessorin taitava spekulaatiokuva neljännestä murroksesta - nyt(?) - liittää yhteen laadullisesti uudenlaiset kansainvälisten yritysten arvoketjut maailmantalouden ytimessä ja eurooppalainen yhteisvastuun ja yhteisen talouspolitiikan rakentamisen vaikeudet Maastrichtin sopimuksen valuvikojen korjaamiseksi. Nykyarvio on pessimistinen ja kirjoittaja turvautuukin (kansallisen) voimapolitiikan käsitteistöön reaalieurotalouden ratkaisujen kuvaamisessa.

Väyrysen rinnalla on jännittävää lukea Pentti Puoskarin kansallisempaa ja kompaktia tulkintaa opetusotsikosta "Suomen talouspolitiikan ja työmarkkinamallin murrokset sotakorvauksista kilpailuyhteiskuntaan". Hän pohtii yhteiskunnan ja erityisesti valtion roolia ohjausjärjestelmien murroksissa, mitä kautta talouspolitiikan jatkuvuus ja katkokset saavat jouhevan tulkinnan. Kirjoittaja ei kuitenkaan halua dramatisoida talouspolitiikan tasapainottelun ja voimien esittelyssä sopimusyhteiskunnan työmarkkinaosapuolia tai kekkoslaista johtamista, joilla tunnetusti on olennainen merkitys kansalaisten modernin järjestäytymisen ja jopa parlamentaarisen demokratian muokkaajina ja rajoittajina. Onkin eri asia analysoida talouspolitiikan ja -kasvun voimatekijöitä kuin (parlamentaarisen) demokratian toimivia osapuolia. Sääntelytaloudesta ja valtalain tulo- ja hintakontrollista Suomi avautui 1960-luvulle yleislakon 


\section{Kari Paakkunainen}

lopulta romuttaman säännöstelyn ja EFTA-sopimuksen myötä. Esseessä haetaan 1960-luvun lopun kasvu- ja hyvinvointipolitiikan taustatekijöitä ontuvasta työmarkkina- ja hintapolitiikasta, maatalouspartnerin erityisasemasta ja varovaisesta teollistamispolitiikasta. Rahoitusmarkkinat, viennin tuki- ja investointipolitiikka eivät kokeneet suuria muutoksia 60-luvulle tultaessa.

Näillä avuin ajauduttiin rakennekriisiin ja mullistavaan "suureen muuttoon". Ilman dramatisointia ja oppikirjakiteytyksin Puoskari kirjoittaa esiin myös toimet (jälki)teollisen kasvun, vapaakauppaisen viennin ja (sektorikorporaatioiden) idänprojektien sekä tulopolitiikan Suomeen ynnä uudet julkiset käsivarret aktiivisen investointi-, julkisen säästö- ja devalvaatiopolitiikan suunnassa. 1970-luvun talouden kuumeneminen ja uudet rajat tulkitaan ekspansiivisen vaiheen loppuna ja sellaisen kehittämis- ja elvytyspolitiikan alkuna, johon myös ammattiyhdistysliike oli Korpilammen hengessä vedettävissä mukaan. Valtionvarainministeriö sai uusia asemia muun muassa inflaationvastaisin ja reaalipalkkatermein ohjatussa talous- ja työelämäratkaisuissa. Puoskari sijoittaa rahoitusmarkkinoiden ja länsiyhteistyön käännevuoden selvästi Holkerin hallitukseen vuonna 1987. Tunnettu 'hallitsematta lamaan' -tulkinta täydentyy tärkeillä huomioilla tulojen uusjaosta, työllisten position 'sisäpiirimäistymisesta', liberaalista julkisen talouden ja palvelujen kehittämisestä ja pankkitukipainotuksista (elvytysvarojen sijaan). Maa alkoikin olla valmis runnattavaksi Lipposen hallitusten eurojäseneksi ja euromaaksi.

Eija Nurmisen "60-luvun sosiaalipolitiikan" (Pekka Kuusi) hengessä sosiaalipolitiikan siunauksellisia kehiä analysoiva ja propagoiva "Sosiaalipolitiikan muutos Suomessa 1960-luvulta tälle vuosituhannelle" -essee sopii kuin sopiikin Puoskarin talouspolitiikan laiminlyöntien ja sosiaalisten uusjakojen kuvaan. Myös Väyrynen kannattaa tuoda lukupöydällä Nurmisen sosiaalipolitiikan valintojen draaman rinnalle ja itse pohtia, kuinka syntyivät kilpailuvaltion preferenssit, eriarvoisuutta oikeuttava välipitämättömyys. Hyvin esiin kirjoitettu normatiivinen lähtökohta ja laajat empiiriset tulonsiirtojen ja sosiaalipalveluiden sekä eriarvoisuuden lähihistorian dokumentoinnit toimivat ja ovat osa kriittistä ihmettelyä ja poliittista tyytymättömyyttä. Opiskelijoiden on hyvä tuntea tämän sosiaalipolitiikan historiallinen järki ymmärtääkseen Nyky-Suomen kyl- 
myyttä - joka kuitenkin on pohjoismaisen haaleata ajatellen New Public Managementin tiukimpia sovellusmaita.

"Hyvinvointivaltion kultakausi" 1970-80 -luvuilla saa relevantit huomionsa: myöhäinen mutta ainutlaatuisen nopea tulonsiirtopolitiikka 1960-luvulla ja universaalien palveluiden rakentaminen hiukan myöhemmin eivät peitä vakuutusjärjestelmien korvaustasojen määrittelykamppailuja tai keskiluokkaista perusturvaintressiä. Yliopistolehtorin vakuuttavalla huolellisuudella Nurminen nimeää 1980-luvun argumentit ja 'löysät pois' -palvelupolitiikan tulkinnat, joissa valittiin tie "1990-luvun lamasta jälkiekspansiiviseen hyvinvointivaltioon" ja hyvinvointiyhteiskunnan puhetapaan, vastuunjakoon ja sosiaalipolitiikan tasa-arvotavoitteiden korvautumiseen köyhyysinterventioilla. Kirjoittaja päättää laajan tarkastelunsa toiveita herättäen. Kataisen hallitusohjelman monet kirjaimet ovat sosiaalisesti vastuullisia - ja toiseksi, talous- ja sosiaalipolitiikan klassikkojen kasvupremissit ja hyvien kehien teoria luottamuksen, sosiaalisen pääoman, eriarvoisuuden kitkemisen ja hyvinvointipanostusten välillä elävät monien tutkijoiden ja kansalaisyhteiskuntapohtijoiden työpöydillä.

Globaalit ympäristö- ja ekologiset riskit ovat ehdoiltaan globaalistuvan talous- ja sosiaalipolitiikan rinnalla vieläkin suoremmin tai raivokkaammin kiinni Telluksen kohtalonyhteyksissä: vastuulliset globaalikansalainen, maapalloista päätöksentekoa vaativat ryhmät ja valtiot eivät usko kansallisten rajojen tai normien pidättelevän riskipilviä maanosien yllä. Arto Lindholm - 2000-luvun alun vaikuttava globaaliliikkeiden sykkeiden tulkki - tarkastelee nyt analyyttisesti erilaisia kansalaisten toimintakulttuureja mukaansa vetävässä esseessä "Kansalaisten vaikutusmahdollisuudet ympäristöpolitiikkaan”. Ympäristöaktivismin, sosiaalisen median ja konsumerismin projektien rinnalla tekstissä huomioidaan laajasti olennainen ja vähemmän toimiva osallistumis- ja osallisuuskulttuuri, ympäristökansalaisuuden pedagogia ja näitä tukeva virallinen institutionaalinen muutos. Tiedon lisäksi ympäristö- ja sosiaalisten ynnä suunnitelmien vaikutusten arviointiin pääsevät "periaatteessa" kiinni ja mukaan kaikki päätösten liikauttamat kansalaiset. Samalla asiantuntijavallan ja salaisen valmistelun avaaminen sekä vapaaehtoisen ympäristömentaliteetin ja -kumppanien mobilisointi ovat muokanneet ympäristöosallisuutta. Monimutkainen ja asiantuntemusta keskittävä ympäristöhallinto - esi- 


\section{Kari Paakkunainen}

merkiksi unionivalmistelut - tulee kuitenkin harvoin häirityksi: asetelmaksi usein jää kansalaisten häly vastaan hallinnon legaali tietovoima ja aikataulujen politiikka.

Kansalaisyhteiskuntaan avautuminen on tuonut mukanaan myös yhteistyön ja erityissopimuksia maanomistajien kanssa. Taustalla on myös poliittisesti sangen kiistelty kehityssuunta, jossa korostetaan ekologisesti ja sosiaalisesti vastuullisen yritysmaailman aktiivisuutta lähestyä ekologisia standardeja, tuotemalleja ja liikkeitä uutena vastuullisena tuotteistamisen ja sidosryhmien mahdollisuutena. Samalla ympäristöavantgardien ja -liikkeiden toiminta on muokkaantunut enemmän puolesta-argumentilla kuin vasta-liikkeiden jatkuvuudella. Taustansa tälle on myös siinä paljolti kielteisessä julkisuudessa, mitä yön pimeydessä tehdyt suoran toiminnan iskut ovat saaneet julkisuudessa. Eläinoikeusliike on tunnetusti vaihtanut turkistarhaiskujensa voimapihdit suurta yleisöä lämmittävään videokameraan - silti turkistarhat ja niiden tukipolicy jatkuvat Suomessa. Samaan aikaan arkielämän ympäristöpolitiikan ratkaisut ovat legitiimi osa kansalaisten ja kuluttajien harkintaa - vaihtoehtonuorista puhutaan vain roskisprojektien yhteydessä. Lindholm on kriittinen kaikkia uusiakin osallistumiskulttuureja kohtaan ja kuvaa niidenkin rajallisuutta. Suurten kuluttajaryhmien eko-rationaalista valintaa ja elämän leppoistamista (downshifting) tai kasvukritiikkiä liioitellaan, valintoja tehdään niukkuuden ja arjen pakkoraoissa ja työttömyyspelkojen keskellä. Pohdintaosiossaan kirjoittaja nostaa esiin ekologisen modernisaation strategian, missä suoran osallistumisen sijaan keskitytään materiaalivirtojen yläjuoksulle, tuotannon suunnittelun ja tuotantotavan ratkaisuihin - joka jää systeemitason teollisuuden ja hallinnon ekotehokkaan yhteistyön ja sille sensitiivisten poliittisten verkostojen varaan. Vasta loppulauseissa Lindholm varaa tilaa ekologiselle vallankumoukselle, jos globaali kasvuun nojaava avoin talous tavoittaa rajansa.

Henri Vogtin tarkasti harkittu ja uusia sävyjä realistiseen varovaisuuteen, jopa joitain ristiriitoja, eksplikoiva kontribuutio "Suomen ulkopolitiikka: monensuuntaista eurooppalaistumista?" koskettelee perspektiivissään monia edellä nimettyjä politiikan aikalaiskulkuja ja mutkikkaita haasteita, liittoja ja dialogeja. Hänkin alleviivaa valtioiden keskinäisriippuvuutta ja taloudellista globalisaatiota ynnä terävöittää kuvaa jo otsikkonsakin tasolla Suomen (1990-luvun) lännettymisestä tai yh- 
teisöllistymisestä refleksiivisemmän eurooppalaisuuden suuntaan. Osana kehitystä pääministerin positio on vahvistunut ja presidentti-instituutio toimii ulkopolitiikassa yhteistoiminnassa valtioneuvoston kanssa. Eduskunta nousi Kekkosen ja Koiviston jälkeen mukaan ainakin suhteellisen rajalliseksi ulkopoliittiseksi vaikuttajaksi. Puolueettomuuspolitiikan sijaan Suomi on ulkopoliittisesti tahtova ja aktiivinen osa EU:ta. Naton kanssa toimitaan tiiviissä yhteistyössä, mutta suhteet ovat mutkikkaat - vaikka optio jäsenyydestä onkin auki. Suomen suhteet eri Euroopan valtioihin ovat edelleen tiivistyneet ja monipuolistuneet. Unionin ytimet ja ydinakselitoimijat ovat edelleen Suomen eurooppapolitiikan sihdissä, vaikka viimeaikainen finanssipolitiikan epävarmuus ja yleisempi pragmatismi ovat kysymyskohtaisesti heijastuneet myös yhteistyökehikkoihin, esimerkiksi pohjoismaisen yhteistyömuotoihin - esimerkiksi sen sosiaalisen mallin globaalin arvon propagoimisen tai puolustusyhteistyön suunnassa.

Suomen suhteet Venäjään on entistä tarkemmin 'multilateralisoitu'; EU:n lisäksi esimerkiksi Arktinen Neuvosto on tällainen monenvälinen yhteistyöfoorumi, joiden kehittyessä historialliset kahdenväliset suhteet Suomen ja Venäjän välillä ovat muuttaneet muotoaan ja julkisuuttaan. Suhteissa kuitenkin riittää hankalia ja lämpimiä kysymyksiä. Euroopan unionista on tullut monipuolinen kehikko, jonka puitteissa Suomi on tulkinnut ja toteuttanut aktiivisesti globaalipolitiikan - kaupan, kehityksen ja ympäristön - arvoja ja vastuitaan. Presidentti Halosen globaalin sosiaalisen ulottuvuuden näkyvät kontribuutiot ja presidentti Martti Ahtisaaren Nobelin rauhanpalkinto osoittavat globaalipolitiikan askeltahtia ja pohjoismaalaisen rauhansovittelun arvoa. Unionin ulko- ja globaalipolitiikka on ollut entistä yksiäänisempää sitten Irakin sodan (2003) perusratkaisujen. Toisaalta finanssikriisissä kansallisvaltio, esimerkiksi Saksa, tai niiden itsekkäät blokit 'lyövät takaisin' integraatiota ja yhteisvastuuta vastaan. Kuten aiemmin tässä johdannossa esitellyt globaalit kytkennät ja markkinavoimien arvoketjut osoittavat, Suomenkin ulkopolitiikassa on tullut entistä hankalammaksi ja mahdottomaksikin toimia yksitahtisesti - esimerkiksi ulkosuhteiden koordinoinnin ja diplomatian kannalta relevantin kauppa-, ympäristö- ja kulttuuri/urheilupolitiikan suunnilla. Samalla tavoin konsensuaalinen Eurooppa-projekti on poliittisesti ainakin säröillyt eri puolueiden ja ulkopolitiikan tähtitoimijoiden kiehtovissakin 


\section{Kari Paakkunainen}

polemiikeissa. Tällaiset eroavat argumentit voivat olla Vogtin hengessä tulkiten myös vahvan ja vakiintuneen eurooppalaisen identiteetin osoitus; maa ei enää vain täydennä EU:n ulkopolitiikalla omaansa tai anna sille jotain, se keskusteluu eurooppalaisena eu-toimijana sen linjasta. Avoin eurooppalainen pikkuvaltiotoimija, jonka kansalaisyhteiskuntakin kurkottaa parempien globaalis-demokraattisten pelisääntöjen puolesta ja jonka argumentit kuuluvat maailmalle, on mahdollinen visio johdonmukaisesti kirjoittavalle Vogtille.

\section{Yleisödemokratia, puolueiden viestin ja vallan muutokset ja uuden hallinnon myytit}

Juba Herkmanin oivallinen ja suhteellisuudentajuinen essee "Politiikan mediajulkisuus Kekkosen jälkeen" tuo komeasti "vilkkaan ja vallattoman" median osaksi keskusteluamme kansainvälistyvästä taloudellisesta kilpailusta sekä valtiollisista aktiviteeteista sen peesaajana, lähinnä markkinasääntelijänä. Hän kirjoittaa tutkija-analyyttisesti yhtä lailla liberaalin vapauden, monipuolisuuden kuin pejoratiivisinkin pinnallisuuden, henkilöllistymisen ja viihteellisyyden termein politiikan julkisuuden drastisesta muodon- ja sisällönmuutoksesta. Kommunikaatioteknologian ja markkinoiden huikea muutos ynnä Kekkosen mediankin lämmittämän hovin hajoaminen on ollut hurjimpia muutoksia suomalaisessa poliittisessa kulttuurissa viimeisen kolmenkymmenen vuoden aikana. Nyt osaamme ja uskallemme jo keskustella suomettumisen käsitteestä ja ilmapiiristäkin - turvautuen erilaisiin median lähteisiin ja valoihin. Kirjoittaja kuvaa osuvasti poliittisen lehdistön ja valtiollisen YLE:n asemien heikentymistä ja muutoksia viestinten kaupallistuvissa painoarvoissa. Median käytöstä ja ilmapiiristä Herkman etenee mediajärjestelmään ja viestintäpolitiikan puitteisiin ja paradokseihin Euroopassa ja internetissä. Julkinenkin sääntely on lähinnä markkinasääntelyä ja esimerkksi YLE kilpailee yksityisten tuottajien kanssa myös sisältöjen tasolla.

Eivät vain poliittisesti relevantin median sääntely- ja omistushallinnan välineet ole muuttuneet, mediatuotteiden ja tekniikoiden tuottajatalot ovat monipuolistuneet ainakin muutamien kentän konsernien ympärillä, kuluttajat ja yleisöt ovat saaneet ainakin aavistuksia (inter)aktiivi- 
semmista ja dialogisimmista toimijuuksista. Netti on muokannut sekä tuotannon ja vastaanottamisen rooleja, muuttanut ratkaisevasti median ajan ja paikan käsitykset.Tämän Herkman kuitenkin näkee lähitulevaisuuden mahdollisuutena, jolloin sosiaalinen tunnemedia, nautintokeskeinen surffaus ja identiteettipolitiikka voisivat paremmin jalostua systeemitasoisten etujen ja kompromissien prässäämiseen uuden internetsukupolven kypsymisen myötä. Myös tässä esseessä jäsennysperustana on Bernard Maninin siirtymäteesi puolue- ja yleisödemokratian välillä. Suomessakin leiriyhteiskunta tukeutui kollektiivisiin puolueideologioihin ja -demokratiaan - "Kekkosen, korporaatioiden ja hyvinvointivaltin rakentamisen kaudella". Jo UKK:n kaudella vahvistuneet ehdokkaan ja poliittisen henkilötoimijan imago- ja tilanne- ja performatiiviset taidot ovat taasen ominaisia yleisö- ja kuluttajakultuurille. Esimerkkien ja taitavin harkinnoin viestinnän yliopistonlehtori erittelee kriittisesti mielikuva-, imago- ja markkinapolitiikan ammattilaistumista ja vahvuuksia äänestäjien mobilisoinnissa kuten myös niiden ohuutta.

Teesiä, jonka mukaan joukkoviestinnän logiikka olisi täysin kolonisoinut politiikan ja ohentanut sen "mediademokratian" teatteriesitykseksi ilman yhteyttä politiikan reaali-ilmiöihin tai sen luovaan tulkintaan, Herkman ei Suomen kulttuurin kuvaksi hyväksy. Poliitikot säilyttävät julkisuudessa myös aktiivisen roolinsa ja vaikuttavat areenan ja kulissien roolituksiin ja tyyleihin - sen sijaan yleisödemokratian kuluttajan passiivisuuteen jäävät usein juuri kansalaiset omilla media-sohvillaan ja nettiasemillaan. Vaikka internetillä onkin mullistava merkitys autoritaaristen järjestysten kaatajana maailmalla ja vahvojen radikaalien liikkeiden demonstraatiossa ja vikkelässä organisoinnissa, sekin saattaa hajota kuppikunniksi, tyytyä asenne- ja halupintoihin ja jättää muun median tavoin poliittisen päätöksenteon kovan ytimen ja keskeiset vääntömentit melko lailla salatuiksi.

Rauli Mickelssonin "Suomalaiset puolueet kertomuksina" ja Jan Sundbergin "Puolueet yhteiskunnan ohjaajina ja ohjattuina" asettuvat oivallisesti rinnakkain, vaikka niiden näkökulmat ja aineistot puolueisiin ovatkin eriseuraiset. Kun pohjoismainen "stein-rokkanilainen" politologia (Sundberg) kohtaa kielitieteellisen käänteen jälkeisen "baumannilaisen huomiokamppailun" ja kertomustulkinnan (Mickelsson), lukija voi oppia yhdistämään puolueiden tehtäviä ja niiden tuottamia merkityksiä. 


\section{Kari Paakkunainen}

Samalla monet puoluekentän usein pejoratiivisena koetut ilmiöt - kuten "teatterimaistuminen" tai "erojen katoaminen, puuroutuminen" - voivat osoittautua ymmärrettäviksi ja monimielisiksi ilmiöiksi, kun pohditaan puolueiden historiallisesti medioituvia toimintatatapoja ja epätoivoisilta näyttäviä yrityksiä tarinallistaa yksilöllistyvää mailmaa. Professori Sundberg erittelee oivalla pedagogisella kepeydellä puolueiden aktiivista roolia ja toisaalta sen valtiollistumisen, medioitumisen ja ammattilaistumisen piirteitä, jotka rajoittavat puolueiden omaa valtaa. Myös Sundberg nojaa Manin historialliseen jäsennykseen parlamentti-, puolue- ja yleisödemokratian vaiheista. Kirjoittaja tuokin jäsennyksen pohjoismaiseen miljööseen ja suomalaiseen historiaan. Samalla professori operoi Stein Rokkanin tulkinnalla yhteiskunnan keskeisistä vastakkaisuuksista kansalaisyhteiskunnan poliittisen mobilisaation perustana. Ne asettuvat samaan opettavaiseen sarjaan politiikan jäsennysperustoja kuin muuallakin kirjassa kommentoidut Jussi Teljon, Jaakko Nousiaisen ja Erik Allardtin kehitelmät. Kirjoittajan tutkijatausta puolue- ja vaalijärjestelmien piirissä näkyy: vaalijärjestelmän kehityslinjoja suoristetaan, suomalaisen valtiollisen tosikkopuolueen standardikuva kirkastuu ja sosialidemokraattisen joukkopuolueen mallin propagoinnin vaiheet jäsentyvät.

Mickelsson osaa jäsentää 1900-luvun puolueita kertomuksina, niiden katkoksina, jatkuvuuksina ja muuttuvina identiteetteinä. Siirtyminen luokkapuolueista - joiden leireihin synnytään ja omaksutaan niiden kollektiiviset ajatustavat - kohti verkosto- ja huomiopuolueita tapahtuu johdonmukaisesti puolueiden puheissa. Artikkeli on kuitenkin sen verran pedagoginen ja lyhyt, että lukija innostuu varmastikin hankkimaan lisää tutkijan julkaisuja: empiiristä tarkennusta puoluemuutosten teorian ja narraatioiden kirjon välillä. Kertomuksen termi onkin ylipäänsä ideologisesti monimielisempi ja taipuvaisempi kuin politiikan instituutiot ja käsitteet. Esseen lukeminen saa aktiivisti poliittisesti maailmaa kokeilleenkin lukijan pohtimaan myös sitä, miten kollektiivisten rintamatarinoiden rapautuminen on syönyt perustan puolueohjelmilta tai miten yksilöllistyminen ja yksityisen sisällön kasvu myös poliittisessa viestinnässä on muokannut kertomuksen paikkaa yhteiskunnassa. Kuka meistä on edes lukenut jonkun puolueohjelman? Toisaalta taitavat verkostopolitiikot vievät syvämerkityksiä ja kuvamaailman ja hektisen netin toimijat solmivat juttua 'ei-niinkään-auki-kirjoitetussa' maailmasuhteessa. 
Mickelsson kuitenkin uskoo, että politiikalle relevanttien kertomusten ydin on puoluejärjestöissä ja -ideologiassa ja sen fraktioiden eritasoisissa yhteisissä puheissa ja teksteissä. Televisio ja tietoverkot eivät ole järkyttäneet tätä perusseikkaa.

Pertti Ahosen tutkimusjohdanto ja hallinnon sekä julkisten toimijoiden muutosta luotaava artikkeli "Suomen julkisen hallinnon ja julkisen sektorin muutoksesta institutionalistisesta tutkimusnäkökulmasta" on - kuten kirjoittaja itsekin korostaa - akateeminen ja vaativa. Esseen perussanomaan pääsee välttävästi käsiksi myös lukematta ajankohtaista ja terävää johdantoa institutionalistisen tutkimuksen viitekehykseen ja fokuksiin. Koko akateemisen artikkelin lukukynnys kannattaa kuitenkin ylittää. Tulkinta opettaa lukijalle teoreettisen kehyksen mahdollisuuksia kuvata ja problematisoida julkisen sektorin muodon ja toimintatavan muutoksia varsinkin 1990-luvun tälle kirjalle olennaisessa koko järjestelmän ympäristön- ja suunnanmuutoksessa. Tuolloin myös hallinnon uudistamisen "puurot ja vellit" eli esimerkiksi julkisen sektorin "löysät pois"-säästönormit ja tulosvastuun tiukasti omaksutut taikasanat saattoivat mennä sekaisin ja tuottaa enemmän ei-tarkoitettuja vaikutuksia. Tämä kansanomainen rinnastus ei tee kunniaa Ahosen kontribuutiolle, mutta kirjoittaja käy surutta läpi lyhyt- ja pitkäaikaisia suomalaisen kirjoitetun hallintoration muutosaspekteja, sen naapurinkin puolelle leviäviä hallitsemattomia rutiineja ja tekniikoita, uusia tehokkaita hallinnon häärääjiä ja eksperttejä sekä drastisempia muutoskulmia. Ensinnäkin, hän analysoi ilmiöita, joita kutsutaan institutionalismin piirissa 'mikroinstitutionalisoitumiseksi': esimerkiksi kaikkialle levinneet työkalut, evaluaatio ja indikaattorit. Toiseksi, hän keskittyy tehokkuuden ja legitimiteetin institutionaaliseen vuorovaikutukseen (institutionalistisen) 'toimijuuden' ilmiön yhteydessa: esimerkiksi tuloksellisuuden myytin nimissä toimeenpannut, legitimaatiopyrkimysten kannalta ristiriitaiset muutokset, kuten tuottavuusohjelma tai näyttöperusteinen ja itsenäiseksi julkisoikeudelliseksi yhteisöksi muokkaantunut yliopisto tai yhtiöittämiset. Näiden rinnalla ja näihin liittyen hän nimeää ja pohtii radikaaleja institutionaalisia muutoksia: esimerkiksi syvät menoleikaukset 1990-luvulla, aiemmat hallintoyksiköiden ja aktuellit kuntien liitokset. Hän ei ota annettuna uuden (monimieliseksi ja tyhjäksi monesti osoittautuvan) 'governance'-hallinta-ajattelun tai hallintotraditiommekaan toimivuutta 


\section{Kari Paakkunainen}

ja läpinäkyvyyttä, muttei myöskään kiiruhda New Public Management -ohjelmaliberaaleja arvostelevaan huutokuoroonkaan.

Näin Ahonen näkee, tutkii ja kirjoittaa paremmin. Artikkeli pysäyttää meidät pohtimaan, mitä instituutiot ovat ja miten latteasti ne syntyvät mitä markkinahenkinen ratio uudenlaisten instituutioiden ja toimijuuksien suhteen merkitsee perinteisen weberiläisen byrokratian kannalta? Hän huolestuu ideologisesta periaatteesta ja sen kumuloituvista seurauksista, kun globaalisti leviävät julkista sektoria supistavat instituutioratkaisut sarjallisesti vähentavat poliittista ja muuta epavarmuutta ja siksi turvaavat hallinnan legitimiteettiä? Ahoselle käytännöllisintä on paras teoria, hän ottaa sen henkilökohtaisille ratkaisuille uskollisella tavallaan tosissaan eikä halua ajautua hallinnon ja sen konsulttien valtavirrassa: yksiviivainen hallinnontutkimuksen pyrkimys välittömaan hyödyllisyyteen vie sen vaivihkaa "jälkijunaan", ja globaalin ja kansallisen terminologian konsultit, globaalisti vikkelä virkamiehistö ja vahvat intressiryhmät alkavat sanoittaa myös tutkimusta.

\section{Poliittinen kulttuuri, demokratia ja parlamentarismin omintakeinen tavoittelu}

Esseekokoelman aloittava Pasi Saukkosen "Suomalaisen yhteiskunnan poliittinen kulttuuri" ja Kari Paakkunaisen päättävä "Omaperäinen parlamentarismi järjestyksen ja ulkoisten tehtävien puristuksessa" ovat kirjan kokonaisuuden kaksi erilaista kokoavaa artikkelia. Saukkosella poliittinen kulttuuri keskittyy 'poliittiseen' muun yhteiskunnallisen järjestelmän ja sen ristitiitojen ratkomisen osana. Kirjoittaja ei salaa Suomen onnistuneen modernissa kansallisessa projektissaan, vaikka 1980-luvun jälkeinen globalisaatio onkin nostanut uusia haasteita ja protesteja integratiiviselle kulttuurille. Poliittisen mobilisaation ja puoluetoiminnan ohessa hän pohtii kansallista identiteettiä, asenneilmapiiriä ja viime vuosikymmenien kulttuurista moniarvoisuutta. Näin hän kirjoittaa uusiksi vuosikymmen sitten oppikirjassaan ja ylipäänsä suomalaisessa valtioopissa omaksuttua realistista kansalaisyhteiskunnan yleisen mielipiteen ja erojen mobilisoinnin historiaa siinä missä Jussi Teljo, Erik Allardt, Jan-Magnus Jansson kuin Jaakko Nousiainenkin. Saukkonen hahmottaa 
esseekokoelmaa kooten suomalaisen poliittisen kulttuurin vahvan mobilisaatiovaiheen - eräänlaisen kulminaatiopisteen - 1980-luvulle ennen 1990-luvun epäjatkuvuuksia.

Tämän huomattavan homogeenisen ja tasa-arvoisen "konsensusSuomen" vahvuus perustui myös puoluerajoja ylittäviin aatteellis-ideologisiin peruskäsityksiin tai "superideologioihin" (Ilkka Heiskanen), joita ovat olleet taloudellinen kasvu, julkisen sektorin hyvinvointitehtävien laajentaminen ja kehittäminen, alueellinen tasainen sosiaalinen ja taloudellinen kehittäminen sekä edustuksellisen ja osallistuvan demokratian kehittäminen. Useat muutkin kirjoittajat (varsinkin Kettunen, Väyrynen ja Paakkunainen) jäävät kommentoimaan Saukkosen tapaan Risto Alapuron kokoavaa tulkintaa, minkä mukaan 1930-luvun kansalliset eheytyspyrkimykset lujittivat omalaatuista yksimielisyyden vaatimisen ja erimielisyyden sietämisen yhdistelmää - jonkinlaista erityistä pikkuvaltion refleksiivistä kulttuuria, suhdetta ulkoiseen ja sisäiseen. Kuitenkin Jaakko Nousiainenkin kuvasi jo 1985 tilannetta, jossa politiikan yksimielisyys- ja kompromissisillat olivat puurouttaneet politiikkaa ja laajentaneet hyvinvointioloissa "gäppiä" eliitin ja rahvaan välillä. Tässä myös edustuksellisen demokratian väsymistä aiheuttaneessa etäisyydessä ja kansallisen suvereenisuuden ja identiteetin haasteiden populistisessa, eriarvoisuuden kasvun vasemmistolaisessa ja monikulttuurisuuden nationalistisessa arvostelussa Saukkonen löytää myös paineen Perussuomalaisten Jytky-Voitolle vuoden 2011 eduskuntavaaleissa.

Paakkunaisen parlamentarismi -esseen tavoitteet ovat enemmän historiallisia ja järjestelmän muutosta demonstroivia ajatellen oppikirjan nuorempaa lukijakuntaa. Suhteuttaen artikkeliaan muihin kirjan tulkintoihin hän pyrkii pohtimaan maan parlamentarismin kehkeytymis- ja tulkintahistoriaa. Aika seikkaperäinen ja historiallinen kuvaus todentaa suomalaisen demokratian haasteita erilaisten parlamantaaristen omap(er) äisten ongelmien, ohuuksien ja sitä muokkaavien yksimielisyysvaatimusten kautta. Hänkin tarvitsee vahvaa historiallista jatkuvuutta ja murroksia (erityisesti 1905-07 ja 1917-18), huomioita ulkoisen ja sisäisen dynamiikkaan osoittaakseen, että puhtoisen ja keskustelukulttuuriltaan parlamentaarisen järjestelmän ideaali on meillä aina ollut ja on ongelmallinen ja aukinainen yritys. Tasavaltalainen ja edustuksellinen poliittinen kulttuuri on ollut yksi kulttuurimme sidos ja edellytys valtiollisen järjen 
ja selviytymisen politiikan perusteluille, vaikka uudetkaan sukupolvet eivät vahvasti hahmota demokratiaa parlamentaarisen järjestelmän tai puhekulttuurin avuin. 


\section{Suomalaisen yhteiskunnan poliittinen kulttuuri}

\section{Johdanto}

Jokaisella maalla on oma poliittinen historiansa ja kulttuurinsa. Tämän artikkelin tarkoituksena on antaa yleiskatsaus suomalaisen yhteiskunnan kehitykseen erityisesti poliittisen järjestelmän rakentumisen näkökulmasta. Lisäksi kirjoitukseni kohteena on suomalainen poliittinen kulttuuri, jolla tarkoitan tässä erityisesti niitä periaatteita ja toimintatapoja, joilla Suomessa on pyritty ratkaisemaan yhteiskunnallisia jännitteitä ja poliittisia ristiriitoja.

Lähden liikkeelle siitä, miten Suomesta tuli Suomi eli minkälaisia asioita liittyy Suomen valtion ja poliittisen järjestelmän kehitykseen, nykyaikaisen yhteiskunnan muodostumiseen ja suomalaisen kansakunnan rakentumiseen. Tarkemmin analysoin Suomea 1980-luvun puolivälissä, jolloin monet aikaisempien vuosikymmenten keskeiset periaatteet ja poliittiset tavoitteet saavuttivat eräänlaisen kulminaatiopisteensä. Näissä analyyseissa huomio kiinnitetään erityisesti valtiollisiin poliittisiin instituutioihin ja suomalaiseen puoluelaitokseen, mutta myös muuhun kansalaisyhteiskuntaan, poliittiseen asenneilmastoon ja kansalliseen identiteettiin (vrt. Saukkonen 2003). Artikkelin viimeisessä osassa käsittelen niitä muutoksia, joita suomalaisessa yhteiskunnassa ja politiikassa on ta- 


\section{Pasi Saukkonen}

pahtunut viime vuosikymmeninä ja millä tavalla suomalainen politiikka on vastannut uusiin jännitteisiin ja ristiriitoihin.

\section{Suomen rakentuminen}

\section{Katkoksia ja jatkuvuutta}

Suomen valtion kehityshistoria sekä suomalaisen yhteiskunnan ja kansakunnan rakentuminen asettuvat varsin hyvin siihen ilmiöön, jota on ollut tapana kutsua yhteiskunnallisen modernisaation nimellä. Tässä prosessissa valtiosta on tullut alueellisesti selkeästi rajattu sekä keskitetysti johdettu yksikkö, joka on tunkeutunut lainsäädännön, verotuksen ja julkisten velvollisuuksien välityksellä koko alueensa väestön arkeen. Vastavuoroisesti yksilöiden ja ryhmien poliittiset oikeudet ovat lisääntyneet edustuksellisen demokratian vakiintumisen myötä.

Taustalla on yleisempi yhteiskunnallinen uudenaikaistuminen, jossa aikaisemmat paikallisyhteisöt ja niissä elävät ihmiset ovat kytkeytyneet toisiinsa kansalliseksi kokonaisuudeksi, teollisuus sekä myöhemmin palveluelinkeinot ovat keskeisinä tuotannon aloina syrjäyttäneet maatalouden ja kaupungistuminen on edennyt maaseudun ja sekularisaatio uskonnollisten arvojen kustannuksella. Valtion ja yhteiskunnan rakentumisille rinnakkainen prosessi on nykyaikaisen kansakunnan muodostuminen: kansallisen kulttuurin rajaaminen ja institutionalisoiminen, kielenkäytön ja tapakulttuurin yhdenmukaistuminen sekä kansakunnan symbolisen kokonaisuuden luominen kansalaisten yhteenkuuluvuuden tunteen kiinnekohdiksi ja lujittajiksi.

Suomi itsenäistyi vuonna 1917, mutta moderni valtiokoneisto oli pitkälle kehittynyt jo autonomian aikana. Vaikka itsehallintoa rajoitettiinkin voimakkaasti venäläisen valtiovallan toimesta 1800-luvun lopulla ja 1900-luvun alussa, Suomen suuriruhtinaskunnalla oli tällöin jo miltei täydellinen oma poliittinen järjestelmänsä. Itsenäistymisen koittaessa keskeisistä poliittisista instituutioista puuttui lähinnä kotimainen valtionpäämies. (Suomen poliittisesta historiasta ks. yleisesti Jussila, Hentilä ja Nevakivi 2009; hallintohistoriasta Selovuori 1999; yhteiskunnan kehityksestä Valkonen 1980.) 
Tasavallan presidentin asema muodostui puolestaan historiallisten tekijöiden ja itsenäistymisen yhteydessä käydyn sisällissodan yhteisvaikutuksesta huomattavan vahvaksi. Valtiosääntöön jäi sekä parlamentaarisia että ylimpien toimielinten vallanjakoon viittaavia dualistisia piirteitä. Täysimääräisesti presidenttien voi kuitenkin katsoa hyödyntäneen valtiosäännön antamia mahdollisuuksiaan vasta J. K. Paasikiven ja Urho Kekkosen presidenttikausien aikana. Tällöin Suomi myös luokiteltiin muun muassa Ranskan ohella puolittain presidenttivaltaiseksi tai semipresidentiaaliseksi maaksi. (Nousiainen 1985b; suomalaisen parlamentarismin vaiheista yleisesti Jansson 1993; Nousiainen 2000.)

Eduskuntauudistus vuonna 1906 merkitsi erittäin suurta hyppäystä poliittisen vallan käyttäjien valintaperusteissa. Sääty-edustukseen perustuvasta järjestelmästä, jossa yhdeksän kymmenesosaa aikuisväestöstä oli vailla poliittisia oikeuksia valtiollisella tasolla, siirryttiin kertaheitolla yleiseen ja yhtäläiseen äänioikeuteen. Muutoksen toteutumista hidastivat ja häiritsivät kuitenkin monet pidäkkeet. Kuntatasolla äänioikeus oli siirretty varallisuusperusteiseksi jo 1860-luvulla, mutta paikallishallinnon täysi demokratisointi lykkääntyi itsenäistymisen jälkeiseen aikaan. Lisäksi keisari kieltäytyi hyväksymästä useita päätöksiä hajottaen toistuvasti eduskunnan ja määräten uudet vaalit. Täysien poliittisten oikeuksien toteutumista kavensivat myös 1930-luvulla niin äärivasemmiston kuin äärioikeistonkin sulkeminen pois poliittisesta järjestelmästä.

Suomalaisen poliittisen järjestelmän historiallisiin erityispiirteisiin kuuluu myös vahvan valtion ja legalistisen hallintokulttuurin perinne. Vahvan valtion tausta on osittain suuriruhtinaskunnan hallitsemistraditioissa, mutta osittain myös suomalaisen puoluelaitoksen ideologioissa. Sisällissodan jälkeen oikeisto pyrki turvaamaan vahvan ydinvaltion sisäisen järjestyksen ja turvallisuuden sekä maanpuolustuksen alueilla. Keskustaryhmistä etenkin Maalaisliitto korosti taas valtion velvollisuutta tukea ja kehittää julkista koulutusjärjestelmää ja kansallista kulttuuria. Vasemmisto puolestaan näki valtiolla keskeisen roolin sosiaaliturvajärjestelmien luomisessa sekä niiden toiminnan takaavien instituutioiden perustamisessa ja rahoittamisessa. (Tiihonen 1999.) Suomalainen poliittinen järjestelmä on perustunut myös vahvan paikallisen itsehallinnon varaan, kun taas aluehallinto on jäänyt merkitykseltään melko vähäiseksi. 


\section{Pasi Saukkonen}

Suomalaisen puoluelaitoksen syntyyn vaikuttivat monet ristiriitaulottuvuudet, jotka heijastelevat suomalaisen nationalismin erikoisluonnetta, Suomen kansainvälistä asemaa sekä maan taloudellista ja sosiaalista rakennetta. Suomen ensimmäisenä puolueena voi pitää fennomaaniideologian varaan rakentuvaa suomalaista puoluetta, joka sai vastapoolikseen ruotsalaisen puolueen. Vuonna 1899 aluksi nimellä Suomen Työväenpuolue perustettu sosialidemokraattinen puolue on ensimmäinen moderni joukkopuolue kehittyneine organisaatioineen. Kotimaista politiikkaa hallitsi vuosisadan vaihteessa kuitenkin erityisen voimakkaana suhde Venäjään, joka oli osaltaan vaikuttamassa suomalaisen puolueen jakautumiseen siten, että vuoden 1918 jälkeen siitä olivat jäljellä Kansallinen Kokoomus ja Kansallinen Edistyspuolue.

Lisäksi itsenäisen talonpoikaiston suuruus ja taloudellinen merkitys johtivat länsieurooppalaisittain vahvan agraaripuolueen, Maalaisliiton, syntyyn. Vasemmiston kahtiajakautuminen oli puolestaan tosiasia Suomen Kommunistisen Puolueen perustamisen jälkeen Moskovassa vuonna 1918, vaikka kyseinen puolue ei laittomana pitkään kyennytkään toimimaan julkisesti Suomessa. Kommunistien ja eräiden muiden vasemmistoryhmittymien vaaliorganisaatioksi perustettiin jatkosodan jälkeen Suomen Kansan Demokraattinen Liitto SKDL. Puoluekentän toiselle laidalle syntyi osana eurooppalaista oikeistoradikalismia lapuanliikkeen kieltämisen jälkeen vuonna 1932 parlamentaariseksi toimijaksi Isänmaallinen Kansanliike, jonka toiminta kiellettiin välirauhansopimuksen nojalla vuonna 1944. (Ks. puolueista Borg 1965; Nousiainen 1998; Rantala 1982; Sundberg 1996.)

Suomessa on siten vahvassa mielessä monipuoluejärjestelmä, jonka olemassaoloa käytössä oleva suhteellinen vaalitapa edelleen edesauttaa. Toisaalta kehityksessä on myös kansallista yhtenäisyyttä edesauttavia piirteitä. Eurooppalaisista aatteista konservatismi ja sosialismi jakautuivat Suomessa useiksi puolueiksi. Sitä vastoin liberalismi ei ole koskaan onnistunut vakiintumaan voimakkaaksi poliittiseksi liikkeeksi, mutta vapaamielisiä pyrkimyksiä ja painotuksia on löytynyt miltei kaikkien puolueiden sisältä. Jako oikeistoon ja vasemmistoon ei puolestaan Suomessa asettunut samaan paikkaan kirkollisen ja antiklerikaalisen asennoitumisen kanssa. Suuri osa vasemmiston kannattajistakin on ollut evankelis-luterilaisen kirkon jäseniä, ja vasemmistopuolueissa on ollut omia 
kristillisiä tai kristinuskon motivoimia ryhmittymiään. Ruotsalainen Kansanpuolue on kerännyt suurimman osan Suomen ruotsinkielisten äänistä, mutta myös muissa puolueissa on aina vaikuttanut ruotsinkielisiä yksilöitä ja ryhmiä (ks. Grönlund 2011).

Kaikesta hajanaisuudesta, polarisaatiosta ja päällekkäisyyksistä sekä jyrkkiin ristiriitoihin perustuvasta historiallisesta taustasta huolimatta suomalainen puoluejärjestelmä on osoittautunut myös hyvin vakaaksi. Yhteiskunnan muutos, radikalisoimispyrkimykset, poliittisen ilmapiirin kiristyminen ja tulehtuneet henkilösuhteet ovat aiheuttaneet puolueiden hajoamisia sekä uusien yrittäjien esiintuloja, mutta valtaosalla nykyisinkin eduskunnassa vaikuttavista puolueista on takanaan pitkä historia. Kääntäen, itsenäisyyden ajan alun merkittävimmistä puolueista miltei kaikki ovat vaikuttaneet keskeytyksettä suomalaisessa politiikassa näihin päiviin saakka, vaikka monet ovatkin vaihtaneet vuosikymmenten saatossa nimeään. Toisen maailmansodan jälkeen perustetut puolueet ovat SKDL:a lukuun ottamatta vain poikkeuksellisesti saaneet kymmenen prosentin äänisaaliin tai enemmän.

\section{Ristiriitoja ja yksimielisyyttä}

Suomalaisen kansakunnan rakentaminen eteni puolestaan pitkälle jo autonomian aikana suppeahkon, mutta tehokkaasti uusia käsityksiä ja esityksiä tuottavien nationalistisesti orientoituneiden intellektuellien toimesta. Fennomaanien kielipolitiikka oli siinä mielessä radikaalia, että heidän edustamansa romanttisen nationalismin mukaisesti yksi kieli, yksi kansa ja yksi valtio kuuluivat elimellisesti yhteen. Tämän ideologian vastapainoksi osa ruotsinkielisistä kehitti oman ruotsinmielisen eli svekomaanisen näkemyksensä, jonka mukaan Suomessa asui kaksi, kahta eri kieltä puhuvaa kansaa.

Fennomaniaa voidaan kuitenkin pitää myös maltillisena poliittisena liikkeenä, koska esimerkiksi J. V. Snellmanin mukaan suomalainen sivistyneistö oli kansallistettava ja kansa sivistettävä - sen sijaan että aikaisempi eliitti olisi korvattu uudella eliitillä. Vaikutusvaltaiseksi osoittautui myös Zachris Topeliuksen Maamme-kirjassa (1. painos 1875) ilmaisema sovitteleva kanta, jonka mukaan Suomen kaikki "pojat ja tyttäret ovat 


\section{Pasi Saukkonen}

samaa kansaa, puhuivat he mitä kieltä hyvänsä’. Itsenäistymisen jälkeen suomi ja ruotsi määriteltiin keskenään tasa-arvoisiksi kansalliskieliksi. Yleisessä tietoisuudessa käsitys Suomesta ja suomalaisuudesta ankkuroitui kuitenkin vahvasti nimenomaan suomenkieliseen väestönosaan ja sen historiallisiin vaiheisiin. (Ks. tarkemmin esim. McRae 1999; Tommila 1989; Saukkonen 1999.)

Kaikkineen suomalaisen poliittisen eliitin ja suurimman osan kansalaisistakin voi sanoa asteittain sisäistäneen huomattavan kokonaisvaltaisesti tietyt kansallisen olemassaolon säilyttämisen ja etujen ajamisen keskeiset periaatteet. Eturistiriitojen sovittamattomuuden sijaan kasvoi käsitys yhteisestä suomalaisesta edusta. Useimmat poliittiset toimijat saattoivat kuvitella saavuttavansa tämän intressin nimissä toimimalla enemmän omia tavoitteitaan kuin ajamalla pelkästään ja muista piittaamatta omia intressejään. Toisaalta maassa, jossa usean puolueen koalitiohallitukset ovat normaalioloissa väistämättömiä, omia tavoitteita saattoi päästä tehokkaasti ajamaan hallituksesta käsin vain tekemällä myönnytyksiä muiden toimijoiden suuntaan. 1930-luvun lopulta 1980-luvun lopulle tämän yhteistyön pääakselin muodosti eräitä välivaiheita lukuun ottamatta sosialidemokraattien ja Maalaisliiton (myöhemmin Keskustapuolue, Suomen Keskusta) välinen punamultayhteistyö. (Jansson 1993; Nousiainen 2000.)

Erityisen merkityksellinen oli käsitys itsenäisyyden turvaamisen ensisijaisuudesta, mikä heijastui vahvasti erityisesti Suomen ulkopolitiikkaan. Paasikiven ja Kekkosen presidenttikausilla hallitukseen pyrkivällä puolueella ei voinut olla presidentin linjasta selvästi poikkeavia käsityksiä etenkään Suomen ja Neuvostoliiton välisistä suhteista. Kuten Risto Alapuro $(1999,103)$ on huomauttanut, ulkoisella vaaralla on ollut poliittisen kulttuurin kehittymisen kannalta kaksoismerkitys. Yhtäältä se johti voimakkaaseen yksimielisyyden paineeseen, koska ulkopoliittista toisinajattelua ei siedetty. Toisaalta se pakotti myös tiettyyn erilaisuuden sietoon, koska järjestelmän vakautta ei saanut uhata vetämällä sisäisten jännitteiden jousta liian kireälle.

Ulkopoliittiselle konsensukselle rinnakkaisena ilmiönä kehittyi ajan mittaan kansallista etua koskeva yhteisymmärrys myös talous- ja sosiaalipolitiikasta. Kauempana taustalla oli jo sisällissodasta kumpuava pyrkimys eheyttää kansaa jakavat ristiriidat ja ylittää yhteiskuntaluokkien ja 
ryhmien väliset kuilut. 1960-luvun lopussa ja 1970-luvun alussa suurin osa radikaalista vasemmistostakin hyväksyi vallitsevan kapitalistisen talous- ja tuotantojärjestelmän ja asettui tukemaan vientiteollisuudesta riippuvaista taloudellista kasvua, jonka hedelmien voitiin puolestaan olettaa koituvan myös työntekijöiden hyödyksi sekä tulonsiirtoina että julkisina palveluina. Toisaalta oikeisto luopui selvästi poikkeavista vaihtoehdoistaan maalaisliiton ja sosialidemokraattien yhteistyön perustalle rakennetuille laajamittaisille sosiaaliturvajärjestelyille sekä vastustuksestaan valtion vahvalle asemalle suomalaisessa talouselämässä. Aluksi sosiaalisen markkinatalouden ja myöhemmin sosiaalisen valintatalouden nimissä kokoomus siirtyi kannattamaan hyvinvointivaltion rakentamisen perusperiaatteita. (Ks. Smolander 2000.)

Muiden Pohjoismaiden tavoin äänestysaktiivisuus kohosi toisen maailmansodan jälkeen verrattain korkeaksi, mikä kielii poliittisen järjestelmän tietystä toimivuudesta. Merkkinä poliittisen kulttuurin vakaudesta voinee pitää myös sitä, ettei Suomessa ole tapahtunut yhtään poliittista murhaa sitten sisäministeri Heikki Ritavuoren surmaamista vuonna 1922. Poliittinen radikalismi on ylipäätään ollut hyvin vähäistä, ja suomalaisia mielenosoituksia on kautta aikojen luonnehdittu järjestyksen sekä virkavallan kanssa tehtävän yhteistyön leimaamiksi. Martti Siisiäisen mukaan niin vanhoille kuin uusillekin poliittisille liikkeille on ollut tyypillistä pyrkimys välttää konflikteja viranomaisten kanssa sekä torjua aktionistisia ja terroristisia keinoja. (Siisiäinen 1998, 238; Alapuro 1997, 25-54).

Kansalaiset integroituivat suomalaiseen yhteiskuntaan ennen muuta koululaitoksen ja armeijan, mutta myös erilaisten kansanliikkeiden kautta. Suomalaisen yhdistyslaitoksen omaleimainen piirre oli osittain kansallisesta ideologiasta, osittain modernin puoluelaitoksen myöhäisestä syntymisestä johtuen vahva valtakunnallisen tason organisatorinen yhtenäisyys. Esimerkiksi nuorisoseura- ja vapaapalokuntatoiminnan kansallinen yleisluontoisuus politisoitui vasta 1900-luvun alussa ja alkoi hajautua aatteellisten ja puoluepoliittisten linjojen mukaisesti vasta sisällissodan jälkeen. Kansalaisyhteiskunta kasvoi myös Suomessa lähelle valtiota, joka tuki monia yhdistyksiä ja järjestöjä taloudellisesti, mutta antoi niille samalla hoidettavaksi julkisia tehtäviä. Henrik Stenius on esittänyt, että yhtenäisyyttä korostava kansalaisyhteiskunnan järjestäytyminen on tuot- 


\section{Pasi Saukkonen}

tanut Suomeen valtion roolia korostavan ja ristiriitoja välttelevän poliittisen kulttuurin. (Stenius ei vuosilukua; 2003; yleisesti kansanliikkeistä Alapuro ym. 1987.)

Suomalaisen yhteiskunnallisen eliitin toimintaperiaatteisiin ovat siten jo pitkään kuuluneet yhtäältä keskipakoisten voimien marginalisointi poliittisesta vallankäytöstä ja toisaalta keskihakuisten voimien kytkeminen valtiolliseen toimintaan. Tämä ajattelu- ja toimintatapa näkyy konsensus- ja kompromissihakuisena politiikkana sekä radikaalien vaihtoehtojen eristymisenä ja kutistumisena, ja se ilmenee selvästi kahdella yleiseurooppalaisen radikalisoitumisen ja polarisaation aikakaudella. Maailmansotien välisenä aikana onnistuttiin puolustautumaan niin vasemmistolaisia kuin oikeistolaisiakin epädemokraattisia pyrkimyksiä vastaan ja aloittamaan maalaisliiton ja sosialidemokraattien punamultayhteistyö. Risto Alapuron mukaan 1930-luvun kansalliset eheytyspyrkimykset lujittivat omalaatuista yksimielisyyden vaatimisen ja erimielisyyden sietämisen yhdistelmää, jossa erilaisuuden sallimisen motiivina oli kansallisen konsensuksen vahvistaminen. 1960-luvulla puolestaan integroitiin äärivasemmisto poliittiseen järjestelmään ottamalla SKDL mukaan hallitusvastuuseen ja hillittiin nuorisoradikalismia suhtautumalla siihen ymmärtäväisesti. Vapautumisen ja moniarvoistumisen sisään rakentui ulkosuhteisiin perustuva vahva kansallinen motiivi, eräänlainen pakotettu pluralismi. (Alapuro 1997; ks. myös Heiskanen 1982.)

Poliittisen järjestelmän jatkuvuus onkin Suomen tapauksessa silmiinpistävää, erityisesti ottaen huomioon ristiriitojen voimakkuuden sekä itsenäistymisen alkuvuosina sisällissodan voittaneen ja hävinneen osapuolen että yhteiskuntaelämän täydellistä suomenkielistämistä vaatineiden jyrkän kansallismielisten liikkeiden ja ruotsinkielisen väestönosan välillä. Ensimmäisen maailmansodan yhteydessä itsenäistyneistä keskisen Euroopan maista Suomi säilytti Tšekkoslovakian ohella ainoana maana valtiojärjestyksensä. Kaikkineen Suomen valtiosääntöön tehtiin ennen Kekkosen presidenttikauden päättymistä vain pienehköjä muutoksia. Itsenäisen Suomen historian jakamista ensimmäiseen ja toiseen tasavaltaan voidaankin pitää harhaanjohtavana (esim. Alasuutari 1996). 


\section{Konsensus-Suomi}

\section{Yhteisymmärrys superideologioista}

1980-luvun puolivälissä Suomi muistutti varsin paljon ideaalia suvereenista eli täysivaltaisesta kansallisvaltiosta. Suomea saattoi pitää poliittisesti huomattavan itsenäisenä ja demokraattisena, sosiaalisesti ja taloudellisesti varsin tasa-arvoisena ja oikeudenmukaisena sekä kulttuurisesti melko suvaitsevaisena maana, jossa konflikti- ja ristiriitatilanteissa suosittiin sovittelumekanismeja ja kompromissiratkaisuja. Tämän "konsensusSuomen" yleisesti jaettuja perusperiaatteita olivat edustuksellinen demokratia ja kunnallinen itsehallinto yhdistettynä kansanvallan edistämiseen, kapitalismi ja markkinatalous yhdistettynä hyvinvointivaltion rakenteisiin, arvoihin ja tavoitteisiin sekä suomenkielisyyteen ja evankelis-luterilaisuuteen nojaavan kansallisen kulttuurin ja suomenruotsalaisen kansanosan vahvan juridisen suojan yhdistelmä.

Erityisesti 1960-luvun puolivälistä lähtien suomalaista yhteiskuntaa oli kehitetty tiettyjen puoluerajoja ylittävien aatteellis-ideologisten peruskäsitysten tai superideologioiden mukaisesti. Ilkka Heiskasen mukaan hyvinvointivaltion rakentamisen kaudella esille nousseita ja voimistuneita superideologioita olivat taloudellisen kasvun ideologia, julkisen sektorin hyvinvointitehtävien laajentamisen ja kehittämisen ideologia, alueellisen tasaisen sosiaalisen ja taloudellisen kehittämisen ideologia sekä edustuksellisen ja osallistuvan demokratian kehittämisen ideologia (Heiskanen 1977, 46). Kaikkineen ne korostivat vahvaa pyrkimystä tasa-arvon edistämiseen ja yhdenvertaisuuden toteutumisen varmistamiseen taloudellisen kasvun tuottamien voimavarojen puitteissa.

Poliittisen, taloudellisen ja sosiaalisen tasa-arvon lisäksi suomalaisessa yhteiskunnassa ja poliittisessa järjestelmässä esiintyi voimakasta kulttuurisen yhtenäisyyden korostamista. Suomalaisen kansallisen identiteetin kulmakiviä olivat käsitykset Suomesta sotilaallisesti puolueettomana maana, länsimaisena demokratiana, pohjoismaisena hyvinvointivaltiona sekä suomen kieleen ja historialliseen perinteeseen nojaavana ja osittain idän ja lännen traditioita yhdistelevänä, osittain omaleimaisen kansallinen kulttuurin pönkittämänä kansakuntana. Suomalaista yhteiskuntaa pidettiin usein miltei määritelmällisesti homogeenisena. Esimerkiksi 


\section{Pasi Saukkonen}

sosiologi Matti Virtasen mukaan Suomi oli etnisessä mielessä ollut pitkään sanan varsinaisessa mielessä kansallisvaltio: "Lähes kaikki suomalaiset kuuluvat samaan rotuun, puhuvat samaa kieltä ja tunnustavat samaa uskontoa. Lähes kaikki suomalaiset asuvat valtiossa nimeltä Suomi. Suomalaiset ovat yksi kansa yhdessä valtiossa." (Virtanen 1988, 1-2; ks. laajemmin Saukkonen 1999.)

Suomalaiset myös identifioivat itsensä vahvasti omaan maahansa ja kokivat suomalaisuuden myönteisenä. Vuonna 1984 yhdeksän kymmenestä suomalaisesta yhtyi väitteeseen, jonka mukaan "on onni ja etuoikeus saada olla suomalainen”. (Haavisto ja Kiljunen 2011; ks. myös Anttila 2007). Ulkomaalaisten asema (pl. muiden Pohjoismaiden kansalaiset) oli puolestaan monella tapaa rajoitettu. Vuoden 1983 ulkomaalaislaki oli parantanut heidän oikeusturvaansa, mutta monet keskeiset toimintaoikeudet rajattiin kuitenkin yhä vain Suomen kansalaisille (Scheinin 1997). Valtioneuvoston jäsenten eli ministereiden tuli lisäksi olla syntyperäisiä Suomen kansalaisia.

\section{Vakaa kansalaisyhteiskunta}

Suomalainen monipuoluejärjestelmä oli 1980-luvun puolivälissä hyvin vakaa. Kaikkien pääpuolueiden eli kansandemokraattien, sosialidemokraattien, keskustapuolueen, kokoomuksen ja ruotsalaisen kansanpuolueen perusta oli jo edellisen vuosisadan vaihteen ristiriidoissa ja niiden ratkaisemista koskevissa ideologioissa. Aatteelliset profilitit olivat kuitenkin vuosikymmenten kuluessa hämärtyneet ja johtaneet ideologiseen hakeutumiseen poliittiseen keskustaan. Yksikään näistä puolueista ei enää tällöin esittänyt radikaaleja muutoksia yhteiskunnallisiin perusratkaisuihin.

Muista puolueista Suomen Maaseudun Puolue sai suurehkon vaalivoiton vuonna 1983. Puolue pääsi hallitukseenkin, mutta sen kannatus hupeni jo seuraavissa vaaleissa. Ympäristöaate teki tuloaan politiikkaan, kun luonnonsuojeluliike sai vuoden 1983 vaaleissa valitsijayhdistyksillä kaksi kansanedustajapaikkaa. Vuonna 1987 liike osallistui vaaleihin Vihreän liiton nimellä, ja se rekisteröitiin puolueeksi vuonna 1988. Arvokonser- 
vatiivinen Suomen Kristillinen Liitto oli vakiinnuttanut asemansa, mutta sen ääniosuus jäi suhteellisen vaatimattomaksi.

Sama konsensuaalinen ilmapiiri vallitsi myös muualla kansalaisyhteiskunnassa. 1960- ja 1970-luvulla oli syntynyt runsaasti niin sanottuja uusia yhteiskunnallisia liikkeitä, mutta hyvin harvat niistä esittivät enää 1980-luvulla radikaaleja muutoksia vallitsevalle yhteiskuntajärjestykselle. Poliittinen radikalismi oli Suomessa huomattavan vähäistä: maassa oli muutamia marginaalisia anarkistiryhmiä, vähäinen määrä vallankumouksellista äärivasemmistoa sekä joitain uuden äärioikeiston sirpaleita. (Ks. esim. Ilmonen ja Siisiäinen 1998; Pekonen 1999.)

Poliittinen järjestelmä ja sen toimintaperiaatteet nauttivat myös laajaa tukea kansalaisten keskuudessa. Jaakko Nousiaisen mukaan suomalainen poliittinen järjestelmä oli ajan mittaan kansanvaltaistunut myös yksilöiden arvojen ja asenteiden tasolla. Demokratia ja kansalaisten perusoikeudet oli yhä yleisemmin tunnustettu pysyviksi edistyksellisiksi saavutuksiksi, vaikka eri poliittisten ryhmien käsitykset ihannevaltiosta saattoivatkin erota toisistaan olennaisesti. Lisäksi orientoituminen auktoriteettirakenteisiin oli muuttunut. 1960-luvulta lähtien ihmiset olivat alkaneet nähdä itsensä "vähemmän alamaisina ja enemmän kansalaisina sekä valtion vähemmän esivaltana ja enemmän yhteiskunnallisena palvelulaitoksena” (Nousiainen 1985a, 24).

Nousiainen kuvaa tuon ajan Suomea myös intensiivisten kansallisten tunteiden leimaamaksi poliittiseksi yhteisöksi. Kansallisuusajatus oli tosin hänen mukaansa muuntunut "ekspressiivisestä isänmaallisuudesta välineellisemmäksi kansallisen solidaarisuuden ideologiaksi, joka korostaa yksimielisyyttä perustavissa kansallis-valtiollista olemassaoloa koskevissa kysymyksissä sekä edellyttää pluralistisella pohjalla kaikkien rakentavaa työtä yhteiskunnan kehittämiseksi ja maan kansainvälisen kilpailukyvyn ja poliittisen aseman vahvistamiseksi” (Nousiainen 1985a, 23; ks. myös 1983). Yksimielisyys olikin kahdeksankymmentäluvun puolivälissä varsin kattava. Vuonna 1984 tehdyn kyselyn perusteella vain kaksi prosenttia vastanneista toivoi muutosta Suomen poliittiseen tai taloudelliseen järjestelmään (Suhonen 1988, 48-49).

1980-luvun puolivälin Suomea voidaan siis hyvällä syyllä pitää yhteiskuntana ja poliittisena järjestelmänä, joka oli sisäisesti integroitunut, tasapainoinen ja vakaa niin rakenteiden, ideologioiden kuin toiminnankin 


\section{Pasi Saukkonen}

puolesta. Suomi ymmärrettiin arvomaailmaltaan pluralistiseksi, mutta kulttuurisesti pohjimmiltaan yhtenäiseksi ja suurissa asiakysymyksissä yksimieliseksi yhteiskunnaksi. Enemmistön mielivaltaa rajoittivat monet vähemmistösuojasäädökset. Tavallaan tuon ajan Suomea voi pitää täydellisenä kansallisvaltiona.

"Täydellisyys" ei tietenkään tarkoita sitä, etteikö maasta olisi löytynyt monenlaista arvostelun aihetta. Merkittävimpinä ongelma-alueina voidaan pitää tiettyä sulkeutuneisuutta kansainväliseltä vuorovaikutukselta sekä talouselämän voimakasta säätelyä ja keskittyneisyyttä sekä liikeelämän kietoutumista poliittiseen päätöksentekoon. Aikalaiskritiikkiä kohdistui myös byrokraattiseksi ja suunnitteluvaltaiseksi koettuun julkiseen sektoriin sekä kunnallisen itsehallinnon rajautumiseen lakisääteisten julkisten palvelujen tuottajaksi. Tasavallan presidentin rooli korostui etenkin Paasikiven ja Kekkosen presidenttikausilla, eikä Neuvostoliiton vaikutusta Suomen sisäpolitiikkaan ja julkiseen keskusteluun ole syytä kiistää. Lisäksi suomalaisen kansalaisuuskonseption sisään oli rakentunut varsin tarkasti rajattu ja etnis-kulttuurisesti määritelty ydinsuomalaisuus: vain osa suomalaisen yhteiskunnan jäsenistä katsottiin "aidoiksi suomalaisiksi”. (Ks. esim. Salminen 1991; Tiihonen ja Tiihonen 1990; Vihavainen 1991; Wuori 1995.)

\section{Suomi ja globalisaatio}

\section{Muuttuva maailma}

1900-luvun lopussa Suomi muuttui merkittävästi. Aikakautta voi pitää yhtenä Suomen rauhanajan historian mielenkiintoisimmista, ja sen analysoinnissa olisi tutkijoilla vielä paljon tehtävää. Osa muutoksista on sisäsyntyisiä, mutta monet niistä ovat lähtöisin maamme rajojen ulkopuolelta. Jotkut tapahtumat ja ratkaisut ovat historiallisen kehityksen kypsyttämiä pitkien prosessien päätepisteitä, toiset taas yllättäviin ongelmiin ja uusiin tilanteisiin liittyviä vastauksia ja keksintöjä.

Merkittävä yksittäinen tapahtumakokonaisuus oli epäilemättä Neuvostoliiton hajoaminen sekä laajemmin sosialistisen järjestelmän kaatuminen. Se muutti perinpohjaisesti Suomen kansainvälistä asemaa ja ul- 
kopolitiikan perustaa ja poisti suomalaisen sisäpolitiikan ulkopoliittiset reunaehdot. Muuttunut tilanne teki mahdolliseksi Suomen liittymisen samanaikaisesti voimakkaasti kehittyneisiin eurooppalaisiin ylikansallisiin järjestelmiin, ensin Euroopan neuvostoon (1989), sitten Euroopan talousalueeseen (1992) ja lopulta Euroopan unioniin (1995). Suomi kytkeytyi myös erilaisiin maailmanlaajuisia ongelmia ratkaisemaan pyrkiviin globaaleihin hallinta- ja ratkaisupyrkimyksiin. (Suomesta Euroopan unionissa ks. esim. Raunio ja Wiberg 2000.)

Neuvostoliiton romahtamisen vaikutusta oli myös se, että pitkälti poliittisiin sopimuksiin perustunut idänkauppa muuttui markkinatalouspohjaiseksi. Suomen taloudellinen kasvu tuli entistä riippuvammaksi kansainvälisistä markkinoista, jotka taloudellisen globalisaation merkeissä samalla laajenivat voimakkaasti. Suomalaiset yritykset alkoivat toimia näillä markkinoilla, mutta samanaikaisesti kansainvälinen pääoma ja talous tulivat Suomeen aikaisempaa paljon voimallisemmin. Informaatioteknologisen kehityksen kiihtyminen ja tiedon merkityksen kasvu tuotannontekijänä tekivät uuden teknologian tuotteiden valmistuksesta ja kaupasta merkittävän vientiteollisuuden haaran ja työllistäjän. (Globalisaatiosta ja Suomesta esim. Väyrynen 1999.)

Länsi-Euroopan taloudellisen kasvun hiipuminen 1990-luvun alussa, idänkaupan tyrehtyminen ja kotimaisen talouden sisäsyntyiset vaikeudet tuottivat yhdessä syvän taloudellisen laman ja työttömyyden jyrkän kasvun, joista selviämiseen valtio joutui ottamaan runsaasti ulkomaista velkaa. Julkisia menoja leikattiin voimakkaasti samaan aikaan kun laajemman uusliberalistisen ideologian mukaisesti valtion ja kuntien hallintoa supistettiin ja uudistettiin. (Ks. lamasta Kiander ja Vartia 1998; Kantola 2002.)

Neuvostoliiton järjestelmämuutos ja lopulta hajoaminen oli keskeinen tekijä myös Suomeen suuntautuneen maahanmuuton kasvussa. Inkeriläiset ja kansallisuudeltaan suomalaiset Venäjällä ja muualla entisen Neuvostoliiton alueella määriteltiin oleskelulupaan oikeutetuiksi paluumuuttajiksi. Venäjänsuomalaisia ja heidän perheenjäseniään on arvioitu siirtyneen Suomeen yli kolmekymmentätuhatta henkilöä (Miettinen 2006). Venäjältä ja Virosta on suuntautunut Suomeen paljon myös muuta muuttoliikettä. Lisäksi turvapaikanhakijoiden määrät Euroopassa kasvoivat voimakkaasti 1980-luvulla, millä oli heijastusvaikutuksensa myös 


\section{Pasi Saukkonen}

Suomeen. Ulkomaan kansalaisten määrä kasvoi nopeasti, vuoden 1987 alle 20 000:sta vuoden 1998 noin 85 000:een. Vuonna 2009 ulkomaan kansalaisia oli jo yli 150000 ja ulkomailla syntyneitä yli 230000 (Tilastokeskus 2011).

\section{Muutokset Suomessa}

Merkittävin muutos Suomen poliittisessa järjestelmässä on ollut siirtyminen semi-presidentialismista normaaliin parlamentaristiseen malliin Mauno Koiviston presidenttikaudella (1982-1994). Siirtymä sinetöitiin valtiosäännön osittaisuudistuksissa sekä lopullisesti uudessa perustuslaissa, joka tuli voimaan keväällä 2000. Kyseisen perustuslainuudistuksen ensisijaisia tavoitteita olivat valtiosäännön kodifikaatio yhdeksi perustuslaiksi sekä normirakenteen yhtenäistäminen ja ajanmukaistaminen. Siihen sisältyi kuitenkin myös vallanjaon tarkistaminen keskeisten valtioelinten osalta, ja tasavallan presidentin asema heikkeni lopulta varsin merkittävästi (Anckar 2000).

Uuteen perustuslakiin sisällytettiin myös jo vuonna 1995 tehdyn perusoikeusuudistuksen tulokset eli kansalaisten perusoikeuksien ulottaminen klassisten vapausoikeuksien lisäksi taloudellisiin ja sosiaalisiin kysymyksiin. Perusoikeuksien soveltaminen laajennettiin myös koskemaan Suomen kansalaisten lisäksi kaikkia maamme oikeusjärjestelmän piirissä olevia ihmisiä. Muutenkin ulkomaalaisten asemaan Suomessa tehtiin joitain parannuksia. Tältä osin tasa-arvoa ja yhdenvertaisuutta korostavien superideologioiden voi sanoa olleen voimissaan vielä vuosituhannen viimeisten vuosien aikana.

Toisaalta muualla poliittisessa toiminnassa on jo nähtävissä, että taloudellista ja sosiaalista eriarvoisuutta ja niiden lisääntymistä alettiin sietää entistä paremmin. Talouskasvun ja kilpailukyvyn ideologisen merkityksen voi puolestaan todeta vahvistuneen entisestään. Pyrkimys talouskasvun ylläpitämiseen ja vahvistamiseen on muodostunut eräänlaiseksi “metasuperideologiaksi”, jonka kanssa muut poliittiset tavoitteet eivät saa olla ristiriidassa.

Pyrkimystä suotuisan taloudellisen kehityksen edellytysten varmistamiseen voidaan pitää turvallisuus- ja identiteettipoliittisten perustelujen 
ohella keskeisenä argumenttina 1990-luvun uuden superideologian eli ytimiin pyrkivän suomalaisen integraatiopolitiikan taustalla. Kun Suomi haki Euroopan unionin jäsenyyttä, luopumista täydestä kansallisesta itsemääräämisoikeudesta perusteltiin sillä, että Suomi pääsisi osallistumaan päätöksentekoon, jolla joka tapauksessa olisi vaikutuksensa suomalaiseen yhteiskuntaan ja sen toimintaedellytyksiin. Tanskasta ja Ruotsista poiketen Suomi liittyi myös Euroopan talous- ja rahaliiton kolmanteen vaiheeseen eli euroalueeseen heti sen perustamisen yhteydessä (v. 1999).

Myös käsitys valtion roolista ja julkisen sektorin rakenteesta ja tehtävistä on muuttunut suhteellisen johdonmukaisesti. Vaikka Suomessa on ollut 1980-luvun puolivälin jälkeen toisistaan selvästi poikkeavia hallituskoalitioita, linja on tältä osin ollut suhteellisen johdonmukainen ja noudattanut niin sanotun uuden julkishallinnon (New Public Management) periaatteita. Keskeistä siinä on ajatus, että julkisia ja yksityisiä organisaatioita tulisi johtaa ja hallinnoida samojen periaatteiden mukaisesti ja samalla tavalla tuloksellisuutta, tehokkuutta ja vaikuttavuutta korostaen. (Ks. esim. Kiviniemi ja Temmes 1997.)

Yhtenäisvaltiomallista on siirrytty eriytyneeseen hallintomalliin niin sanotun hallinta- tai governance-ajattelun mukaisesti. Yhteiskunnan sosiaalisen ja taloudellisen kehityksen keskitetyn ohjaamisen ja johtamisen sijasta alettiin korostaa valtion vastuuta ylläpitää talouden ja yhteiskunnan toimintajärjestelmiä yhteistoiminnassa markkinoiden ja kansalaisyhteiskunnan kanssa. Valtion sisäisissä toiminnoissa on puolestaan alettu hyödyntää erilaisia arvoja ja toimintalogiikkoja: hallinnollisia valtion ydintehtävien hoitamisessa; taloudellisia valtion markkinaehtoisten tehtävien hoitamisessa sekä palvelutoiminnan arvoja ja toimintalogiikkoja valtion palvelutehtävien hoitamisessa. (Tiihonen 2000.)

Sosiaalisten oikeuksien saamasta perustuslaillisesta statuksesta huolimatta suhtautuminen hyvinvointitehtävien laajentamiseen ja kehittämiseen on myös muuttunut, mikä näkyy esimerkiksi terminologisena muutoksena hyvinvointivaltiosta hyvinvointiyhteiskuntaan. Yksilöistä huolenpitämisen ja heidän elämänkaariensa ohjaamisen sijaan alettiin korostaa yksilöiden mahdollisuuksia ja myös heidän velvollisuuttaan oman elämänsä hallintaan ja aktiiviseen osallistumiseen. (Ks. esim. Julkunen 2006.) Aluepolitiikassa pyrkimys omaehtoiseen kehittymiseen ja 


\section{Pasi Saukkonen}

kasvupotentiaalia omaaviin alueisiin panostamiseen on syrjäyttänyt yleisen tasaisen kehityksen ideaalin.

Lisäksi voidaan havaita kulttuurisen erilaisuuden laajempaa hyväksymistä ja tältä osin irtautumista yhtenäiskulttuuria korostavasta kansallisvaltiomallista. Vuoden 1995 uudistuksissa tunnustettiin myös saamelaisten asema alkuperäiskansana sekä romanien ja muiden ryhmien oikeudet ylläpitää ja kehittää omaa kieltään ja kulttuuriaan. Vuonna 1999 säädetyssä kotouttamislaissa oman kielen ja kulttuurin säilyttäminen määriteltiin maahanmuuttajien oikeudeksi. Työvoiman maahanmuuttoon alettiin uuden taloudellisen nousukauden aikana jälleen suhtautua myönteisemmin. Matti Vanhasen ensimmäisen hallituksen (2003-2007) ohjelmaan sisältyi ensimmäisen kerran maininta työperusteisen maahanmuuton edistämisestä.

Ehkä kaikkein näkyvimmin 1990-luvulla muuttui julkisesti ilmaistu käsitys Suomesta ja suomalaisuudesta eli kansallinen identiteetti. Jo EUjäsenyyden yhteydessä alettiin puhua "paluusta Eurooppaan" ja korostaa Suomea länsimaihin yhdistäviä tekijöitä. Yhteiskunnan eurooppalaisuus ja nykyaikaisuus syrjäyttivät aikaisemmin vahvasti esillä ollutta perinteistä kansallista kulttuuria. Yhtenäisyyspuheeseen otettiin etäisyyttä ja monikulttuurisuus tunnustettiin osaksi suomalaisuutta. Erään teoksen esipuheen mukaan: "kansallinen omakuva rakentuu tänään monivivahteisemmasta aineksesta. Kulttuurit kohtaavat kaupungeissa ja monietnisyys johtaa identiteetin sirpaloitumiseen. Myytit ja kollektiiviset kipupisteet kohtaavat." (Löytönen ja Kolbe 1999, 8.)

\section{Uusia jännitteitä}

Suomi on siis muuttunut, mutta suomalainen puoluepolitiikka ja kansalaisyhteiskunta ylipäätään olivat pitkään varsin vakaita. Suurimpien puolueiden kannatusvaihtelut vuosien 1991 ja 2007 välisissä vaaleissa olivat melko pieniä. Tappio vaaleissa korvaantui usein voitolla seuraavalla kerralla ja päinvastoin. Hallituksessa olevilla puolueilla ja erityisesti niin sanotulla pääministeripuolueella on ollut suuri riski hävitä seuraavissa vaaleissa, suurimmalla oppositiopuolueella puolestaan hyvä mahdollisuus voittaa. Mainitulle ajanjaksolle mahtuvat suurimpien puolueiden osalta 
kaikki mahdolliset koalitiovaihtoehdot. Eduskunnassa edustetuista puolueista kaikki muut ovat osallistuneet hallitustoimintaan, paitsi SMP:n perinnönjatkajaksi vuonna 1995 perustettu Perussuomalaiset.

Uudemmista puolueista Vihreät onnistui vakiinnuttamaan asemansa isoimmissa kaupungeissa jopa suurehkona puolueena sekä osallistumaan useisiin hallituksiin vuodesta 1995 lähtien. Kristillisdemokraattien (entinen Suomen Kristillinen Liitto) ja Vasemmistoliiton, samoin kuin ruotsalaisen kansanpuolueen vaalikannatuksen muutokset olivat hyvin vähäisiä. Liberaalia talouspolitiikkaa ja humaania sosiaalipolitiikkaa julistanut Nuorsuomalaiset onnistui saamaan kansanedustajia ainoastaan vuoden 1995 valtiopäiville. Perussuomalaisten kannatus jäi pitkään alle kahden prosentin.

Osa yhteiskunnan uusista jännitteistä sijoittuu puolueiden sisälle. Vasemmisto-oikeisto-akselin rinnalle tulleet muut poliittiset ulottuvuudet kuten kansallinen-kansainvälinen ja arvokonservatismi-arvoliberalismi sekoittivat puolueiden välisiä yhteistyö- ja kilpailukuvioita ja kasvattivat puolueiden sisäisiä linjaerimielisyyksiä. (Ks. esim. Paloheimo ja Wiberg 1997, 304.) Saman puolueen sisällä saattoi olla jyrkkiä näkemyseroja esimerkiksi tärkeistä ulko- ja turvallisuuspoliittisista ratkaisuista, suomalaisen pääoman avaamisesta ulkomaisille sijoittajille tai ulkomaalais- ja pakolaispolitiikasta.

Muutosta tapahtui myös puoluejärjestelmän pinnan alla. Jaakko Nousiainen esitti jo vuonna 1985 tulkinnan, jonka mukaan yhteiskunnallisten eliittien parissa vahvistunut pyrkimys rakentaa konsensuksen, yhteistyön ja kompromissien siltaa oli johtanut eliitin ja massan irtaantumiseen, politiikan muuttumiseen hahmottomaksi ja päätöksenteon loitontumiseen kansalaisista (Nousiainen 1985a, 28). Äänestysaktiivisuus laskikin vuosien 1983 ja 1999 eduskuntavaalien välillä miltei kolmetoista prosenttiyksikköä, ja vuoden 2000 kunnallisvaaleissa äänestysprosentti oli vain hiukan alle 56 prosenttia. Useimpien puolueiden jäsenmäärät olivat pienentyneet dramaattisesti (Sundberg 1996).

Tutkijoiden mukaan tämä kertoi siitä, että osa suomalaisista oli jäänyt kokonaan sosiaalistumatta poliittiseen järjestelmään tai ainakin heidän suhtautumisensa oli muuttunut pysyvästi (Borg 1997, 34; Martikainen ja Wass 2001; Pekonen 1997). Kehitystä leimasikin heikentynyt usko poliittisiin vaikutusmahdollisuuksiin sekä lisääntynyt politiikan ja po- 


\section{Pasi Saukkonen}

liitikkojen arvostelu. Elinkeinoelämän valtuuskunnan vuosituhannen vaihteessa toteuttamassa tutkimuksessa 73 prosenttia vastaajista koki voimakkaan ristiriidan poliitikkojen ja kansan välillä. Puolueita pidettiin tavallisen ihmisen arjesta ja ongelmista vieraantuneina. Yli puolet suomalaisista osoitti jonkinasteista vahvan johtajan kaipuuta, joskin vain pieni vähemmistö suhtautui myönteisesti uusoikeistolaisiin tai äärikansallisiin liikkeisiin. Myös rikkaiden ja köyhien, kasvukeskusten ja syrjäseutujen sekä hyvin koulutettujen ja huonosti koulutettujen väliset ristiriidat koettiin voimakkaina, ja selvä enemmistö vastaajista katsoi ristiriitojen voimistuvan edelleen tulevaisuudessa. (EVA 2001.)

Newsweek-lehti arvioi syksyllä 2010 Suomen maailman parhaaksi maaksi koulutus- ja terveyspalvelujen, elämänlaadun, talouden vireyden ja poliittisten olojen perusteella. Samoihin aikoihin kuitenkin enää 36 prosenttia suomalaisista oli samaa mieltä väitteestä: "On onni ja etuoikeus saada olla suomalainen". Syksyllä 1984 sama väitelause oli saanut täyden kannatuksen miltei kolmelta suomalaiselta neljästä. (Haavisto ja Kiljunen 2011,71.)

Kun kirjoitin tämän artikkelin edellistä versiota (Saukkonen 2003), tein sen päätelmän, että yhteiskunnan muutos oli tuottanut Suomeen jännitteen, joka ei ollut toistaiseksi purkautunut. Yhteiskunta oli muuttunut merkittävästi ja politiikassa oli siirrytty sietämään paremmin eriarvoisuutta ja hyväksymään enemmän erilaisuutta. Läheskään kaikki suomalaiset eivät kuitenkaan pitäneet valittua suuntausta hyvänä tai hyväksyneet uutta, entistä dynaamisempaa ja pluralistisempaa käsitystä suomalaisuudesta. Kansalaisyhteiskunnassa saattoi siten ajatella olevan tilaa ja tilausta erilaisille poliittisen tyytymättömyyden muodoille.

Esitin tuolloin, että poliittisen protestin purkautumismuodot voisivat olla kolmenlaisia. Ensinnäkin, ne voisivat olla "populistisia” reaktiona erityisesti kansallisen suvereenisuuden rapautumiseen ja poliittisen eliitin ja kansan välillä koettuun kuiluun ja luottamuksen puutteeseen. Toiseksi ne saattaisivat olla "vasemmistolaisia" vastauksia taloudellisen ja sosiaalisen eriarvoisuuden lisääntymiseen ja puolueiden kyvyttömyyteen ratkaista näitä ongelmia. Lisäksi protesti voisi olla luonteeltaan "nationalistinen", jolloin se olisi ennen muuta reaktio mahanmuuttoon ja kulttuurisen monimuotoisuuden lisääntymiseen sekä perinteisen suomalaisen identi- 
teetin heikkenemiseen ja korvautumiseen uudenlaisella kansallisella itsekäsityksellä.

Perussuomalaisten poliittinen kannatus lähti ensimmäisen kerran kasvuun keväällä 2007. Tuolloin pidetyissä eduskuntavaaleissa puolue sai neljä prosenttia äänistä. Pitkäkestoisempi kasvukausi alkoi syksyllä 2008, ja se voimistui edelleen maalis-huhtikuussa 2010. Puolueen vaalivoitto kevään 2011 eduskuntavaaleissa, Timo Soinin sanoin "Iso Jytky", kuuluu Suomen poliittisen historian merkittävimpiin. Perussuomalaiset kasvattivat 19 prosentin kannatuksella eduskuntaryhmäänsä viidestä lähes neljäänkymmeneen (39).

Puolueen yleisohjelman sekä vuoden 2011 vaaliohjelman ja -kampanjan perusteella perussuomalaiset onnistui tyhjentämään kaikki edellä mainitut poliittiset pajatsot. Puolue arvosteli voimakkaasti niin kotimaista poliittista eliittiä kuin Euroopan unioniakin. Sen ohjelmat ovat talous- ja sosiaalipoliittisessa mielessä ennemmin vasemmistolaisia kuin oikeistolaisia. Vuoden 2011 ohjelma on myös edeltäjiään selvästi kansallismielisempi, ja siihen integroitiin nationalistisissa liikkeissä vaikuttaneiden ehdokkaiden julkaisema maahanmuuttokriittinen niin sanottu nuiva vaalimanifesti miltei kokonaisuudessaan.

\section{Lopuksi}

Tässä artikkelissa on esitelty ja analysoitu suomalaista poliittista historiaa ja poliittisen kulttuurin kehitystä. Kahdensadan vuoden aikana Suomen yhteiskunnallisessa elämässä on ollut merkittäviä käännekohtia ja murroskausia, jolloin poliittiset pelisäännöt tai valtiolliset instituutiot ovat muuttuneet jopa varsin dramaattisesti. Toisaalta suomalaista poliittista historiaa leimaa vahva jatkuvuus. Täydellisiä järjestelmän- tai suunnanmuutoksia ei ole tapahtunut koskaan. Poliittinen ja yhteiskunnallinen kehitys on pohjimmiltaan ollut tasaista ja muutokset asteittaisia.

Katkoksen ja jatkuvuuden ohella huomio on tässä yhteydessä kiinnitetty suomalaisen yhteiskunnan jännitteisiin ja niiden purkautumiseen sekä poliittisiin ristiriitoihin ja niiden ratkaisemiseen. Vuoden 1918 sisällissota nostetaan usein esille Suomen historiasta puhuttaessa. Sen traagiseen varjoon jää helposti se seikka, että suomalaisen yhteiskunnan poliittiset 


\section{Pasi Saukkonen}

toimijat ovat miltei aina onnistuneet ratkaisemaan vaikeat konfliktinsa ilman väkivaltaa tai päätöksentekojärjestelmän halvaantumista.

Suomi ei ole koskaan ollut täysin yhtenäinen tai tasa-arvoinen kansakunta. Sekä kansalaisten että poliittisen eliitin keskuudessa on kuitenkin vallinnut varsin kattava yksimielisyys suurista kysymyksistä sekä valmius tehdä myönnytyksiä ja rakentaa kompromisseja. Tämä on tehnyt suomalaisesta politiikasta tietyssä mielessä vaihtoehdotonta, ehkä mielenkiinnotontakin. Kansallisen tradition kiistattomia etuja yhteiskuntarauhan säilyttämisessä ja laajojen poliittisten tavoitteiden saavuttamisessa ei kuitenkaan kannata kiistää. Tämä traditio voi oikein sovellettuna auttaa suomalaista yhteiskuntaa menestymään myös tulevaisuuden ristiriita- ja konfliktitilanteissa.

Kahdeksankymmentäluvun puolivälin Suomea voi hieman liioitellen kutsua täydelliseksi demokraattiseksi kansallisvaltioksi, joka oli onnistunut ratkaisemaan suurimmat poliittiset, taloudelliset ja kulttuuriset peruskysymyksensä ja saavuttamaan niille laajojen kansanpiirien hyväksynnän. Edustuksellinen demokratia, kunnallinen itsehallinto, kapitalistinen tuotantojärjestelmä, pohjoismainen hyvinvointivaltio sekä suomen kieleen ja Suomen historiaan nojaava kansallinen identiteetti yhdistettynä merkittävimpien vähemmistöjen tunnustamiseen muodostivat tuon ajan poliittis-yhteiskunnallisen perustan.

Suomi on kuitenkin muuttunut merkittävästi 1990-luvun lopulla ja 2000-luvun ensimmäisellä vuosikymmenellä osin kansainvälisten, osin kotimaisten seikkojen ja kehitysten johdosta. Kansallinen suvereenisuus alkoi rapautua, taloudellinen ja sosiaalinen eriarvoisuus kasvaa ja etninen ja kulttuurinen monimuotoisuus lisääntyä. Politiikassa alueellisia sekä hyvinvointi- ja elintasoeroja alettiin sietää aikaisempaa paremmin, monikulttuurisuuteen alettiin suhtautua avoimen myönteisesti.

Kansanvaltainen ja puoluepoliittinen elämä sekä vapaa kansalaistoiminta säilyivät kuitenkin varsin pitkään entisellään. Puoluelaitoksessa ei tapahtunut juuri muutoksia ja kannatusvaihtelut olivat varsin pieniä. Vaikka hallituskoalitiot vaihtelivat, politiikan suuret linjat eivät muuttuneet. Taloudellisen kasvun edistämisen ja kilpailukyvyn säilyttämisen tavoitteet sekä Eurooppa-politiikan perusperiaatteet jaettiin laajalti poliittisen eliitin keskuudessa. Kansalaisten tyytymättömyys näkyi poliittisena 
passivoitumisena sekä varsinkin vuosituhannen taitteen jälkeen internetin keskustelupalstojen kriittisinä puheenvuoroina.

Suomalaiseen yhteiskuntaan kasvoi siis uusia jännitteitä ja samalla tilausta uusille poliittisille liikkeille. Tähän huutoon perussuomalaiset ovat viime vuosina onnistuneet vastaamaan mobilisoimalla erilaisia tyytymättömyyden muotoja omaksi kannatuksekseen. Vuoden 2011 vaalivoitosta huolimatta puolue jäi oppositioon, ja nähtäväksi jää, millä tavalla suomalainen politiikka vastaa perussuomalaisten haasteeseen ja kuinka hyvin puolue onnistuu säilyttämään kannatuksensa ja sisäisen yhtenäisyytensä.

Perussuomalaisten tulevaa kehitystä Suomen poliittisessa järjestelmässä on hyvä seurata tässä artikkelissa esitettyä suomalaisen politiikan pitkää linjaa vasten. Noudatetaanko vanhoja periaatteita ja toimintatapoja vai tehdäänkö jotain uutta, aikaisemmasta poikkeavaa? On myös helppo ennakoida, että uusien vähemmistöryhmien synty maahanmuuton seurauksena tulee tuottamaan Suomelle lähitulevaisuudessa muitakin poliittisia haasteita kuin ksenofobisen uusnationalismin. Perinpohjainen keskustelu uusien kieli- ja kulttuuriryhmien asemasta sekä yhteiskunnan uusien jäsenten poliittisesta integroitumisesta on vielä pitkälle käymättä. 


\section{Pasi Saukkonen}

\section{Lähteet}

Alapuro, Risto. 1997. Suomen älymystö Venäjän varjossa. Helsinki: Tammi.

Alapuro, Risto. 1999. Kertomus suomalaisista idän ja lännen välissä. Teoksessa Markku Löytönen ja Laura Kolbe (toim.), Suomi - maa, kansa, kulttuurit. Helsinki: SKS, 98-112.

Alapuro, Risto, Liikanen, Ilkka, Smeds, Kerstin ja Stenius, Henrik (toim.). 1987. Kansa liikkeessä. Helsinki: Kirjayhtymä.

Alasuutari, Pertti. 1996. Toinen tasavalta. Suomi 1946-1994. Tampere: Vastapaino.

Anckar, Dag. 2000. Jäähyväiset semipresidentialismille. Politiikka 42:1, s. 9-14.

Anttila, Jorma. 2007. Kansallinen identiteetti ja suomalaiseksi samastuminen. Helsinki: Helsingin yliopiston sosiaalipsykologian laitos.

Borg, Olavi. 1965. Suomen puolueet ja puolueohjelmat. Porvoo: WSOY.

Borg, Sami. 1997. Kansalaisten suhde politiikkaan murroksessa. Teoksessa Pertti Suhonen (toim.), Yleinen mielipide 1997. Helsinki: Tammi, 99-118.

EVA. 2001. Erilaisuuksien Suomi. Raportti suomalaisten asenteista 2001. Helsinki: Elinkeinoelämän valtuuskunta EVA.

Grönlund, Kimmo (toim.). 2011. Språk och politisk mobilisering. Finlandssvenskar i publikdemokrati. Helsingfors: Svenska Litteratursällskapet i Finland.

Haavisto, Ilkka ja Kiljunen, Pentti. 2011. Maailman paras maa. EVAn kansallinen arvo- ja asennetutkimus 2011. Helsinki: Elinkeinoelämän valtuuskunta EVA.

Heiskanen, Ilkka. 1977. Julkinen, kollektiivinen ja markkinaperusteinen. Suomalaisen yhteiskunnan hallintajärjestelmien ja julkisen päätöksenteon ja hallinnon kehitys ja kehittäminen 1960-ja 1970-luvuilla. Helsinki: Helsingin yliopiston yleisen valtio-opin laitos.

Heiskanen, Ilkka. 1982. Yhteiskuntatieteet, käytännön ybteiskuntateoria ja maamme älyllinen ilmasto. Helsinki: Helsingin yliopiston yleisen valtioopin laitos.

Ilmonen, Kaj ja Siisiäinen, Martti (toim.). 1998. Uudet ja vanhat liikkeet. Tampere: Vastapaino.

Jansson, Jan-Magnus. 1993. Hajaannuksesta yhteistoimintaan. Suomalaisen parlamentarismin vaiheita. Helsinki: Gaudeamus.

Julkunen, Raija. 2006. Kuka vastaa? Hyvinvointivaltion rajat ja julkinen vastuu. Helsinki: Sosiaali- ja terveysalan tutkimus- ja kehittämiskeskus. 
Jussila, Osmo, Hentilä, Seppo ja Nevakivi, Jukka. 2009. Suomen poliittinen historia 1809-2003 Helsinki: WSOY.

Kantola, Anu. 2002. Markkinakuri ja managerivalta. Poliittinen hallinta Suomen 1990-luvun talouskriisissä. Helsinki: PALLAS.

Kiander, Jaakko ja Vartia, Pentti. 1998. Suuri lama. Suomen 1990-luvun kriisi ja talouspoliittinen keskustelu. Helsinki: ETLA.

Kiviniemi, Markku ja Temmes, Markku. 1997. Suomen hallinnon muuttuminen. Helsinki: Valtiovarainministeriö ja Helsingin yliopiston yleisen valtioopin laitos.

Löytönen, Markku ja Kolbe, Laura (toim.). 1999. Suomi - maa, kansa, kulttuurit. Helsinki: SKS.

Martikainen, Tuomo ja Wass, Hanna. 2001. Vaienneet ä̈̈net. Äänestäminen vuosien 1987 ja 1999 eduskuntavaaleissa. Helsinki: Tilastokeskus.

McRae, Kenneth D. 1999. Conflict and Compromise in Multilingual Societies. Finland. Helsinki: The Finnish Academy of Science and Letters.

Miettinen, Helena. 2006. Peilistä näkyy muuttunut kuva: ajatuksia ja havaintoja 2000-luvun inkeriläisyydestä. Teoksessa Tuomas Martikainen (toim.), Ylirajainen kulttuuri: etnisyys Suomessa 2000-luvulla. Helsinki: SKS, 144167.

Nousiainen, Jaakko. 1983. Suomen poliittinen kulttuuri. Politiikka: 25: 1, 6-15.

Nousiainen, Jaakko. 1985a. Suomen poliittinen järjestelmä. Helsinki: WSOY.

Nousiainen, Jaakko. 1985b. Suomen presidentit valtiollisina jobtajina K. J. Ståhlbergista Mauno Koivistoon. Porvoo: Werner Söderström.

Nousiainen, Jaakko. 1998. Suomen poliittinen järjestelmä. Helsinki: WSOY.

Nousiainen, Jaakko. 2000. Suomalaisen parlamentarismin kolmas kehitysvaihe: konsensuaalinen enemmistöhallinta, vireytyvä eduskunta. Politiikka 42: 2, 83-96.

Paloheimo, Heikki ja Wiberg, Matti. 1997. Politiikan perusteet. Helsinki: WSOY.

Pekonen, Kyösti. 1997. Puoluevastainen mieliala Suomessa. Politiikka 39: 1, 14-29.

Pekonen, Kyösti (toim.). 1999. The New Radical Right in Finland. Helsinki: The Finnish Political Science Association.

Rantala, Onni.1982. Suomen puolueiden muuttuminen 1945-1980. Helsinki: Gaudeamus. 


\section{Pasi Saukkonen}

Raunio, Tapio ja Wiberg, Matti (toim.). 2000. EU ja Suomi. Unionijäsenyyden vaikutukset suomalaiseen yhteiskuntaan. Helsinki: Edita.

Salminen, Esko. 1996. Vaikeneva valtiomahti? Neuvostoliitto/Venäjä Suomen lehdistössä 1968-1991. Helsinki: Edita.

Saukkonen, Pasi. 1999. Kansallisvaltion identiteettipolitiikka. Tutkimus kansallisen identiteetin poliittisuudesta. Empiirinen sovellutus suomalaisiin ja hollantilaisiin teksteihin. Helsinki: SKS.

Saukkonen, Pasi. 2003. Suomalaisen yhteiskunnan historia, rakenne ja poliittinen kulttuuri. Teoksessa Pasi Saukkonen (toim.), Paikkana politiikka. Tietoja ja tulkintoja Suomen poliittisesta järjestelmästä. Helsinki: Helsingin yliopiston yleisen valtio-opin laitos, 9-42.

Scheinin, Martin. 1997. Kansalaisoikeudet, ihmisoikeudet ja oikeustiede. Teoksessa Timo A. Järvinen ja Antti Kortelainen (toim.), Muukalaiset. Juridiikasta ja asenteista kansojen kohdatessa. Helsinki: Edita, 31-36.

Selovuori, Jorma (toim.). 1999. Valta ja byrokratia Suomessa 1809-1998. Helsinki: Edita ja Valtioneuvoston kanslia.

Siisiäinen, Martti: Uusien ja vanhojen liikkeiden keinovalikoima. Teoksessa Ilmonen, Kaj ja Siisiäinen, Martti (toim.): Uudet ja vanhat liikkeet. Vastapaino 1998, Tampere, 219-244.

Smolander, Jyrki. 2000. Suomalainen oikeisto ja "kansankoti”. Kansallisen Kokoomuksen subtautuminen pohjoismaiseen hyvinvointivaltiomalliin jälleenrakennuskaudelta konsensusajan alkuun. Helsinki: SKS.

Stenius, Henrik. Ei vuosilukua. Folkrörelserna skapade olikartade politiska kulturer. Käsikirjoitus.

Stenius, Henrik. 2003. Kansalainen. Teoksessa Matti Hyvärinen, Jussi Kurunmäki, Kari Palonen, Tuija Pulkkinen ja Henrik Stenius (toim.), Käsitteet liikkeessä. Suomen poliittisen kulttuurin käsitehistoria. Tampere: Vastapaino, 309-362.

Suhonen, Pertti. 1988. Suomalaisten arvot ja politiikka. Helsinki: WSOY.

Sundberg, Jan. 1996. Partier och partisystem i Finland. Helsingfors: Schildts.

Tiihonen, Paula ja Tiihonen, Seppo. 1990. Keskitetyn suunnittelun nousu ja tuho. Jä̈hyväiset alistavalle, pysähtyneisyyden ajan suunnittelulle. Helsinki: Valtion painatuskeskus.

Tiihonen, Seppo. 1999. Suomalaisen hallitsemismallin juuret ja kehitys. Teoksessa Jorma Selovuori (toim.), Valta ja byrokratia Suomessa 1809-1998. Helsinki: Edita ja Valtioneuvoston Kanslia, 9-22. 
Tiihonen, Seppo. 2000. From uniform administration to governance and management of diversity: reforming state functions and public administration in Finland. Helsinki: Ministry of Finance, Public Management Dept.

Tilastokeskus. 2011. Ulkomaalaiset ja siirtolaisuus 2009. Helsinki: Tilastokeskus.

Tommila, Päiviö (toim.). 1989. Herää Suomi. Suomalaisuusliikkeen historia. Kuopio: Kustannuskiila.

Valkonen, Tapani, Alapuro, Risto, Alestalo, Matti, Jallinoja, Riitta ja Sandlund, Tom. 1980. Suomalaiset. Yhteiskunnan rakenne teollistumisen aikana. Helsinki: WSOY.

Vihavainen, Timo. 1991. Kansakunta rähmällä̈n. Suomettumisen lyhyt historia. Helsinki: Otava.

Virtanen, Matti. 1998. Mitä suomalaisuus on? Teoksessa Olli Alho, Aimo Raunio ja Matti Virtanen (toim.), Ihminen ja kulttuuri: suomalainen kansainvälistyvässä maailmassa. Helsinki: Vientikoulutussäätiö, 9-40.

Väyrynen, Raimo. 1999. Globalisaatio ja Suomen politttinen järjestelmä. Helsinki: Taloustieto.

Wuori, Matti. 1995. Faustin uni. Helsinki: WSOY. 



\section{Kansalaisyhteiskunnan ja Suomen ideat, liikkeet ja julkisuudet ennen vuotta 1917}

Kansalaisyhteiskunnan ja kansakunnan ideat kiteytyivät Suomessa ajanjaksona, joka ulottui 1800-luvun jälkipuolelta itsenäistymisvaiheeseen. Kiteytymisen perustana oli uudenlaisten julkisuuksien ja kansalaisia kokovien joukkoliikkeiden muodostuminen.

Käsittelen seuraavassa tätä ideoiden, liikkeiden ja julkisuuksien kehitystä kohdistamalla katseen erityisesti suomalaisuusliikkeeseen eli fennomaniaan sekä sosiaalidemokraattiseen työväenliikkeeseen. Näillä kahdella liikkeellä oli kansalaisyhteiskunnan ja kansakunnan rakentamisessa avainrooli. Pohdin liikkeiden vaikutusta, keskinäistä suhdetta ja sitä, missä määrin työväenliikettä voi pitää fennomaanisen liikkeen jatkeena.

Fennomanian ja työväenliikkeen välityksellä voi tehdä ymmärrettäväksi myös laajemmin suomalaisen järjestökentän muodostumista 1800-luvun lopulla ja 1900-luvun alussa. Avainliikkeiden kautta hahmottuu selvästi se, miten agraarinen sisältö kansalaisyhteiskunnan ja kansakunnan ideoilla Suomessa oli. Kattavaa kokonaiskuvaa kansanliikkeistä ei lyhyeen esitykseen toki mahdu, joten esimerkiksi uskonnolliset liikkeet ja liikehdinnän alueelliset erot jäävät pääosin huomiotta.

Tarkastelun yhtenä lähtökohtana on ajatus siitä, että vetoaminen kansaan ja kansan tahtoon muodosti alusta pitäen suomalaisen poliittisen retoriikan pohjavirran. Kansaan viittaminen iskostui suomalaisen politiikan kieleen 1800-luvun fennomaanien kirjoituksissa, minkä jälkeen liki- 


\section{Sami Suodenjoki}

pitäen kaikki puolueet ovat julistautuneet kansan äänen kannattelijoiksi, monet nimeään myöten. Kansa-käsite on myös hiipinyt osaksi poliittista ydinkäsitteistöä, hyvinä esimerkkeinä termit kansakunta ja kansanvalta. (Liikanen 2003, 257-258.) Kansaan vetoamista eli kansapuhetta on tutkimuksessa kuvattu jatkuvaksi prosessiksi, johon osallistuvat eri toimijat eri paikoissa ja eri aikoina. Esimerkiksi modernin politiikan murtautuessa Suomeen 1800-1900-lukujen taitteessa julkisuudessa käytiin vilkasta keskustelua siitä, mitä kansalla pitäisi tarkoittaa, sillä aikalaiset tiedostivat kansan määrittelytavan vaikuttavan suomalaisen yhteiskunnan kehityssuuntaan. (Anttila ym. 2009, 19-21.) Tähän keskusteluun tuli näkyvästi mukaan työväenliike, jonka tulkinnat kansasta ja kansanvallasta on kiinnostavaa rinnastaa fennomaaniseen kansapuheeseen.

\section{Kansallisuusliikkeen muodostuminen Suomessa}

Useimmissa Euroopan maissa kansallisuusliike ja köyhien kansanluokkien protesti nivoutuivat enemmän tai vähemmän yhteen 1800-luvulla ja 1900-luvun alussa. Risto Alapuro ja Henrik Stenius (1987, 9-11) toteavat, että monissa emävaltioiden alaisissa kansallisissa yksiköissä eli kansallisvaltioiden iduissa paikalliset poliittiset instituutiot olivat heikkoja ja niitä hallitsi emävaltioon sidoksissa oleva yläluokka. Tällaisilla alueilla oli tyypillistä, että kansallinen liike ja luokkaprotesti sulautuivat yhteen. Esimerkiksi Venäjän Baltian makunnissa poliittisia instituutioita hallitsi harvalukuinen saksalainen yläluokka, joka oli vasallisuhteessa keisarihallintoon. Niinpä Baltiassa kansallinen liike suuntautui vahvasti saksalaista eliittiä vastaan ja sai samalla luokkaprotestin muodon.

Eräissä kansallisissa yksiköissä paikalliset poliittiset rakenteet olivat sitä vastoin vahvoja, eivätkä niitä hallinneet ryhmät olleet tiukasti sidoksissa emävaltioon. Tällöin kansallinen liike ei lähtökohtaisesti kohdistunut poliittisia instituutioita ja vallanpitäjiä vastaan. Tällainen tilanne oli Suomessa, joka oli vuonna 1809 liitetty Venäjän keisarikuntaan mutta sai huomattavan hallinnollisen autonomian ja säilytti pääosan Ruotsin aikana muotoutuneista hallintorakenteistaan. Suomessa valtaeliitti ei ollut emävaltion jatke, sillä poliittisia laitoksia hallinneella ruotsin- tai kak- 
sikielisellä säätyläistöllä oli varsin löyhät kulttuuriset ja poliittiset siteet Venäjään.

Näiden tekijöiden vaikutuksesta kansallisuusliike ei käynnistynyt Suomessa köyhien väestönosien protestiliikkeenä vaan pikemminkin yläluokan johtamana. Tästä syystä kansallisuusliike myös löi läpi varsin vaivattomasti verrattuna muihin Itä-Euroopan vähemmistöalueisiin, joissa nationalismin ydinryhmät tulivat etupäässä keskiluokasta ja maaseutuväestöstä ja joutuivat kamppailemaan paljon rajummin kansallisuusliikkeen legitimoimiseksi.

Suomen kansallisuusliikkeen eliittijohtoisuutta selitti se, että yläluokan auktoriteetti ei perustunut maaomaisuuteen vaan asemaan valtion virkakoneistossa. Yläluokka ei nimittäin koostunut maa-aatelista toisin kuin monin paikoin muualla Euroopassa, ja maanomistus oli Suomessa pääosin itsenäisten talonpoikien käsissä. Koska yläluokka koostui etupäässä ylemmästä virkamiehistöstä ja perusti valtansa valtion lujittamiseen, se ei kokenut talonpojiston poliittista heräämistä uhaksi omalle asemalleen. Pyrkiessään lujittamaan valtiota yläluokka omaksui päinvastoin ajatuksen, että talonpoikainen kansa oli muokattava lojaaliksi kansakuntaa ja valtiota kohtaan. Tämä ajatus oli yksi 1800-luvun puolivälissä muotoutuneen fennomaanisen liikkeen perusteista. (Alapuro \& Stenius 1987, 12-14; Alapuro 1988, 91-95.)

Fennomaanien ideologisen ohjelman keskeinen osa oli kansakunnan kielellisen ja kulttuurisen yhtenäisyyden lujittaminen. Tähän pyrittiin heikentämällä ruotsinkielisen kulttuurin valta-asemaa ja vahvistamalla Suomen valtiokokonaisuuden asemaa osana Venäjän keisarikuntaa. Ohjelman tärkeä osa oli myös suomenkielisen kulttuurin ja kirjallisuuden luominen. Lisäksi fennomaanit pyrkivät muuttamaan koulutusjärjestelmää niin, että ylempiin sosiaalisiin kerrostumiin kohoaisi koulutuksen välityksellä uusia ryhmiä, ennen muuta talonpojistoa. Tavoitteena oli rakentaa yläluokka, joka oli kulttuurisesti läheisessä yhteydessä väestön enemmistöön. (Alapuro \& Stenius 1987, 14-17.)

Ajatus kansaan kytkeytyvästä yläluokasta ei merkinnyt sitä, että fennomaaninen liike olisi ollut erityisen demokraattinen. Alapuro ja Stenius (1987, 17-18) korostavat, että fennomaanit eivät esittäneet yhteiskuntaryhmien välisten suhteiden perinpohjaista muuttamista. Liike tähtäsi ennemminkin yläluokan koostumuksen muuttamiseen suomenkieliseksi 


\section{Sami Suodenjoki}

ja -mieliseksi kuin siihen, että yläluokan yhteiskunnallista asemaa olisi heikennetty. Niinpä aateliston, porvariston ja papiston muodostama vanha yläkerros pysyi tukevasti valtion instituutioiden johdossa Suomen itsenäistymiseen saakka, osin pitempäänkin.

Fennomaaninen sivistyneistö mielsi olevansa lähellä suomalaisia kansanjoukkoja ja ajavansa kansan etuja. Samalla se katsoi olevansa eräänlainen etujoukko, joka ansaitsi kansan luottamuksen ja tuen. Esiintyessään kansan tahdon edustajina fennomaanit politisoivat 1860-luvulta alkaen kansa-käsitteen uudella tavalla. Enää kansan viittaamalla ei pyritty yksinomaan vahvistamaan valtiollisia rakenteita, vaan kansan nimissä ryhdyttiin laajentamaan politiikan piiriä ja haastamaan vanhoja valtarakenteita. (Liikanen 2003, 280.)

Fennomaanien hahmottelemassa uudenlaisessa politiikan määrittelyssä valtion oli saatava yksityisten kansalaisten hyväksyntä. Tätä hyväksyntää voitiin lujittaa esimerkiksi erilaisten joukkojärjestäytymisen muotojen avulla. Fennomaanit kuitenkin heräsivät hitaasti tajuamaan yhdistyselämän avaamat uudet yhteiskunnalliset vaikutusmahdollisuudet. Stenius (1987a, 246-254) tähdentääkin, että ensimmäiset vapaaehtoisuuteen ja muodolliseen tasa-arvoon perustuneet joukkojärjestöt eivät syntyneet Suomessa fennomaanisen vaan liberaalin sivistyneistön aloitteesta. Näitä järjestöjä olivat vapaapalokunnat ja käsityöläisten keskusteluseurat, joista tuli merkittäviä kaupunkiväestön kulttuuritoiminnan järjestäjiä.

Fennomaaninen liike itsessään oli hajanainen ja organisoitumaton, sillä se koostui vapaamuotoisista tuttavien yhteenliittymistä, joiden kohtauspaikkoja olivat lehtien toimitukset, kodit ja kahvilat. Vasta 1870-luvulla myös fennomaanit alkoivat pitää tarpeellisena tiiviimpää ja laajempaa kokoontumista, mutta edelleenkään liike ei muotoutunut moderniksi puolueeksi eikä sillä ollut tiivistä järjestöverkkoa. Liikkeen tärkeimmäksi yhdyssiteeksi muodostui vuonna 1874 perustettu sivistystyöhön keskittynyt Kansanvalistusseura. (Rommi \& Pohls 1989, 73, 102.)

1880-luvulle tultaessa fennomaanien asenne tasa-arvoisuudelle perustuvia yhdistyksiä kohtaan muuttui ylipäänsä suopeammaksi. Samalla heidän tavoitteenaan oli kuitenkin vapaan järjestötoiminnan kytkeminen tiiviisti valtioon. Tavoitetta toteuttiin niin, että valtion virkamiehet ottivat aktiivisesti osaa kansalaisjärjestöihin ja näiden toiminta pyrittiin niveltämään suoraan valtiolliseen ja kunnalliseen päätöksentekoon. Tämä 
fennomaaninen valtiokeskeisyys vaikutti näkyvästi esimerkiksi 1880-luvulla nousseeseen raittiusliikkeeseen. (Alapuro \& Stenius 1987, 34-35.)

\section{Maaseudun herääminen}

Suomalaisen talonpojiston yhteiskunnallinen asema lujittui merkittävästi 1800-luvun jälkipuoliskolla. Säätyvaltiopäivien koolle kutsuminen 1860-luvulta alkaen nosti itsenäiset talonpojat ensi kertaa muiden säätyjen rinnalle mukaan yhteiskunnalliseen päätöksentekoon, ja seuraavien vuosikymmenten kapitalistinen murros maataloudessa vahvisti talonpoikia taloudellisesti. (Alapuro 1988, 36.) Vahvistuvasta talonpojistosta tuli merkittävä fennomaanisen liikkeen tukipilari, sillä fennomaanien tavoitteena oli herättää talonpoikaisväestö kansalliseen tietoisuuteen ja luoda talonpojistosta keskeinen valtiota lujittava ryhmä. Tähän fennomaaninen sivistyneistö pyrki muun muassa ottamalla talonpojiston erilaiset järjestäytymismuodot silmäteräkseen.

Fennomanian vanavedessä tapahtunutta talonpoikaiston yhteiskunnallista aktivoitumista on tutkimuksessa nimitetty "maaseudun heräämiseksi". Eri tutkijat ovat ajoittaneet tämän heräämisen eri tavoin. Eräiden tulkintojen mukaan maaseudun herääminen liittyi jo suomenkielisen lehdistön leviämiseen 1800-luvun puolivälissä tai valtiopäivä- ja kansakoulu-uudistuksen sävyttämään 1860-lukuun. Toiset katsovat heräämisen ajoittuneen vasta 1800 -luvun viimeisiin vuosikymmeniin, jolloin suuret kansanliikkeet löivät maaseudulla läpi. (Liikanen 1995, 177-178.)

Vaihteleviin ajoituksiin on vaikuttanut se, millaisten ilmiöiden tulkitaan heijastelevan yhteiskunnallista aktivoitumista ja mitkä väestönosat oikeastaan mielletään talonpojistoksi tai maaseutuväestöksi. Jos tarkastelussa noteerataan vain talollisten etujoukko ja maaseutuväestön sisäinen kirjavuus painetaan piiloon, näyttäytyy herääminen varhaisempana kuin jos huomio kiinnittyy maalaisväestön vähävaraisimpien osien aktivoitumiseen.

Fennomanian ja kansan suhdetta erittelevä Ilkka Liikanen (1995, 179, 205-211) katsoo maaseudun "heräämisen" ajoittuneen 1870-luvulle, jolloin maalaisväestön yhdistystoiminta ja fennomaanisen sivistyneistön valistustyö aktivoituivat samanaikaisesti. Liikasen mukaan fennomaanit 


\section{Sami Suodenjoki}

rohkaisivat maaseudun seura- ja kokoustoiminnan viriämistä, ja tämä viriäminen puolestaan ilmensi talonpojiston yhteiskunnallista nousua. Fennomaanisen sivistyneistön tuella talonpojat tunkeutuivat 1870-luvulla laajasti maaseudun taloudellisten ja sivistysseurojen johtotehtäviin. Lähes joka pitäjässä perustettiin maamiesseuroja ja isäntäyhdistyksiä, joiden välityksellä talonpojan ääni muuttui paikallistasolla entistä kuuluvammaksi.

1870-luvulla alkanut talonpoikainen järjestäytyminen ei kuitenkaan sulkenut piiriinsä maaseudun kaikkia asukkaita. Se ei myöskään merkinnyt säätyajattelusta luopumista, sillä Liikasen $(1995,211)$ mukaan kyse oli ennemminkin säätyrajojen uudelleen merkitsemisestä. Uusissa yhdistyksissä ja sivistysriennoissa talolliset löivät kättä sivistyneistön kanssa, mutta palkollisilta ja muilta köyhimpiin kansankerroksiin kuuluvilta mahdollisuus tasavertaiseen osallistumiseen jäi yhä uupumaan.

Liikanen (1995, 211, 237-238, 329) korostaa, että sivistysrientoja organisoineet talolliset ja säätyläiset näkivät maalaisväestön alimmat kerrokset lähinnä kristillis-siveellisen valistustyön kohteeksi eivät tasaarvoisen kanssakäymisen osapuoleksi. Samanlainen ajattelu leimasi myös liberaalin sivistyneistön kaupungeissa perustamia vapaaehtoisia yhdistyksiä, kuten vapaapalokuntia. Vasta 1880 -luvulta alkaen syntyneet uudet yhdistykset kuten raittius- ja nuorisoseurat tarjosivat myös maattomille mahdollisuuksia osallistumiseen ja siten paikallisten alistussuhteiden ylittämiseen. Näissäkään yhdistyksissä tilaton väestö ei silti välttämättä saavuttanut tasa-arvoisen toimijan asemaa, sillä talollisten, virkamiesten ja säätyläisten ote yhdistysten johdosta oli usein tiukka (Suodenjoki 2010, 71-74).

1880-luvulla virinneestä raittiusliikkeestä kehittyi vuosikymmenen ajaksi siihen asti suurin joukkoliike Suomessa. Paikallisten raittiusseurojen keskuselimeksi muodostettuun Raittiuden Ystäviin kuului 1890-luvun alussa noin kymmenentuhatta jäsentä. Irma Sulkunen ja Risto Alapuro (1987, 142-143) luonnehtivat raittiusliikettä esipoliittiseksi työväen joukkojärjestöksi tai työväenliikkeen esivaiheeksi, koska raittiusseurojen jäsenistön enemmistö oli työväestöä ja seuroilla oli keskeinen merkitys työväestön yhteiskunnallisen tietoisuuden heräämisessä. Raittiusseurat edustivat uudentyyppistä joukkojärjestäytymistä myös sikäli, että kasvava osa niiden jäsenistä oli naisia. 
Raittiusjärjestäytymiisessä oli alkujaan vahvasti paternalistinen sävy, sillä raittiusyhdistyksiä perustanut sivistyneistö tähtäsi ensisijaisesti köyhimpien väestönosien moraalin ja tapojen muuttamiseen. Raittiusliikkeellä oli kuitenkin tärkeä rooli työväestön poliittisessa heräämisessä, sillä se teki alkoholin aiheuttamista kärsimyksistä paitsi kasvatuksellisen myös yhteiskunnallisen kysymyksen. Vuosisadan vaihteeseen tultaessa raittiusväki julisti yhä ponnekkaammin työväestön tarvetta vapautua kapitalismin suojissa rehottavan viinakaupan kahleista. Suurimpana voimannäyttönään raittiusliike organisoi vuonna 1898 juomalakkoliikkeen, johon liittyi seitsemänkymmentä tuhatta kansalaista. Sulkunen kuvaa juomalakkoa työväestön joukkotoiminnan kouluksi ja arvioi sen vaikuttaneen työväenpuolueen organisoitumiseen vuosina 1898-1899. (Sulkunen \& Alapuro 1987, 144, 147-148.)

Raittiusliike menetti asemansa suurimpana joukkoliikkeenä nuorisoseuraliikkeelle 1890-luvulla. Nuorisoseurojen keskuselimeen Suomen Nuorison Liittoon kuului 1900-luvun alkaessa kolmekymmentä tuhatta jäsentä. (Stenius 1987b, 50.) Nuorisoseurat saivat jalansijaa ensimmäiseksi Etelä-Pohjanmaalla, mutta raittiusseurojen tapaan niitä perustettiin kaikkialle Suomeen. Liikkeen kannatus tosin keskittyi raittiusliikettä selvemmin maaseudulle. Nuorisoseurojen tavoitteena oli nuorison sivistäminen ja pitäminen erossa turmelevista ja siveettömistä harrastuksista. Samalla niiden ohjelmassa korostui kansallisuusaate ja säätyrajojen liudentaminen - jäsenistön runko tosin koostui yleensä talollisväestöstä. (Smeds 1987, 154-155).

Sekä raittiusliike että nuorisoseuraliike nojasivat fennomaanisiin järjestäytymisperiaatteisiin. Raittiusliike oli ensimmäinen kansalaisjärjestö, joka esitti kansan nimissä avoimesti lainsäädäntövaatimuksia valtiovallalle ja pyrki näin korjaamaan sosiaalisia epäkohtia. Nuorisoseuraliike puolestaan irrotti maalaisväestön järjestäytymisen ylhäältäpäin tulevasta holhouksesta, kun se korosti täysivaltaisten kansalaisten kykyä ja oikeutta itsensä sivistämiseen ja toteuttamiseen. (Liikanen 2003, 299-300.) Molemmat liikkeet olivat ohjelmaltaan sivistyksellisiä ja kansakuntaa yhtenäistäviä, ja näin ne toimivat ikään kuin valtion apuvälineinä. Molemmat myös välttivät avointa puoluepoliittisuutta. Lisäksi kummallakin liikkeellä oli perustansa perinteisen maalaisyhteiskunnan elämäntavassa 


\section{Sami Suodenjoki}

ja uskonnollisessa maailmankuvassa, mikä sekin kytki liikkeet fennomaaniseen projektiin (Sulkunen \& Alapuro 1987, 152).

\section{Kiistapuolueista vaalipuolueisiin}

Kansanliikkeiden nousun aikaan Suomessa ei vielä ollut vaalipuolueita tai järjestöpuolueita, sillä niiden aika koitti vasta 1900-luvun alussa. Moderni puoluepolitiikka alkoi kuitenkin vähitellen juurtua Suomeen 1860-luvulta alkaen. Puolueiden muodostuminen ilmeni aluksi fennomaanien vastakkainasetteluna ruotsinkieliseen porvariston ja ylimpään virkamiehistöön nojaavien liberaalien kanssa. Lisäksi fennomaanisen liikkeen sisällä nousi jo varhain esiin erilaisia aatteellisia kuppikuntia.

Fennomaanien edustama suomalainen puolue kieltäytyi varsin pitkään tunnustamasta itseään yhdeksi puolueeksi, sillä se katsoi edustavansa yksinoikeutetusti kansan ääntä ja puolustavansa kansakunnan kokonaisuuden etua hajaannusta ja jakautumista vastaan. Näin fennomaanit mielsivät olevansa muiden puolueiden pyrintöjen ja henkilökohtaisten mielipiteiden yläpuolella. Kaikki näkemykset - mitkä poikkesivat heidän tulkinnastaan - edustivat kansakunnan rakentamisen kannalta haitallista "puoluepolitiikkia" tai "puoluekiihkoa". Tämä näkemys puolueista yhteisen edun kannalta haitallisina hajaannuksen kylväjinä eli suomalaisessa kielenkäytössä vielä 1900-luvun alussakin. (Aarnio 2003, 422-430.)

Puolueiden järjestäytymisessä alkoi uusi vaihe vuonna 1880, jolloin liberaalit julkaisivat puolueohjelmansa jä ryhmittyivät Liberaalipuolueeksi. Suomalainen puolue puolestaan jakautui maltillisiin ja radikaaleihin, ja 1890-luvulla puolueen nuorsuomalainen siipi alkoi erkaantua omaksi puolueekseen. Viimeisen sysäyksen suomalaisen puolueen hajaantumiselle antoi 1890-luvun lopulla alkanut keisarihallinnon yhdenmukaistamispolitiikan kausi, joka tunnetaan myös venäläistämiskautena tai sortovuosina. Se repi puolueen kahtia myöntyväisyysmielisiin ja perustuslaillisiin. (Mickelsson 2007, 58-60, 67-68.) Tämä repeytyminen johti vanhasuomalaisen ja nuorsuomalaisen puolueen perustamiseen vuonna 1905.

Samoihin vuosiin ajoittui myös työväenliikkeen läpimurto ja järjestäytyminen sosialidemokraattiseksi puolueeksi. Suomen työväenpuolue oli perustettu vuonna 1899, ja neljä vuotta myöhemmin Forssan puolueko- 
kouksen yhteydessä se muutti nimensä sosialidemokraattiseksi puolueeksi. Forssan kokoukseen mennessä sosialismin opit murtautuivat näkyvästi mukaan puolueen ohjelmaan. Ennen syksyn 1905 suurlakkoa työväenpuolue pysyi jäsenmäärältään kuitenkin varsin pienenä, ja sen kannatus keskittyi kaupunkeihin ja maaseudun teollisuuskeskuksiin.

Vuoden 1905 suurlakon kynnyksellä suomalaisella puoluekentällä oli käytännössä neljä toimijaa: ruotsinmieliset, vanhasuomalaiset, nuorsuomalaiset ja sosialidemokraatit. Suurlakon jälkeen puoluekenttä kuitenkin kirjavoitui nopeasti. Ensimmäisissä yksikamarisen eduskunnan vaaleissa keväällä 1907 äänistä kilpaili moninainen katras vaaliliittoja ja ehdokaslistoja, jotka edustivat muun muassa kristillisiä ryhmittymiä, maalaisväestön eri ryhmiä sekä jyrkkiä reformeja kaihtavia kauppa- ja teollisuusmiehiä. Näistä poliittisista vaihtoehdoista pääosa kuitenkin karsiutui pois jo seuraaviin vaaleihin mennessä (Anttila ym. 2009, 13-15).

\section{Työväenkysymys ja wrightiläisyys}

Teollisuus- ja maataloustyöväestön määrän kasvu 1800-luvun jälkipuolella nosti yhteiskunnalliseen keskusteluun niin sanotun työväenkysymyksen. Sillä viitattiin teollisen palkkatyön laajentumisen sosiaalisiin ja poliittisiin seurauksiin. Sivistyneistöä askarrutti se, miten Suomessa voitiin ehkäistä työväestön radikalisoituminen, josta varoittivat muualla Euroopassa monin paikoin puhjenneet vallankumoukset.

Sivistyneistö lähti ajattelussaan siitä, että työväestön ja työnantajien edut olivat viime kädessä samansuuntaiset. Niinpä työntekijöiden tuli pyytää työnantajilta asemaansa kohtuullisia korjauksia, ja työnantajien tuli tehdä parhaansa työläistensä hyvinvoinnin eteen. Sivistyneistön käsityksen mukaan työntekijöiden radikalisoituminen voitiin ehkäistä, mikäli työntekijät ja työnantajat kävivät jatkuvaa vuoropuhelua ja estivät näin ongelmien kärjistymisen. Vuoropuhelun luonteva kanava olivat yhdistykset, joissa sekä työnantajat että työntekijät olivat mukana. (Suodenjoki \& Peltola 2007, 37.)

Tämän ajattelumallin tuloksena oli Suomessa ns. wrightiläisen työväenliikkeen synty 1880 -luvulla. Wrightiläinen työväenliike on saanut suomalaisessa historiankirjoituksessa runsaasti huomiota, sillä sitä on 


\section{Sami Suodenjoki}

pidetty eräänlaisena sosiaalidemokraattisen työväenliikkeen esivaiheena (esim. Mickelsson 2007, 61-62). Wrightiläistä työväenliikettä ei kuitenkaan voi nimittää joukkoliikkeeksi, sillä wrightiläisten yhdistysten jäsenmärä pysyi pienenä ja ne keskittyivät lähinnä kaupunkeihin ja eräisiin teollisuuskeskuksiin.

Voi myös kysyä, olivatko wrightiläisiksi kutsutut työväenyhdistykset itse asiassa työväen yhdistyksiä lainkaan, koska usein niiden johdossa olivat säätyläiset ja työnantajat. Ennemminkin wrightiläisiä yhdistyksiä voi luonnehtia fennomaanisen kansankasvatusihanteen yhdeksi jatkeeksi, sillä niiden ohjelmista paistoi läpi patriarkaalinen pyrkimys työväestön sivistämiseen ja henkiseen kasvattamiseen "ylhäältäpäin" (Haapala 1986, 190). Yhdistyksiä perustaneiden säätyläisten kuvitelma työläisten ja työnantajien sopuisasta vuoropuhelusta haihtui yleensä siinä vaiheessa, kun työläiset itse ottivat käsiinsä yhdistysten johdon. Tällöin yhdistysten aateperusta yleensä radikalisoitui nopeasti ja työnantajat väistyivät niistä.

Hannu Soikkanen $(1961,27)$ esittää klassikossaan Sosialismin tulo Suomeen, että wrightiläisen työväenliikkeen yhtenä lähtökohtana oli padota sosialismin eteneminen Suomessa. Liikkeen johtajat lähtivät ajattelussaan siitä, että sosialismi oli Suomeen soveltumatonta, koska työnantajat olivat valmiita reformeihin työläisten olojen parantamiseksi ja työväestön sivistyminen esti radikalisoitumisen. Tämä ajatuskulku oli kuitenkin virheellinen. Kuten myöhemmin ilmeni, sosialismin kannatus ei perustunut pelkästään yhteiskunnallisiin epäkohtiin. Työväestön taloudellisen, sosiaalisen ja sivistyksellisen tason noustessa kävi päinvastoin niin, että työväestö alkoi itse kyseenalaistaa yhteiskunnassa näkyvän eriarvoisuuden ja vaatia tasa-arvoisuutta. Viime kädessä wrightiläisyyden esiin nostamat ajatukset ja liikkeen rakentama yhdistysverkko siis osaltaan edistivät sosialismin juurtumista Suomeen.

\section{Työväenliikkeen läpimurto}

Työväestön omaehtoinen järjestäytyminen sosialidemokraattisin tunnuksin käynnistyi Suomessa 1890-luvun jälkipuolella. Järjestäytyminen oli alussa hidasta, sillä työväenyhdistysverkko rajautui kaupunkeihin, 
maaseudun teollisuuskeskuksiin ja eräisiin vireisiin maatalouspitäjiin, eikä yhdistyksiin liittynyt kuin pieni vähemmistö työläisistä.

Tilanne kuitenkin muuttui syksyn 1905 suurlakon jälkeen. Lakon tuloksena keisari antoi lupauksen yleisestä ja yhtäläisestä äänioikeudesta sekä eduskuntauudistuksesta, mikä aktivoi ennennäkemättömällä tavalla suomalaista työväestöä poliittiseen toimintaan. Seuraavan vuoden kuluessa Suomeen perustettiin sadoittain uusia työväenyhdistyksiä ja yhdistysten jäsenmäärä kasvoi räjähdysmäisesti. Työväenliikkeestä tuli hetkessä maan suurin kansanliike, ja sosialidemokraattinen puolue oli vuonna 1906 väestöön suhteutettuna suurin sosialistipuolue maailmassa (Alapuro 1988, 121). Vertailevasta näkökulmasta erityistä oli myös se, että kannattajakunnan perustan muodosti maaseudun tilaton väestö. Liikkeen läpimurto kulminoitui ensimmäisiin eduskuntavaaleihin keväällä 1907. Vaaleissa sosiaalidemokraatit kahmivat 37 prosenttia äänistä ja 80 edustajanpaikkaa, mikä yllätti jopa sosialistit itsensä.

Eduskuntavaalien jälkeen suurin innostus kuitenkin haihtui. Monet yhdistykset kärsivät jäsenkadosta ja lopettivat toimintansa. Järjestötoiminnan lamakausi ei koskenut pelkästään työväenyhdistyksiä, vaan samat vaikeudet koettelivat esimerkiksi nuoriso- ja raittiusseuroja. Kansalaistoiminnan taantumiseen vaikutti kansalaisten pettymys valtaoikeuksiltaan rajatun eduskunnan työhön. Toinen tekijä oli niin sanotun toisen sortokauden alkaminen, sillä venäläishallinto tiivisti jälleen otettaan Suomen suuriruhtinaskunnasta muun muassa rajoittamalla järjestöjen toimintaa ja kokoontumisvapautta. Osaltaan kansalaisjärjestöjen toimintaa vaikeutti myös vuonna 1914 syttynyt maailmansota. (Soikkanen 1975, 186187, 193; Suodenjoki \& Peltola 2007, 145-148.)

Työväen järjestäytyminen ei edennyt Suomessa vähittäisesti eikä tasaisesti vaan murroksittain, kuten Hannu Soikkanen (1961, 392-393) tähdentää. Ensimmäistä murrosta eli vuosien 1905-1907 mobilisaatiota seurasi toinen järjestäytymisen hyökyaalto vuosina 1916-1917. Maailmansodan aiheuttaman elintarvikepulan, maaliskuun vallankumouksen ja keisarivallan kumoutumisen aktivoimana työväenliikkeeseen virtasi jälleen uusia jäseniä. Enimmillään vuonna 1917 sosialidemokraattisen puolueen jäsenmäärä ylsi noin 130 000:een, mutta sisällissodan jälkeen luku romahti parin vuosikymmenen ajaksi (Soikkanen 1975, 260-261, 470). 


\section{Sami Suodenjoki}

Suomalaisen työväenliikkeen ominaispiirre oli ammatillisen työväenliikkeen alisteisuus poliittiselle liikkeelle. Ammattiyhdistysliike jäi Suomessa läntiseen Eurooppaan verrattuna alikehittyneeksi vuoteen 1917 saakka, sillä ammattiyhdistysten jäsenmäärä pysyi selvästi sosialidemokraattisen puolueen jäsenmäärää pienempänä ja työväenliikkeen voima perustui vaalimenestykseen ennemmin kuin esimerkiksi lakkoiluun. Osaltaan ammattiyhdistysliikkeen heikkoutta selitti liikkeen kannattajakunnan tausta: enemmisto sosialidemokraattien äänestäjistä oli maalaistyöläisiä, joiden tavoitteisiin ammatillisten järjestäytymisen keinovalikoima vastasi huonosti. (Alapuro 1988, 123-125.)

Poliittisen ja ammatillisen järjestäytymisen ohella työväestö mobilisoitui myös taloudelliseen yhteistoimintaan ennen muuta osuuskauppojen välityksellä. Itse asiassa osuustoimintaliike oli osuuskauppojen jäsenmäärällä mitattuna Suomen suurin kansanliike vuodesta 1907 alkaen (Stenius 1987b, 51). Alapuron (1994, 81-82) mukaan osuustoiminta oli paikallistasolla ehkä kaikkein näyttävin kansalaisyhteiskunnan ilmenemismuoto, sillä osuuskaupat sitoivat eri sosiaaliset ryhmät toisiinsa kuluttajina ja ohittivat kunnalliseen vallankäyttöön ja työhön liittyvät alistussuhteet. Alapuron päätelmiä tukee oma paikallistason järjestäytymistä koskeva tutkimukseni, joka osoittaa osuuskaupan koonneen jäsenikseen laajasti sekä työläisiä että talollisia ja virkamiehiä. Koska työväestön edustus ulottui myös kauppojen hallintoon, osuusliike edisti osaltaan yhteiskunnan modernia integraatiota ja tutustutti kansalaisia demokraattisiin käytäntöihin (Suodenjoki 2010, 161).

\section{Luokkaprotestin helppo vai kivulias esiinnousu?}

Risto Alapuro (1988, 105-108) korostaa työväenliikkeen ja luokkaprotestin esiinnousun olleen Suomessa poikkeuksellisen kivuton prosessi. Työväenliike ei kohdannut suuria esteitä, koska fennomaaninen liike rohkaisi joukkojärjestäytymistä ja luotti suomalaisen kansan, myös työväestön, lojaaliuteen valtiota kohtaan. Edeltävinä vuosikymmeninä vahvistuneesta talonpoikaistosta ei myöskään ollut Suomessa vielä ehtinyt muodostua konservatiivista voimaa työväestön organisoitumisen tielle. 
Näkemys työväenliikkeen läpimurron suhteellisesta helppoudesta on perusteltu, jos Suomen asettaa eurooppalaiseen tai Venäjän keisarikunnan viitekehykseen. Helppoutta korostaettaessa ei kuitenkaan pidä jättää huomioimatta, että työväenliike kohtasi Suomessakin merkittävää vastarintaa. Paikallisten vallanpitäjien suhdetta työväestön omaehtoiseen organisoitumiseen leimasi paikoitellen pikemminkin vähättely ja ylenkatse kuin suopeus ja rohkaisuhalu. Erityisesti ennen vuoden 1905 suurlakkoa säätyläiset ja isännät pitivät työväenliikkeen aktiiveja tietämättöminä ja hivenen vähämielisinä puuhastelijoina, eikä työväenyhdistyksiä välttämättä kohdeltu tasavertaisina toimijoina paikallisten kansalaisjärjestöjen joukossa. (Suodenjoki 2010, 163-168.) Työväenliikkeen kohtaaman alentuvaisuuden voi rinnastaa esimerkiksi poliittisen eliitin suhtautumiseen perussuomalaisia kohtaan 2000-luvun alkuvuosina.

Vallanpitäjien suhde työväenliikkeeseen kuitenkin muuttui suurlakon ja vuoden 1907 ensimmäisten eduskuntavaalien jälkeen. Vaaleissa sosialistit nousivat suurimmaksi eduskuntaryhmäksi, eikä heitä enää paikallistasollakaan voitu marginalisoida entiseen tapaan. Työväenliikkeestä tuli liian iso voima vähäteltäväksi. Alentuvaisuuden sijaan työväestön reformivaatimukset ja sosialismin aatteet alkoivat yhtäältä herättää entistä enemmän vastakaikua säätyläistenkin piirissä. Toisaalta työväenliike joutui entistä kärkevämpien hyökkäysten kohteeksi porvarillisessa agitaatiossa, mikä edisti poliittisen kentän ja julkisuuden polarisoitumista. Suhtautumisen muutoksessa voi jälleen nähdä samoja piirteitä, joita liittyi perussuomalaisten kohoamiseen poliittisen eliitin silmissä varteenotettavaksi tekijäksi 2000-luvun ensikymmenen vaihteessa.

Työväenliikkeeseen vuosisadan alussa kohdistuneessa vähättelyssä kuului kaikuja aiempien vuosikymmenten fennomaanisesta "valoa kansalle" -ajattelusta, jossa valon tuojien ja valon tarpeessa olevien välille tehtiin selvä ero. Fennomaanisia yhdistyksiä johtaneet säätyläiset ja talolliset tulkitsivat itsensä valistajiksi, jotka ohjasivat työväestöä "siveään ja kunnolliseen elämään”. (Liikanen 1995, 236-239.) Tällaiseen ajattelumalliin työläisten itsensä johtamat työväenyhdistykset sopivat huonosti.

Suhtautumistapa ei kuitenkaan ollut mitenkään erityisen suomalainen. Kyse oli kansalaisyhteiskunnan ja demokratisoitumisen välisistä jännitteistä, joita ilmeni 1900-luvun taitteessa muuallakin Euroopassa. Uusien yhteiskuntaryhmien tempautuminen kansalaistoimintaan yhdistysten 


\section{Sami Suodenjoki}

välityksellä huolestutti sivistyneistöä esimerkiksi Ranskassa, Englannissa ja Saksassa. Näissä maissa työväenjärjestöt olivat muodostuneet 1800-luvulla edistämään sosiaalisia reformeja ja työväestön moraalikasvatusta liberaalin sivistyneistön valvonnassa. Vuosisadan edetessä työväenjärjestöt kuitenkin omaksuivat vaihtoehtoisen kulttuurin, joka hylkäsi liberaalin perinnön ja loi oman visionsa itsekasvatuksesta. Järjestäytyminen yhdistyksiin tarjosi työväestölle väylän edistää omia poliittisia tavoitteitaan ja kiistää näin liberaalin eliitin oikeus esiintyä kansakunnan moraalisena johtajana. Tämä työväestön irtautuminen holhouksesta kauhistutti eurooppalaista sivistyneistöä, joka vinkkelistä järjestäytymisinnon tarttuminen kaikkiin väestöryhmiin näytti johtavan yhteiskunnan moraalisen suuntavaiston katoamiseen. (Hoffmann 2003, 291-295.)

Suomalainen yhteiskunta kohtasi rajuja taloudellisia, sosiaalisia ja kulttuuria muutoksia 1860-luvulta alkaen. Uuden ajan ihmeitä edustivat sähkövalo, tehdaskoneet ja höyrymeijerit samoin kuin uudet yhteiskunnalliset ilmiöt, kuten suhdannevaihtelut, sosialismi, kahdeksan tunnin työpäivä, äänioikeus ja siirtolaisuus. Uudet ilmiöt herättivät innostusta, mutta muutoksia pidettiin myös uhkana. Kuten muualla Euroopassa, myös Suomessa sivistyneistö ilmaisi huolensa yhteiskunnan moraalisesta rapautumisesta. Sekä liberaalin että fennomaanisen sivistyneistön kannanotoista heijastui käsitys, että suomalainen kansa ei ollutkaan valmis nykyaikaan. Sivistyneistön edustajien oli vaikea sopeutua siihen, että kun taloudellinen kehitys kohensi aineellisia oloja, kehityksen seuraukset näyttivät samalla murentavan heidän omaa auktoriteettiaan ja elämäntapaansa. Sivistyneistö alkoi etsiä syyllisiä puhumalla "sosialismin rikkaruohoista" ja moraalisesti kelvottomasta alaluokasta. (Haapala 2003, 156-159.)

Ironista kyllä, sivistyneistön huolten yltyessä Suomessa elettiin ennätyksellisen talouskasvun ja väestöliikkeen aikaa. Teollisuustuotanto ja kaupunkien väkimäärä olivat kaksinkertaistuneet kymmenessä vuodessa. Ihmisten elintaso nousi sekä maaseudulla että kaupungeissa, ja koulunkäynnistä oli tulossa merkittävä luokkarajojen murtaja. Sivistyneistö oli huolissaan maaseudun tilattoman väestön kasvusta ja nimitti sitä "liikaväestöksi”, mutta pysyvää työttömyysongelmaa ei ollut. Päinvastoin, maaseudulle syntyneet uudet työpaikat ja kaupunkeihin suuntautuva muuttoliike kohensivat nimenomaan tilattomien asemaa. Tilattomille itselleen 
palkkatyön tulo maatalouteen ja mahdollisuus muuttaa kaupunkiin merkitsivät vapautta vähintään yhtä paljon kuin turvattomuutta. (Haapala 2003, 160-166). Sosialismin läpimurto suomalaisella maaseudulla onkin syytä liittää kokemukseen vapauden ja mahdollisuuksien lisääntymisestä pikemmin kuin kurjistumiseen.

\section{Fennomaanisista sivistysriennoista työväeniltamiin}

Suomalaisella työväenliikkeellä oli vahvasti agraarinen perusta, sillä maailmansotien väliseen aikaan saakka valtaosa liikkeen kannattajakunnasta oli maaseudun työväestöä. Työväenyhdistysten toiminta kiinnittyi maaseudulla tiiviisti paikallisiin perinteisiin ja talkoovoimin rakennettujen työväentalojen ympärille.

Työväentaloilla virisi monipuolinen kulttuuritoiminta, joka ammensi runsaasti vaikutteita fennomaanisesta sivistysihanteesta. Esimerkiksi työväen iltamatoiminnan muodot kopioitiin suurelta osin 1800-luvun lopun fennomaanisilta järjestöiltä, erityisesti raittius- ja nuorisoseuroilta. Työväeniltamien ohjelmaan tulivat vakiintuneeksi osaksi esimerkiksi näytelmät, runonlausunta, orkesterimusiikki ja kuorolaulu, jotka kaikki olivat aiemmin kuuluneet lähinnä säätyläiskulttuuriin. (Kurkela 2000, 12.)

Fennomaaniset kansanvalistajat tekivät jyrkän jaon jalostavan taiteen ja turmiollisen viihteen välille. Vesa Kurkelan (2000, 11-14, 18-19) mukaan sama jako siirtyi myös työväen iltamatoimintaan, josta tuli hyvin valistushenkistä, koska työväenjohtajat korostivat iltamien merkitystä vakavamielisenä työväestön sivistämisen välineenä. Niinpä iltamaohjelma oli varsin kaavamainen: aluksi oli musiikkiesitys, sitten esitelmä tai juhlapuhe, vaihtelevaa estradiohjelmaa ja lopuksi viihteellisimpänä osiona tanssia. Kansanvalistajien näkökulmasta tanssi sopi tosin kyseenalaisesti iltamien henkisiin tavoitteisiin, mutta tanssin merkitys työväenyhdistysten ja muiden kansalaisjärjestöjen ohjelmistossa oli suuri, koska se oli varmin tae yleisömenestykselle.

Tanssin rooli työväeniltamien ohjelmistossa osoittaa, että iltamiin osallistunut työkansa ei niellyt taidekasvattajien valistusta sellaisenaan. Vaikka iltamaohjelma tukeutui korkeakulttuurin malleihin, törmäsi si- 


\section{Sami Suodenjoki}

vistysidea työväentaloilla yhteen kansanomaisen, viihteellisen ja karnevaalinomaisen kulttuurin kanssa. Iltamayleisölle tapahtumat eivät merkinneet vakavamielistä valistustilaisuutta vaan mahdollisuutta iloiseen ja ruumilliseen huvitteluun. Usein iltamiin liittyikin viinanjuonti ja nahistelu, mikä luonnollisesti kauhistutti kansanvalistajia. (Kurkela 2000, 14, 20-21.)

1900-luvun alun työväenlehdet vilisivät työväenaktiivien kauhistuneita raportteja iltamissa esiintyneestä viinan trokaamisesta, juopottelusta ja tappelemisesta. Lehdet korostivat tällaisen toiminnan olevan järjestäytyneelle työväestölle sopimatonta ja pyrkivät näin ohjaamaan työläisten käyttäytymistä vastuuntuntoisen, raittiin ja säädyllisen työläisen ihanteen mukaiseksi. Tämä kunnollisuusihanne oli pääpiirteittäin sama kuin fennomaanien 1800-luvulla muotoilema kansalaisideaali. (Suodenjoki \& Peltola 2007, 166; Suodenjoki 2010, 283-286.)

\section{Työväenjulkisuuden muodostuminen}

Työväentalojen ympärille kehittynyttä kulttuuritoimintaa voi pitää yhtenä ilmauksena omaleimaisen työväen julkisuuden muodostumisesta 1900-luvun alun Suomessa. Tämän julkisuuden muodostumisessa keskeistä roolia näytteli nopeasti levikkiään kasvattava sosialidemokraattinen puoluelehdistö, joka alkoi muovata paikallistasolla julkisuutta sitä näkyvämmin mitä vahvemmiksi paikalliset työväenjärjestöt kasvoivat. Työväenlehtien suosio perustui suurelta osin paikalliskirjeisiin, joita lehdet julkaisivat levikkialueensa kunnista ja joita kirjoittivat yleensä paikalliset työväenaktiivit, tavalliset työläiset. Näin lehdet tarjosivat ilmaisukanavan myös sellaiselle väestönosalle, jolla ei aikaisemmin juuri ollut mahdollisuuksia julkaista tekstejään sanomalehtien palstoilla. (Suodenjoki 2010, 128-131.)

Työväenlehdissä maaseudun työläisten poliittisille näkemyksille avautui foorumi, jota paikalliset isännät eivät kyenneet kontrolloimaan. Sitä mukaa kun työväenliike omaksui avoimet sosialistiset tunnukset, muuttuivat työväenlehtien paikalliskirjeet sävyltään hyökkäävimmiksi. Työläiset saattoivat nimimerkkien verhossa kiistää jyrkkäsanaisesti paikallisyhteisönsä vallanpitäjien toimet ja arvot, eikä kirjoituksissa läheskään aina 
tunnettu yksityisyydensuojaa. Ajoittain kirjoittelu johti käräjäjuttuihinkin. (Suodenjoki 2010, 130-131.)

Työväenlehdistön rooli vastarintaisen asenteen ilmaisukanavana voidaan rinnastaa internetin keskustelupalstoihin ja niiden anonyymiin kirjoitteluun. Verkkopalstojen kirjoittajia on kritisoitu 2000-luvulla hyvin samankaltaisin argumentein kuin sata vuotta aiemmin työväenlehtien paikalliskirjeenvaihtajia esimerkiksi vihapuheen viljelystä. Kritiikin kääntöpuolena on kuitenkin työväenlehtien ja verkon rooli julkisesta mielipiteenvaihdosta aiemman syrässä olleiden ihmisryhmien aktivoimisessa. Kun syrjässä pysyneet ryhmät tulevat laajamittaisesti mukaan julkiseen keskusteluun, voi heidän tuskin odottaa pidättäytyvän hyökkäävän kielen käytöstä ja osallistuvan keskusteluun vallanpitäjien määrittelemin ehdoin.

Työväenlehdistön vahvistuessa paikallisyhteisöihin muotoutui entistä näkyvämpi vastajulkisuus, joka rikkoi paikallisten vallanpitäjien monopolin joukkotiedonvälityksessä. Työväen julkisuuden tarjoamalla areenalla työläiset saattoivat uudella tapaa hahmottaa paikkaansa paikallisessa työväenyhteisössä sekä luoda normeja, jotka erottivat "meitä" ja "ulkopuolisia". (Suodenjoki 2010, 131.) Joidenkin tulkintojen (esim. Nieminen 2006, 170) mukaan selväpiirteinen työväen julkisuus tosin muodostui vasta vuosien 1917-1918 jälkeen, koska vasta tuolloin työväenliikkeeseen kuuluvien pääsyä tietyille julkisuuden areenoille alettiin rajoittaa luokkapoliittisesti. Julkisuuden polarisoituminen oli kuitenkin ilmeistä jo vuosia ennen sisällissotaa. Kahtiajakautumisen voi havaita helposti tarkastelemalla, miten eri tavoin samoja tapahtumia käsiteltiin työväen- ja porvarilehtien paikalliskirjeissä.

Jari Ehrnrooth (1992) korostaa työväenliikkeen pyrkineen kenttätason agitaatiossaan herättämään luokkavihaa vetoamalla työväestön vihan, kaunan ja katkeruuden tunteisiin. Luokkavastakohtaisuuden nostattaminen oli kuitenkin vain yksi puoli työväenliikkeen ohjelmasta. Yhtä tärkeää oli työväestön sivistämisen ja itsekasvatuksen korostaminen. Työväenaktiivit rakensivat lehdistön ja puhutun agitaation välityksellä määrätietoisesti kunnollisen kansalaisen eli järjestäytyneen työläisen ideaalia. Heidän retoriikassaan järjestäytynyt työläinen oli vastuuntuntoinen, sivistynyt, siveellinen ja raitis. (Suodenjoki 2010, 280-283.) Raittiuden vaatimus siirtyi työväenliikkeeseen raittiusliikkeestä ja sai korostuneen 


\section{Sami Suodenjoki}

roolin, vaikka käytännössä työväenliikkeen johtajillakin oli suuria vaikeuksia toteuttaa raittiusihannetta omakohtaisesti (Sulkunen 1986, 228229).

Myöskään työväenliikkeen rivijäsenistö ei aina yltänyt järjestäytyneen työläisen ihannekuvan tasolle, kuten työväenlehtien uutiset iltamien juopottelusta ja riehumisesta havainnollistavat. Työväenaktiiveille jäsenistön häiriökäyttäytyminen oli merkki siitä, ettei työväestö vielä ollut omaksunut työväenliikkeen ihanteita riittävän hyvin vaan oli edelleen liian tietämätöntä, sivistymätöntä ja raakaa. Säätyläisten ja virkavallan tulkinta työväestön häiriökäyttäytymisen syistä saattoi olla päinvastainen. Esimerkiksi Tammelan kruununvouti laittoi vuosikertomuksessaan kihlakuntansa järjestysongelmat epäröimättä työväenliikkeen tiliin:

Sosiaalidemokraattinen liike osaksi harhaan menneenä on kihlakunnassa vaikuttanut, että raittius ja siveelliset tavat eivät vuoden 1907 aikana ole edistyneet, vaan päinvastoin. Pahoinpitely-, juopumus-, yleisen rauhan häiritsemis- ja viinanmyynti y.m. rikokset ovat vaan lisääntyneet ja vieläpä ennen kuulumattomiakin jumalanpalveluksen häiritsemis- ja aviorikoksia on ilmaantunut, kun osa kansasta on tauonnut antamasta kunnioitusta ja arvoa uskonnolle ja laeille. (Suodenjoki 2010, 287)

Sitaatti ilmentää oivallisesti vallanpitäjien järkytystä työväestön mobilisaation aiheuttamasta yhteiskunnallisesta murroksesta. Sivistyneistö ja virkamieskunta olivat 1900-luvun alussa vahvasti fennomaanisen ajattelun läpäisemiä, ja heidän ajatteluaan sävytti yhä luottamus kansan solidaarisuuteen valtiota kohtaan. Samoin he uskoivat edelleen siihen, että heidän oma kansallismielinen sivistysnäkökulmansa oli kaikkein edistyneintä demokratiaa (Vares 2008, 357). Kun suurlakon tuloksena työväenliike omine demokratia- ja sivistysnäkemyksineen kohosi äkillisesti poliittiseksi voimatekijäksi, vaihtui monien säätyläisten luottamus peloksi yhteiskuntarauhan murenemisesta.

\section{Liikevoimat: kansaan vetoaminen, sivistys ja viha}

Fennomaanit määrittelivät 1800-luvun jälkipuolella kansaa ja kansan tahtoa ylhäältäpäin lujittaakseen omaa asemaansa ja edistääkseen poliittisia 
tavoitteitaan. Tässä vaiheessa Suomesta kuitenkin puuttui vielä sellainen kansallinen julkisuus, jossa olisi käytännössä voitu mitata se, missä määrin kansa oikeastaan antoi tukensa fennomaaniselle projektille. Tilanne muuttui 1900-luvun alkuun tultaessa joukkoliikkeiden kehityksen, julkisuusareenojen eriytymisen ja vaalipolitiikan aikaan siirtymisen myötä.

Säröjä fennomaanisen sivistyneistön ja virkamieskunnan maalaamaan ihanteelliseen kansakuvaan loi Venäjän ja Suomen suhteen kriisiytyminen vuosisadan taitteessa. Keisarihallinnon venäläistämistoimet kiihdyttivät sivistyneistön tarvetta lujittaa kansakuntaa ulkoista vaaraa vastaan.

Sivistyneistö joutui kuitenkin havaitsemaan, ettei koko kansa ollut toivotulla tavalla innostunut liittymään kansalliseen projektiin. Sen sijaan että kaikki Suomen väestöryhmät olisivat yhdessä rintamassa osoittaneet mieltään keisarihallinnon venäläistämispolitiikkaa vastaan, nousivat esiin väestön sisäiset luokkaristiriidat. Nopeasti leviävä työväenliike ei enää kohottanut etusijalle kansallista projektia vaan luokkapohjaiset intressit, kuten torpparivapautuksen, työolojen parannukset ja ennen kaikkea äänioikeuden.

Työväestön omaehtoinen oikeuksien vaatiminen törmäsi yhteen sivistyneistön näkemykseen itsestään kansan etujen ajajana. Tutkimuksessa toisteltiinkin pitkään tulkintaa, jonka mukaan vuoden 1905 suurlakon jälkeen sivistyneistö pettyi kansaan, koska kansa ei kyennyt nousemaan ihannekuvansa mittaiseksi. Tulkinta on tosin viimeaikaisessa tutkimuksessa kyseenalaistettu korostamalla sivistyneistön reagoineen suurlakon murrokseen paljon moninaisemmin kuin vain "pettymällä" (Ojajärvi 2009, 234). Tästä kertoo esimerkiksi vanhasuomalaisten vaikuttajien halu lähentyä liikehtivää kansaa ja tulkita suurlakko uudeksi aluksi kansallisen kulttuurin luomiselle (Kokko 2008, 313).

Työväenliikkeessä oli paljon samaa kuin fennomaniassa, sillä se katsoi edustavansa yksinoikeutetusti todellista kansaa eli "rahvasta", "työkansaa" tai "työväenluokkaa". Fennomaaniseen perintöön kytkeytyi myös työväenliikkeen sivistysprojekti työläisten kohottamiseksi järjestäytyneen työläisen ideaalin mukaiseksi kunnon kansalaiseksi. Kansansivistyksen painottaminen oli itse asiassa yhteinen piirre kaikille fennomaaniseen järjestäytymiseen pohjautuneille poliittisille puolueille, sillä ne pitivät kansalliseen sivistysprosessiin osallistumista kansalaisen ehkä tärkeimpä- 


\section{Sami Suodenjoki}

nä velvollisuutena ja kansakunnan kohtalonkysymyksenä (Stenius 2003, 352-354, 359).

Suomalaisen työväenliikkeen tutkijoita jaotellaan joskus sen mukaan, painottavatko he työväenliikkeen osallisuutta kansakunnan ja kansalaisyhteiskunnan rakentamisprojektiin (esim. Haapala 1986) vai liikkeen nojautumista herravihan perinteeseen ja hyökkävään luokkavastakkainasetteluun (esim. Ehrnrooth 1992). Tällainen jyrkkä jaottelu on kuitenkin nähdäkseni hedelmätöntä, sillä liikkeeseen sisältyivät molemmat puolet - kuin kolikon kruuna ja klaava.

Voidaan myös väittää, että työväenliikkeen tapa yhdistää toisiinsa sivistysprojekti ja vihantunteita kanavoiva protesti ei ollut lopulta mitenkään erityinen. Tapio Bergholmin (2002, 190-192) mukaan vihaa pursuava kielenkäyttö kuului vakiintuneesti aikakauden kirjalliseen ja suulliseen esitystapaan ja leimasi jo fennomaanista kansalaisjärjestäytymistä 1800-luvulla. Myös fennomaanien into toimia kansallisen projektin hyväksi ammensi voimaansa vihasta, kaunasta ja katkeruudesta. Fennomaanit kohdistivat vihansa niihin, jotka edustivat heidän edustamansa kansan tahdon vastustajia - eli ruotsinmielistä eliittiä tai mitä tahansa vastahankaista ryhmää. Liikeinnon luominen perustui siis samankaltaiseen tunnedynamiikan kanavointiin kuin luokkavastakohtaisuutta lietsoneessa työväenliikkeessä. Tältä pohjalta voidaan ehdottaa, että kansalaisliikehdintää tarkasteltaessa valistusintoa ja vihaa ei ole syytä asettaa vastakkain, vaan ne kulkevat käsi kädessä.

\section{Lähteet}

Aarnio, Eeva. 2003. Puolue. Teoksessa Matti Hyvärinen ym. (toim.), Käsitteet liikkeessä. Suomen poliittisen kulttuurin käsitehistoria. Tampere: Vastapaino, 413-466.

Alapuro, Risto. 1988. State and Revolution in Finland. Berkeley: University of California Press. 
Alapuro, Risto. 1994. Suomen synty paikallisena ilmiönä 1890-1933. Helsinki: Hanki ja Jä.

Alapuro, Risto ja Stenius, Henrik. 1987. Kansanliikkeet loivat kansakunnan. Teoksessa Risto Alapuro ym. (toim.), Kansa liikkeessä. Helsinki: Kirjayhtymä, 8-49.

Anttila, Anu-Hanna, Kauranen, Ralf, Löytty, Olli, Pollari, Mikko, Rantanen, Pekka ja Ruuska, Petri. 2009. Kuriton kansa. Poliittinen mielikuvitus vuoden 1905 suurlakon ajan Suomessa. Tampere: Vastapaino.

Bergholm, Tapio. 2002. Edistysusko ja puolueviha. Teoksessa Elina Katainen ja Pirkko Kotila (toim.), Työväki ja tunteet. Väki Voimakas 15. Tampere: Työväen historian ja perinteen tutkimuksen seura, 181-196.

Ehrnrooth, Jari. 1992. Sanan vallassa, vihan voimalla. Sosialistiset vallankumousopit ja niiden vaikutus Suomen työväenliikkeessä 1905-1914. Helsinki: Suomen Historiallinen Seura.

Haapala, Pertti. 1986. Tehtaan valossa. Teollistuminen ja työväestön muodostuminen Tampereella 1820-1920. Helsinki: Suomen Historiallinen Seura.

Haapala, Pertti. 2003. ”Rihkamakansa" - työväki sivistyneistön silmin. Teoksessa Anja Kervanto Nevanlinna ja Laura Kolbe (toim.), Suomen kulttuurihistoria 3. Oma maa ja maailma. Helsinki: Tammi, 156-177.

Hoffmann, Stefan-Ludwig. 2003. Democracy and Associations in the Long Nineteenth Century: Toward a Transnational Perspective. The Journal of Modern History 75:2, 269-299.

Kokko, Heikki. 2008. Sivistyksen surkea tila. Teoksessa Pertti Haapala ym. (toim.), Kansa kaikkivaltias. Suurlakko Suomessa 1905. Helsinki: Teos, 297-319.

Kurkela, Vesa. 2000. Työväeniltamat, valistus ja karnevaali. Teoksessa Joni Krekola ja Kirsti Salmi-Niklander (toim.), Naurava työläinen, naurettava työläinen. Näkökulmia työväen huumoriin. Väki Voimakas 13. Tampere: Työväen historian ja perinteen tutkimuksen seura, 8-33.

Liikanen, Ilkka. 1995. Fennomania ja kansa. Joukkojärjestäytymisen läpimurto ja Suomalaisen puolueen synty. Helsinki: SHS.

Liikanen, Ilkka. 2003. Kansa. Teoksessa Matti Hyvärinen ym. (toim.), Käsitteet liikkeessä. Suomen poliittisen kulttuurin käsitehistoria. Tampere: Vastapaino, 257-307.

Mickelsson, Rauli. 2007. Suomen puolueet. Historia, muutos ja nykypäivä. Tampere: Vastapaino. 


\section{Sami Suodenjoki}

Nieminen, Hannu. 2006. Kansa seisoi loitompana. Kansallisen julkisuuden rakentuminen Suomessa 1809-1917. Tampere: Vastapaino.

Rommi, Pirkko ja Pohls, Maritta. 1989. Poliittisen fennomanian synty ja nousu. Teoksessa Päiviö Tommila ja Maritta Pohls (toim.), Herää Suomi. Kuopio: Kustannuskiila, 67-119.

Smeds, Kerstin. 1987. Nuorisoseurat "kunnon kansalaisen" kasvattajina. Teoksessa Risto Alapuro ym. (toim.), Kansa liikkeessä. Helsinki: Kirjayhtymä, 154-155.

Soikkanen, Hannu. 1961. Sosialismin tulo Suomeen. Helsinki: WSOY.

Soikkanen, Hannu. 1975. Kohti kansanvaltaa 1. 1899-1937. Suomen Sosialidemokraattinen Puolue 75 vuotta. Helsinki: Suomen Sosialidemokraattinen Puolue - Puoluetoimikunta.

Stenius, Henrik. 1987. Suurimmat joukkojärjestöt. Teoksessa Risto Alapuro ym. (toim.), Kansa liikkeessä. Helsinki: Kirjayhtymä, 50-52.

Stenius, Henrik. 2003. Kansalainen. Teoksessa Matti Hyvärinen ym. (toim.), Käsitteet liikkeessä. Suomen poliittisen kulttuurin käsitehistoria. Tampere: Vastapaino, 309-362.

Sulkunen, Irma. 1986. Raittius kansalaisuskontona. Raittius ja kansalaisjärjestäytyminen 1870-luvulta suurlakon jälkeisiin vuosiin. Helsinki: Suomen Historiallinen Seura.

Sulkunen, Irma ja Alapuro, Risto. 1987. Raittiusliike ja työväestön järjestäytyminen. Teoksessa Risto Alapuro ym. (toim.), Kansa liikkeessä. Helsinki: Kirjayhtymä, 142-156.

Suodenjoki, Sami. 2010. Kuriton suutari ja kiistämisen rajat. Työväenliikkeen läpimurto hämäläisessä maalaisyhteisössä 1899-1909. Helsinki: SKS.

Suodenjoki, Sami ja Peltola, Jarmo. 2007. Köyhä Suomen kansa katkoo kableitansa. Luokka, liike ja yhteiskunta 1880-1918. Vasemmistolainen työväenliike Pirkanmaalla I. Tampere: Tampere University Press.

Vares, Vesa. 2008. Suurlakon häviäjät. Teoksessa Pertti Haapala ym. (toim.), Kansa kaikkivaltias. Suurlakko Suomessa 1905. Helsinki: Teos, 349-367. 


\section{Kansallinen toimijuus suomalaisessa politiikassa}

Vuosituhannen vaihteen konsensus-Suomessa on voinut usein kuulla, että suomalainen politiikka kantaa J. V. Snellmanin perintöä: kansakunnalla on oltava yksi mieli. Yhteisten kansallisten ponnistelujen historia on suosittua poliittisen retoriikan ainesta. "Talvisodan henkeä" kutsutaan avuksi tuon tuostakin, ja kaikkien edellytetään osallistuvan "talkoisiin" erilaisten hyvien asioiden puolesta, kuten velkaantumisen pysäyttämiseksi.

Kuitenkin voi vaivatta myös väittää, että Suomen poliittista historiaa ovat hallinneet konfliktit ja katkokset. Todisteiksi käyvät vuoden 1918 sisällissota syineen ja seurauksineen sekä kommunismin vahva kannatus etenkin toisen maailmansodan jälkeisinä vuosikymmeninä. Muutoin niin erinomaisen kansamme eripuraisuus oli pitkään huolenaiheena kansallisten juhlapäivien puheissa. Parlamentarismi oli epävakaata ja hallitukset lyhytikäisiä 1980-luvulle saakka. Vasta silloin säännöksi tulivat koko vaalikauden istuvat enemmistöhallitukset. Kansainvälisissä lakkotilastoissa Suomi sijoittui korkealle 1980- ja 1990-luvun taitteeseen saakka, jolloin lakkoilu väheni jyrkästi. Konsensuksen historia näyttää lyhyeltä.

Eheyden ja ristiriitaisuuden kuvat eivät kuitenkaan sulje toisiaan. Konsensuksen ideaali on voinut toteutua ristiriitojen ehkäisemisenä, heikentämisenä tai peittämisenä, mutta se on pohjustanut myös vaikeasti säänneltäviä konflikteja. Kehittelen ja perustelen seuraavassa tätä tulkintaa 


\section{Pauli Kettunen}

erittelemällä historiallisia kerrostumia ja vaiheita kansallista toimijuutta koskeneista tavoitteenasetteluista ja kamppailuista. ${ }^{1}$ Historiallisen politiikantutkimuksen kentällä lähestymistapani edustaa, Michel Foucault'n ilmaisua lainatakseni, "nykyisen historiaa"2. Tutkija koettaa tarttua oman maailmansa itsestäänselvyyksiin ja siksi hakee selviöistä säröjä, joihin tarttua ja joita syventää (Dean 1994, 28-36). Ajattelu- ja toimintatapaa, jossa kansakunta ja kansallisvaltio nähdään keskeisenä toimijana, voidaan tutkia historiallisesti tällaisena nykyisyytemme säröytyneenä selviönä.

Käsitteitä käyttäessäni erotan konsensuksen kompromissista samaan tapaan kuin Frank Ankersmit (2002, 193-213). Kompromissi lähtee etujen erilaisuudesta ja ristiriitaisuudesta eikä poliittinen prosessi tähtää tämän asiantilan peittämiseen tai lakkauttamiseen. Konsensus sen sijaan perustuu siihen, että ennalta määritellään yhteinen etu ja eri toimijoiden erilaisista eduista etsitään, tunnustetaan ja yhteen sovitetaan vain se, mikä niissä on tuon yhteisen edun ainesta.

\section{Sisäinen tahto ja ulkoiset pakot}

Filosofi Thiodolf Rein arvioi vuonna 1881 Valvojassa, että Suomeen soveltui toisenlainen valtio-oppi kuin Ruotsiin. Ruotsin tapaisessa valtiossa, joka oli suhteellisen suojattu ulkonaisia vaaroja vastaan, saattoi olla paikallaan "tuo indiviidin-omainen valtio-oppi, joka katsoo valtiota ainoastaan kaikellaista yksityishyvää tarkoittavaksi laitokseksi - laitokseksi, jonka vaatimuksista yksityisen sopii pyrkiä vapaaksi mitä helpoimmalla hinnalla”. Tämä oppi ei kuitenkaan kelvannut kansalle, jonka piti ponnistella "pysyäksensä pystyssä olemisen taistelussa”. Tällaisessa kansassa "indiviidin aseman yhteiskuntaa kohtaan pitää oleman toista laatua, s.o. enemmän yhteisen hyvän määrämä, kuin niissä maissa, joita ei mikään vaara uhkaa" ${ }^{3}$

Suomalaista kansallista toimijuutta määrittivät näin Reinin mukaan ulkoiset uhat. Hänen kirjoituksensa käsitteli Snellmanin tekstien suomennoksia ja hän laati sittemmin Snellmanin elämäkerrankin, mutta hänen arvionsa osoitti Snellmanin opetusten muuntuneen kansakunnan rakentajien mielissä. Vuonna 1863, jolloin Venäjän keisarivalta kukisti ankarasti Puolan kapinan ja suostui suopeasti Suomen säätyjen kokoontu- 
miseen valtiopäiville, Snellman oli tuominnut Ruotsiin päin tähyämisen ja "liberaalien fraasit" Suomen valtiollisesta asemasta. Hänen mukaansa "Suomen kansa on saavuttanut nykyisen poliittisen olemassaolonsa nykyisen sukupolven kannalta niin vähällä vaivalla, että sen saavuttamia asioita voidaan pitää odottamattomana taivaan lahjana”. Tästä syystä tarvittiin nöyryyttä, viisautta ja kohtuullisuutta. "Sillä ne, jotka jumala tahtoo tuhota, hän lyö sokeudella. Ja kansan sokeutta on pöyhkeilevä ylimielisyys, joka unohtaa, että kansankuntien oikeus on valta." ${ }^{4}$

Näkökulmaa muutti 1800-luvun lopulla suomalais-kansallisen oppisivistyneistön toimeliaisuus, jolla avulla Suomen kansakunnalle rakennettiin pitkä historia. Suomen kansan "poliittinen olemassaolo" ei enää näyttäytynyt vähällä vaivalla saavutettuna taivaan lahjana, vaan tuloksena vaarojen läpi toteutuneesta ja uhrauksia vaatineesta vuosisataisesta kansallisesta historiasta, ja siksi sen vaaliminen vaati kansallista yhteistahtoa.

Siinä, miten Suomi Venäjän keisarikunnan yhteydessä muotoutui kansakunnaksi ja kansallisvaltioksi, oli piirteitä sekä vanhaa valtiota oikeuttavasta että uutta valtiota luovasta nationalismista. 1830-luvulta lähtien kehiteltiin näkemystä Suomen valtiosta, joka oli syntynyt Aleksanteri I:n hallitsijanvakuutuksella Porvoon tuomiokirkossa 29.3.1809. Näkemyksessä sovitettiin yhteen, kuten Osmo Jussila $(1987,64)$ sanoo, "romantiikkaa, hegelismiä ja luonnonoikeutta sopimusteorioineen". Kaikki nämä "toimivat samansuuntaisesti, yhdistivät kansakunnan ja valtion yhdeksi organismiksi, heijastivat menneisyyteen, vuoteen 1809, yhtenäisen kansallisvaltion syntyaktin ja hetken”. Kun poliittinen julkisuus 1860-luvulta lähtien avautui ja laajeni, "kansalliset herättäjät" rakensivat kansakuntaa jo olemassa olevaksi tulkitsemansa valtion perustukseksi samalla, kun he vahvistivat valtiota kansakunnan voimana ja järjestyksenä. Tämä suuntasi myös vapaaehtoisen yhdistystoiminnan ja kansanliikkeiden kehittymistä."Kansanliikkeet loivat kansakunnan”, kuten Kansa liikkeessä -kirjan kirjoittajat toteavat (Alapuro \& Stenius 1987). Jos vapaaehtoisen yhdistystoiminnan ja kansanliikkeiden kenttää kutsutaan kansalaisyhteiskunnaksi, voidaan sanoa Henrik Steniuksen (1987, 284291) tavoin, että Suomessa valtion ja kansalaisyhteiskunnan välimatka pysyi lyhyenä, lyhyempänä kuin Ruotsissa, jossa kansanliikkeet nousivat selvemmin oppositiossa vallitsevaa valtiota vastaan. Reinin arvio Suomen ja Ruotsin eroavuudesta tuli ennakoineeksi poliittisten kulttuurien 


\section{Pauli Kettunen}

myöhempiä eroja. Suomessa politiikka on mielletty ulkoisesti määräytyvien, kansallisvaltion välittämien kansallisten välttämättömyyksien epäpoliittisena toteuttamisena enemmän kuin Ruotsissa. Tätä selittävät poliittisten kokemusten ja myös valtasuhteiden erot. Niin ulkopolitiikassa kuin talouspolitiikassa kansallisen välttämättömyyden korostus on ollut Suomessa vahva ja vaikutusvaltainen: ulkoa määräytyviä välttämättömyyksiä toteutetaan sisäisen tahdon voimalla. Monet historialliset tilanteet on voitu Suomessa konkreettisemmin kuin Ruotsissa kokea ja tulkita taisteluiksi kansallisesta selviytymisestä, ja nämä kansalliseksi historiaksi työstetyt kokemukset ovat luoneet edellytyksiä kansallisiin välttämättömyyksiin vetoavalle ajattelu- ja puhetavalle (Kettunen 2003, 172-173).

Luottamus valtioon on ollut Suomessa erilaista kuin Ruotsissa. Ruotsalaisen hyvinvointivaltion ja sosiaalidemokratian historiassa on vaikuttanut vahvasti ajatus, että valtio voidaan muuttaa poliittisen tahdon välineeksi, jota sitten käytetään yhteiskunnalliseen suunnitteluun. ${ }^{5}$ Suomessa näkemys valtiosta kulloistenkin poliittisten voimasuhteiden mukaan käytettävänä välineenä ei ole saavuttanut tällaista hyväksyntää. Suunnittelevaa järkeä ei ole ymmärretty niinkään valtiota hyväksikäyttävän politiikan kysymyksenä kuin valtion sisäisenä ominaisuutena. Politiikan ideaalina on ollut toteuttaa valtioon itseensä sisältyvää tahtoa, jota Snellman kutsui "siveellisyydeksi kansallishenkenä". Näiltä pohjin fennomaanien oli luontevaa suomentaa politiikan käsite "valtiolliseksi toiminnaksi".

Virkamiehille on langennut kaksi toisiinsa liittyvää vallankäytön tehtävää valtion järjen toteuttajina. He ovat ensiksikin osoittaneet rajat, joiden sisällä kompromissit on tehtävä, ja toiseksi kääntäneet konfliktit ja kompromissit funktionaalisiksi välttämättömyyksiksi, toisin sanoen siirtäneet asiat intressien alueelta tarpeiden alueelle ja politiikasta hallintoon. Näin he ovat antaneet yhteiskunnallisille intresseille "yleisen, kansallisen merkityksen", mitä Snellman edellytti valtiollisessa toiminnassa edustettavilta intresseiltä.

\section{Kansan nimissä}

Valtio-opissaan Snellman myönsi, että poliittisessa toiminnassa muodostui puolueita. "Puolueiden olemassaoloa on tarkasteltava enemmän tai 
vähemmän innokkaana keskusteluna siitä, mitä kansallishenki kulloinkin vaatii", hän kirjoitti. ${ }^{6}$ Kuten jo Snellmanin omat kiistakirjoitukset ${ }^{7}$ osoittavat, yhteistä kansallishenkeä edellyttävä politiikan perustelu pohjusti kuitenkin myös kärkeviä ristiriitoja.

Konsensusideaalin pohjalta poliittiset kiistat muodostuivat taisteluiksi siitä, kenellä oli oikeus puhua kansan nimissä ja siten määritellä kansa. Tämä näkyi ensinnä fennomaanien ja liberaalien kiistoissa 1860-luvulla, sitten vuosisadan vaihteen niin sanottuina sortovuosina vanhasuomalaisen myöntyvyyssuunnan ja nuorsuomalaisen ja ruotsalaisen perustuslaillisuuden vastakohdassa ja edelleen työväenliikkeen ja porvariston ristiriidoissa. Vuoden 1918 sisällissotaan johtaneen konfliktin teki katkeraksi ja sääntelemättömäksi osaltaan se, että kumpikin osapuoli vaati itselleen oikeutta puhua kansan nimissä. Lopputulos ei voinut olla kompromissi.

Pierre Rosanvallonin $(1998,13)$ kehittelyjä soveltaen voidaan sanoa, että edustaminen liittyi kansan käsitteeseen kahdella tavalla. Ensiksikin kansa edusti: se oli poliittinen representaatio, jossa hajanaisesta ja moninaisesta tuli yksi ja kokonainen. Toiseksi kansaa edustettiin: se antoi poliittisen valtuutuksen. Ilkka Liikanen (1995; 2003, 280-282) tähdentää, että kansan tahdon nostaminen poliittiseksi argumentiksi suomalaiskansallisessa liikkeessä haastoi vallanpitäjät ja tähän haasteeseen sisältyi myös viittaus Ranskan vallankumouksen perintöön. Kansa poliittisen valtuutuksen antajana asetettiin sen ulkopuolelle rajattuja hallitusherroja vastaan. Vallitsevien valtasuhteiden haastamiselle loi kuitenkin edellytyksiä myös kansan käsitteeseen yhdistynyt yhden ja eheän kansakunnan merkitys. Rosanvallonin erotteluja edelleen hyväksikäyttäen voi todeta, että tämä haaste syntyi ykseyttä edellyttäneen "poliittisen" kansan ja hajanaisen ja moninaisen "sosiaalisen" kansan ratkaisemattomasta jännitteestä. Poliittisen kansan, kansakunnan, kehittyminen loi edellytyksiä myös luokkaristiriidan poliittiselle avautumiselle.

Työväenliikkeen tuomio luokkayhteiskunnalle sai voimaa yhteisen kansallisen merkitysjärjestelmän kehittymisestä. Liike nousi kantamaan ja laajentamaan kansakuntaa luonutta kulttuurista merkitysjärjestelmää, kansakuntaa "kuviteltuna yhteisönä", kuten Benedict Andersonin (1983; 2007) käsite kuuluu. Tämä kuviteltu yhteisö voitiin omaksua mittapuuksi, jonka avulla arvosteltiin alistusta ja oikeudettomuutta sekä tuomittiin kansallista yhteisyyttä opettaneet mutta omaa yhteiskunnallista ylem- 


\section{Pauli Kettunen}

myyttään vaalineet herrat ja isännät. Työväenliike saattoi näin tarjota rahvaan sosiaalisen alistuksen kokemuksille ja myös herravihan traditiolle poliittisen tulkintakehyksen, joka liitti paikalliset kokemukset yhteiskuntaa jakavaan luokkaristiriitaan. Samalla kun työväenliike teroitti luokkaristiriitaa, se sitoutui taisteluun oikeudesta edustaa kansan tahtoa.

Eduskuntauudistuksen vaihetta, vuosia 1905-1907, voidaan tarkastella yksilölliseen kansalaisuuteen ja puoluejärjestelmään perustuvan edustuksellisen politiikan muotoutumisena. Se oli kuitenkin myös poliittisen mobilisaation vaihe, jossa sosiaaliset erot ja alistussuhteet kääntyivät poliittisiksi ristiriidoiksi. Venäjän keisarivallan horjunnan käynnistämässä murroksessa esivallan auktoriteetti heikkeni ja samalla myös isäntien ja työnantajien valta alustalaisiinsa ja työläisiinsä. Uudet mahdollisuudet, odotukset ja tavoitteet avautuivat. Miesten ja naisten suhteita määriteltiin uusilla, patriarkaalista ajattelua kyseenalaistaneilla tavoilla. Samaan aikaan oli hahmottumassa, kuten Irma Sulkunen (1986, 157-172) korostaa, sukupuolen mukaan jakautuva moderni kansalaisuus, jonka sukupuolittuneisuus liittyi julkisen ja yksityisen jakoon.

Väittely siitä, kuka puhuu kansan nimissä ja kuka taas itsekkäiden ryhmä- tai luokkaetujen, oli poliittisen retoriikan keskeistä sisältöä vuoden 1906 eduskuntauudistuksen vaiheissa. Se oli pääjuonena myös ”Punaisessa julistuksessa", joka ilmaisi työväenliikkeen tavoitteet marraskuun 1905 suurlakon aikana. "Kansan etuja ja oikeuksia valvomaan valittu komitea" vetosi siinä "koko Suomen kansaan", jotta se asettuisi tukemaan julistuksen vaatimuksia. Niissä "proletariaatti" varoitti kansan nimissä "omistavia luokkia” pyrkimyksestä säilyttää "luokkaeduskunta", kuten säätyvaltiopäiviä työväenliikkeen sanankäytössä tuolloin kutsuttiin. ${ }^{8}$ Tämä argumentti, "kansan tahdon" tai "kansan todellisen tahdon" asettaminen porvariston luokkaitsekkyyttä vastaan, toistui tavan takaa kevään 1906 aikana ja hyvin usein myöhemminkin.

Myös eduskuntauudistuksen toteuttama muodollisesti tasavertainen poliittinen kansalaisuus tarjosi mittapuun arvostella olevissa oloissa havaittua ja koettua epätasa-arvoa ja antoi siten voimaa rahvaan tasa-arvoliikkeelle. Kansalaisuuden tavoitteeseen ja saavutukseen voitiin yhdistää myös omistuksen tasajaon vaatimus (Parikka 1997). Suomen poliittisen kielen erityispiirteet antoivat lisätehoa tälle yhteiskuntakritiikille. Kun suomen kieltä muovattiin 1840-luvulta lähtien poliittisten ilmiöiden kä- 
sittelyyn pystyväksi, "kansa", "kansakunta", "kansallinen" ja "kansalainen" - ja myös "kansanvalta" - nivoutuivat yhteen aivan toisin kuin vastaavat käsitteet ranskassa, englannissa, saksassa tai ruotsissa (Pulkkinen 1999; Liikanen 2003). "Kansalainen” viittaa suoraan "kansan jäsenyyteen” (Stenius 2003). Yhden ja kokonaisen korostaminen oli tätäkin tietä käännettävissä sorron kritiikiksi: puute ja alistus eivät vastanneet sitä, mitä kansan ja kansalaisen käsitteet edellyttivät. Samalla kansan käsite politisoitui myös erontekojen välineeksi. Sen vastakäsitteitä saattoivat olla vallanpitäjät tai sivistyneistö.

\section{Kamppailu kansanvallasta}

Kansan ykseyteen vetoamalla voitiin tuomita toiminta, joka ilmaisi ja avasi sosiaalisia ristiriitoja. Sen perusteella voitiin kuitenkin tuomita myös ne erilaiset tavat, joilla hallitsevat ryhmät väittivät omia etujaan yleiseksi, kansalliseksi eduksi. Nämä molemmat näkemykset kantautuivat käsityksiin "kansanvallasta". Kumpikin tuomio saatettiin langettaa kansanvallan nimissä.

Vuosien 1917-1918 kokemus ja tulos avasivat mahdollisuuksia käyttää kansanvallan käsitettä, kun vastustettiin sosiaalisten erojen ja vastakohtien esiin nostamista, ennen kaikkea luokkataistelusta puhuvaa työväenliikettä. Suomen valtiollinen itsenäisyys ja "vapaussodan perintö" tarkoittivat monille sisällissodan voittajille, että Suomen kansalla, vapaussodan voittaneella kansalla, oli nyt valta ja näin ollen vallitsi kansanvalta (Kettunen 2001, 15-37). Vuoden 1918 valtio- ja hallitusmuototaistelun osapuolet puhuivat "lujasta hallitusvallasta" ja "kansanvallasta", mutta edellinen ei ollut vain monarkistisen oikeiston eikä jälkimmäinen vain tasavaltalaisen keskustan tunnus, vaan vaihtelevin tavoin nämä yhdistettiin (Räsänen 1998, 263-272; Pohjantammi 2003, 398-405).

Toisen maailmansodan jälkeen niiden, jotka vastustivat sosiaalisista ristiriidoista lähtevää - "kansaa jakavaa" - toimintaa, oli aiempaa tärkeämpää kyetä perustelemaan tällainen toiminta kansanvallan vastaiseksi. Maailmansodan tuloksena tuli poliittisesti mahdottomaksi vaatia, että kansan eheyden turvaamiseksi demokratia olisi hylättävä, ja niin Suomes- 


\section{Pauli Kettunen}

sa kuin muuallakin kamppailu ohjautui koskemaan demokratian oikeata määrittelyä.

Työväenliikkeen luokkapohjaisen toiminnan tulkitseminen epäkansanvaltaiseksi oli toisen maailmansodan jälkeisessä Suomessa osa kansallisen jatkuvuuden konservatiivista puolustamista (ks. esim. Smolander 2006, 61-67, 84-91). Tässä voitiin edelleen hyödyntää käsitteellisiä mahdollisuuksia, joita tarjosi se, että suomenkielisen poliittisen sanaston luomisvaiheessa 1800-luvulla "demokratian" vastineeksi oli omaksuttu "kansanvalta". Kansanvaltainen katsomus tarkoitti esimerkiksi historioitsija Pentti Renvallille kokonaisuuden edun huomioonottamista vastakohtana luokkakatsomukselle ja ryhmävallalle. Tällaiseen laaja-alaisuuteen ja kaukokatseisuuteen ihmiset yltivät kulttuurievoluution myötä vinorintamana, joten luokkakatsomusten ollessa vielä voimissaan yleinen äänioikeus oli kansanvallan kannalta ongelmallinen (Kettunen 1997, 173-176).

Kapeakatseisten ja lyhytnäköisten vaikutus oli erityisen haitallista taloudellisissa asioissa. Tämä näkemys oli saanut Euroopassa huomattavaa vaikutusvaltaa ensimmäisen maailmansodan jälkeen. Yleisen äänioikeuden tuolloinen läpimurto ajankohtaisti "määrävallan" uhan. Sen porvaristo halusi salvata valtion hallinto- ja pakkovaltakoneiston avulla sekä erilaisin keinoin, joilla varmistettaisiin "tervettä" taloutta koskeva asiantuntemus poliittisessa päätöksenteossa. Keinovalikoimaan kuului korporatismi, taloudellisten ryhmien valtiollinen edustus. Tämä näkökohta oli esillä Suomessakin, kun osa valtiomuototaistelun monarkisteista vuonna 1918 kaavaili eduskuntaan korporatiivista toista kamaria.

Huolta siitä, miten poliittinen demokratia syrji asiantuntemusta, voitiin kuitenkin perustella myös kansanvallan turvaamisella. Tasavaltalaisten perustamassa kansallisessa edistyspuolueessa monet katsoivat etenkin 1930-luvun lamavuosina, että poliittinen demokratia vaati tuekseen ja turvakseen edustusmuotoja, jotka kanavoivat taloudellisen asiantuntemuksen päätöksentekoon. He kannattivat pysyvän talousneuvoston perustamista, joskin hanke jäi tuolloin toteutumatta. Ajatuksena oli tukea myös "henkisen työn" asiaa. Sen mukaan ruumiillisen työn puolueista muodostunut eduskunnan enemmistö ei ymmärtänyt henkisen työn etenkään virkamiesten tekemän työn - keskeistä merkitystä kansakunnan edistäjänä ja koossapitäjänä (Kettunen \& Turunen 1994, 77-84). 
Oli kaiken kaikkiaan taattava, että äänensä saisivat esille ensiksikin ne lukumäärältään pienet ryhmät, jotka olivat kokonaisuudessa keskeisiä, eli talouselämän toimijat, ja toiseksi ne, joiden nimenomaisena tehtävänä oli toimia kokonaisuuden edun osoittajina, kansakunnan aivoina, kuten henkisen työn asianajajien suosima metafora esitti.

Sosialistisen näkemyksen mukaan porvaristo ajoi omia luokkaetujaan yhteisen kansallisen edun valepuvussa. Renvallin tavoin sosialistitkin sitoivat näkemyksensä maailmanhistorian lainalaisuuksiin. Oikeaa kansallista etua ajoi työväenluokka, jolle sen maailmanhistoriallinen vapautustehtävä antoi oikeuden samastaa omat etunsa ihmiskunnan etuun. Ja viimeistään Snellmanin perinnöstä taistellessaan suomalaiset sosialistit esimerkiksi Yrjö Sirola jo vuonna 1906 (Kurumäki 2006) - omaksuivat luottamuksen siihen, että oikein tulkittu kansallinen etu oli sopusoinnussa ihmiskunnan edun kanssa.

"Valtiollinen kansanvalta" avasi mahdollisuuden muuttaa valtio luokkayhteiskunnan kumoamisen välineeksi. Näin opetti ensimmäistä maailmansotaa edeltäneen kansainvälisen työväenliikkeen aatteellinen pääsuunta, Toisen internationaalin (1889-1914) marxismi. Myöhemmin kansanvallasta tuli Toisen internationaalin perillisille, vaihtelevin tavoin niin sosiaalidemokraateille kuin kommunisteille, myös valtion avulla aikaansaatavan yhteiskunnallisen muutoksen sisältöä kuvaava käsite. Valtiollisessa ja kunnallisessa päätöksenteossa saavutettu kansalaisten tasaarvoinen edustusoikeus voitiin tulkita porvarilliseksi demokratiaksi, joka ei toteuttanut todellista kansanvaltaa, koska se ei ulottunut luokkavastakohtien ja -etujen muotoutumisen alueelle eli talouteen.

Jo ensimmäisen mutta varsinkin toisen maailmansodan jälkeen työväenliikkeen eri suunnilla puhuttiin "taloudellisesta kansanvallasta". Tämä saattoi tarkoittaa samaa kuin sosialismi, sosialismin yhtä ominaisuutta, sosialismin toteuttamisen keinoa, askelmaa kohti sosialismia tai jo sosialismin korvaavaa tavoitetta. Taloudellisen kansanvallan muotoina voitiin pitää demokratisoidun valtion toimintaa kansantalouden ohjaajana ja poliittisen demokratian täydentämistä työntekijäin järjestöjen osallisuudella talous- ja sosiaalipoliittiseen päätöksentekoon. Kuitenkin käsitteen alle kuuluivat myös työpaikoilla ja yrityksissä aikaansaatavat työntekijäin edustuksellisen vaikuttamisen tavat, joita alettiin 1960-luvulla kutsua yritysdemokratiaksi. 


\section{Pauli Kettunen}

Kansanvallan ja talouden kytkiessään niin taloudellisen asiantuntemuksen pelastajat kuin kansanvallan laajentajat tulivat avanneeksi erilaisten ryhmäetujen muotoutumisen, kamppailemisen ja sovittelemisen kenttää. Miten ryhmäedut ja kansallinen etu voitiin sovittaa toisiinsa? Miten voitiin tunnustaa eri ryhmien erityisetuja ja käydä niitä koskevia kamppailuja ja sovitteluja, jos kaikki katsoivat edustavansa yleistä etua ja käsitykset yleisestä edusta olivat vastakkaisia?

\section{Kaksi työtätekevää kansaa}

Kansan käsite edellytti ykseyttä, mutta oli myönnettävä, että kansa oli moninainen ja hajanainen. Vuoden 1918 sisällissodan jälkeen tämä jännite ilmeni jo siinä, että oli olemassa useita "vapaussodan perintöjä" eli vuoden 1918 kokemuksen ja tuloksen valkoisia tulkintoja. Maalaisliiton nousu on tältä kannalta kiinnostava.

Yhtäältä maalaisliiton kohoaminen poliittisen järjestelmän keskeiseksi puolueeksi näytti saattavan täytäntöön vapaussodan tuloksen: voittaja oli ytimeltään talonpoikaiseksi määritelty Suomen kansa. Tämä kehityskulu näytti myös toteuttavan ja vahvistavan suomalaisen kansakunnan rakentamisen voimaa, talonpoikaiston ja sivistyneistön liittoumaa. "Me yhdymme kaikin hänessä, leivänkasvattajamiehessä", maalaisliiton johtaja Santeri Alkio kirjoitti vuonna 1919. Toisaalta kuitenkin maalaisliitto ilmaisi vapaussodan voittaneen kansan sisäistä ristiriitaisuutta. Ensiksikin se kanavoi maalaisväestön epäluuloa valtiokoneiston ja liike-elämän herroja kohtaan. Maalaisliittolaiset tulkitsivat kansanvallan kansan keinoksi suojautua virka- ja rahavallalta, jotka he lisäksi yhdistivät vastustajinaan ruotsinkielisyyteen. Toiseksi puolue ilmaisi kansan sisäistä ristiriitaisuutta yhä enemmän myös sillä tavoin, että se muotoili ja ajoi maanviljelijäväestön taloudellisia erityisetuja. (Kettunen 1986, 235-236, 248-253.)

Jakautuvan työväenliikkeen molempia pääsuuntia, sosiaalidemokratiaa ja kommunismia, ehdollisti se, että oli vaikeata kuvitella mitään rakenteellisten uudistusten linjaa, konkreettista utopiaa, joka olisi ollut enemmän kuin yksittäiset lakiteitse aikaansaatavat uudistukset ja vähemmän kuin sosialistinen yhteiskunta. Vuoden 1918 jälkeinen poliittinen järjestelmä perustui yleiseen äänioikeuteen, joka ulotettiin vihdoin myös 
kunnallishallintoon, mutta samalla valtion pakkovaltakoneisto ja ideologiset laitokset, kuten koulu, kuvastivat ja vakiinnuttivat sisällissodan tulosta. Lähitavoitteiden ja lopullisen päämäärän jako pysyi niin sosiaalidemokraattien kuin kommunistien toiminta- ja ajattelutavoissa, mutta se hahmottui eri tavoin. Sosiaalidemokratia sitoutui parlamentaariseen demokratiaan, kun taas kommunismi eristettiin ja eristäytyi pakkovaltakoneiston vainoamaan kumouksellisuuteen. Kuitenkin kumpaakin suuntaa läpäisi vuoden 1918 punaisen perinnön vahvistama ajatus työväenluokasta leirinä porvarillisessa yhteiskunnassa. Yhteinen leiri-ideologia teki sosiaalidemokraattien ja kommunistien kiistat erityisen katkeriksi, sillä se sai kiistakumppanin toiminnan näyttämään petokselta.

Vuonna 1937 maalaisliitto ja sosiaalidemokraatit sopivat hallitusyhteistyöstä. Muodostettiin ensimmäinen punamultahallitus. Se ei syntynyt samassa määrin talouslamasta tehtyjen uusien talouspoliittisten johtopäätösten pohjalta kuin aiemmin 1930-luvulla Tanskassa, Ruotsissa ja Norjassa aikaansaadut "työmiehen ja talonpojan" yhteistyösopimukset (Kalela 1989, 88-101; Pekkarinen \& Vartiainen 1993, 83-95). Tästä koalitiosta ei myöskään tullut samanlaista askelmaa sosiaalidemokratian tiellä valtaan kuin etenkin Ruotsissa, vaikka sosiaalidemokraattien asema Suomen poliittisessa järjestelmässä ja myös heidän vaalikannatuksensa näytti 1930-luvun lopulla varsin "pohjoismaiselta".

Punamultayhteistyön alkaminen osoittautuu kuitenkin merkittäväksi käänteeksi, kun avuksi otetaan yhteisestä edusta lähtevän konsensuksen ja etujen pysyvästä erilaisuudesta lähtevän kompromissin erottelu. 1920ja 1930-luvun aiemmassa hallitus- ja eduskuntapolitiikassa kamppailivat vastakkaiset konsensusideaalit, kansan käsittämisen tavat. Tämän kamppailun rajoissa tehtiin pragmaattisia kompromisseja. Niihin pakotti jo valtiopäiväjärjestyksessä ilmaistu epäluottamus yksinkertaisella enemmistöllä tehtäviin päätöksiin. Maalaisliittoa ja sosiaalidemokraatteja erotti vuoden 1918 valkoisen ja punaisen kokemuksen vastakohta. Siihen liittyi taistelu, jossa oli vastakkain kaksi käsitystä työtätekevästä kansasta. Toinen oli talonpoikainen kansa, toiseen taas viittasi käsite "työväki”, jolla oli Suomen työväenliikkeen kielenkäytössä sosiaalisesti laaja sisältö mutta ennen kaikkea poliittinen merkitys. Taistelu koski sitä, miten ihmiset poliittisesti tulkitsivat sosiaaliset kokemuksensa, ja päällimmäinen 


\section{Pauli Kettunen}

kysymys oli se, kuuluisiko maaseudun vähäväkinen väestö talonpoikaiseen kansaan vai työväkeen.

Punamultahallitusta muodostettaessa jätettiin taka-alalle kamppailu siitä, kenellä oli oikeus ja valta puhua kansan nimissä ja määritellä kansa. Uuden hallituskoalition puolueet tunnustivat vastavuoroisesti edustavansa vain kansanosia, tiettyjä väestöryhmiä ja näiden erityisetuja, joiden yhteensovitus toteuttaisi kansallisen edun. Samalla ylitettiin myös vuoden 1918 kahden kansan raja.

Ideologinen jännite itsenäisen talonpojan oman työn ja kollektiivisen teollisen palkkatyön välillä pysyi kuitenkin Suomessa poliittisesti merkityksellisempänä kuin muissa Pohjoismaissa. Tämä perustui osaksi siihen, että Suomen elinkeinorakenne säilyi pitempään maatalous- ja maaseutuvaltaisena ja myös maanviljelijäväestöä edustavan puolueen voima suurempana. Kyse oli kuitenkin myös poliittisen hegemonian eroista. Vuoden 1918 sisällissodasta 1950-luvulle saakka itsenäisten pienviljelijöiden kerrostuman vahvistaminen näyttäytyi suurelle osalle porvarillista Suomea yhteiskuntajärjestyksen turvana. Maansa omistavan talonpojan työhalu oli vastavoimana teolliseen palkkatyöhön liitettyjä uhkia, lakkoilua sekä sosialismia ja kommunismia, vastaan.

\section{Ristiriitojen tunnustaminen ja demokratisointi}

Yhtenäisyyden pelastamiseksi oli pakko sietää erimielisyyttä. Tälle ajattelutavalle oli luonut edellytyksiä se, miten kansallisen yhteisyyden sisäiset ja ulkoiset ehdot olivat kietoutuneet toisiinsa: miten - 1900-luvun alun käsittein - "yhteiskunnallinen kysymys" ja "valtiollinen kysymys" eli luokkaristiriidat ja suhde Venäjään/Neuvostoliittoon lomittuivat yhteen. Risto Alapuron $(1997,196)$ mukaan sisällissodan jälkeisessä 1920ja 1930-luvun Suomessa tuli hallitsevaksi "omalaatuinen yksimielisyyden vaatimisen ja erimielisyyden sietämisen yhdistelmä". Niin sanotussa kansallisen eheytyksessä "(e)rilaisuuden sallimisen motiivina oli kansallisen konsensuksen vahvistaminen".

Skandinavian maiden 1930-luvun luokkakompromisseihin kuului jo aiemmin kehittyneen työehtosopimusjärjestelmän lujittaminen ja keskittäminen. Suomessa erityisesti tehdasteollisuuden työnantajat pystyi- 
vät toiseen maailmansotaan saakka pitämään kiinni työehtosopimuksia vastustaneesta toimintalinjasta. Kollektiivinen edunvalvontajärjestelmä pystytettiin sodan, sotakorvausten ja jälleenrakennuksen vuosina, kansallisiksi välttämättömyyksiksi ajateltujen tehtävien kehystäessä ratkaisuntekoa.

Toisen maailmansodan ja sen jälkivaiheen kokemukset kietoutuivat suomalaisen kansakunnan rakentamisvaiheen ja vuoden 1918 sisällissodan poliittis-mentaalisiin seurauksiin. Näiltä pohjin tapa mieltää eturyhmien kompromissin ja yhteiskunnallisen hyvän suhde muotoutui toisenlaiseksi kuin Ruotsissa. Ruotsalaista "kansankotia” rakennettiin sosiaalidemokraattien johdolla sellaisen ajattelun mukaisesti, että organisoituneiden eturyhmien kompromisseista ja demokraattisen valtion yhteiskuntapolitiikasta muodostui taloudellista kasvua, sosiaalista tasoitusta ja laajentuvaa demokratiaa yhdistävä kansallisen yhteishyvän kehä. Suomessa taas kompromissi määrittyi välttämättömyydeksi, johon oli mentävä yhteisen hyvän pelastamiseksi. Näin ajattelivat toisen maailmansodan jälkeen sekä ne, joiden mielestä yhteishyvä edellytti vallitsevan yhteiskuntajärjestelmän säilyttämistä, että ne, joiden mukaan yhteishyvän toteuttaisi vasta järjestelmän muutos.

Kun yhteinen kansallinen tehtävä, miten kukin sen määrittelikin, kävi vähemmän pakottavaksi, sisäpolitiikan ilmiasuksi tulivat 1950-luvulla eturyhmien paljaat tulonjakotaistelut ja lyhyen tähtäyksen kompromissit. Palkkatyöläisten, työnantajien ja maataloustuottajien ristiriidat ilmenivät kärjistyneimmin vuoden 1956 yleislakossa. Ristiriitojen ja kompromissien tuloksena syntyi myös sosiaaliturvan uudistuksia, jotka eivät vastanneet kenenkään alkuperäisiä tavoitteita mutta osoittautuivat merkittäviksi.

Tulonjaon ristiriitoja voimisti niiden kytkeytyminen Erik Allardtin (1964, 144-151) erottelemiin suomalaisen yhteiskunnan "perusvastakohtaisuuksiin". Niissä olivat vastakkain suomenkieliset ja ruotsinkieliset, maalaiset ja kaupunkilaiset, työväenluokka ja porvaristo sekä kommunistit ja kaikki muut. Nämä vastakohtaisuudet olivat kehittyneet eri aikoina, ja ne kerrostuivat ja lomittuivat toisiinsa. Kaikkiin niihin oli niiden muotoutuessa latautunut enemmän kuin vain väestöryhmien etujen ristiriitoja. Ne olivat myös poliittista kamppailua Suomen kansan ja 


\section{Pauli Kettunen}

suomalaisuuden oikeasta määrittelystä ja määrittelyoikeudesta. Yhden ja kokonaisen kansan ideaali oli vahvistanut näitä vastakohtaisuuksia.

Tietoinen irtiotto tästä ideaalista sai tärkeän sijan nopean rakennemuutoksen tulkinnoissa 1960-luvulla. Allardt ja muut sosiologit auttoivat perustelemaan sitä: tunnustettuina ja säänneltyinä ristiriidat olivatkin hyödyllisiä yhteiskunnan toimintakyvylle ja kiinteydelle. Kommunistien tulo hallitukseen vasemmiston vuoden 1966 vaalivoiton jälkeen samoin kuin tulopolitiikaksi kutsutut toimintatavat vuodesta 1968 vastasivat tätä Kekkosen tukemaa näkemystä kansallisesta eheytyksestä. Muutoksessa oli tosin, Alapuron (1997, 195-197) sanoin, "pakotetun pluralismin" piirre. Ulkoisten välttämättömyyksien määrittämä kansallinen yhteisetu oli edelleen vahvana ohjenuorana, liitettiinpä välttämättömyydet sitten Suomen ja Neuvostoliiton suhteisiin tai vientiteollisuuden kansainväliseen kilpailukykyyn. Kamppailu siitä, kuka määritteli kansallisen edun oikein, ei liioin päättynyt. Kuitenkin ristiriitojen tunnistamiseen ja tunnustamiseen liittyi merkittävä ulottuvuus: demokratisointi.

Demokratian laajentaminen sai 1960-luvun lopulla uutta läpäisyvoimaa määriteltäessä poliittisen kamppailun kohteeksi tulevia kysymyksiä eli poliittista agendaa. Demokratisointi prosessikäsitteenä viittasi yhteiskunnan muuttamisen sisältöön eikä vain keinoihin. Se edellytti alistussuhteiden tunnistamista eri elämänalueilta ja niiden osoittamista yhteiskunnallisiksi ristiriidoiksi.

Ongelmien tunnistajat ja ratkaisujen muotoilijat johtivat alistettuja joukkotoimintaan ja tavoittelivat lakeja ja sopimuksia. He etenivät eri suuntiin ja vaihtelevan pitkälle, mutta radikalismi, reformismi ja viileä tieteellisyys myös kietoutuivat yhteen. Tämä näkyi 1960-luvun lopulla perustetuissa uusissa liikkeissä. Niitä saatettiin kutsua yhden asian liikkeiksi, mutta niiden toimijoista monet olivat usean liikkeen aktiiveja ja ne kaikkiaan määrittelivät yhteiskuntaa laajasti poliittisen toimeliaisuuden edellytyksiksi ja politiikkojen kohteiksi. Esimerkiksi kontrollipolitiikkaa kritisoinut Marraskuun liike kannusti poikkeaviksi määriteltyjä ihmisiä joukkotoimintaan, luotti tieteelliseen suunnittelutietoon ja tähtäsi lainsäädännöllisiin uudistuksiin (Honkala 2010).

Yhteiskunnan muuttamisen pääsuunnaksi muotoutui toiminta- ja ajattelutapa, jota voi kuvata valtion ja yhteiskunnan yhdistäväksi demokratisoinniksi. Se kanavoitui ennen kaikkea sosiaalidemokratiassa. Kuta- 
kin yhteiskunnan lohkoa ohjattaisiin demokraattisen valtion tarkoituksenmukaisella, rationaalisella politiikalla, jossa politiikan kohteena olevien ihmisten ääni kuuluisi heidän etujärjestöjensä kautta. Samalla kullekin elämänalueelle - työelämään, kouluihin, yliopistoihin ja niin edelleen luotaisiin demokraattisen osallistumisen edustuksellinen järjestelmä.

Demokratisoinnin viitekehyksessä yhteiskuntaa arvosteltiin siitä, etteivät olevat olot vastanneet tasa-arvoisen yksilöllisen kansalaisuuden vaatimuksia. Yhteiskuntakritiikki kohdistui myös siihen valtaan, joka ilmeni hallitsevien ryhmien mahdollisuuksina esittää erityisetunsa yleisinä etuina. Tämän kritiikin vasemmistolaiset esittäjät hakivat erilaisin muunnelmin tukea sosialistisen työväenliikkeen vanhasta luottamuksesta siihen, että yleisen edun oikeita edustajia olivat alistetut ryhmät, työväenluokka, jonka maailmanhistoriallisena tehtävänä oli alistuksen lakkauttaminen. Yleisen edun edustamisesta käyty kamppailu ei kuitenkaan peittänyt sitä, että 1960- ja 1970-luvun demokratisointi merkitsi käytännössä sen asiapiirin laajentamista, jossa ilmaistiin erityisetuja ja tehtiin niiden kompromisseja. Näin tapahtui etenkin työelämässä. "Pohjoismaisen mallin" mukaisesti ammattiyhdistysliike pyrki ja myös onnistui laajentamaan niiden asioiden ja toimintojen kenttää, joissa niin yritykset kuin valtio ja kunnat joutuivat tunnustamaan työnantajaetunsa vain erityiseduiksi ja sopimaan työntekijöiden erityisetujen edustajien kanssa.

\section{Kansallinen kilpailukyky-yhteisö}

Suunta muuttui 1980-luvulla. Aiemmin ammattiyhdistysliike ja työnantajat olivat kamppailleet siitä, missä märrin managementin kysymyksiä voitiin vetää kollektiivisten neuvottelu- ja sopimussuhteiden piiriin. 1980-luvulla ammattiyhdistysliike joutui puolustusasemiin, joista se pyrkii osoittamaan, että kollektiivisen intressiedustuksen instituutiot ovat tarpeellisia ja hyödyllisiä management-näkökulmasta eli kilpailukykyisen yritystoiminnan kannalta. Työntekijöiltä ja heidän edustajiltaan edellytetään kykyä tarkastella omaa työtään yrityksen tai tuotantoyksikön kilpailukyvyn ja sen kansallisten tai paikallisten edellytysten kannalta.

Tämä oli osa yleisempää muutosta, jossa demokratian ja politiikan rajat määriteltiin uudelleen. Uusliberalismi voimistui 1980-luvulla yli- 


\section{Pauli Kettunen}

kansallisena ideologiana, jossa vapaa markkinatalous ja demokratia lankesivat yhteen. Muutosta vahvisti se, että niin sanotun reaalisosialismin romahduksen myötä kapitalismista tuli globaali talousjärjestelmä vailla varteenotettavaa haastajaa.

Yhteiskunnan sisäinen poliittinen integraatio oli 1980-luvulle saakka olennainen ongelma kansallista toimijuutta koskeneissa kysymyksenasetteluissa. 1980-luvulla huoli yhteiskunnallisista ristiriidoista painui taka-alalle, eikä edes 1990-luvun alkupuolen syvä lama ja suurtyöttömyys nostanut sitä keskeiseksi kysymykseksi. Kun kapitalismin haastaneet järjestelmät ja liikkeet hajosivat, yhteiskunnallisista ristiriidoista purkautui niihin pitkään sisältynyt talous- ja yhteiskuntajärjestelmän perusteita koskenut poliittinen lataus.

Kilpailukyky ei ole uusi vaatimus. Myös pohjoismaisten hyvinvointivaltioiden rakentamisen aikana maailmanmarkkinariippuvuus ja kilpailukyky olivat vaikuttavia näkökohtia. Pohjoismaissa omaksuttiin laajalti ajattelu, jonka mukaan taloudellinen kasvu, sosiaalinen tasoitus ja demokratian laajentaminen tukevat toisiaan. Siinä, miten kansallinen "me" kuvataan globalisaatiokeskustelussa vastaamassa uusiin haasteisiin, näkyy jatkuvuuksia tästä vanhasta hyvän kehän ideologiasta.

Kilpailukyvyn käsite sai kuitenkin uusia merkityksiä eritoten globaalien rahamarkkinoiden myötä. "Meidän" on tuotettava ja markkinoitava kilpailukykyinen toimintaympäristö globaalin talouden toimijoille, jotka vertailevat eri toimintaympäristöjä ja joiden ratkaisut ohjaavat sijoitusten, tuotannon, työpaikkojen ja niin sanotun luovan luokan liikkuvuutta. Tässä kantautui uusin muodoin jatkuvuus ajattelu- ja toimintatavasta, jossa ulkoisiin pakkoihin vastataan sisäisellä tahdolla. Globalisaatio näyttäytyi kansallisen yhteiskunnan ulkoisen toimintaympäristön muutoksena, ulkoisina haasteina, joihin vastataan tekemällä kansallisesta yhteiskunnasta kilpailukykyinen toimintaympäristö. Globalisaatio luonnollistettiin ja kansallinen yhteiskunta tuotteistettiin.

Kun kysymykset, jotka aikaisemmin kuuluivat kansallisen politiikan agendalle, ovat tulkittavissa ulkoisen ympäristön pakottaviksi ehdoiksi, kansallisen yhteisyyden retoriikalle avautuu uusia mahdollisuuksia. Tämä näkyi Suomessa 1990-luvulla suhtautumisessa globalisaatioon ja Euroopan integraation uuteen vaiheeseen, joka oli osa globalisoituvan talouden regionalisoitumista. Talous ja politiikka suhteutettiin toisiinsa 
kahdella tavalla. Yhtälttä kansallinen yhteisyys tuettiin näkemykseen, jonka mukaan politiikan kuuluu verraten vaihtoehdottomasti toteuttaa talouden määräämiä välttämättömyyksiä. Toisaalta kansallinen yhteisö taas hahmottui valtion aktiivisin toimin luotavaksi toimintaympäristöksi rajattoman innovatiiviselle taloudelle. Tätä kuvastivat 1990-luvun alussa julkiseen keskusteluun tulleet tunnukset "tiedon ja osaamisen Suomi" sekä "kansallinen innovaatiojärjestelmä". Politiikka talouden välttämättömyyksien reaktiivisena toteuttamisena ja politiikka innovatiivisen talouden edellytysten aktiivisena luomisena olivat kaksi puolta siinä, miten kansallisvaltio kilpailuvaltiona rakensi ja vaali kansallista kilpailukykyyhteisöä.

Poliittisten kokemusten, perinteiden ja valtasuhteiden erot ovat näkyneet siinä, miten Suomessa ja Ruotsissa on käsitelty globalisaatiota ja Euroopan integraatiota. Ruotsissa kansalliselle poliittiselle agendalle kuuluneiden asioiden siirtymistä ulkoisten välttämättömyyksien maailmaan on ollut vaikeampi hyväksyä. Ainoana Pohjoismaana Suomi päätti 1990-luvun lopulla liittyä euroalueeseen. Suomalaiseen poliittiseen puhuntaan ilmaantui ennen kokematon ylemmyydentunto suhteessa Ruotsiin. Monista Suomen politiikan päättäjistä Ruotsin vitkuttelu tässä asiassa ja lopulta vuoden 2003 kansanäänestyksen nojalla tehty kielteinen päätös johtui johtajuuden puutteesta ja kansalaismielipiteen liiallisesta kunnioituksesta. Kunnon johtajuus merkitsee vastuun ottamista välttämättömien vaikka ehkä epäsuosittujen ratkaisujen tekemisestä, ja hyväksyntä voidaan hankkia jälkikäteen ratkaisujen välttämättömyyden ja peruuttamattomuuden tullessa selväksi.

Suomessa 1990-luvun alkuvuosien syvä lama loi edellytyksiä taloudellisia pakkoja korostavalle konsensualismille, konsensukselle konsensuksen välttämättömyydestä. Lamaan vetoamalla oli mahdollista myös oikeuttaa ratkaisuja, joiden sisältönä oli sopeutuminen ja myötävaikuttaminen jo sitä ennen ja siitä riippumatta alkaneisiin muutoksiin, joita 1990-luvun alkupuolella alettiin kutsua globalisaatioksi. Lama sijoittui uutena vaiheena kansallisten koettelemusten pitkään historiaan, ja siitä tuli myös osa kansallisen selviytymisen kertomusta. Selviytyminen 1990-luvun lamasta nivoutui samalla uuteen tiedon ja osaamisen Suomen menestystarinaan. 


\section{Pauli Kettunen}

\section{Kestokriisin kansallinen työjärjestys ja sen säröt}

Menestystarinoiden hillitseminen on kuitenkin suomalaisen poliittisen kulttuurin pitkää linjaa. Poliittisen vastuuntunnon vastakohtana on kriisitietoisuuden puute eli piittaamattomuus senhetkisen tai odotettavissa olevan kriisin vaatimuksista. Poliittinen tehtävänasettelu on vaivattomasti muotoutunut eräänlaiseksi kestokriisin kansalliseksi työjärjestykseksi.

Antiikin Kreikasta tuleva kriisin käsite viittaa pakottavaan ratkaisuja valintatilanteeseen, kriittiseen tilaan, jossa vaihtoehdot ovat lopullisia, äärimmäisiä. Saksalainen käsitehistorioitsija Reinhart Koselleck (2006, 203-217) on päätellyt, että tämä lääketieteestä kaikille elämän ja tiedon alueille laajentunut käsite on saanut länsimaisen historiakäsityksen historiassa kolme erilaista merkitystä. Ensiksikin kriisin käsite on viitannut johonkin vahvassa mielessä lopulliseksi ajateltuun ratkaisuun, teologisena lähtökohtana viimeinen tuomio. Toisessa merkityksessään kriisi on periodisoiva käsite, joka viittaa yhden ajanjakson päättävään ja toisen aloittavaan murrokseen. Kolmanneksi kriisi on prosessikäsite, Dauerkrise eli kestokriisi, jota ylläpitää kussakin ainutkertaisessa tilanteessa toistuva ratkaisun pakko.

Suomalaisessa kestokriisin kansallisessa työjärjestyksessä yhdistyvät ulkoiset pakottavat välttämättömyydet ja niitä tinkimättä täyttävä sisäinen tahto. Perusteluiksi mobilisoidaan usein myös kahta muuta Koselleckin mainitsemaa kriisin merkitystä. Meidän kerrotaan elävän juuri nyt keskellä syvää murrosta, joka päättää vanhan aikakauden ja aloittaa uuden. Siksi meidän on heitettävä syrjään vanhan aikakauden rasitteet. Samaan aikaan kansallinen "me" kuitenkin edustaa syvää pysyvyyttä ja jatkuvuutta, jota perusteltaessa viitataan kriisin kohtalokkaimpaan, lopullisimpaan merkitykseen, kansallisen olemassaolon uhkaan, sotaan ja siitä selviytymiseen.

Samalla kansallinen olemassaolo yhdistyy vaivattomasti suomalaisen työn tulevaisuuteen. Vuonna 2004 Elinkeinoelämän Valtuuskunta EVA julkaisi raportin Suomen menestyksen eväät. Sen laati Suomen Kuvalehden päätoimittaja Tapani Ruokanen. Raportin lukuisiin toimenpideehdotuksiin kuului muun muassa "Korporaatiovallan purkutalkoot ja tilalle yhteinen kumppanuus suomalaisen työn pelastamiseksi" (Ruokanen 2004, 64). 
"Talkoot" on suosituimpia sanoja, joilla oikeanlaisen työnteon ominaispiirteistä tehdään oikeanlaisen kansallisen päätöksenteon ominaispiirteitä. Sana herättää lämpimän tunteen ystävyydestä, yhteistyöstä ja keskinäisestä avunannosta. Samalla "talkoisiin" liittyy velvoittava mielikuva juuri käsillä olevasta välttämättömästä ja kiireellisestä tehtävästä. Talkoista puhuminen ohjaa ajatukset helposti sotavuosiin. Silloin, ihannekuvan mukaan, kaikki täyttivät talkoissa ja talkoohengessä täyttivät vapaaehtoisesti velvollisuutensa ja tekivät sen mitä kansakunnan olemassaolo vaati.

Suomen menestyksen eväitä haettiin EVA:n raportissa sota-ajasta muutoinkin kuin talkoista puhumalla. Suomalaisilta vaadittiin "talvisodan henkeä", ja valoisaa tulevaisuudenuskoa valettiin vakuuttamalla, että "Suomi selviää seinää vasten" (Ruokanen 2004, 9). Kaikessa tässä ilmenee yleisempi puhe- ja toimintatapa, jolla on Suomessa pitkä historia ja jatkuva elinvoima. Läsnä on kriisi joko juuri koettuna opetuksena, parhaillaan koettavana hätätilana tai odotushorisontin tummentajana, ja kaikissa tapauksissa se vaatii yhteisiä ponnisteluja ja kipeitä ratkaisuja.

Konsensuksen ideaali voi kuitenkin edelleen paitsi ehkäistä tai peittää myös kärjistää ja paljastaa ristiriitoja. Globaalin kapitalismin kilpailulogiikka tukeutuu arkiseen itsestään selvään nationalismiin ja samalla ruokkii sitä. Tasa-arvoa, poliittista vakautta, hyvinvointivaltiota, puhdasta ympäristöä ja monia muita hyviä asioita, historiatietoisuuttakin, on mahdollista perustella kansallisina kilpailuetuina. Kuitenkin luottamus siihen, että kaikki hyvät asiat tukevat toisiaan ja palvelevat myös kilpailukykyä, rajaa näkökenttää. Se voi kääntyä käsitykseksi, että asiat ovat hyviä, mikäli ne palvelevat kilpailukykyä. Tällainen konsensualismi ei tavoita niitä erilaisten ihmisten ja ihmisryhmien erilaisia etuja, tarpeita ja tavoitteita, jotka eivät ole taivutettavissa kilpailukyky-yhteisön projektin palvelukseen.

Politiikan konsensuaalista oikeuttamista vaikeuttaa toisaalta se, että globaali kapitalismi mahdollistaa ja edellyttää osan "meistä" vapautuvan kansallisen solidaarisuuden siteistä ylikansallisiksi toimijoiksi. Tulopolitiikan jatkamista tai lopettamista koskenut kiistely 2000-luvun ensimmäisen vuosikymmenen lopulla osoitti, että liike-elämän toimijoilla on vaikeuksia pitäytyä kansallisen konsensuksen totunnaisissa pelisäännöissä, kuten työn ja pääoman pariteettisessa neuvottelu- ja sopimusjärjes- 


\section{Pauli Kettunen}

telmässä. Heillä on poliittisen agendan asettamisessa kaksinaisrooli. $\mathrm{He}$ edustavat ylikansallista taloudellista toimeliaisuutta ja sen vaatimuksia, ja he ovat määrittämässä kansallisia vastauksia näihin vaatimuksiin. ${ }^{9}$ Tähän asetelmaan sisältyvä valta on rakenteellista ja ankkuroituu globaalien finanssimarkkinoiden toimintatapoihin, mutta se, miten palkinnot ja rangaistukset sosiaalisesti ja alueellisesti jakautuvat, murentaa vallan legitiimiyttä.

Euroopan finanssikriisin myötä on tullut uusia piirteitä siihen, miten globaalin finanssikapitalismin vaatimukset välittyvät kansallisen politiikan rajoitteiksi. Euroopan unionin ja erityisesti euroryhmän päätöksenteko on kriisin aikana muotoutunut tällaiseksi välitysmekanismiksi. Siihen sitoutuneet kansalliset poliittiset eliitit kohtaavat kansalaisten protesteja muuallakin kuin velkakriisin syyllisiksi leimatuissa maissa, myös luottoluokittajien suosikkimaassa Suomessa.

Kansallisen konsensuksen elitismiä kyseenalaistavassa kritiikissä on näkyvillä kaksi vastakkaista suuntaa. Toiset haluavat suojata kansallista "meitä" ulkoa tulevilta uhilta ja omien vallanpitäjien petokselta, toiset tavoittelevat kansalaisten ylikansallista poliittista toimijuutta. Perussuomalaisten suurnousu vuoden 2011 eduskuntavaaleissa kanavoi ja politisoi monien muutosten kokemuksia yhdeksi suureksi uhkakuvaksi. Siinä kietoutuivat yhteen maasta muuttavina työpaikkoina ja maahan muuttavina ulkomaalaisina näkyvä globalisaatio ja suomalaisten elämää rajoittava, varojamme nielevä ja kriisejään tartuttava Euroopan unioni. Uhkakuvaa pohjustavissa muutoksissa kansallisen politiikan vaikutusmahdollisuudet ovat pienet, ja tämä tosiasia kääntyy monien mielissä todisteeksi poliitikkojen osallisuudesta samaan pahaan muutokseen.

Toisaalta voidaan entistä vakuuttavammin väittää, että hyvätkään vastaukset kansallisen kilpailukyvyn kysymyksiin eivät riitä vastauksiksi kysymyksiin demokratiasta, kansalaisuudesta, sosiaalisesta tasa-arvosta ja elämän ekologisista ehdoista. On kyseenalaista, miten pitkälle kansallisen hyvinvointi- ja koulutusjärjestelmän tasa-arvoperiaatteita voidaan puolustaa kilpailuetuina globaalissa kapitalismissa. Finanssikriisi on osoittanut, ettei kansallisen kilpailuvaltion logiikka riitä turvaamaan myöskään itse talousärjestelmän toimivuutta. Punavihreäksi kutsutun vaihtoehdon edustajat ovat Suomessakin koettaneet kehitellä kysymyksiä ja vastauksia, jotka olisivat yhtä aikaa paikallisia, kansallisia, eurooppalaisia ja globaa- 
leja. Tämä merkitsee irtautumista ajattelusta, jossa kansallisvaltiollinen yhteiskunta on solidaarisuuden, ristiriitojen ja poliittisen toimijuuden kehys. Silloin myös "me" määrittyy toisin, monikerroksisemmin, kuin kilpailukykynationalismin, hyvinvointinationalismin ja muukalaispelkoisen nationalismin eri muunnelmissa ja yhdistelmissä.

\section{Lähteet:}

Alapuro, Risto. 1997. Suomen älymystö Venäjän varjossa. Helsinki: Tammi. Alapuro, Risto \& Stenius, Henrik. 1987. Kansanliikkeet loivat kansakunnan. Teoksessa Risto Alapuro et al. (toim.), Kansa liikkeessä. Helsinki: Kirjayhtymä.

Allardt, Erik. 1964. Yhteiskunnan rakenne ja sosiaalinen paine. Porvoo: WSOY.

Anderson, Benedict. 1983. Imagined Communities. Reflection on the Origin and Spread of Nationalism. London \& New York: Verso. - Suomennos: 2007. Kuvitellut yhteisöt. Nationalismin alkuperän ja leviämisen tarkastelua. Tampere: Vastapaino.

Ankersmit, Frank. 2002. Political Representation. Stanford: Stanford University Press.

Dean, Mitchel. 1994. Critical and effective histories. Foucault's methods and historical sociology. London and New York: Routledge.

Eloranta, Jorma. 2012. Investointeja Suomeen. Ehdotus strategiaksi ja toimintaohjelmaksi Suomen houkuttelevunden lisäämiseksi investointikohteena. Julkaisuja 9/2012. Helsinki: Työ- ja elinkeinoministeriö, konserni.

Esping-Andersen, Gösta. 1992. The Making of a Social Democratic Welfare State. Teoksessa Klaus Misgeld, Karl Molin \& Klas Åmark (toim.), Creating Social Democracy. A Century of the Social Democratic Labour Party in Sweden. University Park Pa.: The Pennsylvania State University Press.

Foucault, Michel. 1977. Surveiller et punir. Naissance de la prison. Paris: Bibliothèque des histoires. - Suomennos: 1983. Tarkkailla ja rangaista. Helsinki: Otava. 


\section{Pauli Kettunen}

Götz, Norbert. 2001. Ungleiche Geschwister: Die Konstruktion von nationalsozialistischer Volksgemeinschaft und schwedischem Volksheim. Die kulturelle Konstruktion von Gemeinschaften. 4. Diss. Baden-Baden: Nomos.

Honkala, Kaisa. 2010. "YK:n ibmisoikeudet vankiloibin!" - Marraskuun liikkeen suomalaisen kontrollipolitiikan kritiikki 1967-1972. Poliittisen historian pro gradu -tutkielma, Helsingin yliopisto.

Hirdman, Yvonne. 1997. "Social Planning under Rational Control". Social Engineering in Sweden in the 1930s and 1940s. Teoksessa Pauli Kettunen \& Hanna Eskola (toim.), Models, Modernity and the Myrdals. Renvall Institute Publications 8. Helsinki: The Renvall Institute for Area and Cultural Studies, University of Helsinki.

Jussila, Osmo. 1987. Maakunnasta valtioksi. Suomen valtion synty. Porvoo: WSOY.

Kalela, Jorma. 1989. Työttömyys 1900-luvun suomalaisessa yhteiskuntapolitiikassa. Helsinki: Valtion painatuskeskus / Työvoimaministeriö.

Kettunen, Pauli. 1986. Poliittinen liike ja sosiaalinen kollektiivisuus. Tutkimus sosialidemokratiasta ja ammattiyhdistysliikkeestä Suomessa 1918-1930. Historiallisia tutkimuksia 1938. Helsinki: Suomen Historiallinen Seura.

Kettunen, Pauli. 1997. Työjärjestys. Tutkielmia työn ja tiedon poliittisesta historiasta. Helsinki: Tutkijaliitto.

Kettunen, Pauli. 2001. Kansallinen työ. Suomalaisen suorituskyvyn vaalimisesta. Helsinki: Yliopistopaino.

Kettunen, Pauli. 2003. Yhteiskunta. Teoksessa Matti Hyvärinen, Jussi Kurunmäki, Kari Palonen, Tuija Pulkkinen \& Henrik Stenius (toim.), Käsitteet liikkeessä. Suomen poliittisen kulttuurin käsitehistoria. Tampere: Vastapaino.

Kettunen, Pauli. 2008. Globalisaatio ja kansallinen me. Kansallisen katseen historiallinen kritiikki. Tampere: Vastapaino.

Kettunen, Pauli \& Turunen, Ilkka. 1994. The Middle Class, Knowledge and the Idea of the Third Factor. Scandinavian Journal of History, Vol. 19, No. 1.

Koselleck, Reinhart. 2006. Begriffseschichten. Studien zur Semantik und Pragmatik der politischen und sozialen Sprache. Frankfurt am Main: Sührkamp Verlag.

Kurunmäki, Jussi (2006) Snellman-tulkinnoilla politikoitiin 2006. Teoksessa Pentti Kurunmäki (toim.), J. V. Snellman 200 vuotta. Helsinki: Sanomalehtien Liitto.

Lahtinen, Mikko. 2006. Snellmanin Suomi. Tampere: Vastapaino 
Liikanen, Ilkka. 1995. Fennomania ja kansa. Joukkojärjestäytymisen läpimurto ja Suomalaisen puolueen synty. Historiallisia tutkimuksia 191. Helsinki: Suomen Historiallinen Seura.

Liikanen Ilkka. 2003. Kansa. Teoksessa Matti Hyvärinen et al. (toim.), Käsitteet liikkeessä. Suomen poliittisen kulttuurin käsitehistoria. Tampere: Vastapaino.

Parikka, Raimo. 1997. "Varo veli, topora yksin matkustaa" - rahvas, vastarinta, politiikka. Teoksessa Raimo Parikka (toim.), Työväestö ja kansakunta. Väki voimakas 10. Helsinki: Työväen historian ja perinteen tutkimuksen seura.

Pekkarinen, Jukka \& Vartiainen, Juhana. 1993. Suomen talouspolitiikan pitkä linja. Porvoo: WSOY.

Pohjantammi, Ismo. 2003. Edustus. Teoksessa Matti Hyvärinen et al. (toim.), Käsitteet liikkeessä. Suomen poliittisen kulttuurin käsitehistoria. Tampere: Vastapaino.

Pulkkinen, Tuija. 1999. Kielen ja mielen yhteys. 1800-luvun suomalaisen nationalismin erityispiirteistä ja perinnöstä poliittisessa ajattelussa. Teoksessa Tuomas M. S. Lehtonen (toim.), Suomi - outo pohjoinen maa? Näkökulmia Euroopan äären historiaan ja kulttuuriin. Jyväskylä: PS-Kustannus.

Rosanvallon, Pierre. 1998. Le peuple introuvable. Histoire de la representation démocratique en France. Paris: Gallimard.

Ruokanen, Tapani. 2004. Suomen menestyksen eväät. Tiekartta tulevaisuuteen. Helsinki: Elinkeinoelämän Valtuuskunta.

Räsänen, Iisa. 1998. Järjestystä vai itsehallintoa? Vallan käsite Suomen hallitusmuotokeskustelussa 1918. Politiikka 4/1998.

Smolander, Jyrki. 2000. Suomalainen oikeisto ja "kansankoti". Kansallisen Kokoomuksen subtautuminen pohjoismaiseen hyvinvointivaltiomalliin jälleenrakennuskaudelta konsensusajan alkuun. Bibliotheca Historica 63. Helsinki: Suomalaisen Kirjallisuuden Seura.

Snellman, J. V.. 2000-2005. Kootut teokset 1-24. Helsinki: Opetusministerio.

Stenius, Henrik. 1987. Frivilligt, jämlikt, samfällt. Föreningsväsendets utveckling i Finland fram till 1900-talets början med speciell hänsyn till massorganisationsprincipens genombrott. Helsingfors: Svenska litteratursällskapet i Finland.

Stenius, Henrik. 2003. Kansalainen. Teoksessa Matti Hyvärinen et al. (toim.), Käsitteet liikkeessä. Suomen poliittisen kulttuurin käsitehistoria. Tampere: Vastapaino. 


\section{Pauli Kettunen}

Sulkunen, Irma. 1986. Raittius kansalaisuskontona. Raittiusliike ja järjestäytyminen 1870-luvulta suurlakon jälkeisiin vuosiin. Historiallisia tutkimuksia 134. Helsinki: Suomen Historiallinen Seura.

\section{Viitteet}

1 Kirjoitus perustuu pääosin kirjaani Globalisaatio ja kansallinen me (Kettunen 2008).

2 Teoksesa Surveiller et punir (1975) aloitusluvussa Foucault ilmoittaa ohjelmakseen une histoire du présent, mutta suomennoksessa Tarkkailla ja rangaista $(1983,39)$ ajatus on kääntynyt päälaelleen ja syntyy kuva, että "nykyhetken historia" olisi Foucault'n mielestä "pelkkä anakronismi".

3 Th. R.: Kotimaan kirjallisuutta 1. Valtiollista y.m. Valvoja 1, 1881, 66-69.

4 J.V.S.: Om medborgerlig och politisk frihet. Litteraturblad n:o 6 juni 1863, suomennos Kootuista teoksista, osa 20 (Helsinki 2004), 72.

5 Tätä ajattelua kuvaavat vaihtelevin tavoin esim. Esping-Andersen 1992; Hirdman 1997; Götz 2001.

6 J. V. Snellman: Läran om staten (Stockholm 1842), suomennos Kootuista teoksista, osa 5 (Helsinki 2001), 223.

7 Ks. Lahtinen 2006, joka analysoi Snellmania mitä moninaisimmista ajankohtaisista asioista kriittisesti kirjoittavana filosofi-intellektuellina.

8 "Julistuskirja Suomen kansalle" on nähtävissä internet-osoitteessa http://www.uta.fi/yky/arkisto/koskivoimaa/dokut/pjulistus.htm (huhtikuu 2012).

9 Dokumentteina tästä esim. Metso Oyj:n entisen toimitusjohtajan, vuorineuvos Jorma Elorannan työ- ja elinkeinoministeriölle laatima "ehdotus strategiaksi ja toimintaohjelmaksi Suomen houkuttelevuuden lisäämiseksi investointikohteena" (Eloranta 2012) sekä Nokian yhteiskuntasuhteista vastaavan johtajan Esko Ahon ja Suomen Microsoftin toimitusjohtajan Ari Rahkosen kirjoitus "Suomesta tehtävä ulkomailta tuleville osaajille houkutteleva maa", Helsingin Sanomat 26.3.2012, C 4. 


\section{Suomalaiset puolueet kertomuksina}

Tässä artikkelissa tarkastelen suomalaisia puolueita yli sadan vuoden ajalta kertomuksen näkökulmasta. Tulkintani mukaan niin politiikka kuin puolueetkin ovat käsitteiden rakenteistumia. Ne ovat kielen tuotoksia ja tavallisimmin kieltä käytetään puolueista puhuttaessa kertomusmuodossa. Jos kertomuksia ei aina avata, niihin ainakin viitataan, kuten esimerkiksi puolueen vaakuna, merkki ja logo ilmaistaan kielellisesti nimenomaan tarinan muodossa. Kertomukseen kuuluu ilmoittaa: keitä olemme, mistä olemme tulleet, mitä tarkoitusta varten olemme perustettu, kenen/minkä puolesta ja ketä/mitä vastaan me toimimme. Puolueiden rakenteistamiseen liittyviä kertomuksia kirjoitetaan aina tietyssä tilanteessa, jossa on omalaatuisensa yhteiskunnalliset ja tekniset rajoitteet ja mahdollisuudet. Luokkayhteisö tuottaa erilaisia puolueita rakenteistavia kertomuksia kuin luokaton yhteisö. Kirjapainotekniikka mahdollisti laajempien kuin kasvokkaisten yhteisöjen - muun muassa kansakuntien ja myös puolueiden - olemassaolon, internet mahdollistaa maailmanlaajuisen identiteetin. Televisiopolitikointi perustuu yksisuuntaiseen viestintään, kun kasvokkaisuus ja internetpolitikointi ovat vuorovaikutteisia. 


\section{Kertomus, katkos, jatkuvuus ja identiteetti}

Puolueen ideologia eli käsitys maailmasta ja sen muutoksen toivottavasta suunnasta ja strategiasta on keskeinen elementti puolueen kollektiivisessa subjektiudessa (ks. Heywood 2007). Puolueita - kuten muitakin kollektiivisubjekteja - luodaan ja ylläpidetään merkitysten avulla. Niinpä puolueetkin ovat käsitteiden rakenteistumia. Subjektiuden luominen ja uusintaminen tapahtuu diskurssissa, jota käydään puoluetta ja sen tavoitteita määriteltäessä ja sitä arvioitaessa (Neuman 1995, 6). Hayward Alkerin ja David Sylvanin mukaan teksti legitimoi niin yksilön kuin poliittisen yhteisönkin. Yksilö konstituoidaan esimerkiksi tietynlaiseksi kansalaiseksi tai objektiksi. Kirjoittajien mukaan:

Myös poliittisia yhteisöjä rakennetaan samalla tavalla (kuin sosiaalista yksilöä, R.M.) antamalla niille tietynlaisia ominaisuuksia. Kuhunkin diskurssiin liittyvä tekstualisaation prosessi konstituoi tuon diskurssin poliittisen yhteisön niin, että sille asetetaan tekstualisaatiossa joukko erityisiä piirteitä, jotka liittyvät kyseessä olevalle yhteiskunnalle luonteenomaiseen tapaan tuottaa legitimaatiota. (Alker ja Sylvan 1994, 16.)

Edellä olevan mukaan on tulkittavissa, että puolueohjelma, puolueen säännöissä (organisaatiossa) tapahtuva määrittely ja puolueen tavoitteista käyty keskustelu ovat sekä konstituoimassa että legitimoimassa puolueita. Alkerin ja Sylvanin käsityksen mukaan poliittinen yhteisö konstituoituu tiettyjen yhteisymmärrysten ja tiettyjen erojen kautta. Tämä käsitestruktuuri on kaiken poliittisen toiminnan sydämessä (Alker ja Sylvan 1994, 11). Kenneth Burke olisi varmaan jakanut saman ajatuksen, kun hän korosti identifikaation olevan kaiken määrittelyn perusteena. Sosiaalinen järjestys syntyy ja sitä ylläpidetään identifikaation kautta (Summa 1996, 56-57; Burke 1950, 19-23). Varsinkin puolueilla on tärkeää erottaa "meidät" "muista".

Kollektiivisubjekti oikeutetaan kertomuksella, josta on luettavissa miksi subjekti on syntynyt, mitä tehtävää se on suorittanut ja mitä suorittaa, kenen puolesta ja ketä vastaan se toimii (Ricoeur, 1983, 55). Hayden Whiten sanoin kertomus on irrallisten tosiasioiden joukkojen toisiinsa yhdistämistä, menneisyys on mykkää, se ei sinänsä kerro miten asiat ovat 
ja miten ne ovat tulleet joksikin (White 1990, ix). Kertomus on looginen ja aikajärjestykseen perustuva tapahtumaketju, jolle on tavanomaista ajallinen ulottuvuus (Alasuutari 1994, 107). Kertomusanalyysillä pyritään tutkimaan yksilö- tai kollektiivisubjektin identifiointia, konstituointia ja legitimointia. White painottaa, että kertomus- ja juonistruktuuri eivät ole neutraaleja, vaan sisältävät moraalisia valintoja (Majander 2000, 500; White 1990, 3). Kertomuksen esittäjällä onkin suuri vapaus valita ja painottaa kertomuksen juonistruktuurin elementtejä omien motiiviensa ja intentioidensa mukaisesti muotoillessaan ja uudelleen muotoillessaan kertomusta. (Ricouer 1983, 75-82; White 1990 ix.)

Tämän vuoksi kertomuksen esittäminen on mitä poliittisin teko. Kertojan vallassa on paitsi muotoilla kertomus tietynlaiseen juoneen, olla jälkiviisas, korostaa ja jättää pois tiettyjä tapahtuneeseen kuuluneita seikkoja sekä määrätä kertomuksen alku- ja loppuajankohdat. Oleellista kertomuksen poliittisuuden kannalta on myös, kenet/mitä subjektivoidaan ja desubjektivoidaan sekä mitä politisoidaan ja mitä depolitisoidaan. Kertomuksen juonistruktuurin muotoilu ja valinta antaa mahdollisuudet ja rajoittaa erilaiset subjetivoinnit/desubjektivoinnit sekä politisoinnit/depolitisoinnit. (Alker ja Sylvan 1994, 19-22.)

Kertomusta kerrotaan ja tulkitaan aina nykyisyyden kontekstissa, mutta se saattaa käsitellä menneisyyttä, nykyisyyttä ja/tai tulevaisuutta (Ricoeur 1983, 60). Kertomus saattaa sisältää myös nämä kaikki kolme aikatasoa. Kertomukset esiintyvät joskus kokonaisina, mutta useimmiten fragmentteina eri kirjoituksissa. Esimerkiksi edistyskertomuksen uusintamiseen osallistutaan viittaamalla "uudistamiseen", "edistämiseen", "kehittämiseen" ja "laajentamiseen”. Käsitteiden samanlainen ymmärtäminen ja samansuuntainen käyttö viittaavat siihen, että jäsenistö ymmärtää niiden viittaavan johonkin yhtenäiseen kertomukseen.

\section{Leiri-Suomen edistyskertomukset}

Suomalaisia puolueita on viimeisen sadan vuoden ajan oikeutettu ja muutettu ajanjaksoilla tyypillisillä kertomuksilla. Kertomusten rakenteeseen on vaikuttanut käsitys maailmaa ohjaavien ydintotuuksien olemassaolosta tai niiden puuttumisesta sekä näistä johdetuista tulevaisuuden tavoit- 
teista (Pulkkinen 1998, 46-64). Puolueen oikeuttavassa kertomuksessa on oleellisena elementtinä myös määrittely meistä ja muista, mistä aineksista puoluekollektiivi on syntynyt, onko se määritelty jäseniin liittyvien ominaisuuksien, kuten kansallisuuden tai luokan perusteella, vai onko kiinnittyminen puolueeseen tapahtunut hänen itsensä luoman identiteetin mukaisesti. Zygmunt Bauman puhuu pakonomaisesta individualisoitumisesta ja Scott Lash pakonomaisen kollektivistien yhdenmukaisuuden korvautumisella individualistisella kollektiivisuudella (Bauman 2002; Lash 1995, 160-161).

Mainittuun identiteettien rakenteistumiseen vaikuttavat paljon myös tekniset edellytykset. Suomalaisten puolueiden syntyessä ihmisten oli pakko turvautua alueelliseen tai luokkakohtaiseen kollektiiviseen identiteettiin, kun ei ollut juuri muitakaan mahdollisuuksia. Ihmiset samaistuivat paitsi asuinalueensa (pakollisiin ja ohittamattomiin) yhteisöihinsä sekä samankaltaisten ihmisten luokkayhteisöihin. Toki ihmisten intresseillä oli myös merkittävä rooli puoluesamaistumisessa, tämä näkyi erittäin hyvin 1950-luvulla puolueiden oikeutuksia määriteltäessä. Suurin osa kanssakäymisestä oli kasvokkaista kohtaamista, jota puoluepiireissä ilmestyvät puolueiden omat lehdet tukivat. Tällä tavalla rakentuivat alueelliset, puoluepiirikohtaiset, valtakunnalliset ja kansainväliset puolueyhteisöt. Näin syntyi Leiri-Suomi, jossa ihminen pystyi viettämään aikansa omassa yhteiskunnallisessa leirissään aamusta iltaan ja kehdosta hautaan. Puolueiden ympärille olivat muodostuneet työläisten, maalaisten sekä suomenkielisten porvareiden sekä ruotsinkielisten leirit. Leireillä olivat omat kauppansa, pankkinsa, huvitilansa ynnä puolueilla vielä voimakas puoluelehdistönsä. Vaikka pääosa puolueiden ja niiden leiriyhteisöjen rakentamista perustui henkilökohtaiseen läsnäoloon, oli puolueiden organisaatio hierarkkista. Samoin oli muissakin leiriyhteisöissä (Mickelsson 2007). Hierarkiaa tarvittiin ennen kaikkea teknisistä syistä: ei ollut mahdollista järjestää kaikkien jäsenten yhteistä kokousta, koska se oli kommunikaatioteknologisesti monin tavoin mahdotonta. Piti valita edustajat kaupungin, piirin ja valtakunnallisiin kokouksiin. Myös erisuuruisten alueiden välit nähtiin hierarkkisina. Valtakunnan tason päätökset nähtiin arvokkaimpana. 
Leiri-Suomen puolueet oikeuttivat itsensä rajaamalla tarkasti itsensä: työläisten, maalaisten, suomenkielisten ja ruotsinkielisten leirit poissulkivat jo määritelmällisesti muut. Tämän luokkaan tai kansalliseen identiteettiin perustuvan ohittamattoman kollektiivisubjektiuden lisäksi toinen keskeinen elementti oli jostain aksiomaattiseksi ymmärretystä ydintotuudesta johdettu maailmanselitys ja sen mukainen pelastussuunnitelma. Ydintotuus saattoi perustua oletukseen kansallisesta tai luokan tehtävästä (kuten kokoomus, SKP ja myös SDP), oman elämäntavan paremmuudesta (kuten maalaisliittolainen alkiolaisuus) tai edistyksen vääjäämättömyydestä (kuten SKP ja SDP). Edistyskertomus olikin kaikkia puolueita yhdistävä tekijä - varsinkin 1960-1970 -luvuilla. Edistyskertomukset olivat tavallisesti reformistisia, vain äärikommunisteilla ne perustuivat vallankumouksen valmisteluun ja odotteluun. Sosialidemokraattien lineaarinen edistyskertomus oli reformistinen. Sen mukaan Suomi muuttui paremmaksi parlamentaarisesti tehtyjen uudistusten kautta. Ensin sosialidemokraatit tavoittelivat valtiollista demokratiaa ja saivatkin sen vuoden 1907 eduskuntauudistuksessa. Sen jälkeen oli vuorossa sosiaalinen ja sivistyksellinen demokratia, jotka toteutuivat viimeistään 1960- ja 1970-lukujen reformeissa. Tämän jälkeen sosialidemokraatit valmistelivat ainoastaan taloudellisen demokratian toteutumista. SDP:n puheenjohtaja Rafael Paasio vaati tätä jo 1963, jolloin hän puhui yritysdemokratian puolesta. (Mickelsson 1999, 122-124.)

Taloudellinen demokratia ja sen myötä demokraattinen sosialismi jäivät toteutumatta kuten kaikki muutkin puolueiden yhteiskuntaihanteet. Keskustan tavoite desentralisoidusta yhteiskunnasta koki vastustusta, kuten nuorten kokoomuslaisten kehittämä sosiaalisen valintataloudenkin idea. Kommunismikin romahti. (mt.)

\section{Leiri-Suomen purku, edistyskertomuksen loppu ja ekologinen angsti}

Ohittamattomiin (pakollisiin) kollektiivivaatimuksiin perustuva LeiriSuomi oli purkautumassa jo 1970-luvun lopulla. Uudet ja vanhemmatkin sukupolvet valitsivat individualismin kollektivismin sijaan. Tasa-arvoistuminen oli hävittänyt ulkoiset luokkien tunnusmerkit, kuten vaikka- 
pa erilaisen pukeutumisen ja puhetavan. Kasvanut keskiluokka kävi samoissa marketeissa samanlaisilla autoilla. Kehitys oli samanlaista ympäri läntistä maailmaa. Tähän ovat kiinnittäneet huomiota monet sosiologit ja politologit muun muassa Zygmunt Bauman (2002, 237-239). Hän korosti, ettei individualisoituminen ollut kaikille vapauttava prosessi, vaan monille se oli pakko tulla toimeen omillaan, ilman kollektiivi-identiteettiä. (mt). Edistyskertomukset olivat perustuneet rationalistiseen käsitykseen olevasta ja tulevaisuuden uskoon. Usko niihin alkoi horjua, kun yhä enemmän oltiin huolestuneita maailman kehityksen epätasaarvoisuudesta, ydinsodan uhasta ja ympäristön tuhoutumisesta. Rationaalinen yksisilmäinen edistys tuotti paljon myös ei-odottamattomia seurauksia, muun muassa ekologisen angstin seurauksena alettiin puhua postmodernismista. Tuija Pulkkinen on löytänyt eron modernin ja postmodernin kertomuksen välillä. Modernin kertomuksen lähtökohtana on aksiomaattinen ydintotuus, josta johdetaan pelastussuunnitelma. Postmodernissa kertomuksessa on hukattu ydintotuus ja pelastusta ei enää ole (Pulkkinen 1998, 46-64).

Bauman kiistää modernin loppuneen, kuten käsite postmoderni edellyttää. Sitä vastoin teollisuusajan raskas moderni on muuttunut jälkiteollisuusajan notkeaksi moderniksi.

Bauman korostaa, että edistys on nykyhetken itseluottamusta. Jotta ihmiset pystyvät muuttamaan maailmaa paremmaksi tarvitaan tieto elämää pyörittävistä syy- ja seuraussuhteista ja usko siihen, että juuri me pystymme muuttamaan maailman paremmaksi. Raskas moderni perustui illuusioille paremmasta maailmasta ja kaikkivoipaisesta suunnittelusta. Notkean modernin epävarmassa olotilassa on vaikeaa suunnitella mitään. Alussa valistuksen alulle panema edistys oli vain välitila matkalla kohti parempaa maailmaa, nyt se on alati jatkuvaa. Raskaan moderni yhteiskunta oli kiihtyvällä ja jatkuvalla matkalla jonnekin parempaan, notkeassa modernissa on vauhti vain kiihtynyt ja kanssamatkalaiset hävinneet, luokat ovat kadonneet yksilöitymisen tieltä. Bauman korostaa, että yksilöityminen ei ole valinta, vaan kohtalo. Se merkitsee sitä, että identiteetti ei ole annettu, vaan jokaisen on rakennettava jatkuvasti omaa itseään. $\mathrm{Ny}$ kyihmisten huolet on tehty yksin kärsittäviksi. Viimeaikaiset muutokset ovat rikkoneet aiemman solidaarisuuden perustan, yhteiskunta ei enää pelasta kuten raskaan modernin aikana. (Bauman 2002, 88.) 
Kun raskaassa modernissa ihmiset identifioituvat pysyvästi johonkin luokkaan tai muuhun ryhmään, ovat notkean modernin yhteisöt "naulakkoyhteisöjä". Ihmiset liittyvät johonkin yhteisöön tiettyä tilaisuutta varten, pukeutuvat johonkin rooliin ja kun esitys on päättynyt, he pukevat taas arkiset vaatteet päällensä ja lähtevät omiin toimiinsa (Bauman 2002, 237-239).

Yksilöitymisen myötä on myös yhteinen julkinen tila kaventunut. Tämä avoin tila syntyi kun ryhdyttiin käsittelemään yhteisiä asioita - asioita, jotka eivät olleet perheen sisäisiä, vaan yhteiskunnan omia asioita. Julkisen tilan varaan rakentuivat ensiksi lehdistö, sitten puolueet. Esimerkiksi Suomessa julkisen tilan ensimmäisiä asioita olivat patriotismi ja kielikysymys, sitten raittiuskysymys ja työväenliike ja viimein feministinen ja ekologinen tietoisuus. Baumanin mukaan nyky-yhteiskunnassa yksityinen kolonisoi julkista. Julkiset kysymykset ovat nykyisin julkisten ihmisten yksityisiä kysymyksiä, politiikka on typistynyt juorupalstaksi. (mt.).

Politiikka (isolla P:llä) edellyttää, että yksityiset asiat muutetaan yhteisiksi ja julkisiksi. Jos nykyinen julkinen tila ei sisällä juurikaan yhteisiä, vaan julkisten ihmisten yksityisiä kysymyksiä, niin missä tilassa politiikka ja puolueet voivat hengittää? Onko vaarana, että politiikka ja puolueet katoavat tässä muodossa? Onko vaarana, että niistä tulee yksittäisten poliitikkojen manageritoimistoja? Onko vaarana, että politiikan tärkeimmiksi kysymyksiksi tulevat poliitikkojen ihmissuhteet ja pukeutuminen? Onko vaarana, että puolueen äänestäminen ei enää merkitse jonkun ideologian vaan tietyn tyylin kannattamista?

Suomalaiset puolueet alkoivat toden teolla tarttua ekologiseen angstiin jo 1980-luvun alkupuolella. Sosialidemokraattien vuonna 1987 hyväksymä periaateohjelma tuo heti alkusanoissaan esiin luonnon tuhoutumisen uhan ja sota-aseiden tuhovoiman korostaen maailmanlaajuisen näkökulman tarpeellisuutta (SDP 1987). Keskusta (1982) oli ottanut ekologisen kysymyksen ohjelmiinsa jo 1980-luvun alussa ja kokoomuslaistenkin vuonna 1993 hyväksytty periaateohjelma paaluttaa keskeiseksi lähtökohdakseen ekologisen angstin ja maailmanlaajuisen näkökulman tarpeellisuuden.

Ekologisesta angstista ja maailmanlaajuisen näkökulman tarpeellisuudesta ei kyennyt laatimaan modernin tyyppistä ideologiakertomusta mikään muu puolue kuin Vihreä liitto. Ekokatastrofi ja sen uhka oli vihrei- 
den ideologiakertomukselle ydintotuus, josta johdettiin pelastussuunnitelma. Sen sijaan muiden puolueiden ideologiakertomukset muuttuivat postmodernin kaltaisiksi, maailmaa ei ollutkaan enää hallittavissa, eikä sen mukaan myöskään muutettavissa oman katsomuksen mukaiseksi. Siksi puolueiden piti ikään kuin varustautua arvositoumuksillaan; esimerkiksi sosialidemokraatit halusivat muuttaa tavoitteen tasa-arvon lisäämisestä arvoksi. Sen mukaan sosialidemokraattien keskeinen arvo olisi tasa-arvo, jolla tavalla he suhtautuvat kaikkiin eteen tuleviin (yllätyksellisiinkin) asioihin. (Mickelsson 2002.)

Ydintotuuskertomusten kuoleminen oli toinen piirre puolueiden muutoksessa kahdeksankymmenluvulla, toinen piirre oli jo alussa mainittu Leiri-Suomen ja sen mukaisen puoluekäytännön hiljainen mureneminen. Järjestöpuolue alkoi muuttua televisiopuolueeksi. Puolueen merkityksellistämistä tapahtui yhä vähemmän kasvokkaisissa tapaamisissa, pikemminkin politiikka ja niin myös puolueet tulvivat ihmisten tietoisuuteen tiedotusvälineiden kautta. Keskeinen tiedotusväline oli televisio - se pystyi hyvin vähän ilmaisemaan aatetta, sitä paremmin se pystyi kuvaamaan henkilöä. Niinpä puolueiden puheenjohtajista tuli puolueiden ikoneita - julkisia edustajia, joihin puoluekertomukset ankkuroitiin (vrt. Panebianco 1988). Suomessakin puheenjohtajan epäonnistuneesta televisioesiintymisestä on käyty monta keskustelua. Vuonna 1983 tulilinjalla oli Ilkka Suominen, kun hän vaisulla esiintymisellään television suuressa vaalikeskustelussa pilasi mahdollisuudet kokoomuslaisten odottamaan vaalivoittoon. Vuonna 1991 joutui sosialidemokraattien puheenjohtaja Pertti Paasio eroamaan, hän olikin mieluimmin järjestöpuolue- kuin televisiopuoluemies. Samalla tavalla kävi vielä Kokoomuksen puheenjohtaja Ville Itälälle. Hänen huonoa mainettaan seliteltiin television satiiriohjelmassa olleella piirroshahmolla. (Mickelsson 2004; 2007.) Ranskalaisen sosiologi Michel Maffesoli on esittänyt että tunteisiin vetoavan kuvan hallitsemassa postmodernissa yhteiskunnassa ihmiset eivät enää identifioidu samalla tapaa kuin tekstin hallitsemassa päämäärärationaalisuuteen vetoavassa yhteiskunnassa. Kuvan hallitsemassa yhteiskunnassa syntyy saman tyylin omaksuneista ihmisistä "heimoja". Maffesolin mukaan nämä heimot ovat ottaneet luokka- ja intressiryhmäyhteisöjen paikan samaistumisen kohteina. (Maffesoli 1995.) Voimme siis pohtia, muodostiko voimistuva televisiopuolueisuus heimoja luokkien sijaan Suomessakin. 


\section{Globaali angsti ja internet-puolueen paradigma}

Kahdeksankymmenluvun rauhan-, kehitysmaa- ja ympäristöliikkeet herättivät globaalin tietoisuuden. Globalisaatio alkoi levitä myös toista (ideologialtaan vastakkaista) tietä - uusliberalistisen vapaakauppapolitiikan saatua runsaasti vaikutusvaltaa; globaali keskinäisriippuvuus kasvoi (ks. Harvey 2008). Suomen liityttyä Euroopan unioniin kansallinen liikkumatila kapeni, mutta toisaalta suomalaiset saivat vaikutusvaltaa Euroopan politiikassa.

Globalisaation vaikutusten, kuten siirtolaisten määrän lisääntyminen, vastainen liike sai Suomessa suurempaa vaikutusvaltaa vasta vuoden 2008 kunnallisvaaleissa. Vuoden 2011 eduskuntavaaleihin osallistui kolme nationalisti- ja äärinationalistipuoluetta. Näistä ainoastaan Perussuomalaiset pääsivät eduskuntaan ja saivat lähes kaksikymmentä prosenttia äänistä. Nationalistipuolueet korostavat sumeilematta isänmaallisia arvoja. Siksi alla oleva sitaatti Suomen kansasta Perussuomalaisten vaaliohjelmasta pystyy kuvaamaan kaikkien puolueiden suhdetta suomalaisuuteen.

Historiantunneilla on korostettava suomalaista ihmettä, kuinka köyhästä ja syrjäisestä maasta nousi koko maailman tunnustama edistyksen ja vaurauden kansakunta - vieläpä ilman suuria luonnonrikkauksia. On myös tuotava esiin, kuinka tärkeää itsenäisyys on ollut suomalaiselle menestystarinalle, ja kuinka se onnistuttiin säilyttämään sodissa, joista selviytyminen oli sekin jo yksistään ihmeellistä. Ilman itsenäisyyttä kansakunta ei saa itse pitää oman työnsä tuloksia. Ilman itsenäisyyttä kulttuurin, yhteiskunnan, omaleimaisen sivistyksen kuin materiaalisen hyvinvoinnin kehittäminen on muissa kuin omissa käsissä. (PS 2011.)

Kertomus on jatkoa perinteiselle runebergiläis-sävytteiselle Suomi-kertomukselle, jossa tämä maa koetaan köyhänä ja pienenä kansakuntana, jota suuret naapurit uhkaavat. Suomen hyvinvointi on syntynyt raadannan ja taistelun kautta ja tämän maan menestys - niin kuin lainauksessa todetaan - on ainoastaan suomalaisten ansiota. Kansakunta koetaan tässä kertomustyypissä orgaanisena itsestään selvänä kokonaisuutena, jota yhdistää kieli ja kulttuuri. Varsinkin Perussuomalaisten vaaliohjelma ja sen joidenkin kansanedustajien retoriikka saavat joskus 1920- ja 1930-luvul- 
ta tuttuja aitosuomalaisia sävyjä (ks. Alapuro 1973). Kaikissa puolueissa suhtaudutaan "pakkoruotsiin" kielteisesti ja se nostetaan usein erittäin tärkeään asemaan. Varsinkin perussuomalaisten kansallisuuskertomukseen kuuluvat myös militarismi ja armeija. Esimerkiksi Jussi Halla-Aho kampanjoi rajoittavaa aselainsäädäntöä vastaan ja Timo Soini irvailee asevelvollisuusajan lyhentämisellä. Itsenäisyyden korostamisessa saavat käydyt sodat tärkeän sijan. Kansakunta on myös keskenään solidaarinen yhteisö, jota viime vuosina ovat kalvaneet individualistiset pyrkimykset. Kertomuksen mukaan itsenäinen Suomi ei ole velkaa kenellekään. Sen ei pidä olla maailman sosiaalitoimisto eikä elättää verovaroilla muualta tulevia ja suomalaiseen kulttuurin sopeutumattomia elintasopakolaisia. Usein toistetun kannan mukaan islamilaiset pakolaiset tuhoavat suomalaisen luoman hyvän kulttuurin.

Kenneth Burken mukaan identiteetin rakentamisessa on tärkeä määritellä itsen lisäksi se mitä ei ainakaan ole. Tämä toisen määrittely tehdään dikotomisesti: mies on ehdottomasti ei-nainen eikä suomalaisella voi olla suomi-identiteetin lisäksi tunnetta kuulumisesta jonkin toisen maan kansakunnan osaksi. (Burke 1950; Mickelsson 1999.) Perussuomalaisten eduskuntaryhmään kuuluu (2011) neljä äärinationalisteja 2000-luvun alussa koonneen Suomen Sisun jäsentä. ${ }^{1}$ Järjestön periaateohjelmassa puhutaan herderiläisittäin orgaanisesta kansalaisuudesta, kansallisesta yhtenäisyydestä ja solidaarisuudesta (Suomen Sisu 2006; Karkama 2007). Tekstien mukaan kansa on itsestään selvä essentiaalinen pakkoyhteisö, johon kuulumista ei voi valita. Kansan tehtävänä on vaalia omaa kieltään ja kulttuuriaan seuraaville sukupolville. Oma kulttuuri nähdään ainutlaatuisena ja sen puhtautta on syytä vaalia. Muun muassa Perussuomalaisten vaaliohjelmassa korostetaan suomalaisen kulttuurin alkuperäisyyttä ja kavahdetaan muun muassa "postmodernia tekotaiteellisuutta" (Perussuomalaiset 2011). Varsinkin edellä mainitut "sisulaiset" ja heidän seuraajansa korostavat, että todellinen monikulttuurisuus syntyy, kun kukin kansakunta voi keskittyä omaan kulttuuriinsa. Niinpä kansasubjektien yhteistyö on todellista monikulttuurisuutta. Sen sijaan vieraan kulttuuriin ilmiöiden tuominen johonkin toiseen kulttuuriin tuhoaa sekä oman että vieraan kulttuurin (Eerola 2011).

Kaikki käsiteltävänä olevat puolueet ovat erittäin kansallisia. Ohjelmissa ja teksteissä ei huomioida juurikaan muita kuin suomalaisia. Aino- 
astaan Muutos 2011 ohjelmassa käsitellään globaalista vastuusta (Muutos 2011, julk.2010). Näin ollen myös politiikan maantieteellinen ulottuvuus käsiteltävissä teksteissä rajoittuu pääasiassa Suomeen tai jossain tapauksissa Eurooppaan. Hyvällä syyllä voidaan puhua siis puolueiden etnosentrisyydestä. Tämän lisäksi teksteissä ilmeni aukottomasti myös kristinuskokeskeisyys: Turkin liittymistä Euroopan Unionin jäseneksi pidetään mahdottomana Euroopan ja Turkin erilaisten uskonnollisten ja kulttuuristen traditioiden vuoksi.

Erilaiset järjestöt olivat käyttäneet tietokoneverkostoja poliittiseen toimintaan jo vuosisadan alusta lähtien. Usein nämä järjestöt kritisoivat globaalia kapitalismia ja niiden oli helppo organisoida erilaisia kampanjoita kansalliset rajat ylittäen (esim. Lappalainen 2005). Suomalaiset järjestö- ja televisiopuolueet eivät panostaneet vuorovaikutteiseen internetiin, vaan ne luottivat hierarkkisiin organisaatioihin ja vertikaalisiin vaikutuskeinoihin, kuten yksisuuntaiseen mediaan. Niinpä ne tulivat yllätetyiksi, kun lähes ilman mitään perinteisiä tiedotusvälineitä olleet äärikansalliset liikkeet saivat huomattavan suosion vuoden 2011 eduskuntavaaleissa. Perussuomalaiset eivät kuitenkaan ole pelkästään verkostopuolue, esimerkiksi puheenjohtaja Soini on ennen kaikkea televisiopoliitikko; toisaalta puolueen äärikansallisen siiven johtaja Jussi Halla-aho on selvä verkostopoliitikko, jolla ei ole lainkaan kyvykkyyksiä, joita tarvittaisiin perinteisessä mediassa.

Verkostopuolueisuuden leviäminen ei ole ollut pelkästään perussuomalaisten varassa, vaan useat muutkin kansanedustajaehdokkaat tukeutuivat yhä laajemmin verkostoon. Seurattuja verkostopoliitikkoja ovat muun muassa Erkki Tuomioja (sd) ja Osmo Soininvaara (vihr.). He kirjoittavat blogejaan, joita seurataan paljon ja tarkasti. Internet-verkostoon turvautunut kansanedustajaehdokas mainosti useimmiten itseään erittäin vähän perinteisessä mediassa, kuten sanomalehdissä.

Verkostopolitikointi eroaa huomattavasti järjestö- ja televisiopolitikoinnissa. Järjestöpuolueisuuden hierarkkisuus ja televisiopuolueisuuden vertikaalinen tiedonvälitys ovat korvautuneet verkostopuolueissa tasa-arvoisuudella ja vuorovaikutteisuudella. Tasa-arvoa lisää se, että internetin käyttö on lähes ilmaista, lisäksi se ei ole välitteistä, kuten perinteisten tiedotusvälineiden käyttö. Erilaisiin verkostoihin on huomattavan helppo liittyä ja toisaalta ne eivät ole kovin sitovia, kuten 
henkilökohtaiset suhteet ovat. Toisaalta sitoutuminen verkostoihin voi olla erittäin intensiivistä ja kiinteää. Tällöin on uhkana se, että verkostosta tulee erittäin kiinteä, oman kehittämänsä totuuden varassa toimiva suljettu samanmielisten yhteisö - enklaavi (Setälä 2009, 115; Sunstein 2002). Kun yhden näkemyksen varaan vannotaan, kehitetään omaa identiteettiä, konstruoidaan vastustaja eikä suvaita toisinajattelua, verkostopolitikointi voi johtaa arvaamattomiin seurauksiin.

Vielä vuonna 2011 verkostokommunikointi toimii tekstin varassa. Maffesolilaisittain voimme päätellä, että se vetoaa näin ollen rationaalisuuteen, kun (televisio) kuva vetoaa tunteisiin. Suosituimpien verkostovaikuttamiseen tukeutuneiden kansanedustajaehdokkaiden kirjoitustyyli oli rationaaliselta ja johdonmukaiselta vaikuttavaa, kun esimerkiksi televisiopoliitikko Timo Soinin "plokissa" teksti oli televisiomaisen sound-bittimäistä, irrallisia huudahduksia, joita ei mitenkään tarkemmin perusteltu. (Mickelsson 2011.)

\section{Puolueita oikeuttaneet kertomukset ovat vaihdelleet vuosisadan aikana}

Tässä artikkelissa on tarkasteltu millaisilla kertomuksilla suomalaisia puolueita on rakenteistettu ja oikeutettu viimeisen sadan vuoden aikana. Puolueita on rakenteistettu jyrkän dikotomisen me/muut - mallin mukaisesti. Porvarit vastaan työläiset -identifikaatio innosti ihmisiä toimimaan 1900 - luvun alkupuolella, samaan tapaan kuin vastakkainasettelu kaupunkilaiset vastaan maalaiset -hengessä. Myös polarisaatio suomenja ruotsinkielisten välillä on saanut aikaan palaviakin puheenvuoroja. Näkyvien luokkaerojen hävittyä ja ihmisten - myös politiikkojen - yksilöidyttyä puolueisuuden tämäntyyppinen vastakkainasettelun aika jollei päättynyt, niin menetti ainakin suuresti merkitystänsä. Puolue-elämän fokus on ollut aluksi puoluejärjestöissä, tämän jälkeen televisiossa ja nykyisin yhä enemmän puolue-elämästä tapahtuu tietoverkoissa.

Nykypäivän puolue-elämä koostuu kaikkien näiden kolmen tason kompositiosta. Kaikkia tasoja rakenteistetaan erilaisilla kertomuksilla. Kertomusten ydin on puolueideologiassa, mutta myös muussa puolue- 
diskurssissa, kuten säännöissä, juhlapuheissa ja jäsenten puoluetta käsittelevässä keskustelussa.

\section{Lähteet:}

Alapuro, Risto. 1973. Akateeminen Karjala-Seura. Ylioppilasliike ja kansa 1920ja 1930-luvulla. Helsinki: WSOY.

Alasuutari, Pertti. 1994. Laadullinen tutkimus. Vastapaino, Tampere.

Alker, Hayward R. ja David Sylvan. 1994. Kuinka diskurssianalyysi voi edesauttaa politiikkatieteen kehittymistä?, suomentanut Heikki Patomäki. Kosmopolis, vol 24:3/94, s. 5-26.

Bauman, Zygmunt. 2002. Notkea moderni. Suom. Jyrki Vainonen. Tampere: Vastapaino.

Burke, Kenneth. 1950. A Rhetoric of Motives. Prentice-Hall, New York.

Eerola, Juho. 2011. Juho Eerolan kotisivut, http://www.perussuomalaiset.fi/eduskuntavaalit2011. (5.7.2011)

Harvey, David. 2008. Uusliberalismin lyhyt historia. Vastapaino, Tampere

Heywood, Andrew. 2007. Political Ideologies, an Introduction. 4. painos. Palgarve, MacMillan, New York.

Karkama, Pertti. 2010. Kadonnutta ihmisyyttä etsimässä: Johdatusta Johann Gottfried Herderin ajatteluun ja herderiläisyyteen Suomessa. Suomalaisen Kirjallisuuden Seuran toimituksia 1134. Helsinki: Suomalaisen Kirjallisuuden Seura.

Keskusta 1982. Keskustapuolueen periaateohjelma. http://www.fsd.uta.fi/ pohtiva/ohjelma?tunniste=keskperiaate1982. (31.8.11.)

Lash, Scott. 1995. Refleksivisyys ja sen vastinparit. Kirjassa U.Beck - A.Giddens - S.Lash: Nykyajan jäljillä. Vastapaino, Tampere. 153 - 235.

Majander, Mikko. 2000. Yrjö Koskisen suuri kertomus Suomen kansan historiasta - Postmoderni linja. Teoksessa: Kettunen, Pekka - Auli Kultanen - Timo Soikkanen (toim.) Jäljillä. Kirjoituksia historian ongelmista. Jublakirja Jorma Kalelalle hänen 60 -vuotispäivänä̈n 12.11.2000. 
Mickelsson, Rauli. 1999. Samanlaiset ja erilaiset puolueet. Retoriikka- ja diskurssianalyyttinen tutkimus kokoomuslaisten ja sosialidemokraattien jäsenlehdissä ilmaisemista käsityksistä omista puolueistaan vuosina 1965-1995. Turku: Turun yliopisto.

Mickelsson, Rauli. 2002. Sosialidemokraattien kertomukset. SDP:n periaateohjelmakeskustelu 1995-1999 kertomusanalyysin valossa. Politiikka 1/2002, 31-47.

Mickelsson, Rauli. 2004. Ovatko politiikan pilat osuvia. Helsingin Sanomat 18.3.2011. Vieraskynä.

http://www.hs.fi/arkisto/artikkeli/Ovatko+politiikan+pilat+osuvia/HS2 0040318SI1 MP01 pmb?free=Mickelsson\&date=year2004\&advancedSear $\mathrm{ch}=\&(1.9 .2011)$

Mickelsson Rauli. 2007. Suomen puolueet, historia, muutos ja nykyaika. Vastapaino. Tampere.

Mickelsson, Rauli. 2011. Suomalaisten nationalistipopulistien ideologiat. Kirjassa Matti Wiberg (toim.) Populismi, kriittinen arvio. Edita, Helsinki.

Muutos 2011. 2010. Muutos 2011. Periaatteet ja tavoiteohjelma: http://www. muutos2011.fi/cms/index.php?option=com_content\&view $=$ article\&id $=1$ 64\&Itemid=10 Katsottu 2.6.2011

Neumann, Iver B. 1995. Kollektiivin identiteetin muodostus ja toiseus kansainvälisten suhteiden teoriassa. Kosmopolis vol 25:4/95. s. 5-22.

Panebianco, Angelo. 1988. Political Parties: Organization and Power. Cambridge: Cambridge University Press.

Perussuomalaiset. 2011. Suomalaisille sopivin, Perussuomalaisten eduskuntavaaliohjelma 2011. http://www.perussuomalaiset.fi/ohjelmat. (2.6.2011)

Perussuomalaisten kansanedustajien kampanjasivut. 2011. http://www.perussuomalaiset.fi/eduskuntavaalit2011. (5.7.2011)

SDP. 1987. Suomen Sosialidemokraattisen puolueen periaateohjelma http:// www.fsd.uta.fi/pohtiva/ohjelma?tunniste=sdpperiaate1987. (31.8.11)

Pulkkinen, Tuija. 1998. Postmoderni politiikan filosofia. Tampere: Gaudeamus.

Ricoeur, Paul. 1984. Time and narrative, volume 2. Translated by Katheleen Mc Laughlin and David Pellaur. The University of Chicago Press. Chicago and London.

Setälä, Maija. 2009. Puolueet ja deliberatiivinen demokratia. Teoksessa: Puolueiden tulevaisuus, toimittanut Rauli Mickelsson. Oikeusministeriö. 
Summa, Hilkka. 1996. Kolme näkökulmaa uuteen retoriikkaan: Burke, Perelman ja Toulmin. Kirjassa Pelkkää retoriikkaa, toimittaneet Kari Palonen ja Hilkka Summa, Tampere. s. 51-84.

Sunstein, Cass. 2002. The Law of Group Polarization. The Journal of Political Philosophy 10:2 175-195.

Suomen Sisu. 2006. Periaateohjelma. http://www.suomensisu.org/content/ wiew/75/87 (1.5.2011)

White, Hayden. 1990. Metahistory. The Imagination in Nineteenh-Century Europe. Seventh printing. The John Hopkins University Press. London.

\section{Viitteet}

1 Juho Eerola, Jussi Halla-aho, James Hirvisaari ja Olli Immonen 



\section{Puolueet yhteiskunnan ohjaajina ja ohjattuina ${ }^{1}$}

Puolueet poikkeavat muista organisaatioista siinä, että niillä on ratkaiseva vaikutusvalta lainsäädännössä, julkisessa taloudessa ja kansainvälisten suhteiden ohjaamisessa. Toisaalta puolueet joutuvat aktiivisen poliittisen keskustelun ja valintojen lisäksi sopeutumaan historiallisiin rakenteisiin ja sukupolvimuutoksiin. Vaikka silmiinpistävän suuret äänestäjäryhmät sitä toivoisivatkin, äkkinäisiä muutoksia puoluetoiminnassa on vaikea toteuttaa lyhyellä aikataululla. Julkinen byrokratia ja valtiollistuneet rakenteet ovat esteitä drastisille muutoksille ja yhtä lailla perustuslakiin on rakennettu jarrumekanismeja. Historia kylläkin tarjoaa esimerkkejä siitä, millä tavalla radikaaleja pesäeroja menneeseen puoluedemokratiaan on tehty ja yksi puolue on riistänyt vallan itselleen. Puoluedemokratia ei ole paras mahdollinen järjestelmä, mutta muut tarjolla olevat poliittiset päätöksentekotavat ovat huomattavasti huonompia. Suunnilleen näin Englannin pääministeri Winston Churchill kuvasi tilannetta, kun Saksan natsipuolue havitteli maailman herruutta.

Puolueet voivat siis olla demokratian rakentajia ja demokratian vastustajia. Samoin puolueet muokkaavat ja ovat mukana parlamentaarisen demokratian kehitysvaiheissa. Ranskalainen Bernard Manin (2002) jäsentää hyvin edustuksellisen demokratian kehittymistä kolmen vaiheen kategorioilla: parlamentti-, puolue- ja yleisödemokratia. Kaikissa näissä kolmessa vaiheissa puoluemuoto, niiden suhde äänestäjiin ja organisaa- 


\section{Jan Sundberg}

tio ovat muokkaantuneet uusiksi. Teoriat yksinkertaistavat todellisuutta, mutta jos ne ovat selkeitä ja harkittuja tulkintamalleja, niistä on apua todellisuuden ymmärtämisessä ja selittämisessä. Hämärästi ajateltuja ja kirjoitettuja teorioita on yllin kyllin pölyttymässä arkistojen hyllyillä. Manin teoria ei vanhene historian tomuisilla hyllyillä, se toimii mielestäni oivallisesti: voitte itse päättää olenko oikeassa vai väärässä?

Tarjoan teille nyt luettavaksi ja pohdittavaksi tulkintareitin, millä Manin perämiehenä ohjaa meitä ymmärtämään ja selittämään puolueiden kehitystä Suomen olosuhteissa. Huomautan heti aluksi, että tarkasteluni ei suinkaan ole värittynyt nationalistisesti kuten usein koulun historiakirjoissa - vaan pyrin ottamaan viimeisimmät, ilahduttavan tuoreet ja eurooppalaiset tutkimukset avuksi.

\section{Puolueet ja parlamenttidemokratia}

Parlamenttidemokratian läpimurto liittyi ajankohtaan, jolloin valinta parlamenttiin ei vielä kuulunut kansalle vaan kvalifioiduille eliittiryhmille. Ehdokkaat olivat tunnettuja henkilöitä, joilla oli rajattujen äänestäjäryhmien luottamus. Heidän henkilökohtainen verkostonsa ja kontaktinsa edesauttoivat valintaa edustustehtäviin. Tyypillistä oli, että nämä valitut edustivat tiettyjä kollektiivisia intressejä kuten kauppaa ja maataloutta. Nämä intressit kytkeytyvät usein edustajan elinkeinotaustaan, yhteisöön ja alueeseen. Edustaja valtiopäivillä oli ikään kuin äänestäjien luottamusmies, naiset olivat politiikassa taustavoimina (Manin 2002, 218-222). Maninin luonnehdinnat kytkeytyvät myös Suomen kehitykseen. Meilläkin eliittien kautta rakentunut edustuksellinen malli on ollut vallalla huomattavasti kauemmin kuin yleiset vaalit. Kollektiivit, joista Manin puhuu, olivat meillä säätyjä, jotka koostuivat aatelistosta, porvareista, papeista ja talonpojista. Ruotsi poikkesi rajusti muusta Euroopasta, koska talonpojat, jotka olivat sen ajan työväenluokkaa, muodostivat keskeisen poliittisen toimijuuden eikä meillä ollut maaorjuutta Venäjän tapaan. Ensimmäiset edustajat lähetettiin valtiopäiville Arbogan luostariin jo 1435 ja 1436 - jolloin Ruotsi otti ensimmäiset askeleet kohti yhtenäistä valtiolaitosta (Schück 1987, 22-27). Katolinen Ruotsi oli este yhtenäisvaltion 
synnylle, Kustaa Vaasan voitokas vallanotto 1523 teki lopun Vatikaanin ohjauksesta ja Tukholmasta tehtiin pääkaupunki.

Suomi oli yhtä lailla integroitunut Ruotsin valtioon kuten tuolloiset Götaland, Svealand ja Norrland - vieläpä niin, että Varsinais-Suomen makunta kuului valtion ytimeen. Ainoastaan Käkisalmen lääni oli vailla vastaavaa edustusta valtiopäivillä, sillä se yhdistyi vasta myöhemmin valtiokokonaisuuteen (Tarkiainen 2008). Näin edustus jatkui vuosisatoja ja vielä senkin jälkeen, kun Venäjä valloitti Ruotsin itäiset läänit ja osan Västerbottenia, jonka itäraja kulki Kemijokea pitkin. Säätyedustus sai kuitenkin jatkua rajoitetusti uuden vallan varjossa ja pitkän periodin ajaksi hajotettuna aina 1800-luvun puoliväliin. Instituutio oli voimassa nyt ainoastaan autonomisessa Suomessa. Kollektiivinen säätyedustus alkoi kuitenkin käydä vanhentuneeksi. Ruotsissa se poistettiin 1866 ja tilalle tuli kaksikamarinen edustus (Carlsson 1987, 193-195). Suomessa vanha järjestelmä sai paradoksaalisesti jatkua. Kollektiivisessa edustuksessa edustajat olivat parlamentaarikkoja sanan vahvassa edustuksellisessa ja puheaktiviteettia korostavassa merkityksessä, sillä puoluesidonnaisuus oli vähäistä. Puoluelaitos sopi erittäin huonosti tällaiseen järjestelmään.

Yhteiskunnan kehitys dynamisoitui monessa suhteessa ja sosiaalisia jakoja ja ristiriitoja alkoi esiintyä yhä vahvemmin ja niitä alettiin tiedostaa yhteiskunnallisena liikeprojekteina eikä jumalan antamina koettelemuksina. Vahvistuva ja organisoituva nationalismi kärjisti kielikysymyksen suomen ja ruotsin välillä - mikä aiemmin ei ollut iso ongelma, ainoastaan käytännöllinen asia Ruotsin kansalaisilla. Suomenkieliset olivat pääosiltaan hyviä protestantteja ja siksi luotettavia ruotsalaisia, ortodoksisuus herätti syviä epäilyjä vaarallisesta venäläismielisyydestä itäisillä rajaseuduilla. Suomi ei ollut kehittynyt hallinnon kieleksi - toisin kuin kirkon piirissä: näissä oloissa enemmistöltään suomenkielinen talonpoikaissääty vaati, että hallinnon kieli Suomessa pitää olla ruotsi eikä venäjä tai saksa (Villstrand 2009). Toisaalla venäläinen kansallismielisyys kasvoi Pietarissa ja valtiovalta pyrki keskittämällä integroimaan ja venäläistämään kaikkia valtakunnan eri vaiheissa valloittamia osia - myös niitä, joille oli annettu erivapauksia ja autonomisia taloudellisia ja poliittisia oikeuksia kuten Suomelle. Toisaalta liberaalit ja sosialistiset työväen mobilisaatioaallot manner-Euroopassa inspiroivat ja paljastivat poliittisia epäkohtia, 


\section{Jan Sundberg}

sosiaalisia repeämiä ja luokkavastaisuuksia. Nämä puitteet loivat puoluelaitoksen uudenaikaisen kontekstin myös Suomessa.

\section{Puoluedemokratia Suomessa}

Äänestäjäkunta kasvoi hurjasti kansallisvaltioiden ja erilaisten parlamentaaristen uudistusten läpimurron kaudella. Äänioikeuksien laajennettua aiempaa läheistä ja henkilökohtaista suhdetta äänestäjän ja edustajan välillä ei voitu ylläpitää. Joukkopuolueiden ja -vaalien oloissa äänestäjät eivät enää henkilökohtaisesti tunteneet ehdokastaan. Suurpuolueet nousivat mobilisoivilla ideoilla - organisaation tuli kerätä laajat kannattajajoukot ja ohjata äänestäjäjoukkoja. Joukkuepuolueiden (sosialidemokraatit) alunperäinen ajatus oli viedä tavallinen äänestäjä vallan ytimeen. Ajatus oli, että entinen parlamentin eliittiluonne tuli lakkauttaa. Puoluedemokratiassa valitsija äänestää lähinnä puoluetta eikä henkilöä. Tähän liittyy puoluesidonnaisuus, minkä jatkuvuudella oli merkitystä ehdokkaiden vaihtumisesta ja uusista äänestäjäsukupolvista riippumattakin. Parlamentissa puoluesidonnaisuus oli vahvaa ja se aika - jolloin edustajat saivat äänestää oman uskomuksensa mukaan - oli ohi (Manin 2002, 222-234).

Suurruhtinaskunnassa tämä vaihdos puoluedemokratiaan tapahtui äkillisesti, kun taas muissa Pohjoismaissa tämä tapahtui asteittain. Tämä koskee myös naapurimaatamme Norjaa, jonka löyhä unioni Ruotsiin raukesi 1905. On kuitenkin huomattava, ettei puoluedemokratia Manin teoriassa sovi kuvaamaan demokratian esimuotoja Suomen suurruhtinaskunnassa. Suomessa ei oltu lähelläkään demokratiaa, vaikka keisari oli hyväksynyt uuden vaalilain ja valtiopäiväjärjestyksen 1906. Venäjän yksinvaltius joidenkin modernien instituutioiden kanssa oli saanut poliisivaltion piirteitä ja Suomen eduskunta eli sen armoilla. Senaatti ei ollut parlamentaarinen hallitus, koska sen toiminta olisi vaatinut eduskunnan luottamuksen. Sen lisäksi ainoastaan noin neljäkymmentä viisi prosenttia väestöstä sai äänioikeuden. Ikäraja oli kaksikymmentä neljä vuotta ja sen lisäksi äänioikeus evättiin suurelta ryhmältä äänioikeusikäisistä, missä kansalaisluottamuksen epääminen oli keskeinen seikka (13-15\%). (Taras- 
ti 1998, 62). Tästä syystä Suomessa oli selvästi enemmän äänioikeutettuja naisia kuin miehiä, ehdokkaat ja valitut olivat puolestaan pääosin miehiä.

Robert Hermanssonin komitea loi joka tapauksessa vaalilain, josta puolueiden edustajat vetivät köyttä komiteassa. Periaatteessa sama normipohja on edelleen voimassa. Suomeen luotiin suhteellinen vaalijärjestelmä kaikissa vaalipiirissä paitsi Pohjois-Lapissa (Kommittébetänkande 1906:12: Vallag 1906). Siellä oli vallalla englantilaismallinen enemmistövaalitapa vuoteen 1938 saakka, jolloin Lapin lääni perustettiin. Sama järjestelmä siirtyi Ahvenanmaalle ennen vaaleja 1948 ja oli voimassa vaaleihin 1983 saakka. Ennen vuotta 1948 Ahvenanmaa kuului Turun läänin eteläiseen vaalipiiriin (Sundberg 2011, 163-204). Suhteellinen vaalitapa loi institutionaaliset puitteet, mistä modernit puolueet syntyivät. Suomen työväenpuolue oli perustettu jo vuonna 1899 Turussa ja nimi muutettiin nykyiseksi Suomen Sosialidemokraattiseksi Puolueeksi vuonna 1903 - kuuluisessa Forssan kokouksessa. Myös ruotsinkielinen Finlandssvenska arbetarförbund perustettiin 1800-luvun viimeisen vuoden aikana ja se liitettiin SDP:een vuonna 1906: nykyisin yhdistys toimii Finlandssvenska socialdemokrater -nimellä.

Myös porvarilliset puolueet järjestäytyivät nopeasti uudella joukkoja kokoavalla tavalla ennen ensimmäisiä yleisiä vaaleja. Maalaisliitto sai alkunsa ja sama järjestäytymisen muutos koskee myös Ruotsalaista kansanpuoluetta. Vanhat säätyajan puolueet kuten vanhasuomalaiset ja nuorsuomalaiset jatkoivat entisillä nimillä, mutta joutuivat sopeutumaan uuteen tilanteeseen. Instituutioilla on merkitys ja tämä koskee kipeästi myös puolueita, jotka joutuivat sopeutumaan uusiin odotuksiin ja aktiivisiin ryhmiin uuden vaalilain myötä. Niinpä kaikki puolueet organisoivat järjestönsä niin, että alueelliset piirit vastasivat vaalipiirijakoa. Suurissa vaalipiireissä saattoi toimia useampi kuin yksi piirijärjestö. Sen lisäksi oli paikallisjärjestöjä, jotka myöhemmin saivat tehtäväkseen kunnallispolitiikan kentän ja vaalit.

Kunnallisdemokratia toteutui myöhään Suomessa. Asia oli keskeinen sosialidemokraattien agendalla - mutta porvarillinen vastustus oli jyrkkää ja sai tukea Pietarissa. Vasta 1918 Suomessa pidettiin ensimmäiset kunnallisvaalit. Puoluenimikkeitä ei juuri käytetty, mutta blokkijako sosialistien ja porvarien välillä oli sitäkin selvempi. Politiikka oli tullut 


\section{Jan Sundberg}

kunnallistasolle ja niin puolueiden tehtävät ja institutionaaliset roolit hallinnossa laajentuivat (Sundberg 1989, 60-69).

Puolueiden elämä ei tietenkään ole yksinomaan instituutioiden varassa. Aatteet, luokkajako ja kielirajat antoivat polttoainetta kerätä ääniä ja päästä vallan ytimeen. Suomi sai oman perustuslain vuonna 1919, jolloin demokratia vihdonkin sai virallisen sijansa ja institutionaaliset puitteensa maassa. Mikään oikeusvaltio Suomi kuitenkaan ollut, vainot ja keskitysleirit olivat osa poliittista kulttuuria pitkään. Viimeistään ne synnyttivät syvän haavan Suomen poliittisessa ja ihmisten jokapäiväisessä elämässä.

Mitkä olivat silloiset poliittiset päätoimijat ja millainen on niiden suhde nykypäivän poliittisen kamppailun ja yhteistyön partnereihin? Norjalainen Stein Rokkan on kuvaillut kolmikantamallilla Norjan keskeisiä vastakohtia ja sitä, miten puolueet ovat ryhmittyneet näiden ongelmien ratkomisen hengessä. Sama malli sopii muihin pohjoismaihin ja siten myös Suomeen. Sen mukaan on olemassa jako työn ja pääoman välillä - mikä on yleistä Euroopan maiden yhteiskuntien ristiriidoille. Pohjoismaat poikkeavat tästä perusjaosta siinä, että toinen jako kulkee maaseudun ja kaupunkien välillä jota voi myös kuvata keskusta-periferia -vastakohdalla. Näiden kolmen ulottuvuuden päissä on syntynyt työväenpuolue, talonpoikaispuolue ja konservatiivinen puolue. Tämän lisäksi työväenpuolueita vahvistivat ammattiliitot, talonpoikaispuolueita tuottajajärjestöt ja konservatiivisia puolueita työnantajaliitot. (Rokkan 1987, 63-110.)

Mutta miten Rokkanin kuulu malli sopii Suomeen? Ensinnäkin on muistettava se, että ilman katolisen kirkon (paavin) määräystä integroida pohjolaa Vatikaanin alaiseksi Canterburyn ja Hamburg-Bremenin piispojen avulla tilanne olisi toinen: uskonto olisi ortodoksinen ja kulttuuri bysanttinen, mitkä attribuutit poikkeavat merkittävästi länsieurooppalaisesta modernista historiasta (Tarkiainen 2008). Toiseksi, maaorjuus olisi ollut vallalla. Agraarinen paikallis-yhteisöllinen ilmanala ja talonpoikaisten ryhmien itsenäinen asema Ruotsissa loivat pohjan sille, että Suomi ylipäänsä sopii Rokkanin pohjoismaiseen malliin. On myös korostettava sitä, että Ruotsi loi oikeusjärjestelmän, johon kuului lain seuraamisvelvollisuus sekä kansalaisille että kuninkaalle. Tämä oikeusvaltion linja erottaa pohjoismaita selvästi Venäläisestä järjestelmästä ja ajattelusta. 
Suomessa Sosialidemokraattinen puolue organisoi työntekijöitä sekä kaupungeissa että maaseudulla - pääosa kansasta eli viimeksi mainitussa yhteisössä, kun oma valtio kehkeytyi ja oli nuori. Sama koskee ammattiliittoja, jotka oli alussa läheisesti kytketty puolueeseen. Itse asiassa jako ammattiliiton ja puolueen välillä oli käytännöllinen työnjako. Maalaisliitto keräsi talonpoikia ja MTK ajoi heidän tuottajaetujaan. Pääomaa puolustamaan nousi myöhemmin Kokoomus joka sai nimensä pian itsenäisyyden alussa. Työnantajaliitot olivat löyhästi sidoksissa puolueeseen. Näiden puolueiden kytkentä etujärjestöihin antoi niille lisävaltaa suhteessa muihin puolueisiin. Äänestäjät aktualisoivat valtansa kerran neljässä vuodessa (joskus useimmin), mutta etujärjestöt jäsenineen ajavat poliittisia etujaan aina kuin valtion budjettia rakennetaan.

Demokratiaa tuli koeteltiin dramaattisesti taloudellisen kriisin levittyä ympäri maailmaa vuoden 1929 jälkeen. Fasismi ja natsismi saivat kannatusta ja nuoret demokratiat kaatuivat monessa Euroopan maissa. Uhka oli erittäin suuri myös Suomessa. Tanska ja Ruotsi näyttivät mallia samana vuotena kuin Hitler nousi valtaan 1933. Siellä solmittiin talonpoikien ja työläisten yhteinen hallitusliitto, koska molemmat osapuolet kärsivät taloudellisesta ahdingosta. Ruotsissa tämä liitto sai kuvaavan nimen kohandel eli lehmänkauppa, joka tarkoittaa, että molemmat osapuolet jakoivat tasaisesti kakkua ja erimitallisia etuja. Norja tuli mukaan vuonna 1935 ja pian eli 1937 oli Suomen vuoro, jolloin "punamultahallitus" sai alkunsa (Karvonen 1991, 49-81). Torpparit ja duunarit löysivät vahvasti toisensa uudessa yhtenäisyydessä ja vuoden 1918 vastakohdat osaksi rapautuivat.

Tämä loi pohjaa pohjoiselle hyvinvointivaltiolle ja toimeenpanovalta teki selkotavalla pesäeron sekä äärivasemmalle että -oikealle poliittisella kentällä. Demokratia oli voittanut ja työväenluokka puolusti maata sinnikkäästi Talvisodassa 1939-1940 vastoin Stalinin ja Otto Ville Kuusisen odotuksia. Näillä yleisillä sosiaalisilla ja poliittisilla murroshuomioilla on luotu puitteet vanhojen puolueiden identiteetille ja kehitykselle. Mutta miten puolueiden sisäinen elämä kehittyi tästä eteenpäin? 


\section{Jan Sundberg}

\section{Puolueiden sisäinen organisaatio}

Sosialidemokraattiset työväenpuolueet olivat pitkälti malli puolueiden organisoinnille. Olennainen osa toimintatapaa oli tehokas vapaaehtoisten värväys puoluetoimintaan ja ääntenhankinnan sosiaaliseen verkostoon. Ajatuksena oli, että Sosialidemokraattinen puolue on rakenteeltaan demokraattinen samaan tapaan kuin demokraattinen valtiokin. Puolueella ei alun perin ollut muita resursseja kuin sen jäsenet. Heillä oli sekä etuja että velvollisuuksia. Samalla puoluekoneisto oli koulu työväelle siitä, miten yhteiskunta toimii ja sen arvoja ja intressäjä kootaan. Miten toimia yhteisön ja poliittisen yhdistysorganisaation puheenjohtajana tai sihteerinä sekä kohdata kokouksissa myös erimielisyyksiä, jotka ovat arkea modernissa yhteiskunnassa? Kun kurinalaiset ja valistushenkiset kansanliikkeet politisoituivat 1900-luvun taitteen muutoksessa, myös taisteluretoriikka, vastustaja ja vihollinen, muokkasivat poliittista osallistumiskulttuuria. Kapinan (1918) jälkeen järjestysideologia heijastui myös puolueaktiviteetteihin ja sen hyväksyttyihin muotoihin. Nämä opit olivat tärkeitä silloin kun työväenluokka sai sijan kunnallisessa päätöksenteossa. Ei ollut harvinaista, että kapinan jälkeen 1920-luvulla työmies oli lautakunnan tai valtuuston puheenjohtaja ja työnantaja oli tavallinen rivijäsen. Viimeksi mainituille tämä oli kova pala, mutta toisaalta puoluekoneisto oli rahvaalle hyvä koulu. Moni akateemisesti koulutettu oli vailla näitä politikoinnin perustaitoja, joita työmies oli hankkinut.

Suuri jäsenmäärä puolueissa oli vaaleissa etu kolmesta syystä. Ensinnäkin, jäsenet toimivat puolueen asiassa työpaikoilla ja vapaa-aikana. Henkilökohtaiset kontaktit olivat tärkeitä vaalityössä - osaltaan se nosti äänestysvilkkautta ja ohjasi ihmisiä äänestämään ensimmäisinä vaalivuosikymmeninä sosialidemokraatteja. Toiseksi, jäsenet ovat kiinnittyneempiä puolueeseen kuin muut äänestäjät. Tämä on turva poliittiselle yhdistykselle silloin, kun äänestäjävirrat lähtevät liikkeelle ja epävarmuus tuloksesta on suuri. Kolmanneksi paikalliset jäsenjärjestöt antoivat tärkeää tietoa puoluejohdolle äänestäjien toiveista ja ongelmista - ei turhaan puhuta kansallisista yhdistyksistä, tupailloista ja työväentalon opintokerhoista ja debateista.

Muut puolueet omaksuivat pian sosialidemokraattien mallin. Ranskalainen tutkija Maurice Duverger kuvasi tätä kielikuvassaan "tartunta 
vasemmalta" (Duverger 1978, 23-27). Porvarillisilla puolueilla oli tyypillisesti heikohko organisaatio ja jäsenmäärät olivat suhteellisen pieniä. Päöosiltaan organisaatio elpyi ennen vaaleja, jolloin vapaaehtoisia tarvittiin. Tyypillistä oli myös ehdokkaiden pätevyyden ja maineen korostaminen - pääomat, jotka olivat usein kertyneet muualla kuin politiikassa. Puoluekonventiot ja niiden erot kuitenkin muuttuivat ja ylipäänsä puolueet saivat pian kiinteämmän organisaation ja jäsenistön. Tutkijan on kuitenkin vaikeaa saada täsmällisempää tietoa porvarillisten puolueiden jäsenistä ja sukupuolijakaumista varhaisen puoluetoiminnan ajoilta. Sosialidemokraattien tilastot ovat puolestaan esimerkillisiä, ja niitä voi verrata tilastokeskuksen dokumentointiin. Kamppailu kommunisteja vastaan sodan jälkeen tosin hämärsi arkistointikulttuuria, sillä suurta jäsenmenetystä kansandemokraateille ei haluttu julkisesti kirjata.

Puolueiden järjestöllisen identiteetin ja myöhemmän samankaltaistumisen kannalta olennainen institutionaalinen muutos tapahtui vuonna 1969. Tätä aiemmin puolue oli tuntematon termi lainsäädännössä. Puolueorganisaatiot toimivat aiemmin pelkän yhdistyslain varassa samalla tavalla kuin muut ei-poliittiset järjestöt. Vaalilaki ei ennen murroksellisen 60-luvun loppua maininnut puolueita vaan ainoastaan valitsijayhdistykset. Tilanne muuttui vuonna 1967, jolloin valtion puoluetuki sai alkunsa. Nousi lainopillinen ongelma - mille toimijalla saatettiin myöntää tukirahaa, kun laki ei tuntenut puolueita? Tilanne korjaantui pari vuotta myöhemmin, kun puolue- ja vaalilaki astuivat voimaan samana vuonna (Vallag 1969; Partilag 1969). Nämä kaksi lakia jättivät merkittävät jäljet, mitkä poikkeavat muista pohjoismaista. Kuten jo on mainittu, lain noudattamisen kulttuuri oli ajat sitten syvästi juurtunut ruotsalaiseen kansaan ja se jatkui samana suomalaisen nationalismin herättyä Venäjän vallan aikana ja edelleen itsenäistymisen jälkeen. Puolueet 1960-luvun lopulla eivät olleet mikään poikkeus legalistisen kunnioituksen hengessään.

Puoluelain mukaan Suomen puolueilla on oltava demokraattinen ohjelma ja järjestö. Sen lisäksi puoluetta ei voi perustaa ilman viiden tuhannen äänioikeutetun nimikirjoitusta. Vaalilaki sääti miten ehdokasasettelun perusnormit ja myöhemmin paljon hehkua herättänyt uusi laki vaalirahoituksesta sääteli, miten ehdokkaat kirjaavat vaalitukiaktiviteetit. Sen lisäksi yhdistyslaki säätelee piiri-, kunnallis- ja paikallisjärjestöjen toimintaa. Muissa Pohjoismaissa ei tunneta puolue- eikä yhdistyslakia. 


\section{Jan Sundberg}

Suomen eduskunta nojaa tiukasti lainopillisiin traditioihin, jotka meidän yhteiset valtiopäivämme Tukholmassa sääti ja jota nykyisessä Ruotsissa monesti ihmetellään.

Lain sääntelystä johtuen puolueilla Suomessa on eräänlaiset mallisäännöt, jotka vertailussa ovat melkein samannäköisiä. Demokratiaa vaarantavia puolueita ei voi perustaa, mikä joidenkin mielestä onkin juuri epädemokraattista. Sen lisäksi Ahvenanmaalla ei lain mukaan ole puolueita, koska siellä nimikirjoituksia on käytännössä mahdotonta kerätä riittävää määrää. Lagting-vaaleissa käytetään termiä politiska föreningar eli puhutaan poliittisista yhdistyksistä, joilla on puoluemaiset oikeudet ehdokasasettelussa. Tiukka lakinormisto Suomessa on lähinnä verrattavissa Saksaan. Siellä on säädetty kommunisminvastaisia pykäliä samaan tapaan kuin Suomessa ennen sotia. Toisaalta Keski-Euroopasta löytyy myös natsismin vastaisia pykäliä, joita myös meillä säädettiin sotien jälkeen.

Suomen puolueilla on merkittäviä eroja, kun vertailemme niiden organisaatioiden hierarkkisuutta. Jos arvosteluperusteina ovat organisaatioiden 'litteys' eli kuinka läheisesti jäsenet pystyvät vaikuttamaan päätöksentekoon ja tasavertainen sukupuolijakauma, niin silloin erot puoluerekisterin toimijoiden välillä vahvistuvat. Karkeasti voi tulkita, että vanhat porvarilliset puolueet (Kokoomus ja Keskusta) kuuluvat siihen tyyppiin, joiden organisaatio koostuu monista päällekkäisistä elimistä, puoluekokous kokoontuu harvoin ja puoluejohtajalle on annettu suurta päätösvaltaa. Sosialidemokraatit ja Ruotsalainen kansanpuolue ovat ääripäiden keskivaiheella. RKP nimenomaan siksi, että puoluekokouksia pidetään joka vuosi - jolloin myös kysymys puolueen puheenjohtajuudesta voi nousta esille, jos osallistujat niin tahtovat. Omaa luokkansa ovat Vasemmistoliitto ja Vihreät, jotka ovat suhteellisen uusia puolueita ja uudet virtaukset suorasta demokratiasta ja sukupuolten tasavahvasta edustuksesta ovat parhaiten heijastuneet heidän säännöissään (Sundberg 1997, 97-117). Perussuomalaiset ei ole mukana vertailussa; silti voi helposti huomata, että karismaattinen johtajuus oikeistopopulistisessa puolueessa on tiukasti keskittynyt yhteen henkilöön ja populistipuolueen jäsenistö on selvästi miesvaltainen. 


\section{Aatteellisia eroja}

Puolueiden aatteellisia eroja voi kuvata monin tavoin. Tavallisin keino on vasemmisto-oikeisto -dimensio. Vasen ja oikea periytyy Ranskan vallankumouksesta 1789-1799, jolloin uudistusmieliset istuivat parlamenttisalissa vasemmalla ja konservatiivit oikealla. Mainittu vasemmisto - oikeisto akseli ei kuitenkaan parhaalla tavalla kuvaa puolueita. Miettikääpä, minne sijoittaisitte vihreät ja perussuomalaiset? Vasemmisto-oikeisto -akseliin on usein lisätty (post)materialismin vahvuutta kuvaava pystyakseli ja näin muodostettu kaksiulotteinen konteksti. Minun suosikkini on hevosenkenkä sen havainnollisuuden vuoksi. Hevosenkengän ääripäissä on kommunistit ja toisessa päässä natsit ja fasistit, jotka kuuluvat samaan perheeseen, vaikka niiden aatteellis-poliitiset muodot olivat vähän erilaiset Saksassa ja Italiassa. Hevosenkengän havainnollinen etu on se, että nämä ääripuolueet eivät ole toisistaan totaalisesti erillään siten kuin vasemmisto - oikeisto akseli demonstroi. Itse asiassa näillä autoritaarisilla ryhmillä on paljon yhteistä, mutta kuitenkin ne kuuluvat eri aatteelliseen maailmaan.

Vaikka kommunistit ja fasistit kuvataan perivihollisiksi, muun muassa kokemus 1930-luvun Saksasta antaa mahdollisuuden toisenlaiseen tulkintaan. Siellä oli suhteellisen helppo käännyttää kommunisteja natseiksi mutta sosialidemokraatteja oli lähes mahdotonta saada värvätyiksi. ItäSaksassa sotien jälkeen värväys kääntyi päälaelleen. Kuten puoluenimikin osoittaa, natsipuolue oli kansallis-sosialistinen, eli se sisälsi sosialistisia lainauksia, joista vähitellen luovuttiin. Oikeistopopulistiset puolueet kuten perussuomalaiset toimivat vähän samalla periaatteella. Heidän sosiaalipoliittinen ohjelmansa on osiltaan lähellä vasemmistoa lukuun ottamatta perhe- ja sukupuolten tasa-arvopolitiikkaa, mutta kansallismielinen, maahanmuuttovastainen, ruotsinkieltä vastustava ja maanpuolustusintoinen ryhmä PS sijoittuu hevosenkengän oikeistoradikalistisen pään läheisyyteen. Monesti tiedotusvälineissä perussuomalaisia aprikoidaan vasemmistolaisiksi, mutta popularisointi kuvastaa kommentoijien tietämättömyyttä tällaisten populistipuolueiden olemuksesta.

Olemme jo huomioineet, että puoluedemokratian aikaan kuului vahva kiinnittyminen puolueeseen eikä yksittäisen kansanedustajan tai aktiivisen järjestötoimijan poliittinen merkitys ja pelivara olleet etusijalla. 


\section{Jan Sundberg}

Sosialidemokraattinen puolue Suomessa on ehkä paras esimerkki tästä kulttuurista. Alunperäinen ajatus sosialistisilla puolueilla oli pyrkiä sosialismiin parlamentaarisin keinoin - mikä kiteytyi ajatuksessa saada enemmistö parlamentissa. Ongelmana oli se, että tietoisin osa työväenluokkaa oli tehdastyöläiset. Heidän äänensä ei riittänyt valtaan pääsyyn ja Sosialidemokraatit oli tuomittu ulkopuoliseksi haastajaksi. Puoluestrateginen harkinta oli kekseliästä, pian ryhdyttiin uusiin valistus- ja värväysyrityksiin työmiesten vaimojen ja työläisnaisten suunnissa; näin nostettiin vaalivilkkautta, eli heille tarjottiin aktiivisesti miesten hallitsemia ehdokaslistoja. (Sundberg 1995, 83-111.)

Kun tämäkään ei riittänyt, seuraava askel oli laajentaa kohderyhmää työväenluokasta heikon identiteetin tai osapäiväisten työläisten ja myöhemmin laajan palkansaajayhteisön suunnnissa. Tämä strategia oli menestyksellinen. Ongelmana olivat uudet äänestäjäryhmät ja jäsenet, joille puolueen aatteelliset peruskysymykset olivat vieraita. Olikin aika muuttaa retoriikkaa ja muokata aatteellisia päämääriä. Jo varhain Sosialidemokraatit meillä ja muualla puhuivat ja kamppailivat käytännön poliittisilla asioilla, perustavissa poliittisissa instituutioissa kuten kunnallisvaltuustoissa ja aatteelliset päämäärät alkoivat hiljalleen pölyttyä puoluearkistoissa. Erittäin tuottelias ruotsalainen tutkija ja sanomalehtimies Herbert Tingsten on kuvannut tätä vaihetta erinomaisella tavalla. (Ks. erit. Tingstenin, 1941, värikkäät ja monipuoliset analyysit muutoksesta). Saksalainen eliittiteoreetikko Robert Michels on havainnoinut tätä muutosprosessia käsitteellä transgressio ${ }^{2}$ (Michels 1925, 25-28).

Sosialidemokraattien tapaan myös keskusta ja kokoomus ovat muokanneet politiikan sisältöjä ja pelitilaa uusien sosiaalisten ryhmien suunnassa. Alun perin keskusta - joka jätti 1960-luvun Suuren muuton keskellä nimensä Maalaisliitto - oli selvästi talonpoikaispuolue. Tänään se on enemmänkin maaseudun ja periferian Suomi-puolue. Muutos on käynyt suhteellisen kivuttomasti, vaikka maanviljelijäväestö on rajusti kaventunut. Suurin uhka keskustan asemalle on ollut ja on populistiryhmien äkillinen nousu. Kokoomus on muuttunut konservatiivisesta puolueesta hyvinvoivien ryhmien palkansaajapuolueeksi. Sen etu on ollut keskiluokan ja siihen samastuneiden ryhmien kasvu, millä vesillä myös keskusta, sosialidemokraatit ja vihreät kalastelevat. Lyhyesti summattuna, puolueiden transgression kautta äänestäjät ja puolueiden kulloisetkin kannatta- 
jaryhmät ovat yhä laajemmin heterogeenista joukkoa - liikkuvia ja yksilöllisiä harkitsijoita - jota on vaikea ohjata ja pitää uskollisina äänestäjinä.

\section{Yleisödemokratia Suomessa}

Manin mallin mukaan puoluedemokratia sai loppunsa joskus 1970-luvulla. Sen tilalle nousi hiljakseen yleisödemokratia, jolla on tiettyjä yhtymäkohtia parlamenttidemokratiaan. Lyhyesti sanottuna kysymys on siitä, että sosiaaliset ja taloudelliset tekijät vaikuttavat selvästi vähemmän äänestäjien valintoihin kuin ennen. Muita tekijöitä on noussut tilalle, kuten yksilöllisyys ja ehdokkaiden henkilökohtaiset ominaisuudet. Modernit tiedotusvälineet kuten radio, televisio ja internet ovat voimakkaasti vaikuttaneet tähän kehitykseen. Poliitikot voivat kommunikoida suoraan äänestäjille ja verkossa jopa dialogisesti kannattajiensa kanssa ilman puoluekoneiston välitystä. Näin edustaja on tietyin osin saanut takaisin sen henkilökohtaisen kontaktin äänestäjään, minkä parlamenttidemokratia aikoinaan tarjosi hänelle. Sen lisäksi ovat ehdokkaiden henkilökohtaiset ominaisuudet nousseet vaaliohjelman rinnalle; imago ja henkilöbrändi korostuvat myös siksi, että politiikan asialistat muuttuvat hektisesti (media)demokratiassa ja kokeneetkin poliitikot ovat epävarmoja sen suhteen, mitkä ongelmat nousevat esille yhteiskunnassa ja monien toimijoiden poliittisessa pelissä (Manin 2002, 234-251). Ehdokkaan poliittinen imago ja yksityiselämä ovat osittain nousseet politiikan tilalle. Äänestäjistä on tullut yleisö, joita poliitikot puhuttelevat ja viihdyttävät tiedotusvälineiden kautta.

Vaikuttaako tulkinta tutulta vai onko Manin hakoteillä? Suomessa henkilöehdokkaiden asema vaaleissa on alun perinkin ollut keskeisempi kuin muissa pohjoismaissa. Selityksenä tälle on vaaliemme yksilöllinen ehdokasasettelu. Valtio-opissa luokitellaan erikseen toisaalta avoimet ja toisaalta suljetut ehdokaslistat. Suljetun listan kulttuurissa puolue päattää, ketkä ovat ehdokkaita ja ketkä valitaan - äänestäjien asia on päättää, kuinka monta listalta tulee valituksi. Toisin sanoen puolue päättää, kuka on ykköspaikalla, toisella tilalla ja niin edelleen. Tällainen järjestelmä on voimassa Norjassa ja vähän muutettuna Ruotsissa. Tiedotusvälineissä 


\section{Jan Sundberg}

esiintyy silloin tällöin puhetta pitkistä listoista, jotka olivat ennen käytössä Suomessa. Tällaiset yleishöpinät on syytä unohtaa. Suomessa oli listoja, joissa oli pääehdokas ja enintään kaksi ehdokasnimeä hänen alapuolellaan, varalla. Ensimmäinen ehdokas listalla sai yhden äänen, toinen puolikkaan ja kolmas yhden kolmasosan äänestä (Törnudd 1968, 35-40). Samat ehdokkaat olivat usein ehdokkaana monissa listoissa ja monissa vaalipiireissä joko ensimmäisenä tai varapaikoilla. Järjestelmä oli hyvin yksilöllinen, sillä äänestäjällä oli oikeus valita tai 'nimittää' oma ehdokkaansa kirjoittamalla hänen nimensä, ammattinsa ja osoitteensa.

Avoimissa listoissa puolue päättää, ketkä ovat ehdokkaita, ja äänestäjät päättävät ketkä ja kuinka monta tulevat valituiksi. Nykyinen järjestelmä (vuodesta 1954) voidaan siis mieltää avoimeksi. Suomessa ei siis ole voinut äänestää puoluetta, on ollut pakko äänestää ehdokasta. Pitkälle juuri tästä johtuen yleisödemokratiassa puolueiden ehdokaslistat muistuttavat tavarataloa, jossa eri vaalipiirien osien tunnetut nimet, kirjavat ammatit ja toimijat sekä julkkikset kilpailevat eduskuntapaikasta. Kilpailua käydään, ei ainoastaan puolueiden välillä, vaan myös saman puolueen ehdokkaiden kesken. Kun selaatte seuraavan kerran ehdokkaita vaalikoneissa, niin huomioikaa ihmeessä, miten tavarataloefekti hämärtää puoluerajojen merkitystä.

On paradoksaalista, kuinka vaikeaa äänestäjällä on valita mieleisensä henkilö, vaikka ehdokkaita löytyy yllin kyllin. Usein ongelmana on henkilökohtainen samastuminen ehdokkaaseen. Samastuminen toteutuu harvoin täydellisesti; ongelmaksi nousee usein sekin, että lupaava ehdokas on "väärän” puolueen ehdokkaana. Kysymys, kumpi on tärkeämpi valintaperuste, puolue vai ehdokas, on entistä tiukemman vaalitutkimuksen alla. Yleissuunta vie yksilöllisiä, henkilöiden ja fraktioiden tasolla refleksiivisiä, valintoja kohden varsinkin nuorempien äänestäjien keskuudessa. Mutta hyväkään yksilöehdokas ei aina tule äänestysvalinnaksi, jos puolue on liian etäällä valitsijan arvostuksista ja henkilöhistoriasta; vankka kokoomuslainen ei äänestä omasta mielestään erittäin mallikasta ehdokasta, jos hän on vaikkapa vasemmistoliiton listalla.

Yksilöllisyys heijastuu myös tukiryhmien toiminnassa. Tukiryhmät organisoituvat tavallaan puoluekoneiston ulkopuolella. Jokaisella varteenotettavalla ehdokkaalla on oma tukiryhmänsä, mikä kerää varoja ja järjestää tilaisuuksia ja mainontaa. Tukiryhmän jäseneksi rekrytoidaan 
mielellään tunnettuja henkilöitä julkisten asemien ja elinkeinoelämän eri puolilta. Usein tukiryhmät keräävät tukinimilistoja ja ne julkistetaan mielellään - varsinkin, kun ne ovat laajoja ja arvovaltaisia. Puolueorganisaatio toimii vaaleissa tukipylväänä ja nostavat esiin ehdokkaat ja sopivat heidän erilaiset tukisummansa. Sekä ehdokkaat että puolue hyötyvät toisistaan. Puolue tarjoaa ehdokkaalle ponnahduslaudan, sillä valitsijamiesyhdistyksen perustaminen on työläistä ja mahdollisuudet pärjätä yksin ilman puolueverkostoa ovat pienet. Toisaalta puolue hyötyy nimenomaan julkkisehdokkaista, koska heidän saamansa huomio nostaa kokonaisäänimäärää ja tätä kautta ehdokkaiden listalla saamia vertauslukuja sekä täten luo mahdollisuuksia muille ehdokkaille tulla valituksi. Eduskunnassa toiminta kuitenkin edellyttää puoluekuria. Sen toteuttaminen ei aina onnistu. Tiettyjä vapauksia ja pelivaroja on mahdollista antaa esimerkiksi omantunnon kysymyksissä, vahvojen edustajien huomiopeleissä tai puoleen monien kasvojen ylläpitämisessä; kuitenkin useimmissa asioissa - usein juuri enemmistöparlamentarismin luottamuskysymyksissä - yksilölliset irtiotot ja oppositiokannat voivat taasen johtaa eduskuntaryhmästä erottamiseen.

\section{Puoluemuutos herättää monia selityksiä}

Aina 1960-luvulta asti on esitetty teorioita ja selityksiä sille, miten puolueet menettävät roolinsa ja usein on nostettu esiin puolueiden kriisi. Polttoainetta tällaisille spekulaatioille ovat antaneet jäsenmäärien lasku ja yleinen haluttomuus tehdä vapaaehtoistyötä puolueelle. Onkin kysyttävä, miten yleisödemokratia on vaikuttanut puolueiden toimintaan? Ensinnäkin, inflatorisesta kriisi-termistä voi luopua saman tien. Sitä käytetään ajattelematta sen syvällistä merkitystä ja sen aktualisoimaa puolueen tai puoluejärjestelmän hajoamisen vaaraa. Kriisipuhe on yksi parlamentaarisen demokratian arvostelun muotiretoriikka - median lisäksi jopa tutkijoiden keskuudessa.

Tieteellinen systemaattisuus ja aineiston tarkastelu (lähdekritiikki) auttavat meitä kaikkia pitämään päämme kylmänä. Historian tunteminen auttaa meitä pohtimaan paremmin sitä, mikä on murros ja mikä taas keveämpi aaltoliike poliittisessa kulttuurissa. Selityksiä puolueiden ase- 


\section{Jan Sundberg}

man ja roolin muutoksesta on monia ja minun on pakko valita joitain keskeisiä. Tehtävä mutkistuu, sillä monet teorioista ovat samankaltaisia, konvergoituneet. Voi kuitenkin erottaa kahden tyyppiset selitykset toisistaan: lineaarinen ja dialektinen.

Lineaariset selitysmallit ovat huomattavasti yleisimpiä. Sen mukaan puolueiden kehitys lähtee liikkeelle eräänlaisesta alkupisteestä ja vie kuin suora kohoava linja uuteen saavutettuun pisteeseen. Lähtöprosessi on aina puoluedemokratian aikaa, jolloin vapaaehtoisuus, tykästyminen liikemuotoihin ja suuret jäsenjoukot nimenomaan joukkopuolueissa ovat vallitsevia piirteitä. Mitä pidemmälle aika rientää, sitä heikommaksi puolueen rooli ja organisaatio rapautuvat. Tästä seuraa helposti kriisikeskustelu. Dialektinen tulkinta lähtee puoluehistorian alkulähteiltä ja hahmottaa puolueiden kehityksen isojen aaltojen kuohunnan kautta. Kehityssuunnat saavat vastareaktionsa ja tietyt piirteet - jotka olivat ennestään tuttuja, mutta usein unohdettuja varsinkin parlamenttidemokratiassa - nousevat esille uusissa muodoissaan. Näin ollen puoluedemokratian aika oli ainoastaan väliaikainen.

Palataan Stein Rokkanin kolmikantamalliin. Se kuvastaa yhteiskunnan vastakohtaisuuksia, joihin puolueet nojasivat viime vuosisadan alussa. Mallin toimivuus on asetettu vahvasti kyseenalaiseksi. Monet kriitikot esittävätkin, että vastakohtaisuudet ovat häipyneet tai olennaisesti muuttuneet ja se perusta, mihin puolueet nojautuivat, on kadonnut. Puolueet ovat tulkinnan mukaan epätoivoisesti tarraamassa menneeseen, ja puoluelaitosta olisikin aika kokonaan uudistaa. Tämän käsityksen mukaan vanha puoluelaitos organisaatioineen on kykenemätön uudistumaan ja tästä syystä puolueet muun muassa Suomessa ovat kriisissä.

Vaikka ohitammekin kokonaiskriisin, tulee huomiota kiinnittää juuri vanhojen organisaatioiden kyvyttömyyteen uusiutua. Käytän omintakeista vertailevaa tulkintatapaa, jota on paljon käytetty anglo-amerikkalaisissa oppikirjoissa. Esimerkkini on organisaatioista, jotka ovat suurin piirtein yhtä vanhoja kuin edelleen toimivat poliittiset puolueet. Monet autoja valmistavat organisaatiot ovat tällaisia. Jos ne tehdasvalmistuksessa olisivat kyvyttömiä vastaamaan kysyntään ja uusimaan mallejaan, autojen ulkonäkö ja tekniikka olisivat samanlaisia kuin sata vuotta sitten (Sundberg 2002, 181-216). Kuten tiedätte, tällaista ei ole tapahtunut, kilpailu ja kehitys ovat pakottaneet organisaatioita uudistamaan tuotteitaan 
- perusmalleista on päästy eteenpäin automallien rikkaaseen kirjoon ja puhutaan jopa massaräätälöinnistä, missä asiakas sensitiivisesti vaikuttaa tuotannon kulkuun ja tuotteisiin. Vastaavasti puolueorganisaatiot on kansalais-asiakkaiden toimin pakotettu sopeutumaan yhteiskunnan muutoksiin - missä ne itse omilla poliittisilla toimillaan ovat olleet vahvasti mukana.

Niin kutsuttu sosiologinen (ja lineaarinen) selitys lähtee siitä, että yhteiskuntarakenteet selittävät puolueen menestystä vaaleissa. Mitä suurempi työväenluokka, sitä suuremmaksi kasvaa työväenpuolue. Mutta mitä tapahtuu tilanteessa, kun työväenluokka ei enää kasva vaan pienenee, kuten yhteiskunnassa on tapahtunut. Mallin mukaan puolueen kannatus vastaavasti vähenee. Puolueiden vastaus siihen on transgressio eli puolue on pakotettu huomioimaan uusi tilanne ja toimimaan sen mukaan. Monasti se onnistuukin, muttei välttämättä jokaisessa murrosvaiheessa. Uusia puolueita nousee areenalle ja ne ovat valmiita viemään osansa äänestäjistä, jos vanhojen organisaatioiden reformointi ei onnistu tai muutokset jäävät pinnallisiksi tai tekemättä.

Toisenlainen selitys joukkopuolueiden jäsenkatoon lähtee rationaalisesta teoriasta. Sen mukaan ihminen on itsekäs ja tavoittelee omia etujaan, joista taloudelliset resurssit ja vaikutusvalta ovat tärkeimpiä. Ajatukset on tietenkin lainattu taloustieteestä. Amerikkalainen Leon D. Epstein kirjoitti tässä hengessä kirjan jo 1960-luvun loppupuolella. Se on nostettu esiin tässä, koska hänen teoriansa esittämisestä on kulunut niin paljon aikaa, että sitä voidaan empiirisesti arvioida. Hän lähtee hypoteesistä, että työväenpuolueiden aika on ohitse, koska unelma sosialismista on aikaa sitten kuollut. Niin kauan kuin sosialismin idea ja utopia elivät, voi hyvin ymmärtää jäsenten innostuksen tehdä ilmaista työtä puolueen hyväksi. Nyt tilanne on toinen eikä ole mitään rationaalista syytä ylläpitää suurta jäsenjoukkoa. Argumentit ovat seuraavat.

Ensinnäkään, puolueet eivät enää tarvitse vapaaehtoisia työntekijöitä. Puoluetyö on ammatillistunut ja markkinoistunut (hyödykeperustaistuminen). Mielipidemittaukset ovat sivuttaneet jäsenten informaation ja keskustelut paikallisosastotasolla. Lisäksi puolueet ostavat palveluja mainostoimistoista ja ammattilaiset hoitavat ja auttavat mainontaa tiedotusvälineissä. Sen lisäksi politologi Epstein on ihmeissään, miksi joku haluaisi tehdä vapaehtoista työtä toiselle ihmiselle (ehdokkaalle), jos siitä 


\section{Jan Sundberg}

ei ole itselle muuta ilmeistä hyötyä kuin mahdolliset (vaali)pullakahvit ja taputus olalle. Lopputulos ei ole yllättävä, jäsenyys tulee romahtamaan ja joukkopuolueista tulee samantapaisia kuin porvarilliset puolueet (Epstein 1967, 130-166). On kuitenkin kestänyt yllättävän kauan ennen kuin puoluejäsenyys lähti hänen teoriansa mukaiseen yleiseen laskuun - muun muassa 1960-luvun nuoren polven uusvasemmisto sekotti mallia lännessä. Toisaalta tulee huomioida, kuinka ajankohtainen vapaaehtoistyö uusin tavoin rakentuu yksittäisten ehdokkaiden ympärille tukiryhmissä. Vapaaehtoistyö on myös ratkaisevaa kunnallisvaaleissa, mutta sekin on meillä vaarassa osaltaan romuttua suurten kuntaliitosten takia. Jos kuntien integrointiaikeet toteutetaan, vapaaehtoistyö siirtyy helposti kylä- ja kaupunkiosatoimikuntiin. Niissä puolueet eivät suoranaisesti ole mukana - ja näin ollen voi sanoa, että teorialla on selitysvoimaa. Puoluekriiseistä hän ei kuitenkaan puhu vaan rajoittaa argumentit keskusteluun työväenpuolueiden jäsenkadosta. Mutta palataanpa takaisin suureen kysymykseen, miten selittää puoluemuutosta, joka ei ole kriisi vaan sopeutumista uuteen tilanteeseen.

\section{Aika sitoa langat yhteen}

Jotta te hyvät lukijanaiset ja -herrat ette jäisi ihmettelemään, mitä uskoa puoluekulttuurien tulevaisuudelta, esitän lopuksi dialektisen ajattelun mukaisen mallin. Itse asiassa se on hyvin yhteensopiva Manin teorian kanssa, vaikka tulkinnat onkin kehitetty toisistaan erillään. Richard Katz ja Peter Mair johtivat suurta puoluetutkimusprojektia, mikä oli vailla vertaansa 1980-luvun lopulla ja 1990-luvun alussa. Siinä me kaikki tutkijapartnerit monesta maasta keräsimme valtavan määrän dataa, jota sitten yhdessä standardisoitiin ja verrattiin. Puoluevertailu eri kulttuurikonteksteissa oli hikistä puuhaa, mutta loppusynteesi sai kaikkien hyväksynnän ja ymmärsimme, että mallilla oli kuin olikin oma relevanssinsa.

Malli lähtee liikkeelle 1800-luvun puolueista, jotka muistuttavat Manin täällä esitettyä näkemystä. Joudun tässä ohittamaan sen vaiheen. Sen sijaan katsomme lähemmin sitä, miten puolueet ovat muuttuneet Stein Rokkanin kuvaustavasta. Siihen aikaan kansalaisyhteiskunta ja valtio oli kytketty toisiinsa puolueiden välityksellä. Porvarilliset puolueet eli kaa- 
deripuolueet ja heidän aktiivinsa olivat osa tätä kansalaisyhteiskuntaa mutta olivat määrältään vähäisiä ja edustivat kansalaisten jonkinlaista eliittiä (jolla oli yhteys taloudellis-hallinnolliseen toimeenpanoon). Puolueen kautta he vaikuttivat eduskunnassa ja hallituksessa ja pitivät yhteyttä kansalaisyhteiskunnan tiettyihin piireihin. Joukkopuolueissa taas puolue ja kansalaisyhteisö olivat lähekkäisiä ja päällekkäisiä, mutta niitä erotti työnjako. Puolue ajoi kansallisen poliittisen järjestelmän termein etuja ja asioita eduskunnassa ja myöhemmin hallituksessa. Vuorovaikutus ja vastuu puolueiden kautta alkoi elää vahvasti molempiin suuntiin.

Puolueiden samankaltaistuttua - jota vaihetta kutsutaan myös 'catchall'- eli kaikki kattavaksi puoluekulttuuriksi - tilanne on muuttunut. Pitkäaikaisten hallitusvastuujaksojen ja julkisen puoluerahoituksen myötä puolueet elävät riippumattomammalla tavalla, mitä muun muassa Epstein on dokumentoinut. Puolueista on tullut osa valtiota ja toinen jalka on irtaantunut kansalaisyhteiskunnasta (Katz \& Mair 1995, 5-28). Periaatteessa puolueet pystyvät toimimaan ilman suurta jäsenistöä turvautumalla yleisödemokratian kommunikaatioon - ja rahaa tulee valtiolta, minkä suuruudesta he itse päättävät. Kysymys tietenkin on, kuinka suuressa määrässä irtaantuminen on tapahtunut kansalaisyhteiskunnasta ja kuinka suuressa määrin puolueet ovat osa valtiota?

Suomessa on helppo huomata, kuinka voimakkaasti puolueet ovat osa valtiota jo tiukan ja laajan lainsäädännön johdosta, mikä säätelee puolueiden toimintaa. Puolueet ovat itse päättäneet olla mukana. Verrattuna muihin maihin Suomi on tässä suhteessa malliesimerkki - tämän kirjan muutkin esseet korostavat suomalaista valtiossa kiteytyvää yksimielisyysvaatimusta. Kytkennän heikkous kansalaisyhteiskunnan muuttuviin ryhmiin näyttäytyy siinäkin, miten helposti populistipuolue voi voittaa ääniä vanhoilta puolueilta. Paluuta entiseen ei kuitenkaan ole näkyvissä. Parlamenttidemokratian aikana edustaja oli äänestäjien luottohenkilö, mutta nykyään - mallin tulkinnan mukaan - kansanedustaja on valtiollistunut toimija.

Politiikka on yhä enemmän ammattilaisten käsissä, ja siinä mielessä se on elitisoitunut. Robet Putnam on varoittaen visioinut, mitä seuraa demokratialle, jos kansalaisyhteiskunnan sosiaalinen mobilisaatio rapautuu (Putnam 2000). Tästä voi keskustella, mutta edelleen elämme epävarmuudesssa - missä ja milloin tulee Putnamin varoituksen hengessä 
vastaan raja, jolloin demokratia on vaarassa. Selvä kuitenkin on, että puolueiden tehtävät ovat lisääntyneet; entistä enemmän julkinen valta ja hallinta säätelevät kansalaisten elämää, kehdosta hautaan. Suomen puolueet vaikuttavat paitsi täällä myös Euroopan Unionissa. Myös siellä puolueet tarvitsevat ammattiväkeä hoitamaan asioita.

\section{Loppusanat}

Yliopiston tehtävä on kouluttaa ja kannustaa kriittiseen ajatteluun. Polku refleksiiviseen arvosteluun ei rakennu itsestään, vaan se vaatii opiskelua ja tiedon hankkimista. Sama tietenkin koskee puolueita, demokratiaa ja vaalijärjestelmiä. Jos teitä kiinnostaa syventyä asioihin, mihin olen teitä esseessäni johdatellut, olette tervetulleita osallistumaan ja kyseenalaistamaan ajatuksiani Helsingin yliopiston yleisen valtio-opin oppiaineen luennoille. Se - jos jokin - piristää ja saa aivot toimimaan. Pidän luennot toisella kotimaisella kielellä. Välkommen!

\section{Lähteet}

Kirjallisuus

Carlsson, Sten. 1987. From Four Estates to Two Chambers: The Riksdag in a Period of Transition 1809-1921. In Metcalf, Michael (ed.), The Riksdag: A History of the Swedish Parliament. New York: St. Martin's Press.

Duverger, Maurice. 1978. Political Parties. London: Methuen \& Co

Epstein, Leon. 1967. Political Parties in Western Democracies. New York: Frederick A. Praeger Publishers

Helenius, Ralf .1969. The Profile of Party Ideologies. Helsinki 
Karvonen, Lauri.1991. 'A Nation of Workers and Peasants'. Ideology and Compromise in the Interwar Years. In Karvonen, Lauri \& Sundberg, Jan (eds.), Social Democracy in Transition. Aldershot: Dartmouth

Katz, Richard \& Mair, Peter .1995. Changing Models of Party Organizations and Party Democracy: The Emergence of the Cartel Part. Party Politics vol. 1

Manin, Bernard. 2002. Den representativa demokratins principer. Stockholm: SNS Förlag

Michels, Robert. 1925. Zur Soziologie des Parteiwesens. Leipzig: Alfred Kröner Verlag

Putnam, Robert. 2000. Bowling Alone. New York: Simon \& Schuster

Przeworski, Adam \& Sprague, John.1986. Paper Stones. A History of Electoral Socialism. Chicago: The University of Chicago Press

Rokkan, Stein.1987. Stat, nasjon, klasse. Oslo: Universitetsforlaget

Schück, Herman.1987. Sweden's Parliamentary Institutions from the Thirteenth Century to 1611. In Metcalf, Michael (ed.), The Riksdag: A History of the Swedish Parliament. New York: St. Martin's Press

Sundberg, Jan. 2011. Riksdagsval på Åland. I Grönlund, Kimmo (red.), Språk och politisk mobilisering. Helsingfors: Svenska Litteratursällskapet i Finland

Sundberg, Jan. 2002. The Scandinavian Party Model at the Crossroads. In Webb Paul, Farrell David and Holliday Ian (eds.), Political Parties in Advanced Industrial Democracies. Oxford: Oxford University Press

Sundberg, Jan. 1997. Compulsory Party Democracy: Finland as a Deviant Case in Scandinavia, Party Politics, Vol 3:1

Sundberg, Jan. 1995. Women in Scandinavian party organizations. In Karvonen, Lauri \& Selle, Per (eds.), Women in Nordic Politics. Aldershot: Dartmouth

Sundberg, Jan.1989. Lokala partiorganisationer i kommunala och nationella val. Helsingfors: Finska Vetenskaps-Societeten

Tarasti, Lauri.1998. Suomen vaalilainsä̈̈äntö. Helsinki: Edita

Tarkiainen, Kari. 2008. Sveriges Österland. Finlands svenska historia I. Helsingfors: Svenska litteratursällskapet i Finland (on myös suomeksi)

Tingsten, Herbert.1941. Den svenska socialdemokratins idéutveckling I och II. Stockholm: Tidens Förlag

Törnudd, Klaus.1968. The Electoral System of Finland. London: Hugh Evelyn 


\section{Jan Sundberg}

Villstrand, Nils Erik. 2009. Riksdelen. Stormakt och rikssprängning 1560-1812. Finlands svenska historia II. Helsingfors: Svenska litteratursällskapet i Finland

Laki- ja komitealähteet:

Kommittébetänkande 1906: 12, till Hans Kejserliga Majestät från representationskomitén underdånigst. Helsingfors: Senaten Partilag 10.1. 1969/10 Vallag för storfurstendömet Finland. Given i Peterhof, den 26 juli 1906/26 Vallag 1969. Lag om riksdagsmannaval 13.6. 1969/391

\section{Viitteet}

1 Kiitokset Kari Paakkunaiselle, joka ystävällisesti on korjannut minun vajavaista suomenkieltäni.

2 Svenska Handelshögskolanin edesmennyt professori Ralf Helenius teki hienon vertailevan analyysin siitä, mitä transgressiossa tapahtuu, kun puolueet yrittävät sille ominaisin keinoin voittaa uusia äänestäjiä (Helenius 1969). Valitettavasti hän omin sanoin lankesi väitöskirjan jälkeen diskursiiviseen viidakkoon jonne hän lopulta eksyi. Transgressio on modernimmassa muodossaan saanut otsikon Electoral socialism eli vaalisosialismi joka on erityisen kiinnostavaa luettavaa ja tieteelle rikastuttavaa koska teoriaa voi empiirisesti hyödyntää (Przeworski \& Sprague 1986). 


\section{Suomen talouspolitiikan ja työmarkkinamallin murrokset sotakorvauksista kilpailuyhteiskuntaan}

Institutionaalisen teorian näkökulmasta murros voidaan määritellä yhteiskunnallisen kehityksen kriisitilanteeksi, joissa rakenteellisten muutosten paine purkautuu nopeasti. Vaikka etuvastakohtien kasautuminen voi osaltaan laukaista liikkeelle äkkinäisiä muutoksia, murros ei yleensä aiheudu tavanomaisista ja jatkuvista taloudellis-sosiaalisista etukonflikteista. Murrokseen liittyy yleensä myös ristiriitoja eli yhteiskunnan ohjausperiaatteiden yhteensopimattomuutta uusien, alaa valtaavien ajatusten, järkevän toiminnan sääntöjen ja ohjausstrategioiden kanssa. Erotettaessa näin, etenkin Anthony Giddensin (1984) ehdottamia käsitteitä seuraten, konflikti ja ristiriita tosistaan voidaan kohdistaa huomio siihen, että murroksissa järkkyvät rakenteet eli yhteiskunnassa tapahtuu voimavarojen jaon sekä hallinnan ja ohjausperiaatteiden merkittäviä muutoksia. Pidettäessä tarkastelun kiintopisteenä rakenteita voidaan myös erottaa ja valaista yhteiskunnallisessa kehityksessä ilmeneviä jatkuvuuksia ja katkoksia sekä nähdä taitekohtaa edeltävä kehityksen ura tai institutionaalinen malli - alusta seuraavan tasaisemman kehityksen kauden käytäntöihin ja hallinnan rutiinien muodostumiseen.

Tarkasteltaessa talouden ja talouspolitiikan kehityksen taitekohdissa tapahtuneita rakennemuutoksia on taloushistoriallisen tutkimuksen valossa tärkeätä kiinnittää erityistä huomiota valtion rooliin, jos kohta pitää kuitenkin varoa näkemästä tapahtumat ja muutokset suoraan valtioteko- 


\section{Pentti Puoskari}

jen erillisinä funktioina irrallaan koko talousjärjestelmän toiminnasta. Näkökulmaksi eivät siis riitä taloustieteen oppikirjojen suppea talouspolitiikan käsite ja järjestelmän kuvaukset, vaan valtio on perusteltua nähdä niin tavoitteiden asettamisessa kuin talouspolitiikan keinojen käytössä yhtenä laajan ja monitahoisen talouspolitiikan järjestelmän ohjauskeskuksena, jonka asema suhteessa eri markkinoihin ja kansalaisyhteiskuntaan muuntuu etenkin yhteiskunnan kriiseissä ja murroksissa.

Laajan käsitteen mukaisen talouspolitiikan kauaskantoiset muutokset liittyvät Suomessa sotien jälkeen, kuten myös edeltävän sadan vuoden aikana, erottamattomasti ulkomaankauppa- ja elinkeinopolitiikan perusratkaisuihin. Sotakorvausten ja jälleenrakennusvuosien jäätyä taakse muutoksiin nivoutuu kuitenkin tämän lisäksi elimellisesti julkisen sektorin perusrakenne- ja hyvinvointipoliittisten tehtävien laajeneminen sekä suunnittelun ja toimeenpanevan hallintokoneiston paisuminen. Siksi seuraavassa murrosten tarkastelussa kiinnitetään huomiota erityisesti: 1) rahoitusmarkkinapolitiikkaan, 2) valtion tehtävien määrittelyyn ja valtiontalouden hoitoon eli finanssipolitiikkaan ja 3) työmarkkinapolitiikkaan. Keinojen kannalta rahoitusmarkkinapolitiikassa voidaan ja on tärkeätä erottaa oman valuutan vaihtoarvon ja korkojen määrittely valuuttakurssi- ja yleisen rahapolitiikan keinoin ja suora yritysten ja kotitalouksien rahoituksen säätely. Finanssipolitiikassa on puolestaan kyse yhtäältä julkisen talouden menojen ja tulojen tasapainon ja mitoituksen säätelystä ja toisaalta verotuksen ja julkisen menojen kohdentamisesta tehokkuuden ja oikeudenmukaisuuden kannalta.

Kun nykyään talouspolitiikkaa kuvataan usein myös sopimusyhteiskunnan käsitteellä, taustalla on silloin yleensä oletus, että talouspolitiikan suuri muutos sotien jälkeen on tapahtunut keskeisesti työmarkkinoilla tapahtuvan sopimisen kautta, ja että rakenteellinen muutos on kuvattavissa pitkälti tulonjakopolitiikan ja työmarkkinamallin kautta. Tätä talouspolitiikan muutoksen ulottuvuutta ei olekaan syytä vähätellä, saatikka ohittaa, mutta seuraavassa talouspolitiikan periodien kuvauksessa pyritään taitekohdat ja murrokset liittämään järjestelmän yleisten ehtojen ja keinojen muutoksiin. 


\section{Säännöstelytaloudesta vapaakauppaan sopeutumiseen}

Sotavuosina valtion harjoittama talouden ja kansalaisyhteiskunnan säätely purkautui melko nopeasti, mutta aineellisen puutteen ja niukkuuden sekä Neuvostoliiton paineen alla itsenäisenä kansakuntana selviytymisen ehdollistama säännöstelytalous jatkui laajana vuoteen 1956, jolloin hallitukselle laajat säännöstelyvaltuudet antaneen valtalain voimassaolo päättyi. Valtion tehtävien kannalta arvioiden talouspolitiikan pohjana tuolloin olivat: 1) Asutuspolitiikka ja elintarviketuotannon omavaraisuuden kohottaminen lähtökohtana sotavuosien elintarvikepula ja maailmansotien välisen ajan maatalouspolitiikka, jonka taustana oli Venäjän viljasiilon umpeutuminen vuonna 1918; 2) Puutuotteiden länsiviennin turvaaminen ja näin saadun tulovirran käyttö vientiteollisuutemme perinteisen pääsektorin kehittämiseen kansainvälisesti johtavaksi "vihreän kullan” jalostajaksi; 3 ) Sotakorvaustoimitusten päätyttyä ripeästi laajennettu, kahdenkeskiseen tavaroiden ja palvelusten vaihtosopimuksiin ja hinnoitteluun perustuva, niin sanottu bilateraalikauppa Neuvostoliiton kanssa; ja 4) Teollistamisen vauhditus niin läntisen lankku- kuin itäisen metalli- ja öljysillan turvin (Kuisma 1997).

Kauden talouspolitiikan keskeiset keinot puolestaan olivat: 1) Rahoitusmarkkinoiden tiukka säätely vientiteollisuuden ehdoin; 2) Valtionyhtiöiden ja pakkosäästämisen käyttö korkean investointitason turvaamiseksi ja pohjoisen teollistamiseksi vasemmiston ideologia huomioiden; ja 3) Palkkojen, maataloustulon ja hintojen säätely valtalain nojalla. Rahoitusmarkkinapolitiikassa länteen suuntautuvan puunjalostusteollisuuden tarpeita toteutti etenkin keskuspankki valuuttakurssipolitiikalla ja pankkien lainanantoa ohjeistamalla. Kun yrityksiä säästöjen suuntaamisessa suosinut rahapolitiikka ei riittänyt keinoksi luoda ja laajentaa muuta teollisuutta, jonka keskeinen vientialue oli idässä ja jonka ehdot eivät olleet bilateraalikaupassa suoraan valuuttakurssipolitiikan keinoin ohjattavissa, pääministeri Urho Kekkonen julkisti ohjelmakirjasessa Onko maallamme malttia vaurastua? (1952) komiteatyönä ajatellun teollistamisstrategian, joka rakentui pyrkimykselle nostaa säästämis- ja investointiastetta pidättymällä kulutuksesta, valtiontalouden ylijäämällä ja sen sijoittamisella valtionyhtiöihin. Säästämis- ja investointiohjelman toteuttaminen lähinnä valtionyhtiöinvestoinnein ja Pohjois-Suomeen painottuen takasi 


\section{Pentti Puoskari}

strategian valmistelleiden katsannossa yhtä aikaa yhteiskunnallisen ja alueellisen tasapainon. Palkka- ja hintasääntelyyn osallistuivat sodista lähtien myös järjestöt, mutta valtio teki päätökset. (Pekkarinen \& Vartiainen 1995, Pohjola 1996 ja Pekkarinen ym. 1984.)

Talouspolitiikan ja työmarkkinamallin murrokset tapahtuvat yleensä muutospaineiden patoutuessa kriiseiksi ja purkautuessa ilman ennalta laadittua käsikirjoitusta tai suunnitelmaa, mutta säännöstelytalouden politiikan hylkääminen voidaan sen sijaan jäljittää yksiselitteisesti eduskunnan elinkeinoelämää myötäilleen määrävähemmistön kantaan, ettei märäaikaista valtalakia enää jatketa. Ratkaisusta seurasi maataloustuotteiden hintojen korotukset ja SAK:n julistama yleislakko 1. maaliskuuta 1956 Kekkosen astuessa presidentin virkaan, mutta murrokseen ei liittynyt muutoin huomattavaa muutosta elinkeinopolitiikkaan. Asutus- ja maatalouspolitiikkaa jatkettiin pitkälti entisin tavoittein ja näkemyksin talonpoikaista yhteiskuntamuotoa ja omavaraisuutta vaalien - eli eräänlaista maatalouden elinkeinopoliittiseen ensisijaisuuteen perustuvaa defensiivisen fysiokratismin oppia seuraten. Samankaltaista omiin raakaaineisiin ja voimavaroihin turvautumisen linjaa tähdennettiin säännönmukaisesti myös teollistamiseen tähdänneissä hankkeissa.

Paineet elinkeinopolitiikan mallia kohtaan patoutuivat kuitenkin vähitellen ulkoisista muutoksista, maataloustuotteiden maailmanmarkkinahintojen suhteellisten hintojen alentumisesta yhtä aikaa kasvavan ylituotannon kanssa ja EFTA- sopimukseen vuonna 1961 päättyneistä toimista ulkomaankaupan vapauttamiseksi (Hokkanen 2002). Vaikka talous kasvoi yhä 1960- luvulla liki viittä prosenttia vuodessa, talouden suorituskyvyssä alettiin havaita puutteita - ja se jopa heikkeni verrattaessa maita elintasolla asukasta kohti - alkutuotannon tuottavuus- ja rakenneongelmien ja kotimarkkinateollisuuden vaikeuksien vuoksi.

Rahoitusmarkkinapolitiikassa jatkettiin pitkälti 1950- luvun linjalla eli Suomen Pankki noudatti vuosikymmenen välein toteuttavaan devalvaatioon mukautuvaa valuutta- ja rahapolitiikkaa, rahamarkkinoiden säätelyä ja matalan koron strategiaa investointien edistämiseksi. Valtiontalouden tulojen enemmyys juokseviin menoihin verrattuna eli nettosäästäjäasema turvasi korkean investointiasteen, mutta paineet politiikkamallia kohtaan alkoivat lisääntyä maatalouden ylituotannon vientitukimenojen kasvaessa ja eduskunnassa vasemmistoenemmistön kaudella 1958-62 
alulle pantujen sosiaaliturvauudistusten vuoksi. Samaan suuntaan toimi nopea maa- ja metsätalouden teknologinen muutos, joka kiihdytti paineita uudistaa taloudellisen kasvun strategiaa, edistää rakennemuutosta ja suunnata uudelleen valtion tehtäviä. Koetelluista asutus- ja maatalouspolitiikan järjestelmistä pidettiin silti sitkeästi kiinni läpi 1960-luvun alkupuolen, jolloin eduskunnassa oli noottikriisin sävyttämien vuoden 1962 alun presidentin- ja aikaistettujen eduskuntavaalien jälkeen - paitsi porvarillinen myös - selkeä kekkoslainen enemmistö. Maalaisliiton ja presidentin sisäpoliittisen otteen lujituttua markkinoiden ja valtiontalouden paineisiin vastattiin lähinnä tarkistamalla varovasti teollistamispolitiikan strategiaa, valmistelemalla valtionyhtiöiden rinnalle ja sijaan kehitysaluelainsäädäntöä ja -politiikkaa sekä reagoimalla kasvupoliittiseen ajattelun leviämiseen ja inhimilliseen pääomaan investoimisen vaatimuksiin alueellisella korkeakoulupolitiikalla.

Tulonjako- ja työmarkkinapolitiikan malli muuttui sen sijaan radikaalisti jo valtalain voimassaolon lakattua eli käytännössä Kekkosen viimeisen hallituksen lopettaessa ja hänen aloittaessa presidenttinä. Kun ennen sekä maataloustuloa että palkkoja säädeltiin valtion päätöksin, siirryttiin nyt periaatteiltaan lähes samanlaisena vuosikymmenen noudatettuun järjestelmään, jossa oli lailla turvattu maataloustulon muihin tuloihin nähden verrannollinen kehitys, mutta ei enää palkkoja. Siten vuoden 1956 yleislakon tuloksen valuessa hintoihin, ja tehtäessä työmarkkinoilla palkkasopimuksia jopa alikompensoivalla indeksillä, maatalouden tulo oli sidottu yleiseen ansiotason kehitykseen, alimmillaan 85 prosentilla ja vuosikymmenen taitteesta 100 prosentilla. Niinpä kun maatalouspolitiikan umpikuja häämötti 1960- luvun alkupuolella, työmarkkinoiden pääjärjestöjen kannat rakennepolitiikassa lähenivät, samalla kun sosiaalivakuutuksen käsittely eduskunnassa ja ay- liikkeen hajaannus myös olivat omiaan ajamaan STK:ta ja SAK:ta tiivistyvään yhteistyöhön. Tuloksena oli erilaisia keskitettyjä SAK:n ja STK:n raamisopimuksia, mutta Johannes Virolaisen hallituksen (1964- 66) yritykset neuvotella kattavasta linnarauhasta sitä vastoin kuivuivat tyhjiin. (Bergholm 2007.) 


\section{Pentti Puoskari}

\section{Rakennekriisistä valtiokeskiseen kasvu- ja hyvinvointipolitiikkaan}

Maa- ja metsätalouden koneellistuessa maaseudulla patoutunut työvoiman liikatarjonta, suurten ikäluokkien virta työnhakuun ja viennin kilpailukyvyn rapautuminen vaativat kansainvälisen taantuman koittaessa pakosta muutoksia politiikkaan vuoden 1966 poliittisen käänteen jälkeen. Murros toteutui kuitenkin hallitsemattoman liberaalisti rajulla devalvaatiolla ja massasiirtolaisuudella, jossa Suomi menetti kymmenesosan nuoresta työvoimasta. Vuodesta 1967 kiihtynyt purkaus oli rajuudessaan sikälikin historiallinen, että maan väkiluku jopa supistui vuosina 1969 -70. Lähimmät vertailukohdat suurelle muutolle ja 1960-luvun lopun murrokselle löytyvät siten ehkä viime vuosikymmenten Irlannin kehityksestä. Meidän ja Irlannin myöhemmän murroskauden politiikan edellytyksissä oli tosin selkeänä erona, että Suomessa oli jo 1960-luvulla yksi kansainvälisesti - osaamisen ja innovointikyvyn mielessä - johtavan sektorin roolia tavoitellut teollisuudenala, puunjalostusteollisuus, ja ainakin siinä suhteessa selvästi enemmän teollisen kasvupolitiikan potentiaalia.

Ulkomaankaupan - talouden avoimuuden - kehittämisessä jatkettiin kaudella pitkälti entisillä raiteilla. Idänkaupan edistämisestä muodostui monellakin tapaa dynaaminen, uusille aloille laajentuva valtiollisen sektorikorporatismin järjestelmä, ja Suomen ja NL:n välisen kauppakomission puheenjohtajan paikasta kilpailtiin kunnianhimoisin odotuksin kuin konsanaan EU-huippukokousten lautasesta 1990- luvulta lähtien. Läntisessä integraatiossa puolestaan edettiin NORDEK-väliepisodin kautta EEC-vapaakauppasopimuksen valmisteluun ja lopulta hyväksymiseen vuonna 1973.

Elinkeinopolitiikassa ryhdyttiin mukautumaan teollisen, ja sittemmin oikeastaan suoraan jälkiteollisen, yhteiskunnan vaatimuksiin yhtäältä maatalouden rakennepolitiikalla - omavaraisuuden ylittävää tuottamista hilliten ja rationalisointia edistäen - ja toisaalta vankan valtiollisella teollisuus- ja yrittäjyyspolitiikalla, jossa erottui Keskustapuoleen ajama kehitysaluepolitiikka - nimikkohankkeena Kehitysaluerahasto KERA - ja SDP:n valtakunnallinen teollisuuspolitiikka - nimikkohankkeina Investointirahasto INRA ja valtionyhtiöiden kehittäminen ja perustaminen uusille aloille. 
Kasvustrategiassa tukeuduttiin edelleen korkean investointiasteen ja valtion nettosäästäjäaseman tavoitteluun, mikä linja piti 1970-luvun lopulle saakka. Rahoituspolitiikassa pysyi samoin säädeltyjen rahamarkkinoiden ja matalan koron linja, joskin jo 1970-luvulla alkupuolella käynnistyi keskustelu devalvaatiosyklin vaikutuksista talouskasvuun ja mahdollisuuksista irtaantua vuosikymmenen välein toistuvan devalvaation mallista. Kun samaan aikaan kehitettiin valtiontalouden ja yhteiskuntasuunnittelua, ja toteutettiin ripeästi hyvinvointivaltiota rakentavia, palvelu- ja sosiaaliturvauudistuksia, kasvuhakuinen elinkeino- ja hyvinvointipolitiikka merkitsivät nopeaa verotuksen kiristymistä. Se toteutettiin muun muassa pidättymällä veroasteikkojen inflaatiotarkistuksista - ainoastaan Kokoomuksen käyttäessä politiikan kilpailukeinona verotuksen alentamisen lupauksia. Finanssipolitiikan suuntautumiseen vaikutti lisäksi se, että 1960- luvun lopulta alkaen kilpailivat suunnittelun kehittämisessä keskenään valtiovarainministeriö keskityslinjallaan ja valtioneuvoston kanslia, jossa koetettiin luoda pääministeri- ja kansliaministerivetoisesti pitkän ajan yhteiskunta- ja aluepoliittista suunnittelua ja talousministeriön alkiota (ks. Heikkinen \& Tiihonen 2010).

Tulonjakopolitiikassa Liinamaa I -sopimusta vuonna 1968 solmittaessa oli taustalla OECD:n piirissä levinnyt makrotaloudellinen pohdinta mahdollisuuksista hillitä työvoiman ylikysynnän oloissa palkka- ja kustannusinflaatiota valtion ja keskeisten eturyhmien kattavilla tulopoliittisilla sopimuksilla ja ratkomalla niissä tulo- ja hintakysymysten lisäksi rakenteellisen kehittämisen kysymyksiä. Käytännössä sopimus syntyi kuitenkin devalvaation jälkihoidon kriisiratkaisuna, jonka keskeisiä toimia palkkaratkaisun ohella oli indeksisidonnaisuuksien purkaminen ja määräaikainen hinta-, vuokra- ja palkkasäätely eduskunnan määräenemmistöllä sädetyn valtuuslain nojalla. Sopimuksen muita - tulonjakopolitiikkaa ja työmarkkinamallia muovaavia - elementtejä olivat pennilinja palkkojen korotuksissa, etujärjestöjen jäsenmaksun verovähennysoikeus ja ay- jäsenmaksujen työnantajaperintä, useat laajakantoiset sosiaaliuudistukset. Hinta- ja palkkaneuvoston ja tulopolitiikan vakiintumisen myötä vauhdittui myös lakien ja päätösten korporatiivinen valmistelu, välillisen valtionhallinnon laajentuminen ja etujärjestövallan kasvu eduskuntaan nähden. (Bergholm 2007, 382-433.) 


\section{Pentti Puoskari}

Vasta siirtolaisuusaallossa kotimaahan jäävän työvoiman - työmarkkinoiden "sisäpiiriläisten" - ylikysynnän riski loi kansainvälisten esikuvien mukaisen tulopolitiikan tarpeen. Toisessa Liinanmaan tulopoliittisessa sopimuksessa vuonna 1969 oli merkkejä tästä perustelusta, kun ratkaisussa suuntauduttiin hyvän taloussuhdanteen ja siirtolaisuuden myötä viriävien palkankorotuspaineiden hillintään ja palkkaeroja tasoittavaan pennilinjaan liitettiin prosenttikorotuksia - joskin kokonaisuutena sopimus ennen muuta jatkoi Liinamaa ykkösen avaamaa sopimusyhteiskunnan uraa, valtion ja järjestöjen yhteistyön institutionalisointia, samalla kun eturyhmien järjestäytymisen aste kohosi.

\section{0-luvun lopun talouskriisi ja elvytyspolitiikan malli}

Vuoden 1970 murrosvaalien, lyhytikäisten hallitusten ja eduskunnan hajotuksen ja 1971 eduskuntavaalien jälkeen koettiin Suomessa poliittisesti vakaa jakso Sorsa-Virolaisen hallituksen (1972-75) kaudella. Samaan aikaan kuitenkin kasvoi taustalla kansantaloudessa uuden talouspolitiikan ja työmarkkinamallin murroksen lataus sekä ulkoisista että sisäisistä tekijöistä. Kriisiin ajautumisen kotimaisina taustatekijöinä olivat tulopolitiikan ongelmat - tulokilpa ja inflaation kiihtyminen - ja "investointijuhla" eli vilkas investoiminen - aina maailmanennätyslukuihin saakka - sekä tuonnin kasvun mukana tapahtunut vaihtotaseen vajeen repeäminen noin seitsemään prosenttiin bruttokansantuotteesta ja lisääntyvä työttömyys kasvun notkahtaessa. Kansainvälisestä taloudesta puolestaan säteili kriisipaineita niin ensimmäisen öljykriisin jälkiseurauksina - vaihtotaseongelmina ja stagflaationa eli yhtäaikaisena työttömyytenä ja korkeana inflaationa - kuin alkavina hyvinvointivaltion kriisipuheina, maantieteellisesti lähimpänä huolen merkkinä Tanskan ajautuminen "perunakuurille".

Meillä öljyn hinnan kohoaminen oli kuitenkin ulkomaankauppapolitiikassa omiaan tukemaan kauan - kansainvälisesti verraten myöhään 1960- luvulla omaksuttua - kasvupolitiikan linjaa, koska raakaöljyn NL:sta tuonnin arvoa vastaavasti kasvoi idänkaupan vientikysyntä. Vuosikymmenen puolivälin jälkeen elinkeinopolitiikassa tapahtui silti lopulta käänne suorastaan dramaattisesti, kun suurin odotuksin perus- 
tettu kuvaputkitehdas Valco Oy ajautui vaikeuksiin ja valtiontalouden tasapaino-ongelmien myötä luovuttiin Kalevi Sorsan toisen hallituksen ns. elvytysohjelmassa valtionyhtiöihin investoimisesta ja valtiontalouden ylijäämän kerryttämisestä sekä alettiin hallituksen vero- ja budjettipolitiikassa tukea yrityksiä mm. sosiaaliturvamaksujen alennuksella. Keskuspankin rahapolitiikkaa alettiin samaan aikaan virittää devalvaatiosyklin vastaiseksi ja valuuttapolitiikassa omaksuttiin kaksisuuntaisten vaihtokurssimuutosten tie eli toteutettiin pienten devalvaatioiden ohella ensi kertaa myös revalvaatio (ks. Korpinen \& Kykkänen 1974, Korkman 1981, Pekkarinen \& Sauramo 1985). Koiviston toisen hallituksen nimityksen myötä mitätöityivät myös vasemmistopuolueissa viritellyt suunnitelmat alistaa keskuspankki parlamentaarisen hallituksen ohjaukseen.

Vielä ensimmäisen hallituksensa lopetellessa Sorsa arveli - tai toimittaja arvion tulkitsi, kuten hän lentävää lausahdusta jälkikäteen selitti - Suomen pääsevän myös kansainvälisen talouden kriisistä kuin koira veräjästä. Maaherra Miettusen hätätilahallituksen jälkeen hän käänsi kuitenkin toisen hallituksen pääministerinä - valtiovarainministeriksi nimitetyn, valtiovarainministeriötaustaisen Paul Paavelan tukena - talouspolitiikan kurssia. Hallituksen kehittelemillä elvytysohjelmilla muutettiin samalla merkittävästi koko yhteiskuntapolitiikan linjaa ja suunnittelun hallinnollinen reviiririita ratkesi vähin äänin valtiovarainministeriön voittoon, kun hyvinvointipolitiikassa siirryttiin ekspansiosta kehittämiseen. Verotuksen alueella muutosta kuvasti kilpailukykynäkökohtien korostamisen ohella erityisesti pyrkimys hillitä veroasteen nousua muun muassa aloittamalla tuloveroasteikkojen inflaatiotarkistukset ja muutokset verotuksen painopisteen siirtämiseksi välillisiin veroihin.

Tuki elvytyspolitiikalle hankittiin Korpilammen konferenssiksi kutsutusta seminaarista alkaen vankistamalla konsensusta ja tulopoliittista yhteistyötä. Inflaation hillinnästä muodostui siten pian konsensuspolitiikan yhteinen tavoite, ja ay-liikkeessä alettiin nähdä työllisyyden turvaaminen ja palkkojen ostovoima niiden nimelliskorotuksia tärkeämmäksi. Elvytysprojektin politiikkamuutokset ja uusi työmarkkinamalli institutionalisoituivat 1980-luvun hallitsemismalliksi osittain myös sen ansiosta, että kommunistien vähemmistösiiven tulopolitiikan arvostelu menetti voimansa liikkeen hajotessa ja SKDL:n kannatuksen kääntyessä myös kokonaisuutena laskuun vuoden 1979 vaaleista. 


\section{Pentti Puoskari}

\section{Hallitun rakennemuutoksen ohjelmalla hallitsematta lamaan}

Vuoden 1987 poliittisen käänteen taustalla vaikutti Suomen Pankin ilman poliittista valmistelua käynnistämä rahoitusmarkkinoiden vapauttaminen ja siihen liittynyt vakaan markan oppi sekä julkilausumaton suuntautuminen EC:n jäsenyyteen. Euroopan Japaniksi uhosta lamaa kohti Harri Holkerin hallituskauden lopulla ajauduttaessa murroksen syinä vaikuttivat sitten yritysten ja kotitalouksien velkaantuminen eli paitsi kulutus- myös investointijuhla, idänkaupan romahdus ja raha- ja valuuttapolitiikkaan nähden liian löysä - vastasyklisyyden hylännyt - finanssipolitiikan oppi.

Kriisiä pidäteltäessä ja aikalisiä lamaan ajautuessa otettaessa voidaan erottaa monia välietappeja, joista ensimmäinen oli vakaan markan oppia ajaneita vastaan hangoitellen vuonna 1989 päätetty revalvaatio ylikuumenemisen estämiseksi. Myöhästyneenä toimenpide jyrkensi käännettä viennin lamaan, ja kun markka liitettiin vahvana EC:n valuuttakurssimekanismiin ERM:iin Esko Ahon hallituksen ensi töinä vuonna 1991, kansantalouden velka oli kohonnut kestämättömän korkeaksi ja huippukoroilla taistelu devalvaatio-odotuksia vastaan alkoi. Hallituksen yritettyä toteuttaa työmarkkinajärjestöjen kanssa ns. sisäisen devalvaation palkanalennuksia, sopimusesityksen kaatuminen johti markan irrottamiseen ERM:stä. Markan kelluessa eli vaihtokurssin määräytyessä markkinoilla, pankkien järjestämiä valuuttalainoja ottaneet ajautuivat laajasti vararikkoon samalla kun kysynnän sekä asuntojen ja kiinteistöjen ja muun vakuutena olleen varallisuuden arvon romahtaessa velallisten vaikeudet laajenivat ja aiheuttivat pankkikriisiin.

Suomen vuosisadan syvimmän laman aiheuttanutta pankkikriisiä hoidettiin monista länsimaista poiketen tukemalla pankkeja ja erottelemalla hoitamattomia lainoja ja niiden vakuudeksi otettua varallisuutta valtion roskapankkiin. Pankkikriisi ja sitä hoidettaessa sovelletut menetelmät johtivat nopeasti merkittävään varallisuuden uusjakoon, julkisten menojen leikkauksiin, taloudellisen liberalismin vahvistumiseen julkisen sektorin ohjauksen sekä valtion ja kansalaisten vastuun järjestämisen periaatteena ja lopulta tulo- ja varallisuuserojen kasvuun ja oikeuttamiseen tehokkuudella. 
Elinkeinostrategiaksi muodostui markan kelluessa korkoelvytys ja uusteollistaminen, viennillä korkeata työttömyyttä sietäen - mikä esti inflaation purkautumisen devalvaatiosyklin mukaisesti ja auttoi etenkin vientiyrityksiä kohentamaan nopeasti kannattavuuttaan ja taseitaan. Samalla strategia kuitenkin vahvisti taloustieteen työmarkkinateorian hysteresis-hypoteesin mukaisesti työllisten mukautumista sisäpiiriläisiksi ja toisaalta työttömyyden sitkistymistä ja työttömien joutumista ulkopuolisiksi - ja tätä kautta koko yhteiskunnan jakautumista. Työvoimapolitiikka ja muu valtion työmarkkinoihin kohdistuva toiminta alkoi mukautua niin sanotun Rinteen ja Leppäsen mallin hylkäämisen jälkeen valittuun elvytysstrategiaan, kun valtiontalouden suunnitteluun yhtä aikaa tuotu tulosbudjetointi ja kehysohjaus kuihtuivat lyhytjänteisessä leikkausohjelmien ja vuosibudjettien valmistelussa rahaohjaukseksi olipa kyse menojen tasosta eli finanssipolitiikan stabilisaatio- tai allokaatiotehtävästä. Suunnittelun menettäessä samalla sisältöään päädyttiin sitten vähitellen hyvinvointivaltion kipupisteiden korjailuun, köyhyysohjelmien rustailuun ja erillisongelmien loputtomaan selvittelyyn.

Työmarkkinoiden keskitetyn sopimisen malli kesti perusteiltaan yli lamakauden toisin kuin Ruotsissa. Sen jälkeen kun sisäisen devalvaation yritykseen liittynyt yhteiskuntasopimuksen idea oli jäänt pääministerin ideaksi, hallitus neuvotteli työmarkkinajärjestöjen kanssa sopimuksia jopa yleislakkouhan alla, mutta vuonna 1994 hallituksen ja Elinkeinoelämän Keskusliiton toivein ajauduttiin jo hajautettua liittokohtaista sopimista kohti, kunnes Keskustapuolueen esittelemä työreformi yhdessä taloudellisen ja poliittisen tilanteen kanssa vuoden 1995 eduskuntavaalien jälkeen johtivat erittäin vahvan tulopoliittisen sopimisen kauteen yli vuosikymmeneksi.

\section{Euromaaksi vuodesta 1995 alkaen}

Euroopan unioni, jonka säännösperusta ja nimi juontuvat vuoden 1993 Maastrichtin sopimuksesta, ei vaikuttanut enä dramaattisesti ulkomaankauppa- tai elinkeinopolitiikan linjaan Suomen liittyessä jäseneksi vuonna 1995. Lainsäädäntöä sekä julkishallinnon yritysten toimintastrategioita oli kehitetty jo vuosia unionioption mukaan. Näin ollen jäsenyyden 


\section{Pentti Puoskari}

varmistuessa merkittävän muutos koettiin siinä, että hallituksessa, hallinnossa ja etujärjestöissä aloitettiin välittömästi valmistautuminen Suomen liittämiseksi ensimmäisten joukossa rakenteilla olleeseen euroalueeseen. Pyrkimys määritteli Paavo Lipposen sateenkaarihallituksen alusta asti politiikan vapausasteita, valintoja ja suuntaa, ja kun niin raha- ja finanssipolitiikan kuin työmarkkinapolitiikan tavoitteeksi omaksuttiin sinänsä laajan selvitysprojektin jälkeen talous- ja rahaliiton kriteereiden täyttäminen, keskustelu rajautui lähinnä siihen, miten luoda puskurit julkiseen ja yrityssektoriin pientä jäsentaloutta uhkaavista epäsymmetrisistä shokeista selviämiseksi. Näin vientivetoinen lamasta toipumisen strategia korostui europrojektin myötä entisestään ja sulautui puheeseen eurooppalaisesta kilpailukykyprojektista Lissabonin prosesseineen, tietoyhteiskuntavisioineen ja osaamisohjelmineen.

Korko laski, ja talous tasapainottui jopa odotettua nopeammin vuosikymmenen puolivälistä, mihin vaikutti paitsi aloittaessa päätetyt 3-4 miljardin euron leikkaukset valtion menoihin ja ansiotuloverotuksen kevennykset ynnä myös finanssipolitiikan linjan määrittely poikkeuksellisen tarkasti koko nelivuotiskaudeksi heti hallitusohjelmassa sekä Nokia-onnen mukana vireästi kohonnut informaatiotekniikan (ICT) alan yritysten tuotanto, vienti ja kannattavuus. Menojen leikkausten kääntöpuolena olivat kuitenkin kotimarkkinasektorin nihkeä elpyminen ja poliittisessa keskustelussa tuskallisen hitaaksi hämmästelty työttömyyden lasku sekä köyhyyden lisääntyminen. Kaksijakoisen kehityksen seurauksena vaihtotase kääntyi nopeasti ylijäämäiseksi ja velkaantuminen katkesi paitsi kansantalouden tasolla myös julkisessa taloudessa. Samoin tapahtui kuitenkin myös Ruotsissa, jossa valittiin monipuolisemmin kansantaloutta elvyttävä ja laman seurauksia korjaava politiikka ja jonka tuhoisan velkaantumisuran väitteillä Suomessa perusteltiin omaa lamapolitiikan valintaa.

Kun sateenkaarihallitusten kauden talousstrategia rakentui kuitenkin keskitettyjen työmarkkinasopimusten ja kolmikantaisen sosiaalipolitiikan varaan, sopimusyhteiskunnan ideologia ehkäisi tehokkaasti mallin epäilyn, eikä talouspolitiikan ja työmarkkinamallin murrokseen jouduttu, kun samaan aikaan euron käyttöönoton kanssa koettiin ICT-sektorin lama. Päinvastoin talouden ja työmarkkinoiden kahtiajakautumisen näkymä osoittautui monien mielestä turhaksi peloksi, ja talous- ja työ- 
markkinapolitiikassa keskityttiin setvimään yritysten kansainvälistyessä kasautuvien ja entistä monitahoisempien kilpailukykyongelmien vyyhteä ja sanoittamaan sen tuottamaa tuskaa globalisaatiopuheella - aina siihen saakka, kun kansainvälinen finanssikriisi puhkesi. Sitten niin kuin useasti aiemmin murroksissa hallinto, etenkin valtiovarainministeri Jyrki Katainen, vakuutti alkuun kriisin menevän Suomen ohi, mutta murroksen jatkokertomusta tehdään ja luodaan yhä tätä kirjoitettaessa, joten muutosten vaikutusta talouspolitiikan uraan ja työmarkkinamalliin voisi vain aavistella.

\section{Lähteet}

Bergholm, Tapio. 2007. Sopimusyhteiskunnan synty II. Hajaannuksesta tulopolitiikkaan. Suomen Ammattiyhdistysten Keskusliitto 1956-1969. Keuruu.

Giddens, Anthony. 1984. Yhteiskuntateorian keskeisiä ongelmia. Toiminnan, rakenteen ja ristiriidan käsitteet yhteiskunta-analyysissa. Keuruu.

Heikkinen, Sakari \& Tiihonen, Seppo. 2010. Hyvinvoinnin turvaaja. Valtiovarainministeriön historia 3. Helsinki.

Hokkanen, Kari. 2002. Kekkosen maalaisliitto 1950-1962. Maalaisliitto-Keskustan historia 4. Keuruu.

Kekkonen Urho. 1952. Onko maallamme malttia vaurastua? Helsinki.

Korkman, Sixten. 1981. Kohti uutta valuuttakurssipolitiikkaa. Työväen taloudellisen tutkimuslaitoksen katsaus 1/1981.

Korpinen, Pekka \& Kykkänen, Seppo. 1974. Suomen Pankin valuuttakurssipolitiikka 1945-73. Työväen taloudellisen tutkimuslaitoksen katsaus 3/1974.

Kuisma, Markku. 1997. Kylmä sota, kuuma öljy - Neste. Suomi ja kaksi Eurooppaa 1948-1979. Porvoo.

Pekkarinen, Jukka \& Sauramo, Pekka. 1985. Devalvaatiosykli: Mallit ja valuuttakurssipoliittinen keskustelu. Kansantaloudellinen Aikakauskirja 3/1985. 
Pekkarinen, Jukka \& Vartiainen, Juhana. 1995. Suomen talouspolitiikan pitkä linja. Juva.

Pekkarinen, Jukka \& Vartiainen, Juhana \& Väisänen, Jarmo \& Åkerholm, Johnny. 1984. Suomalainen finanssipolitiikka ja kysynnän säätely, teoksessa Sata vuotta suomalaista kansantaloustiedettä. Kansantaloudellinen yhdistys 1884 -1984. Vammala. 
Eija Nurminen

\section{Sosiaalipolitiikan muutos Suomessa 1960-luvulta tälle vuosituhannelle}

Taloudellinen ja sosiaalinen eriarvoisuus ovat kasvaneet viime vuosina Suomessa huomattavan nopeasti. Eriarvoisuus ei ole lisääntynyt vain tuloerojen kasvuna, vaan se näkyy monilla muillakin elämän alueilla: työssäkäynnissä, terveydessä, koulutuksessa, asumisessa, kulutuksessa ja edelleen myös sukupuolten välillä. (Hiilamo ym. 2010.)

Viime vuosina tuloerojen kasvu on ollut meillä nopeinta muihin OECD-maihin verrattuna. Tuloerot ovat revenneet takaisin 1970-luvun tasolle. Reaaliansiot kasvoivat 1990-2004 välisenä aikana noin 30\% kuitenkin niin, että rikkaimman kymmenyksen reaalitulot kasvoivat moninkertaisesti alimpaan kymmenykseen verrattuna (Riihelä ym. 2005). Tuloerojen kasvun on todettu olevan yhteydessä erityisesti 1990-luvulla tehtyihin verotuksen muutoksiin, jossa pääomatulojen verotusta kevennettiin. Tuloerojen kasvun lisääntyessä myös köyhien kotitalouksien määrä on kasvanut; hyvin ansaitsevien väestöryhmien rikastuminen ja elintason nousu eivät ole kohentaneet kokonaistaloutta ja "tihkuneet alaspäin" (trickle-down) huono-osaisille. Presidentti Ronald Reagan käytti käsitettä trickle-down kuvaamaan ajattelua, jossa suurituloisten verotuksen keventäminen eli veroprogression lieventäminen nähtiin tehostavan talouden toimintaa ja tuottojen välittyvän ajan mittaan myös huono-osaisille parantaen heidän elintasoaan. (Hiilamo ym. 2010; Kajanoja 2003, 186-188.) 


\section{Eija Nurminen}

Kansainvälisten asiantuntijoiden mukaan, useiden kotimaisten lisäksi, suomalainen yhteiskunta on jakaantunut voimakkaasti sisä- ja ulkopuolisiin (insider vs. outsider). Jakoa voidaan kuvata myös siten, että eri väestöryhmät kuuluvat eri "klubeihin": joko ansiovakuutus- tai tarveharkintaluokkaan. Tämä työmarkkinoihin perustuva jako on nähtävissä niin sosiaalisissa tulonsiirroissa kuin useissa keskeisimmissä palvelujärjestelmissä. Ne suomalaiset, jotka eivät ole mukana työmarkkinoilla, näyttävät syrjäytyvän monella eri elämän alueella. Suomen sosiaaliturvajärjestelmä takaa suhteellisen hyvän turvan sisäpiiriläisille, mutta työmarkkinoiden ulkopuolisten toimeentulon turvaamiseksi tarkoitetut perusturvaetuudet ovat kansainvälisesti tarkasteltuna suhteellisen heikot. Pohjoismaisen vertailun mukaan suomalainen sosiaaliturva on erityisen matala, vaikka Suomessa perusturvan varassa elää huomattavasti suurempi joukko ihmisiä kuin muissa Pohjoismaissa. Tilanne näkyy lisääntyvänä eriarvoisuuden kasvuna - köyhyytenä ja syrjäytymisenä. (Hiilamo ym. 2010, 7-9; Julkunen 2001, 205-211.)

Suomi on seurannut muita Pohjoismaita sosiaaliturvapolitiikan kehittämisessä ja päätavoitteina ovat olleet sosiaalisen eriarvoisuuden vähentäminen ja köyhyyden lieventäminen. Miten on ollut mahdollista, että huolimatta näistä tavoitteista, sosiaalinen eriarvoisuus ja köyhyys ovat alkaneet kasvaa näin voimakkaasti viime vuosina erityisesti Suomessa?

Käsittelen tässä esseessä sosiaalipolitiikan rakentumista 1960-luvulta näihin päiviin asti muutamien perustavien taitekohtien avulla. Tarkastelen ensinnäkin 1960-luvun sosiaalipolitiikan suurta murrosta Pekka Kuusen ohjelmassaan kehittelemän tulonsiirtomekanismin avulla. Tämän jälkeen käsittelen niin sanottua kultakautta, 1970- ja 1980-lukuja, jolloin luotiin hyvinvointivaltion palvelujärjestelmä. Nostan esimerkkeinä esille vain muutaman tärkeimmän palvelujärjestelmän kehittymisen. Tämän jälkeen tarkastelen 1990-luvun taloudellisen laman seurauksia sosiaalipolitiikassa, tulonsiirtojen leikkauksia ja palvelujärjestelmän kaventamista eli hyvinvointivaltion supistamista. Esseessä seuraan suomalaisen sosiaalipolitiikan polkua (Julkunen 2001), jossa ensimmäisessä vaiheessa kansalaisille luotiin sosiaalinen perusturva ja toisessa vaiheessa tavoitteena oli taata hyvinvointi kaikille kansalaisille universaalien palvelujen avulla. Kun hyvinvointivaltio saadaan ikään kuin "valmiiksi", alkaakin sen kaventaminen sosiaaliturvaa ja palveluja priorisoimalla ja leikkaamal- 
la. Lopuksi tarkastelen nykyistä vastuudiskurssia, jossa sosiaalisen turvan tuottamista siirretään julkiselta vallalta yksilöille ja perheille sekä pohdin sitä, miten suomalainen hyvinvointivaltio voitaisiin ymmärtää ja rakentaa uudella tavalla.

\section{Sosiaalipolitiikka 1960-luvulla}

1960-luvulle tultaessa Suomen sosiaaliturva oli jälkeenjäänyttä muihin Pohjoismaihin verrattuna (ks. taulukko 1 sivulla 174). Sosiaaliturva ei ollut vain aineellisesti vähäistä, vaan järjestelmät kertoivat myös rakenteiden, asenteiden ja sosiaalipolitiikan vanhakantaisuudesta. Suomessa autonomian aikana vallalla oli Venäjän autoritaarinen hallintomalli, jossa tsaari käytti ylintä päätäntävaltaa eikä eduskuntavetoinen sosiaalipolitiikka aloitteista huolimatta onnistunut. Suomen itsenäistyminenkään ei tuonut helpotusta tilanteeseen, koska itsenäistymisen jälkeinen sisällissota jakoi maan poliittisesti ja yhteiskunnallisesti kahtia eikä sosiaaliturvan kehittämiselle löytynyt yhteisiä tavoitteita. Sosiaalipolitiikan painopiste oli tuolloin vahvasti yksilöllisessä selviytymisessä; liian suurien sosiaalisten etuuksien epäiltiin johtavan yksilöiden passivoitumiseen ja laiskistumiseen. Sosiaaliturva nähtiin pitkälti viimesijaisena turvana niiden ihmisten kohdalla, jotka eivät pystyneet sairauden tai työkyvyttömyyden vuoksi itse hankkimaan elantoaan työmarkkinoilta. (Karisto ym. 1998, 227-282 ; Niemelä 2004.)

Vasta1960- ja 70-luvuilla alkoi sosiaaliturvajärjestelmän systemaattinen rakentaminen, jolloin laadittiin tärkeimmät sosiaaliturvalait ja uudistettiin vanhoja lakeja, jotka tarjosivat varsin matalan turvan tason ja vain osalle väestöstä. Sosiaaliturvan rakentamista edesauttoi tulopoliittisten kokonaisratkaisujen synty, joissa usein sovittiin tärkeitä sosiaalipoliittisia uudistuksia, ay-liikkeen voimistuminen sekä vasemmiston nousu. (Karisto ym. 1998, 74-82.) Tärkeintä sosiaalipoliittisia järjestelmiä luodessa oli kuitenkin miettiä kenelle etuudet ja palvelut suunnataan. Suunnataanko ne vain köyhille vai koko väestölle eli olivatko etuudet ja palvelut selektiivisiä vai universaaleja ja millaisen turvan tason ne antavat yksilöille?

Erityisesti 1960-luvulla Suomessa toteutettiin merkittäviä tulonsiirtoihin keskittyviä sosiaalipoliittisia uudistuksia. Tätä suuruusluokkaa 


\section{Eija Nurminen}

olevia uudistuksia ei aiemmin ole toteutettu eikä tämän jälkeenkään ole ilmennyt tarvetta luoda niitä samassa mittakaavassa, vaikka järjestelmiä onkin kehitetty jatkuvasti. (Riihinen 2009, 142.) Uudistukset pohjautuivat pitkälti Pekka Kuusen kirjoittamaan teokseen 60-luvun sosiaalipolitiikka, jossa maallemme luotiin uusi sosiaalipoliittinen ohjelma. Teoksesta tuli suomalaisen yhteiskunnan rakennemuutoksen ja modernisaation käsikirja. Kuusen mukaan suomalaisen yhteiskunnan kehittämistä piti voimistaa teollistamisen avulla ja vähentämällä maatalouden tukemista. Modernisaation edistämisen välineenä toimi rationaalinen suunnitteluideologia. Tarkoituksena oli rakentaa kokonaisvaltaisen suunnittelutiedon avulla parempaa yhteiskuntaa ja maailmaa. (Riihinen 2009, 123128; Tuomioja 1996; 2002.)

Pekka Kuusi (1961) esitti ohjelmassaan kolmiportaisen tavoitteen: kansalaisen paras, kansantulon kartuttaminen ja tasoittaminen. Kuusen mukaan silloin, kun mahdollisimman monen kansalaisen elintaso nousee, kansantulo karttuu. Uutta kasvun jakovaraa voidaan jälleen kuluttaa ja jakaa muille eli tasoittaa tuloeroja kansalaisten välillä. Kansantulon karttumisen hän asetti yhteiskuntapolitiikan kokoavaksi tavoitteeksi ja kaikkia yhteiskuntaluokkia yhdistäväksi intressiksi. Kaikilla kansalaisilla piti olla oikeus toimeentuloturvaan ja peruspalveluihin sillä ansiosidonnainen turva jättäisi liian monet vaille etuuksia ja palveluja. Tavoitteena oli nimenomaan nostaa sosiaalisten tulonsiirtojen osuutta. Kuusi pyrki osoittamaan, kuinka sosiaalipoliittisella tulontasauksella voidaan säädellä taloudellisia häiriöitä ja edistää tuotannon kasvua. Kun tulonsiirtoja ohjataan pienituloisille, hyötyy tästä saajien lisäksi koko kansantalous. Tulonsiirrot laajentavat kulutuspohjaa, lisäävät kokonaiskysyntää ja vetävät uusia yksilöitä tuotannon palvelukseen. Tulonsiirroilla ja keynesiläisen talouspolitiikan opeilla - jotka antoivat oikeutuksen markkinoiden aktiiviselle sääntelylle ja suhdanteiden tasaukselle hallituksen toimesta - säädeltiin myös yhteiskunnallisia ristiriitoja eri luokkien ja ryhmittymien välillä. Tavoitteena oli rakentaa pohjoismainen hyvinvointivaltiomalli sosiaalisen turvallisuuden varaan. Ensimmäiseksi luotiin pakollinen sosiaalivakuutusjärjestelmä, koko väestöön ulottuva eläketurva ja sairausvakuutus. (Riihinen 2009, 123-128; Karisto ym. 1998, 61-62, 286-288; Jokinen \& Saaristo 2002, 118-120.) 
Eläketurva oli toisen maailmansodan jälkeen varsin puutteellinen. Eläkepolitiikan kehittämisessä esiintyi kaksi vastakkaista linjaa. Ansaintaperiaatteen mukaan eläkkeen (työeläke) tuli määräytyä eläkkeensaajan työikäisten palkkatulojen perusteella tarkoituksena säilyttää hankittu elintaso. Tämän näkemyksen takana olivat erityisesti työmarkkinajärjestöt ja sosialidemokraatit. Tasaeläkeperiaatteen mukaan eläke (kansaneläke) nähtiin perusturvana eli kansalaisuuteen perustuvana yhtäläisenä sosiaalisena oikeutena, joka olisi samansuuruinen kaikille yksilöille. Tämän näkemyksen takana olivat Maalaisliitto ja kansandemokraatit. Kansaneläkelain kokonaisuudistus tuli voimaan 1957 tasaeläkejärjestelmän pohjalta ja samassa yhteydessä vakuutussäästämiseen ja rahastointiin perustuvasta henkilökohtaisten tilien järjestelmästä siirryttiin jakojärjestelmään, jossa eläkkeen maksun suoritti valtio pääasiassa kuluvan kalenterivuoden eläkekertymistä. Eläkepolitiikan painopiste siirtyi jatkossa kuitenkin työeläkejärjestelmän puolelle. (Hellsten 2008; Karisto ym. 1998, 294-296.)

Työeläkejärjestelmää laajennettiin koko 1960-luvun ajan asteittain, kunnes kaikki ansiotyötä tekevät tulivat eläketurvan piiriin. Yleinen yksityisalojen työeläkelaki (TEL) säädettiin 1961, ja se tuli voimaan 1962. Samaan aikaan säädettiin myös erillinen lyhytaikaisissa työsuhteissa olevien työntekijöiden eläkelaki (LEL), joka oli kynnyskysymys TEL:in läpimenolle. Vuonna 1964 hyväksyttiin kunnallisten viranhaltijain ja työntekijäin eläkelaki. Valtion eläkelaki hyväksyttiin vuoden 1966 alkupuolella. Tämän jälkeen palkansaajien eläketurva muodosti yhtenäisen järjestelmän, jossa tavoitteena oli saavutetun kulutustason takaava vanhuus- ja työkyvyttömyysturva. Vasta 1970-luvulla yrittäjät ja siihen asti järjestelmän ulkopuolella olleet työntekijäryhmät pääsivät osallisiksi lakisääteiseen työeläketurvaan. Tällöin myös työeläkkeiden tavoitetaso nostettiin 40 prosentista 60 prosenttiin eläkepalkasta. Joka tapauksessa 1960-luvun taitteesta alkoi aina 1990-luvulle kestänyt eläke-etujen laajentamisen aika. Laajentamista on auttanut se, että eläkeläisiä on ollut suhteessa työssäkäyvään väestöön verraten vähän ja lisäksi hyvä rahoituspohja on mahdollistanut uudistukset. Eläkejärjestelmän uudistaminen liittyi työmarkkina-aloitteisen sosiaalipolitiikan kehittämiseen, joka alkoi 1960-luvulla. (Hellsten 2008; Karisto ym. 1998, 294-296.)

Eläketurvan parantamisen ohella sairasvakuutuksen kehittäminen oli 1960-luvulla erityisen tärkeä tavoite. Sairastavuus oli suurin sosiaalinen 
ongelma 1960-luvun Suomessa, jossa oli Euroopan alhaisin lääkäritiheys: Suomessa oli yksi lääkäri 1360 asukasta kohti, kun Euroopan keskiarvo oli yksi lääkäri kuutta sataa asukasta kohti. Sairausmenot vuonna 1954 yhdessä työkyvyttömyys- ja vanhuusmenojen kanssa olivat muissa Pohjoismaissa 61-66 \% sosiaalimenoista, kun Suomessa jäätiin alle kolmanneksen. Väestön terveydentilan ja terveydenhuollon osalta Suomi kuului Euroopan köyhimpiin kansoihin. Sairaan henkilön taloudellinen tilanne oli heikko ja sairaus oli yleisimpiä syitä köyhäinhoitoon. Erityisesti avoterveydenhuollossa oli puutteita ja siinä suurimmat ongelmat kohdistuivat sairauksien ennaltaehkäisyyn. Tilanne vaatikin kunnallisen kansanterveystyön uudelleen järjestämistä ja ratkaisuksi suunniteltiin koko maan kattava terveysasemaverkoston luominen. (Riihinen 2009, 135-137; Niemelä 2004, 105-106.)

Sairausvakuutuksen toteutuminen viivästyi Suomessa aina 1960-luvulle asti, kun se monissa Länsi-Euroopan maissa oli toteutettu jo 1900-luvun alkupuolella. Viivästyminen johtui historiallisista, poliittisista ja rakenteellisista syistä, joita on käsitelty tämän kirjan muissa esseissä. Lisäksi sosiaalivakuutuksen kehittämisessä palkansaajajärjestöt ja viljelijäväestö olivat erimielisiä. Pohdinnan alla oli kysymys siitä, pitäisikö sairausvakuutus sekä vanhuus- ja työkyvyttömyysvakuutus ulottaa vain palkansaajille vai koko väestöön? Tämän ristiriidan vuoksi sairausvakuutus joutui antamaan tilaa vuosien 1937 ja 1956 kansaeläkeuudistuksille ja vielä työeläkejärjestelmän synnylle 1961. Hidastuminen johtui yhteiskuntarakenteen agraarisuudesta ja Maalaisliiton vahvasta asemasta. Sairausvakuutuksella pyrittiin tasaamaan sairauskustannuksia sekä eri väestöryhmien kesken että alueellisesti. Sairausvakuutuslaki astui voimaan vuonna 1964 ja se käsitti sairaanhoito-, päiväraha- ja äitiysvakuutuksen. (Niemelä 2004, 105-106; Riihinen 2009,135-137; Karisto ym. 1998, 296.)

Työttömyysturva sai nykyisen perusmuotonsa vuonna 1960, kun ammattiliittojen hoitama työttömyyskassa-avustus sai rinnalleen valtion hoitaman työttömyyskorvausjärjestelmän. Työttömyyskorvaukset saivat kuitenkin todellista merkitystä vasta vuoden 1972 työllisyyslaista, kun korvausten saantiehtoja lievennettiin. Työttömyysturvaa uudistettiin seuraavan kerran vuonna 1985, jolloin sitä koskevat säädökset koottiin yhteen lakiin. Tällöin työttömyyspäivärahan taso sidottiin ansiotuloi- 
hin ja se oli veronalaista tuloa. Työttömyysturva säilyi kuitenkin kaksijakoisena. Työttömyysavustuksesta tuli ansiosidonnainen päiväraha ja se laskettiin ansioihin suhteutettuna (ansioturva), johon olivat oikeutettuja määräajan työttömyyskassan jäseninä olleet työttömät. Työttömyyskorvauksesta muodostui sen sijaan peruspäiväraha (perusturva), jonka maksatus siirtyi Kelalle. Siihen olivat oikeutettuja ne työttömät, jotka eivät saaneet ansioturvaa ja jotka olivat taloudellisen tuen tarpeessa. (Karisto ym. 1998, 299-300.)

Pekka Kuusen sosiaalipoliittinen ohjelma ilmestyi otolliseen, palkkatyöläistymisen ja kasvun aikaan, joka mahdollisti siirtymän selektiivisestä kohti universalistista ajattelua. Toinen Kuusen teoksen merkittävä oivallus oli työn ja pääoman välille luotu uusi ymmärrys. Niitä ei nähty vastakkaisina osapuolina, vaan Kuusen ohjelmassa luotiin hedelmällinen suhde sosiaalipolitiikan ja talouskasvun välille, jossa sosiaalipolitiikka nähtiin nimenomaan talouden hallittavuutta lisäävänä investointina, jolloin se oikein suunnattuna tukee talouden kehitystä eikä rasita sitä. (Riihinen 2009, 123-128; Jokinen \& Saaristo 2002, 118-120; Tuomioja 1996.)

Kuusen teos edistikin hyvinvointivaltion kehitystä Suomessa. Toisaalta yhteiskuntarakenteen nopeassa muutosliikkeessä sairasvakuutusta ja ansiosidonnaisen eläkkeen kehitystä ei olisi voitu enää lykätä. Kuusen teoksen menestys selittyy kahdella tekijällä: ensinnäkin suomalainen yhteiskunta kävi läpi nopean modernisaation ja joutui reagoimaan sen mukanaan tuomiin sosiaalipoliittisten uudistusten paineeseen. Toiseksi Suomessa tunnettiin tuolloin heikosti muiden maiden sosiaalista kehitystä, ja siksi Kuusen sanoma tuntui uudelta, jopa käänteentekevältä. (Riihinen 2009, 142143.) Seuraavasta taulukosta käy ilmi kuinka jälkeenjäänyt suomalainen sosiaaliturva oli muihin Pohjoismaihin ja Englantiin verrattuna. 
Taulukko 1: Sosiaaliturvan kattavuus Suomessa ja muissa maissa 1920-1970.

\begin{tabular}{|l|l|l|l|l|l|l|}
\hline & 1920 & 1930 & 1940 & 1950 & 1960 & 1970 \\
\hline Suomi & 4 & 5 & 40 & 49 & 63 & 107 \\
\hline Ruotsi & 60 & 60 & 65 & 77 & 117 & 122 \\
\hline Norja & 27 & 15 & 90 & 95 & 130 & 125 \\
\hline Tanska & 30 & 38 & 87 & 87 & 88 & 90 \\
\hline Englanti & 60 & 75 & 87 & 102 & 100 & 98 \\
\hline
\end{tabular}

Lähde: Hellsten 1981, 247; ks. Karisto ym. 1998, 271.

Taulukossa on esitetty Suomessakin tunnettu Peter Floran indeksi, joka vertaa keskitetysti sosiaalivakuutuksen kattavuutta eli eri sosiaalivakuutusmuotojen vaikutuspiirissä olevien osuutta ammatissa toimivasta väestöstä, ${ }^{1}$ Taulukosta käy ilmi, että vain harva suomalainen kuului vuosina 1920 ja 1930 johonkin vakuutuspohjaiseen sosiaaliturvajärjestelmään. Sosiaalimenojen osuus bruttokansantuotteesta (bkt) jäi maailmansotien välillä yhtä poikkeusta lukuun ottamatta alle puolen prosentin, eikä niiden osuus valtion budjettimenoista noussut 1-2 prosenttia korkeammalle. (Karisto ym. 1998, 271-272.) 1940 kansaneläkelain säätämisen jälkeen suomalaisista $40 \%$ kuului sosiaaliturvajärjestelmän piiriin ja vasta 1960 yli puolet suomalaisista oli sosiaaliturvajärjestelmän jäseniä. Pekka Kososen $(1987,199)$ mukaan Suomi, perässähiihtäjämaana, täytti pohjoismaisen hyvinvointivaltion merkit 1960-luvun puolivälissä ja tässä keskeisenä asiana oli varsin nopeasti tapahtunut siirtymä minimiturvasta ansiosidonnaiseen sosiaaliturvaan.

\section{"Hyvinvointivaltion kultakausi"}

Suomessa1960-luku oli ollut tulonsiirtojen luomisen aikaa ja sosiaalivakuutus saatiin pohjoismaisen hyvinvointivaltion tasolle. Siksi1970-1980 -luvuilla keskityttiin hyvinvointipalvelujen rakentamiseen. Tulonjakovaltiosta siirryttiin kohti palveluvaltiota parantamalla erityisesti julkisia 
sosiaali-, koulutus- ja terveyssektoreita. Palvelujen kehittämistä edisti yhteiskunnan nopea muutos: elinkeinorakenteen murros, kaupungistuminen, uudet elämäntavat, perheen ja suvun toimintojen heikentyminen ja erityisesti naisten tulo työmarkkinoille. Hyvinvointivaltion laaja ja monipuolinen palvelutuotanto rakennettiin kultakaudella, vaikka nostankin siitä esille vain muutaman pääasiallisen uudistuksen.

Terveyspalvelujen kehittäminen oli ensisijaista. Jo 1950-luvulla oli alkanut voimakas sairaalarakentaminen ja vuonna 1956 sairaalalain myötä sairaaloiden omistus siirtyi valtiolta kunnille. Erityissairaanhoito oli tuolloin varsin hyvässä kunnossa, mutta avohoidossa oli suuria puutteita. Vuonna 1972 säädettiin kansanterveyslaki, jonka tavoitteeksi asetettiin mahdollisimman suuri terveyden määrä ja sen tasainen jakautuminen yhteiskunnassa. Tällöin agendalle nostettiin myös palvelujen laatupohdinta ja ennalta ehkäisevät toimintatavat. Tavoitteena oli vaikuttaa suoraan palvelujen tarjontaan ja kuroa umpeen avohoidon aukkoja. Kuntien tai kuntainliittojen oli pakko perustaa alueelleen terveyskeskuksia, joita valtio avusti runsaskätisesti. (Haatanen 1993, 56; Karisto ym. 1998, 296297.)

Toinen merkittävä julkisen palvelutuotannon uudistus oli lasten päivähoidon rakentaminen (1972). Vuonna 1960 vain joka neljäs lapsiperheiden äideistä oli palkansaajia tai yrittäjiä, mutta vuonna 1972 jo lähes kolme viidesosaa. Kunnallinen päiväkoti- ja perhepäivähoitojärjestelmä helpotti ansioäitien elämäntilannetta ja purki "pimeitä" päivähoitomarkkinoita. Lasten julkisesti tuettu ja turvallinen päivähoito edesauttoi äitien työmarkkinoille hakeutumista. Julkisen sektorin voimakas palvelutuotannon kehittäminen tarjosi myös uusia työpaikkoja kansalaisille ja erityisesti naiset tarttuivat tähän mahdollisuuteen. Julkisen sektorin palveluammatit vetivät naisia sankoin joukoin töihin kodin ulkopuolella, mutta tekivät naisille samalla myös "karhunpalveluksen" sitomalla heidät matalapalkkaisiin hoivatöihin. Päivähoitojärjestelmän kehittämisen avulla naisille tarjoutui kuitenkin aivan uudenlainen mahdollisuus itselliseen työuraan yksityisillä tai julkisilla työmarkkinoilla. Vielä kun vanhus- ja vammaispalveluja uudistettiin, naisten mahdollisuudet ansiotyöhön paranivat entisestään. (Haatanen 1993, 56-57; Karisto ym. 1998, 297-298.) 


\section{Eija Nurminen}

Suomen tulevaisuuden kannalta 1970-luvun merkittävin uudistus tehtiin koulutuspolitiikassa. Vuoteen 1972 Suomessa oli ollut rinnakkaiskoulujärjestelmä, jossa osa lapsista opiskeli kansakoulun jälkeen kansalaiskoulussa ja sen jälkeen usein ammatillisissa oppilaitoksissa. Osa lapsista pyrki kansakoulun jälkeen oppikouluun ja suoritti joko keskikoulun tai jatkoi keskikoulun jälkeen vielä lukioon. Oppikoulu oli maksullinen - vaikkakin lukukausimaksut olivat maltilliset. Koulutusjärjestelmää uudistettaessa tarjottiin kaikille mahdollisuus hankkia entisen keskikouluasteen tasoinen koulutus peruskoulujärjestelmän avulla, joka toteutui askeleittain vuosina 1972-1977. Kyseessä oli niin iso uudistus, että sitä ei voitu toteuttaa kerralla koko maassa, vaan uudet peruskoulut alkoivat toimintansa Pohjois-Suomesta ja etenivät vuosittain kohti Etelä-Suomea, jossa koululaiset pääsivät uuden järjestelmän opinahjoihin vuonna 1977. (Antikainen ym. 2000, 89-99.)

Koulutusta ei uudistettu vain peruskoulujärjestelmän avulla, vaan myös yliopistoja perustettiin ympäri Suomea. Suuret ikäluokat, vuosina 1945-50 syntyneet ikäkohortit, olivat poikkeuksellisen suuria ja siksi jo koululaisten määrät aiheuttivat suuria haasteita ei vain peruskoulujen ja ammatillisten oppilaitosten määrän kasvattamisessa, mutta myös lukion jälkeisten opintomahdollisuuksien lisäämisessä. Uusia yliopistoja perustettaessa alueelliset ja sukupolvisesti määrittyneet yhteiskuntapoliittiset lähtökohdat olivat vahvoilla. Näin saatiin korkeakouluja eri puolille Suomea. Opiskelijat jäivät usein valmistumisensa jälkeen töihin oman yliopistokaupunkinsa läheisyyteen. Yliopistokaupungeista kehittyikin nopeasti oman alueensa kasvukeskuksia, koska siellä oli saatavilla hyvin koulutettua työvoimaa, joka mahdollisti uusien innovaatioiden, ideoiden ja yrityksien syntymistä ja jonne hakeutui myös jo olemassa olevia yrityksiä. (Nevala 1999, 94-99, 114-117; Antikainen ym. 2000, 99-122.)

Koulutuspolitiikan uudistamiseen oli monia syitä: ensinnäkin haluttiin vähentää koulutuksen eriarvoisuutta niin alueellisesti, sukupuolten välillä kuin sosiaalisen taustankin mukaan. Alueellisen eriarvoisuuden vähentäminen onnistui varsin hyvin. Sukupuolten välillä se ei onnistunut yhtä hyvin. Vaikka naisten koulutukseen osallistumisluvut ovat nousseet miehiä korkeammiksi, naisten sijoittuminen työmarkkinoille ei ole ollut yhtä helppoa kuin miehillä: mitä korkeampaa ammattistatusta tarkastellaan, sitä vähemmän sieltä löytyy naisia. Sosiaalisen taustan tuomien 
erojen tasoittumisessakaan ei ole onnistuttu kovin hyvin, vaikka 1960- ja 1970-luvuilla maanviljelijä- ja työväestön lapsille tarjoutuikin uusi mahdollisuus sosiaaliseen nousuun ja se myös toteutui useampien kohdalla kuin aiempina vuosikymmeninä. Opintotukijärjestelmän voimaantulo 1972, valtion takaaman opintolainan muodossa, edesauttoi alemmista yhteiskuntaluokista tulevien lasten yliopistokouluttautumista. Opintotukijärjestelmää parannettiin vuonna 1994, jolloin opintotuesta tuli opintoraha- ja asumistukipainotteinen valtion takaaman opintolainan jäädessä vähemmälle painoarvolle. Yksi merkittävä tekijä koulutusuudistuksessa oli kuitenkin satsaus inhimillisen pääoman kasvattamiseksi, jolla nähtiin olevan suurta merkitystä Suomen tulevaisuudessa. Hyvin koulutetun työvoiman avulla uskottiin jo tuolloin kansalaisten elintason nousevan ja kansantalouden kohenevan sekä maan kilpailukyvyn parantuvan. (Elovainio 1993; Karisto ym. 1998, 87-88; Nevala 1999.)

Kaiken kaikkiaan 1970- ja 1980-luvuilla rakennettiin Suomeen universaali ja varsin kattava julkinen palvelujärjestelmä, joka toimi niin sosiaali-, terveys-, työ-, asunto- kuin opetus-, harrastus- ja kulttuuripolitiikassa. Palveluja kehitettiin pitkälti pohjoismaisen hyvinvointivaltiomallin mukaisesti ja palvelujärjestelmän uudistaminen mahdollistui talouden voimakkaan kasvun avulla, vaikka samanaikaisesti alennettiin veroja. Edes 1970-luvun öljykriisit eivät hidastaneet tahtia kovin paljon, koska Suomessa niistä selvittiin nopeasti. Myös sosiaaliturvaa parannettiin ja monien 1960-luvulla tehtyjen sosiaaliturvaetuuksien tasoja nostettiin 1980-luvulla. Keskeiset sosiaaliset oikeudet, eläke-, sairaus- ja työttömyysturva, olivat 1980-luvun lopussa niin kattavuudeltaan kuin tasoltaankin hyvää eurooppalaista luokkaa, mutta silti jäljessä pohjoismaisesta "Mallimaa"-Ruotsista. Hienosäätöä piti tehdä vielä 1990-luvulla perusturvaetuuksissa ja sosiaaliturvajärjestelmien yhteensovittamisessa sekä hyvinvointipalvelujen kohentamisessa ja alueellisten erojen kaventamisessa; varsinkin sosiaali- ja terveyspalvelujen tarve koettiin lähes rajattomana. Suomi kuroi kuilua umpeen muihin Pohjoismaihin noin kolmessakymmenessä vuodessa modernisoimalla elinkeinorakennetta ja kasvattamalla taloutta voimakkaasti. Tämän mahdollisti runsaat verotulot, joiden avulla voitiin lisätä julkisia palveluja ja parantaa sosiaaliturvaa. Talouden kasvu, korkea työllisyysaste ja kattava sosiaaliturva palveluineen ruokkivat toisiaan ja saivat aikaan "hyvän kehän", jota kierrettiin 


\section{Eija Nurminen}

aina hyvinvointivaltion kriisiin ja 1990-luvun lamaan asti. (Haatanen 1993, 58-61; Hagfors \& Kajanoja 2010.)

Kultakauden tuloksista voidaan todeta seuraavaa (Anttonen \& Sipilä 2000, 78):

1. Sosiaalipolitiikasta tuli yhä selvemmin keskiluokan elintasoa turvaavaa politiikkaa

2. Minimitoimeentulon varmistaminen niille, joilla ei ollut tuloja

3. Terveyspalvelujen laajentaminen ja koulutusmahdollisuuksien tasaarvoistaminen

4. Sosiaaliturvan ja -palveluiden radikaali uudistaminen

5.Sosiaalipolitiikan muuttaminen entistä enemmän naisten intressejä toteuttavaksi hyvinvointipolitiikaksi.

Kuvio 1: Sosiaalimenot suhteessa bruttokansantuotteeseen (bkt) vuosina 19602006 (\%).

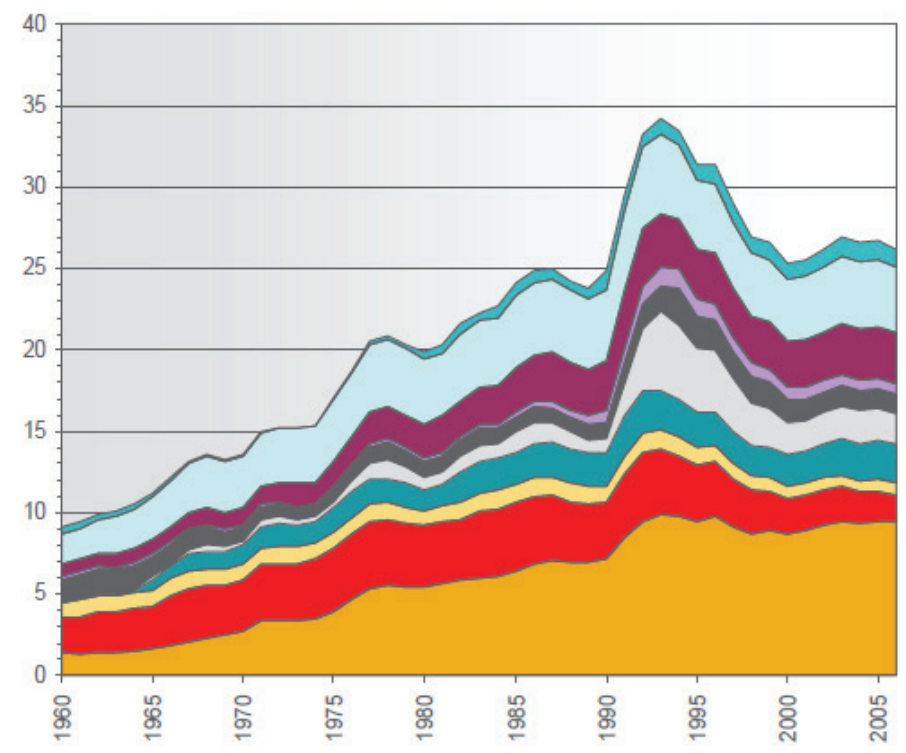

Lähde: STM, Stakes 2008.

\section{口 Muu}

$\square$ Kuntien terveyspalvelut

- Kuntien sosiaalipalvelut

口 Kuntien avustukset

- Valtion avustukset ja palvelut

口 Työttömyysturva

- Sairausvakuutus

$\square$ Solita

- Kansaneläkkeet

口 Työeläkkeet 
Suomalaisen hyvinvointivaltion tavoitteena ollut eriarvoisuuden vähentäminen ja köyhyyden lieventäminen onnistuivat hyvin 1960-1980 -luvuilla. Suomalaisten toimeentuloerot supistuivat tuona ajanjaksona ja Suomi kuului 1980-luvulla tasaisen tulonjaon ja vähäisen köyhyyden maihin. Hyvinvointivaltion tuloja uudelleenjakava vaikutus selitti suuren osan toimeentuloerojen kaventumisesta ja köyhien määrän vähenemisestä. Sosiaali- ja veropolitiikan voi siis katsoa olleen tehokkaita ja niiden avulla päästiin asetettuihin tavoitteisiin. (Uusitalo 1988; 1989, ks. Haatanen 1992, 61.) Kuviossa 1 (sivulla 178) näkyy sosiaalimenojen kehitys vuosina 1960-2006.

Kuviosta käy selkeästi ilmi, että sosiaaliturvajärjestelmä oli varsin kehittymätön 1940- ja 1950 -luvuilla. 1960-luvulta lähtien on havaittavissa sosiaalimenojen voimakas ja tasainen kasvu, jolloin tulonsiirtoja alettiin systemaattisesti kehittää ja uusia palveluja rakentaa. Etuuksien ja palvelujen korvaustasoa nostettiin tasaisesti aina 1990-luvun lamaan asti, jonka jälkeen työttömyysturva- ja eläkemenoihin tuli voimakas kasvupiikki taloudellisen laman aiheuttaman massatyöttömyyden vuoksi. Kasvupiikin aleneminen kesti noin kymmenen vuotta.

\section{0-luvun lamasta jälkiekspansiiviseen hyvinvointivaltioon}

Suomalaista hyvinvointivaltiota laajennettiin vielä koko 1980-luvun sekä palvelujen että tulonsiirtojen osalta, kun samaan aikaan muualla näkyi merkkejä hyvinvointivaltion purkamisesta. Hyvinvointivaltion "kriisipuhe" yltyi 1980-luvulla anglosaksisissa maissa ja hyvinvointivaltiota kohtaan esitettiinkin kritiikkiä, joka nousi esille voimallisemmin "uusoikeiston" taholta. Hyvinvointivaltiota syytettiin tehottomuudesta (tehokkuuskriisi), kalleudesta (kustannuskriisi) sekä oikeutuksen ja hyväksyttävyyden puutteesta (legitimiteettikriisi). Samoihin aikoihin anglosaksisissa maissa aloitettiin jo hyvinvointivaltion supistaminen. (Haatanen 1992, 58-63; Karisto ym. 1998, 337-342.)

Suomessa 1990-luvun taloudellinen lama muutti kaiken. Lama oli syvin kehittyneitä markkinatalousmaita kohdannut tuotannon romahdus toisen maailmansodan jälkeen. Bruttokansantuotteen puoli vuosisataa jatkunut kasvu pysähtyi vuonna 1990 ja kääntyi yli kuuden prosentin 


\section{Eija Nurminen}

miinukselle seuraavana vuonna. 1993, kun talouden syöksykierre pysähtyi, bkt oli pudonnut peräti kolmetoista prosenttia. Talouskriisi tuhosi suuren osan pankeista.1980-luvun lopulla pelätty työvoimapula kääntyi loppuvuodesta 1991 noin kolmen ja puolen sadan tuhannen ihmisen työttömyydeksi. Syksyllä 1993 "työn puutteesta kärsiviä" oli jo kahdenksansataa tuhatta. (Nätti 1996; ks. Karisto ym. 1998, 97). Pelkästään työttömyydestä aiheutuneet kustannukset kolminkertaistuivat. Valtio ja kunnat olivat ajautumassa kustannuskriisiin menojen lisääntyessä ja tulojen vähentyessä. Veroja oli korotettava ja menoja karsittava. Karsinnan kohteeksi valittiin koko julkinen sektori - laajalla rintamalla omaksuttiin "löysät pois"-politiikka: työntekijöitä oli vähennettävä, etuuksia supistettava, sosiaaliturvaa leikattava, palveluja yksityistettävä ja ilmaiset palvelut muutettava maksullisiksi. Voimakkaammat hyvinvointivaltion supistamisvaatimukset tulivat Suomessa "uusoikeiston" sijaan maan hallitukselta, virkamiehiltä ja teollisuuden "voimahahmoilta". Teollisuuden keskusliiton mielestä valtionvarainministeriön "juustohöylämekanismi" (viipale pois kaikkialta mistä se on mahdollista) ei riittänyt, vaan tarvittiin järeämpiä aseita korjaamaan väristyneitä rakenteita ja samalla vaadittiin koko tuottamattoman julkisen sektorin yksityistämistä. Eivät edes poliittinen vasemmisto tai ammattiyhdistysliike kyenneet varjelemaan sosiaaliturvaa leikkauksilta. (Haatanen 1993, 62-65; Karisto ym. 1998, 91-92.)

Laman syyt olivat kuitenkin muualla kuin teollisuuden väittämässä julkisen sektorin "paisumisessa". 1990-luvulle tultaessa Suomen julkinen sektori oli mallikunnossa. Julkisten menojen osuus bkt:sta vaihteli 1990-luvulla 40-45 \%, kun se muissa Pohjoismaissa vaihteli 55-60\% välillä. Suomen julkisen talouden velka suhteessa bkt:hen oli $15 \%$, kun EU:n keskiarvo oli $60 \%$. Sosiaalimenojen osuus oli alle neljännes bkt:sta. Ennen 1990-luvun lamaa ja sen jälkeenkin olemme olleet EU-maiden keskimääräisten osuuksien alapuolella - poikkeuksena laman jälkeiset vuodet (kuvio 2 seuraavalla sivulla). 
Kuvio 2 : Sosiaalimenojen osuus bkt:stä \% 1980-2010 Suomessa ja EU-maissa.

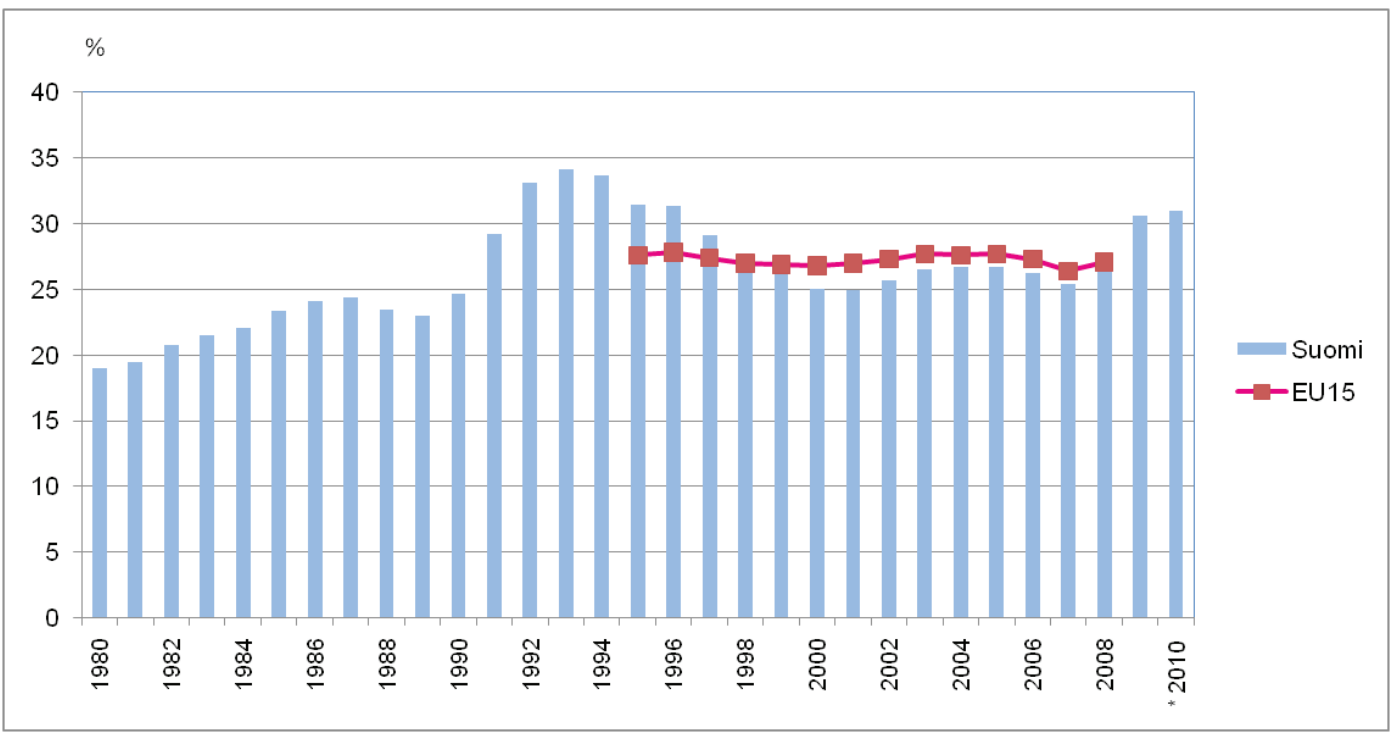

Lähteet: Vuodet 1980-2009 THL: Sosiaalimenot ja rahoitus-tilasto. Vuosi 2010 STM:n ennuste.

Laman syyt löytyivät julkisen sektorin ekspansion sijaan idänkaupan romahtamisesta (Neuvostoliiton hajoaminen) ja Länsi-Euroopan samanaikaisesta taantumasta, mutta erityisesti kotimaisista tapahtumista: rahoitusmarkkinoiden hallitsemattomasta vapauttamisesta, joka johti hölläkätiseen luotonantoon ja talouden ylikuumentumiseen sekä Suomen liittymisestä Euroopan unioniin ja rahaliittoon, joka toi mukanaan uusliberalistisia ajatuksia julkisen sektorin taloudenhoitoon. (Pekkarinen \& Vartiainen 1993; Kukkonen 1997; ks. Karisto ym. 1998, 92; Julkunen 2001, 63-66.)

Miksi sitten julkista sektoria leikattiin niin rajusti, vaikka syyt olivat muualla? Raija Julkusen $(2001,63)$ mukaan selitys löytyy ensinnäkin siitä, että rahoituskriisi edellytti säästötoimia, mutta toiseksi taloudellisesta eliitistä, joka esitti jo 1980-luvulla myös Suomessa kovaa kritiikkiä hyvinvointivaltion ekspansiota kohtaan ja vaati markkinoita korvaamaan julkisen sektorin palvelutuotantoa. Lama ja rahoituskriisi antoivat päättäjille 


\section{Eija Nurminen}

mandaatin toteuttaa kansalaisten vastustamia, mutta eliitin toivomia, julkisen sektorin leikkauksia.

Säästöpolitiikan toteuttamisessa vuosi 1993 osoittautui kohtalokkaaksi. Samana vuonna toteutettiin kaksi isoa muutosta: verotusjärjestelmän ja valtionosuusjärjestelmän muutokset. Verotuksessa palkkatyön ja pääomatulojen verotus eriytettiin ja pääomatulojen verotusta kevennettiin. Tämä loi pohjan tuloerojen kasvulle. (Julkunen 2006, 220.) Verotukseen tehtiin merkittäviä muutoksia jo 1989 verouudistuksessa, jolloin veroluokkien määrää vähennettiin yhdestätoista neljään. Tämän lisäksi tuloveroasteikon alarajoja on nostettu inflaatiota nopeammin. Vuonna 1989 tuloeroja kaventavan progressiivisen tuloverotuksen piiriin kuului lähes kuusikymmentä prosenttia verovelvollisista, mikä tarkoitti lähes kolmea miljoonaa suomalaista. Verohallinon mukaan vuonna 2009 enää kolmannes verotettavista (1,75 miljoonaa) maksoi vastaavia veroja. Yksinkertaistaen voidaan arvioida, että nykypäivän keskituloinen maksaa tuloistaan neljänneksen tuloveroa. Tästä samasta reaalitulosta olisi maksettu tasan kolmannes veroa vuoden 1988 veroasteikon mukaan. Progressiivisen tuloverotuksen piiriin kuuluvien osuus pieneni edelleen, koska pääomaverotukseen tehtiin 2005 muutos, joka mahdollisti verottomat osinkotulot aina 90000 euroon asti, joka houkutti monien ammattiryhmien edustajia (lääkärit, asianajajat, yrittäjät) nostamaan palkkansa palkkatulojen sijaan osinkotuloina. Verotukseen vaikutti lisäksi vuonna 2006 varallisuusveron poistaminen. Verotusta on myös kevennetty vuosina 2010 ja 2011. Suomessa onkin siirrytty työn verottamisesta kulutuksen verottamiseen arvonlisäveron avulla. (Turkkila 2011; Ruotsalainen 2011.)

Toiseksi vuonna 1993 toteutettiin kuntien valtionosuusjärjestelmän muutos, jossa kunnille annettiin "könttäsumma" rahaa (jolla piti hoitaa kaikki lakisääteiset palveluvelvoitteet) entisen "korvamerkityn" rahan (tietylle palvelulle suunnattu rahaosuus) sijaan tarkoituksena se, että kunnat alkaisivat tehostaa toimintojaan tuottamalla niitä vähemmällä rahalla. Tavoitteena oli, että tehostaminen tehtäisiin uusien julkisjohtamisoppien (new public management) avulla, joka merkitsi palvelujen kilpailuttamista, tilaaja-tuottaja -malleja, ulkoistamista, ostopalvelusopimuksia ja palveluseteleitä. Tehostaminen on usein kuitenkin kääntynyt päinvastaiseksi: toiminta on muuttunut jäykemmäksi, kalliimmaksi ja tehottomammaksi. Tällä hetkellä terveydenhuolto on pisimmällä 
yksityistämisessä ja ulkoistamisessa. Valtiohan oli jo 1990-luvulla liikelaitostanut, yhtiöittänyt ja yksityistänyt osan omasta palvelutuotannostaan. Valtionosuusjärjestelmän muutoksessa valtiolle jäi ohjausvastuu, vastuu palvelujen toteuttamisesta siirtyi kokonaan kunnille. Tämä merkitsee sitä, että kenelläkään ei ole kokonaisvastuuta; ministeriö vain ohjaa "keppien ja porkkanoiden" avulla. Valtakunnan tason politiikka on korvautunut alueellisella politiikalla ja projekteilla. Tästä seuraa helposti tilanteita, joissa esim. potilaita "pallotellaan" paikasta toiseen tai pidetään hoitojonoissa, jos maksaja on toinen kuin toimenpiteen suorittaja - valtio (Kela) maksaa esim. sairaspäivärahat ja lääkkeet, kun taas kunnat maksavat hoitotoimenpiteet. Kokonaisuutta ajatellen tällainen toiminta ei ole kovin rationaalista tehokkuudesta tai taloudellisuudesta puhumattakaan. Lisäksi alueelliset erot ovat kasvaneet huomattavasti, koska palvelutarjonta riippuu pitkälti kuntien taloudesta. (Eräsaari 2007; Julkunen 2006, 77-104.)

Millainen sosiaaliturvareformi 1990-luvulla sitten toteutettiin Raija Julkusen (2001, 151-156) mukaan? Ensinnäkin kavennettiin tulonsiirtoja: sosiaaliturvaetuuksia karsittiin ja etuuksien saamista vaikeutettiin. Sosiaalivakuutuksen maksuja nostettiin ja ohjattiin kansalaisia ottamaan yksityisiä vakuutuksia lisäturvan saamiseksi. Myös eläketurvaa rationalisoitiin ja tuleviin eläkemenoihin tehtiin merkittävä leikkaus. Toiseksi supistettiin palvelujen tarjoamista: julkisia palveluja kavennettiin ja kansalaisia ohjattiin hakemaan palveluja ja turvaa enenevämmässä määrin lähiyhteisöltä, kolmannelta sektorilta tai markkinoilta. Vapaaehtoissektorin järjestöjä ja kirkon roolia vakiinnutettiin osana huono-osaispolitiikkaa. Kolmanneksi työllisyyspolitiikassa suosittiin aktiivisuutta ja kannustimia: työttömät piti saada aktiivisiksi työntekijöiksi, työllistämisessä suunnattiin avoimille markkinoille ja julkisen sektorin työllistämistehtävää kavennettiin. Sosiaaliturva jakaantui kahdeksi eri "klubiksi". Reformin toteutuksen jälkeen Suomi oli palannut entiselle paikalleen pohjoismaisen mallin hännille.

Reformin seurauksena tuloerot alkoivat kasvaa Suomessa voimakkaasti ja köyhyys lisääntyä.1990-luvun laman jälkeisessä vero- ja sosiaaliturvapolitiikassa kasvavan tuloeriarvoisuuden syitä ovat Raija Julkusen (2006, 219-223) mukaan seuraavat tekijät: ensinnäkin verotuksen uudelleenjakovaikutukset ovat vähentyneet merkittävästi. Verotuksen keventäminen 
on suosinut erityisesti pääomatuloja, mutta myös ansiotyötuloja; sen sijaan sosiaaliturvaetuuksien verotusta ei ole kevennetty. Toiseksi työllisyys- ja aktivointipolitiikka ei ole onnistunut integroimaan syrjäytyneitä ja pitkäaikaistyöttömiä työmarkkinoille työllisyyden kasvusta huolimatta. Kolmanneksi sekä poliittiset valinnat että institutionaaliset mekanismit ovat jättäneet sosiaaliturvaetuudet ja erityisesti perusturva- ja vähimmäisetuudet reaaliansioiden kehityksestä pahasti jälkeen. Reaalitulojen kasvu ilmenee taulukosta 2.

Taulukko 2: Kotitalouksien reaalitulojen kasvu 1990-2007 tulodesiileittäin.

\begin{tabular}{|l|l|}
\hline 1 & $12,1 \%$ \\
\hline 2 & $15,5 \%$ \\
\hline 3 & $20,7 \%$ \\
\hline 4 & $24,8 \%$ \\
\hline 5 & $27,8 \%$ \\
\hline 6 & $29,3 \%$ \\
\hline 7 & $32,2 \%$ \\
\hline 8 & $36,1 \%$ \\
\hline 9 & $40,8 \%$ \\
\hline 10 & $82,7 \%$ \\
\hline Ylin $1 \%$ & $214,2 \%$ \\
\hline Kaikki & $40,8 \%$ \\
\hline
\end{tabular}

Lähde: Tulonjakotilasto 2007, Tilastokeskus; ks. Soininvaara 2010.

Suomalaisten käytettävissä olevat reaalitulot kasvoivat peräti 40 \% vuodesta 1990 vuoteen 2007. Tulojen lisäys jakautui kuitenkin hyvin epätasaisesti. Rikkaimman kymmenyksen tulot lähes kaksinkertaistuivat - ja ylimmän prosentin peräti kolminkertaistuivat - kun taas alimman kymmenyksen tulot kasvoivat vain $12 \%$. Keskimäärin käytettävissä olevat reaalitulot nousivat $40 \%$ eli enemmän kuin reaalipalkat, jotka nousivat 33 \%. Erotus selittyy pääomatulojen kasvulla, verotuksen muutoksilla ja kasvaneilla eläkkeillä. Samana ajankohtana suhteellinen köyhyys suurinpiirtein kaksinkertaistui mitattiin sitä millä tahansa käytetyistä suhteellisen köyhyyden mittareista. (Soininvaara 2010.) 
Tuloerot laskivat selvästi 1990-luvulle asti, mitattiin sitä sitten bruttotuloilla tai käytettävissä olevilla tuloilla, ja alkoivat nousta sen jälkeen voimakkaasti aina 2007 asti. Pienimmillään tuloerot olivat 1980-luvun lopulla ennen 1990-luvun taloudellisen laman alkua. 1990-luvun alussa tulonsiirrot vielä estivät tuloerojen nousun, mutta työttömyyden pitkittyessä ja lisääntyessä sekä julkisen sektorin tulonsiirtojen leikkausohjelman jälkeen tuloerot alkoivat kasvaa ja erityisen nopeasti ne kasvoivat 1990-luvun loppupuoliskolla ja huippu saavutettiin 2007. Lisäksi tuloerojen kasvua edesauttoi verotuksen progression lieveneminen sekä ansio- ja pääomatulojen erilainen verokohtelu. Finanssikriisi tasoitti tuloerojen voimakasta nousua osinkotulojen ja myyntivoittojen pienentymisestä johtuen vuosina 2008 ja 2009, mutta 2010 tuloerot ovat kääntyneet jälleen kasvuun. (Ruotsalainen 2011.)

Eurooppalaisessa vertailussa Suomi on ollut epämiellyttävällä kärkipaikalla, kun tuloerojen kasvua on tarkasteltu ajanjaksolla 1995-2004 Gini-kertoimella ${ }^{2}$ mitattuna. Myös 1980-luvun puoliväliin verrattunsa tuloerojen kasvu on ollut Suomessa suurempaa kuin useimmissa OECDmaissa. Kahdenkymmenen vuoden ajanjaksolla Gini-kertoimen muutos on ollut kuusi prosenttiyksikköä ja se on ollut toiseksi suurinta UudenSeelannin jälkeen. Keskimääräinen Gini-kertoimen muutos OECDmaissa oli samana ajanjaksona noin kaksi yksikköä. (Tilastokeskus 2007.) Useissa maissa on harjoitettu päinvastaista politiikkaa kuin Suomessa ja tuloeroja on saatu pienenemään samana aikana kun ne ovat kasvaneet meillä voimakkaasti. Poliittisilla valinnoilla on siis merkitystä ja niillä pystytään vaikuttamaan kansalaisten elinolojen välisiin eroihin. Kansallisella politiikalla on mahdollisuus vaikuttaa myös globalisaation oloissa. Silti on hyvä muistaa, että kuulumme edelleen varsin alhaisten tuloerojen maihin. Nopeasta tuloerojen kasvusta on kuitenkin syytä olla huolissaan. Sillä on seurauksena, johon paneudun seuraavissa alaluvuissa.

\section{Hyvinvointivaltiosta hyvinvointiyhteiskuntaan}

Tällä hetkellä Suomessa on käynnissä kamppailu sosiaaliturvan periaatteellisesta rakenteesta. Hyvinvointivaltion rakenteet ovat vielä pystyssä ja kansainvälisesti korkeassa luokassa, vaikka supistamista on tehty huo- 
mattavassa määrin niin etuuksien kuin palvelujenkin kohdalla. Hyvinvointipolitiikkaan ei lisätä enää uusia resursseja, vaan hoidetaan se, mihin on sitouduttu sekä kontrolloidaan erityisesti valtionvarainministeriöstä käsin koko ajan kustannusten kasvua. Jälkiteollisen talouden ja elämän epävarmuudet aiheuttavat lisääntyvää kuilua hyvinvointipolitiikan kysynnän ja julkisen tarjonnan välille. Tämä johtaa yhä suuremmassa määrin vakuutus- ja palvelujärjestelmien eriytymiseen väestöryhmien välillä samoin kuin alueellisten erojen kasvuun. Riskien hallinta on muuttunut kollektiivisesta vakuutuksesta yksilölliseksi strategiaksi.(Julkunen 2006.)

Miksi näin on tapahtunut? Suomessa kansainvälinen kilpailukyky on asetettu tärkeämmiksi kuin eriarvoisuuden vähentämisen. Globaalin talouden oloissa ei nosteta veroastetta, vaan palkkaverotuksesta siirrytään asteittain kohti kulutuksen verottamista, mikä vain voimistaa eriarvoisuuden kasvua. Yksilöllisen strategian voimistuminen ja hyvinvointivaltion vastuun väheneminen näkyy tuloerojen kasvun lisäksi erityisen voimakkaasti köyhyyden ja syrjäytymisen lisääntymisenä sekä sosioekonomisten terveyserojen kasvuna.

\section{Lisääntyvä köyhyys ja kasvavat terveyserot}

Tuloerojen kasvu on heijastunut köyhyyden lisääntymisenä, joka on kasvanut viime aikoina huolestuttavasti. Köyhyyden lisääntymisen on todettu olevan Suomessa yhteydessä erityisesti pitkäaikaistyöttömyyteen, pitkäaikaiseen toimeentuloasiakkuuteen, lastensuojelutoimiin ja terveyserojen kasvuun. Valtiovarainministeriön alivaltiosihteeri Martti Hetemäen (2011) mukaan pienituloisten ${ }^{3}$ määrä on kasvanut räjähdysmäisesti Suomessa: vuonna 1990 pienituloisia oli kaikkiaan lähes neljä sataa tuhatta henkilöä, kun heitä oli vuonna 2008 melko lailla tasan seitsemänsataa tuhatta.

Toimeentulotukitilastojen ja kirkon diakoniatyön tilastojen perusteella köyhimpien ahdinko on lisääntynyt vuoden 1990-lamasta lähtien ja voimistunut 2008 talouskriisin jälkeen. Perusturvan taso on jäänyt merkittävästi jälkeen ansiotason kehityksestä. Perusturvan varassa elävien kotitalouksien köyhyysriski on kasvanut 1990-luvun alusta ja se on tällä hetkellä hyvin korkea - noin yhdeksänkymmentä prosenttia. 
Mikäli perusturvan annetaan edelleen heikentyä suhteessa ansiotasoon ja ansioturvaan, köyhyysongelma uhkaa muuttua Suomessa krooniseksi. Kirkon diakoniatyö on yrittänyt viimeisen 20 vuoden aikana paikata viimesijaisen sosiaaliturvan aukkoja. Aukoissa on kyse toimeentulotuesta ja perusturvaetuuksista eli vähimmäismääräisistä työttömyys-, sairaus-, ja vanhempainpäivärahoista sekä Kelan täydestä kansaneläkkeestä ja asumistuesta. (Perusturvan riittävyyden arviointiraportti 2011, 82-83; Hiilamo \& Karjalainen 2010, 105.)

Vuonna 2009 noin 150000 suomalaista eli kotitalouksissa, joiden bruttotuloista yli 90 \% koostui perusturvaetuuksista, ja heidän määränsä on kaksinkertaistunut vuodesta 1990. Kansainvälisessä vertailussa suomalainen vähimmäisturvan taso ennen asumismenoja on keskimääräistä tasoa, mutta asumismenojen jälkeen tarkasteltuna suomalaisen vähimmäisturvan taso jää hieman alle länsieurooppalaisen keskitason. Suomen perusturvan taso on selvästi alempi kuin muilla Pohjoismailla. (Perusturvan riittävyyden arviointiraportti 2011, 82-83.)

Perusturvaetuuksien matalaa tasoa kuvaa niiden suhde toimeentulotuen tasoon. Eläkeläisiä lukuun ottamatta kaikki perustulon varassa elävät väestöryhmät ovat olleet oikeutettuja saamaan toimeentulotukea. (Perusturvan riittävyyden arviointiraportti 2011,82.) Toimeentulotuen saaminen ja sen resurssoiminen ovat yhteydessä työttömyyden kasvuun (kuvio 3 seuraavalla sivulla). Tämä näkyy sekä 1990-luvun laman toimeentulotukien saajissa että vuonna 2008 alkaneen laman vaikutuksissa toimeentulotukien saajien määriin. 


\section{Eija Nurminen}

Kuvio 3: Toimeentulotuen menot (vuoden 2010 hinnoin), toimeentulotukea saaneet kotitaloudet ja työttömien märän vuosikeskiarvo koko maassa vuosina 1990-2010.

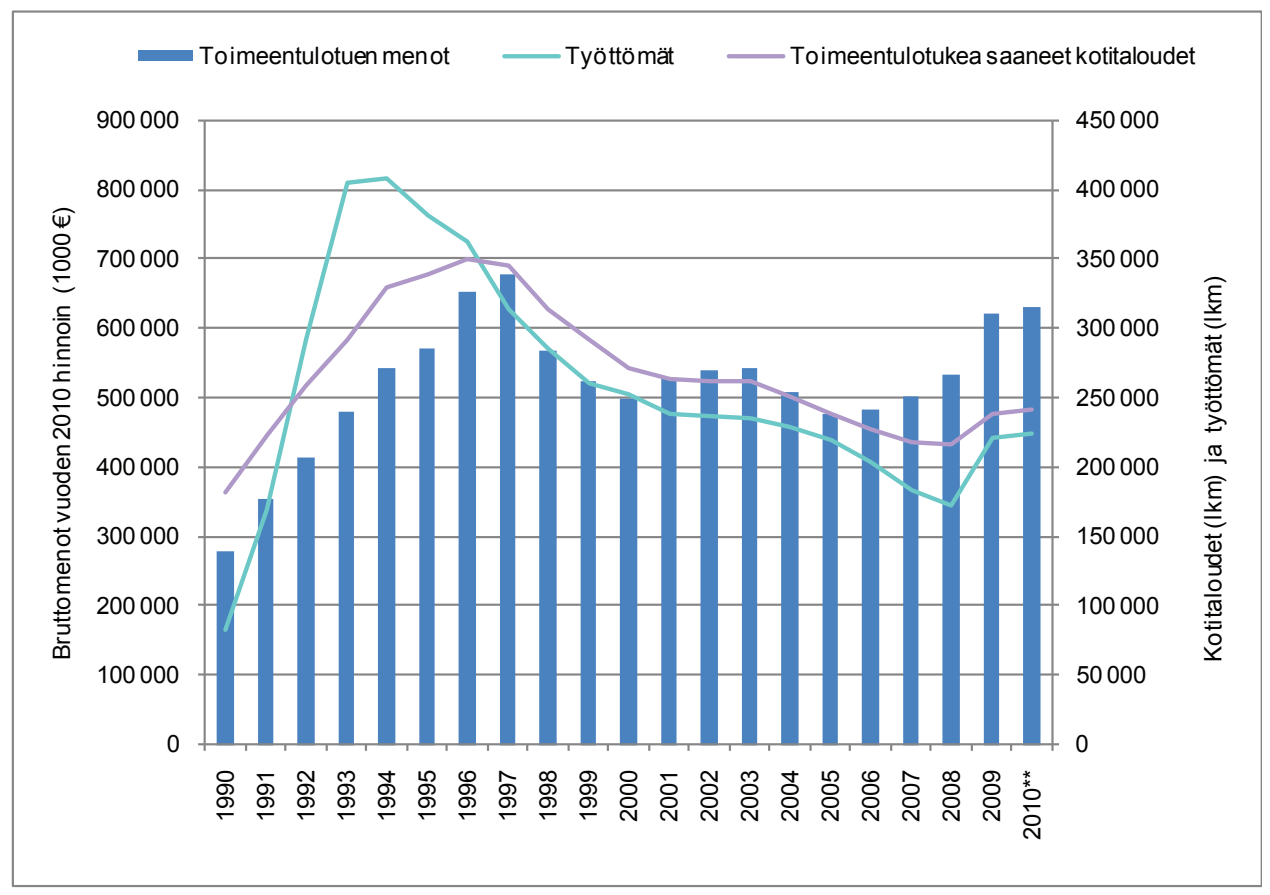

Lähde: THL 2011.

1990-luvun alkuun asti suomalainen terveydenhuolto nähtiin erilaisten reformien avulla asteittain täydentyvänä WHO:n mallimaana. Terveysolot ovat kuitenkin kokeneet drastisen muutoksen. Kansainvälisessä vertailussa Suomi asettui 2000-luvun alussa lääkäripalvelujen käytön oikeudenmukaisuudessa Yhdysvaltojen ja Portugalin rinnalle eniten hyväosaisten palvelujen käyttöä suosivaksi maaksi. (Keskimäki 2010.) Lähes kaikki terveysongelmat ovat Suomessa yleisempiä vähiten koulutettujen, työntekijäammatissa toimivien tai toimineiden ja pienituloisten keskuudessa. 
Sairastavuudessa ja toimintakyvyn rajoitteissa sosioekonomisten ryhmien välillä on yhtä suuret erot kuin kuolleisuudessakin. Keski-ikäisessä väestössä perusasteen koulutuksen saaneiden kuolleisuus on miehillä kaksinkertainen ja naisilla lähes kaksinkertainen korkea-asteen koulutuksen saaneisiin verrattuna. Myös keskinkertainen tai sitä huonommin koettu terveys tai pitkäaikaissairastavuus ovat alimmassa koulutusryhmässä kaksi kertaa niin yleisiä kuin ylimmässä ryhmässä. Liikkumisvaikeuksia kokeneiden kohdalla koulutusryhmien välinen ero on vieläkin suurempi. (Koskinen 2006.)

Terveyspalvelut eivät jakaannu niin oikeudenmukaisesti kuin on uskottu eikä perustuslain edellyttämä yhdenvertaisuus toteudu suomalaisessa terveydenhuoltojärjestelmässä. Myös julkisen sektorin tuottamissa sairaalapalvelujen käytössä on todettu olevan yllättävän suuria sosiaaliryhmien välisiä eroja. Kun sairaalapalvelujen käyttöä tutkittiin lähemmin, huomattiin, että ylemmille sosiaaliryhmille tehtiin enemmän kirurgisia toimenpiteitä kuin alemmille. 1990-luvun laman jälkeisissä tehostumistoimenpiteissä, joissa toimenpiteiden määrät kasvoivat, hyötyjinä olivat suhteellisesti eniten ylempien sosiaaliryhmien potilaat, mikä kasvatti eroja entisestään. (Keskimäki 2010; Koskinen 2006.)

Mistä sosioekonomiset terveyserot sitten johtuvat? Erityisesti erot näyttävät kytkeytyvän sosiaalisiin rakenteisiin eli työn, vallan sekä tulojen ja varallisuuden jakautumiseen yhteiskunnassa. Vähäinen koulutus, alempiin sosiaaliluokkiin kuuluminen ja heikko työmarkkina-asema näyttävät muodostavan vakavan terveysriskin. Hyvä sosiaalinen asema, korkea koulutus, hyvät tulot ja työmarkkinastatus puolestaan luovat ylipäätään paremmat tiedolliset ja taloudelliset edellytykset asua ja työskennellä terveyden kannalta hyvässä ympäristössä ja valita terveyttä edistäviä käyttäytymismalleja. (Koskinen 2006; Hiilamo ym. 2010.)

Terveyserojen kaventamista pidetäänkin yhtenä tärkeimmistä tulevaisuuden tehtävistä, koska tästä seuraa terveyskustannusten alenemista, syrjäytymisen vähenemistä työelämästä ja työllisyysasteen kohoamista sekä siten kykyä vastata ikääntyvien hoidon tarpeisiin. Terveydenhuollon kehittämisessä voitaisiin palata 1960-luvun Pekka Kuusen luoman rationaalisen yhteiskuntapolitiikan henkeen ja uutta sosiaali- ja terveydenhuollon rahoitus- ja ohjausjärjestelmää olisi hyvä suunnitella sosiaali- ja terveyspoliittisista tavoitteista lähtien jättäen eri intressitahojen (yksi- 


\section{Eija Nurminen}

tyiset terveydenhoito- ja vakuutusyritykset) etujen varjelu vähemmälle. (Keskimäki 2010.) Briitta Koskiaho (2008) onkin todennut, että taloudellinen intressi voittaa aina, jos ei ole raudanlujaa, ulkoapäin ohjattua ja kansalaisten intressejä suojelevaa sekä palvelujen laatutasoa tarkkailevaa valvontajärjestelmää.

\section{Miksi eriarvoisuuden kasvusta ei välitetä?}

Väestö on eriytynyt voimakkaasti 1990-luvun laman jälkeen niin tulojen, terveyden kuin köyhyydenkin mukaan tarkasteltuna. Miksi eri väestöryhmien välisestä eriarvoisuuden kasvusta ei sitten välitetä? Juho Saari käsitteli samaa kysymystä Sosiaalipolitiikan päivillä 2010 ja esitti seuraavia syitä. Ennen päättäjien huolena oli taata taloudellinen kasvu ja korkea työllisyysaste ja vähentää samanaikaisesti eriarvoisuutta. Nyt huomio on kiinnitetty taloudelliseen kasvuun ja työllisyyteen sekä "hyvinvointikakun jakamiseen" työllisyyden kautta. 1990-luvun tehokas sosiaalipolitiikka vähensi eriarvoisuutta sekä väestöryhmien että sukupuolien ja sukupolvien välillä. Nykyään sosiaalipolitiikka on muuttumassa köyhyyspolitiikaksi, välineeksi muiden tavoitteiden saavuttamiseksi, ei itsessään päämääräksi.

Juho Saari (2010) kiteytti eriarvoisuuden kasvun taustalla olevan välinpitämättömyyden syyt kolmeen tekijään: ensinnäkin tyytyväisen enemmistön diktatuuriin, sosiaalisen etäisyyden kasvamiseen väestöryhmien välillä sekä kolmanneksi kollektiivisen muistin rapautumiseen. Saari perusteli ajatusta enemmistön diktatuurista sillä, että Suomessa hyvän elintason kokeminen on korkeampaa verrattuna muihin EU-maihin. Valtaosa kokee elintasonsa varsin hyväksi. Suomessa on ollut kiinnostusta erityisesti täydentäviin ansioihin vakuutusjärjestelmän kautta (työeläkkeet, ansioon sidottu turva, yksityisvakuutus). Hyvin toimeentulevat eivät ole kiinnostuneita viimesijaisen tuen kehittämisestä eli perusturvasta; toimeentulotuki onkin laskenut suhteessa ansiotuloihin lähes kolmanneksen viimeisten kymmenen vuoden aikana.

Toiseksi Saari mainitsee sosiaalisen etäisyyden kasvun eri väestöryhmien välillä. Enää kansalaiset eivät koe olevansa samassa veneessä. Ennen oltiin samassa "tilassa", vaikka oltiinkin eri asemissa. Nyt ollaan eri tilois- 
sakin. Tästä seuraa se, että "sosiaaliset maailmat" eroavat eri väestöryhmien välillä. Tapahtuu jako "meihin ja heihin". Solidaarisuus, empatia ja sympatia ovat vähentyneet tai kadonneet erityisesti "toisia" kohtaan. Myös päättäjien harjoittama taloudellinen kieli (kannustinloukut, aktivointi jne.) ei edistä viimesijaisten inkluusiota.

Viimeiseksi Saari mainitsee kollektiivisen muistin rapautumisen. Tämä liittyy siihen, miten muistamme historian. Onko meillä yhteinen ymmärrys siitä, mitä 1990-luvulla tapahtui? Päättäjät muistavat 1990-luvun, erityisesti sen loppupuolen, taloudellisena ja teknologisena menestystarina. Kansa muistaa eriarvoisuuden ja leipäjonot. Taloudellinen eliitti ei jaa kansallista kokemusta 1990-luvusta.

Sosiaalipolitiikassa on jo tapahtunut 1990-luvun laman jälkeen siirtymä tasa-arvosta ja universalismista kohti selektivismiä, kannustavuutta, aktiivisuutta ja omaa vastuuta. Olemme osin jo palanneet takaisin 1960-70-luvun sosiaaliturvan ja palveluiden tasolle. Olemmeko matkalla kohti köyhyyspolitiikkaa, jossa sosiaaliturvaetuuksia ja julkisia palveluita kohdennetaan vain huono-osaisimmille?

\section{Eriarvoisuuden vähentäminen on hallitusohjelman painopistealue}

Pääministeri Jyrki Kataisen hallituksen yksi keskeinen tavoitekokonaisuus on köyhyyden, eriarvoisuuden ja syrjäytymisen vähentäminen. Aiempia hallituksia enemmän ainakin nykyinen hallituksen ohjelmateksti painottaa sosiaalista ja ekologista vastuuta kilpailuyhteiskuntapolitiikassaan Suomessa ja globaalisti. Hallitusohjelmassa (2011) todetaan:

Suomen tulevaisuuden menestys ja hyvinvointi nojaavat yhteiskunnan korkeaan työllisyysasteeseen, sosiaaliseen eheyteen ja tasa-arvoisuuteen. Työ on parasta sosiaaliturvaa. Työmarkkinoita, verotusta ja sosiaaliturvaa on kehitettävä osallisuuden ja työllisyyden näkökulmasta. Sukupolvelta toiselle periytyvä köyhyys ja syrjäytyminen on katkaistava. Jokainen ansaitsee reilun alun ja aidot tasaveroiset mahdollisuudet elämälleen. Yhteiskunnan vastuun rinnalla on yhteisön vastuu. Ihmisten omaa vastuuta itsestään, perheistään ja yhteisöistään tuetaan. Kansalaisjärjestöjen tekemä arvokas työ täydentää yhteiskunnan palveluita ja lisää hyvinvointia. Tavoitteena on kaventaa tulo- 


\section{Eija Nurminen}

, hyvinvointi- ja terveyseroja. Tavoitteen saavuttamiseksi peruspalveluita vahvistetaan ja uudistetaan, turvataan ikäihmisille ihmisarvoinen vanhuus, panostetaan sosiaalisten ja terveydellisten ongelmien ennaltaehkäisyyn, mielenterveys- ja päihdepalveluihin sekä parannetaan toimeentuloturvaa ja estetään asuinalueiden eriytymistä. Koulupudokkuuteen puututaan. Hallitus valmistelee vanhuspalvelulain sekä laaja-alaisen, köyhyyttä, eriarvoisuutta ja syrjäytymistä vähentävän toimenpideohjelman.

Edellä olevan sitaatin mukaan ohjelmassa nimettiin köyhyyden ja syrjäytymisen ehkäisy päätavoitteeksi. Se on ollut ykköstavoitteena tähän asti lähinnä vain "paperilla", vaikka perusturvaan saatiinkin pieni korotus, kansaneläkkeisiin 650 euron takuu Sata-komitean suositusten mukaisesti ja nuorille takuu työstä tai koulutuksesta. Valtioneuvosto on delegoinut köyhyyden ja syrjäytymisen ehkäisyn hoitamisen erityisesti sosiaali- ja terveysministeriölle, joka onkin kirjannut uuteen strategiaansa kolme keskeistä tavoitetta: "hyvinvoinnille vahva perusta, kaikille mahdollisuus hyvinvointiin ja elinympäristö tukemaan terveyttä ja turvallisuutta" (STM 2011; ks. Saari 2011). Miksi hallitusohjelman ykköstavoite pitäisi ottaa vakavasti?

Juho Saari listaa muutaman pääasiallisen argumentin, jotka puoltavat ottamaan yhteiskunnallisen eriarvoisuuden vakavasti. Ensinnäkin, mielipidetutkimusten mukaan suomalaiset näkevät yhteiskuntansa muuttuneen liian eriarvoiseksi ja sosiaaliturvan taso arvioidaan selvästi liian alhaiseksi. Pääasiallinen jako kansalaisten mielestä on rikkaiden ja köyhien välillä ja tätä jakoa pitäisi kaventaa. (Saari 2011.) Jos yhteiskunnan jakautumiseen ei kiinnitetä riittävästi huomiota, saattaa sillä olla vakavampia vaikutuksia. Jorma Sipilän (2009) mukaan turvattomuus on myös järjestelmäuhka. Universalismin mukana haihtuu perusturvakansalaisten usko yhteiseen kansakuntaan ja solidaarisuuteen. Kun osa väestöstä kokee joutuneensa eliitin ja keskiluokan hylkäämiksi, edessä olevat talouden ja työn muutokset sekä sosiaaliturvaleikkaukset otetaan vastaan aggressiivisesti. Niin rasismi kuin fasismikin viihtyvät turvattomien ihmisten keskuudessa.

Toiseksi Saaren (2011; myös Kangas 2010) mukaan valtioneuvosto retorisesti edistää mieluummin hyvinvointia ja terveyttä sekä korostaa yksilön omaa vastuuta sekä kansalaisyhteiskunnan toimia kuin tekee panostuksia eri yhteiskuntaluokkien tai -ryhmien väliseen eriarvoisuuden 
vähentämiseen. Tulonsiirroissa painotetaan viimesijaisen turvan aukkoja paikkaavaa kannustin- ja köyhyyspolitiikkaa, joka kohdistuu alimpiin tulodesiileihin eikä huomiota kohdisteta eriarvoistumisen kannalta merkittävämpään sosioekonomisten erojen supistamiseen tähtäävään politiikkaan. Olisi pohdittava, mitä työurien pidentäminen merkitsee eri sosioekonomisissa ryhmissä oleville yksilöille sekä miten sosiaali- ja terveyspalvelut saataisiin palvelemaan paremmin huono-osaisia ryhmiä. Samoin olisi selvitettävä, missä määrin koulutus- työllisyys- ja sosiaaliturvajärjestelmään sisältyy eriarvoistumista ylläpitäviä ja lisääviä institutionaalisia rakenteita.

Kolmanneksi Saari (2011) tuo esille sen, miten käsitys eriarvoisuudesta ja hyvinvoinnista on muuttumassa aikaisempaa moniulotteisemmaksi. Koettu hyvinvointi on muuttumassa yksilön asiasta yhteiskuntapoliittiseksi asiaksi ja samalla sen painopiste on siirtynyt koetun hyvinvoinnin tasosta sen jakauman eli eriarvoisuuden tutkimiseen. Hyvinvointierojen tarkastelussa otetaan tulojen lisäksi huomioon muut resurssit kuten koulutus, työ, terveys ja asuminen, mutta myös koetut statuserot ja sosiaaliset suhteet. On hyvä kysyä, missä määrin talouden kasvuun, kilpailukykyyn ja työllisyyteen tähtäävä politiikka heikentää kansalaisyhteiskunnan ja hyvinvointivaltion välistä liittoa ja minkälaisia eriarvoistavia vaikutuksia tällä kehityksellä on tulojen uudelleenjakoon ja kansalaisten keskinäiseen solidaarisuuteen.

Mitä merkitystä eriarvoisuuden vähentämisellä sitten on? Tasa-arvoisemmissa yhteiskunnissa kaikki kansalaiset voivat paremmin. Eriarvoisuuden lisääminen ei heikennä vain häviäjien asemaa, vaan koskee koko väestöä. Eriarvoisuus lisää kustannuksia, pelkoa, turvattomuutta, eristäytyneisyyttä, sosiaalista etäisyyttä, rikollisuutta ja mielensairauksia. Huippuyksilöiden taloudellisen menestyksen korostaminen koko yhteiskunnan tasa-arvon kustannuksella johtaa lyhyempään, sairaampaan ja onnettomampaan elämään. Tulotaso ei selitä enää hyvinvointia, vaan se, miten tulot ovat jakautuneet. Kansallisella politiikalla on merkitystä, vaikka eriarvoisuuden kasvu johtuisi globaaleista tekijöistä. (Wilkinson \& Pickett 2011.)

Valtioneuvoston kannattaisi siis panostaa retoriikan sijaan myös tekoihin eriarvoisuuden kaventamiseksi. Sipilän (2011) mukaan eriarvoisuuden kasvu voitaisiin katkaista ymmärtämällä hyvinvointivaltio jälleen 


\section{Eija Nurminen}

sosiaalisena investointina, jossa hyvinvointivaltio on modernisoitava käsittelemään yhteiskunnassa tapahtuvia riskejä ja tarpeita sekä varmistamaan valtion taloudellista ja poliittista kestävyyttä tietoon pohjautuvassa taloudessa. Tällöin on pyrittävä valmentamaan ihmiset, perheet ja yhteiskunnat näihin muutoksiin eikä julkisen sektorin tehtäväksi jää vain korjata tapahtuneiden riskien aiheuttamia toimeentulomenetyksiä. Valmentava, sosiaalinen toiminta kohdistetaan erityisesti yksilöihin, joilla ei ole mahdollisuuksia investoida itseensä eikä elinympäristöönsä. Toiminta vahvistaa ja luo toimintakykyä ja avaa yksilölle mahdollisuuksia. Tämänkaltaiset sosiaaliset ohjelmat pitää nähdä investointeina, jotka saavat aikaan taloudelle hyödyllisiä tuloksia, jotka realisoituvat eriarvoisuutta vähentävänä sosiaalipolitiikkana. Hyvinvointi pitää nähdä Amartya Senin (2009) lailla toimintakyvykkyyksien luomisena - ei kulutuksena. Erityisesti pitää panostaa koulutukseen, perhepolitiikkaan ja sosiaalisen pääoman kasvattamiseen. Sosiaalinen toiminta tulee pitkällä aikavälillä supistamaan julkisen talouden tulevia kustannuksia. Samalla se ylläpitää yhteiskunnallista integraatiota ja estää syrjäytymistä. Tavoitteena on tehdä ihmisistä vahvempia toimijoita markkinoilla ja tasoittaa eroja sisäja ulkopuolella olevien välillä tuottamalla kaikille osallisuutta. (Sipilä 2011.)

Eriarvoisuuden kasvun suunta saataisiin myös käännettyä kehittämällä hyvinvointivaltiota hyvän kehän teorian pohjalta (Hagfors \& Kajanoja 2010), jossa ilmenee monia yhteneväisyyksiä Sipilän ”sosiaalisen investointivaltion" kanssa. Hyvän kehän teorian mukaan hyvinvointipanostusten keskeinen tehtävä on tarjota hyvinvoinnin edellytykset mahdollisimman monille siten, että mahdollisimman harva jää syrjään yhteiskunnan kehityksestä ja sen rakentamisesta. Samalla teoria perustuu ajatukseen, että huono-osaisuuden ehkäiseminen johtaa myös yleiseen eriarvoisuuden vähenemiseen, mikä lisää yhteenkuuluvuutta. Robert Hagfors ja Jouko Kajanoja painottavat, että nimenomaan eriarvoisuuskuilut heikentävät ihmisten mahdollisuuksia ja yhteiskunnan integraatiota. Tällöin ihmisten keskinäinen luottamus vähenee ja yhteisöllinen osallistuminen eli sosiaalinen pääoma rapautuu. Hyvä kehä toimii päinvastaisesti: hyvinvointipanostus vähentää eriarvoisuutta, vähentynyt eriarvoisuus vahvistaa sosiaalista pääomaa, vahvistunut sosiaalinen pääoma lisää hyvinvointia ja lisääntynyt hyvinvointi lisää hyvinvointipanostusta. 
Tekijät lisäsivät hyvän kehän teoriansa muuttujiksi Doyalin ja Goughin (1991) tarveteorian mukaiset päätarpeet: autonomian ja terveyden. He testasivat hyvän kehän toimivuuden kahdenkymmenen kolmen OECDmaan vertailuna ja tulivat siihen tulokseen, että "kehä pyörii” oletetulla tavalla. Kuviosta 4 käy ilmi kehän pyörimisliike.

Kuvio 4: Hyvän kehän teoria.

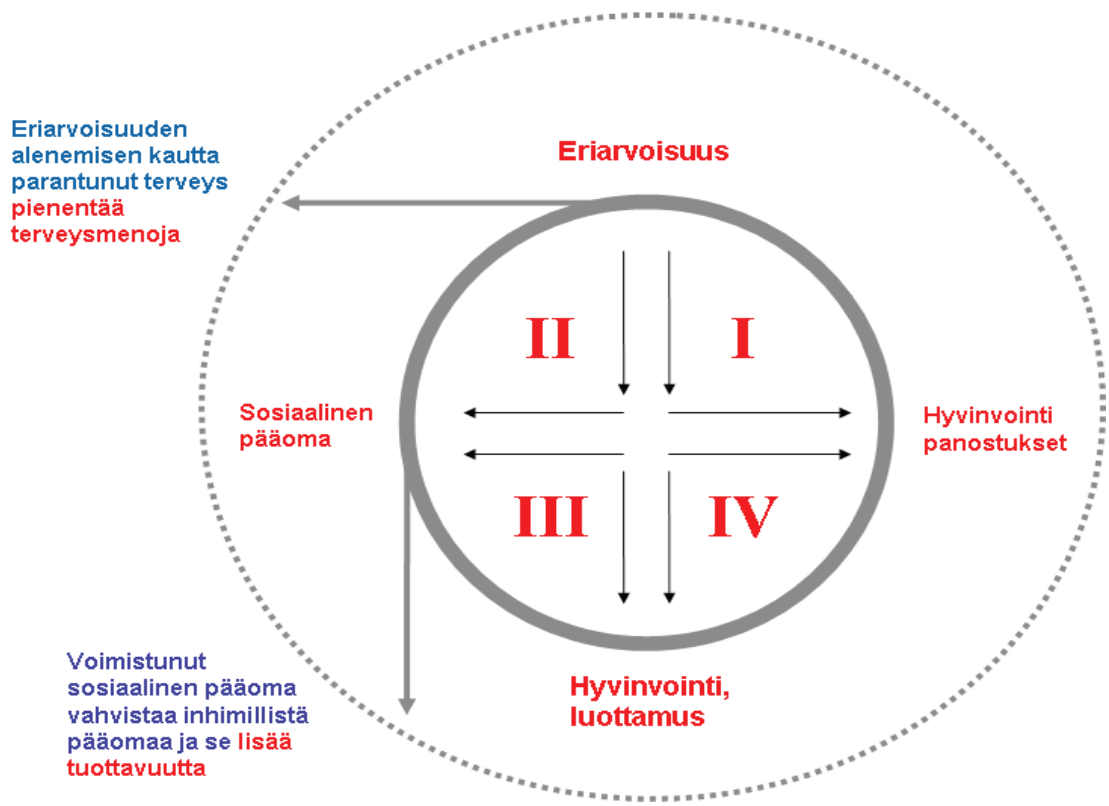

Lähde: Hagfors 2009.

Tutkimuksessaan Hagfors ja Kajanoja (2010) saivat päätulokseksi sen, että mitä enemmän koettiin luottamusta, osallistumista ja hyvinvointia, sitä enemmän oli tarjolla myös sosiaalisia mahdollisuuksia. Eriarvoisuus ja sosiaalinen pääoma muodostavat teorian ytimen. Vähenevä eriarvoisuus parantaa terveyttä ja se lisää toimintakykyä ja pienentää terveysmenoja. Sosiaalinen pääoma parantaa terveyttä ja inhimillistä pääomaa ja ne vuorostaan lisäävät toimintakykyä, autonomiaa ja koulutukseen osallistumista sekä terveyttä. Kun väestön koulutustaso nousee ja terveys paranee, 


\section{Eija Nurminen}

niin siitä seuraa hyvinvoinnin kasvua ja luottamusta yhteiskuntaa kohtaa, joka saa aikaa kokonaistaloudellisesti säästöä ja kansallista menestystä. Kohonnut hyvinvointi ja luottamus saavat aikaan myönteistä asennetta sosiaaliturvaa kohtaan ja potentiaalinen resurssien kasvu vaikuttaa puolestaan positiivisesti hyvinvointipanostuksiin. Hyvinvointivaltion panostukset saavat aikaan hyötyvaikutuksia yksilöiden suorituskykyyn, joiden kautta saadaan eriarvoisuus vähenemään.

Useat tutkijat, niin ulkomailla kuin kotimaassa, ovat osoittaneet, että eriarvoisuuden kaventaminen tulee julkiselle sektorille pitkän aikavälin tarkastelussa edulliseksi. Monet maat ovat myös valinneet tämän politiikan omaksi ohjelmakseen. Pitäisikö suomalaisten poliitikkojen ja virkamiesten kaivaa Pekka Kuusen 60-luvun sosiaalipolitiikka -teos esille ja alkaa opiskella Kuusen Gunnar Myrdalilta lainaamaa kasvuteoriaan pohjautuvaa hyvää kehää ja päivittää Myrdalin teoriaa tutustumalla uusiin sosiaalipoliittisiin näkemyksiin ja tutkimuksiin, jossa hyvää kehää kehitellään tämän päivän tarpeisiin ja luodaan samalla sosiaalipolitiikalle uutta sosiaalisten mahdollisuuksien politiikkaa?

\section{Lähteet:}

Antikainen, Ari, Rinne, Risto \& Koski, Leena. 2000. Kasvatussosiologia. Helsinki: WSOY.

Anttonen, Anneli \& Sipilä, Jorma. 2000. Suomalaista sosiaalipolitiikkaa. Tampere: Vastapaino.

Doyal, Len \& Gough, Ian. 1991. The Theory of Human Needs. Hampshire and London: Macmillan.

Elovainio, Päivi. 1993. Muuttuva koulutus. Teoksessa Olavi Riihinen (toim.) Sosiaalipolitiikka 2017. Näkökulmia suomalaisen ybteiskunnan kehitykseen ja tulevaisuuteen. Sitra. Helsinki: WSOY, 413-432. 
Eräsaari, Leena. 2007. Millainen yhteiskunta on hyvinvointivaltion jälkeen? Teoksessa Heikki Taimio (toim.) Talouskasvun hedelmät - kuka sai ja kuka jäi ilman? Helsinki: Työväen Sivistysliitto, 211-225.

Haatanen, Pekka. 1993. Suomalaisen hyvinvointivaltion kehitys. Teoksessa Olavi Riihinen (toim.) Sosiaalipolitiikka 2017. Näkökulmia suomalaisen yhteiskunnan kehitykseen ja tulevaisuuteen. Sitra. Helsinki: WSOY, 31 -67.

Hagfors, Robert. 2009. Terveys ja sosiaaliset mahdollisuudet. Kansainvälinen vertailu. Alustus terveydenhuoltotutkimuksen päivillä 23.10.2009 Tampereen yliopistossa. http://www.socialmedicine.fi/pdf/ttpaivat2009/Hagfors. $\operatorname{pdf}(28.10 .11$.)

Hagfors, Robert \& Kajanoja, Jouko. 2010. Hyvän kehän teoria ja sosiaaliset mahdollisuudet. Teoksessa Heikki Hiilamo \& Juho Saari toim. Hyvinvoinnin uusi politiikka - johdatus sosiaalisiin mabdollisuuksiin. Diakoniaammattikorkeakoulu. A Tutkimuksia 27. Helsinki: Diak, 107-132.

Hallitusohjelma. 2011 Pääministeri Jyrki Kataisen hallituksen ohjelma 22.6.2011. http://www.vn.fi/hallitus/hallitusohjelma/fi.jsp (28.10.11.)

Hellsten, Katri. 1981. Sosiaalinen turvallisuus - sosiaaliturva muuttuvassa yhteiskunnassa. Teoksessa Risto Jaakkola, Antti Karisto, J.P.Roos (toim.) Sosiaalipolitiikka, historiallinen kehitys ja yhteiskunnallinen muutos. Helsinki: Weilin \& Göös.

Hellsten, Katri. 2008. ”Miten turvataan niiden toimeentulo, joiden käsissä kynä hidastuu ja kirves herpoaa?" Teoksessa Robert Hagfors, Katri Hellsten ja Maija Sakslin (toim.) Suomen kansan eläke. Kelan tutkimusosasto. Helsinki: Kela, 18-59.

Hetemäki, Martti. 2011. Köyhyys, työttömyys, tuottavuus ja kestävyys. Kansantaloudellinen aikakauskirja 107:1, 30-49.

Hiilamo, Heikki \& Karjalainen, Jouko. 2010. Köyhät talouskriisin kurimuksessa. Teoksessa Heikki Taimio (toim.) Hyvinvointivaltion suunta - nousu vai lasku? Helsinki: TSL, 90-107.

Hiilamo, Heikki, Kangas, Olli, Manderbacka, Kristiina, Mattila-Wiro, Päivi, Niemelä, Mikko \& Vuorenkoski, Lauri. 2010. Hyvinvoinnin turvaamisen rajat. Näköaloja talouskriisiin ja hyvinvointivaltion kehitykseen Suomessa. Kelan tutkimusosasto Helsinki: Kela.

Jokinen, Kimmo \& Saaristo, Kimmo. 2002. Suomalainen yhteiskunta. Helsinki: WSOY.

Julkunen, Raija. 2001. Suunnanmuutos. 1990-luvun sosiaalipoliittinen reformi Suomessa. Tampere: Vastapaino. 


\section{Eija Nurminen}

Julkunen, Raija. 2006. Kuka vastaa? Hyvinvointivaltion rajat ja julkinen vastuu. Helsinki: Stakes.

Kajanoja, Jouko. 2003. Sosiaalipolitiikka ja talousteoria. Teoksessa Tuula Helne, Raija Julkunen, Jouko Kajanoja, Sini Laitinen-Kuikka, Tiina Silvasti ja Jussi Simpura Sosiaalinen politiikka. Helsinki: WSOY, 183-213.

Kangas, Olli. 2010. Perusturvan puutteet, 2010-luvun sosiaaliset ongelmat, köyhyys ja syrjäytyminen. Pääpuheenvuoro Sosiaalipolitiikan päivillä 21.10.2010 Helsingin yliopistossa. http://blogs.helsinki.fi/sosiaalipolitiikanpaivat/files/2010/10/Ollikangas.pdf (28.10.11.)

Karisto, Antti, Takala, Pentti, Haapola, Ilkka (1998) Matkalla nykyaikaan. Helsinki: WSOY.

Keskimäki, Ilmo. 2010. Sosioekonomiset erot ja oikeudenmukaisuus Suomen terveydenhuollossa. Juhlaluennon lyhennelmä 29.4.2010. Tampereen yliopisto. http://www.uta.fi/ajankohtaista/tiedotteet/2010/o42.html (28.10.11.)

Koskiaho, Briitta. 2008. Hyvinvointipalvelujen tavaratalossa. Tampere: Vastapaino.

Koskinen, Seppo. 2006. Sosioekonomiset terveyserot - Suomen kansanterveyden keskeinen ongelma. Kansanterveys 2/2006, 7-9.

Kosonen, Pekka. 1987. Hyvinvointivaltion haasteet ja pohjoismaiset mallit. Tampere: Vastapaino.

Kukkonen, Pertti.1997. Rahapolitiikka ja Suomen kriisi. Pellervon taloudellinen tutkimuslaitos, PTT. Julkaisuja 16. Helsinki: PTT.

Kuusi, Pekka. 1961. 60-luvun sosiaalipolitiikka. Helsinki: WSOY.

Nevala, Arto. 1999. Korkeakoulutuksen kasvu, lobkoutuminen ja eriarvoisuus Suomessa. Bibliotheca Historica 43. Helsinki: Suomen Historiallinen Seura.

Niemelä, Heikki. 2004. Suomen sairausvakuutusjärjestelmän synty. Teoksessa Katri Hellsten \& Tuula Helne (toim.) Vakuuttava sosiaalivakuutus? Kelan tutkimusosasto. Helsinki: Kela, 90-116.

Nätti, Jouko. 1996. Eriytyvät ja riskiytyvät työmarkkinat. Teoksessa Aila-Leena Matthies, Ulla Kotakari ja Marianne Nylund (toim.) Välittävät verkostot. Tampere: Vastapaino, 75-90.

Pekkarinen, Jukka \& Vartiainen, Juhana. 1993. Suomen talouspolitiikan pitkä linja. Helsinki: WSOY.

Perusturvan riittävyyden arviointiraportti. 2011. Helsinki: THL. 
Riihelä, Marja, Sullström, Risto, Tuomala, Matti. 2005. Trends in top income shares in Finland. VATT Discussion Papers 371. Helsinki: Government Institute for Economic Research. https://www.vatt.fi/file/vatt_publication_pdf/j52.pdf. (28.10.11.)

Riihinen, Olavi. 2009. Pekka Kuusesta Terho Pulkkiseen 1957-1969. Teoksessa Risto Jaakkola, Sakari Kainulainen \& Keijo Rahkonen (toim.) Työväensuojelusta sosiaalipolitiikkaan. Sosiaalipoliittinen yhdistys 1908-2008. Helsinki: Edita, 97-143.

Ruotsalainen, Pekka. 2011. Jäävätkö tuloerot pysyvästi suuriksi ? Hyvinvointikatsaus 1/2011. Helsinki: Tilastokeskus. http://www.stat.fi/tup/hyvinvointikatsaus/hyka_2011_01.html. (28.10.11)

Saari, Juho. 2010. Paneelikeskustelu perusturvasta. 2010-luvun sosiaaliset ongelmat: köyhyys, syrjäytyminen ja perusturvan puutteet. Sosiaalipolitiikan päivät 21.- 22.10.2010. Helsinki.

Saari, Juho. 2011. Eriarvoisuus kasvun ja työllisyyden Suomessa. Yhteiskuntapolitiikka 76:1,76-84.

Sen, Amartya. 2009. Inequality Reexamined. Oxford: Oxford University Press.

Sipilä, Jorma. 2009. Universalismi ahtaalla: Suomalaisen yhteiskunnan uudet kasvot. Juhlaluento Sosiaalipoliittisen yhdistyksen juhlaseminaarissa Helsingin yliopistossa 12.5.2009. http://www.sosiaalipoliittinenyhdistys.fi/ jormasipila.pdf (28.10.12.)

Sipilä, Jorma. 2011. Hyvinvointivaltio sosiaalisena investointina: älä anna köyhälle kalaa vaan koulutus! Yhteiskuntapolitiikka 76: 4, 359-372.

Soininvaara, Osmo. 2010. Tuloerojen kasvu. http://www.soininvaara. fi/2010/01/09/tuloerojen-kasvu_ (28.10.11.)

STM, Stakes.2008. Sosiaalimenojen kehitys Suomessa. Sosiaalimenot suhteessa bkt:hen vuosina 1960-2006, prosenttia bkt:sta. STM:n muistio Sata-komitealle 01.09.2008. http://www.stm.fi/c/document_library/get_file?folderI $\mathrm{d}=41254 \&$ name $=$ DLFE-4808.pdf (28.10.11.)

STM. 2011. Sosiaalisesti kestävä Suomi - Sosiaali- ja terveyspolitiikan strategia. Helsinki: STM. http://www.stm.fi/c/document_library/get_file?folde $\mathrm{rId}=39503 \&$ name $=$ DLFE-14357.pdf

THL .2010. Sosiaalimenot ja rahoitus 2010. http://www.stakes.fi/FI/tilastot/ aiheittain/Sosiaalipalvelut/sosiaalimenot.htm (28.10.11.)

THL. 2011. Toimeentulotuen menot, toimeentulotukea saaneet kotitaloudet ja työttömien määrän vuosikeskiarvo koko maassa vuosina 1990-2010. 


\section{Eija Nurminen}

http://www.stakes.fi/FI/tilastot/aiheittain/Sosiaalipalvelut/Toimeentulotuki/toitunmenotilasto.htm (28.10.11.)

Tilastokeskus. 2007. Tulonjakotilasto. Suomen tuloerot kansainvälisessä vertailussa. http://tilastokeskus.fi/til/tjt/2007/tjt_2007_2009_05_20_ kat_005_fi.html (28.10.11.)

Toimeentulotuki 2010. Toimeentulontuen menot 2010. THL 2011. http:// www.stakes.fi/tilastot/tilastotiedotteet/2011/Tr17_11.pdf (28.10.11.)

Tuomala, Matti.2009. Income Poverty in Finland. Past and Future. Esitys Sosiaalipolitiikan tulevaisuusseminaarissa 29.10.2009. Helsinki: Kela.

Tuomioja, Erkki.1996. Pekka Kuusi: alkoholipoliitikko, sosiaalipoliitikko, ihmiskuntapoliitikko. Helsinki: Tammi.

Tuomioja, Erkki. 2002. Pekka Kuusi ja 60-luvun sosiaalipolitiikka Suomen suunnannäyttäjinä. Janus 10:2, 308-320.

Turkkila, Juhani. 2011. Tuloverotuksen reaalinen muuttuminen Suomessa - Kuusikymmentä vuotta verojen vuoristorataa. Sarja A 46. Helsinki: Etla.

Uusitalo, Hannu. 1988. Muuttuva tulonjako. Hyvinvointivaltion ja yhteiskunnan rakennemuutoksen vaikutukset tulonjakoon 1966 - 85. Tutkimuksia 148. Helsinki: Tilastokeskus.

Uusitalo, Hannu. 1989. Tulonjako ja köyhyys 1966 - 85: kohti polarisaatiota vai eriarvoisuuden lieventymistä. Sosiaalinen aikakauskirja 1/1989.

Wilkinson, Richard \& Pickett, Kate. 2011. Tasa-arvo ja hyvinvointi. Miksi tasaarvo on hyväksi kaikille? Helsinki: HS-kirjat.

\section{Viitteet}

1 Se, että indeksin arvot joissakin maissa kohoavat yli 100:n, johtuu indeksin laskentatavasta: vanhuuseläkkeet saavat painon 1.5 , sairaus- ja työttömyysvakuutus painon 1.0 ja työtapaturmavakuutus painon 0.5. Eri sosiaalivakuutusmuotoja on painotettu niiden ajatellun tärkeyden mukaan.

2 Tuloeroja on tyypillisesti mitattu Gini-kertoimen avulla. Mitä alhaisempi kerroin on, sitä tasaisempi tulonjako on eri väestöryhmien ja yksilöiden välillä. 
3 Köyhyyttä mitataan yleensä pienituloisuudella ja pienituloisiksi määritellään henkilöt, joiden kotitalouden kulutusyksikköä kohden lasketut käytettävissä olevat tulot ovat alle $60 \%$ mediaanitulosta. Vuonna 2009 väestöstä $13 \%$ alitti tuon köyhyysrajan Hetemäen mukaan. Hänkin korostaa, etteivät kaikki pienituloiset välttämättä ole köyhiä ja siksi toimeentulotuen tarve saattaa kertoa köyhyydestä enemmän kuin pienituloisuus. 



\author{
Juha Herkman
}

\title{
Politiikan mediajulkisuus Kekkosen jälkeen
}

Kekkosen valtakauden päättymistä on pidetty jonkinlaisena suomalaisen median ja politiikan välisten suhteiden rajapyykkinä. Kekkosen jälkeen Suomi avautui kansainväliselle markkinakilpailulle. Samassa rytäkässä suomalainen media alkoi vapautua poliittisesta ohjailusta ja siirtyä markkinaohjailevuuteen. Voidaan puhua median kaikkinaisesta markkinoitumisesta. Samalla kun kaupallisesta liiketoiminnasta on tullut median keskeinen toimintaperiaate, on mediakenttä mullistunut viestintäteknologisen kehityksen myötä. Digitalisoituminen ja erityisesti internetin leviäminen ovat 1990-luvulta lähtien haastaneet perinteisen medialiiketoiminnan lähtökohdat. Suomalainen mediamaisema on 2010-luvulla verrattomasti moninaisempi kuin Kekkosen aikana. ${ }^{1}$

Kekkosen aikana Suomessa oli kaksi kansallista televisiokanavaa, ja Mainostelevisio vuokrasi Yleisradiolta ohjelma-aikaa. Radiotoiminnassa Yleisradiolla oli monopoli. 2000-luvun taitteessa Suomessa oli jo neljä valtakunnallista tv-kanavaa, joista kaksi kaupallisia, lukuisia pienempiä kaapelikanavia ja mahdollisuus nähdä kymmeniä lisäkanavia satelliittitelevision kautta. Kaupallinen radio oli lähes saavuttanut Yleisradion kanavien kuunteluosuuden ja toimi yhteistyössä ketjuuntuneiden paikallis- ja maakuntalehtien kanssa. 2010-luvulla Suomessa on 14 kansallista digitaalista tv-kanavaa. Kaupallisen radion kuunteluosuus on tavoittanut Yleisradion kanavien kuunteluosuuden. Internetistä on tullut erityisesti 


\section{Juha Herkman}

nuorten keskuudessa tärkein viestintäväline, joka yhdistää kaikkia perinteisiä viestimiä lehdistöstä televisioon. 2000-luvulla kansallinen mediaympäristö törmää päivittäin globaaliin viestintäverkostoon.

\section{Suomen mediajärjestelmän muutos}

Vaikka Suomi on avautunut ja tullut osaksi globaalia viestintäverkostoa, on mediaa silti mahdollista tarkastella kansallisessa viitekehyksessä. Suomen omintakeinen kieli, kulttuuri ja sijainti määrittävät edelleen mediaa kansallisesti. Kansallisen kontekstin merkityksestä kertoo muun muassa se, että kansainväliset televisioformaatit täytyy aina muokata ja "kääntää" kansalliseen ympäristöön, jos niiden mielitään saavuttavan laaja kansallinen suosio (Nieminen 2000, 207-209). Nimenomaan Suomen BigBrother (Subtv), Suomen Idols (MTV3) ja Suomen Tanssii tähtien kanssa (MTV3) ovat meillä suosittuja, vaikka ohjelmien amerikkalaisia ja muita versioita on mahdollista nähdä myös Suomessa. Toisaalta Suomi on niin pieni markkina-alue, että se ei ole ollut kansainvälisten toimijoiden näkökulmasta kaikkein houkuttelevin kohde. Tämä on osaltaan "suojellut" kansallista mediamaisemaa, jota säännellään myös suomalaisella ja eurooppalaisella viestintä- ja kilpailulainsäädännöllä.

Näin ollen on mahdollista puhua suomalaisesta mediajärjestelmästä hiukan samaan tapaan kuin puhutaan poliittisesta järjestelmästä (esimerkiksi Nordenstreng \& Wiio 2001).

Suomalainen mediajärjestelmä kattaa kansalliset mediainstituutiot ja -organisaatiot, kuten yleisradiotoiminnan, suomalaiset kaupalliset mediayritykset ja yksittäiset viestintävälineet. Se kattaa myös erilaiset viestintäpoliittiset toimijat, kuten Liikenne- ja viestintäministeriön, Viestintäviraston sekä viestintään liittyvät etu- ja ammattijärjestöt, jotka määrittelevät ja kontrolloivat mediaan liittyvää itsesääntelyä. Euroopan unionin tapaiset kansainväliset toimijat kehystävät erityisesti viestinnän ja median markkinoihin liittyvillä säännöksillään suomalaista mediajärjestelmää, ja globaali verkkoviestintä haastaa kansallisen lähestymistavan mediaan. Näistä haasteista huolimatta kansallisvaltio luo edelleen tietyt rajat järjestelmälle. 


\section{Politiikan mediajulkisuus Kekkosen jälkeen}

Suomen mediajärjestelmän muutosta 1980-luvulta 2000-luvulle voi tarkastella ainakin kolmen tekijän kautta. Ne ovat (1) poliittisen lehdistön heikentyminen, (2) Yleisradion aseman heikentyminen radio- ja televisiojulkisuudessa ja (3) muutokset viestinten painoarvoissa ja osuuksissa mediamarkkinoilla (ks. taulukko).

Taulukko. Suomen mediajärjestelmän muutos 1985-2005. Lähde: Tilastokeskus

\begin{tabular}{|l|l|l|l|}
\hline & $\mathbf{1 9 8 5}$ & $\mathbf{1 9 9 5}$ & $\mathbf{2 0 0 5}$ \\
\hline Lehdistötuki (miljoonaa euroa) & 79 & 25,2 & 14,4 \\
\hline Sanomalehtien lukumäärä & 229 & 231 & 205 \\
\hline Aikakauslehtien lukumäärä & 4275 & 4818 & 4922 \\
\hline Yleisradion osuus radion kuuntelusta (\%) & 100 & 69 & 51 \\
\hline Kaupallisten kanavien osuus radion kuuntelusta (\%) & $-*$ & 31 & 49 \\
\hline Yleisradion osuus tv-katselusta (\%) & $(70)$ & 47 & 44 \\
\hline Kaupallisten kanavien osuus tv-katselusta (\%) & $(30) * *$ & 53 & 56 \\
\hline $\begin{array}{l}\text { Suurin kaupallinen mediayritys (ja sen liikevaihto mil- } \\
\text { joonissa euroissa) }\end{array}$ & $\begin{array}{l}\text { Sanoma } \\
\text { OY (243) }\end{array}$ & $\begin{array}{l}\text { Sanoma }(313) \\
\text { OY }\end{array}$ & $\begin{array}{l}\text { Sanoma- } \\
(2.622)\end{array}$ \\
\hline YLE: liikevaihto miljoonissa euroissa & 201 & 354 & 375 \\
\hline Internetiin liitetyt kotitaloudet (\%) & - & $7(1996)$ & 58 \\
\hline
\end{tabular}

* Yksityiset paikallisradiot aloittivat 1985.

** MTV-kanavan osuus kaikesta tv-katselusta 1985.

Lehdistötuki oli Suomessa korkeimmillaan 1980-luvulla lähes 80 miljoonaa euroa vuodessa. 1990-luvulla tukea leikattiin merkittävästi, kun lehdistön jakeluun suunnattu tuki lakkautettiin. Sen jälkeen vuosittainen lehdistötuki on ollut 13-14 miljoonaa euroa, viime vuosina tosin muutaman miljoonaa suurempi (Joukkoviestimet 2006, 282; Nieminen ym. 2005, 17). Nykyisin tuki kanavoidaan kuitenkin suureksi osaksi puolueille. Tämä on johtanut puoluelehdistön entistä suurempaan ahdinkoon, koska tuki ohjautuu puolueilta helposti muuhun kuin lehtien toimintaan (Mäntylä 2009). 


\section{Juha Herkman}

Ilmestyvien sanomalehtien määrä on 2000-luvulle tultaessa laskenut reilut kymmenen prosenttia. Suurempi lehdistön rakennemuutos on ollut se, että monet poliittisesti sitoutuneet ja rahoitetut lehdet joko lopettivat 1980-1990-luvuilla toimintansa tai sulautuivat osaksi suuria lehtikonserneja (Jyrkiäinen 1994). Muutoksen jälkeen poliittisesti "riippumattomat" lehdet kilpailevat suurten, usein pörssinoteerattujen monialakonsernien osina osuuksistaan mediamarkkinoilla. Samalla aikakauslehtien, juorulehtien ja iltapäivälehtien osuudet lehtimarkkinoilla ovat kasvaneet. Painopisteen muutos kertoo suomalaisen lehdistön kaikkinaisesta kaupallistumisesta.

Vastaava voimasuhteiden muutos on näkynyt myös suomalaisessa radio- ja tv-toiminnassa. Yleisradiolla oli vielä 1980-luvun alkupuolella monopoli radiotoiminnassa. Vuonna 1985 myönnettiin ensimmäiset toimiluvat kaupallisille paikallisradiokanaville. YLE hallitsi myös televisiota, vaikka vuokrasi Mainostelevisiolle kanava-aikaa viihdeohjelmien lähetykseen 1950-luvun lopulta lähtien. MTV sai vuonna 1981 oikeuden omaan uutislähetystoimintaan, mikä alkoi kiristää kilpailua Yleisradion kanssa (ks. Salokangas 1996, 343). Kolmostelevisio aloitti vuonna 1987, mutta varsinainen voitto kaupalliselle televisiolle oli MTV3-kanavan aloittaminen itsenäisenä tv-kanavana vuonna 1993.

MTV3 osoittautui heti ensimmäisenä vuonna katsotuimmaksi tvkanavaksi. Sen jälkeen kaupallisten kanavien katsojaosuus on toistuvasti ylittänyt Yleisradion osuuden. Mediatutkija ja journalisti Heikki Hellman (1999) onkin kuvannut kanavamuutosta siirtymäksi "kumppaneista kilpailijoiksi". Nelosen aloittaminen vuonna 1997 ja satelliittikanavien suosion lisääntyminen 2000-luvulla pienensivät edelleen Yleisradion osuutta suomalaisten tv-katsomisesta (Joukkoviestimet 2006, 170). Televisiolähetysten digitalisoiminen vuonna 2007 tosin vahvisti hiukan joitakin Yleisradion kanavaosuuksia. Myös radion kuuntelijaosuuksissa Yleisradio on joutunut jatkuvasti antamaan tilaa kaupallisille kanaville, jotka nykyään jakavat kuuntelun suurin piirtein puoliksi Yleisradion kanssa (mt., 196).

Muutokset kertovat, että suomalainen media on nykyään markkinavetoisempi kuin koskaan aiemmin. Yksi syy median markkinoitumiseen on valtion harjoittaman sääntelyn uudelleen muotoilu tavalla, joka painottaa ideologisen sääntelyn sijaan markkinasääntelyä. Viestinnän tutkijoi- 


\section{Politiikan mediajulkisuus Kekkosen jälkeen}

den Hannu Niemisen ja Mervi Pantin (2004, 22-23) mukaan Suomessa onkin siirrytty paljolti median "kulttuuris-moraalisesta sääntelystä taloudellis-kaupalliseen sääntelyyn". Suomalainen mediajärjestelmä perustuu vuonna 2010 monin verroin enemmän myyvyyden ja voiton tavoittelun periaatteelle kuin vuonna 1980.

Kansainvälisessä vertailussa Yleisradion osuus kansallisesta radio- ja tv-toiminnasta jäi vuonna 2002 jälkeen esimerkiksi sellaisista maista kuin Iso-Britannia, Espanja, Italia, Itävalta, Puola ja Venäjä (Joukkoviestimet 2002, 259). Ranskaan verrattuna osuus oli sama. Tiukka kilpailu kaupallisten toimijoiden kanssa on johtanut suuriin organisaatiouudistuksiin ja säästökuureihin Yleisradiossa. Yleisradioon on kilpailun myötä omaksuttu organisaatio- ja johtamiskulttuuri, johon aiemmin törmäsi lähinnä kaupallisissa mediayrityksissä (ks. Hujanen 2002).

Edellä kuvatut muutokset kertovat Suomen mediamarkkinoiden murroksesta, jossa viestinten ja mediayritysten painoarvot ovat vaihtaneet paikkaa. Vaikka Suomi on edelleen "sanomalehtimaa", jossa luetaan ja julkaistaan eniten sanomalehtiä asukasta kohden Ruotsin, Japanin ja Norjan ohella (Joukkoviestimet 2006, 256), ovat päivälehtien levikit ja lukijamäärät olleet jatkuvassa laskussa 1990-luvun alun laman jälkeen. Lukijaosuuksiaan ovat kasvattaneet lähinnä viihteelliset aikakaus- ja juorulehdet sekä iltapäivä- ja ilmaisjakelulehdet (mt., 195, 203), joista myös jälkimmäiset ovat vuoden 2007 jälkeen menettäneet lukijoitaan. Vuonna 2009 ilmoitusmyyntiä supisti kansainvälinen lama, mutta myynti alkoi jälleen nousta vuonna 2010. Parhaiten 2000-luvun alussa on menestynyt viihteellinen aikakauslehdistö, jonka "lippulaiva" Seiska on lähes kolminkertaistanut levikkinsä 1990-luvun alusta.

Median markkinoituminen ja muutokset sääntelyssä ovat johtaneet Suomessa ja muissa Pohjoismaissa median keskittymiseen oligopolisiin (ks. Picard 1989, 31-33) mediamarkkinoihin, joilla muutama suuryritys jakaa markkinat keskenään. Pohjoismainen erityispiirre on se, että jokaisessa maassa on yksi konserni, joka on selvästi muita suurempi ja kansainvälisempi. Suomessa tällainen konserni on Sanoma Oyj, jonka liikevaihto oli vuonna 2007 jo lähes kahdeksan kertaa suurempi kuin toiseksi suurimman mediayrityksen Yleisradion liikevaihto. Konsernin liikevaihdosta yli puolet tuli Suomen ulkopuolelta (Nordic Media Market 2009, 
19-26). Mediayritykset ovat nykyään pääsääntöisesti enemmän voittoa tavoittelevia liikeyrityksiä kuin yhteiskunnallisia instituutioita.

Mediajärjestelmän muutoksilla on ollut vaikutuksensa myös politiikan journalismiin. Journalismi on Suomessa ollut historiallisesti melko eliittivetoista (Nieminen 2006). Vaikka yleisradiotoiminnassa ja lehdistötuella tähdättiin 1960-1970-luvuilla mediajulkisuuden monimuotoisuuteen, Kekkosen hallinto, suhteet Neuvostoliittoon ja taloudellinen valta kontrolloivat suomalaista mediaa ainakin kansallisesti merkittävissä kysymyksissä (Luostarinen \& Uskali 2006). Poliittinen konsensus ja eliitin valta hallitsivat järjestelmää. Vasta yhteiskunnan avautuminen ja median markkinoituminen liberalisoivat 1980-luvulla suomalaista mediaa niin, että se alkoi irtaantua eliitin talutusnuorasta. Lähinnä Hymyn ja Jallun kaltaiset ajanvietelehdet löivät kiilaa 1960-1970 -lukujen eliittilähtöiseen julkisuuteen.

Median markkinoituminen ja irtautuminen politiikan ideologisesta ohjailusta eivät kuitenkaan väistämättä tarkoita neutraalia poliittista journalismia. Eliitillä ja medialla on edelleen läheiset suhteet. Samalla kun toimittajien ja poliitikkojen vanhat sitoumukset ovat murtuneet, tilalle on tullut uusia (Hallin \& Mancini 2004, 286; Koski 2007, 212). Kaupallisen median toimittajat ovat yhtä lailla riippuvaisia poliitikoista ja muusta eliitistä uutislähteinä. Suhteiden keskeisiin poliitikkoihin on oltava kunnossa, mikäli mielii tehdä politiikasta kilpailukykyisiä ajankohtaisia uutisia. Suomessa on muun muassa 2010-luvulla yleistynyt käytäntö, jossa johtavat poliitikot kutsuvat valtamedian edustajia "off the record"-tilaisuuksiin, joista ei ole lupa kirjoittaa julkisesti mutta jotka rakentavat poliitikkojen ja median välisiä suhteita ja välittävät taustatietoa median edustajille (Haltsonen 2011). Tällaisten epävirallisten suhteiden seurauksena saattaa olla uudenlaisia sisäistetyn kontrollin muotoja.

\section{Puoluedemokratiasta yleisödemokratiaan}

Puoluepolitiikan houkuttelevuuden jatkuva heikentyminen, median markkinoituminen ja politiikan kasvava riippuvuus mediajulkisuudesta ovat osaltaan muuttaneet edustuksellista demokratiaa. Amerikkalainen politiikan tutkija Bernard Manin on kuvannut tätä muutosta siirtymäksi 


\section{Politiikan mediajulkisuus Kekkosen jälkeen}

puoluedemokratiasta yleisödemokratiaan. Puoluedemokratia kuvaa aikaa, jolloin yhteiskunta jakautui melko selkeästi erilaisiin ideologisiin ja massapuolueiden edustamiin leireihin. Luokkajaolla oli keskeinen merkitys, minkä seurauksena jako oikeistoon ja vasemmistoon oli melko selvä (Manin 1997, 206-211). Julkisuudessa poliittisella lehdistöllä oli paljon valtaa. Suomessa puoluedemokratia toteutui selvimmin sotien jälkeisellä ajalla 1950-1970-luvuilla - Kekkosen, korporaatioiden ja hyvinvointivaltion rakentamisen aikakaudella (esim. Mickelsson 2007).

Puoluedemokratian aikana puolueiden erot olivat nykyistä suurempia ja poliitikot kiinnittyivät selkeästi puolueiden ohjelmiin. Äänestäjät saattoivat siten luottaa puolueen ideologiseen lähtökohtaan ja valita ehdokkaansa sen perusteella. Puolueuskollisuus oli vahvaa. Yleisödemokratian aikana puolueiden ideologiset erot ovat kaventuneet ja politiikka kansainvälistynyt. Poliitikot eivät enää toimi tietyn asialistan ja aatteen takuumiehinä tai -naisina, vaan he joutuvat tekemään nopeita päätöksiä kulloisenkin tilanteen mukaisesti. Poliitikot tunnetaan lähinnä median välityksellä ja heidän ansioitaan arvioidaan sen perusteella, kuinka he menestyvät julkisuuden henkilöinä. Yleisödemokratiassa puolueen merkitys äänestyspäätöksissä vähenee ja ehdokkaan korostuu. (Manin 1997, 228-232.)

Yleisödemokratia alkoi Kekkosen jälkeen vahvistua ja puoluepolitiikka menettää sitä roolia, joka sillä oli suunnittelutalouden, korporaatioiden ja hyvinvointivaltioihanteen hallitsemassa Suomessa. Tästä kertovat puolueosallistumisen raju väheneminen, puolueuskollisuuden heikkeneminen, äänestysaktiivisuuden lasku ja elämänvalintoihin liittyvän politiikan vahvistuminen. Samanaikainen median markkinoituminen ja vapautuminen poliittisesta sääntelystä on lisännyt imagojen ja mielikuvien rakentamisen ja markkinoinnin painotuksia poliittisessa viestinnässä (Karvonen 1999; Uimonen \& Ikävalko 1996). Korporaatioajan ja puoluedemokratian kansalaisten tiedottamisesta on siirrytty yleisödemokratian kilpailuun fragmentoituneista mediayleisöistä.

Yleisödemokratiassa äänestetään pääosin vallassa pysymisen puolesta tai sitä vastaan. Poliittisen vallan näkökulmasta tämä tarkoittaa lähinnä vaalikamppailua opposition ja hallituspuolueiden välillä. Julkiset mielikuvat ratkaisevat poliittisen nokkimisjärjestyksen, minkä takia imagoilla ja markkinoinnilla koetaan olevan niin suuri merkitys. Esimerkiksi Tony 


\section{Juha Herkman}

Blairin ja työväenpuolueen nousu valtaan Margaret Thatcherin kauden jälkeen Isossa-Britanniassa vuonna 1997 liittyi toisaalta Thatcherin politiikan herättämään vastareaktioon ja "luonnolliseen" oppositioasetelman vaihteluun, toisaalta Blairin erinomaiseen esiintymiskykyyn ja massiiviseen poliittiseen markkinointiin, jossa "rautarouva" vaikutti kylmältä ja etäiseltä jopa oikeiston silmissä. "Uusi työväenpuolue" (New Labour) onnistui sen sijaan vakuuttamaan uudistuneella ilmeellään ja siirtymällä vasemmistosta kohti poliittista keskustaa (ks. McNair 2007, 100-111).

Suomessa Kokoomuksen nousu 2010-luvun valtapuolueeksi alkoi vastaavasti onnistuneella nuorennusleikkauksella - Jyrki Kataisen valinnalla puolueen johtoon vuonna 2004 sekä menestyksekkäillä vaalikampanjoilla vuoden 2006 presidentinvaaleissa ja vuoden 2007 eduskuntavaaleissa. Bob Helsingin suunnittelemat "työväen presidentti" ja "työväen puolue"kampanjat eivät välttämättä sinänsä vakuuttaneet äänestäjiä siitä, että "vastakkainasettelujen aika on ohi" - saattoivat jopa joitakin äänestäjiä ärsyttää. Kokoomus onnistui kuitenkin markkinoinnin ja johtavien ehdokkaiden avulla rakentamaan itsestään mielikuvan nuorekkaana ja muutosvoimaisena mahdollisuutena, joka tavoittelee enemmän poliittista keskustaa kuin pelkkää liike-elämän edustamista. Muutoksen mielikuvalla se erottui edukseen muista suurista puolueista, joiden imago kiinnittyi vallan säilyttämiseen ja vanhahtavaan korporaatioajan henkeen. Tähän mielikuvaan perustui "vallanvaihto" vuoden 2007 eduskuntavaaleissa.

Yleisödemokratiassa liikkuvien ja passiivisten äänestäjien osuus on jatkuvassa kasvussa, joten imagoseikat vaikuttavat äänestyspäätöksiin. Muutoksen ja eteenpäin pyrkimisen mielikuva voi kerätä ääniä juuri sellaisilta ryhmiltä, jotka ovat kyllästyneitä vallitsevaan politiikkaan ja siksi joko valmiita vaihtamaan puoluetta tai jättämään äänestämättä. Perussuomalaisten nousu suurten puolueiden haastajaksi vuoden 2011 eduskuntavaaleissa perustui samaan logiikkaan: paljon mediajulkisuutta saavaan taitavaan esiintyjään puheenjohtaja Timo Soiniin ja kansalaisten kyllästymiseen suurten puolueiden politiikkaan.

Poliittisen markkinoinnin merkitystä Suomessa on korostanut vaalimainonnan salliminen televisiossa 1990-luvun alussa - samoihin aikoihin kun media markkinoitui voimakkaasti ja presidentin valinnassa siirryttiin suoraan vaalitapaan (ks. Moring \& Himmelstein 1993, 6). Monissa muissa Euroopan maissa poliittista mainontaa on rajoitettu enemmän. 


\section{Politiikan mediajulkisuus Kekkosen jälkeen}

Esimerkiksi Ruotsissa vaalimainonta televisiossa on edelleen kielletty. Tässä suhteessa suomalainen politiikan mediajulkisuus muistuttaa enemmän amerikkalaista mallia kuin monien muiden eurooppalaisten demokratioiden viestintäkulttuuri.

Henkilöihin keskittyvä markkinointi ja lisääntynyt media-ammattilaisten tarve ovat ammatillistaneet poliittista viestintää. Poliittiseen markkinointiin käytettyjen resurssien kasvu on ollut myös yksi syy siihen, että vaalibudjetit ovat räjähtäneet käsiin. Voi väittää, että vuonna 2008 alkanut vaalirahakohu on yksi yleisödemokratian paradoksaalinen ilmentymä: sen lähtökohta on kalliissa mediajulkisuudessa ja mediamainonnassa, mutta sitä myös käsitellään mediajulkisuudessa kriittisesti.

Imagokampanjoiden ja poliittisen markkinoinnin läpäisevyys puolueiden mediajulkisuudessa ovat saaneet puhumaan "mielikuvapolitiikasta" ja "mielikuvavaaleista" (esim. Pernaa ym. 2007). Mielikuvien avulla kampanjointi ja poliittinen markkinointi eivät sinällään ole huolestuttavaa, vaan se voi toimia keinona havainnollistaa asioita ja saada sanoma paremmin perille. Parhaimmillaan mielikuvat auttavat tekemään eroa puoluepoliittisten näkemysten välille ja edistävät siten puoluepoliittisen kentän hahmottamista. Uhkakuva mielikuvapolitiikassa on puolestaan se, että kampanjoissa rakennetut mielikuvat eivät vastaa toteutettavaa politiikkaa tai johtavat jopa sen suhteen harhaan (Herkman 2008, 97). Ristiriita markkinoinnin ja kampanjoiden avulla rakennettujen mielikuvien sekä poliittisten päätösten välillä nakertaa politiikan yleistä uskottavuutta ja on omiaan vieraannuttamaan kansalaisia puoluepolitiikasta. Tämä taas syö puolestaan kaikkinensa edustuksellisen demokratian legitimiteettiä.

Median kilpailu yleisöistä on korostanut myös journalismin teollista luonnetta ja nostanut "kiinnostavuuden" keskeiseksi uutiskriteeriksi. Uutisteollisuus tarvitsee jatkuvasti aiheita ja henkilöitä, jotka kiinnostavat yleisöjä. Niitä sille tarjoaa politiikka. Politiikan pääuutisvirta muodostaa tärkeän osan päivittäisestä mediatarjonnasta, mutta sen avulla viestinten on vaikea erottua toisistaan, myydä sisältöjä yleisöille ja yleisöjä mainostajille. Politiikasta on siten löydettävä kiinnostavia aiheita ja henkilöitä, mikä on lisännyt politiikan henkilöjulkisuutta, yksityiselämän käsittelyä ja kohujen ja skandaalien osuutta julkisuudessa. Ei ole sattumaa, että politiikan skandaalit alkoivat yleistyä suomalaisen median tarjonnassa vasta 1990-luvulla, kun media markkinoitui voimakkaasti. 


\section{Juha Herkman}

Skuuppien metsästys, kiristynyt uutiskilpailu ja kiinnostavuuden tavoittelu ovat herättäneet huolen politiikan julkisuuden viihteellistymisestä. On puhuttu muun muassa journalismin "tabloidisoitumisesta" tai "iltapäivälehtimäistymisestä", millä on tarkoitettu kaiken journalismin muuttumista iltapäivälehtijournalismin kaltaiseksi. Käytännössä huolta on kannettu politiikan vähenemisestä journalismin aiheena urheilun, elämäntapajuttujen, ihmissuhteiden ja viihteen kustannuksella. Tabloidisoitumisella on viitattu myös journalistisen tyylin muuttumiseen henkilölähtöiseksi ja kepeäksi: yhteiskunnallisia ilmiöitä ei enää käsitellä rakenteellisina ongelmina vaan yksittäisten, mieluusti tunnettujen henkilöiden kautta (Sparks 2000, 26). Suomessa on 2000-luvulla puhuttu myös "seiskapäiväistymisestä" - siitä, että journalismin asialistaa eivät määritä enää edes iltapäivälehdet vaan Seiskan tapaiset juorulehdet (ks. Juntunen \& Väliverronen 2009, 281).

Toinen median keino rakentaa poliittista draamaa ovat mielipidekyselyt. Puolueet ja muut organisaatiot - etujärjestöt, liikeyritykset - tilaavat tutkimusyrityksiltä mielipidetiedusteluja saadakseen selville poliittisen kannatuksen jakautumista, ihmisten kulutustottumuksia tai arvoja ja asenteita. Yhä useammin mielipidetiedustelujen tilaaja on kuitenkin jokin viestintäväline tai mediatalo. Mielipidetiedustelujen avulla tavallisista aiheista tulee uutisia. Säännölliset kyselytutkimukset puolueiden kannatuksista rakentavat suomalaista politiikan mediajulkisuutta, jossa edustuksellinen demokratia esiintyy puhtaimmillaan kannatusprosentteina. Kyselyjen uutisointi on omiaan vahvistamaan kuvaa politiikasta teknokraattisena ja mitattavana ilmiönä.

Kyselytutkimukset tuottavat eittämättä tärkeää tietoa poliittisen kannatuksen jakautumisesta ja muutoksista. Tutkijat ovat kuitenkin jo pitkään varoitelleet mielipidetiedustelujen ongelmista ja liiallisesta vaikutuksesta esimerkiksi vaaleissa. Kampanjoiden kuumassa vaiheessa ei ole juuri päivää, etteikö joku viestintäväline julkaisisi omaa tutkimustaan. Erityisesti siirtyminen suoraan vaalitapaan on vahvistanut mielipidetiedustelujen merkitystä presidentinvaaleissa (ks Suhonen 1996; 2000). Vaalit alkavat muistuttaa urheilu-uutisointia tai laukkakilpailun (horse race) selostusta, jossa jokin puolue johtaa turvan mitalla, sitten toinen kirii ohi ja kolmas jää kavionmitan. Huomio kiinnittyy kannatuslukujen tarkkailuun ja varsinainen poliittinen keskustelu jää sivurooliin. Ää- 
nestäjät saattavat mukauttaa käyttäytymistään kyselyjen mukaan, koska yksi tärkeä äänestyskriteeri on ehdokkaan tai puolueen mahdollisuus menestyä. Syntyy suosion kehä, joka selittää osittain Perussuomalaisten kannatuksen jatkuvaa kasvua 2011 eduskuntavaaleja ennakoinneissa mielipidekyselyissä. Tällöin mielipidetiedustelut todella vaikuttavat vaalien lopputulokseen, ja media on ollut aktiivinen osapuoli vaikutusten aikaansaamisessa (ks. Suhonen 1996).

Yleisödemokratian käsite kuvaa siten tilannetta, jossa mediajulkisuuden merkitys on politiikan kannalta korostunut - politiikka on toisin sanoen medioitunut. Politiikan tutkija Thomas Meyer (2002) on nimittänyt tällaista politiikan ja mediajulkisuuden suhdetta myös käsitteellä mediademokratia. Meyerin mukaan joukkoviestinnän logiikka on kolonisoinut politiikan ja uhkaa siten edustuksellista demokratiaa, koska se rapauttaa puolueiden ideologisen merkityksen. Politiikasta tulee teatteriin verrattava esitys, jossa kaikki tähtää mediatapahtumien rakentamiseen.

Meyerin havainnot vaikuttavat paikoin osuvilta, mutta ainakin suomalaisesta näkökulmasta liian kärjistetyiltä. Empiiriset tutkimukset eivät tue näkemystä politiikan syvästä medioitumisesta. Politiikan toimijat eivät ole kaikilta osin muuttaneet toimintatapojaan medialogiikan mukaiseksi, eikä kaikkea politiikassa rakenneta mediatapahtumia varten. Esimerkiksi poliittisen päätöksenteon kova ydin on edelleen melko salattua ja tapahtuu kenties jopa enemmän piilossa kuin ennen nykyistä "avoimuuden aikaa". Päättäjät suhtautuvat julkisuuteen edelleen varsin strategisesti ja pyrkivät ohjailemaan sitä omien tavoitteidensa kannalta mahdollisimman suotuisaksi (Kunelius ym. 2009). Sanottu ei tarkoita, että päättäjät onnistuisivat tavoitteissaan ja että poliittiset toimijat eivät miettisi tarkoin miten ja missä asiat tuodaan julki. On kuitenkin liioiteltua väittää, että media olisi kolonisoinut politiikan.

Tässä mielessä yleisödemokratian käsite on osuva. Se kuvaa hyvin edustuksellisen demokratian tilannetta, jossa politiikan mediajulkisuudesta on tullut areena, jossa "vallan vahtikoirat" ja poliittiset toimijat kamppailevat politiikan näkyvyydestä, imagoista, mielikuvista ja asialistasta. Politiikka näyttäytyy teatterina, mutta poliitikot eivät kuitenkaan ole toimettomina tai sivuroolissa. He pyrkivät yhtä hyvin näytelmän käsi- 


\section{Juha Herkman}

kirjoittajaksi kuin median edustajat. Sivulliseksi näytelmässä jää lähinnä yleisö: kansalaiset.

Yleisödemokratiassa kansalaisten tehtävä on seurata poliittista näytelmää ja antaa sille joko suosionosoituksensa tai buuauksensa - tai kuten Facebookissa tykätä tai olla tykkäämättä. Kansalaisyleisö äänestää myös mediankäyttötottumuksillaan. Se seuraa jotakin politiikkaan liittyvää esitystä, kiinnostuu joistakin poliittisista toimijoista, ja jättää toiset ulkopuolelle. Tällä tavoin se vaikuttaa median tarjontaan. Yleisödemokratiassa kansalaiset käyvät vuoropuhelua mediakuvastojen ja mielikuvien kanssa. Dialogiin varsinaisten politiikan toimijoiden kanssa ei päästä.

\section{Politiikan julkisuus internet-ajalla}

Viestintä- ja mediaympäristön muutos on kuitenkin haastanut yleisödemokratian 2000-luvulle tultaessa. Digitalisoituminen ja sen myötä yleistynyt verkko- ja mobiiliviestintä ovat muuttaneet peruuttamattomasti myös suomalaista mediamaisemaa 1990-luvun lopulta lähtien. Suomen mediajärjestelmä on muutosten takia 2010-luvulla uuden murroksen edessä. Murros vaikuttaa vähintään yhtä merkittävältä kuin 1980-1990-luvuilla tapahtunut median markkinoitumiskehitys.

Suurin muuttava tekijä on ollut internet. Internetistä on muodostunut kaikkia viestimiä yhdistävä julkisuuden foorumi, jonka suosio suomalaisten mediakäytössä on jatkuvasti kasvanut. Internet on haastanut perinteisen median keskeiset eronteot niin viestintävälineiden kuin tuotannon ja vastaanoton välillä. Internet on myös mullistanut mediaan liittyvät ajan ja paikan käsitykset (Rinne 2011, 95-99). Perinteisen median näkökulmasta suurin ongelma on ollut se, että internetin käyttäjät ovat tottuneet ilmaisuuteen. Internetissä kukoistaa piratismi ja olemassa olevan materiaalin sämpläys. Tekijänoikeuksien kontrollointi ja uusien ansaintakeinojen keksiminen on ollut mediataloille internetin aikakaudella vaikeaa.

Internet ja muut uudet viestintäympäristöt ovat muuttaneet poliittista viestintää ja jopa poliittisen toiminnan tapoja. Monet tutkimukset osoittavat, että erilaiset kansalaisjärjestöt ja aktivistiryhmät ovat saaneet verrattomasti apua verkkoviestinnän uusista muodoista mobilisoidessaan kansallisia ja kansainvälisiä tapahtumia, kuten globalisaation vastaisia 
mielenosoituksia Seattlessa ja Göteborgissa (Ylä-Anttila 2010; Rinne 2011, 100-103). Erityisesti totalitaarisesti hallituissa maissa internet on ollut tärkeä aktivistien foorumi, jonka merkitystä vaikkapa Kiinan ja Pohjois-Afrikan arabivaltioiden kansalaisliikkeissä ei voi väheksyä. Internet toimii tällaisille aktivismin muodoille myös tärkeänä näyteikkunana muuhun maailmaan. Internetiin voi tuottaa materiaalia ilman journalistista kontrollia ja sen kautta voi potentiaalisesti tavoittaa maailmanlaajuisen julkisuuden, minkä takia se on tärkeä julkaisukanava kaikille poliittisille toimijoille puolueista kansalaisaktivisteihin ja ministereistä terroristijärjestöihin.

Internetin merkitys poliittisessa markkinoinnissa ja kampanjoinnissa onkin laajalti huomattu. Poliitikot ottavat aina innokkaasti ensimmäisten joukossa uudet viestinnän keinot käyttöönsä (Koski 2007, 203). Ei ole merkittävää poliittista toimijaa, joka ei nykyään näkyisi Facebookissa, YouTubessa ja Twitterissä. Sosiaalisen median sovelluksissa ja käytössä Suomi on kuitenkin tullut jälkijunassa. Poliittiseen kampanjointiin malli otetaan Yhdysvalloista, jossa uusia viestinnän muotoja käytetään yleensä pari vuotta ennen Suomea. Esimerkiksi blogit olivat Yhdysvaltain presidentinvaaleissa kova juttu vuonna 2004 (ks. Trammel 2006; Jenkins 2008, 227-229). Suomessa niitä käytettiin ensimmäisen kerran vahvasti poliittiseen markkinointiin Yhdysvaltain esimerkin innoittamana vuoden 2006 presidentinvaaleissa (Carlson 2006). YouTuben vaalivideot ja niistä tehdyt parodiat sekä sosiaalisen median varainhankinta olivat puolestaan paljon esillä vuoden 2008 presidentinvaaleissa Yhdysvalloissa (Jenkins 2008, 272-277; Tryon 2008; Kaid 2009; Spaeth 2009). Suomessa nämä poliittisen markkinoinnin muodot ovat yleistyneet vasta 2010-luvulla.

Uudet viestinnän muodot ovat mullistaneet myös poliittisten toimijoiden ryhmäviestintää. Samalla tavoin kuin internet on mahdollistanut aktivistien yhteydenpidon aikaan ja paikkaan katsomatta, se on auttanut myös puoluepolitiikan toimijoita mobilisoitumaan vaalikampanjoissa. Esimerkiksi vuoden 2006 presidentinvaalien yhteydessä kävi ilmi, että sähköpostilistat ja tekstiviestit olivat olennainen keino pitää yllä reaaliaikaista yhteyttä kampanjatiimeissä. Tämä vahvisti kampanjoiden me-henkeä ja lisäsi kampanjoihin osallistuneiden tietoutta hektisesti muuttuvista vaalitilanteista (Herkman 2008, 85). Tiedonkulku on verkkoviestinnän 


\section{Juha Herkman}

aikakaudella paljon nopeampaa kuin aiemmin, eikä viestinnällisiä katveita pääse syntymään poliittisiin kampanjoihin yhtä herkästi kuin ennen.

Eniten keskustelua verkkoviestinnän poliittisista mahdollisuuksista on kuitenkin herättänyt sen rooli kansalaisfoorumina. Internetiä on luonnehdittu äärimmäisen demokraattiseksi mediaksi, ja sen on uskottu rakentavan ensimmäisen kerran viestintäteknisesti foorumin, jossa kaikki voivat tasavertaisesti osallistua poliittiseen mielipiteenvaihtoon ja tahdonmuodostukseen. Monet kansalaisliikkeet ja yhden asian liikkeet kanavoivatkin toimintaansa internetin kautta. Internetin avulla on helppo kerätä allekirjoituksia adresseihin ja mielenilmauksiin. Internetin keskustelupalstoilla ja blogeissa on vaivatonta nostaa esille aiheita, jotka eivät muuten läpäisisi mediajulkisuuden kynnystä. Kun keskustelu laajenee tai kiihtyy internetissä tarpeeksi, perinteinen media tarttuu siihen ja nostaa aiheen myös valtavirtajulkisuuteen. Tällä tavoin internet toimii kansalaisten poliittisen informaation lähteenä, poliittisen keskustelun foorumina ja poliittisen toiminnan areenana.

Puheet e-demokratiasta ja internetin poliittisesta mullistavuudesta ovat kuitenkin toistaiseksi olleet ennenaikaisia ja usein liioiteltuja. Internetiin pätee sama kuin muuhunkin mediaan: se on vain yksi osa poliittista toimintaa, eikä politiikan medioituminen yllä internetin yhteydessä yleensä sen syvemmälle kuin perinteisen mediajulkisuuden yhteydessä, vaikka internetin vuorovaikutteisuus antaisi tähän edellytyksiä. Empiiriset tutkimukset osoittavat, että demokratian toteutumisessa on ylipäätään enemmän kyse politiikan kulttuureista ja vakiintuneista toimintatavoista kuin viestintätekniikasta. Suoran poliittisen vaikuttamisen ajatusta on mahdollista toteuttaa niin välittömän viestinnän, perinteisen joukkoviestinnän kuin verkkoviestinnän avulla, ja päinvastoin, verkkoviestintä ei itsestään selvästi muuta puoluepolitiikkaa kansalaisia kiinnostavammaksi eikä väistämättä synnytä suoran vaikuttamisen muotoja. Nykyään Suomen poliittisessa järjestelmässä limittyvät yhteen puoluedemokratian, yleisödemokratian ja internetin mahdollistaman kansalaisaktiivisuuden piirteet. Yleisödemokratia on kuitenkin edelleen niskan päällä.

Vaaleihin liittyvät tutkimukset osoittavat, että Suomessa ja monissa muissakin maissa internet on otettu lähinnä muuta poliittista markkinointia ja kampanjointia täydentäväksi kanavaksi, jossa ehdokkaat ja puolueet pyrkivät harjoittamaan strategista viestintää. Esimerkiksi vuoden 


\section{Politiikan mediajulkisuus Kekkosen jälkeen}

2003 eduskuntavaaleissa useimmat ehdokkaat eivät vielä kampanjoineet internetissä, ja ne, joilla oli kampanjaan liittyvä sivusto, eivät juuri edistäneet vuorovaikutusta tai sivustojen käyttäjien osallistumista. Ehdokkaiden internet-kampanjointi asettui osaksi muuta kampanjajulkisuutta, jossa muutamat näkyvimmät ehdokkaat olivat pääosassa (Strandberg 2009). Vuoden 2006 presidentinvaalien ehdokasblogeista tehtiin hyvin samankaltaisia havaintoja: vain puolet kahdeksasta ehdokkaasta piti blogia ja vain yhdessä blogissa oli interaktiivinen mahdollisuus keskusteluun. Blogeja myös luettiin melko vähän (Carlson 2006).

Poliittiset toimijat näkevät internetsivustot ja blogit strategisesti keinona välttää journalistinen kontrolli ja nostaa siten esille omia näkemyksiä julkisuudessa (Carlson 2006, 72; Lilleker \& Malagón 2010, 39). Heitä ei ensisijaisesti kiinnosta vuorovaikutus kansalaisten, äänestäjien tai muiden tahojen kanssa. Tämä on täysin päinvastoin kuin yleinen mielikuva internetistä vuorovaikutteisen demokratian areenana antaisi olettaa. Esimerkiksi vuoden 2006 presidentinvaalien yhteydessä haastattelemani kampanjaan osallistuneet ehdokkaat, kampanjatyön tekijät ja median edustajat uskoivat blogien olleen nimenomaan ehdokkaiden henkilökohtainen vuorovaikutuskanava äänestäjien kanssa, vaikka tutkimus on osoittanut niiden keskittyneen varsin selvästi kampanjoiden poliittisiin teemoihin ja ehdokkaiden markkinointiin.

Internetin vaikutuksista politiikkaan ei siten ole toistaiseksi mitään kovin rohkaisevia tutkimustuloksia, vaikka sosiaalinen media saattaa muuttaa tilannetta 2010-luvulla. Analyysi suomalaisten poliittisista keskusteluista internetin keskustelualueilla osoittaa kuitenkin todeksi usein intuitiivisestikin syntyvän vaikutelman: keskustelu polarisoituu kahden vastakkaisen näkemyksen väliseksi väittelyksi, jossa ei synny aitoa keskusteluyhteyttä (Strandberg 2008, 83-85). Keskustelufoorumi ei toimi areenana, jossa parhaat argumentaatiot kohtaavat, kilpailevat keskenään ja jalostuvat lopulta yhteiseksi mielipiteeksi. Useimmiten väittelyt kärjistyvät kilpalaulannaksi, epäasiallisiksi ivailuiksi, jopa tarkoitushakuiseksi mollaamiseksi. Sanottu koskee erityisesti keskustelufoorumeita, joissa voi esiintyä nimettömänä tai nimimerkillä.

Empiiriset tutkimukset tukevat siten näkemystä, että parhaimmillaan internet toimii tärkeänä poliittisen informaation lähteenä ja on omiaan lisäämään kansalaisten politiikkatietämystä. Sanottu on olennaista eri- 


\section{Juha Herkman}

tyisesti nuorten ikäluokkien kannalta, koska heidän uskotaan kiinnostuvan politiikasta helpommin internetin kuin perinteisen median kautta (Xenos \& Moy 2007; Brundidge 2010). Internet tai uusimmat sosiaalisen median keksinnöt eivät tässä kuitenkaan eroa muista politiikan mediajulkisuuden muodoista, jotka kaikkinensa lisäävät ihmisten politiikkatietämyksen tasoa ja usein myös kiinnostusta politiikkaa kohtaan (esim. Norris 2000; Elo \& Rapeli 2008; McKinney \& Rill 2009).

Tutkimustulokset tukevat ajatusta kahtiajakautuneesta poliittisesta julkisuudesta, jossa perinteinen media ja sosiaalinen media törmäävät toisiinsa. Suuret ikäluokat ja valtaa pitävät elävät yleisödemokratiassa, jossa valtavirtamedia ja poliittiset auktoriteetit hallitsevat julkisuutta. Poliittisesti aktiiviset nuoremmat ikäluokat, joita ei kuitenkaan kiinnosta puoluepolitiikka, elävät vuorovaikutuksen, kollektiivisen toiminnan ja virtuaaliyhteisöjen läpäisemässä internet-maailmassa. Kun ensin mainitut yrittävät päästä jälkimmäisten maailmaan, heidän keinonsa ovat väärät: yleisödemokratian strateginen viestintä ja ammattijournalismi eivät istu sosiaaliseen mediaan, jossa avoimuus, yhdessä tekeminen ja asioiden jakaminen ovat toiminnan lähtökohtia. Kun jälkimmäiset taas tekevät poliitikoista videoparodioita YouTubeen tai muodostavat jonkin asian kannatusryhmiä Facebookiin, heidän toimintansa harvoin vaikuttaa poliittisiin päätöksiin.

Nykyinen politiikan mediajulkisuus on yhdistelmä yleisödemokratian ja internet-sukupolven käytäntöjä, joista ensin mainitut hallitsevat edustuksellisen demokratian järjestelmäpolitiikkaa ja jälkimmäiset vastademokratian kansalaistoimintaa (ks. Koski 2007, 217). Valtajulkisuus ja perinteiset viestintävälineet tukevat yleisödemokratian hegemoniaa, internetin mahdollistama vastajulkisuus pyrkii usein sen haastamaan. Nämä kaksi julkisuuden muotoa ovat kuitenkin lisääntyvissä määrin vuorovaikutuksessa. Sosiaalisesta mediasta saattaa nousta aiheita ja näkökulmia valtavirtajulkisuuteen, jolloin niiden todennäköisyys politisoitua - tulla järjestelmäpolitiikan piiriin - kasvaa. Valtajulkisuus saattaa puolestaan omaksua sosiaalisesta mediasta piirteitä, jotka demokratisoivat sen käytäntöjä. Esimerkiksi kansalaisten näkemysten ja itse tuottaman materiaalin lisääntyminen journalismissa kertovat uutisteollisuuden muutoksista. 


\section{Politiikan mediajulkisuus Kekkosen jälkeen}

Yleisödemokratian ja konvergenssikulttuurin sekoittumista jarruttavat kuitenkin monet rakenteelliset tekijät. Edustuksellisissa demokratioissa poliittinen hallinta perustuu edelleen kansallisvaltioihin ja niiden välisiin valtioliittoihin, joissa erilaiset vaaleissa valitut poliittiset instituutiot käyttävät päätösvaltaa. Ajan ja paikan rajoitukset ylittävä internet ei istu suoraan mihinkään viralliseen poliittisen päätöksenteon instituutioon. Sama ongelma liittyy kaikkeen kansalaisaktivismiin, joka keikkuu paikallisen ja globaalin toiminnan rajamaastossa. Pirstoutuneessa maailmassa on vaikea rakentaa globaalia poliittista julkisuutta, jossa käytäisiin aitoa keskustelua yhteisistä poliittisista kysymyksistä. Poliittinen toiminta on aina lopulta paikallista, eikä julkisuus yksin riitä ratkaisemaan poliittiseen toimintaan liittyviä ongelmia. Internetin ongelmana on juuri pidetty sen hajanaisuutta, kyvyttömyyttä muodostaa laajapohjaista yhteisöllisyyttä rakentavaa julkisuutta (esim. Nieminen 2000).

Internetin mahdollistamissa käytännöissä on monia hyviä puolia, joiden soisi yleistyvän politiikan mediajulkisuudessa laajemminkin. Avoimuuden tavoittelu, yhdessä toimiminen, innostunut osallistuminen ja vuorovaikutuksen lisääminen ovat kaikki kannatettavia tavoitteita politiikan ja mediajulkisuuden suhteita pohdittaessa. Tämä edellyttäisi, että sosiaaliseen mediaan sitoutuneet ihmisjoukot alkaisivat kanavoida aktiivisuuttaan enenevässä määrin populaarikulttuurin nautintojen ja identiteettipolitiikan lisäksi sellaiseen poliittiseen toimintaan, joka liittyy yhteisten asioiden hoitamiseen yhteiskunnan järjestelmätasolla. Tällainen muutos on kenties mahdollinen sitten, kun nuoremmat mediasukupolvet alkavat vallata alaa poliittisessa järjestelmässä.

\section{Lähteet}

Brundidge, Jennifer. 2010. Political Discussion and News Use in the Contemporary Public Sphere: The 'Accessibility' and 'Traversability' of the Interenet. Javnost - The Public 17:2, 63-82.

Carlson, Tom. 2007. Kandidatbloggar I det finländska presidentvalet 2006. Strategier och effecter. Politiikka 49:2, 61-75. 


\section{Juha Herkman}

Elo, Kimmo \& Lauri Rapeli. 2008. Suomalaisten politiikkatietämys. Helsinki: Oikeusministeriö.

Hallin, Daniel C. \& Paulo Mancini. 2004. Comparing Media Systems. Three Models of Media and Politics. Cambridge: Cambridge University Press.

Haltsonen, Eeva. 2011. Off the record: siunaus vai suukapula? Journalisti 87(2011), 10.2.2011, 12-13.

Hellman, Heikki. 1999. From Companions to Competitors. The Changing Broadcasting Markets and Television Programming in Finland. Acta Universitatis Tamperensis 652. Tampere: University of Tampere.

Herkman, Juha. 2008. Politiikan viihteellistymistä vai professionalisoitumista? Haastattelututkimus vuoden 2006 presidentinvaaleista. Politiikka 50:2, 87-99.

Jenkins, Henry. 2008. Convergence Culture. Where Old and New Media Collide. New York: New York University Press.

Joukkoviestimet 2006. Finnish Mass Media 2006. Helsinki: Tilastokeskus.

Joukkoviestimet 2002. Finnish Mass Media 2002. Helsinki: Tilastokeskus.

Juntunen, Laura \& Esa Väliverronen. 2009. Intiimin politiikka ja skandaalin yhteiskunnallinen merkitys. Teoksessa Esa Väliverronen (toim.), Journalismi murroksessa, 262-284. Helsinki: Gaudeamus.

Jyrkiäinen, Jyrki. 1994. Sanomalehdistön keskittyminen. Acta Universitatis Tamperensis, ser A, vol. 409. Tampere: University of Tampere.

Kaid, Lynda Lee. 2009. Changing and Staying the Same: Communication in Campaign 2008. Journalism Studies 10:3, 417-423.

Karvonen, Erkki. 1999. Elämää mielikuvayhteiskunnassa. Imago ja maine menestystekijöinä myöhäismodernissa maailmassa. Helsinki: Gaudeamus.

Koski, Anne. 2007. Siirtoja kuvaruudulla. Television poliittisten ohjelmien poliittisuus 1960-luvulta nykypäivään. Teoksessa Juhani Wiio (toim.) Television viisi vuosikymmentä, 202-217. Helsinki: SKS.

Kunelius, Risto, Elina Noppari \& Esa Reunanen. 2009. Media vallan verkoissa. Tiedotusopin laitoksen julkaisusarja A112/2009. Tampere: Tampereen yliopisto.

Lilleker, Darren G. \& Casilda Malagón. 2010. Levels of Interactivity in the 2007 French Presidential Candidates' Websites. European Journal of Communication 25(1): 25-42.

Luostarinen, Heikki \& Turo Uskali. 2006. Suomalainen journalismi ja yhteiskunnan muutos. Teoksessa Risto Heiskala \& Eeva Luhtakallio (toim.), Uusi 
jako. Miten Suomesta tuli kilpailukyky-yhteiskunta?, 179-201. Helsinki: Gaudeamus.

Manin, Bernard. 1997. The Principles of Representative Government. Cambridge: Cambridge University Press.

McKinney, Mitchell S. and Leslie A. Rill. 2009. "Not Your Parents' Presidential Debates": Examining the Effects of the CNN/YouTube Debates on Young Citizens' Civic Engagement. Communication Studies 60:4, 392-406.

McNair, Brian. 2007. An Introduction to Political Communication. London: Routledge.

Meyer, Thomas. 2002. Media Democracy: How the Media Colonize Politics. Cambridge: Polity Press.

Mickelsson, Rauli. 2007. Suomen puolueet. Historia, muutos ja nykypäivä. Tampere: Vastapaino.

Moring, Tom \& Hal Himmelstein. 1993. Politiikkaa riisuttuna. Tutkimusraportti 6/1993. Helsinki: Yleisradio.

Mäntylä, Jorma. 2009 Puoluelehdet siirtyvät verkkoon. Journalisti 20/2009, 4-5.

Nieminen, Hannu. 2006. Kansa seisoi loitompana. Kansallisen julkisuuden rakentuminen Suomessa 1809-1917. Tampere: Vastapaino.

Nieminen, Hannu. 2000. Julkisuuden kohtalo myöhäismodernissa: globalisaatio vai pirstoutuminen? Teoksessa Anu Koivunen, Susanna Paasonen \& Mari Pajala (toim.), Populaarin lumo - mediat ja arki, 188-213. Turku: Turun yliopisto, Mediatutkimus.

Nieminen, Hannu \& Mervi Pantti. 2004. Media markkinoilla. Johdatus joukkoviestintä̈n ja sen tutkimukseen. Helsinki: Loki.

Nieminen, Hannu, Minna Aslama \& Mervi Pantti. 2005. Media ja demokratia Suomessa. Helsinki: Oikeusministeriö.

Nordenstreng, Kaarle \& Osmo A. Wiio (toim.). 2001. Suomen mediamaisema. Helsinki: WSOY.

Nordic Media Market 2009. The Nordic Media Market: Media Companies and Business Activities 2009. Gothenburg: Nordicom.

Norris, Pippa. 2000. A Virtuous Circle. Political Communications in Postindustrial Societies. Cambridge (NY): Cambridge University Press.

Pernaa, Ville, Mari K. Niemi, \& Ville Pitkänen (toim.). 2007. Mielikuvavaalit. Kevään 2007 eduskuntavaalien mediailmiöt. Turku: Kirja-Aurora. 
Picard, Robert G. 1989. Media Economics: Concepts and Issues. Newbury Park/ California: Sage.

Rinne, Jarmo. 2011. Henkilökohtaistuva politiikka. Tutkimusmatkoja refleksiiviseen kansalaistoimintaan. Tampere: Tampereen yliopisto.

Salokangas, Raimo. 1996. Aikansa oloinen. Yleisradion historia 1926-1996. Helsinki: Yleisradio.

Spaeth, M. 2009. Presidential Politics and Public Relations in 2008: Marshall McLuhan 2.0. Journalism Studies 10:3, 438-443.

Sparks, Colin. 2000. Introduction: The Panic over Tabloid News. Teoksessa Colin Sparks \& John Tulloch (toim.), Tabloid Tales. Global Debates over Media Standards, 1-42. Lanham: Rowman \& Littlefield.

Strandberg, Kim. 2009 Online campaigning: an opening for the outsiders? An analysis of Finnish parliamentary candidates' websites in the 2003 election campaign. New Media \& Society 11:5, 835-854.

Strandberg, Kim. 2008. Public Deliberation Goes On-line? An Analysis of Citizens' Political Discussions on the Internet Prior to the Finnish Parliamentary Elections in 2007. Javnost - The Public 15:1, 71-90.

Suhonen, Pertti. 2000. Mielipidetutkimusten rooli presidentinvaaleissa. Teoksessa Pekka Isotalus \& Eeva Aarnio (toim.), Presidentti 2000. Mistä vaalit on tehty?, 63-87. Jyväskylä: SoPhi.

Suhonen, Pertti. 1996. Mielipidetutkimukset, journalismi ja politiikka. Tiedotustutkimus 19:2, 36-51.

Trammell, K. D. 2006. The Blogging of the President. Teoksessa A. P. Williams and J. C. Tedesco (toim.), The Internet Election: Perspectives on the Web in Campaign 2004, 133-146. Lanham: Rowman \& Littlefield.

Tryon, C. 2008. Pop Politics: Online Parody Videos, Intertextuality, and Political Participation. Popular Communication 6: 209-213.

Uimonen, Risto \& Elisa Ikävalko. 1996. Mielikuvien maailma. Miten mediajulkisuutta muokataan ja imagoja rakennetaan. Helsinki: Inforviestintä.

Ylä-Anttila, Tuomas. 2010. Politiikan paluu. Globalisaatioliike ja julkisuus. Tampere: Vastapaino.

Xenos, M. \& P. Moy. 2007. Direct and Differential Effects of the Internet on Political and Civic Engagement. Journal of Communication 57, 704-718. 


\section{Viitteet}

1 Teksti on toimitettu lyhennelmä Juha Herkmanin kirjan Politiikka ja mediajulkisuus (Vastapaino, 2011) luvusta 5. Muuttuva julkisuus. 



\section{Suomen julkisen hallinnon ja julkisen sektorin muutoksesta institutionalistisesta tutkimusnäkökulmasta}

Tarkoituksenani on artikkelissani tarkastella maamme julkisen hallinnon ja julkisen sektorin muutosta. Koska olen tieteenharjoittaja, minulle ei voi olla olemassa "selvää", teoria- ja käsitevapaata kuvailevaa empiriaa. Siksi, ensiksi, avaan erittelynäkökulmaa tietyn eli 'institutionalismiksi' kutsutun teoreettisen liikehdinnän näkökulmasta. Toiseksi, tarkastelen pääasiassa tiiviisti ja esimerkkien avulla - maamme julkisen hallinnon ja julkisen sektorin muutosta soveltamastani näkökulmasta. Tutkin - sekä luodessani katsauksen teoreettisiin kysymyksiin että edetessäni kohden empiirisiä sovellutuksia - pääasiassa kolmea seikkaa: ilmiöitä, joita kutsutaan institutionalismin piirissä 'mikro-institutionalisoitumiseksi', tehokkuuden ja legitimiteetin institutionaalista vuorovaikusta institutionalistisen 'toimijuuden' ('agenssin', engl. agency) ilmiön yhteydessä sekä radikaaleja institutionaalisia muutoksia. Tarkasteluani taustoittaa se, että toisin kuin maassamme, kussakin muussa kolmessa suuremmassa Pohjoismaassa juuri institutionalismi kuuluu keskeisiin julkista hallintoa ja julkista koskeviin tutkimuksen lähestymistapoihin. Sen useat pohjoismaiset edustajat ovat muodostuneet tutkimusalansa maailmannimiksi.

Sen jälkeen, kun laadin tämän tekstin ensimmäisen version vuodenvaihteessa 2011-2012, olen valmistellut kahtakin kansainvälistä artikkelia paneutuen tässäkin yhteydessä tarkastelemani asiakokonaisuuden empiriaan. Vastaavia tutkimustuloksiani käytän hyväkseni tekstiini sisäl- 


\section{Pertti Ahonen}

lyttämissäni "laatikoissa”. Jos lukija haluaa, hän voi perehtyä vain empiriaa koskettelevaan jälkiosaan artikkeliani, paneutua tuohon osaan ennen kuin teoreettisempaan alkuosaan - tai edetä tavanomaisessa järjestyksessä, aloittaen teoriasta ja jatkaen sitten empiriaan.

\section{Institutionalistisen tutkimusnäkökulman avaus ja tutkimustavoitteet}

Vuonna 1977 oli ilmestynyt kaksi avainartikkelia (Meyer \& Rowan 1977; Zucker 1977). Muutaman vuoden kuluttua ne miellettiin 'neoinstitutionalismiksi' tai 'uudeksi institutionalismiksi' kutsutun tutkimussuuntauksen ensimmäisiksi töiksi. Nyttemmin suuntauksen nimike on typistynyt monissa yhteyksissä pelkäksi 'institutionalismiksi'. Tarkastelen kohdettani, maamme julkisen hallinnon ja julkisen sektorin uudistumista, institutionalistisesta näkökulmasta, joka käy yksiselitteisesti ilmi niistä lähteistä, joihin viittaan, alkaen mainituista klassikkoartikkeleista. Näkökulma on sittemmin täsmentynyt muissa julkaisuissa (esim. Jepperson 1991; Meyer \& Jepperson 2000; Jepperson 2001; Meyer 2009; Krücken \& Drori 2009). Tarkasteluni tavoitteet ovat seuraavat:

Ensimmäinen tavoitteeni on eritellä institutionalisoitumisen mikrokysymyksiä kuten nimikkeistö-, kategorisointi-, rajanveto- ja identiteettikysymyksiä. Tarkastelun logiikka on seuraava: mitään muuta kuin nimeämällä kielen piiriin saatettua ei ole mahdollista tarkastella sen enempää arjen käytännöissä kuin tutkimuksessa, nimeämiseen kytkeytyvät läheisesti asianomaisten ilmiöiden kategorisoinnit (niiden sijoittelut eri luokkiin ja samalla yhteen tiettyjen muiden ilmiöiden kanssa ja eroon joistakin muista ilmiöistä), vastaavissa yhteyksissä toteutuvat rajanvedot (jotka liittyvät elimelliset niin nimeämiseen kuin kategorisointiin) ja samalla muodostuvat identiteetit (käsitykset siitä, mitä mikin ilmiö on, sen sisäpiirin ja toisaalta muiden näkemyksen mukaan).

Toisen tavoitteeni muodostaa paneutuminen mimeettiseen eli kirjaimellisesti sovellettuja esikuvia, malleja ja toimintaprosessien luonnoksia 'jäljittelevään' institutionalisoitumiseen. Tuossa yhteydessä analysoin erityisesti institutionaalista vaihtelua englannin kielen ilmauksen tradeoffs merkityksessä yhtäältä tuloksellisuuden (performance) ja toisaalta 
legitimiteetin (legitimacy) painotuksen kesken. Samassa yhteydessä tarkastelen institutionaalisen 'toimijuuden' ('agenssin', englanniksi agency) kysymyksiä.

Kolmantena tavoitteenani on analysoida radikaalia institutionaalista muutosta.

Jaan artikkelini kahteen pääasialliseen osaan. Edellisessä niistä avaan kolmea kysymystäni, ja jälkimmäinen osa valottaa jatkotutkimuksia silmällä pitäen omaksumaani institutionalismin perspektiiviä ja sen sovelluksia maamme julkisen sektorin muuttumisessa.

\section{Mikroinstitutionalisoituminen, institutionalisoituminen ylipäätään ja radikaali institutionaalinen muutos}

\section{Mikroinstitutionalisoituminen}

Powellin ja Colyvasin (2008) mukaan institutionalisoitumisen mikroperusteina erottuu ensinnäkin rakentuminen tietyiltä osin Garfinkelin (1967) etnometodologiselle tutkimussuuntaukselle, johon nykyinstitutionalismin avainartikkeleista Zuckerin (1977) laatima teksti suorastaan sijoittuu. Analyysin polttopisteeksi muodostuu sosiaalisen järjestyksen muodostuminen mikrokonteksteissa. Samoin kohteeksi tulee tuollaisen järjestyksen reproduktio eli uusiintuminen, kun toimijat rakentavat toimintansa muodostuneille ja vakiintuneille institutionaalisille olettamuksille. Toiseksi, institutionalismin mikroperusteisiin lukeutuvat Goffmanin (mm. 1959, 1967, 1969) työt erotteluineen instituutioiden julkisen - ja hyvinkin silkoisen - 'etualan' (front stage) ja niiden piilossa pysyvän - ja hyvinkin raadollisen - 'taka-alan' (back stage) kesken. Asiaan liittyy myös se, että harvassa instituutiossa tosiasiallisesti pannaan toimeen vain sen piirissä muodollisesti voimassa olevia normeja ja toimintasääntöjä, joista osaa sitä paitsi tuskin sovelletaan. Kolmas taustaelementti koostuu Bergerin ja Luckmannin (1966) teoksesta. Siinä nämä eri vaikutelähteet huomioidaan ja niiden synteesi muodostaa ajatusrakennelman, joka sittemmin omalta osaltaan perusteli konstruktionistiseksi kutsuttua yhteiskuntatutkimuksen suuntausta (Holstein \& Gubrium 2008). En kuitenkaan ilmoittaudu konstruktionistisen tieteellisen ideologian kannatta- 


\section{Pertti Ahonen}

jaksi, vaan ainoastaan erittelen ilmiöiden konstruoituneisuutta - sikäli kuin siitä on kysymys.

Fokustaessaan vaikutelähteisiinsä institutionalismi nostaa etualalle mikroprosessit, jotka synnyttävät vahvaa institutionaalista itsestäänselvyyttä (taken-for-grantedness), sekä noiden prosessien tulokset, jotka koostuvat nimenomaan itsestäänselvyyksistä, joista institutionalisoituminen ja institutionalisoituneisuus juuri koostuvat. Kun tarkastellaan, millaiset prosessit saavat aikaan institutionalisoitumista ja mitä niiden seurauksena institutionalisoituu, havaitaan tosin, että ilmiasultaan sekä prosessit että tulokset ovat tosiaankin latteita ja kulttuurisesti köyhiä. Siitä huolimatta - ja juuri siksi, ilmeisessä latteudessaan ja tylsyydessään - ne toimivat mikrovallan mekanismeina pitäen yllä erilaisia sekä tuloksellisuuden että legitimiteetin alkuehtoja. "(T)ekoja, jotka toteuttaa jonkin määrätyn tehtävän haltija, [pidetään] määritelmänomaisesti institutionalisoituneina [ja siksi erityisen uskottavina]", kirjoitti nasevasti jo Zucker (1977, 729, suomennos PA). "Virka antaa järjen", on eräs tuolle ajatukselle rakentuva sarkastinen sananlasku, jonka muuten jo G.W.F. Hegel aikanaan nimenomaan kiisti.

Garfinkel tutki aikanaan muun muassa rekistereiden - kuten potilasrekistereiden ja niihin sisältyvien sairauksien määritysten - ylläpitoa itsestäänselvyyksien tuotannon ja reproduktion prosessina (Garfinkel, 1967, 186-207). Goffman (1969/1961) puolestaan eritteli sitä asukkien sisäistämien itsestäänselvyyksien kautta tapahtuvaa hallintaa, joka on luonteenomaista pakkolaitoksille sekä lievemmässä mitassa koulutuslaitoksille ja muille formaaleille organisaatioille. Vastaavasti on sittemmin tutkittu myös yleisintä talouden ja rahoituksen informaatiojärjestelmää eli laskentatointa (esim. Modell 2009) sekä suunnittelua ja arviointia eli evaluointia (esim. Brunsson 1989, 2009). Kaikki tuollaiset käytännöt katalysoivat itsestäänselvyyksien tuotantoa ja uusintamista. Mitä heikommin ne näyttävät tekevän juuri niin, sen pahempi se on meille kaikille kansalaisina ja ihmisinä ja sen vaikeampia ovat vastaavasti ne analyysihaasteet, joita asettuu noihin ilmiöihin pureutuville tutkijoille. Mikroinstitutionalisoitumista koskeviin tutkimusteemoihin kuuluvat muun muassa seuraavat:

- Institutionalisoitumisen kannalta perustavanlaatuiset luokittelut, kategorisoinnit ja rajanvedot (Gieryn 1983; Zerubavel 1995; Lamont 
\& Molnár 2002; Hannan 2010; Zietsma \& Lawrence 2010). Huomio kiinnittyy institutionalisoitumiseen ankkuroituvaan ilmiöiden sijoittamiseen samoihin ryhmiin tai toisaalta erilaisiksi luonnehdittavien ilmiöryhmien erottamiseen toisistaan, arvottamiseen (ei-)toivottavuuden mukaan sekä rajojen vetämiseen eri ryhmiin ja eri tavoin luokiteltujen seikkojen välille. Analogioita voidaan vetää sellaisiin ilmiöihin kuin othering, 'toiseutuminen' ja 'toiseuttaminen' (esim. gender-perusteisen tai etnisen syrjinnän tilanteissa).

- Edellisissä yhteyksissä muodostuvat myös instituutioiden sisäiset ja väliset rajat, jotka samoin muodostavat tutkimuksessa eritellyn teeman. - Tärkeitä ovat myös ilmiöt, joista kirjallisuudessa käytetään nimitystä naming, 'nimeäminen' (Charmaz 2006; Guenther 2009; Pollitt \& Hupe 2009; Negro ym. 2010). Tavallista on esimerkiksi vihollishahmoja kiteyttävä kielenkäyttö. Mitäpä muuta kuin vahvaa - mutta imaginaariseksi jäävää - identiteettiä yritetään tuolla epätoivoisella tavalla kiteyttää (vrt. esim. Glynn \& Abzug 2002; Gioia ym. 2010). Pollitt ja Hupe (2009) puolestaan suuntaavat taidokkaan kritiikin moninaisia sellaisia julkisen sektorin muoti-ilmauksia ja-sanoja kohtaan kuin 'hallinta' (governance), 'johtaminen', 'tilivelvollisuus' (accountability) ja 'kompleksisuus'. Useimmiten niiden takaa ei löydy yhtään mitään. Korkeintaan kohtaamme kiistoja siitä, mitä kukin noista sanoista "oikeastaan" tarkoittaa - tilanteissa, joissa kukin kiistelijä yrittāä saavuttaa monopolia avainsanan määrittelemisessä.

\section{Vaihtelu tehokkuuden ja legitimiteetin kesken sekä käsitys toimijuudesta}

Institutionalismin keskeisiin kysymyksiin kuuluu se, miksi, millä perusteella ja miten tapahtuu institutionaalisten elementtien omaksuminen. Tuollaisia elementtejä muodostaa ylipäätään kaikki se, mistä formaalit organisaatiot ja muut instituutiot koostuvat ja joita hallinnon, organisaatioiden ja johtamisen tutkimus vastaavasti erittelee:

- pystysuorat rakenteet (esim. hierarkian, johtamisen, fyysisen ylivallan sekä ideologisen ylivallan eli hegemonian rakenteet),

- vaakasuorat rakenteet (toiminnaltaan sekä alueellisesti tai muuten tilassa funktionaalisesti tai muuten eriytyneet rakenteet), 


\section{Pertti Ahonen}

- normit ja muut toimintasäännöt, toimintarutiinit ja muut pysyväisproseduurit ja

- kaikki edellä mainitut elementit sanastoineen, kielikuvineen, puheenparsineen, "diskursseineen" ja muine muodostumineen eli se kieli, joka merkityksellistää, jäsentää, taustoittaa, selventää mutta kenties myös strategisesti ja ideologisesti sumentaa, peittää ja piilottaa institutionalisoitumista ja institutionalisoituneisuutta.

Institutionalismi kiinnittää huomiota siihen, että joskin institutionaaliset elementit saattavat edistää tuloksellisuutta, jonka parantamisen merkeissä monet niistä ainakin otetaan käyttöön. Samaiset elementit saattavatkin tuloksellisuuden edistämisen rinnalla tai asemesta tukea epävarmuuden vähentämistä legitimiteetin pönkittämiseksi (Meyer \& Rowan 1977; DiMaggio \& Powell 1983; Tolbert \& Zucker 1983). Vastaavasti yhdeksi huomion aiheeksi nousee se, mikä "todella", aikamme suosikkiilmausta käyttäen 'näyttöperusteisesti', lisää tuloksellisuutta. Toiselta kohtiolta löydämme sen, minkä yleisesti tai laajalti uskotaan, toivotaan (vaikkei ehkä niinkään uskottaisi) tai retorista suostuttelua harjoittaen väitetään olevan jollakin nimenomaisella tavalla. Institutionalistisen tutkimuksen yleisiin tähdennyksiin kuuluu myös se, että vaikka jokin tietty institutionaalinen ratkaisu aluksi näyttäisi pitkäänkin edistävän tuloksellisuutta, sittemmin se kenties leviää omalakisesti, suosittuna ja legitiiminä oletettuna tapana epävarmuuden vähentämisessä. Avainartikkeleihin asiasta kuuluu Tolbertin ja Zuckerin (1983) teksti Yhdysvaltain kaupunkihallinnon uudistusten leviämisestä. Joskin aluksi uudistukset levisivät tehokkuusperusteella, ennen pitkää leviämistä selitti pääasiassa se, että vastaavista instituutiomalleista oli muodostunut jo niin laajalti sovellettuja. Mikäli tiettyjen instituutioratkaisujen legitimiteetti muodostuu kyllin vakaaksi, kroonisetkaan tuloksellisuusvajeet eivät kenties hievauta instituutioita raiteiltaan, kuten puolestaan Meyerin ja Zuckerin (1989) teos kärkevästi korostaa. Tarkkakorvainen kuulee tässä yhteydessä historian siipien uudempaa havinaa. Noinhan taisi myös euroalue toimia, ennen kuin ongelmalliseksi tiedetty Kreikka laukaisi euroalueen vakavan kriisin.

Institutionalistinen vastaus kysymykseen institutionaalisten elementtien omaksumisen syistä korostaa 'isomorfiaa' (isomorphism) eli saman- 
muotoisuutta sekä isomorfian syvenemisestä eli edelleen etenevää samanmuotoistumista alkujaan kenties hyvinkin erilaisten instituutioiden tai tiettyä instituutiotyyppiä edustavien organisaatioiden kesken. Institutionalismi katsoo nimenomaan institutionaalisen legitimiteetin etsinnän epävarmuuden välttämiseksi synnyttävän tendenssejä, joista käytetään nimitystä 'mimeettinen' (mimetic institutionalization) eli 'jäljittelevä institutionalisoituminen'. Ilmauksen ottivat käyttöön DiMaggio ja Powell (1983) artikkelissaan, jossa mimeettinen institutionalisoituminen kuitenkin esiintyy osana kirjoittajien kiteyttämää ulkoasultaan hyvinkin "positivistista" institutionalisoitumisen muotojen funktionalistista sarjaa. Tästä hairahduksesta Meyer (2008) heitä kitkerästi arvostelee. Jäljittelevä institutionalisoituminen ei koostu vain orjallisesta omaksuttujen esikuvien kopioinnista, vaan myös 'adaptiivisesta emulaatiosta', 'sopeuttavasta jäljittelystä’ (Strang \& Macy 2001; Lee \& Strang 2006), kunhan taustalla jyllää usko omaksuttujen ratkaisujen itsestäänselvyyteen, takenfor-grantedness. Juuri tällainen uskomus selittää globaalia 'pikku-Harvardien' kasvustoakin - joka useimmissa tapauksissa muodostaa ideaaliinsa verrattuna surkean irvikuvan (Meyer ym. 1997, 145; ks. myös Meyer ym. 2007).

Ottaakseni toisen esimerkin, globaalisti jo pitkään - suunnilleen 1970 -luvulta alkaen - muotiaaltona levinnyt uusliberalistinen ja New Public Management -henkinen julkisen sektorin supistaminen (Lee \& Strang 2006) ei ole toteutunut eikä toteudu täsmälleen samoin eri maissa. Oleellista on tuossakin tapauksessa se itsestäänselvyydeksi muodostunut ideologinen vakuuttuneisuus, että julkista sektoria supistavat instituutioratkaisut vähentävät poliittista ja muuta epävarmuutta ja siksi turvaavat hallinnan legitimiteettiä.

Alkuvaiheissaan nykyinstitutionalismi paneutui etenkin koulutusalan instituutioiden erittelyyn korostaessaan nimenomaan niiden huomattavaa institutionalisoituneisuutta (ks. esim. Meyer \& Rowan 1983) yliopistojakaan sittemmin unohtamatta (Meyer ym. 2007). Myöhemmin analyysin ala laajeni koskemaan mitä tahansa instituutioita ja kaikkea institutionalisoitumista.

Varhaisempi nykyinstitutionalismi pyrki siis kohdistamaan analyysia erityisesti kohteisiin, joita se luonnehti erityisen 'institutionalisoituneiksi' kuten 'institutionalisoituneiksi organisaatioiksi', joissa se katsoi yh- 


\section{Pertti Ahonen}

täältä tuloksellisuutta ja toisaalta legitimiteettiä ylläpitävien elementtien selvimmin eriytyvän toisistaan. Sittemmin institutionalistit ovat paneutuneet erittelemään mitä tahansa organisaatioita kuten kilpailutilanteessa toimivia yrityksiä korostaen, että myös niiden toiminnassa tuloksellisuuden ohella painottuu myös legitimiteetin tavoittelu. Miksipä muuten yritysmaailma olisi niin herkkää johtamis- ja organisointimuodeille (Meyer 2002)? Meyer lähimpine työtovereineen työsti vähitellen 'maailmanyhteiskuntateoriansa, world society theory (Krücken \& Drori 2009). Sen piirissä nousi esiin etenevä mimeettinen institutionalisoituminen, jonka voittokulkua eivät estä tuloksellisuuden puute tai ongelmat - kunhan legitimiteettiä turvataan ja epävarmuus vastaavasti lievenee. Tältä pohjalta kehkeytyvä skenaario on huolestuttava: entäpä mikäli nopeimmin globalisoituvien alojen kuten ihmisoikeusaihepiirin, EU:n kokonaisuutena muodostaman talousalueen, ympäristöpolitiikan, terveyden- ja sosiaalihuollon, yleissivistävän koulutuksen tai yliopistojen tuloksellisuus ei niinkään parannu ja joissakin tapauksissa jopa huonontuu, kun legitimiteetin vaalinta epävarmuuden välttämiseksi pysyy uudistusten ja muutosten ensisijaisena tarkoituksena?

Problematiikkaan liittyy myös käsityksiä yhteiskuntatutkimuksen teorianmuodostuksen keskeisestä teemasta otsikolla agency, 'agenssi' eli suomeksi lähinnä 'toimijuus'. Eräät institutionalistit ovat arvioineet voivansa kuitata koko 'agenssin' ongelman Giddensin (esim. 1979) luonnehdinnalla siitä, etteivät 'rakenteet' vain rajoita (constrain) toimijoiden toimintaa vaan myös mahdollistavat (enable) sitä. Perusteltuun kritiikkiin kuuluu Archerin (esim. 2007) termi central conflation, lähinnä 'keskusreduktio' - mikä luo arvosteluperusteet Giddensin mallia kohtaan, jonka Archer katsoo edellyttävän levotonta heilahtelua toiminnan rakennekeskeisen ja toimijalähtöisen määräytymisen kesken. Institutionalismin omimpiin ratkaisuihin toimijuuden ongelman tarkastelemiseksi kuuluu agentic actorhood, kömpelösti mutta sanatarkasti suomennettuna 'toimijuudellinen toimijuus'. Meyer (2008, 792, minun suomennokseni) kirjoittaa: “Toimijuuden (actorhood) ... käsikirjoitus on kirjoitettu (scripted) instituutiorakenteisiin, eikä suhde toimijan ja toiminnan kesken muodostu ... pelkästään kausaaliseksi, vaan kummankin elementin taustalla ovat institutionaaliset käsikirjoitukset (institutional scripts), ja niiden keskinäisellä suhteella on, kausaalisesti ilmaisten, vahvoja sosiaalisesti konstruoidun 
tautologian piirteitä". En ryhdy puntaroimaan tuota luonnehdintaa etsien argumentteja sen puolesta tai sitä vastaan, vaan tyydyn tarkastelemaan, mitä luonnehdinnasta seuraa, jos sitä sovelletaan institutionalistisessa analyysissa.

Meyer ja Jepperson $(2000,108)$ katsovat omaksumaansa tutkimusperspektiiviä soveltaen, että vaikutusvaltaiset toimijaryhmät kuten sellaiset professiot kuin juristit, professorit, konsultit ja laskentatoimen ekspertit (accountants) sekä radikaalit poliittiset ja muut aktivistit (McAdam ym. 2006; Schneiberg \& Lounsbury, 2008) eivät institutionaalisissa rooleissaan juuri muuta teekään kuin pane toimeen jotakin tiettyä 'periaatteellista toimijuutta' ('agency for principle'). Meyerin ja Jeppersonin $(2000,117)$ mukaan runsaita aineksia instituutioiden muodostumiselle tarjoavat globaalisti, kansallisesti, sektorikohtaisesti tai muuten saatavilla olevat 'standardoidut toimijuusauktoriteetin teknologiat' (Meyer \& Jepperson 2000, 117), joita kielikuvaa käyttäen 'lojuu ylt'ympäriinsä instituutioiden lähimaastossa' (Meyer \& Rowan 1977, 345; vrt. Meyer ym. 1997, 149, 168). Nämä tekniikat ovat periaatteessa vapaasti institutionaalisiksi innovaattoreiksi ryhtyvien valittavissa, sovellettavissa ja eri tarkoituksiin mukautettavissa. Sen enempää professorin, konsultin kuin radikaalin aktivistin ei siksi tarvitse itse keksiä toimijuutensa elementtejä, vaan kullekin heistä on tarjolla runsain mitoin globaaleja ja kansallisia virikkeitä, jota kukin heistä voi myös säätää mieleisekseen jos kykenee. Samoin kukin niistä instituutioista, joiden mahdollistamana ja rajaamana kukin kolmesta toimijasta aktivoituu, sisältää erilaisia institutionaalisia käsikirjoituksia siitä, kuinka asioiden tulisi sujua.

Meyerin ja Rowanin (1977, 343-346) avainkäsitteiden joukkoon lukeutuu myös 'rationalisoitu myytti', ('rationalized myth'). Kukin tuollainen myytti, joita institutionalisoitumiseen ja kuhunkin sen tulokseen kuten kuhunkin formaaliin organisaatioon sisältyy, koostuu luonteeltaan ideologisista instituutiorakenteista. Kutakin niistä vakauttaa se, että niitä pidetään itsestään selvyydellä rationaalisina jopa siitä riippumatta, mikä niitä itse asiassa luonnehtii. Institutionalistit ovat tutkineet rationaalisista myyteistä niitä, jotka liittyvät lainsäädäntöön, organisaatioihin, johtamiseen, tieteelliseen tutkimukseen ja korkeakoulutukseen kuin myös toisenlaisia myyttejä, jotka vaikuttavat kansallisvaltion rakenteissa ja 


\section{Pertti Ahonen}

toiminnassa (Edelman ym.; Bittner 1965; Meyer \& Rowan 1977; SmithDoerr 2005; Meyer \& Jepperson 2000, 110; Meyer ym. 1997).

Kohdistaen tarkastelunsa legitimoivien instituutiopiirteiden ja niiden oikeuttamien kohteiden suhteisiin Meyer and Rowan (1977) esittivät sen käsityksen, että instituutioiden ytimen "kaikkein pyhin" saa tyypillisesti suojaa institutionalistisilta legitimaatioita ylläpitäviltä käytännöiltä, kunhan jälkimmäiset on vain löysästi kytketty ('loosely coupled') tuohon ytimeen. Asiaa ovat tarkan empiirisesti tutkineet useat alan tutkijat (esim. Brunsson 1989, 2009; Schuyt \& Schuijt 1998; Power ym. 2009). He ovat eritelleet julkistettuja poliittisia ja strategisia toimintaohjelmia sekä suunnittelu-, arviointi-, tarkastus-, auditointi- ja laadunvarmistuskäytäntöjä ja tarkastelleet kutakin niistä instituutioiden ydinprosesseihin vain löysästi kytkeytyvinä legitimointikäytäntöinä. Sen sijaan, legitimoivien käytäntöjen ja institutionaalisten ydinprosessien tiukka kytkeminen (tight coupling) toisiinsa on omiaan lisäämään epävarmuutta ja vahingoittamaan instituutioydintä (Meyer ja Rowan 1977; Perrow 2008; Power 2009). Tätä eivät harkitsemattomat, hätäilevät, tärkeilevät tai osaamattomat reformaattorit ja kehittämisprofessiot ota huomioon, mistä aiheutuu surullisia seurauksia asianomaisille instituutioille. Meyer ja Rowan (1977, 350-351, 359) vetivät myös analogian nykyaikaisten muodollisten instituutiokäytäntöjen ja riittien, rituaalien ja seremonioiden kesken. Tosin Jepperson $(2001,23)$ joutuu valittelemaan, että analogian nojalla on harjoitettu vain vähän tutkimusta ja sitäkin pääasiassa institutionalismin ulkorajoilla tai ulkopuolella (esim. Islam \& Zyphur 2009; Pollitt \& Hupe 2009).

\section{Radikaalit instituutiomuutokset}

Alan tutkimusta on 1980-luvulta lähtien arvosteltu siitä, ettei se kykenisi tarkastelemaan varsinkaan radikaaleja institutionaalisia muutoksia (Suddaby 2010; Clegg 2010). Tällaiset olettamat ovat saattaneet johtaa tutkijoita etsimään virikkeitä rationaalisen valinnan käsityksiin sitoutuneilta institutionalismin suunnilta tai niiden lähialueilta. Kiinnostusta on herättänyt esimerkiksi muutosten luonnehdinta polkuriippuvuuden mallin sovelluksilla (path dependency model), jotka puolestaan rakentuvat 
taloustieteen skaalaedun eli laskevien keskimääräiskustannusten teorialle ('increasing returns to scale,' 'economies of scale') (ks. esim. Mahoney 2001). Biogeneetikko Gouldin hyppäyksittäisiä muutoksia kuvaava 'punctuated equilibrium' -malli on sekin saanut sovelluksia etenkin osassa historiallisiin kysymyksiin paneutuvaa institutionalismia (Baumgartner \& Jones 1993; Pierson 2004). Lähemmäksi soveltamaani institutionalismia sijoittuu Greenwoodin ja Hiningsin (2006, 827-831) kehitelmä Tolbertin ja Zuckerin (1996) mallista, joka sinänsä koskee nimenomaan radikaalia institutionalistista muutosta. Malli ei kuitenkaan yllä kuin kuvaukseen radikaalin institutionaalisen muutoksen oletetuista vaiheista tarjoamattaan edellytyksiä varsinaiselle kohteeseen pureutumiselle.

Viitekehystä soveltaen on mahdollista lausua julki myös radikaalin institutionaalisen muutoksen analyysin pääperiaatteet. Siinä, missä osa institutionalisoitumisesta koostuu hitaasta, ikään kuin kasvullisesta muutoksesta, radikaali institutionaalinen muutos sisältää hyppäyksellisen tai muun kertakaikkisen epäjatkuvuusmomentin, jota kenties taustoittaa aikaisemman institutionalisoitumisen romahduksenomainen purkautuminen. Tarkastelun taustalle sijoittuvat institutionalistiset perusargumentit siitä, että kaiken institutionaalisen toimijuuden ja toiminnan taustalle sijoittuvat 'institutionaaliset käsikirjoitukset'. Siellä, mistä ne puuttuvat, on kysymys elottoman ja elollisen luonnon spontaaneja prosesseja vastaavista luonnonvoimaisista prosesseista, jollaiset toisinaan saattavat päteä myös yhteiskuntatutkimuksessa

Radikaalien institutionaalisten muutosten erittelyn avain voisi sisältyä siihen, että monilla noista muutoksista on nimenomaiset, vaikkakin ehkä vain karkeat, institutionaaliset käsikirjoituksensa. Vaikka substanssikysymykset vaihtelevat, moni radikaali institutionaalinen muutos toteutunee kuitenkin hyvinkin pitkälti "perheyhtäläisin” muodoin. Tämä koskee esimerkiksi John W. Meyerin maailmanyhteiskuntateorian soveltajia suuresti kiinnostanutta ihmisoikeuksien globaalia leviämistä ja vahvistumista paitsi muodollisessa mielessä, myös sillä mobilisaatiotuella, jota ovat antaneet ihmisoikeuksien merkeissä virinneet, jopa sortohallituksen kumoamisen katalysoineet kansanliikkeet. 'Periaatteellinen toimijuus' ei kenties oleellisesti poikkea tässä muodoiltaan. Sen sijaan toimijuuden sisällöt vaihtelevat: esimerkiksi tietyn valtion kansan valtaistamiseksi ylipäätään, gender-perusteisen enemmistön eli naisten voimaistamiseksi tai 


\section{Pertti Ahonen}

jonkin tai useamman siihen saakka sorretun etnisen, uskonnollisen, etnouskonnollisen tai muun vähemmistöryhmän nostamiseksi sorron yöstä. Radikaaliaktivisti toimijafiguurina ja -hahmona omaa institutionalistisesta näkökulmasta tarkasteltuna hyvinkin huomattavia perheyhtäläisiä piirteitä siitä riippumatta, mikä on aktivistin ajama poliittinen agenda.

Tarkastelun rajoja tulee vastaan siellä, missä tulee ottaa kantaa radikaalin institutionaalisen muutoksen seurauksena toimeenpantavan uuden institutionalisoitumisen sisältöön. Yleisemmän esimerkin tarjoavat kysymykset väestöään ja etenkin poliittisesti kriittisiä kansalaisiaan sortavien valtioiden toivottavista tulevista institutionaalisista kehityssuunnista. Ellemme kelpuuta toiveskenaarioiden joukkoon mitä tahansa muodollista demokratiamallia ja sääntelemätöntä markkinataloutta, eteemme nousevat kiperät demarkaatiokysymykset. Esimerkiksi soveltuu organisaatioiden kehittäminen. Riittääkö meille esimerkiksi se, että edes jokin maamme yliopistoista sijoittuu hyvin sinänsä yksipuolisissa globaaleissa yliopistojen "mestaruussarjataulukoissa"? Onko sen sijaan tärkeää, missä määrin yliopistot pysyvät yliopistoina, vapaan, instrumentalistisesti ja professionaalisesti tukahduttamattoman tutkimuksen ja sille perustuvan korkeimman opetuksen ahjoina? Onko sekään yhdentekevää, hallitsevatko yliopistoa yliopistolaiset itse vai yliopistoon nähden ulkopuolisten hallitsemat hallintoelimet ja elinkeinoelämästä palkatut karriäärijohtajat?

Suomen julkisen hallinnon ja julkisen sektorin muutos institutionalistisesti tarkasteltuna: päätelmiä ja hypoteeseja tutkimusta varten

\section{Maamme julkisen hallinnon ja julkisen sektorin muutoksen mikroinstitutionalisoituminen}

Paneutuessamme tutkimaan maamme julkisen hallinnon muutosta ensimmäisen teoriamme viitoittaman tutkimusaiheen muodostavat mikroinstitutionalisoitumisen kysymykset. Tältä osin on tutkittava sekä aihepiirin institutionaalisia itsestäänselvyyksiä (vrt. Garfinkel 1967) että niiden muodostumista ja uusiintumista. 
Se ilmeinen mutta toistaiseksi tarkemmin erittelemätön regiimin muutos, mikä aihepiirissä on tapahtunut, jos verrataan esimerkiksi tilannetta 1970-luvun alussa ja nykyisin tai olosuhteita vielä 1980-luvun lopulla ja nykyhetkellä, näyttää jääneen liian kyntämättömäksi tutkimussaraksi. Näin voidaan väittää, kun pohdimme institutionaalisten itsestäänselvyyksien kysymyksiä. Deskriptiivisempää tutkimusta on kyllä käytettävissä - ja edelleen jalostettavissa. Taustoittavina havaintoina nousee esiin muun muassa, että maamme hallituksen kannanotot viestintämielipiteen säestäminä 1970-luvulla ja vielä 1980-luvun loppupuolella korostivat sellaisia kysymyksiä kuin kansalaisten hyvinvointia, sosiaalisen ja taloudellisen tasa-arvon vaalintaa ja tasapainoista alueellista kehitystä ja noiden päämäärien mukaisia institutionaalisia ratkaisuja. Toistaiseksi tarkemmin tutkimattomien murrosten kautta nyky-institutionalisoituminen korostaa yritystoiminnan kilpailuedellytysten vaalintaa, taloudellista kannustamista sekä tutkimuksen ja kehittämistoiminnan tuen kohdistamista niin lähelle varsinaista kaupallistamisen vaihetta kuin mahdollista.

Institutionalistinen "etuala" ratkaisuineen näyttää jäävän parhaiten rauhaan siellä, missä "taka-ala" eli tuloksellisuuden käyttövoimat näyttävät toimivan parhaiten, kuten OECD:n PISA-tutkimusten nojalla maamme koulujärjestelmän 'yläkouluissa', jotka taannoin tunnettiin 'peruskoulun yläasteina' (vrt. Goffman 1959). Sen sijaan siellä, missä "takaala" ei kykene "etualaa" tarkasteltaessa osoittamaan kykenevänsä takaamaan kiistatonta legitimoivaa tuloksellisuutta, havaitsemme levotonta institutionaalista muuttumista. Tällaista liikehdintää löytyy yliopistoissa niiden siirryttyä uuteen, ennestään tuntemattomaan ja edelleen kiisteltyyn instituutiomuotoon vuoden 2010 alusta, tai maamme kunnissa, jotka ovat joutuneet hyvinkin pitkään jatkuvan kiihkeän kuntaliitosaallon kouriin. Alituisen uudistamistyön "potilaista" voidaan mainita myös maamme terveydenhuolto ja erityisen moneen osasektoriin jakautunut sosiaaliala.

Maamme julkisen hallinnon ja julkisen sektorin uudistumiseen ja muuttumiseen liittyvän mikroinstitutionalisoitumisen tutkimuksen oleellisiin kohteisiin lukeutuvat myös moninaiset muuttuneet tai tyystin uudet, uusia itsestäänselvyyksiä tuottavat ja uusintavat instituutiokäytännöt. Niihin lukeutuvat tilasto- ja indikaattorijärjestelmät, jollaisista jälkimmäisiin tukeutui tähänastisista hallituksista vahvimmin Vanhasen II 


\section{Pertti Ahonen}

hallitus vuodesta 2007 lähtien soveltaessaan määrältään toiselle sadalle nousevaa osoitinten joukkoa seurantatarkoituksiaan varten (ks. Ahonen ym. 2009). Arviointi eli evaluaatio puolestaan kehkeytyi maassamme kahdessa vaiheessa, ensiksi vuodesta 1986 lähtien, jolloin valtiovarainministeriö ensimmäistä kertaa edellytti sen harjoittamista budjetin laadintaohjeissaan. Toiseksi vuodesta 1995 alkaen, josta alkaen maamme liittyminen Euroopan unioniin edellytti aikaisempaan verrattuna huomattavasti kiteytetympää evaluaatiotoimintaa nykyisin koheesiopolitiikaksi kutsutulla politiikkasektorilla. Julkisen sektorin yleisölle tuntemattomimpiin käytäntöihin lukeutuva julkisen sektorin laskentatoimi on puolestaan jokseenkin tyystin uudistunut 1980-luvun lopulta lähtien yleisen eli - virheellisen epätarkasti - liikekirjanpidoksi kutsutun kirjanpidon sovellusalueen laajetessa myös perinteisten hallintotointen alalle. Moni seikka on kuitenkin jäänyt keskentekoiseksi kuten julkisen sektorin kirjanpidon ja toisaalta evaluaatiotoiminnan aukoton keskinäinen integrointi sekä ennakollisen evaluaatiotoiminnan vankka institutionalisointi lainsäädännön vaikuttavuuden tueksi (Ahonen ym. 2009).

Evaluaatiotoiminta on myös eriytyessään muodostunut huomattavan epäyhtenäiseksi. Sillä on lisäksi sellaisia, globaalisti tunnettuja jatkeita kuten korkeakouluihin suuntautuva, Korkeakoulujen arviointineuvoston ohjastama auditointitoiminta. Jälkimmäinen toiminta on - näennäisessä ilmeisessä merkityksettömyydessään ja sanktioiden puuttumisessa siinäkään tapauksessa, etteivät auditoinnin kohteet täytä niille asetettuja edellytyksiä - eräs analyyttisesti kiinnostavia esimerkkejä siitä, mitä nykyisessä mikroinstitutionalisoitumisessa tapahtuu. Korkeakoulujen auditointitoimintaa olisi aiheellista lähestyä institutionalistisesta näkökulmasta; olisi tutkittava niitä legitimiteetin ylläpitoon ja epävarmuuden torjuntaan liittyviä syitä, joiden johdosta harjoitetaan tuollaisia toimintoja, jotka eivät millään osoitettavissa olevalla tavalla suoranaisesti paranna kohteena olevan toiminnan tuloksellisuutta. Globaalisti isomorfinen samanlaistuminen saattaa näytellä roolia tuollaisissa yhteyksissä; sen sijaan, että keskiöön sijoittuisi toiminnan tuloksellisuuden edistäminen, painopisteeseen sijoittuu globaalin konformismin, yhdenmukaisuuden, vaalinta.

Maamme julkisen sektorin uudistumisen ja muun muuttumisen mikroinstitutionaalisen analyysin suoranaisen millimikrotasoisen juonteen 
paikannan tutkimukseen, joka kohdistuisi julkisella sektorilla sovellettuihin identiteetin määrityksiin, luokituksiin, kategorisointeihin, rajanvetoihin sekä nimeämisiin. Osa aihepiirin kysymyksistä on näennäisesti varsin teknisiä mutta ei siksi vähemmän kiintoisia kuten budjettien ja julkisyhteisöjen laskentatoimen luokitukset huomattavine vaikutuksineen, sairauksien luokitukset kytkentöineen sairausvakuutusjärjestelmän soveltamiin korvauskriteeristöihin sekä tieteenalojen luokittelut seurausvaikutuksineen tutkimusrahoituksen saamiselle. Vähemmän teknisiä ovat esimerkiksi nimenomaiset identiteetin rakennusyritykset alkaen Suomen virallisesta "maabrändäyksestä". Samoin tulee huomata se moninainen ja monimutkainen suoranainen nimeämis- ja uudelleennimeämispolitiikka, joka muodostaa erottamattoman osan julkisen sektorin uudistus- ja muutoshankkeita. Hyvän esimerkin tarjoaa nimike 'hyvinvointivaltio', joka miltei katosi poliittisesta ja hallinnollisesta nykykielestämme 1990-luvun ensi puoliskolla korvautuen ilmauksella 'hyvinvointiyhteiskunta'. 
Asialaatikko ja taulukko 1. Mikroinstitutionalisoitumisen tuloksia Suomen julkisessa hallinnossa ja julkisella sektorilla

Mikroinstitutionalisoitumisen tuloksiin maamme julkisessa hallinnossa ja julkisella sektorilla lukeutuu huomattava instituutioiden kirjo. Asiaa taustoittavat - soveliaasti julkisen hallinnon ja 'julkisen' laajuutta koskevat bruttokansantuotepohjaiset ja henkilömäärien laskentaan perustuvat - mittaluvut ovat epämääräiset.

Ahtaasti rajaten maamme julkisen sektorin bruttokansantuoteosuus on vain kolmekymmenenkahdeksan prosentin suuruusluokkaa, mutta koska osuuteen lasketaan mukaan myös työeläkerahastot, virallinen osuus on kuin onkin viisikymmentäviisi prosenttia. Vastaavanlaiseen tapaan, vaikka julkisen hallinnon henkilöstömäärä on tiettyjen virallisten ilmoitusten mukaan vain vajaa neljännes maan koko työllisestä työvoimasta, viralliset tilastot laskevat siihen mukaan myös kaiken muun julkisen sektorin työvoiman kuin vain julkisen hallinnon työvoiman. Päädytäänkin lukemaan, joka lähenee kolmeakymmentä prosenttia. Edelleen, viralliset tilastotkaan eivät sisällytä julkisen sektorin työvoimaan valtion ja kuntien omistamien osakeyhtiöiden henkilöstöä, jonka kokonaismäärä voidaan arvioida noin sadaksituhanneksi hengeksi eli vajaaksi neljäksi prosentiksi kansantalouden koko työllisestä työvoimasta.

Institutionalistinen tutkija joutuu kysymään, miksi noin ilmeisen oleelliset asiat ovat tuossa määrin epämääräisiä. Vastausta on etsittävä muun muassa suunnilta, joilla on ollut kysymys julkisen sektorin vuosikymmenisestä määrätietoisesta supistamisesta - mutta sillä tuloksella, että julkinen sektori on pikemminkin laajentunut ja sitä paitsi monin tavoin edelleen kietoutunut yhteen yritys- ja vapaaehtoissektorin kanssa. Eurojärjestelmän kriisi on oleellisesti laajentamassa julkista sektoria, sen roolia ja sen ulottuvuutta kautta koko maanosamme - vuosikymmeniksi eteenpäin. 


\begin{tabular}{lllll}
\hline Instituutiot & $\begin{array}{l}\text { Luku- } \\
\text { määrä }\end{array}$ & Henkilöstö & Rahoitus & $\begin{array}{l}\text { Virka- } \\
\text { miehiä }\end{array}$ \\
\hline
\end{tabular}

1 "Valtioyhteisö/valtiokonserni”; työllisiä pl. valtionyhtiöt, 153,000)

1.1 Valtio (työllisiä pl. valtionyhtiöt, 85,000)

1.1.1 Eduskunnan yhteydessä

\begin{tabular}{|c|c|c|c|c|}
\hline 1.1.1.1 Eduskunta & 1 & $\begin{array}{l}200 \text { kansan- } \\
\text { edustajaa/hen- } \\
\text { kilöstöä } 500\end{array}$ & Budjetti & $\begin{array}{l}\text { Ei/ } \\
\text { kyllä }\end{array}$ \\
\hline 1.1.1.2 Valtiontalouden tarkastusvirasto ym. & 1 & 200 & Budjetti & Kyllä \\
\hline \multicolumn{5}{|l|}{ 1.1.2 Valtioneuvoston johtovallassa } \\
\hline 1.1.2.1 Hallitus & 1 & $\leq 18$ ministeriä & Budjetti & $\mathrm{Ei}$ \\
\hline 1.1.2.2 Ministerilöt & 12 & 3,500 & Budjetti & Kyllä \\
\hline 1.1.2.3 Virastot jne. & N. 230 & 78,000 & Budjetti, maksut & paljon \\
\hline 1.1.2.4 Budjetin ulkopuoliset rahastot & N. 20 & Vähän & $\begin{array}{l}\text { Maksut, bud- } \\
\text { jetti }\end{array}$ & Kyllä \\
\hline 1.1.2.5 Liikelaitokset & 2 & 2,300 & Myyntituotot & $\mathrm{Ei}$ \\
\hline
\end{tabular}

\subsection{Itsenäiset oikeushenkilöt osina "valtioyhteisöä”}

1.2.1 Eduskunnan yhteydessä

1.2.1.1 Kansaneläkelaitos

1.2.1.2 Suomen Pankki

1.2.2 Valtioneuvoston johtovallassa

1.2.2.1 Yliopistot

1.2.2.2 Julkisoikeudelliset yhdistykset

1.2.2.3 Erityissäännellyt yhtiöt

1.2.2.4 Vain osakeyhtiölain alaiset yhtiöt

\section{Osittain itsenäinen Ahvenanmaa}

2.1 Maapäivät, hallitus, hallinto

2.2 Kunnat

\begin{tabular}{|c|c|}
\hline 1 & 6,000 \\
\hline 1 & 500 \\
\hline 16 & 33,000 \\
\hline Satoja & Tuhansia \\
\hline Muutamia & $\begin{array}{l}7,000 \text { (+tytär- } \\
\text { yhtiöt) }\end{array}$ \\
\hline $\begin{array}{l}\text { N. } 50 \text { pää- } \\
\text { yhtiötä }\end{array}$ & $\begin{array}{l}78,000(+ \text { ty- } \\
\text { täryhtiöt })\end{array}$ \\
\hline
\end{tabular}

Sosiaaliturva- Kyllä maksut

Itsekannattava Kyllä

Pääasiassa valtio- Ei navut ja hankevarat

Maksut, myynti- Ei tuotot

Myyntituotot, Ei maksut

Myyntituotot, Ei pääomansijoitukset

Verot, siirrot Kyllä Suomen valtiolta

Kunnallisvero, Kyllä valtionavut, maksut 


\section{Pertti Ahonen}

3 Manner-Suomen kunnallishallinto (työllisiä pl. yhtiöt, 515,000)

3.1 Kuntakonsernit)

3.1.1 Kunnat

3.1.2 Liikelaitokset ja vastaavat

3.1.3 Osakeyhtiöt

\subsection{Kuntayhtymäkonsernit}

3.2.1 Kuntayhtymät

3.2.2 Liikelaitokset jne.

3.2.3 Yhtiöt

4 Välillinen julkinen hallinto

5 Luterilainen ja ortodoksinen valt. kirkko
320

Satoja

2,100

140

120,000

Ei voida tilastollisesti erottaa jäsenkuntien vastaavista

Tuhansia

20,000

28,000
Ks. kohta 2.2

Myyntituotot

Myyntituotot, maksut
Kyllä

Ei

$\mathrm{Ei}$

Jäsenkuntien suoritukset, valtionavut

Myyntituotot

Myyntituotot

$\mathrm{Ei}$

Pääasiassa

Ei

maksut

Kirkkollisvero,

Ei omaisuustuotot, lahjoitukset

1-5 yhteensä, arvio

Koko työllinen työvoima 
Institutionalisoituminen, vaihtelu tehokkuuden ja legitimiteetin kesken sekä toimijuus maamme julkisen sektorin uudistumisessa ja muutoksessa

Maamme julkisen hallinnon ja julkisen sektorin muutosta koskevan keskeisen tutkimusaiheen muodostaa myös institutionalisoituminen mimeettisessä muodossaan. Olisi tutkittava, miksi, millä perusteella ja miten on tapahtunut ja tapahtuu se institutionaalisten elementtien omaksuminen, jollaista maamme julkisella sektorilla on harjoitettu ja harjoitetaan. Analyysille asettaa ankaria vaatimuksia myös se, että tuollaisia elementtejä erottuu useita erilaisia päätyyppejä, että kuhunkin päätyyppiin sijoittuu hyvinkin monenlaisia yksittäisiä institutionaalisia ratkaisuja ja että niin päätyypit kuin niihin sijoittuvat ratkaisut saattavat yhdistyä toisiinsa moninaisina yhdistelminä. Kysymys on kaikesta siitä, mistä formaalit organisaatiot ja muutkin instituutiot koostuvat: pystysuorista ja vaakasuorista rakenteista, toimintasäännöistä, rutiineista ja muista pysyväisproseduureista sekä kielestä (elementtien esittely edellä, tutkimuskappaleessa). Voidakseen paneutua tuohon aihepiiriin tutkimuksen tulisi kyetä erittelemään julkisen hallinnon sisäistä tietä sekä kansallisista että globaaleista lähteistä - esimerkiksi OECD:n katalysoimana tai EUtahoilta - ammentaen tapahtunutta ja tapahtuvaa mimeettistä institutionalisoitumista samoin kuin julkisen sektorin palkkaamien kotimaisten ja globaalien konsulttien sekä alan akateemisen tutkimuksen edustajineen välittämiä, suosittelemia ja kehittelemiä institutionalisoitumisen tapoja. Tutkija joutuu myös erottelemaan toisistaan tuloksellisuuden kannalta näennäisen mutta kuitenkin tuloksellisuuden nimissä institutionaalisten rationalisoitujen myttien tapaan toimeenpannun ja legitimaatiopyrkimysten kannalta hyvinkin tähdellisen institutionalisoitumisen ja toisaalta ne toimet, jotka "todella" - näyttöperusteisesti - ovat parantaneet ja parantavat tuloksellisuutta.

Institutionalistinen maamme julkisen hallinnon ja julkisen sektorin muutoksen tutkimus muodostuu huomattavalta osin globaalihallinnan, 'global governancen', maassamme omaamien ulottuvuuksien ja maassamme saamien erityisten ilmenemismuotojen tutkimukseksi. Tutkimus joutuu silti edelleen rajautumaan myös jäljellä olevat kansallisvaltiolliset ja muut kansalliset erityispiirteet huomioon ottaen. Kansallisia oikeusjärjestyksiä ei suinkaan ole tyystin purettu ja kansalliset kielet ovat edelleen 


\section{Pertti Ahonen}

jäljellä globaalista englanninkielen ylivallan vahvistumisesta huolimatta. Tutkijalle tarjoutuu valinnanvaraa: esimerkiksi maamme julkisen hallinnon ja muun julkisen sektorin harjoittama kansainvälinen kehitysyhteistyö ilmenee selvästi globalisoituneempana aiheena kuin vaikkapa edelleen purkautuvan hyvinvointivaltion sosiaali- ja terveyspoliittisten kansallisten jäänteiden institutionaalinen erittely tai koulutuksen määrättyjen, edelleen kansallisesti korostuvien instituutiopiirteiden analyysi. Oman erityisen institutionalistisen analyysikohteensa muodostaa 'toimijuuden' erittely. Osan avautuvaa problematiikkaa muodostavat kysymykset siitä, millaista, kenties uudenlaista 'periaatteellista toimijuutta', on muodostunut. Kandidaatteja tutkimuskohteiksi ovat niin ihmisoikeusjuristit ja nykyaikaiset hallintojuristit, maamme uusien etnisten vähemmistöryhmien edustajat ja esitaistelijat sekä aihepiirin vihkiytyneet tutkijat kuin ne mahdolliseksi nimikkeen "populisti” saavat tahot, jotka asettuvat syntyperäisten maamme kansalaisten edunvalvojiksi kannanotoissaan ja poliittisessa asianajossaan. Näköjään neutraalimpaa, teknisempää, teknokraattisempaa ja "ekspertokraattisempaa" periaatteellista toimijuutta edustavat esimerkiksi johtamisen, organisoinnin ja muiden alojen konsultit, laskentatoimen ja muiden informaatiojärjestelmien ekspertit sekä ekonomistit.

Maamme julkisen hallinnon ja julkisen sektorin muutosta tutkittaessa on samoin eriteltävä Meyerin ja Rowanin (1977, 343-346) mainitsemia muodostumia nimeltä 'rationalisoidut myytit', joita luonnehtii niiden aihepiiriinsä sulkemien seikkojen ilmeneminen suorastaan itsestään selvyydellä rationaalisina. Hyvän - joskin alaltaan kapean - esimerkin tarjoaa maamme valtionhallinnon pitkäaikainen tuottavuusohjelma. Kun valtiontalouden tarkastusvirasto toteutti sitä koskevan arvioivan tarkastuksen, kävi ilmi, että ohjelma oli lakannut olemasta sitä, mitä sen nimi edelleen antoi ymmärtää eli kansantaloustieteellisen marginaaliajattelun vaatimukset täyttävä tuottavuuden edistämisväline ja -menettelytapa. Siitä oli sen sijaan tullut kaavamainen, säästäväisyyteen viittaamalla legitimoitu menojenleikkausprosessi. (VTV 2010.) Ihmeenä ei voida pitää sitä, että tehtäviinsä vuonna 2011 astunut Kataisen hallitus päätti korvata tuottavuusohjelman tuloksellisuus- ja vaikuttavuusohjelmalla (Valtioneuvosto 2011). Toivottavasti uusi nimike muodostuu myönteisellä tavalla hallituskoalitiota velvoittavaksi. 
Maamme julkisen hallinnon ja julkisen sektorin uudistamisen ja muun muuttumisen erittelyssä rationalisoituja myyttejä tarjoutuu eriteltäviksi myös lainsäädännön alalta (Riittävätkö lainsäädännössä ilmaistut aikeet niiden toteuttamisen takeiksi?) sekä organisaatioiden piiristä (Turvaako uusien organisaatioiden perustaminen - kuten maamme yliopistojen muuttaminen omiksi oikeushenkilöikseen ja omiksi itsenäisiksi talousyksiköikseen - sellaisenaan tuloksellisuutta?). Analogisia myyttejä kätkeytyy johtamiseen (Parantaako päätoimisten johtajanasemien perustaminen tuloksellisuutta vai joiltakin osin huonontaa sitä vallan keskittyessä ja informaatiopullonkaulojen muodostuessa?), tieteelliseen tutkimukseen (Turvaako tiedepoliittinen tutkimuksen ohjelmointi maamme tieteen kansainvälistä menestystä vai joiltakin osin luuduttaa tieteen kehitystä? Onko maahamme fuusioteitse muodostettu runsaasti rahoitettu uusi yliopistoyksikkö näyttöperusteisesti kohoamassa kansainvälisen tieteen huipulle vai ei?) ja korkeakoulutukseen (Onko vuoden 2010 yliopistouudistus aiheuttanut vain hyöty- vai kenties myös haittaseurauksia?). Myyteistä vapaa ei ole nykyaikainen kansallisvaltiokaan (Onko osallistumisella EU-integraatioon vain hyötyvaikutuksia vai myös haittapuolia? Onko maamme muutos monikulttuuriseen suuntaan missä määrin mahdollisuus ja missä määrin ja keille myös uhka?).

Tutkimuskohteista on mainittava myös institutionaaliset kytkennät, joita olisi eriteltävä sekä niiden löyhyyden että niiden tiukkuuden kannalta. Tutkia voidaan 'löyhien kytkentöjen' mahdollisia myönteisiä seurauksia sekä siinä tapauksessa, että niiden löyhyys lausutaan perustellen julki että silloin, kun kytkentöjä itse asiassa luonnehtiva löyhyys suorastaan retorisesti naamioiden peitellään. Jälkimmäisessä tapauksessa on nostettava esiin ne rationalisoidun myytin omaiset perustelut, joiden mukaan tuloksellisuus muka kirjaimellisesti edistyisi myös siellä, missä tuloksellisuutta koskevat retoriset argumentit sen sijaan palvelevat vain legitimaation tarkoituksia. Samoin on tutkittava seurauksia siitä, mikäli kytkennät legitimoivien instituutioelementtien ja niiden suojaan saatettujen herkkien institutionaalisten ydinosien kesken muodostetaan 'tiukoiksi', jolloin institutionalisti on taipuvainen odottamaan vakavia vaikeuksia. 
Asialaatikko ja taulukko 2. Agentointi (agentification) ja vastaava institutionalisoituminen Suomen julkisessa hallinnossa ja julkisella sektorilla

Kirjoittaja on vastikään toisessa yhteydessä eritellyt maamme julkisen hallinnon ja julkisen sektorin keskeisimmät elementit institutionalistista tutkimusnäkökulmaa soveltaen. Koska erittely on liian laaja tässä yhteydessä esitettäväksi ja julkaistaan sitä paitsi aluksi kansainväliselle lukijakunnalle, tässä yhteydessä nostetaan esiin eräs institutionalisoitumisen keskeinen yleinen globaali nykypiirre. Sillä ei ole vakiintunutta suomenkielistä nimeä, mutta englannin kielessä ilmiö tunnetaan nimellä agentification, äidinkielellämme lähinnä 'agentointi' (jos on kysymys nimenomaisista reformeista) tai 'agentifioituminen' (jos on kysymys spontaaneista prosesseista).

Kysymys on vahvoista, jo muutamia vuosikymmeniä jatkuneista globaalitendensseistä muuttaa julkisen hallinnon ja laajemman julkisen sektorin osia entistä itsenäisemmiksi, joko pysyttäen ne julkisen hallinnon sisällä tai siirtäen ne sen piiristä pois. Looginen ääritapaus on täydellinen 'yksityistäminen', 'privatisointi', jossa julkinen hallinto tai muu osa julkista sektoria luopuu kokonaan tietyn toiminnan järjestämisestä. 'Agentointia' on mahdollista jakaa eri muotoihin, joista 'korporatisaatio' ('Corporatization'), lähinnä 'yhtiöittäminen' mutta myös muut sen suuntaiset ratkaisut kuten muodostaminen itsenäiseksi julkisoikeudelliseksi yhteisöksi maamme nyky-yliopistojen tapaan ovat hyviä esimerkkejä. 


\begin{tabular}{|c|c|c|}
\hline $\begin{array}{l}\text { Instituutiomallit ja institu- } \\
\text { tionaaliset toimintakäsikir- } \\
\text { joitukset }\end{array}$ & Maassamme alkaen & Kommentteja \\
\hline \multicolumn{3}{|c|}{1 Tulosjohtaminen: tulossopimuksia solmivat tahot: } \\
\hline $\begin{array}{l}1.1 \text { Virastot }(2012, \text { n. } 230) \text { minis- } \\
\text { teriöiden kanssa }\end{array}$ & 1990-luvun alusta & \multirow{5}{*}{$\begin{array}{l}\text { Vain ns. kvasisopi- } \\
\text { muksia, joita mikään } \\
\text { oikeusistuin ei paneta } \\
\text { toimeen, mahdollisesti } \\
\text { kuitenkin pl. } 1.5\end{array}$} \\
\hline $\begin{array}{l}1.2 \text { Kunnalliset virastot kuntiensa } \\
\text { kanssa }\end{array}$ & $-"$ & \\
\hline $\begin{array}{l}1.3 \text { Johtajat valtion tai kunnan } \\
\text { virastonsa kanssa }\end{array}$ & $-"-$ & \\
\hline $\begin{array}{l}\text { 1.4 Julkisen hallinnon henkilöstön } \\
\text { jäsenet johtajiensa kanssa }\end{array}$ & -"- & \\
\hline $\begin{array}{l}1.5 \text { Valtio ja kunnat ylimpien } \\
\text { johtajiensa kanssa }\end{array}$ & $-"$ & \\
\hline $\begin{array}{l}2 \text { Osan tai kaikkien kustannusten } \\
\text { kattaminen ja jopa ylijäämän } \\
\text { tuottaminen valtion ja kuntien } \\
\text { maksuin }\end{array}$ & 1980-luvulta & $\begin{array}{l}\text { Monissa peruspalveluissa mak- } \\
\text { sut vain nimelliset }\end{array}$ \\
\hline $\begin{array}{l}3 \text { Valtion ja kuntien budjetointi } \\
\text { nettoehdoin (vähentäen menoista } \\
\text { tulot tai tuloista menot) }\end{array}$ & 1930-luvulta & Laajentunut 1980-luvulta lähtien \\
\hline $\begin{array}{l}4 \text { Yleinen ns. liikekirjanpito } \\
\text { valtion ja kuntien julkisessa } \\
\text { hallinnossa }\end{array}$ & 1990-luvulta & $\begin{array}{l}\text { Monet laskentatoimen tutkijat } \\
\text { asettavat kyseenalaiseksi }\end{array}$ \\
\hline $\begin{array}{l}5 \text { Valtion ja kuntien budjetin } \\
\text { ulkopuoliset rahastot erityistar- } \\
\text { koituksiin }\end{array}$ & 1800-luvulta & $\begin{array}{l}\text { Esim. valtion eläkkeet, eräät } \\
\text { EU-politiikat, eräät kuntien } \\
\text { liikelaitokset }\end{array}$ \\
\hline \multicolumn{3}{|c|}{6 Liikelaitokset (viimekätinen taloudellinen vastuu valtiolla tai kunnalla) } \\
\hline 6.1 Valtiolla & $1985 / 1989$ & $\begin{array}{l}\text { Mallista ollaan luopumassa } \\
\text { EU:n se tuomittua }\end{array}$ \\
\hline 6.2 Kunnissa & 1990-luvulta & $\begin{array}{l}\text { Kilpailullisilla markkinoilla } \\
\text { toimivista muodostettava osake- } \\
\text { yhtiöitä vuoteen } 2013 \text { mennessä }\end{array}$ \\
\hline
\end{tabular}

7 Yksilöllisesti räätälöidyt instituutiomuodot (valtio t. kunta ei vastuussa sitoumuksista)

7.1 Suomen Pankki

7.2 Kansaneläkelaitos

7.3 Raha-automaattiyhdistys

7.4 Kaikki yliopistot

7.5 Välillinen julkinen hallinto, yli 20 alalajia
1811

1938

1938

2010

1800-luvulta
7.1-7.3 kukin oma mallinsa, 7.4 jakaantuu kahteen malliin, kohta 7.5 lukuisiin eri malleihin 
8 Yhtiöittäminen

8.1 Valtio (tai kunta) hankkii omistukseensa enemmistön osakkeista osakeyhtiöissä, lähinnä kohdennetulla osakeannilla, ja saattaa voimaan oy-lakia täydentäviä erityssäännöksiä

8.2 Valtio (tai kunta) perustaa toimintoja osakeyhtiömuotoon, jossa oy-lakia täydentävät erityissäännökset

8.3 Valtio (tai kunta) hankkii omistukseensa tai perustaa osakeyhtiöitä, jotka toimivat juridiselta kannalta puhtaasti kaupallisella perusteella

8.4 Valtion tai kuntien virastojen muuttaminen osakeyhtiöiksi

8.5 Liikelaitosten muuttaminen osakeyhtiöiksi

8.6 Valtion tai kunnan yhtiön yksityistäminen 1930-luvulta Esim. Yleisradio

1930-luvulta Lukuisia yhtiöitä vuosien varrella; 1990-luvulta lähtien myös valtion haltuun tulleita kriisiyhtiöitä

1930-luvulta Monia tapauksia

1990-luvulta Lähes kaikki toimineet valtion liikelaitokset

Monia tapauksia 
Radikaaleja institutionaalisia muutoksia maamme julkisen sektorin uudistumiseen ja muuhun muuttumiseen liittyvinä tutkimuskohteina luonnehtii näköjään se, että tuota suuruusluokkaa edustavia muutoksia tarjoutuu tarkasteluun vain niukalti. Tilannetta muuttaa ensinnäkin se, mikäli kohteiksi voidaan omaksua myös vanhempia historiallisia muutoksia. Toiseksi, eräät institutionaaliset muutokset ovat radikaalista luonteestaan huolimatta toteutuneet äkillisen asemesta pitkähkön ajanjakson kuluessa. Kolmanneksi, vaikka maamme julkisen hallinnon ja julkisen sektorin muutos ei jollakin tietyllä ajanjaksolla tarkasteltuna nostaisikaan näkyviin suoranaisia radikaaleja institutionaalisia muutoksia, sellaisia kenties tarjoutuu eriteltäviksi, mikäli näkökulmaa kohdennetaan edelleen. Omalta toimintakentältäni tarjoutuu etsimättä eriteltäväksi maamme yliopistojen mullistus erityisesti 1.1.2010 voimaan tulleesta yliopistouudistuksesta lähtien. Olen edellä maininnut myös maamme kuntien mullistuksen. Sen näkyvin ulkoisin joskaan ei suinkaan ainoa ilmenemismuoto koostuu etenevästä kuntaliitosboomista.

Kuten ylipäätään institutionalismille rakennettaessa, eriteltäessä maamme julkisen hallinnon ja julkisen sektorin radikaaleja institutionaalisia muutoksia tarkasteluun tulevat erityisesti kaksi seikkaa. Niistä edellinen muodostuu niistä 'institutionaalisista käsikirjoituksista', jotka voidaan konstruoiden ja rekonstruoiden sijoittaa muutoksen taustalle. Jälkimmäisen seikan muodostaa asianomainen 'toimijuus', ja erityisesti se kohde, jota institutionalismissa kutsutaan termillä 'periaatteellinen toimijuus'. Sen edustajista olen edellä esittänyt esimerkkejä, ihmisoikeusjuristeista ja radikaaleista aktivisteista sellaisiin neutraaliuteen verhoutuneisiin tahoihin saakka kuin kansainväliset ja kansalliset konsultit, laskentatoimen asiantuntijat ja ekonomistit. Mikäli tutkija kohdistaa huomionsa tarjoutuvaa karkeaa yleiskuvaa tarkentaen vain tietyntyyppiseen muutokseen saati vain johonkin yksittäiseen muutosepisodiin, 'institutionaaliset käsikirjoitukset' ja 'periaatteellinen toimijuus' heräävät suoranaiseen eloon, joka luonnehtii kutakin tapahtunutta, tapahtuvaa tai vasta edessä häämöttävää konkreettista muutosta. 
Asialaatikko ja taulukko 3. Radikaaleja instituutiomuutoksia Suomen julkisessa hallinnossa ja sektorissa

Tiettyjen maamme julkisen hallinnon ja julkisen sektorin instituutiomuutosten luonnehtiminen radikaaleiksi perustuu kirjoittajan laajempaan, instituutioelementtejä koskevaan tutkimukseen. 'Radikaalius' ei tarkoita välttämättä vain suurimuotoisuutta, vaan myös vaikutusalaltaan ainakin aluksi pienimuotoinen muutos voi muokata institutionaalisia perusteita ja olla siksi luonteeltaan radikaalia.

Viereisen sivun taulukon 3 selitteet:

IFAC/IPSAS: International Federation of Accountants/

International Public Sector Accounting Standards.

PfP on lyhenne ilmauksesta 'pay for performance' eli 'tulospalkkaus.' 


\begin{tabular}{|c|c|c|c|c|c|}
\hline Elementti & I Alkoi & II Toimeenpano & III Vaikutukset & IV Peruutukset & V Toteutumatta \\
\hline $\begin{array}{l}\text { Agentointi (ks. } \\
\text { Laatikko 2) }\end{array}$ & $\begin{array}{l}\text { 1930-lu- } \\
\text { vulla }\end{array}$ & $\begin{array}{l}\text { Useita tyyppejä } \\
\text { kuten } 1,5 \text { ja } 6 \\
\text { Asialaatikossa } 2\end{array}$ & $\begin{array}{l}\text { Rajoitetumpaa } \\
\text { kuin useissa } \\
\text { muissa maissa }\end{array}$ & $\begin{array}{l}\text { Muutamia; } \\
\text { monet sittem- } \\
\text { min yhtiöitetty }\end{array}$ & Vrt. sarake IV \\
\hline Yhtiöittäminen & -“" & $\begin{array}{l}\text { Kaksi päälajia, } \\
\text { joilla alalajeja; ks. } \\
7 \text { ja } 8 \text { Asialaati- } \\
\text { kossa } 2\end{array}$ & $\begin{array}{l}\text { Eri tapaukset } \\
\text { keskenään liian } \\
\text { erilaisia arviointia } \\
\text { ajatellen }\end{array}$ & Muutamia & -“'- \\
\hline $\begin{array}{l}\text { Yleinen kirjan } \\
\text { pito eli "lii- } \\
\text { kekirjanpito" } \\
\text { julkisessa hal- } \\
\text { linnossa }\end{array}$ & $\begin{array}{l}\text { 1990-lu- } \\
\text { vulta }\end{array}$ & $\begin{array}{l}\text { Lähes kaikki or- } \\
\text { ganisaatiot Asia- } \\
\text { laatikossa } 1\end{array}$ & $\begin{array}{l}\text { Sovelletaan mo- } \\
\text { nessa tapauksessa } \\
\text { rinnakkain perin- } \\
\text { teisen hallinnol- } \\
\text { lisen kirjanpidon } \\
\text { kanssa }\end{array}$ & $\mathrm{Ei}$ & $\begin{array}{l}\text { IFAC/ } \\
\text { IPSAS -stan- } \\
\text { dardeja ei otettu } \\
\text { käyttöön }\end{array}$ \\
\hline $\begin{array}{l}\text { Maksullista- } \\
\text { minen }\end{array}$ & $\begin{array}{l}\text { 1980-lu- } \\
\text { vulta }\end{array}$ & $\begin{array}{l}\text { Sovelletaan erit- } \\
\text { täin laajalti }\end{array}$ & $\begin{array}{l}\text { Tulolähde valtio- } \\
\text { lle ja kunnille }\end{array}$ & $\begin{array}{l}\text { Jätetty ni- } \\
\text { mellisiksi } \\
\text { useilla hyv- } \\
\text { invointisek- } \\
\text { toreilla }\end{array}$ & Vrt. sarake IV \\
\hline $\begin{array}{l}\text { Yksityistämi- } \\
\text { nen (koulut) }\end{array}$ & $\begin{array}{l}\text { 1990-lu- } \\
\text { vulta }\end{array}$ & $\begin{array}{l}\text { Lähinnä kristil- } \\
\text { lisiä kouluja ja } \\
\text { Steiner-kouluja }\end{array}$ & $\begin{array}{l}\text { Rajoitetut vaiku- } \\
\text { tukset; täysi riip- } \\
\text { puvuus julkisesta } \\
\text { tuesta }\end{array}$ & - & $\begin{array}{l}\text { Täydellinen } \\
\text { yksityistäminen }\end{array}$ \\
\hline $\begin{array}{l}\text { Yksityis- } \\
\text { täminen (val- } \\
\text { tionyhtiöt) }\end{array}$ & $\begin{array}{l}\text { 1990-lu- } \\
\text { vulta }\end{array}$ & $\begin{array}{l}\text { Radikaalit ehdo- } \\
\text { tukset jääneet } \\
\text { toteuttamatta }\end{array}$ & $\begin{array}{l}\text { Hallinnan (go- } \\
\text { vernance) virta- } \\
\text { viivaistaminen }\end{array}$ & $\begin{array}{l}\text { Useimmat } \\
\text { ehdotukset }\end{array}$ & Vrt. sarake IV \\
\hline $\begin{array}{l}\text { Tulosohjaus ja } \\
\text {-johtaminen }\end{array}$ & $\begin{array}{l}\text { 1990-lu- } \\
\text { vulta }\end{array}$ & $\begin{array}{l}\text { Saavutetut tulok- } \\
\text { set tyypillisesti } \\
\text { vain löyhästi } \\
\text { kytketty tulevaan } \\
\text { rahoitukseen }\end{array}$ & $\begin{array}{l}\text { Korostanut mi- } \\
\text { nisteriöiden valta- } \\
\text { asemaa }\end{array}$ & - & $\begin{array}{l}\text { Tiukka kytkentä } \\
\text { (vrt. sarake II) }\end{array}$ \\
\hline $\begin{array}{l}\text { Järjestelmälli- } \\
\text { set, syvät me- } \\
\text { nonleikkaukset }\end{array}$ & $\begin{array}{l}\text { 1990-lu- } \\
\text { vulta }\end{array}$ & $\begin{array}{l}\text { Usein kutsuttu } \\
\text { 'säästöiksi' tai } \\
\text { 'tuottavuuden' } \\
\text { parantamiseksi }\end{array}$ & $\begin{array}{l}\text { Menettelytapoja } \\
\text { usein arvosteltu }\end{array}$ & $\begin{array}{l}\text { Monet aiotut } \\
\text { leikkaukset } \\
\text { peruttu }\end{array}$ & $\begin{array}{l}\text { Kytkeminen tu- } \\
\text { losjohtamiseen }\end{array}$ \\
\hline $\begin{array}{l}\text { PfP ja vastaa- } \\
\text { vat menettelyt }\end{array}$ & $\begin{array}{l}\text { 1990-lu- } \\
\text { vulta }\end{array}$ & $\begin{array}{l}\text { Tiukan julkisen } \\
\text { talouden rajoissa }\end{array}$ & $\begin{array}{l}\text { Fiskaalisista ja } \\
\text { muista syistä, } \\
\text { rajoitettu }\end{array}$ & - & - \\
\hline $\begin{array}{l}\text { Hallintoyk- } \\
\text { siköiden ja } \\
\text { kuntien liitok- } \\
\text { set }\end{array}$ & - & $\begin{array}{l}\text { Monia liitoksia } \\
\text { valtiolla, varsin } \\
\text { lukuisia kuntalii- } \\
\text { toksia vv. 1946- } \\
\text { 2011, suurehko } \\
\text { kuntaliitosaalto } \\
\text { odotettavissa } \\
\text { 2014-2017 }\end{array}$ & $\begin{array}{l}\text { Ei selvästi tiedos- } \\
\text { sa; ei järjestel- } \\
\text { mällisesti tutkittu }\end{array}$ & $\begin{array}{l}\text { Erittäin monet } \\
\text { etenkin ehdo- } \\
\text { tetuista kunta- } \\
\text { liitoksista }\end{array}$ & Vrt. sarake IV \\
\hline
\end{tabular}




\section{Pertti Ahonen}

\section{Loppusanat}

Arvioin erääksi maamme hallinnontutkimuksen tähänastisista ongelmista sen, ettei alalla ole riittävästi sovellettu globaaleja tutkimuksen suuntauksia, vaan on pikemminkin tähdätty välittömään käytännön hyötyyn. Jälkimmäistä ei toki tule vähätellä, mutta oleellista on se, että tuon hyödyn luonnehdinta ja määrittely on kansanvaltaisissa oloissa, ajatellen julkista hallintoa ja julkista sektoria, mitä kiistanalaisin kysymys. Se kuuluukin demokraattisen prosessin keskeisiin aiheisiin. Siksi on aiheellista tuntea epäluuloa, mikäli noista kysymyksistä pyritään tekemään muka vankkumattoman asiantuntemuksen alueita, joita älköön tutkimuksessakaan reposteltako.

Jos hallinnontutkimus pyrkii yksiviivaiseen välittömään hyödyllisyyteen, se tuomitsee itsensä auttamattomaan "jälkijunaan" suhteessa globaaleihin ja kansallisiin konsultteihin, globaalisti liikkuvimpaan osaan virkamiehistöstä sekä keskeisiin, vaikutusvaltaisiin intressiryhmiin yhteiskunnassamme. Siksi eräänlainen pienin paha yliopistollisessa hallinnontutkimuksessa on suostumus ottaa huomioon juuri alan globaalinen kärkitutkimus tinkimättä intellektuaalisistakaan vaatimuksista. Maamme hallinnontutkimus on toistaiseksi jäänyt globaalisti niin tuntemattomaksi, - maahamme nähden vertailukelpoisiin muihin kolmeen suurempaan Pohjoismaahan nähden - ettei aikoihin ole mitään uhkaa joutumisesta orjallisesti tanssimaan globaalien tieteellisten viiteindeksien ja noita indeksejä soveltavien kansallisten ja ylikansallisten tutkimus- ja korkeakoulupolitiikka-auktoriteettien "pillin" mukaan.

Haluan esittää oman muunnelmani siitä sinänsä vanhasta ajatuksesta, että "käytännöllisintä on paras teoria”. Muistutan, että klassisessa antiikissa "käytäntö" jakaantui tarkkaan kahteen osaan: tekhneen ja varsinaiseen praxikseen. Edellinen oli teknisen osaajan tai sujuvan suorittajan taitoa, jonka usein yhdistämme samaa sananjuurta oleviin 'tekniikan' ja 'teknologian' käsitteisiin. Jälkimmäinen sen sijaan sijoittuu poliittiseen ja sosiaaliseen maailmaan, joka ei ole ja jonka ei tule kuvitella olevan koskaan valmiin. Sen sijaan sen piirissä asiat ovat, ja niiden tulee olla, alati kiistanalaisia. Analogiseen tapaan kuin poliittisessa demokratiassa - parlamentissa, yleisen mielipiteen ilmaisussa, vaaliuurnilla, kansalaisvaikuttamisessa - alituinen kiistely vallitsee siitä, miten asiat ovat ja miten niiden tulisi 
olla. Toivottakaamme tuollainen kiistely tervetulleeksi myös tieteen ja tutkimuksen piiriin. Niin toivon vastaavasti myös itse voivani tehdä, vaikka sitten tulisikin alati asettaa kiistanalaisiksi monetkin niistä käsityksistä, joihin alani tieteelliset ja muut auktoriteetit ovat sitoutuneet tai joita rakkaudella vaalitaan vaikkapa maamme julkisen hallinnon ja laajemman julkisen sektorin vahvoissa vaikuttajapiireissä.

\section{Lähteet}

Ahonen, P., J. Tala \& K. Hämäläinen. 2010. Politiikkatoimien vaikuttavuusarvioinnin menetelmien ja toimintatapojen kehittäminen. Sektoritutkimuksenneuvottelukunnan julkaisuja 8/2009. Helsinki: Opetusministeriö.

Archer, M., 2007. The trajectory of the morphogenetic approach. Sociologia, $54,35-47$.

Baumgartner, F. \& B.D. Jones. 1993. Agendas and instability in American politics. Chicago: University of Chicago Press.

Berger, P. \& T. Luckmann. 1966. The social construction of reality. Garden City, NY: Anchor Books.

Bittner, E. 1965. The concept of organization. Social Research, 32, 239-255.

Brunsson, N., 1989. The organization of hypocrisy: talk, decisions and action in organizations. New York: Wiley.

Brunsson, N., 2009. Reform as routine: organizational change in modern world. Oxford: Oxford University Press.

Charmaz, K. 2006. The power of names. Journal of Contemporary Ethnography, 35, 396-399.

Clegg, S. 2010. The state, power, and agency: missing in action in institutional theory? Journal of Management Inquiry, 19, 4-13.

DiMaggio, P. J. \& Powell, W.W. 1983. The iron cage revisited: institutional isomorphism and collective rationality in organizational fields. American Sociological Review, 48, 147-160.

Edelman, L.B., C. Uggen \& H.S. Erlanger 1999. The endogeneity of legal regulation: grievance procedures as rational myth. American Journal of Sociology, 105, 406-454. 


\section{Pertti Ahonen}

Garfinkel, H. 1967. Studies in ethnomethodology. Sivuviittaukset ovat käyttääni teoksen painokseen vuodelta 2010. Englewood Cliffs, NJ: Prentice-Hall.

Giddens, A., 1979. Central problems in social theory: action, structure and contradiction in social analysis. London: Macmillan.

Gieryn, T.F. 1983 Boundary-work and the demarcation of science from nonscience. American Sociological Review, 48, 781-795.

Gioia, D.A., K.N. Price \& J.B. Thomas. 2010. Forging and identity: an insideroutsider study of processes involved in the formation of organizational identity. Administrative Science Quarterly, 55, 1-46.

Glynn, M.A. \& R. Abzug. 2002. Institutionalizing identity: symbolic isomorphism and organizational names. Academy of Management Journal, 45, 267-280.

Goffman, E. 1959. The presentation of self in everyday life. New York: Doubleday.

Goffman, E. 1969. Minuuden riistäjät: tutkielma totaalisista laitoksista. Engl. alkuteos Asylums, 1961. Helsinki: Marraskuun like.

Goffman, E. 1967. Interaction ritual: essays on face-to-face behavior. New York: Anchor Books.

Greenwood, J. \& C.R. Hinings 2006. Radical organizational change. In: S. Clegg, C. Hardy, T.B. Lawrence \& W.R. Nord, toim. The Sage handbook of organization studies. 2. p. London: Sage.

Guenther, K.M. 2009. The politics of names: rethinking the methodological and ethical significance of naming people, organizations, and places. Qualitative Research, 9, 411-421.

Hannan, M.T. 2010. Partiality of membership in categories and audiences. Annual Review of Sociology, 36, 159-181

Holstein, J.A. \& J.F. Gubrium, toim. 2008. Handbook of constructionist research. New York: The Guilford Press.

Islam, G. \& M.J. Zyphur. 2009. Rituals in organizations: a review and expansion of current theory. Group and Organization Management, 34, 114-139.

Jepperson, R.L. 1991. Institutions, institutional effects, and institutionalization. In W.W. Powell \& P.J. DiMaggio, toim. The new institutionalism in organizational analysis. Chicago: University of Chicago Press.

Jepperson, R.L. 2001. The development and application of sociological neoinstitutionalism. European University Institute, Robert Schuman Centre, Working Paper 2001/5. Florence: EUI. 
Jepperson, R.L. \& J.W. Meyer 2011. Multiple levels of analysis and the limitations of methodological individualisms. Sociological Theory, 29, 54-73.

Krücken, G. \& G.S. Drori, toim. 2009. World society: the writings of John W. Meyer. Oxford: Oxford University Press.

Lamont, M. \& V. Molnár. 2002. The study of boundaries in the social sciences. Annual Review of Sociology, 28, 167-195.

Lee, C.K. \& D. Strang 2006. The international diffusion of public-sector downsizing: network emulation and theory-driven learning. International Organization, 60, 883-909.

Mahoney, J. 2001. Path-dependent explanations of regime change: Central America in comparative perspective. Studies in Comparative International Development, 36, 111-141.

McAdam, D., S. Tarrow \& C. Tilly. 2006. To map contentious politics. Mobilization: An International Journal, 1, 17-34.

Meyer, J.W. 2002. Globalization and the expansion and standardization of management. Teoksessa Kerstin Sahlin-Andersson \& Lars Engwall, toim. The expansion of management knowledge, 33-44. Stanford, CA: Stanford University Press.

Meyer, J.W. 2008.Reflections on institutional theories of organizations. Teoksessa R. Greenwood, C. Oliver, R. Suddaby \& K. Sahlin-Anderson, toim. The Sage handbook of organizational institutionalism. London: Sage.

Meyer, J.W. 2009. Reflections: institutional theory and world society. In G. Krücken \& G. Drori, toim. World society: the writings of John W. Meyer. Oxford: Oxford University Press.

Meyer, J.W., J. Boli, G.M. Thomas \& F.O. Ramirez. 1997. World society and the nation-state. American Journal of Sociology, 103: 144-181.

Meyer, J.W. \& R.L. Jepperson. 2000. The 'actors' of modern society: the cultural construction of social agency. Sociological Theory, 18, 100-120.

Meyer, J.W., F.O. Ramirez, D.J. Frank \& E. Schofer 2007. Higher education as an institution. Teoksessa P.J. Gumport, toim. The sociology of higher education. Baltimore, MD: The Johns Hopkins University Press.

Meyer, J.W. \& B. Rowan. 1977. Institutional organizations: formal structure as myth and ceremony. American Journal of Sociology, 83: 340-363.

Meyer, J.W. \& B. Rowan. 1983. The structure of educational organizations. Teoksessa, J.W. Meyer \& W.R. Scott, toim. Organizational environments: ritual and rationality. Beverly Hills, CA: Sage. 
Meyer, M.W. \& L.G. Zucker. 1989. Permanently failing organizations. Newbury Park, CA: Sage.

Modell, S. 2009. Institutional research on performance measurement and management in the public sector accounting literature. Financial Accountability and Management, 25, 277-303.

Negro, G., Ö. Koçak \& G. Hsu, G. 2010. Research on categories in the sociology of organizations. Research in the Sociology of Organizations, 31, 3-35.

Ocasio, W. \& Joseph, J. 2005. Cultural adaptation and institutional change: the evolution of vocabularies of corporate governance, 1972 -2003. Poetics, 33, 163-178.

Perrow, C.B. 2008. Complexity, catastrophe, and modularity. Sociological Inquiry, 78, 162-173.

Pierson, P. 2004. Politics in time: history, institutions, and social analysis. Princeton: Princeton University Press.

Pollitt, C. \& P. Hupe. 2009. Talking governance: the role of magic concepts. Paper at the EGPA 2009 Conference, 1-5 September, 2009. Malta: EGPA. Ilmestyy artikkelina P. Hupe \& C. Pollitt. 2011. Talking about government: The role of magic concepts. Public Management Review, 13.

Powell, W.W. \& J.A. Colyvas. 2008. Microfoundations of institutional theory. Teoksessa R. Greenwood, C. Oliver, R. Suddaby \& K. Sahlin-Andersson, toim. The Sage handbook of organizational institutionalism. London: Sage.

Power, M. 2009. The risk management of nothing. Accounting, Organizations and Society, 34, 849-855.

Power, M., T. Scheyt, K. Soin \& K. Sahlin. 2009. Reputational risk as a logic of organizing in late modernity. Organization Studies, 30, 301-324.

Schneiberg, M. \& M. Lounsbury 2008. Social movements and institutional analysis. Teoksessa R. Greenwood, C. Oliver, R. Suddaby \& K. SahlinAndersson, toim. The Sage handbook of organizational institutionalism. London: Sage.

Schuyt, T.N.M. \& J.J.M. Schuijt. 1998. 'Rituals and rules: about magic in consultancy. Journal of Organizational Change, 11, 399-406.

Strang, D. \& M.W. Macy. 2001. In search of excellence: fads, success stories, and adaptive emulation. American Journal of Sociology, 107, 147-182.

Suddaby, R. 2010. Challenges for institutional theory. Journal for Management Inquiry, 19, 14-20. 
Tolbert, P.S. \& L.G. Zucker. 1983. Institutional sources of change in the formal structure of organizations: the diffusion of civil service reform, 1880-1935. Administrative Science Quarterly, 28, 22-39.

Tolbert, P.S. \& L.G. Zucker. 1996. The institutionalization of institutional theory. Teoksessa S. Clegg, C. Hardy \& W.R. Nord, toim. Handbook of organization studies. Thousand Oaks, CA: Sage.

Valtioneuvosto. 2011. Pääministeri Jyrki Kataisen hallituksen ohjelma 22.6.2011. Helsinki: Valtioneuvosto.

VTV (Valtiontalouden tarkastuvirasto). 2010. Tuottavuusohjelman valmistelu ja johtaminen. Valtiontalouden tarkastusviraston tuloksellisuustarkastuskertomukset 207/2010. Helsinki: VTV.

Zerubavel, E. 1995. The rigid, the fuzzy, and the flexible: notes on the mental sculpting of academic identity. Social Research, 62, 1093-1106.

Zietsma, C. \& T.B. Lawrence. 2010. Institutional work in the transformation of an organizational field: the interplay of boundary work and practice work. Administrative Science Quarterly, 55, 189-221.

Zucker, L.G. 1977. The role of institutionalization in cultural persistence. American Sociological Review, 42, 726-743. 



\section{Kansalaisten vaikutusmahdollisuudet ympäristöpolitiikkaan}

Ympäristöpolitiikan oikeutus nojautuu isolta osaltaan siihen, että ihmiset haluavat turvallista ja puhdasta ympäristöä ja heillä on tähän oikeus ja ympäristöhallinnon velvollisuus on edistää tätä oikeutta (Jalkanen 1999, 5-6). Kansalaisten vaikutusmahdollisuuksia ympäristöpolitiikkaan on lisätty monin tavoin koko modernin ympäristöpolitiikan lyhyen historian ajan. Esimerkiksi vuonna 2000 voimaan tullut maankäyttö- ja rakennuslaki tähdentää vuorovaikutteista suunnittelua. Lain mukaan on selvitettävä hankkeiden merkittävät vaikutukset ihmisten elinoloihin ja elinympäristöön. Ympäristövaikutusten arviointimenettelyssä puolestaan selvitetään hankkeen vaikutuksia sekä luontoon että ihmisten terveyteen, elinoloihin ja viihtyvyyteen. Muita osallistumismahdollisuuksia lisääviä lakeja ovat mm. sosiaalisten vaikutusten arviointi (SVA) ja sekä suunnitelmien ja ohjelmien vaikutusten arviointi (SOVA). Osallisten piiri kaikissa näissä laeissa ja menettelyissä on koko se joukko, jota päätökset koskevat.

Kansalaisten vaikuttamismahdollisuuksia on edistetty myös hallitusten politiikkaohjelmissa ja hankkeissa. Vuosina 1998-2001 oli käynnissä sisäministeriön koordinoima osallisuushanke, jonka lukuisissa projekteissa pyrittiin edistämään kuntalaisten ja kunnallisten päätöksentekijöiden vuorovaikutusta (Kettunen 2002, 19). Matti Vanhasen ensimmäisen hallitus puolestaan käynnisti oikeusministeriön johdolla kansalaisvai- 


\section{Arto Lindholm}

kuttamisen politiikkaohjelman, jonka tarkoitus oli muun muassa edistää aktiivista kansalaisuutta ja edustuksellisen demokratian toimivuutta. Hankkeet kertovat lähinnä siitä, että valtiolla on suuri tarve tukea sopivan kilttiä kansalaisaktivismia saadakseen paremman oikeutuksen omalle politiikalleen.

Viime aikoina kansalaisvaikuttaminen on saanut uudenlaisen muodon, kun sosiaalisen median läpimurto on lähentänyt kansalaisia moniin päättäjiin. Kansalaiset voivat olla ministereiden ja muiden politiikkojen Facebook-kavereita ja yrittää viestittää oman mielipiteensä suoraan päättäjille. Lisäksi kansalaisia pyritään kouluttamaan vaikuttajiksi: ympäristökasvatuksen yksi keskeinen tavoite on innostaa lapsia ja nuoria ympäristöpoliittisiksi vaikuttajiksi ja osoittaa, millä eri tavoilla yksittäiset kansalaiset voivat vaikuttaa asioiden kulkuun (Koskinen 2010).

Kansalaisten osallistaminen on yhteiskunnallinen megatrendi, joka vaikuttaa lähes kaikkiin instituutioiden ja kansalaisten välisiin suhteisiin. Esimerkiksi yritykset eivät enää näe asiakkaita palveluiden passiivisina vastaanottajina, ja tulevaisuudessa asiakkaat ja kuluttajat sidotaan vielä nykyistäkin tiiviimmin tuotteiden ja palveluiden kehitystyöhön. Kulttuuripolitiikassa taas pyritään tukemaan kansalaisten omaehtoista tuotantoa ja osallistamaan kansalaisia vaikuttamaan taiteen sisältöihin. Ympäristöpolitiikassa osallistamiseetos näkyy kuitenkin selvempänä kuin millään muulla yhteiskuntapolitiikan sektorilla. Kansalaisten osallistamisella ympäristöpolitiikkaan on tavoiteltu päätösten parempaa hyväksyntää ja haluttu välttää konflikteja (Daley 2008, 22).

Kansalaisvaikuttamisen tärkeys on sisäänrakennettu kestävän kehityksen käsitteeseen. Vielä 1970-luvun alussa ympäristöliikkeet vaativat nollakasvua tai negatiivista talouskasvua ympäristötuhojen hillitsemiseksi. Kun sitten vuoden 1973 öljykriisin aiheuttama lama todellakin pienensi bruttokansantuloa ja aiheutti vakavan työttömyyden, vaimenivat vaatimukset talouskasvun kääntämisestä laskuun ${ }^{1}$. Kestävän kehityksen käsite sopi paremmin poliittiseen ilmapiiriin, ja hyväksytyksi lähestymistavaksi tuli talouskasvun, ympäristönsuojelun ja yhteisöllisyyden harmonia eli taloudellinen, ekologinen ja sosiaalinen kestävyys. (Buttel 2003.) Kansalaisten osallistaminen päätöksentekoon ja paikallisyhteisöjen mielipiteen huomioiminen alettiin nähdä tärkeänä osana kestävän kehityksen kaikkia kolmea ulottuvuutta. 
Ympäristöpolitiikkaan osallistumista jo 1990-luvulla tutkinut Jari Paldanius (1992, 18-22) jaottelee osallistumisen 1) institutionaaliseen välilliseen osallistumiseen (vaikuttaminen puolueiden kautta), 2) institutionaaliseen suoraan osallistumiseen (esim. osallistava kaavoituspolitiikka) ja 3) omaehtoiseen suoraan osallistumiseen (vaikuttaminen kansalaisjärjestöjen ja -liikkeiden kautta, suora toiminta, elämäntapa). Institutionaalisessa osallistumisessa aloitteentekijä on julkinen valta tai elinkeinoelämä ja omaehtoisessa osallistumisessa kansalaiset itse tai kansalaisjärjestöt. Institutionaalinen osallistuminen on suoraa silloin, kun instituutio tarjoaa puitteet ja kanavat osallistumiselle, mutta itse osallistuminen vaatii kansalaisen omaa panosta toimintaan. Tällaisia osallistumisen muotoja ovat esimerkiksi osallistava kaupunkisuunnittelu ja ympäristövaikutusten arviointimenettely. Välillisellä institutionaalisella osallistumisella Paldanius tarkoittaa parlamentaarista järjestelmää, jossa ihmiset ovat "poliittisia toimijoita lähinnä vain äänestäessään tai osallistuessaan puolueiden ja etujärjestöjen toimintaan” (emt., 21).

Paldaniuksen jaottelu on edelleen käyttökelpoinen tarkastelun lähtökohta, vaikka suomalainen kansalaisyhteiskunta on muuttunut kahden vuosikymmenen aikana melko paljon. Suurin muutos lienee se, että suoria institutionaalisia vaikutusmahdollisuuksia on huomattavasti lisätty ja epäsuorat vaikutusmahdollisuudet esimerkiksi sosiaalisen median kautta ovat ainakin teoriassa lisääntyneet. Nuori sukupolvi on myös omaksunut suoran omaehtoisen vaikuttamisen itselleen sopivammaksi vaikuttamistavaksi kuin vanhempi sukupolvi, mistä Villiina Hellsten ja Tuomo Martikainen (2001) puhuvat uutena politiikkana.

Ympäristöpolitiikan tutkijat ovat tarkastelleet kansalaisten vaikutusmahdollisuuksia osana demokraattista päätöksentekoprosessia (mm. Dryzek 1990). Uusin suuntaus tuntuisi olevan se, että tutkijat arvioivat kansalaisten osallistumisen vaikutusta ympäristölakien sisältöön (Daley 2008, 21). Ympäristötietous on levinnyt niin laajalle yhteiskuntaan ja vaikutusmahdollisuuksia on lisätty niin paljon, että Adrew Dobson ja Dereck Bell puhuvat jopa ympäristökansalaisuuden syntymisestä. Tällä he tarkoittavat ihmisten kasvamista alamaisuudesta, toiminnan kohteesta, aktiiviseksi toimijaksi. (Behme 2006.)

Vaikutusmahdollisuuksien lisääntyminen liittyy ympäristöpolitiikan hallintomentaliteetin muutokseen. Asiantuntijavaltaista normiohjausta 


\section{Arto Lindholm}

on purettu, ympäristöpoliittiset ohjauskeinot ovat monipuolistuneet ja päätöksenteosta on tehty avoimempaa kuin aikaisemmin. Ympäristöhallinto on tietoisesti pyrkinyt avautumaan kansalaisyhteiskunnan suuntaan ja suosimaan vapaaehtoisuuteen perustuvia ohjauskeinoja pakkojen ja märäysten sijasta. (Sairinen 2000.) Esimerkiksi luonnonsuojelupolitiikassa on otettu käyttöön maanomistajalähtöisyyteen perustuvia menetelmiä, kuten määräaikainen suojelu ja luonnonarvokauppa (Paloniemi 2008). Ympäristöhallinto ei ole enää luonnonsuojelutiedon yksinomainen hallitsija, vaan suojelusta päätetään vuorovaikutteisesti yksittäisten maanomistajien kanssa. Tämä on lisännyt maanomistajien vaikutusmahdollisuuksien lisääntymistä ilman, että kiintymyssuhdetta omaan maahan on tarvinnut purkaa.

\section{Kansalaisten vaikutusmahdollisuuksien rajoitukset}

Hallinnon muuttunut strategia on lisännyt luonnonsuojelun suosiota etenkin maaseudulla mutta aiheuttanut myös kritiikkiä. Kun maa- ja metsätalousministeri Sirkka-Liisa Anttila ei halunnut ehdottomia kieltoja verkkokalastukseen saimaannorpan pesimäalueella Saimaalla vuonna 2009, vaan pikemminkin luotti vapaaehtoisiin rajoituksiin, hän noudatti täysin ympäristöhallinnon uutta lähestymistapaa. Samalla kuitenkin monet kansalaisjärjestöt syyttivät ministeriä saimaannorpan ajamisesta sukupuuton partaalle. Tapaus osoittaa, että vastuun siirtämisellä kansalaisille on rajansa ja yhteiskunnassa tultaneen käymään vielä paljon keskustelua siitä, missä virallisten ja epävirallisten normien rajat kulkevat.

Kansalaisten ja kansalaisjärjestöjen vaikutusmahdollisuuksia ympäristöpolitiikassa ei muutenkaan pidä yliarvioida. Monet ympäristöpoliittiset kysymykset ovat erittäin monimutkaisia sekä teknisesti että juridisesti. Ympäristöjärjestöillä vain harvoin riittää asiantuntemusta ja aikaa perehtyä asioiden yksityiskohtiin - saati sitten yksityisten kansalaisten. Kun tutkin 2000-luvun alkupuolella Suomen roolia Euroopan unionin ympäristöpolitiikassa, havaitsin että Suomen kannat hyvin pitkälti määriteltiin suhteellisen suppeassa valmistelevien virkamiesten piirissä. Ympäristöjärjestöt saivat tietoa valmisteilla olevista laeista myöhäisessä vaiheessa 
ja usein tyytyivät toistamaan sen, mitä eurooppalainen kattojärjestö EEB oli asiasta jo sanonut. (Lindholm 2002, Ks. myös Daley 2008,22.)

Ympäristövaikutusten arviointimenettely (YVA) on myös hyvä esimerkki kansalaisten vaikutusmahdollisuuksien rajallisuudesta, vaikka paperilla kaikki näyttääkin hyvältä. Ympäristöhallinnon verkkosivujen (Ymparisto.fi 2011) mukaan YVAssa "vaikutusten arviointi tehdään suunnittelun yhteydessä ennen päätöksentekoa, jolloin on hyvät mahdollisuudet vaikuttaa ratkaisuihin ja jolloin voidaan vielä pohtia vaihtoehtoisia lähestymistapoja”. Kansalaisten osallistumismahdollisuuksia arvioinut Terhi Niinimäki (2011) kuitenkin näkee kansalaisten osallistumismahdollisuuksissa paljon puutteita. Hänen mukaansa kansalaisilla ei ole hankkeista riittävästi tietoa ja olennaiset päätökset on tosiasiassa tehty jo ennen vaikutusten arviointia. Kansalaisia kuunnellaan vain pinnallisesti eikä heidän mielipiteitään ole aina tarkoituskaan ottaa huomioon. YVAvaikuttaminen on pikemminkin kuulemista kuin aitoa kumppanuutta. (emt.)

Ei pidä myöskään liikaa innostua vaikuttamisesta sosiaalisessa mediassa. Saattaa olla, että aktivismi todella muuttaa muotoaan ja perinteinen kollektiivinen toiminta muuttuu solidaarisuudeksi tietoverkoissa. Toinen, ja paljon todennäköisemmältä tuntuva vaihtoehto on, että ihmiset huomaavat nettiklikkailun olevan loppujen lopuksi tehotonta ja kyllästyvät siihen uutuudenviehätyksen haihduttua. Vielä on liian aikaista sanoa, onko sosiaalisen median läpimurto todella lisännyt kansalaisten vaikutusmahdollisuuksia ympäristöpolitiikassa.

Kansalaisvaikuttamista ympäristöasioissa rajoittaa myös se, että suomalaiset eivät välttämättä pidä Suomea vastuullisena ympäristötuhoihin. Monet ympäristöasennetutkimukset (mm. Sairinen 1996) osoittavat, että suomalaiset kyllä ovat ympäristömyönteisiä, mutta suomalaisten mielestä ympäristöongelmat sijaitsevat jossain muualla kuin Suomessa, eivätkä suomalaiset ole näihin ongelmiin syypäitä. Rauno Sairisen (emt.) mukaan suomalaisilla on erityisen hyvä ekologinen omatunto, mutta tällainen lähtökohta ei välttämättä ole suotuisa kansalaisvaikuttamisen kannalta. Monet ympäristöliikkeet ovat joutuneet tekemään töitä tähdentäessään Suomen velvollisuuksia esimerkiksi ilmastopolitiikassa. Lisäksi asenteiden ja tekojen välillä on kuitenkin melkoisia ristiriitaisuuksia. Suomalaiset esimerkiksi kannattavat yrityksille suunnattujen ympäris- 


\section{Arto Lindholm}

töverojen korotuksia, mutta vastustavat tästä aiheutuvaa hinnannousua (emt.).

\section{Muuttuva kansalaisaktivismi}

Mitä kanavia pitkin kansalaisilla on mahdollisuus vaikuttaa? Suomea sanotaan usein järjestöjen ja yhdistysten luvatuksi maaksi eikä ihme, sillä yhdistysrekisterin (2011) mukaan Suomessa on reilusti yli sata tuhatta rekisteröityä yhdistystä. Kaikki aktiiviset kansalaiset eivät kuitenkaan halua olla mukana järjestötoiminnassa, jossa on omat hierarkiansa ja tarkoin määritellyt sallitut toimintatavat. Martti Siisiäinen (1998, 220) kutsuukin suomalaista kansalaisjärjestöinstituutiota vakavamieliseksi, sääntöihin takertuvaksi, puolueisiin kiinnittyneeksi ja jäsenistön spontaanin tahdon tukahduttavaksi toiminnaksi. Monet haluavat mieluummin toimia epämuodollisemmissa verkostoissa, joissa ilmapiiri on spontaanimpaa, tilapäisempää, vapaampaa ja vähemmän johtajakeskeistä kuin järjestöorganisaatioissa.

Kutsuin väitöstutkimuksessani (Lindholm 2005, 195-206) epämuodollisen aktivismin nousua verkostosukupolven aktivismiksi erotuksena järjestökeskeisen vaiheen kulta-ajasta. Myöhemmin Leo Stranius (2008) on puhunut samasta ilmiöstä osuvasti kevytaktivismina, jonka keskustassa on yksittäinen ihminen järjestön sijasta. Tällaisesta aktivismista tekee kevyttä sen vähäinen sitoutuminen mihinkään muuhun kuin omiin periaatteisiin ja omiin sosiaalisiin tarpeisiin. The Guardian-lehden toimittaja Micah White (2010) on puhunut kliktivismistä (clictivism) uutena vaikutusmuotona: yhä suurempi joukko ihmisiä kuuluu johonkin boikottitai solidaarisuusryhmään, johon on voinut liittyä esimerkiksi Facebookin tai Adressit.comin kautta. Kliktivismi haastaa perinteisen järjestötoiminnan: miksi vaivautua järjestöjen kokouksiin, kun voi vaikuttaa, tai ainakin kokea vaikuttavansa, omalta kotisohvalta? Järjestöillä kuitenkin on jatkuvuutta, varsinkin kun valtio tukee useimpien ympäristöjärjestöjen toimintaa ja tarjoaa niille vaikutusmahdollisuuksia. En siis väitä organisaation muotoon kehittyneiden järjestöjen olevan katoamassa, mutta jonkinlaisia muutospaineita niiden toimintaan liittyy. 
Kansalaisaktiivisuuden kenttä muuttaa muotoaan myös aaltomaisesti aktiivisuuden kasautuessa aika ajoin suoranaisiksi protestiaalloiksi. Protestiaaltojen aikana kansalaisjärjestöihin virtaa nopeasti uusia jäseniä ja eri järjestöt alkavat toimia yhteisen asian puolesta. Suuntaus tuntuisi olevan sellainen, että kun kansalaisten aktiivisuus muutenkin lisääntyy, verkostomainen aktiivisuus nousee järjestöjä tärkeämpään rooliin. Protestiaaltojen välissä olevina hiljaisina aikoina järjestötoiminta on jatkuvuutensa vuoksi epämuodollisia verkostoja tärkeämpää. Kansalaisten vaikuttamismahdollisuudet ovat erilaisia aallon eri vaiheissa: aallon huippuina suuretkin muutokset ovat ainakin periaatteessa mahdollisia, kun taas aaltojen välissä olevina hiljaisina aikoina kärsivällinen järjestötoiminta on ensisijainen vaikuttamisen muoto. (Lindholm 2005; Siisiäinen 1998.) Vaikuttaminen on aallon eri vaiheissa erilaista myös tunnetasolla: protestiaallon nousuvaiheessa innostuminen, humoristisuus ja ylpeys ovat päällimmäisiä tunteita, kun taas aallon lakastumisvaiheessa alistuminen ja kyynisyys saavat ylivallan (Lindholm \& Lundbom 2010, 178-179).

Esa Konttinen ja Jukka Peltokoski (2004) erottelevat suomalaisesta ympäristöaktivismista neljä aaltoa: ensimmäinen aalto liittyi 1960-luvun myllerryksiin, jolloin uuden polven luonnonsuojelujärjestöt alkoivat esittää yhteiskunnallisia vaatimuksia eivätkä enää tyytyneet luontoharrastuksen edistämiseen. Toinen aalto liittyy 1980-luvun taitteen ns. Koijärvi-liikkeeseen, joilla oli paljon suurempi yhteiskunnallinen merkitys kuin sinänsä arvokkaan lintujärven pelastaminen. Koijärvi-liike nautti kansalaisten laajaa kannatusta, edesauttoi ympäristöministeriön perustamista ja johti lopulta uuden puolueen, Vihreän liiton, perustamiseen. Ympäristöaktivismin kolmas aalto leimahti 1980-luvun lopussa nk. metsäsotina. Neljännen aallon harjalla kulki eläinoikeusliike, joka otti käyttöönsä Suomen oloissa poikkeuksellisen laittoman ja maanalaisen toiminnan. Eläinoikeusliike ehkä kuihtui protestiaaltona 1990-luvun lopussa, mutta Oikeutta eläimille jatkaa edelleen aktiivista toimintaansa. Liike on kuitenkin vaihtanut häkkien avaamiseen tarvittavat voimapihdit eläinten olojen videokuvaamiseen, ja saavuttanut uudella taktiikallaan ainakin osavoittoja.

Kun tarkastelin globalisaatiokriittistä aktivismia väitöstutkimuksessani (Lindholm 2005), oli kansalaisaktivismi uuden aaltonsa harjalla niin Suomessa kuin monissa muissakin maissa. Vaikka ympäristöasiat eivät 


\section{Arto Lindholm}

suoranaisesti olleet globalisaatiokritiikin ytimessä, tavoittelivat kriitikot myös ekologisesti tasapainoista ja oikeudenmukaista yhteiskuntaa. Globalisaatiokriittisen protestiaallon hulluina hetkinä aktivistit nousivat barrikadeille Göteborgin, Prahan, Genovan ja New Yorkin kaduilla vastustamaan talouden globalisaatiota sekä ylikansallisten yhtiöiden ja instituutioiden valtaa. Pienen hetken näytti jopa siltä, että kiivaaksi yltynyt aktivismi todella kykenee haastamaan poliittisen järjestelmän. Globaali kapitalismi kuitenkin tällä kertaa osoittautui joustavaksi ja itseään korjaavaksi järjestelmäksi, joka tuskin edes horjui siihen kohdistetun kritiikin voimasta.

Myös ympäristöjärjestöjen ja elinkeinoelämän suhde on huomattavasti muuttunut 1990-luvun alkupuolelta alkaen. Vielä 1980-luvulla yritykset pääsääntöisesti suhtautuivat suojeluvaatimuksiin pelkkinä kustannuksina, ja ympäristöasioista vastasi yrityksen lakimies. Nykyään useimmat yritykset arvioivat, miten he voisivat hyötyä ympäristöystävällisestä toiminnasta: esimerkiksi energian ja materiaalien säästäminen merkitsevät sekä kustannussäästöjä että ympäristönsuojelua. Hyvämaineisen yrityksen tuotteet käyvät paremmin kaupaksi ja näihin yrityksiin on helpompi värvätä ympäristötietoisia työntekijöitä. Ympäristöjärjestöt ovat monille yrityksille pikemminkin sidosryhmiä kuin vastustajia. Ympäristöjärjestöt ovat itsekin muuttuneet ja toimivat nykyään mieluummin hyvien asioiden puolesta kuin jotakin vastaan. (Ks. Joutsenvirta 2004, 83-85.)

Yritysten ja ympäristöjärjestöjen lähentymisen taustalla on yhteiskunnan läpiekologisoituminen. Tietous ympäristöongelmista on levinnyt laajalle yhteiskuntaan ja monissa yrityksissä on nykyään erittäin vahvaa ympäristöosaamista. Yleensä sekä yritykset että ympäristöjärjestöt pyrkivät win-win -tilanteeseen, jossa sekä ympäristö että talouselämä hyötyvät pitkässä juoksussa. Ympäristönsuojelulle on vaikeaa löytää selviä vastustajia, vaikkakin viime aikoina perussuomalaisia on syytetty jonkinlaisesta ympäristöänkyröinnistä.

Yhteistyö yritysten kanssa ei tarkoita sitä, että ympäristöjärjestöt olisivat yritysten talutushihnassa. Rauno Sairinen (2011) itse asiassa nostaa kansalaissäätelyn muiden ympäristöpoliittisten ohjauskeinojen, kuten normiohjauksen ja taloudellisten ohjauskeinojen, rinnalle. Kansalaisten boikottiuhka, hyvän imagon menettämisen pelko, ympäristöliikkeiden valvonta ja ympäristöjärjestöjen omat sertifiointijärjestelmät ovat ym- 
päristöpoliittisia ohjauskeinoja samalla tavalla kuin hallinnon toimenpiteet. Maria Joutsenvirta (2004, 74-82) erottelee viisi erityyppistä keinoa, joilla ympäristöliikkeet voivat vaikuttaa elinkeinoelämän toimintaan. Nämä ovat julkisuus, vaikuttaminen yritysasiakkaisiin ja kuluttajiin, vaikuttaminen lainsäädäntöön, vaikuttaminen yrityksiin osakeomistuksen kautta ja suora toiminta.

\section{Suora toiminta}

Suora toiminta on käsitteenä monimerkityksellinen. Yleensä sillä tarkoitetaan sellaista toimintaa, jossa kansalaiset ottavat tavalla tai toisella oikeuden omiin käsiinsä. Tästä näkökulmasta suoraa toimintaa ovat kansalaistottelemattomuustempaukset ja suoranainen maanalainen laiton toiminta, johon usein liittyy jonkinlainen väkivallan uhka. Ympäristöja eläinsuojelujärjestöjen valtavirta on irtisanoutunut tällaisesta suorasta toiminnasta säilyttääkseen vaikutusmahdollisuutensa ja taloudellisen tukensa. Kansalaisaktivistit itse tosin huomauttavat usein, että suoraa toimintaa on kaikki mihin ei liity välittävää tahoa. Tästä näkökulmasta esimerkiksi elämäntapavalinnat ovat suoraa toimintaa.

Nykyhetkessä on yleensä mahdotonta sanoa, ovatko kansalaistottelemattomat tulevaisuudessa sankareita vai roistoja. Kun esimerkiksi mustaihoinen Rosa Parks kieltäytyi luovuttamasta paikkaansa valkoihoiselle miehelle alabamalaisessa bussissa 1950-luvulla, hänet pidätettiin tästä rikoksesta. Nykyään lähes kaikki lienevät sitä mieltä, että Parks teki aivan oikein riippumatta siitä, mitä laki asiasta sanoi.

Toisena esimerkkinä voisi mainita Julia "Butterfly" Hillin, joka ei hyväksynyt tuhatvuotisen punapuumetsän kaatamista Kaliforniassa. Hill linnoittautui viisikymmentä viisi metriä korkeaan, Lunaksi nimeämänsä punapuun latvustoon eikä suostunut tulemaan siitä alas ennen kuin metsä on suojeltu. Hill pysyi Lunan latvassa yli seisemänsataa vuorokautta huolimatta jääkylmistä sateista, El Niño -myrskystä ja Pasific Lumber Companyn alituisista uhkailuista. Kamppailu päättyi Hillin voittoon ja nykyään Luna ja suojeltu punapuumetsä ovat Kalifornian eräs ylpeys ja suosittu matkailukohde. (Hill 2001.) 


\section{Arto Lindholm}

Läheskään aina kansalaisaktivisteista ei tule Parksin tai Hillin kaltaisia sankareita. Useimmiten yleinen mielipide on kansalaistottelemattomuutta vastaan - varsinkin jos toimitaan naamioituneena tai yön pimeydessä. Ympäristöjärjestöjä pidetään helposti jopa maanpettureina, jos ne pyrkivät tahraamaan esimerkiksi suomalaisen metsäteollisuuden maineen. Suomessa kansalaisaktivismin rauhanomaisuuden periaate on ollut erityisen voimakas, mutta radikaali eläinoikeusliike asettui räikeästi tätä periaatetta vastaan 1990-luvulla. Laittoman toiminnan tarkoitus oli avata häkkien ovia, päästää eläimiä karkuun ja aiheuttaa erityisesti turkistarhaajille huomattavia taloudellisia vahinkoja. Liike ei aluksi saanut kansalaisten keskuudessa juuri mitään kannatusta, mutta tilanne muuttui, kun eläinaktivistit ryhtyivät videokuvaamaan eläinten oloja turkistarhoilla ja sikaloissa. Voimapihtien vaihtaminen videokameraan siirsi aktivistit osittain samalle puolelle kuin viranomaiset ja yleinen mielipide, mikä osoittaa, kuinka tärkeää kansalaisaktivisteille on saavuttaa mediajulkisuutta. Merkittäviä konkreettisia tuloksia eläinoikeusliike ei kuitenkaan ole vielä saavuttanut, ja esimerkiksi turkistarhaus saa edelleen jatkua Suomessa.

\section{Arkielämän ympäristöpolitiikka}

Ilmo Massa työtovereineen (Massa ja Haverinen 2001; Massa \& Ahonen 2004) on puhunut arkielämän ympäristöpolitiikasta. Massan mukaan ympäristöpolitiikkaa ei voi ymmärtää pelkästään skenaarioina ja ohjauskeinoina, vaan yksittäisten ihmisten valinnat on myös nähtävänä poliittisena toimintana, pienenä ympäristöpolitiikkana. Ihmisten kulutusvalinnat ovat ilmeisintä pientä arkielämän ympäristöpolitiikkaa: jokainen ostopäätös voidaan ajatella äänestyslippuna, jolloin ihmiset voivat omalla toiminnallaan konkreettisesti vaikuttaa paremman ympäristön puolesta. Itse tosin haluaisin nähdä arkielämän ympäristöpolitiikan muunakin kuin kulutusmatematiikkana: mielestäni arkielämän ympäristöteot kumpuavat pienen ihmisen naiveistakin teoista, esimerkiksi roskien keräämisestä, puutarhan hoidosta tai vaikkapa puiden halaamisesta.

Ostosvalinnoilla vaikuttamisen tehoakaan ei pidä liioitella. Yleisesti ottaen ihmiset pitävät omia vaikutusmahdollisuuksiaan paljon parempina kuin ympäristöpolitiikan tutkijat ajattelevat niiden olevan. Tutkijoi- 
den mukaan monet syyt rajoittavat vaikuttamismahdollisuuksia ja toisinaan vaikuttaminen on näennäistä. Esimerkiksi Kirsi Eräranta ja Johanna Moisander (2004) huomauttavat, että ihmisten oletetaan tekevänsä päätöksensä rationaalisesti. Ihmisten kannattaa ostaa hinta-laatu -suhteeltaan mahdollisimman hyvä tuote, ja ympäristöystävällisin vaihtoehto ei yleensä tällainen ole. Toiseksi markkinat eivät ainoastaan tyydytä ihmisten tarpeita, vaan myös luovat ihmisille tarpeita, ja monet näistä tarpeista eivät liity suoraan tuotteen funktioon. Ostamalla esimerkiksi Nike-lenkkarit, ostetaan tossujen lisäksi vapautta tehdä mitä haluaa. Tuotteiden ympäristövaikutuksista on myös vaikea saada luotettavaa tietoa - erityisesti maailmanlaajuisista sosiaalisista vaikutuksista ja ympäristövaikutuksista. (emt., 2004.)

Kulutuskäyttäytymistä ohjaavat näkymättömät sosiaaliset normit ja sukupuoliroolit. Ihmisen esimerkiksi tuskin olisi pakko peseytyä joka päivä, mutta useimpien sosiaalinen normi käskee niin tekemään (Ks. Douglas 2011.). Miehen nössö auto taas viestittää siitä, että suorituskykyä ei löydy muillakaan elämänalueilla. Ihmisten valinnanvara on sekin osittain näennäistä. Vaikka isojen automarkettien hyllyillä vaikuttaa olevan runsaasti vaihtoehtoja, ovat tuotanto- ja jakeluketjut yksipuolistuneet ja tuhonneet satojen vuosien aikana syntyneen ruuantuotannon moninaisuuden (Silvasti 2004, 35).

Ehkä kaikkein eniten vaikutusmahdollisuuksia kuitenkin rajoittaa arjen pakkorako, suoranainen arjen terrori. Moni vanhempi herää varhain, vie lapset päivähoitoon, hakee lapset työpäivän jälkeen, käy kaupassa, valmistelee seuraavan päivän työt ja parhaana päivänä saa tunnin aikaa katsoa sarjaohjelmaa televisiosta. Voidaan kysyä kuinka monella tällaisella vanhemmalla on aikaa ja voimia tehdä itse ruokaa, kulkea hitailla ja hankalilla busseilla, pestä kestovaippoja ja muutenkin elää ympäristöystävällisesti? Jari Lyytimäki (2006) onkin puhunut kiireestä ympäristöongelmana. Arkielämän ympäristöpolitiikka vaatii aikaa, jota monella ei ole. Jos taas arkielämän ympäristöteot on varattu vain kaupunkien keskustoissa asuville sinkuille, ei sillä juurikaan ole merkitystä ympäristökuormituksen kannalta.

Viimeaikoina yleistynyt vaatimus elämän leppoistamisesta (downshifting) on aate, joka tähdentää elämänlaatuun liittyviä kysymyksiä hyläten jatkuvan suorittamisen ja kilpailun. Käytännössä leppoistaminen on vain 


\section{Arto Lindholm}

ani harvalle realistinen vaihtoehto. Erityisesti nykyisen epävarman taloustilanteen aikana ihmiset pikemminkin haluavat osoittaa kaikin keinoin olevansa tarpeellisia työntekijöitä. Tehokkuuden jatkuva parantaminen on myös Suomen ja Euroopan Unionin yhteiskuntapoliittinen tavoite, joka on kirjattu moniin keskeisiin asiakirjoihin (Lindholm 2002). Mikään ei todella viittaa siihen, että Allan Schneibergin (1980) tarkoittamasta tuotannon ja kulutuksen oravanpyörästä olisi oikeasti mahdollisuus irrottautua. Valtio edelleen tukee monin tavoin talouskasvua ja jo kasvun hidastuminen merkitsee joukkotyöttömyyttä ja muita vaikeuksia.

\section{Lopuksi: tarvitseeko ympäristöpolitiikka sittenkään aktiivisia kansalaisia?}

Olen tässä artikkelissa kuvannut kansalaisten ja ympäristöliikkeiden vaikutusmahdollisuuksia, mutta myös vaikuttamismahdollisuuksien rajallisuutta. Ihmisten osallistaminen päätöksentekoon aiheuttaa monenlaisia häiriötä päätöksentekojärjestelmään. Pia Bäcklundin ym. (2002, 10) mukaan "modernia yhteiskuntaa leimaa pitkälle eriytynyt työnjako, jossa erikoistutaan kapeasti määräytyviin ja erityistä asiantuntemusta vaativiin tehtäviin”. Ympäristöpoliittiset asiat ovat usein erityisen monimutkaisia ja erityistä asiantuntemusta vaativia. Maallikkojen osallistuminen asiantuntijatyöhön oman kokemuksensa kautta aiheuttaa usein tilanteita, joissa osapuolet eivät ymmärrä toisiaan eivätkä kielet kohtaa. Kansalaisten osallistuminen merkitsee väistämättä päätöksentekoprosessin hankaloitumista.

Kansalaisten osallistumismahdollisuuksien lisääminen on joka tapauksessa niin voimakas trendi, että päätöksenteon mutkistumisesta huolimatta paluuta vanhaan ei ole. Osallistuminen ympäristöpolitiikkaan vaatii hallinnolta sen modernille ajalle tyypillisen ajattelun hylkäämistä, että olisi jokin yhteisesti jaettu todellisuus, joka olisi saavutettavissa järkeilyllä ja keskusteluilla (ks. emt., 11). Kun todellisuudet ovat toisilleen ristiriitaisia, vaikuttaa siltä, että kansalaisten ääni jää hälyksi asiantuntijajärjestelmän taakse.

Kansalaiset voivat vaikuttaa suoraan päätöksentekoon tai ympäristöjärjestöjen kautta epäsuorasti. On kuitenkin kysyttävä, edustavatko ym- 
päristöjärjestöjen nokkamiesten äänet kansan mielipidettä sen paremmin kuin hallinnon asiantuntijan tai vaikkapa kansanedustajan? Osallistuminen kasautuu tietyille aktiivisille kansalaisille, joilla on valtaa vaikuttaa edustamiensa järjestöjen kautta. Näiden osallistumisen superkansalaisten käsitykset hyvästä ympäristöstä voivat kuitenkin olla hyvinkin erilaisia kuin niin sanottujen tavallisten ihmisten. Ympäristöjärjestöjen ääntä pidetään ehkä tarpeettomankin usein samana kuin kansalaisten ääni.

Ihmiset voivat yrittää vaikuttaa myös suoraan asioiden kulkuun, ilman järjestöjä välikätenä. Olen kuitenkin esittänyt, että nämä mahdollisuudet ovat kovin rajalliset. Jos ihmisten vaikutusmahdollisuudet ovat niin vähäiset kuin väitetään eikä arkisilla valinnoillakaan ole kovin paljon merkitystä, niin miten yhteiskunnan rakenteet muuttuvat vihreämmiksi? Materiaalivirtojen yläjuoksulla, siellä missä todella suuret ympäristövaikutukset syntyvät, vastaa Joseph Huber (2004). Tällä Huber tarkoittaa sitä, että tuotteiden suunnittelulla ja tuotantotavalla on paljon suurempi ympäristöpoliittinen merkitys kuin kuluttamisella materiaalivirtojen alajuoksulla.

Vaikuttamista koko tuotantoketjuihin ja etenkin tuotteiden suunnitteluun, kutsutaan ekologiseksi modernisaation strategiaksi. Tällöin luotetaan systeemitason ympäristöpoliittisiin ohjauskeinoihin sekä hallinnon ja teollisuuden yhteistyöhön. Olennaista ekologisessa modernisaatiossa on, että ihmisten nykyistä elämäntapaa ei olennaisesti tarvitse muuttaa. Yhteiskunnan perusrakenteissa oleva valuvirhe on mahdollista korjata parantamalla ekotehokkuus moninkertaiseksi parhaalla tekniikalla, teknologisilla innovaatioilla ja siirtymällä hiilineutraaliin tuotantojärjestelmään. Ekologisen modernisaation yhteiskunnassa edelleen voi kuluttaa surutta, ajella yksityisautoilla ja asua omakotitaloissa: kulutustavarat vain ovat fiksummin suunniteltuja, autot kulkevat vihreällä sähköllä ja talot ovat älykkäästi rakennettuja. Ekologisen modernisaation strategiaa ovat tehneet tunnetuksi muun muassa Joseph Huber (emt.), Gert Spaargaarden (1997) ja kotimaassa Ilmo Massa (1998) sekä Rauno Sairinen (2000).

Ekologisen modernisaation strategia on hyväksytty vallitsevaksi yhteiskuntapoliittiseksi linjaksi, vaikka siitä ei tätä nimeä käytettäisikään. Pyrkimys on joka tapauksessa talouskasvuun ja ympäristönsuojeluun samalla kertaa, josta usein puhutaan win-win -politiikkana - tai win- 


\section{Arto Lindholm}

win-win jos myös sosiaaliset tekijät halutaan huomioida. Vaatimuksia paluusta johonkin menneeseen ei oteta vakavasti, vaan yhteiskunnan rakennemuutosta pyritään kiihdyttämään. Tässä strategiassa kansalaisilla ja ympäristöjärjestöillä on vain politiikkaa tukeva merkitys: kannattamalla verotuksen painopisteen siirtämistä ja ostamalla ekotehokkaita tuotteita, kansalainen voi edesauttaa hyväksyttyä toimintalinjaa. Vaikuttaisi siltä, että myös ympäristötutkijoiden valtavirta luottaa ekologisen modernisaation linjaan, vaikkakin esimerkiksi Ilmo Massan (mm. 2008) kirjoituksista paistaakin tietty pessimismi ja paluu ajatukseen siitä, että avoin talous ei rajallisella maapallolla ole mahdollinen. Jos asia on näin, kansalaisia tarvitaan vallankumouksen tielle.

\section{Lähteet}

Behme, Christina 2006. Review: Environmental Citizenship. Andrew Dobson \& Derek Bell (Eds.). EGJ: Electronic Green Journal. http://escholarship.org/ uc/item/9hf9g0tp\#page-1. (20.11.2011.)

Buttel, Frederick 2003. Environmental Sociology and the Explanation of Environmental Reform. Luento Helsingin yliopiston sosiaalipolitiikan laitoksella.

Bäcklund, Pia \& Häkli, Jouni \& Schulman, Harry 2002. Osallisuuden jäljillä. Teoksessa Bäcklund, Pia \& Häkli, Jouni \& Schulman, Harry (toim. ) Osalliset ja osaajat. Helsinki: Gaudeamus, 7-17.

Daley, Dorothy 2008. Public Participation and Environmental Policy: What Factors Shape State Agency's Public Participation Provisions? Review of Policy Research, vol 25, issue 1, 21-25.

Douglas, Mary 2011. Pubtaus ja vaara. 4. painos. Suom. Virpi Blom \& Anna Maria Viljanen. Alkuteos Purity and Danger. An analysis of the concepts of pollution and taboo. USA: Routledge, 1992.

Dryzek, John 1990. Discursive democracy: Politics, policy, and political science. Cambridge: Cambridge University Press. 
Eräranta, Kirsi \& Moisander, Johanna 2006. Miten kuluttajaa hallitaan ympäristöpoliittisena toimijana? Teoksessa Massa, Ilmo \& Ahonen Sanna (toim.) Arkielämän ympäristöpolitiikka. Helsinki: Gaudeamus, 17-32.

Hellsten, Villiina \& Martikainen, Tuomo 2001. Nuoret ja uusi politiikka. Tutkimus pä̈̈kaupunkiseudun nuorten poliittisista suuntauksista. Helsinki: Helsingin kaupungin tietokeskus.

Huber, Joseph 2004. New Technologies and Environmental Innovation. Cheltenham: Edward Elgar Publishing.

Jalkanen, Pekka 1999. Esipuhe. Teoksessa Sairinen, Rauno \& Viinikainen, Tytti \& Kanninen, Vesa \& Lindholm, Arto: Suomen ympäristöpolitiikan tulevaisuuskuvat. Helsinki: Gaudeamus, 5-6.

Joutsenvirta, Maria 2004. Miten yritys kohtaa ympäristöaktivismin? Teoksessa Eva Heiskanen (toim.) Ympäristö ja liiketoiminta. Helsinki: Gaudeamus, 6990.

Kettunen, Pekka 2002. Miksi osallistumisesta puhutaan? Osallistumisen kehittäminen suomalaisissa kunnissa. Teoksessa Bäcklund, Pia \& Häkli, Jouni \& Schulman, Harry (toim. ) Osalliset ja osaajat. Helsinki: Gaudeamus, 18-35.

Konttinen, Esa \& Peltokoski, Jukka 2004. Ympäristöprotestin neljäs aalto. Jyväksylä: SopHi.

Koskinen, Sanna 2010. Lapset ja nuoret ympäristökansalaisina. Ympäristökasvatuksen näkökulma osallistumiseen. Helsinki: Nuorisotutkimusverkosto \& Nuorisotutkimusseura, Julkaisuja 98.

Levy, Neil 2005. Downshifting and Meaning in Life. Ratio, Vol. 18, Issue 2, $176-$ 189.

Lindholm, Arto 2002. Finland in EU environmental policy. Helsinki: Ministry of the Environment.

Lindholm, Arto 2005. Maailman parantajat. Helsinki: Gaudeamus.

Lyytimäki, Jari 2006. Unohdetut ympäristöongelmat. Helsinki: Gaudeamus.

Massa, Ilmo \& Ahonen, Sanna 2006 (toim.). Arkielämän ympäristöpolitiikka. Helsinki: Gaudeamus.

Massa, Ilmo 1998. Toinen ympäristötiede. Helsinki: Gaudeamus.

Massa, Ilmo \& Haverinen, Risto 2001. Arkielämän ympäristöpolitiikka. Esitutkimus. Helsinki: Ympäristöministeriö.

Massa, Ilmo 2009. Yhteiskuntatieteellisen ympäristötutkimuksen paradigmat ja keskeisimmät suuntaukset. Teoksessa Massa, Ilmo (toim.) Vihreä teoria. Helsinki: Gaudeamus, 9-46. 


\section{Arto Lindholm}

Niinimäki, Terhi 2011. Kansalaisten ja järjestöjen osallistumisen parantamismahdollisuudet Suomen ympäristövaikutusten arviointiprosessissa. Pro gradu -tutkielma. Helsinki: Helsingin yliopisto, bio- ja ympäristötieteellinen tiedekunta.

Paldanius, Jari 1992. Kansalaisten osallistuminen energiapolitiikkaan. Helsinki: Kuluttajatutkimuskeskus, julkaisuja 11.

Paloniemi, Riikka 2008. Luonnonsuojelu arjessa : maanomistajien näkemyksiä ja kokemuksia yksityismaiden tilapäisestä luonnonsuojelusta ja sen uudistumisen prosessista. Helsinki : Helsingin yliopisto, bio- ja ympäristötieteiden laitos.

Sairinen, Rauno 1996. Suomalaiset ja ympäristöpolitiikka. Helsinki: Tilastokeskus.

Sairinen, Rauno 2000. Regulatory Reform of Finnish Environmental Policy. Centre for Urban and Regional Studies Publications. Espoo 2000.

Sairinen, Rauno 2011. Ympäristöpolitiikan objauskeinot. Luentodiat. http:// www.joensuu.fi/oikeustieteet/nettirungot/Sairinen_2010_Ymp_ohjauskeinot_pdf. (20.11.2011.)

Schnaiberg, Allan 1980. The Environment. From Surplus to Scarcity. New York: St. Martin's Press.

Siisiäinen, Martti (1998). Uusien ja vanhojen liikkeiden keinovalikoimat. Teoksessa Ilmonen, Kaj \& Siisiäinen, Martti (toim.): Uudet ja vanhat liikkeet. Tampere: Vastapaino, 219-244.

Silvasti, Tiina 2006. Ruoka globalisoituu: kasvaako valinnanvapaus? Teoksessa Massa, Ilmo \& Ahonen Sanna (toim.) Arkielämän ympäristöpolitiikka. Helsinki: Gaudeamus, 33-56.

Spaargarden, Gert 1997. The ecological modernization of production and consumption: essays in environmental sociology. Wageningen.

White, Micah 2010. Clicktivism is ruining leftist activism. The Guardian. http:// www.guardian.co.uk/commentisfree/2010/aug/12/clicktivism-ruiningleftist-activism. (19.11.2011.)

Ymparisto.fi 2011. Ympäristövaikutusten arviointi YVA ja SOVA. Ympäristöhallinnon verkkosivut.

http://www.ymparisto.fi/default.asp?contentid=397473\&lan=FI. (20.11.2011.) 


\section{Viitteet}

1 Vaatimukset talouden hallituksi supistamiseksi ovat virinneet uudelleen degrowth-liikkeen myötä. Tämäkään liike ei ole kyennyt esittämään vakavasti otettavaa vaihtoehtoa tuotannon ja kulutuksen oravanpyörästä poishyppäämiseksi. 

Raimo Väyrynen

\section{Suomen pitkä linja: politiikka, talous ja globalisaatio}

Suomi on kehittynyt pohjimmiltaan murrosten ja kriisien kautta. Historiassa voidaan havaita kolme suurta murrosta, jossa maan taloudellinen tuotantotapa, poliittinen järjestelmä ja kansainvälinen asema ovat yhdessä ja erikseen muuttuneet. Jos jätetään pois Suomen liittäminen Venäjään vuonna 1809, joka muutti lähinnä vain maan kansainvälistä asemaa, niin keskeisiä murroksia on ollut kolme. Ensimmäinen niistä alkoi 1860-luvulla politiikan alkaessa järjestäytyä uudelleen ja teollisuuden lähtiessä kasvuun. Tämä muutos kiteytyi puoluejärjestelmän organisoitumiseen 1900-luvun alussa ja maan itsenäistymiseen vuonna 1917. Monissa suhteissa tämä murros jatkui kuitenkin aina toiseen maailmansotaan saakka.

Toisen maailmansodan jälkeen alkoi uusi murros, joka näkyi sekä taloudessa että politiikan rakenteissa ja sisällössä. Esiin nousi uusia poliittisia voimia ja valtion sananvalta taloudessa kasvoi. Maan politiikka oli epävakaata, vaikka sdp:n ja maalaisliiton koalitiota voidaan pitää eräänlaisena perusmallina. Uudenlainen aikakausi alkoi nostaa päätään 1980-luvulla ja muutoksen kätilönä toimi 1990-luvun alun syvä lama hieman samalla tavalla kuin 1930-luvun alun lama muokkasi maan politiikkaa. Edellistä kriisiä seurasi kasvuhakuinen punamultakoalitio, joka sulki kommunistit ja äärioikeiston poliittisen vallan ulkopuolelle. Jälkimmäisen yhteydessä Suomi taas siirtyi vakaiden, joskin vaihtuvien hallituskoalitioiden aikaan. 
Tähän kehitykseen vaikutti myös perinteisen luokkayhteiskunnan hajoaminen osaksi keskiluokan vahvistumisen vuoksi.

Taloudessa syvin muutos oli 1980-luvulta lähtien sen avautuminen globalisoituvaan maailmaan. Tosin se ei tapahtunut ilman taloudellista tuskaa, eikä Holkerin hallituksen "hallittu rakennemuutos" vuosina 1987-91 riittänyt hallitsemaan kasinotaloudeksikin kutsuttua murrosta, vaan ajauduttiin kriisipolitiikkaan. Kasinotalous oli seurausta luotonannon kasvusta, kevyestä talouspolitiikasta sekä pörssikurssien räjähtävästä kasvusta (Kiander \& Vartia 1998, 69-73). Jäsenyys Euroopan unionissa vuodesta 1995 vaikutti voimakkaasti koko yhteiskuntaan. Kun edellisellä kaudella valtion merkitys taloudessa oli ollut vahva, niin se alkoi nyt supistua. Poliittisen ohjauksen heikkeneminen yhteiskunnassa merkitsi tavallaan paradoksaalisesti sitä, että hallituskoalitioista tuli pysyvämpiä (Väyrynen 1999a).

\section{Suomen asema vuodesta 1809}

Suomea koskeneissa muutoskriiseissä ovat yhdistyneet geopolitiikan ja talouden murrokset sekä toisaalta jatkuvuus. Yleensä geopolitiikka on kulkenut Suomen historiassa kylki edellä ja talous on saanut mukautua poliittisiin muutoksiin. Geopolitiikan suurena kysymyksenä on ollut Suomen sijainti Venäjän/Neuvostoliiton luoteisella raja-alueella, pääkaupunki Pietarin sijaitessa pari vuosisataa rajan pinnassa. Suomen valloitus vuosien 1808-1809 sodassa voidaan johtaa tsaarinvallan pyrkimykseen suojata strateginen ja taloudellinen ydinalueensa Ruotsia vastaan (Lieven 2000, 214-15). Tämä oli luonnollinen näkemys, koska Ruotsi näki Suomen suurvalta-asemansa etulinjassa ja puskurina Venäjää vastaan. Vastaava strateginen intressi oli 1900-luvulla Neuvostoliitolla, jolle ensiksi Saksa ja sitten Yhdysvallat nousivat strategisiksi haastajiksi. Paasikiven toteamus itänaapurin strategisesta puolustusintressistä Suomessa kannattaa ottaa vakavasti.

Suomen sota 1808-1809 merkitsi tietysti kansalle inhimillisiä ja taloudellisia kärsimyksiä, mutta eliitti sopeutui nopeasti Pietarin komentoon, ja kansakin alkoi rakastaa tsaaria. Eliitin sopeutumisessa keskeisenä syynä oli, että Venäjä integroi aateliston tehokkaasti osaksi virkakoneistoaan. 
Ruotsin kaudelta periytyneiden aatelisarvojen lisäksi tsaari aateloi myös suomalaisia sukuja ja lujitti näin suhdettaan uuteen suuriruhtinaskuntaansa. Uudet aateliset saivat myös vahvan otteen julkiseen hallintoon: "aateli ja hallitseva byrokratia samastettiin". Tämän seurauksena aatelisto alkoi muuttua asteittain virkamiessäädyksi. Toisaalta sen poliittinen vaikutusvalta säilyi vähintäänkin säätyvaltiopäivien päättymiseen vuonna 1906. Itse asiassa näiden valtiopäivien perustaminen antoi aatelistolle ensimmäisenä säätynä muodollisen poliittisen aseman ja eräänlaisen vetooikeuden politiikassa (Ruuskanen, Snellman \& Widgrén 2010, 37-48).

Eliitin sopeutumista uuteen komentoon helpotti siis Pietarin päätös antaa sen pitää vanhat etuoikeutensa - jopa mahdollisuuden hankkia uusia etenemisväyliä imperiaalisessa hallinnossa. Suomelle vakiintui poliittinen väliasema, jossa yhdistyivät itäinen riippuvuus, läntiset laitokset ja oma kansantalous. Siitä tuli "eräänlainen valtiomuodostuma" (Alapuro 2011, 529-30). Keskeisenä syynä Venäjän myöntyvyydelle oli sen strateginen intressi: Pietarille riitti Suomen poliittis-sotilaallinen hallinta, eikä maahan yritetty tuoda vierasta aristokratiaa ja maaorjuutta. Takapakkia tuli vasta vuonna 1899 alkaneessa panslavistisessa sortokaudessa, joka johti venäläistämispolitiikkaan osana laajempaa eurooppalaista kehitystä.

Strategisesti Suomen asemaa helpotti se, että Ruotsi luopui vanhasta politiikastaan, eikä harjoittanut enää taloudellisten ja sotilaallisten resurssien puuttuessa voimapolitiikkaa Itämerellä, vaikka pitikin suotavana Englannin läsnäoloa alueella. Vuoden 1809 jälkeen Suomen ja Venäjän raja oli "luonnollinen": se oli fyysisesti olemassa mutta läpikuljettavissa. Heikki Talvitie (2008) on kutsunut Ruotsin tätä aina 1990-luvulle kestänyttä ratkaisua "vuoden 1812 politiikaksi". Tosin tämän ratkaisun aikaansaaminen ei Tukholmassa ollut mitenkään yksiselitteinen prosessi, vaan hallinnossa oli voimakkaitakin fraktioita, jotka halusivat Englannin avulla valloittaa Suomen takaisin. Uuden kuninkaan Carl Johanin eli Bernadotten linjana oli kuitenkin katsoa tilannetta reaalipoliittisesti ja pikemminkin sopia Venäjän kanssa kuin uhitella sitä alakynnestä uudella sodalla. Tärkeämpää oli hankkia omistusoikeus Norjaan ja siten oma "luonnollinen" raja Atlantille (Willestrand 2009, 321-39; Wahlbäck 2011, 17-27).

Poliittisesti Suomen asema muuttui vuonna 1809 Ruotsin alamaisuudesta autonomiseksi osaksi venäläistä imperiumia. Kuten todettua, tämä 
muutos ei ollut institutionaalisesti järisyttävä, koska oikeudessa ja kulttuurissa säilyi pohjoismainen järjestelmä. Ruotsin valtiosäännön kuningaskeskeisyys helpotti sopeutumista Venäjän vallan alle sikäli, että tsaari sai tätä kautta tavallaan automaattisesti haluamansa valtaoikeudet myös Suomessa. Hänen Porvoon maapäivillä antamansa tunnustus Suomen asemalle ei siis ollut mikään syvällinen myönnytys, vaan se heijasti valloituksen strategisia tavoitteita ja siihen liittyvää pehmeänpuoleista poliittista linjaa.

Henry Kissinger (1994, 78-102) on korostanut, kuinka Napoleonin sotien jälkeinen aikakausi korosti dynastioiden merkitystä, hallitsijakeskeisyyttä ja kotimaista järjestystä. Se oli nationalismin ja siihen liittyvien muutosvaatimusten vastaista. Suomen eliitin sujuva siirtyminen, vailla kapinointia, tsaarin alamaisiksi sopi hyvin tähän Zeitgeistiin. Maassa vahvistui ylhäältä päin ohjattu autoritaarinen säätyläisvalta, jota vasta kieliriita 1800-luvun lopulla vasta alkoi hajottaa (Haapala 2010, 27-30). Suomalaisten reaalipolitiikka ja keisarilojaliteetti saavuttivat huippunsa vuonna 1863, kun J.V. Snellmanin johdolla maan poliittinen eliitti varoitti ottamasta oppia Puolan kansannoususta Venäjää vastaan (Savolainen 2006, 709-11).

Ruotsalaisperäisen järjestelmän säilymisellä Suomessa oli myös pitemmän aikavälin vaikutuksia. Ilman sitä olisi ollut huomattavasti vaikeampaa siirtyä 1860-luvulla säätydemokratiaan ja omaan markkavaluuttaan. Kuusi vuosisataa, vaikka alisteisena Ruotsin valtakunnan osana, olivat luoneet Suomeen idean oikeusvaltiosta ja sittemmin kansalaisyhteiskunnasta. Niistä kumpaakaan ei ole koskaan varsinaisesti ollut itänaapurissamme. Itsenäiset talonpojat ja nouseva älymystö vahvistivat näitä piirteitä, kun taas vahva virkamieskunta oli kansallisessa muutoksessa varovainen ja jopa hidastava voima. Virkamiehet olivat sitä paitsi siviiliviroissa, koska Ruotsin vallan aikainen ruotujakolaitos oli lakkautettu vuonna 1810, eikä Suomessa ollut omaa varsinaista armeijaa.

Kun Suomi irtautui Ruotsista, mutta sidottiin Venäjään hallitsijatasolla, niin maasta tuli eräänlainen välivyöhyke. Kun taloudelliset siteet olivat molempiin suuntiin osittaisia, niin voidaan puhua Osmo Jussilan mainitsemasta omasta "talousvaltiosta nimeltä Suomi", jolla ei kuitenkaan ollut erillistä perustuslaillista asemaa. Tällä "talousvaltiolla" oli kui- 
tenkin omat rajansa, jotka mahdollistivat kansantalouden ja kansallisten markkinoiden synnyn.

Suuriruhtinaskuntana Suomi ei ollut Venäjän imperiumissa poliittisesti itsenäinen, mutta sillä oli oma liikkumavaransa, kansallinen autonomiansa. Jussilalla on varma näkemys siitä, että osana Ruotsia Suomesta ei olisi tullut itsenäistä valtiota. Sen sijaan ”Venäjän keisarikunnan monikansallinen ja monivaltioinen...rakenne teki mahdolliseksi niin Suomen valtion synnyn kuin kehityksenkin” (Jussila 2004, 793). Tämän Suomen kansainvälisen väliaseman mahdollisti kansalaisten lojaalisuus Venäjää ja erityisesti keisaria kohtaan, jota varsinkin ennen sortovuosia suorastaan palvottiin ja joka toisaalta koki Suomen suorastaan turvapaikkana (Engman 2009, 192-214). Suomi haki liikkumavaraa olemalla poliittisesti harmiton ja jopa myötäsukainen. Myöntyvyyspolitiikalla, suomettumisella jos niin halutaan, on meillä vanhat perinteet.

Koko autonomian ajan omavarainen maatalous oli talouden ydin: sen osuus kansantaloudesta oli kahdeksankymmentä prosenttia. Huonoina vuosina ja pohjoisessa osassa maata oltiin riippuvaisia viljan tuonnista. Tervakaupan ehtyessä vienti supistui entisestään ja Suomi eristäytyi taloudellisesti. Kun Ruotsin markkinat pääosin sulkeutuivat vuoden 1809 jälkeen, niin talouden uudenaikaistuminen aluksi viivästyi. Erityisen pahasti markkinoiden sulkeutuminen iski rautateollisuuteen, jota ruotsalaiset olivat sijoittaneet Suomeen säästääkseen omia metsävarojaan. Suomen oli löydettävä uusia markkinoita vientituotteilleen ja kun vanhat eivät vetäneet, niin tarvittiin rakennemuutosta taloudessa. Koski- ja höyryvoiman valjastaminen mahdollistivat metalli- ja koneteollisuuden mekanisoinnin. Vesi- ja rautateihin nojaavaa infrastruktuuria alettiin kehittää valtion johdolla nousevan talouden tarpeisiin. Rautatie- ja kanavapuolue saivat keskenään aikaan kotimaisen poliittisen kädenväännön (yleisesti ks. Junnila 1986, 57-76; Savolainen 2006, 658-61).

Tultaessa 1800-luvun jälkipuoliskolle Suomen suuriruhtinaskunnan taloudellinen yhdentyminen emämaahan voimistui: talous seurasi politiikan lippua osaksi siksi, että muita vaihtoehtoja ei juuri ollut. Saimaan kanava, Pietarin rata ja muut valtion tukemat talouden perusrakenteen hankkeet mahdollistivat sekä teollisuustuotteiden että kulutushyödykkeiden kasvavan viennin Venäjälle. Suomi alkoi yhdentyä strategisesti läheiseen Pietarin talousalueeseen jopa niin, että ennen itsenäisyyttä Ve- 
näjän kanssa käytiin kahdeksankymmentä prosenttia Suomen rajat ylittävästä kaupasta. Venäjän paperiteollisuuden alikehityksen vuoksi suomalaisille yrityksille syntyivät siellä valtavat markkinat. Sanottiin jopa, että suomalaiset "hallitsivat Venäjän paperimarkkinoita", joilla suomalainen puuta hyödyntävä, sellupohjainen tuotanto sai etulyöntiaseman. Toisaalta Venäjän epätasaiseen taloudelliseen kehitykseen liittyi, että sen sahatavaran vienti kilpaili länsimarkkinoilla Suomen kanssa. Kotimarkkinateollisuus alkoi myös vahvistua (yleisesti ks. Apunen 1987, 82-92).

Suomen teollisuuden kannalta oli tärkeää Englannin siirtyminen vapaakauppaan 1840-luvulla. Suomalaisen ja ruotsalaisen puutavaran kilpailuasetelma parani tullien laskun myötä ennen kaikkea Kanadaan verrattuna. Samalla kansainvälisten markkinoiden avautuminen mahdollisti Suomessa siirtymisen tervasta sahateollisuuden nousuun ja siten uutta arvoketjua luovan sahateollisuuden syntyyn. Liikenne- ja kommunikaatioyhteyksien paraneminen edisti talouden rakennemuutosta (Kuisma 2011, 25-41). Suomi hyötyi Englannin 1800-luvun maailmanlaajuisesta taloudellisesta hegemoniasta ja sen avaamista taloudellisista rajoista, mikä auttoi puolestaan pääoman "primitiivistä" kasautumista. Tässä kamppailussa perinteinen rannikkojen kauppaporvaristo ja metsiä omistavat talonpojat joutuivat hakauksiin ja jälkimmäisten suhteellinen voitto vahvisti heidän yhteiskunnallisia asemiaan (Kuisma 2011, 93-99).

\section{Periferian geopolitiikkaa}

Suomen kansainvälistä taloudellista asemaa on kuvattu wallersteinilaisen maailmanjärjestelmäanalyysin käsitteillä, jonka mukaan se on edennyt periferiasta semiperiferian kautta maailmantalouden ytimeen (Nyyssölä 2011). Suomen asemoiminen tähän luokitteluun ei ole kuitenkaan helppoa sen taloudellisen väliaseman vuoksi: kyse oli "välittäjätaloudesta". Pitkälle toisen maailmansodan jälkeistä aikaa Suomi vei länteen metsäteollisuuden bulkkitavaraa ja itään pitemmälle jalostettuja tuotteita. Tämän mahdollisti autonomian aikana hankittu asema "privilegiotaloutena" sekä sotakorvausten tuottama viennin monipuolistuminen metalliteollisuuteen. Suomen suhdetta länteen on taas kuvattu Kanadan mallin mukaan "tapulitaloutena", mihin ei kuitenkaan sovi hyvin se, että Suomen 
viennissä jo suhteellisen aikaisin oli mukana sangen pitkälle jalostettuja tuotteita (Kerkelä 2006, 70-83). ${ }^{1}$

Voidaan sanoa, että osana Venäjän imperiumia Suomi saavutti teollisuuden teknisen kehityksen vuoksi aseman, jolla se saattoi aloittaa itsenäisyyden jälkeen puun ja paperin avulla kilpailun länsimarkkinoilla kun itäraja sulkeutui vuoden 1918 jälkeen. Teollistumisen myötä Suomeen syntyi perinteisen kauppaporvariston rinnalle uusi teollisuuseliitti, joka suhteellisen pienillä pääomapanoksilla, toki riskejä ottaen, hankki määräysvallan maan taloudessa ja politiikassakin. Tämä eliitti oli keskeisesti mukana Suomen itsenäisen valtion rakentamisessa - otti sen tavallaan haltuunsa - ja ohjasi ulkopolitiikkaa eurooppalaiseen ja erityisesti anglosaksiseen suuntaan. On jopa puhuttu rosvoparoneista (Kuisma 2010), joita tuskin kuitenkaan olisi ollut ilman autonomian suojassa tapahtunutta alkuperäistä vaurastumista. Suurta osaa talouselämää hallitsivat toiseen maailmansotaan saakka viralliset tai epäviralliset kartellit, joiden talouselämän eliitti solmi keskenään (Kallioinen ym. 2010, 59-61).

Itsenäistyminen oli aloitettava tavallaan nollatilanteesta: prioriteetteina olivat ulkosuhteissa kansainvälisen tunnustuksen hankkiminen sekä taloussuhteiden avaaminen. Tunnustuksen osalta avainasemassa oli Venäjän myönteinen päätös, mikä saatiinkin, tosin bolshevikkien omilla tausta-ajatuksilla. Ulkomaankaupassa poliittinen ohjaus oli vähäistä ja vastuu jäikin talouselämän edustajille, jotka käyttivät sitä mielellään, tosin osaksi pakkotilanteessa. Valtion vaikutus näkyi ensisijaisesti yritysten kiristyneenä verotuksena ja vientitullien perimisessä. Suomeen syntyi kauppapolitiikassa heti itsenäisyyden jälkeen voimakas korporatiivinen järjestelmä, jossa liike-elämä edusti myös valtion etuja. Paperiyhtiöt, samoin kuin tekstiiliteollisuus, perustivat nyrkikseen kartellimaisen keskitetyn myyntijärjestelmän (Aunesluoma 2011, 23-33). Ei tarvitse paljoakaan liioitella, kun toteaa, että tämä korporatiivinen järjestelmä säilyi koko maailmansotien välisen ajan ja jatkui ainakin 1970-luvulle, tosin toisen maailmansodan jälkeen uusissa kansainvälisissä olosuhteissa.

Siirtyminen Ruotsin vallasta Venäjän alamaiseksi merkitsi tuntuvaa muutosta Suomen kansainvälisessä asemassa. Todellisuudessa Suomi irrotettiin suurvaltapolitiikasta noin sadaksi vuodeksi, vaikka esimerkiksi Puolan kapinat vuosina 1830 ja 1863 loiskivat myös Suomen rannoille. Tosin "Oolannin sota" toi brittilaivaston toisen rintaman avaamiseksi Itä- 
merelle ja Suomen rannoille, mutta mitään mittavia taisteluita ei käyty; vaikka voidaan mainita Viaporin pommitus, Bomarsundin hävittäminen ja Halkokarin kahakka. Tässä mielessä Englannin sodanpäämäärät Krimin sodassa epäonnistuivat Itämerellä, vaikka Palmerston pyrki jatkamaan Krimin sotaa Venäjän tehokkaammaksi patoamiseksi. Tähän politiikkaan kuului Suomen irrottaminen Venäjästä ja Baltian maiden liittäminen Preussiin (Figes 2010, 400-402). Krimin sota erotti myös lopullisesti Suomen ja Ruotsin poliittisesti, ja osin kulttuurisesti, toisistaan: siitä tuli "vedenjakaja" suomalaisten alkaessa yhä vahvemmin kehittää omaa kansallista kulttuuriaan. (Wahlbäck 2011, 73-82).

Geopolitiikka oli siis läsnä Suomen suhteissa ulkomaailmaan myös 1800-luvun pitkän rauhan vuosina. Tosin noina vuosina poliittinen johto Helsingissä pyrki eristämään Suomen eurooppalaisesta voimapolitiikasta, koska siihen kietoutumisesta ei kuitenkaan seuraisi mitään hyvää. Eurooppalaisen valtapolitiikan ei sallittu tunkeutua kotimaiseen kehitykseen. Krimin sodan aikana suomalaiset päättäjät valitsivat kuitenkin geopoliittisen puolensa: kuulumisen autonomisena osana Venäjän imperiumiin.

Kansalaisyhteiskunnan kehityksessä nouseva liberalismi ja sosialismi olivat tärkeitä poliittisia voimia. Ne laajensivat sekä henkistä että sosiaalista liikkumatilaa. Suomen kansallinen nousu on usein selitetty poliittisten puolueiden, nuorisoseurojen, raittiusliikkeen ja muiden kansalaisjärjestöjen sosiaalisena mobilisaationa. Epäilemättä on näin, mutta toisaalta suomalainen kapitalismi, selviydyttyään nälkävuosien kuripolitiikasta ja venäläispainostuksesta, loi pohjaa kansallisen liikkeen nousulle, mutta samalla alkoi luoda omaa poliittista agendaansa. Suomalaisen nationalismin nousua ei voi ymmärtää ilman uuden nousevan taloudellisen eliitin panosta.

\section{Kohti uutta yhteiskuntaa}

Itsenäisyyden koittaessa suomalaisen yhteiskunnan merkittävimpiä kysymyksiä, sisällissodan traumojen lisäksi, olivat sen demokraattisen luonteen määrittely ja suhteen rakentaminen kapitalistiseen maailmanta- 
louteen. Sisällissota oli erityisen traumaattinen siksi, että siinä romahti usko kansalliseen edistykseen ja yhtenäisyyteen. Risto Alapuro korostaa, kuinka kyseessä oli "erittäin epätodennäköinen sota”. Vaikka maassa oli eriarvoisuutta ja tyytymättömyyttä, niin hän katsoo kuitenkin Venäjän vallankumouksen aikaansaaman nopean poliittisen kriisin, siis ulkoisen vaikutuksen, olleen sodan keskeinen ponnin. Vaikka sota ja sitä edeltävä poliittinen kriisi olivat lyhyitä, niin seuraukset olivat pitkäkestoisia. Niihin kuului valkoisen Suomen 1920- ja 1930-luvuilla kokema "viiden kolonnan ongelma" eli kommunistien sulkeminen poliittisen yhteiskunnan ulkopuolelle (Alapuro 2011, 530-33).

Hieman Alapurosta poiketen voidaan kuitenkin sanoa, että yleisesti myönnettiin maanomistusolojen epäoikeudenmukaisuuden olleen sisällissodan taustalla. Suomalaiseen demokratiaan tarvittiin sosiaalista ulottuvuutta, jota toi maareformi 1920-luvun alussa. Sitä tuskin olisi toteutettu samassa mitassa ilman sisällissotaa, joka siten toimi tavallaan yhden sosiaalireformin siemenenä. Lex Kalliolla luotiin itsenäinen (pien) talonpoikien luokka, joka maalaisliiton kautta lopulta suuntautui poliittiseen demokratiaan. Samalla uudistus pirstoi puuyhtiöiden valtavia metsäomaisuuksia. Poliittisesti merkittävää on, että reformi kohdistui talonpoikiin, eikä työväestöön, jota pidettiin sotaan syyllisenä. Työväestöä koskevat uudistukset viivästyivät ja alkoivat toden teolla vasta toisen maailmansodan jälkeen.

Maailmansotien välillä ei ollut toimivaa kapitalistista maailmantaloutta: tosiasiallisesti johtava talousvalta Yhdysvallat oli poliittisesti eristäytynyt, Englanti oli vetäytymässä hegemoniastaan, Venäjä sulki rajansa, kultakanta oli henkitoreissaan, eikä vapaakaupalle saatu pitäviä kansainvälisiä takeita. Poliittiset tavoitteet alkoivat ohjata useimman valtion talous- ja kauppapolitiikkaa. Saksa nosti päätään vaatimalla alueellista Lebensraumia oman poliittisen ja taloudellisen asemansa vahvistamiseksi. Suomi yritti näissä tukalissa oloissa pitäytyä mahdollisuuksiensa mukaan kartellipohjaiseen vapaakauppaan yhdessä muiden pohjoismaiden kanssa (Aunesluoma 2011, 47-49).

Suomella oli maailmansotien välillä kaksoishaaste: sen piti rakentaa sekä valtio että markkinat, joskaan ei aivan tyhjästä, niin kuitenkin uudelta pohjalta. Teoreettisessa kirjallisuudessa on painotettu, että siirtyminen kapitalismiin edellyttää sopimusta omistusoikeuden luonteesta, ta- 
loudellisen vaihdon säännöistä sekä hallintarakenteista. Tehtäessä näitä sopimuksia syntyy erilaisia liittoja kapitalistien, työläisten, maanviljelijöiden ja byrokratian välillä, jotka ovat lopulta sangen pysyviä luonteeltaan. Markkinatalouden sopimusten ja allianssien sekä niitä ylläpitävien valtarakenteiden kestävyys testataan toistuvissa taloudellisissa ja poliittisissa kriiseissä. Niissä on yleensä kyse jakokonflikteista, joissa materiaalisia ja symbolisia arvoja jaetaan uudelleen (Fligstein 2001, 36-53).

Maailmansotien välillä Suomessa vallitseva allianssi solmittiin porvarillisten puolueiden ja puunjalostusteollisuuden välille. Tosin hallitukset toimivat usein vähemmistön varassa ja olivat lyhytaikaisia, kun taas teollisuuden puolella oli jatkuvaa kädenvääntöä vientiteollisuuden ja tuontia korvaavan kotimarkkinateollisuuden välillä. Maatalous oli pitkälle omavaraista, vaikka varsinkin voita vietiin ulkomaille, ja sen tuottavuus oli sangen alhainen. Kapitalismin läpimurtoa koskevissa tutkimuksissa on painotettu, kuinka teollistumisen edellytyksenä oli maatalouden tehostaminen, jotta teollisuuteen saataisiin maaseudulta työväkeä ja sille riittävästi ruokaa. Elintarvikkeiden kansainvälinen kauppa alkaa kasvaa, jolloin merenrantavaltioiden etu lisääntyi (Appleby 2010, 56-86).

Suomalaisen kapitalismin kehitys vaikuttaa tässä suhteessa ainakin osittain poikkeavalta, sillä huolimatta teollisuuden laajenemisesta maatalous säilyi vahvana aina 1960-luvulle saakka, jolloin vasta sen tuottavuus alkoi mainittavasti kohota. Tämä saattaa selittyä sillä, että teollisuus keskittyi alueille, kuten Tampereelle, joissa suurtilat olivat yleisiä. Näiden alueiden maaseudulla oli siten ylijäämäväestöä, jolle edes torppariuudistus ei voinut tarjota riittävästi työtilaisuuksia.

Ammatillinen järjestäytyminen lähti liikkeelle jo 1900-luvun alussa, mutta sen poliittinen paino oli pitkään vähäinen siksikin, että monet työnantajat pyrkivät aktiivisesti sen tukahduttamiseen. Suuri lama 1930-luvun alussa rikkoi edellisen vuosikymmenen alustavaa yhteiskuntapaktia konkurssien, työttömyyden ja maanviljelijöiden vaikeuksien vuoksi (yli 15.000 tilaa joutui vasaran alle). Tästä seurauksena oli oikeistolaisten ja nationalististen ääriliikkeiden nousu, ja maaseudulla esiintyi erilaisia pulaliikkeitä.

Voidaan sanoa, että lamakauden seurauksena markkinasopimuksen luonne alkoi muuttua. Sosialidemokraattien ja maalaisliiton koalitio 1930-luvun lopulla onnistui tukemaan taloudellista kasvua, jota maail- 
manmarkkinoiden elpyminen edelleen auttoi (vuosina 1933-38 yllettiin keskimäärin seitsemän prosentin vuosikasvuun). Kultakannasta luopuminen vuonna 1931 devalvoi markan viidelläkymmenellä prosentilla suhteessa dollariin ja viidellätoista prosentilla suhteessa puntaan. Tämä mahdollisti 1930-luvulla vientivetoisen kasvun samalla kun keynesiläiset aatteet alkoivat pikkuhiljaa levitä talouspolitiikkaan (Kiander \& Vartia 1998, 7-13).

Itsenäisessä Suomessa saatiin 1930-luvun lopulla ensimmäisen kerran aikaan kestävä hallituspohja, jossa myös vasemmistolla oli vaikutusvaltaa. Punamullalle loivat pohjaa viljelijäväestön tulojen nopea kasvu ja teollisuuden nousu, jossa sahatavara-, sellu- ja paperiteollisuus oli selvästi johtava ala (niiden osuus viennistä oli kahdeksankymmentä prosenttia vielä 1950-luvun alussa). Siirtyminen yhä enemmän paperintuotantoon lisäsi pääomantarvetta investointeihin, mikä taas kasvatti pankkien määräysvaltaa teollisuudessa. Virkamiesten suhteellinen elintaso alkoi laskea ja he siirtyivät osaksi kasvavaa keskiluokkaa, kuitenkin ilman mainittavaa poliittista protestia (Meinander 1999, 95-103, 112-14; Kerkelä 2006, 83$85)$. Teollisuus suuntautui sotien välillä voimakkaasti länteen ja niin teki myös ulkopolitiikka, vaikka sen painopisteet vaihtelivat vuosien mittaan ja varsinkin punamulta kannatti pohjoismaista suuntausta. Päinvastoin kuin usein ajatellaan, Suomen ulkosuhteet olivat pohjoismaiden lisäksi enemmän kallellaan Englantiin kuin Saksaan.

\section{Sodan jälkeen}

Talvi- ja jatkosota koettelivat suomalaisia raskaasti. Samalla katkesi poliittinen jatkuvuus maailmansotien väliseen aikaan. Aivan perustellusti puhutaan ensimmäisestä ja toisesta tasavallasta. Tämä katkeama näkyi sekä yhteiskunnan hallintarakenteissa että ulkopolitiikassa (eikä niitä voi oikeastaan erottaa toisistaan). Politiikassa siirryttiin aina 1970-luvulle saakka kahteen suunnilleen tasavahvaan vasemmistopuolueeseen, joiden kannatus oli puolestaan jokseenkin sama kuin kaikkien porvarillisten puolueiden yhteensä. Kansandemokraatit olivat 1940-luvun lopussa poliittisesti vahvassa asemassa Neuvostoliiton asettaman poliittisen imperatiivin ja sotaväsymyksen vuoksi. Maan talous ponnisteli sotakorvausten 
maksamiseksi ja länsimarkkinoiden avaamiseksi. Moskova halusi rajoittaa Suomen poliittista liikkumavapautta, mutta toisaalta harjoitti reaalipolitiikkaa eikä pohjimmiltaan uskonut poliittisen kumouksen mahdollisuuteen.

Talous alkoi kasvaa 1950-luvulla keskimäärin neljän prosentin vauhtia, mikä vastasi lähtötason huomioon ottaen eurooppalaista keskitasoa, mutta kasvu oli hitaampaa kuin suunnilleen samalta tasolta ponnistavilla Italialla ja Itävallalla. Kasvun lähteenä oli mahdollisuus nostaa tuottavuutta sangen alhaiselta tasolta ja luoda uusia toimialoja teollisuudessa. Uudessa tilanteessa tarvittiin tehokkaampaa poliittista koordinaatiota, joka näkyi sekä valtiovetoisessa talouspolitiikassa että Euroopan integraation liikkeellelähdössä. Siirryttiin koordinoidun kapitalismin kauteen, joka näkyi tulopolitiikassa ja muissa korporatistisissa järjestelyissä (Eichengreen 2007, 89-93).

Suomessa talouden rakenteessa dominoivat teollisuus ja maanviljelys, jotka molemmat laajenivat vielä 1950-luvulla. Talouden arvoketjut olivat edelleen pääasiassa kotimaisia luonteeltaan. Todellinen rakennemuutos lähti liikkeelle vasta 1960-luvulla, jolloin alkoi maatalouden alasajo. Samalla metsätalouden rakennemuutos ja korjuun koneistuminen heikensivät alan teollisuuden orgaanista yhteyttä maaseutuun (Kerkelä 2006, 87-89). Palvelut alkoivat laajentua ja monipuolistua sekä yksityisellä että eri toten julkisella sektorilla. Suomen kehitykseen vaikutti voimakkaasti sodanjälkeinen demografinen murros: suuret ikäluokat ja eliniän piteneminen. Enimmillään yli sataantuhanteen lapseen nousseet ikäluokat toivat yhteiskuntaan uutta potentiaalia, mutta samalla loivat uusia vaatimuksia. Ainoastaan suhteellisen nopea talouskasvu mahdollisti, että näille ikäluokille avautui tilaisuus koulutukseen ja pääsyyn julkisen terveydenhuollon piiriin; käyntiin sisään hyvinvointivaltion portista. Koulutuksen merkitys eliittien muodostumisessa ja professionalisoitumisessa tuli selvemmin näkyviin (Häkkinen, Linnanmäki \& Leino-Kaukiainen 2005; Ruuskanen, Snellman \& Widgrén 2010, 51-53).

Siirryttäessä 1950-luvulle poliittiseksi peruskoalitioksi muodostui sdp:n ja maalaisliiton allianssi, jota tosin repivät eturistiriidat tuottajien ja kuluttajien välillä sekä erilaiset painotukset ulkopolitiikassa, mutta jota toisaalta yhdisti yhteinen intressi metsä- ja paperiteollisuuden hyvinvoinnista. Metsäklusteri ja sen intressit ohjasivat sodanjälkeiset vuo- 
sikymmenet sekä Suomen ulkomaankauppapolitiikkaa että sisäpolitiikan rakentumista. Paperiteollisuudessa ei juurikaan lakkoiltu, kun taas metalliteollisuus oli tässä suhteessa arempi ala. Osaselitys tälle on se, että paperissa sosialidemokraatit olivat vallitseva vasemmistovoima ja siinä voitiin tehdä kompromisseja kapitalistien kanssa, kun taas metallissa olivat vastakkain suhteellisen tasavahvat vasemmistopuolueet. Yhdeksi keskeiseksi haasteeksi 1960- ja 1970-luvuilla nousi kansallisen konsensuksen vahvistaminen. Tämä edellytti kommunistien hyväksymistä poliittisen yhteiskunnan täysivaltaisiksi jäseniksi, mikä taas vaati ongelman "työstämistä" muuttamalla asenteita ja kieltä (Alapuro 2011, 533-36). Toisaalta on ilmeisen liioittelevaa kutsua näitä vuosikymmeniä sosialidemokraattien aseman "hegemonisoitumisen" kaudeksi (Nyyssölä 2011, 266-67).

Varsinaisten porvarillisten puolueiden, kokoomus ja kansanpuolue, valtakunnallinen merkitys oli vähäinen, ja kansandemokraatit olivat suurimman osan aikaa syrjässä valtakunnan politiikan keskiöstä. Suhtautumisesta yksityiseen omistusoikeuteen käytiin väittelyä, mutta missään vaiheessa ei vakavasti ollut esillä laajamittainen sosialisointi. Sen sijaan pääomaköyhässä maassa valtion merkitys investoijana kasvoi ennen kaikkea raskaassa teollisuudessa ja julkisessa terveydenhuollossa, kuten keskussairaaloiden rakentamisessa. Maalla oli kohtuullisessa mitassa "malttia vaurastua”, joka samalla käynnisti aluepolitiikan. Vientiteollisuus pidettiin käynnissä toistuvilla devalvaatioilla. Valtion keskeinen merkitys pääomien hankkijana, talouspolitiikassa ja valuuttapolitiikassa on antanut aihetta luonnehtia Suomea "kehitysvaltioksi" (Kerkelä 2006, 85-87). ${ }^{2}$

Sosialisoinnin sijaan nousi taloudellinen suunnittelu sekä koordinaation että sijaintipäätösten osalta. Demokratiassa suunnittelulla haettiin taloudellista tehokkuutta, joita markkinat yksin eivät voineet tuottaa, sekä sosiaalista ja taloudellista tasavertaisuutta. Talouden suunnittelun idea oli peräisin jo 1930-luvulta, mutta varsinaista voimaa se alkoi saada vasta 1950-luvulla, jolloin se institutionalisoitiin osaksi julkista hallintoa (Kettunen 2008, 104-20). Suunnitteluidean käyttövoimana oli epäilemättä etujen ajaminen, mutta myös sosialidemokraattien ja maalaisliittolaisten ideologiset, joskin eriävät tavoitteet. Suunnittelu sopi aikakaudelle tyypilliseen rationaalisuuden tavoitteluun. Toisenlaiseen koordinoituun kapitalismiin siirryttiin vuonna 1968, kun ensimmäinen tulopoliittinen 
sopimus solmittiin. Todellisia ristiriitoja työmarkkinoilla ratkaistiin, ja peiteltiin, poliittisella konsensuksella.

Suunnittelun ja koordinoinnin rinnalla siirryttiin 1950-luvun lopulta lähtien talouden deregulaatioon, joka sekin edellytti koordinaation tehostamista. Sääntelytalouden sisällä alettiin turvautua vähitellen kilpailuretoriikkaan ja kilpailun normien voimistuessa alettiin säätää ensimmäisiä kilpailulakeja (Kallioinen ym. 2010, 62-68). Sännöstelyn purkaminen oli osaksi kotimainen päätös, mutta liittyi myös koko Euroopan mitassa tapahtuvaan kaupan esteiden poistamiseen ja valuuttaliikenteen asteittaiseen vapauttamiseen (Aunesluoma 2011, 152-65; Eichengreen 2007, 167-76). Taloudellisen vaihdon säännöt olivat muuttumassa. Suomen oli mukauduttava eurooppalaiseen integraatioon, mitä vaikeutti idänsuhteista johtuva ulkopoliittinen imperatiivi ja huoli aikaisemmin suljettujen kotimarkkinoiden kohtalosta, mukaan lukien maatalouden asema. Näistä syistä johtuen Suomen tie Euroopan "ytimeen" oli hidas ja mutkikas: ensiksi FINEFTA-sopimus, sitten vapaakauppasopimus EEC:n kanssa vuonna 1973 ja lopulta Euroopan yhteisön jäsenyys vuonna 1995. Koko ajan hoidettiin bilateraalisia kauppasuhteita Neuvostoliittoon sekä taloudellisen hyödyn ja poliittisen vakuutuksen vuoksi että varmuuden vuoksi myös pienempiin SEV-maihin (taustaksi ks. Aunesluoma 2011).

Toisessa tasavallassa myös kulttuuri sai uutta voimaa. Yhteiskunnallisten rajojen murtuminen näkyi kirjallisuudessa modernismin vahvistumisena, mutta myös uutena sosiaalisena realismina, kuvataiteessa uusien tyylisuuntien kokeiluna sekä muotoilun uutena kultakautena. Uudet kokeilut mobilisoivat luonnollisesti konservatiivisia vastareaktioita kuten niin sanottuja kirjasotia. Kulttuurissa sukupolvikonflikti alkoi kärjistyä saavuttaakseen täyden mittansa 1960-luvulla. Toisaalta niin sanotulla rahvaankulttuurilla oli vahva sija elokuvassa ja kevyessä musiikissa. Molemmissa niistä alkoivat ulkomaiset, erityisesti amerikkalaiset vaikutteet vahvistua. "Lännen lokarilla" oli kaksisuuntaista merkitystä (yleisesti ks. von Bagh 2007). Kyseessä oli yleiseurooppalainen ilmiö. Suomessa Amerikan vaikutukset näkyivät ensiksi musiikissa ja elokuvissa, kun taas konsumerismi murtautui läpi elintason nousun myötä oikeastaan vasta 1980-luvulla (de Grazia 2005).

Suomen poliittista järjestelmää voidaan tulkita monella tavalla. Sitä voidaan vertailla vallanjaon ja vaalijärjestelmän kaltaisilla rakenteellisilla 
kriteereillä muiden teollisuusmaiden vastaaviin järjestelmiin. Toisaalta poliittinen järjestelmä ja erityisesti puolueet voidaan suhteuttaa maan talouspoliittiseen malliin ja työmarkkinajärjestelmään, jolloin korporatistisia, markkinapohjaisia ja sekamalleja voidaan verrata niiden instituutioiden tuottaman talouden ja tuottavuuden kasvun, työllisyyden, tulonjaon ja inflaation perusteella toisiinsa. Tästä näkökulmasta Suomi on ollut korporatismia lähestynyt sekamalli, jossa mainituilla mittareilla arvioituna taloudellinen tulos on ollut sangen hyvä, mutta epätasainen (Paloheimo 1984; Väyrynen 2000). Korporatismi ja konsensushakuisuus yhdistyivät tulopoliittisessa järjestelmässä, joka Suomessa oli poikkeuksellinen voimakas ja toimi liki neljä vuosikymmentä (Kiander \& Vartia 1998, 30-39).

Huolimatta sosiaalietuuksien leikkauksista 1990-luvun alun talouskriisin hoidossa Suomi on säilyttänyt asemansa pohjoismaisena hyvinvointivaltiona, jonka toimintaperiaatteet eivät ole uusliberaalisia (Swank 2002: 147-50, 153-56). Tämä ei kuitenkaan tarkoita sitä, etteikö suomalainen hyvinvointiyhteiskunta olisi jatkuvien paineiden alaisena. Jo vuosikymmen sitten pohdittiin väestön ikääntymisen, sosiaalisen syrjäytymisen, alueellisen eriytymisen ja keskiluokan muuttuvan aseman vaikutuksia suomalaisen hyvinvointimallin tulevaisuudelle. Julkisten palveluiden taloudellinen ja sosiaalinen kestävyys on ollut jatkuvana huolenaiheena (Kantola \& Kautto 2002). Sen jälkeen ovat kasvava taloudellinen eriarvoisuus ja uusi, koulutukseen perustuva uusi luokkajako, nousseet yhä keskeisemmiksi huolenaiheiksi. Vuosina 1990-2007 suomalaisten käteen jäävät tulot nousivat keskimäärin 2.4 prosenttia, kun ylimmällä prosentilla nousi oli 12.3. Tuona aikana parhaiten ansainneen viidenkymmenentuhannen suomalaisen tulot kasvoivat viisi kertaa nopeammin kuin keskituloisten. Eriarvoisuuden kasvu on 2000-luvulla ollut tätäkin nopeampaa.

Poliittisten prosessien tarkasteluun voidaan liittää vielä enemmän politiikan talouteen vievä tarkastelutapa, jossa poliittinen järjestelmä pyritään kytkemään suoraan talouden rakenteeseen ja tuotantofunktioihin. Poliittisten kantojen katsotaan muotoutuvan pitkälti sen perusteella, onko kannattajakunta kiinni liikkuvassa vai kiinteässä pääomassa tai alhaisen tai korkean tuottavuuden aloilla. Tässä suhteessa maalaisliitto on perinteisesti sitoutunut ensisijaisesti kiinteään alhaisen tuottavuuden 
päöomaan, joka merkitsee politiikassa status quon puolustamista. Sosialidemokraateissa erityisesti vientiteollisuuteen kytkeytynyt kannattajakunta joutuu johtamaan etunsa liikkuvasta pääomasta, joka helpottaa kapitalistisen logiikan ymmärtämistä. Kansandemokraattien kannattajat olivat perinteisesti maatalouden ja kotimarkkinateollisuuden kautta enemmän kiinteään pääomaan sitoutuneita (Väyrynen 1999b).

Tiettyyn rajaan saakka tämä pitääkin paikkansa: keskusta ja kansandemokraatit ovat suhtautuneet varauksellisesti Euroopan unionin ja euroalueen jäsenyyteen, kun taas sosialidemokraatit ovat kannattaneet niitä. Näin yksinkertainen tilanne ei kuitenkaan ole, sillä keskusta on kytkeytynyt maailmanmarkkinoihin metsä-ja paperiteollisuuden kautta, minkä vuoksi se on ajanut sangen järjestelmällisesti vapaakauppaa, mutta vastustanut ylikansallisia järjestelyitä. Ehkä voidaan sanoa, että keskusta on historiallisesti ollut vapaakauppa- mutta ei varsinaisesti integraatiopuolue. Tämä jako puolueen sisällä on nähtävissä edelleen. Tietysti hallitusvastuu on pakottanut EU-jäsenyyden oloissa keskustan hoitamaan myös integraatiopolitiikkaa, mutta ei yhtä ponnekkaasti kuin mitä Sdp teki varsinkin Lipposen hallitusten aikana.

Historiallisesti sosialidemokraatit ovat olleet vapaakaupan kannalla, koska se on laskenut tuontituotteiden hintoja ja siten parantanut palkkatyöläisten elintasoa. Sdp:n piirissä esiintyi kuitenkin 1970-luvun alussa voimakasta vapaakaupan arvostelua, joka liittyi silloisen EEC:n kanssa solmittuun vapaakauppasopimukseen. Teoreettisesti kritiikkiä perusteltiin erilaisilla epätasaisen vaihdon sekä keskus-periferiaa koskevilla teorioilla, mutta poliittisesti kantoihin vaikutti myös Neuvostoliiton sopimukseen ottama kriittinen kanta, jota sen arvostelijat myötäilivät. Neuvostotekijä vaikutti vielä voimakkaammin kansandemokraattien politiikkaan, minkä työläisten luokkaetujen vuoksi olisi pitänyt olla vapaakaupalle myönteinen. On tietysti huomattava, että vapaakauppa tappoi heikosti tuottavia aloja, kuten tekstiili- ja nahkateollisuuden, ja kärjisti siten työttömyysongelmaa.

Sodanjälkeisistä keskeisistä puolueista siis keskustan ja sosialidemokraattien kannattajat olivat kytkeytyneet, tosin eriasteisesti, sekä vientiettä kotimarkkinoihin. Maatalouden osuuden nopea lasku ja maaltapako kaupunkeihin ja Ruotsiin 1960-luvulta lähtien muuttivat keskustan kannattajakunnan luonnetta. Puolueen tukijat siirtyivät aikaisempaa enem- 
män maaseudun asutuskeskuksiin ja siten kasvavien julkisten palvelujen pariin. Irtautuminen luontaiselinkeinosta teki heistä tuottajien sijasta kuluttajia ja julkisten palveluiden kysyjiä. Tämä korosti puolueen asemaa johtava kuntapuolueena erityisesti maaseudulla sekä pienissä ja keskisuurissa kaupungeissa, kun taas suurempien kaupunkien johtaminen jäi sosialidemokraattien ja kokoomuksen teollisuuskoalitiolle siihen saakka, kun vihreiden nousu varsinkin pääkaupunkiseudulla alkoi.

Toisen maailmansodan jälkeinen muutos näkyi erityisen selvästi ulkopolitiikassa, jossa muutos johtui käytännön pakosta; puna-armeijan voitosta ja sen luomasta poliittisesta yleistilanteesta. Poliittiset päättäjät tekivät sen, mikä oli välttämätöntä niissä olosuhteissa. Vaikka sisä- ja ulkopolitiikka ovat aina kytkeytyneet toisiinsa, niin sodan jälkeen tämä kytkös oli vielä tavallista voimakkaampi (Ylikangas 1987: 206-12). Osmo Apunen on korostanut, kuinka ns. Paasikiven-Kekkosen linja yhdisti ulkopolitiikassa toisiinsa horisontaalilinjan ja vertikaalipolitiikan. Edelliseen kuuluivat Suomen valtion ja puolueiden suhteet vastinpareihin Neuvostoliitossa ja jälkimmäiseen NKP:n ja KGB:n Moskovasta hoitamat suhteet puolueisiin ja yksittäisiin päättäjiin (Apunen 2005, 27-29). Vertikaalipolitiikalla tunkeuduttiin Suomen sisäiseen päätöksentekoon, jonka tulisi ideaalimallissa olla valtion suvereenia tilaa. Puhuttiin suomettumisesta.

Suomen poliittista järjestelmää ja maan ulkopolitiikkaa ei voi ymmärtää ottamatta huomioon presidentin keskeistä merkitystä. Tosin presidentin valta on vaihdellut presidentistä ja poliittisesta tilanteesta toiseen. Presidentillä on ollut vahva perustuslaillinen asema, jota tosin on lievennetty vuosien 2000 ja 2011 valtiosäännön uudistuksissa, mutta ulkopolitiikassa se on pääosin säilynyt. Puolustuspolitiikassa presidentti on ylipäällikkönä keskeisessä asemassa, mutta hänen suhteensa kenraaleihin on vaihdellut ja pysynyt pitkälti julkisuudelta piilossa. Keskeisistä aloista puolustuspolitiikka on Suomessa ollut kaikkein heikoimmin parlamentaarisessa valvonnassa. Suomen liityttyä Euroopan unioniin on presidentin kansainvälinen toiminta-ala kaventunut siihen liittyviin valtiosopimuksiin ja EU:n ulkopuolisiin valtioihin (Hallberg, Martikainen, Nousiainen \& Tiikkainen 2009; Visuri 2010).

Kun presidentti aikaisemmin johti uhanalaista ja haavoittuvaa kansallisvaltiota, niin Urho Kekkosen pitkän kauden jälkipuoliskolla al- 
koi tapahtua muutos. Poliittisesti tilanne Euroopassa alkoi vakiintua 1970-alusta lähtien, vaikka "toinen kylmä sota" koettiinkin 1980-luvun alussa. Ulkoisten paineiden vaikutuksesta Suomi joutui aikaisempaa aktiivisemmin mukaan eurooppalaiseen ja sittemmin maailmanlaajuiseen taloudelliseen kilpailuun, jossa markkinavoimat alkoivat yhä enemmän vaikuttaa politiikkaan. Erityisesti pienten valtioiden ainoa vaihtoehto oli osallistua ja sopeutua taloudelliseen integraatioon, jossa yhtäältä suvereenisuuden säilyttäminen ja toisaalta kustannusten jako olivat keskeisiä haasteita (Eichengreen 2007, 335-44).

Suomessa presidentin keskeisenä tehtävänä oli luoda ulkopoliittiset ja osaksi myös sisäpoliittiset edellytykset maan osallistumiselle eurooppalaiseen integraatioon. Tämä edellytti Moskovan kanssa neuvotteluja, joissa yhdistyivät vaatimukset, myönnytykset ja kompromissit. Kotimaassa presidentti edisti kapitalismin koordinaatiota, josta konkreettinen osoitus oli presidentti Kekkosen osallistuminen tulopolitiikkaan ja idänkaupan ohjaamiseen. Voidaan sanoa, että Kekkonen loi ympärilleen eräänlaisen poliittis-taloudellisen eliittipaktin, jonka jäsenet politiikassa ja teollisuudessa olivat riippuvaisia hänen koordinaatiostaan. Jälkeen jääneet paperit osoittavat, kuinka pikkutarkasti ja välillä ärhäkkäästi Kekkonen ohjasi tämän paktin toimintaa.

Sen sijaan pankkimaailmaan Kekkosen vaikutusvalta ei koskaan yltänyt samaan mittaan kuten näkyy hänet haastaneen Matti Virkkusen presidenttiehdokkuudessa 1968 vaaleissa. Tuohon aikaan useimmat suomalaiset suuryritykset olivat pankkien valvonnassa, joten Kekkosen valta ei ulottunut kapitalistisen ketjun alkupäähän, vaan rajoittui tuotantoon ja kauppaan. Poliittisista syistä se oli erityisen korostunut idänkaupassa. Talouden finansialisoituessa on myös pankkien suhde taloudelliseen ja poliittiseen valtaan muuttunut.

Kekkosen kauden jälkimmäistä puoliskoa voitaneen kuvata gramscilaisen hegemonian käsitteellä, jonka mukaan valtaa voidaan käyttää suostumuksen, eikä vain pakon avulla. Kekkosen pitkää valtakautta luonnehti poliittisen pakottamisen, "ruoskaparlamentarismin", ja laajamittaisen suostumuksen yhdistelmä (Väyrynen 1992). Kekkoseen verrattuna Mauno Koivisto oli, jo taustansa vuoksi, ensisijaisesti rahapoliitikko, jolle markan arvo oli ilmeisesti keskeisempi tekijä kuin vaikkapa idänkauppa. Hän korosti taloudellisen vakauden merkitystä poliittiselle järjestelmälle 
ja hyvinvoinnille, ja vastusti inflaation ja devalvaation varaan rakentuvaa politiikkaa. Koivisto tuki 1990-luvun vaihteessa Suomen Pankin revalvoivaa vahvan markan politiikkaa, jota on pidetty yhdessä devalvaation torjumisen kanssa yhtenä syynä talouskriisin syvenemiseen (Kiander \& Vartia 1998, 77-89, 121-30). Tultaessa 1990-luvulle Koivisto oli vankkumaton länsi-integraation kannattaja, vaikka se ei julkisuudessa aina näkynytkään. Myöhemmillä presidenteillä ei ole ollut, jo valtiosäännön muutoksistakin johtuen, samalla tavalla selkeää talouspoliittista linjaa.

\section{Uusi murros}

Olen aikaisemmin katsonut kolmannen suuren murroksen alkaneen 1990-luvun alussa. Murrokselle oli ominaista talouden, erityisesti suuryritysten ja yhteiskunnan voimakas kansainvälistyminen, markkinoiden ensisijaistuminen valtion kustannuksella sekä tietoteollisuuden ja -yhteiskunnan läpimurto. Murroksen taustalla oli siis useita keskenään kumuloituvia kehityskulkuja, jotka vapauttivat ja individualisoivat yhteiskuntaa. Kyseessä on pohjimmiltaan nopean teknologisen kehityksen ja globalisaation keskinäinen vuorovaikutus: kolmas teollinen vallankumous tai eriytyminen. Lähtien 1990-luvulta Suomessa kehitettiin uutta teknologiaa, erityisesti ICT-teknologiaa, nopeasti ja talouden avautuessa tuottavuudesta nostaneesta teknologiasta saatiin huomattavaa taloudellista hyötyä. Sen sijaan ICT-teknologian soveltamisessa yhteiskunnan käytäntöihin Suomi on ollut huomattavasti hitaampi (Rouvinen, Vartia \& Ylä-Anttila 2007, 31-39). Toisen maailmansodan jälkeisestä ajasta puhuttiin kuitenkin taloudellisessa mielessä yleisesti "Suomen menestystarinana” (Kerkelä 2006, 89-90).

Maailmantaloudessa tapahtui 1980-luvulla suuria muutoksia: pääomaliikkeitä vapautettiin ja keskuspankkien merkitystä talouspolitiikassa kevennettiin. Niiden tehtäväksi tuli entistä enemmän rahanarvon ja inflaation vartiointi, ja varsinkin työllisyydestä huolehtiminen jäi takaalalle. Yritysten kilpailukykyä ja talouden vakautta korostava politiikka astui kuvaan kautta koko teollisen maailman. Kansainvälisen taloudellisen työnjaon syvät muutokset alkoivat siirtää tuotantoa sekä maiden sisällä että välillä alhaisen tuottavuuden ja voittoasteen aloilta tuottaville 
aloille. Tämä näkyi muun muassa Aasian alkavana valtiovetoisena teollistumisena ja alueen merkityksen kasvuna maailmankaupassa (Frieden 2006, 416-26).

Suomessa 1980-luvulla alkanut pääomaliikkeiden vapauttaminen hoidettiin puutteellisesti. Sen poliittiset instituutiot ja koalitiot eivät olleet valmiita hallitsemaan nopeasti tapahtunutta avautumista kapitalistiseen maailmantalouteen. Pankkivalvonnan ollessa riittämätöntä maahan alkoi virrata hallitsematta lyhytaikaista ulkomaista päöomaa ja yritykset, jopa yksittäiset kansalaiset, alkoivat ottaa valuuttavelkaa. Seurauksena oli keinottelu- ja kuplatalous, joka puhkesi vakavin seurauksin 1990-luvun alussa. Näitä seurauksia kärjisti neuvostomarkkinoiden hajoaminen sekä laskusuhdanne länsimarkkinoilla. Kuitenkin 1990-luvun kriisi oli myös suomalaisten instituutioiden kriisi: vanhan kansallisen säätelytalouden pankkipohjaiset järjestelmät eivät kestäneet ja niiden murtuessa myös teollisuus joutui viennin kuivuessa syviin vaikeuksiin. Mielenkiintoista kyllä poliittinen järjestelmä säilyi miltei kuivin jaloin: suurin historiallinen väantöliike hallitusvallassa käytiin keskustan ja sosialidemokraattien välillä. Niiden molempien politiikka muuttui markkinamyötäisemmäksi, ja jälkimmäisten vielä enemmän. Tämä SDP:n kannanotto on 2010-luvun poliittisessa ilmapiirissä kävellyt puoluetta vastaan.

Suomen liityttyä jäsenäänestyksen jälkeen Euroopan unioniin vuonna 1995 Lipposen hallitusten harjoittama politiikka, joka perustui sosialidemokraattien ja kokoomuksen akselille, oli selkeää. Suomen tavoitteena oli pyrkiä unionin ytimeen, joka tietysti voidaan mäaritellä monella eri tavalla. Keskeistä oli kuitenkin vaikuttaminen EU:n elinten toimintaan, erityisesti komission aseman korostaminen, sekä matka kohti yhteistä valuuttaa ja Schengen-aluetta. Ytimeen osallistumisen korostaminen heijasti epäilemättä halua irtautua Suomen alun perin periferisestä asemasta, jossa taloudellinen kehitys ja (ulko)poliittinen autonomia olivat vaillinaisia. Suomi halusi olla täysivaltainen tasavalta osana eurooppalaista taloudellista ja poliittista yhteisöä ja painia siten sarjaansa ylempänä (ks. Stubb 2006).

Tämän aktiivisen ja innostuneen kauden jälkeen Suomen EU-politiikkaa ei ole samalla tavalla ohjannut päämäärätietoinen vaikuttaminen, vaan pikemminkin kyseessä on ollut paneutuminen yksittäisiin asioihin, sopeutumiseen ja tasapainon hakemiseen. Eurokriisi 2010-luvulla on 
ajanut Suomen politiikan miltei paniikkiin, jossa on vaikea puhua johdonmukaisesta linjasta ja kansallisesta yksimielisyydestä.

EU-jäsenyyden jälkeen Suomen merkittävin päätös oli liittyminen Euroopan rahaunioniin (EMU), luopuminen kansallisesta valuutasta sekä yhteisvaluutta euron omaksuminen arvon mitaksi ja maksuvälineeksi. Siirtyminen euroon oli poliittinen ratkaisu, joka heijasti maan taloudessa ja politiikassa pitkään vallinneita ryhmittymiä. Yritysten suhtautumisessa nousi ehkä viimeisen kerran esiin vienti- ja kotimarkkinateollisuuden erilaiset intressit. Kanadalainen nobelisti Robert Mundell kehitti jo 1960-luvulla oman mahdottomuusteoreemansa, jonka mukaan maa voi saavuttaa vain kaksi seuraavasta kolmesta tavoitteesta: pääoman vapaa liikkuvuus, rahapoliittinen itsenäisyys ja vakaa valuuttakurssi. Ajan mittaan tämä "epäpyhä kolminaisuus" on osoittautunut entistä pitävämmäksi kansainvälisen talouden toimintatavan kuvaajaksi (Frieden 2006, 46062; Väyrynen 1999b). Yksinkertaistaen, jos halutaan pääoman liikkuvan vapaasti ja pitää vakaa valuuttakurssi, niin rahapolitiikan itsenäisyydestä on luovuttava.

Suomessa valuuttakurssin epävakaus on historiallinen tosiasia. Vientiyritykset, erityisesti paperiteollisuus, ovat ostaneet kansainvälistä kilpailukykyä devalvaatioilla. Suomen Pankin politiikka, Koiviston pääjohtajakaudella ja myöhemmin hänen presidentillisellä myötävaikutuksellaan, tähtäsi devalvaatiokierteen lopettamiseen, jota tavoitetta vahvistivat vaikeat kokemukset 1990-luvun alun valuuttamyrskyissä. Kun pääomaliikkeet oli jo pitkälle vapautettu, niin Mundellin teoreeman mukaan liikkuvaksi tekijäksi jäi rahapoliittinen autonomia. Siitä luovuttiin omaksumalla euro maan valuutaksi. Tämä ratkaisu on epäilemättä tuottanut taloudellista hyötyä alhaisen korkotason ja kansainvälisten transaktiokustannusten supistumisen vuoksi. Toisaalta euroalueen yhteinen valuutta ilman yhteistä talouspolitiikkaa, paljon puhuttu valuvika, on tuottanut 2010-luvulla syvän eurooppalaisen kriisin, jota näyttää olevan erittäin hankalaa ratkaista. Eurokriisin ratkaisemisen vaikeus, ellei peräti mahdottomuus, on osoittanut, kuinka vaikeaa poliittisen päätöksenteon ja markkinoiden koordinaatio on, ja kuinka ohutta on näiden toimijatyyppien välinen luottamus. 


\section{Neljäs murros?}

Maailmantalouden kehitys on osoittautunut epävakaaksi, mikä johtuu suurelta osalta finanssijärjestelmän ylikorostumisesta, sen sisäisen kansainvälisen riippuvuuden kasvusta sekä suoranaisista väärinkäytöksistä. Olettamus tehokkaista markkinoista, niiden erehtymättömyydestä, on osoittautunut harhaksi ensiksi vuonna 2008 alkaneessa ja edelleen jatkuvassa kriisissä. Suomessa on monissa suhteissa opittu 1990-luvun alun lamasta ja siksi vältetty pahimmat virheet muun muassa suomalaisten pankkien suhteellisen hyvän kriisikestävyyden vuoksi. Sen sijaan muiden maiden politiikassa ja kansainvälisillä markkinoilla tehdyt virheet ovat sakottaneet Suomen taloutta niin pahasti, että vuonna 2009 bruttokansantuote putosi kahdeksan prosenttia. Suomen kokoisella maalla ei ole mahdollisuuksia olennaisesti vaikuttaa muuttuvaan kansainväliseen työnjakoon ja sen hallintaan, vaan politiikassa pääpaino on sopeutumisessa ulkoisiin realiteetteihin (Väyrynen 2010).

Vaikka Suomella on kansainvälisiltä luottoluokittajilta selkeä AAAasema, niin monet tarkkailijat ovat alkaneet ennakoida sille vaikeita aikoja ennen nopeasti heikkenevän huoltosuhteen sekä negatiiviseksi kääntyneen maksutaseen vuoksi (Hugh 2011). Toisin sanoen ikääntyvä väestö, viennin rakenteen heikkeneminen ja sen hidas elpyminen vuoden 2008-2009 kriisistä saattavat tuottaa pitemmän päälle pahoja ongelmia velkaantuvassa ja viennistä riippuvassa Suomen taloudessa.

Tässä tilanteessa on syytä kysyä, onko Suomen taloudellisessa ja poliittisessa järjestelmässä alkamassa neljäs suuri murros? Tälle kysymykselle antaa pohjaa kansainvälisissä suhteissa tapahtuva syvällinen rakennemuutos. Nousevat taloudet, BRICS-maat, kasvavat huomattavasti nopeammin kuin vanhat teollisuusmaat, joista Euroopan unionin kasvu on jumiutunut nollatasolle ja sen kriisimaiden konkurssi on mahdollinen. Kansainvälisen talouden painopisteen muutos vaikuttaa instituutioihin ja päätöksentekoon, jossa nousevat maat vaativat suurempaa sananvaltaa esimerkiksi Kansainvälisessä valuuttarahastossa (IMF). "Form follows the function" eli kansainväliset instituutiot muuttuvat, tosin pitkällä viiveellä, vastaamaan uutta kansainvälistä tehtävänjakoa. Viiveen merkitystä osoittaa se, että nousevat taloudet eivät ole innostuneita tulemaan 
eurooppalaisten pelastajaksi, ellei niiden sijoituksia taata ja niille anneta vahvempaa kansainvälistä asemaa.

Euroopan unionissa tarvitaan perusteellista institutionaalista muutosta, jonka keskeinen osa on yhteisen talouspolitiikan luominen yhteisen valuuttapolitiikan rinnalle, jolla tavalla Maastrichtin sopimuksen "valuvika” saataisiin korjatuksi. Tämä edellyttää talouspolitiikan koordinaation vahvistamista ja monien mielestä jonkinasteista talousunionia. Tarvitaan kokonaisratkaisua, jossa yhdistyvät euroalueen mittainen yhteisvastuu rahoitusjärjestelmän toimivuudesta ja kansallinen vastuu talouspolitiikassa. Valitettavasti euroalue näyttää kulkevan pirstoutumisen suuntaan: unionin yhteiset instituutiot jätetään taka-alalle ja päätöksenteko siirtyy johtavien jäsenmaiden bi- tai minilateraalisiin järjestelyihin. Talouspolitiikkaa hoidetaan taloudellisen voimapolitiikan keinoin.

Tämä kansainvälinen taloudellinen ja poliittinen rakennemuutos ei voi olla vaikuttamatta Suomen asemaan. Muiden euromaiden tapaan Suomen täytyy ratkaista, missä mitassa se on valmis ottamaan yhteistä vastuuta euroalueen toiminnasta ja kriisiin ajautuneiden maiden tukemisesta. Vastakkain ovat käsitykset, joiden mukaan Suomen täytyy säilyttää täysimittainen päätösvalta kaikissa euroalueen ratkaisuissa ja toisaalta vaatimus ottaa kannettavakseen myös enemmistöpäätöksillä tehtäviä ratkaisuja. Tällä kahtiajaolla on vakavia (talous)poliittisia seurauksia, jotka heijastuvat eurobondien ja pankkijärjestelmän säätelyn kaltaisiin kysymyksiin. Kyse on vakavista eurooppalaisen yhteisvastuun ja kansallisen suvereniteetin kaltaisista periaatteista.

Kyse ei ole vain kansallisesta valinnasta, vaan myös EU-maiden asemasta muuttuvassa kansainvälisessä taloudellisessa työnjaossa, mikä väistämättä määrittää myös Suomen asemaa maailmassa. Taustalla on syvä jännite kansallisen, jopa nationalistisen näkökulman ja maailmanmarkkinoista riippuvan ja niihin sopeutuvan pienvaltiokäsityksen välillä. Tämä jännite heijastuu myös sisäpolitiikassa, jossa voimistuva kansallismielinen reaktio ja nurkkaan ahdistettu euroeliitti asettuvat vastakohdiksi. On silmiinpistävää, kuinka heikoille eurooppalaisen yhteisvastuun periaate on jäänyt.

Kyse ei ole kuitenkaan vain Euroopasta, sillä maailmantalous on aidosti globaalia. Se ei ole enää puristettavissa yksittäisten tai edes klustereiden väliseksi kilpailuksi, kuten voitiin tehdä 1980-luvulle saakka. Maa- 
ilmantalouden ytimessä ovat globaalit arvoketjut, jotka eivät noudata valtioiden, eikä edes teollisuussektoreiden välisiä rajoja. Kansainväliset yritykset määrittävät, mitkä toiminnan halutaan pitää sisäisinä ja mitkä ulkoistetaan, ja kummassakin tapauksessa kysytään, missä maassa tapahtuva toiminta palvelee niiden kokonaistulosta parhaiten. Tämän seurauksena erityisesti Kiinasta on tullut maailman teollinen työpaja, joka toistaiseksi vielä kansallisella strategialla pyrkii korkeammalle arvoketjuissa panostamalla tutkimus- kehitys- ja innovaatiotoimintaan (TKI). Toisaalta varsinkin saksalaiset yritykset ovat luoneet arvoketjuja, jotka ulottuvat entisiin sosialistimaihin Keski- ja Itä-Euroopassa, missä tuotantokustannukset ovat vielä alhaisemmat kuin vanhoissa teollisuusmaissa. Peruskysymykseksi nousee se, että monikansalliset yritykset luovat globaaleja tehtävärakenteita, joissa ne pyrkivät maksimoimaan oman arvonmuodostuksensa (Pajarinen, Rouvinen \& Ylä-Anttila 2010, 69-82).

Arvoketjujen korostaminen merkitsee, että maailmantalouden rakennemuutosta ei voi tarkastella vain bruttokansantuotteen jakautumisen, tavaravirtojen ja pääomaliikkeiden avulla. Arvoketjujen jakotulokset muuttuvat hitaammin kuin suoran taloudellisen vallan jakautuminen. Tosin arvoketjuista ei ole mitään kattavia tilastoja, vaan niihin täytyy paneutua tapaustutkimusten avulla. Ne osoittavat, että varsinaista tuotantoa huomattavasti enemmän luovat arvoa TKI, informaatiovirrat, palveluratkaisut ja yritystoiminnan koordinaatio (tämä tulee näkyviin Nokian toiminnassa, ks. Pajarinen, Rouvinen \& Ylä-Anttila 2010, 76-80). Monet johtavat suomalaisyritykset, kuten Kone ja Wärtsilä, alkavat olla voittopuolisesti palveluiden kehittäjiä ja viejiä: ne toimittavat "älykästä rautaa". Palveluvienti ei kuitenkaan toimi pitemmän päälle, ellei maassa säily riittävän vahva teollinen ydin, mikä taas edellyttää riittäviä investointeja (Eloranta, Ranta, Salmi \& Ylä-Anttila 2010).

Globalisaatioon liittyvä markkinapenetraatio lisää eriarvoisuutta ja jakaa kansaa sosiaalisesti. Markkinoiden syvetessä tuloerot lisääntyvät, mikä kehitys hidastuu talouden ajautuessa vaikeuksiin, mutta nopeutuu taas talouden kasvaessa. Suomi on ollut ja on edelleen suhteellisen tasaisen tulonjaon maa, mutta kun eriarvoisuus supistui 1970- ja 1980-luvuilla, niin sen jälkeen sekä suhteellinen köyhyys että eriarvoisuus ovat lisääntyneet. Tämä kehitys heijastaa yhtäältä työttömyyden kielteisiä vaikutuksia ja toisaalta pääomatulojen, erityisesti osinkojen, lisääntynyttä 
merkitystä suhteessa työtuloihin. Erityisen ongelmallista on se, että työttömyydestä ja toimeentulotuen varassa elämisestä on tullut yhä pitkäkestoisempaa ja se näkyy varsinkin nuorison keskuudessa. Markkinoiden logiikan lisäksi eriarvoisuuskehitykseen vaikuttavat myös veropolitiikka ja muut talouspolitiikkaa koskevat ratkaisut (Moisio 2010; Saari 2011). Koulutustaso ja sijoittuminen työelämään ovat riippuvaisia, jopa aikaisempaa suuremmassa märin, vanhempien luokka-asemasta (Naumanen \& Silvennoinen 2010). Työttömyys, terveys ja sosiaaliset ongelmat ovat suomalaisessa yhteiskunnassa sosiaalisesti periytyviä.

Kansainvälisistä ja kotimaisista juurista lähtevä polarisaatio saa aikaan sen, että virallinen totuus ja ihmisten arkikokemukset alkavat erkaantua toisistaan. Virallisen mielikuvan mukaan Suomi on maailman paras maa (Newsweek) ja menestyjien yhteiskunta (maabrändityöryhmä), jossa koululaisten tiedot ovat maailman huippuluokkaa (PISA). Tälle yleiskuvalle antavat tukea erilaiset kansainväliset hyvinvointi-indikaattorit, joissa Suomi on miltei poikkeuksetta tusinan parhaan maan joukossa. Silti tämä maailmalle markkinoitu mielikuva ei välttämättä vastaa suuren ihmisjoukon omia kokemuksia, joissa on mukana irtisanomisia, kroonikkojen terveydenhuollon ongelmia, poliittista korruptiota ja yhtenäiskulttuurin murenemista. Tuoreet mielipidetiedustelut ovat osoittaneet kansalaisten kasvavaa yhteiskunnallista epäluuloisuutta, jonka osatekijät ovat kuitenkin osittain ristiriidassa keskenään (Haavisto \& Kiljunen 2011). Joka tapauksessa virallisen ja todellisen maailman välinen kuilu ruokkii poliittista protestia, joka näkyi erityisesti perussuomalaisten murskavoittona huhtikuun 2011 eduskuntavaaleissa.

Kokoomuksen kasvava kannatus on kytkeytynyt liikkuvasta pääomasta hyötyviin ja nuoriin äänestäjiin, kun taas keskustan alamäki liittyy kiinteän pääoman huonoon tuottavuuteen. Keskustan kannattaminen ei tuo enää samoja etuja kuin suljetussa taloudessa, mistä taas kumpuaa EU-kritiikkiä. Tunnetusti keskustan valta perustuu vahvaan asemaan maaseudun kunnissa ja pienemmissä kaupungeissa, jota kuntauudistus nyt uhkaa. Keskustan kannattajat ovat siis sekä taloudellisen että poliittis-hallinnollisen muutoksen ristipaineessa. Ilman EU:n maataloudelle ja maaseudulle jakamia erilaisia tukia, kansallisen tuen rinnalla, tilanne olisi vielä synkempi. 
Keskustan tapaan sosialidemokraattien kannattajakunta on myös jakautunut perinteisen ja modernin talouden pohjalta. Senkin kohdalla vanha kannatuspohja on pettämässä, kun perinteiset teolliset työpaikat katoavat alta erityisesti paperiteollisuudessa, eikä uutta kannatuspohjaa ole löytynyt. Silti SDP:n kannatus ammattiyhdistysliikkeessä on säilynyt vahvempana kuin vasemmistoliiton, jonka kasvusuunta on ollut punavihreiden suuntaan. Vaikuttaa ilmeiseltä, että perussuomalaisilla on mahdollisuus vallata osansa teollisuusliittojen toiminnassa, mihin keskusta ei ole kyennyt. Akateemisten koulutettujen ja toimihenkilöiden ay-toiminnassa kokoomuksella on jo pitkään ollut oma roolinsa. Keskeisinä ongelmina ammattiyhdistystoiminnassa ovat vaikeudet tarttua tehokkaasti globaaleihin arvoketjuihin ja niiden seurauksiin sekä paineet julkisen talouden "tuottavuusprojekteihin".

Suomalaisessa yhteiskunnassa ovat entistä selvemmin vastakkain urbaanit hyväosaiset, joiden joukossa on myös keskustalaisia ja sosialidemokraatteja, sekä eri tavoin sosiaaliselle laita-alueelle, joko todellisuudessa tai kokemuksissaan, joutuneet ihmiset. Protesti olisi vielä voimakkaampi, jos tämä laitaosa äänestäisi yhtä aktiivisesti kuin hyväosaiset. Tästä jaosta on tullut poliittisesti hyväksytty tosiasia. Se on omiaan ruokkimaan yhteiskunnallisessa keskustelussa mustaa mieltä: suvaitsemattomuutta, syrjintää ja vihapuhetta. Epäilemättä maahanmuutto antaa motiiveja tällaiselle suhtautumiselle, mutta sen syyt ovat kyllä muuallakin yhteiskunnan muutoksessa.

Kaiken tietävien markkinoiden aika on, ainakin toistaiseksi, ohi. Pankkisektorin vakavaraisuussäädöksiä ollaan kiristämässä, harmaata taloutta yritetään panna kuriin ja tuloerojen kasvu saa osakseen entistä voimakkaampaa arvostelua. Kyse on kansainvälisestä trendistä, joka realisoituu myös Suomessa. Tulkinta trendin merkityksestä vaihtelee kuitenkin tuntuvasti puolueesta toiseen.

Poliittinen järjestelmä yrittää suojautua markkinapaineita vastaan, tehdä markkinoista autonomisen järjestelmän sijasta osa yhteiskuntaa. Tämä suojautuminen näkyy monin tavoin, myös Kataisen hallituksen ohjelmassa: perusturvaa halutaan parantaa, verotusta pyritään suuntaamaan pääomaa enemmän rasittavaksi ja työmarkkinoiden koordinaatioon kiinnitetään enemmän huomiota (Pääministeri Jyrki Kataisen hallituksen ohjelma 22.6.2011). Useimmat näistä uudistuksista ovat vai- 
kutuksiltaan marginaalisia, mutta niissä voidaan kuitenkin nähdä merkkejä Karl Polanyin luonnostelemasta vastaliikkeestä, joka pyrkii saamaan markkinat takaisin yhteiskunnan ohjaukseen rikkomatta silti kapitalismin perimmäisiä toimintaperiaatteita. Tästä huolimatta epäröin viedä johtopäätöstä yhtä pitkälle kuin Pertti Haapala, jonka mukaan "tämän päivän Suomessa kysymys vallan rakenteista on kysymys julkisesta vallasta ... yhteiskuntamme on rakennettu täydellisen ohjattavuuden idealle ja tavoitteelle" (Haapala 2010, 32-33). Viime aikojen vaikeudet taltuttaa finanssimarkkinat osoittavat, että julkisen vallan kyky ohjata kapitalismia on sittenkin rajallinen.

Vanhan säätelyvaltion tilalle noussut kilpailuvaltio on edelleen keskeinen osa poliittista todellisuutta. Kilpailuvaltion tehtävänä ei ole puuttua merkittävästi markkinoiden toimintaan, vaan sen on panostettava innovaatiotoimintaan, infrastruktuuriin ja taloudelliseen lainsäädäntöön, jotka parantavat yritysten kilpailuedellytyksiä maailmanmarkkinoilla. Poliittista keskustelua käydään edelleenkin tämän käsitteen rajoissa: onko esimerkiksi tehokkaampaa tukea innovaatiotoimintaa suoralla valtiontuella vai verohelpotuksilla. Silti kilpailuvaltiossakin on nähtävissä uusia merkkejä, kuten valtion omistamien yhtiöiden omistajaohjauksen tehostuminen, harmaan talouden suitsiminen ja yleensä siirtyminen markkinoilta julkisen vallan suuntaan. Samalla kun uuden markkinatilanteen vaatimaa sääntelyä tehostetaan, niin julkisen hallinnon resursseja supistetaan niin sanotun kestävyysvajeen kattamiseksi. Julkisessa sääntelyssä voidaan havaita kasvava kuilu vaatimusten ja kapasiteetin välillä.

Pienissä pohjoisissa teollisuusmaissa kapitalismi ja reformismi sovitettiin yhteen niin sanotussa pohjoismaisessa mallissa, jossa avoimet markkinat ja mahdollisuuksien yhdenvertaisuus on yritetty sovittaa toisiinsa. Tämä on todettu aina 1970-luvulta lähtien useissa tutkimuksissa ja raporteissa mahdolliseksi ja itse asiassa toivottavaksi yhdistelmäksi. Pohjoismaiden valttina ovat korkea koulutustaso, naisten laajamittainen osallistuminen työelämään, suhteellisen tasainen tulonjako sekä sosiaalireformistinen tasauspolitiikka (Andersen et al. 2007; Korkman 2010). Pohjoismaiden sangen kestävä asema kansainvälisessä taloudessa, huolimatta niiden erilaisista integraatio- ja valuuttapoliittisista ratkaisuista, antaa aihetta uskoa että niiden sosiaalinen malli on kestävämmällä poh- 
jalla kuin puhdas markkinamalli, jota Euroopassa edustaa kaikkein selvimmin Englanti, tai eteläisen Euroopan katolinen perhekeskeinen malli.

\section{Kohti kokonaisnäkemystä}

Suomalaisen yhteiskunnan historiallisen kehityksen perussuunta on ollut taloudellista periferiasta ja poliittisesta riippuvuudesta kohti hyvinvoivaa kansainvälistä ydintä ja poliittista suvereenisuutta, jota EU:n jäsenyys nyt tosin rajoittaa. Ensisijaisena käyttövoimana tässä historiallisessa muutoksessa on ollut teknologian ajoittain harppausmainen kehitys, sen mukanaan tuoma tuottavuuden kasvu sekä taloudellisen toiminnan monipuolistuminen aluksi maataloudesta teollisuuteen ja edelleen palveluihin, sekä sitten alojen sisäinen erikoistuminen. Taloudelliseen edistykseen on liittynyt osallistuminen syvempään kansainväliseen integraatioon, joka on jatkuvasti määrittänyt uudelleen kansallista roolia ja yhä enemmän keskeisten yritysten asemaa kansainvälisessä työnjaossa (Rouvinen, Vartia \& Ylä-Anttila 2007; Väyrynen 2008; Kuisma 2011).

Maailmanjärjestelmäteorian käsittein Suomi on kulkenut periferiasta semiperiferian kautta järjestelmän ytimeen. Tosin syrjäinen maantieteellinen asemamme tuottaa jatkuvasti logistisia ja muita käytännöllisiä ongelmia.

Suomen taloudellisen aseman muutosta ja sosiaalista kehitystä ei voi ymmärtää ilman geopolitiikan huomioimista. Vuoteen 1809 saakka Suomi oli osa Ruotsin itäistä etuvartiota, mutta sai sen piirissä toisaalta kansanvaltaisen poliittisen ja oikeudellisen kehityksen siemenet. Venäjän vallan aikana Suomi toimi Pietarin suojavyöhykkeenä, ja niin kauan kuin se täytti tämän tehtävän ja sisäisen poliittisen vakauden vaatimukset, maan talouden ja yhteiskunnan annettiin kehittyä sangen omaehtoisesti. Voidaan sanoa, että autonominen asema Venäjän imperiumissa mahdollisti teollistumisen ja kansalaisyhteiskunnan liikkeellelähdön sekä omien poliittisten protoinstituutioiden perustamisen. Euroopan suuri muutos ensimmäisen maailmansodan jälkeen teki Suomen kansainvälisestä asemasta epävakaan, joka yhdistyi sisäpolitiikan epävarmuuteen ja ennustamattomuuteen. 
Toisen maailmansodan jälkeen Suomen teollistuminen sai, osaksi itämarkkinoiden vuoksi, uutta vauhtia. Samalla ymmärrettiin, ettei Suomi voi kehittyä taloudellisesti ja rakentaa hyvinvointiyhteiskuntaa ilman pääsyä läntisille markkinoille. Talouden sangen nopea kasvu 1950- ja 1960-luvuilla kärjisti yhteiskunnallista jakokonfliktia erityisesti maalaisliiton ja sosialidemokraattien välillä. Seurauksena oli poliittista epävakaisuutta - lyhytikäisiä hallituksia ja lakkoja - mutta samalla tunnustettiin imperatiivi, että ilman "punamultaa" ei maata voitu hallita. Orkesterin johtajana toimi Urho Kekkonen, joka myös usein kirjoitti sille omat nuottinsa. Kulttuurissa kansallinen elementti joutui antamaan sijaa kansainvälisille vaikutteille, jotka 1900-luvun taitteessa olivat yhteytyneet kansallisen mytologian kanssa, mutta alkoivat nyt sukupolvien vaihtuessa saada omaa voimaa.

Suomen nykyinen murros alkoi kuin hiipien 1980-luvulla. Presidentti Koiviston aikana maan poliittista elämää alettiin parlamentarisoida, ja maan rajat avattiin aktiivisemmalle vuorovaikutukselle sekä yritysten että poliittisten instituutioiden tasolla. Neuvostoliiton asteittainen murentuminen avasi Suomella uutta kansainvälistä poliittista tilaa, jonka hyödyntäminen oli kuitenkin taitolaji: harvat asiat ulkopolitiikassa olivat varmoja tai annettuja. Suomen katsotaan kuitenkin pyrkineen määrätietoisesti vahvistamaan turvallisuuttaan ja suvereniteettiaan (Blomberg 2011). Jäsenyys Euroopan unionissa lopullisesti paalutti Suomen taloudellisen ja poliittisen aseman länsieurooppalaisena kapitalistisena ja demokraattisena pikkuvaltiona. Nyt arktisten alueiden avautuminen kansainväliselle yhteistyölle tarjoaa uusia mahdollisuuksia.

Integroituminen avoimeen maailmantalouteen, mukaan lukien siirtyminen euroon, ovat olleet suomalaisille taloudelliseksi hyödyksi. Samalla yritysten voimakas kansainvälistyminen ja talouden haavoittuvuus ulkoisille shokeille ovat muokanneet yhteiskuntaa perustavalla tavalla. Suomalainen yhteiskunta polarisoituu taloudellisesti taas uudelleen: siihen on syntynyt uusia jakokonflikteja, jotka ruokkivat uudenlaista poliittista kilpailua, johon "vanhat puolueet" eivät ole tottuneet sitten 1950-luvun. Markkinatalouden poliittinen koordinaatio ei toimi enää tavalla, johon tulopolitiikan neljän vuosikymmenen aikana totuttiin. Näin syntyvää kotimaista poliittista epävarmuutta ruokkii eurooppalainen taloudellinen kriisi ja Euroopan unionin pessimistiset näköalat kansainvälisessä 
työn- ja vallanjaossa. Keskeiset yritykset pyrkivät varmistamaan asemansa kansainvälisissä arvoketjuissa, missä onnistuminen ei välttämättä takaa kansantalouksille myönteistä tulevaisuutta, vaikka yksittäiset yritykset saattavat menestyä. Politiikan ja talouden rajoja ja suhteita piirretään taas kerran uudelleen.

\section{Lähteet}

Alapuro, Risto. 2011. Ulkoinen ja sisäinen: Suomen poliittisen kulttuurin pitkä linja. Yhteiskuntapolitiikka (75)5, s. 528-37.

Andersen Torben et al. 2007. The Nordic Model Embracing Globalization and Sharing Risk. Helsinki: Taloustieto.

Appleby, Joyce. 2010. The Relentless Revolution. A History of Capitalism. New York: W.W. Norton.

Apunen, Osmo. 1987. Rajamaasta tasavallaksi. Teoksessa Jukka Tarkka (päätoim.), Suomen historia, osa 6. Espoo: Weilin + Göös, s. 46-404.

Apunen, Osmo. 2005. Linjamiehet. Paasikivi-seuran historia. Helsinki: Tammi.

Aunesluoma, Juhana. 2011. Vapaakaupan tiellä. Suomen kauppa-ja integraatiopolitiikka maailmansodista EU-aikaan. Helsinki. SKS.

Bagh, Peter von. 2007. Sininen laulu. Helsinki: WSOY.

Blomberg, Jaakko.2011. Vakauden kaipuu. Kylmän sodan loppu ja Suomi. Helsinki: WSOY.

de Grazia, Victoria. 2005. Irresistible Empire. America's Advance through $20^{\text {th }}$ Century Europe. Cambridge, MA: Harvard University Press.

Eichengreen, Barry. 2007. The European Economy since 1945. Coordinated Capitalism and Beyond. Princeton, NJ: Princeton University Press.

Eloranta, Eero, Jukka Ranta, Pekka Salmi \& Pekka Ylä-Anttila. 2010. Teollinen Suomi. Tuotannon uudistuminen kriisin jälkeen. Helsinki: Edita.

Engman, Max. 2009. Pitkät jäähyväiset. Suomi Ruotsin ja Venäjän välissä vuoden 1809 jälkeen. Helsinki. WSOY

Figes, Orlando. 2010. Crimea. The Last Crusade. London: Penguin. 
Fliegstein, Neil. 2001. The Architecture of Markets. An Economic Sociology of Twenty-First-Century Capitalist Societies. Princeton, NJ: Princeton University Press.

Frieden, Jeffry A. 2006. Global Capitalism. Its Fall and Rise in the Twentieth Century. New York: Norton.

Haapala, Pertti. 2010. Vallan rakenteet ja yhteiskunnan muutos. Mielikuvaharjoitus 1800-2000-lukujen Suomesta. Teoksessa Petteri Pietikäinen (toim.), Valta Suomessa. Helsinki: Gaudeamus, s. 21-33.

Haavisto, Ilkka \& Pentti Kiljunen.2011. Maailman paras maa. EVAn kansallinen arvo- ja asennetutkimus 2011. Helsinki: Taloustieto Oy.

Hallberg, Pekka, Tuomo Martikainen, Jaakko Nousiainen \& Päivi Tiikkainen. 2009. Presidentin valta. Hallitsijanvallan ja parlamentarismin välinen jännite Suomessa 1919-2009. Helsinki: WSOY.

Hugh, Edward. 2011. Is Finland Really a Closet Member of the Eurozone Periphery. Www.economonitor.com/edwardhugh, 18.12.

Häkkinen, Antti, Eila Linnanmäki \& Pirkko Leino-Kaukiainen. 2005. Suomi suurten ikäluokkien lapsuudessa. Teoksessa Antti Karisto (toim.). Suuret ikäluokat. Tampere: Vastapaino, s. 61-91.

Junnila, Olavi. 1986. Autonomian rakentamisen ja kansallisen nousun aika. Teoksessa Jukka Tarkka (päätoim.) Suomen historia, osa 5.. Espoo: Weilin + Göös, s. 11-165.

Jussila, Osmo. 2004. Suomen suurirubtinaskunta 1809-1917. Helsinki: WSOY.

Kallioinen, Mika ym.. 2010. Kilpailun voittokulku: kartelleista ja säännöstelystä globaaliin markkinatalouteen. Teoksessa Petteri Pietikäinen (toim.), Valta Suomessa. Helsinki: Gaudeamus, s. 56-78.

Kantola, Anu \& Mikko Kautto. 2002. Hyvinvoinnin valinnat. Suomen malli 2000-luvulla. Helsinki: Edita.

Kerkelä, Heikki. 2006. Kehityksen ongelma ja Suomen tie. Teoksessa Juho Saari (toim.), Historiallinen käänne. Johdatus pitkän aikavälin historian tutkimukseen. Helsinki: Gaudeamus, s. 64-90.

Kettunen, Pauli. 2008. Globalisaatio ja kansallinen me. Kansallisen katseen bistoriallinen kritiikki. Tampere: Vastapaino.

Kiander, Jaakko \& Pentti Vartia. 1998. Suuri lama. Suomen 1990-luvun kriisi ja talouspoliittinen keskustelu. Helsinki: Taloustieto.

Kissinger, Henry.1994. Diplomacy. New York: Simon \& Schuster. 


\section{Raimo Väyrynen}

Korkman, Sixten. 2010. Kestääkö pohjoismainen malli? Teoksessa Petri Rouvinen ja Pekka Ylä-Anttila (toim.) Kriisin jälkeen. Helsinki: Sitra, s.177-190.

Kuisma, Markku. 2010. Rosvoparonien paluu. Raha ja valta Suomen historiassa. Helsinki: Siltala.

Kuisma, Markku. 2011. Saha. Tarina Suomen modernisaatiosta ja ihmisistä jotka sen tekivät. Helsinki: Siltala.

Lieven, Dominic. 2000. Empire. The Russian Empire and Its Rivals. New Haven, CT: Yale University Press.

Meinander, Henrik. 1999. Tasavallan tiellä. Suomi Kansalaissodasta 2000-luvulle. Helsinki: Schildts.

Moisio, Pasi. 2010. Tuloerojen, köyhyyden ja toimeentulo-ongelmien kehitys, teoksessa Marja Vaarama, Pasi Moisio \& Sakari Karvonen (toim.), Suomalaisten hyvinvointi 2010. Helsinki: Terveyden ja hyvinvoinnin laitos, s. 180-97.

Naumanen, Päivi \& Heikki Silvennoinen.2010. Koulutus, yhteiskuntaluokat ja eriarvoisuus. Teoksessa Jani Erola (toim.), Luokaton Suomi. Yhteiskuntaluokat 2000-luvun Suomessa. Helsinki: Gaudeamus, s. 67-88.

Nyyssölä, Kari. 2011. Semiperiferisen Suomen taloudellinen ja poliittinen kehitys. Politiikka 53(4), s. 259-70.

Pajarinen, Mika, Petri Rouvinen \& Pekka Ylä-Anttila. 2010. Missä arvo syntyy? Suomi globaalissa kilpailussa. Helsinki: Taloustieto.

Paloheimo, Heikki. 1984. Distributive Struggle, Corporatist Power Structures and Economic Policy of the 1970s in Developed Capitalist Countries. Teoksessa Heikki Paloheimo (toim.), Politics in the Era of Corporatism and Planning. Tampere: Finnish Political Science Association, s. 1-46.

Pääministeri Jyrki Kataisen hallituksen ohjelma. Helsinki: Valtioneuvoston kanslia 22.6.2001. http://valtioneuvosto.fi/hallitus/hallitusohjelma/pdf/ fi.pdf, (23.4.2012).

Rouvinen, Petri, Pentti Vartia \& Pekka Ylä-Anttila.2007. Seuraavat sata vuotta. Aikamatka maailmaan ja Suomeen 1907-2107. Helsinki: Taloustieto.

Ruuskanen, Olli-Pekka, Alex Snellman \& Mika Widgrén. 2010. Yhteiskunnan huipulla: eliittirakenne muutoksessa 1809-2009, teoksessa Petteri Pietikäinen (toim.), Valta Suomessa. Helsinki: Gaudeamus, s. 34-55.

Saari, Juho. 2011. Eriarvoisuus kasvun ja työllisyyden Suomessa. Yhteiskuntapolitiikka 76(1), s. 76-84. 
Savolainen, Raimo.2006. Sivistyksen voimalla. J.V. Snellmanin elämä. Helsinki: Edita.

Stubb, Alexander (toim.). 2006. Marginaalista ytimeen. Suomi Euroopan unionissa 1989-2003. Helsinki: Tammi.

Swank, Duane. 2002. Global Capital, Political Institutions, and Policy Change in Developed Welfare State. Cambridge: Cambridge University Press.

Talvitie, Heikki. 2008. Ruotsin vuoden 1812 politiikan synty, toteutuminen ja sovellutukset. Teoksessa Reima T. A. Luoto, Heikki Talvitie ja Pekka Visuri, Suomen sota 1808-1809. Taustat, tapahtumat, muistomerkit. Espoo: Fenixkustannus, s. 133-196.

Visuri, Pekka. 2010. Idän ja lännen välissä. Puolustuspolitiikka presidentti Kekkosen kaudella. Espoo: Fenix-kustannus.

Väyrynen, Raimo. 1992. Urho Kekkonen. Tasavallan presidentti. Tasavalta kasvaa ja kansainvälistyy. Espoo: Weilin+Göös.

Väyrynen, Raimo ym.. 1999a. Suomi avoimessa maailmassa. Globalisaatio ja sen vaikutukset. Helsinki: Taloustieto Oy.

Väyrynen, Raimo. 1999b. Globalisaatio ja Suomen poliittinen järjestelmä. Helsinki: Taloustieto Oy.

Väyrynen, Raimo. 2000. Globalization and the Politics of Labour in Finland. Teoksessa Lauri Karvonen \& Krister Ståhlberg (toim.), Festschrift for Dag Anckar on his 60th Birthday on February 12, 2000. Åbo: Åbo Akademis Förlag, s. 188-224.

Väyrynen, Raimo.2008. Ninety Years of Finland's Independence: Transition from the Periphery to a Knowledge-Based Economy. Revista de Economia \& Relaciones Internacionais (Sao Paulo) 13(2), 189-202.

Väyrynen, Raimo. 2010. Finanssikriisi ja globalisaation hallinta. Teoksessa Petri Rouvinen ja Pekka Ylä-Anttila (toim.) Kriisin jälkeen. Helsinki: Sitra, s. 113-26.

Wahlbäck, Krister. 2011. Jättens andedräkt. Finlandsfrågan i svensk politik 1809-2009. Stockholm: Atlantis.

Willestrand, Nils Erik. 2009. Riksdelen, Stormakt och riksspraingning 15601812. Helsingfors: Svenska Litteratursällskapet i Finland.

Ylikangas, Heikki. 1987. Käännekohdat Suomen historiassa. Pohdiskeluja kehityslinjoista ja niiden muntoksista undella ajalla. Helsinki. WSOY. 


\section{Viitteet}

1 Nyyssölä (2011) ei kovin selkeästi ratkaise sitä, milloin Suomi siirtyi semiperiferiaan - se näyttää tapahtuneen joko 1930- tai 1960-luvulla - mutta toteaa kyllä selkeästi, että ydinasema saavutettiin 1990-luvulla. Itse olisin taipuvainen aikaistamaan näitä siirtymiä siten, että Suomessa alkoi siirtymä semiperiferiaan jo 1900-luvun taitteessa ja maailmantalouden ytimeen 1960-luvulla.

2 Englanninkielisessä kirjallisuudesta käytetään säännöllisesti vastaavaa käsitettä "developmental state", joka viittaa valtion keskeiseen merkitykseen nousevan talouden pyrkiessä etenemään kansainvälisessä taloushierarkiassa. 
Henri Vogt

\section{Suomen ulkopolitiikka: monensuuntaista eurooppalaistumista?}

Tämän kirjan henkiseen edeltäjään, Pasi Saukkosen toimittamaan Paikkana politiikka -teokseen vuodelta 2003 kirjoitimme Tuomas Forsbergin kanssa $^{1}$ Suomen ulkopolitiikan eurooppalaistumisesta. Tuo termi nähdäksemme kuvasi erityisen hyvin Suomen ulkopolitiikan muutosta sen jälkeen, kun kommunismi oli kukistunut itäisessä Euroopassa 1989-1991 ja Suomi liittynyt Euroopan unioniin vuonna 1995 - paremmin kuin esimerkiksi sellaiset kirjallisuudessa hiukan aiemmin käytetyt termit kuin "lännettyminen", "yhteisöllistyminen" tai "puolueettomuudesta sitoutumiseen".

Erottelimme viisi eri seikkaa, joiden myötä Suomen ulkopolitiikan voitiin sanoa muuttuneen yhä eurooppalaisempaan suuntaan. EU-jäsenyyden vaatimukset olivat tietysti tärkein konkreettinen tekijä tämän muutoksen taustalla, mutta kyse oli myös laajemmista maailmanpoliittisista muutoksista, ennen kaikkea yhä voimistuneesta taloudellisesta globalisaatiosta ja siitä johtuvasta valtioiden keskinäisriippuvuudesta.

Ensinnäkin oli selvää, että pääministerin ulkopoliittinen valta oli kasvanut. Uusi, vuonna 2000 voimaan astunut perustuslaki määräsi kaikkien EU-asioiden valmistelun valtioneuvostolle ja myös unionin "ulkopuolisissa" ulkopoliittisissa kysymyksissä presidentin, ulkopolitiikan perinteisen suvereenin johtajan, tuli toimia yhteistyössä valtioneuvoston kanssa. Näin Eurooppa-neuvostossa, unionin laajat kehityskulut viitoittavassa 


\section{Henri Vogt}

elimessä, jonka toimivaltaan ulkoasiat kuuluivat (ja kuuluvat), pääministeristä tuli ensisijainen osallistuja, kun taas presidentti osallistui niihin vain harkintansa mukaan. Tämä suomalaisten erityiskohtelu eli kahden eri toimijan samanaikainen osallistuminen unionin ylimpään päätöksentekoon (niin sanottu lautasongelma) on nykyisin ratkennut niin, että vain pääministeri enää lähtökohtaisesti osallistuu neuvoston kokouksiin. Unionijäsenyyden myötä myös eduskunnan rooli ulkopoliittisessa toiminnassa vahvistui, ennen kaikkea sen vuoksi, että eduskunnan suuresta valiokunnasta tuli myös EU-valiokunta. Kaikesta huolimatta rooli on kuitenkin pysynyt suhteellisen rajallisena.

Toiseksi Suomen sodanjälkeisen ulkopolitiikan peruslinja, puolueettomuus, oli saanut antaa tilaa yhteiselle eurooppalaiselle ulko- ja turvallisuuspolitiikalle. 1990-luvulla puolueettomuus virallisena ilmaisuna vähitellen hävisi ja alettiin sen sijaan puhua ennen kaikkea "sotilaallisesta liittoutumattomuudesta ja itsenäisestä puolustuksesta”. Tämä linja on viimeisen vajaan kymmenen vuoden aikana vain entisestään vahvistunut. Jyrki Kataisen hallitusohjelma (kesäkuulta 2011) esimerkiksi muotoilee asian niin, että "Suomi on sotilasliittoon kuulumaton maa". Sen sijaan varauksetonta sitoutumista EU:iin, mukaan lukien sen voimistuva sotilaallinen ja kriisinhallinnallinen ulottuvuus, korostetaan toistuvasti erilaisissa poliittisissa dokumenteissa. Uusin tuvallisuuspoliittinen selonteko vuodelta 2009 muotoilee tämän selkokielisesti: "Jäsenyys Euroopan unionissa on Suomelle perustavanlaatuinen turvallisuuspoliittinen valinta. Unionin jäsenenä Suomi on osa tiivistä poliittista liittoa, jonka jäseniä yhdistää vahva yhteenkuuluvuus ja tahto toimia yhdessä. Suomi on tähän vahvasti sitoutunut." (s. 69)

Suhteet Pohjois-Atlantin liittoon (Nato) ovat samanaikaisesti säilyneet joltisenkin mutkikkaina. Naton kanssa kuitenkin tehdään jatkuvasti vahvaa yhteistyötä, myös EU:n kautta, ja optio jäsenyydestä halutaan jatkuvasti pitää avoinna. Tilanne ei näin olennaisesti ole muuttunut viimeisen vajaan kymmenen vuoden aikana. ${ }^{2}$

Kolmanneksi Suomen suhteet eri Euroopan valtioihin olivat tiivistyneet ja monipuolistuneet. Aikaisempi ensisijainen viitekehys eli pohjoismainen yhteistyö oli heikentynyt ja erityisesti suhteet Saksaan ja myös jossain määrin Ranskaan olivat vahvistuneet; niin presidentti Martti Ahtisaari (1994 -2000) kuin pääministeri Paavo Lipponen (1995-2003) 
pitivät henkilökohtaisesti Saksaa luontevana ja luotettavana yhteistyötahona. Politiikka suuntautui siis vahvasti integraatioprojektin ydinakselille, ja paljon puhuttiin siitä, kuinka Suomi halusi päästä Euroopan unionin ytimeen - tai pikemminkin sen kaikkiin mahdollisiin ytimiin. Analyyttisemmassa mielessä kyse oli ennen kaikkea siitä, että yhteistyötahot erilaisissa EU-kysymyksissä, myös ulkopolitiikan alueella, haettiin pragmaattisesti sieltä, mistä yhteistyötaho kulloinkin oli löydettävissä. Tämänkaltainen toiminta on edelleenkin Suomen, ja toki myös muiden EU-maiden, toiminnalle tyypillistä, vaikka myös unionin sisäisillä alueellisilla yhteistyökehikoilla - Suomen tapauksessa pohjoiseurooppalaisella - on merkitystä.

Neljänneksi, Suomen suhteet Venäjään oli 'multilateralisoitu'. Se erityinen kahdenvälinen suhde, joka oli kylmän sodan aikana ja toimivan kauppakumppanuuden myötä Neuvostoliittoon luotu, oli nopeasti alkanut näyttää jo varsin kaukaiselta, ja miltei kummalliselta, historialta. Suhteet Venäjään oli siis ensisijaisesti viety Euroopan unionin toimintapiiriin, vaikkakin myös muiden kansainvälisten valtiollisten organisaatioiden rooli oli idänsuhteissa vahvistunut, sellaisten kuin Arktinen neuvosto (perustettu 1996) ja Itämeren valtioiden neuvosto (1992). EU-Suomen merkittävin ulkopoliittinen aloite eli "Pohjoinen ulottuvuus" - aloite tehtiin Luxemburgin Eurooppa-neuvostossa vuonna 1997 - on mahdollista nähdä nimenomaan tästä näkökulmasta, siis yrityksenä luoda sellainen monenvälinen yhteistyökehikko pohjoiseen Eurooppaan, jossa myös Venäjä voi luontevasti olla mukana. Vuonna 2006 uudistettu Pohjoisen ulottuvuuden politiikka edustaa nykyisin "neljän tasa-arvoisen kumppanin, EU:n, Venäjän, Islannin ja Norjan" yhteistyötä ja sen "tavoitteena on käytännön yhteistyön avulla tukea vakautta, hyvinvointia ja kestävää kehitystä alueella" (UM 2009). ${ }^{3}$

Monenvälisen Venäjä-politiikan vahvuudesta huolimatta myös kahdenvälinen politiikka on Venäjä-suhteissa edelleenkin hyvin merkityksellistä. Voi olla, että se on taas viime aikoina jopa voimistunut, sillä jatkuvasti lisääntyvä kahdenvälinen kohtaaminen venäläisten kanssa ikään kuin pakottaa kehittämään myös kahdenvälisiä suhteita. Venäläisperäisen väestön määrä Suomessa on jatkuvasti kasvanut, ja maiden välinen turismi on laajentunut nopeasti; viisumikysymykset ovat alati tapetilla. Kahdenväliset kauppasuhteet ovat kehittyneet varsin positiivisesti 


\section{Henri Vogt}

2000-luvulla. Tosin myös Venäjän ja Suomen välinen viime vuosien merkittävin kiista - ongelma puutulleista 2008-09 - on nimenomaan ollut kauppapoliittinen kysymys.

Viidenneksi myös Suomen globaalipolitiikkaa oli alettu harjoittaa yhä vahvemmin Euroopan unionin tarjoamassa kehikossa. Tuo kehikko on monitahoinen: Kansainvälinen kauppapolitiikka on tietysti koko integraation keskeisiä osa-alueita, ja myös kehityspolitiikka on ollut vahvasti unionin agendalla alusta saakka - lähinnä jäsenmaiden siirtomaamenneisyydestä johtuen. Ympäristöpolitiikka puolestaan on nimenomaan ollut alue, jolla kansainvälinen yhteistyö on ollut välttämätöntä ja jossa EU:lla on ollut maailmanlaajuisesti selkeästi johtava rooli viimeisen 20 vuoden aikana. Globaalipolitiikan peruslinja on pysynyt muuttumattomana 2000-luvulla; Suomi on systemaattisesti korostanut näkemystä, jonka mukaan vain vahvistamalla EU:a globaalina toimijana Suomen kaltainen pieni maa voi saada äänensä kuuluviin maailman mittaisissa asioissa. Suomen sitoutuminen globaalitoimija-EU:iin vielä korostui Alexander Stubbin ulkoministerikaudella 2008-11. Toisaalta 2000-luvulla on kuitenkin ollut hankkeita, joilla Suomi on myös hakenut selkeää omaa profiilia globaalipolitiikassa. Eurooppalaisesta pääministeripolitiikasta huolimatta Suomen presidentti-instituutio on tarjonnut tämäntyyppiseen toimintaan luontevan kanavan.

Tasavallan presidentti Tarja Halonen on profiloitunut vahvana globaalina vaikuttajana, esimerkiksi toimiessaan ILO:n asettaman Globalisaation sosiaalisen ulottuvuuden maailmankomission puheenjohtajana (2002-04) ja YK:n kestävän kehityksen toimikunnan puheenjohtajana vuodesta 2010 alkaen. ${ }^{4}$ Myös Itämeren suojelussa Halonen ja Suomen muukin poliittinen johto on ollut aktiivinen, hyvänä esimerkkinä helmikuun 2010 Baltic Sea Action Summit, jossa koko laajennetun Itämeren alueen poliittinen johto vakuutti sitoutumistaan meren suojeluun. Rauhanturvaamisen ja konfliktinratkaisun suurvalta-asemaa on myös haviteltu, ja presidentti Martti Ahtisaaren saama Nobelin rauhanpalkinto vuonna 2008 osoitti, että tällaisille tavoitteille saattaisi olla katetta (vrt. Joenniemi 2009, HS 26.7). Myös kansallinen kehityspolitiikka on EU:sta huolimatta pysynyt vahvana, jopa suomalais-pohjoismaalaisen hyvinvointivaltioidentiteetin kannalta tärkeänä. Ulkoasianministeriön esittelemä, kehityskysymyksiin ja pohjois-etelä suhteisiin laajasti paneutunut 
niin sanottu uusi Helsinki-prosessi 2000-luvun alkupuolella voidaan myös nähdä Suomen omana brändäystyönä kehityspolitiikan alalla. ${ }^{5}$

\section{Kuva monipuolistuu}

Yllä esitetty tuntuisi osoittavan, että monessa suhteessa vuoden 2003 analyysimme puolustaa edelleenkin paikkaansa. Eurooppalaistuminen laajassa mielessä on jatkunut ja se on edelleen se perustrendi, josta meidän on kehitystä syvällisesti ymmärtääksemme lähdettävä liikkeelle. On kuitenkin myös seikkoja, joiden myötä kuva on nyt selvästi vivahteikkaampi, ristiriitaisempikin, kuin se oli vajaa kymmenen vuotta sitten. Muutosta selittävät niin koko Euroopan tason kuin Suomen sisäisetkin tekijät. Tämän vivahteikkuuden näkyväksi tekeminen on käsillä olevan tekstin keskeinen tavoite.

Jo pelkästään Eurooppa-tason tekijät piirtävät kaksitahoisen kuvan. Yhtäältä EU:n ulkopolitiikka on edelleen vahvistunut, ja Suomi on tätä halunnut johdonmukaisesti edistää. Erityisesti unionin globaaliroolia, johtavaa asemaa monella politiikan suursektorilla, on jatkuvasti korostettu. Tämä ei ole ollut pelkästään juhlapuheiden retoriikkaa, vaan myös toiminnallisesti on menty eteenpäin - kansainvälinen ympäristöpolitiikka ehkä parhaana esimerkkinä. Myös tutkimustulokset osoittavat, että unionin sisäisistä institutionaalisista ongelmista huolimatta EU käytännössä puhuu yhä useammin yhdellä äänellä maailmanpolitiikassa ja konkreettisemmin erilaisten hallitustenvälisten organisaatioiden sisällä. ${ }^{6}$ Irakin sodan yhteydessä vuonna 2003 pahasti kahtia jakautunut Eurooppa onkin monissa keskeisissä kysymyksissä ulkopoliittisesti ollut viime vuosina suhteellisen yhtenäinen. Esimerkkejä tästä ovat suhtautuminen Venäjän ja Georgian konfliktiin 2007 ja toiminta suhteessa Israel-Palestiina-konfliktiin.

Samalla kuitenkin näyttäisi siltä, varsinkin vuonna 2008 alkaneen taloudellisen kriisin myötä, että kansallinen ajattelu ja kansalliset intressit ovat vahvistuneet koko Euroopan tasolla. Ulkopoliittisen eurooppalaistumisen lähtökohtaongelma, ylikansallisten tavoitteiden ja kansallisten, elintärkeiksi määriteltyjen etujen kohtaamattomuus, on siis alkanut korostua entistä enemmän. Yhteisen eurooppalaisen ulkopolitiikan muo- 
dostaminen astuu perinteisen kansallisen suvereniteettikäsityksen ytimeen, eikä kansallisvaltioilla vieläkään aina näytä olevan halua luovuttaa valtaansa erityisessä määrin niiden yläpuolisille tahoille, ei vaikka se niiden pitkän tähtäimen etujen kannalta voisikin olla rationaalista.

Muutos "eurooppalaisuuden" suuntaan on sis niin Suomessa kuin muuallakin Euroopassa vielä jäänyt puolitiehen. Jopa Saksa, kansleri Angela Merkelin toistuvasti käyttämin sanankääntein, käyttäytyy yhä enemmän tiukan kansallisten etujensa mukaisesti, siten kuin kaikki muutkin "tavalliset" kansallisvaltiot. Jossain mielessä myös kansallinen identiteettipuhe, ennen kaikkea suhteessa globalisaatioon, on voimistunut, kansallismieliset puolueet vahvistuneet, ja myös tämä vaikeuttaa yhteisen eurooppalaisen ulkopoliittisen linjan löytymistä. (Vogt 2010.)

Suomen kohdalla on tässä suhteessa myös huomattava, että pohjoismaista yhteistyötä on jälleen alettu korostaa ulkopoliittisissa puheenvuoroissa yhä enemmän. On ikään kuin oltu palaamassa vanhaan yhteistyökehikkoon, mutta voisimme kenties myös puhua uusalueellistumisesta Euroopan sisällä. Kenties konkreettisin esimerkki tästä on norjalaisen veteraanidiplomaatin Thorvald Stoltenbergin työryhmä ja sen loppuraportti "Pohjoismaiden ulko- ja turvallisuuspoliittinen yhteistyö" helmikuulta 2009, jonka yhtenä alkulähtökohtana oli käsitys siitä, että "kaikissa Pohjoismaissa toivotaan tällä hetkellä laajalti pohjoismaisen yhteistyön vahvistamista" (s. 3). Tätä toivetta täyttämään raportin pitkä, kolmentoista kohdan ehdotuslista yhteistyömahdollisuuksista päättyy ehdotukseen pohjoismaisesta turvallisuuspoliittisesta solidaarisuusjulistuksesta, siis varsin pitkälle menevään yhtenäisyyden osoitukseen. On pohdinnan arvoista, olisivatko Pohjoismaiden samantyyppiset kokemukset globalisaation aikakaudella - niiden selviäminen poikkeuksellisen hyvin - tuoneet näitä maita entistäkin vahvempaan yhteyteen toistensa kanssa. (Ks. myös Tiilikainen ja Korhonen 2011.)

Sisäisten ja Eurooppa-tason tekijöiden yhdistelmä, joka on vaikuttanut lisääntyvään ulkopoliittiseen vivahteikkuuteen, on, että politiikan teosta yleensä, ja ulkopolitiikasta erityisesti, on tullut EU:n kontekstissa ja myös globaalien vaatimusten myötä, huomattavasti entistä mutkikkaampaa. Euroopan unionin sisällä joudutaan huomioimaan hyvin monia erilaisia toimijoita eri politiikan tasoilla, ja politiikan tehtävänä on yrittää koordinoida näitä eriäviä näkemyksiä yhteen. Koordinoinnin ja suuren 
toimijajoukon vuoksi on hyvin vaikea joskus sanoa, missä päätökset tehdään ja kuka ne itse asiassa tekee. Samalla hyvin moni politiikkalohko näyttää sisältävän ulkopoliittisen ulottuvuuden. Esimerkiksi (Suomen) ympäristö- ja kulttuuriministeriöillä on myös oma ulkosuhdetoimintansa, vähintäänkin eurooppalaisen politiikan kentällä. Ulkopolitiikan paikka on näin tullut yhä vaikeammaksi määritellä, institutionaalinen moninaisuus hämärtää kuvaa, perinteinen diplomatia on yhä vahvemmin vain yksi ulkosuhteiden osa-alue. Suomessa on vasta viimeisen kymmenen vuoden aikana todella käytännön ulkoministeriötyössäkin herätty tähän todellisuuteen.

Tämä merkitsee myös, että ulkopoliittinen koherenssi, eri politiikkasektorien toiminnan samansuuntaisuus, on tullut yhä vaikeammaksi saavuttaa. EU:n sisällä tämä on merkittävä ongelma, jonka poistamiseen on käytetty viime vuosina huonolla menestyksellä paljon voimavaroja, mutta sama ongelma esiintyy pienemmässä mittakaavassa myös unionin jäsenmaissa.

Suomen sisäinen, tosin edelliseen vahvasti liittyvä tekijä on se, että ulkopolitiikka on nyt selvästi aiempaa avoimemmin poliittista, eri poliittisten, maailmankatsomuksellisten näkemyksien välistä yhteensovittamista. Vielä EU-taipaleen alussa kansallinen konsensus, eurooppalaistumisen toteuttamistavoite, näytti varsin suurelta ja vaikka se edelleenkin toisinaan löytyy yllättävän helposti, on tilanne nykyisin aivan erilainen. Eri puolueilla voi olla toisistaan jyrkästi poikkeaviakin kantoja; sosialidemokraattien ja kokoomuksen ulkopoliittinen linja on ollut jossain määrin erilainen, perussuomalaiset näkemykset ovat tuoneet vielä oman lisänsä keskusteluun. Paavo Lipponen, Matti Vanhanen, Erkki Tuomioja, Alexander Stubb ja Mari Kiviniemi ovat olleet jo hahmoinakin hyvin erilaisia Suomen etujen edistäjiä eurooppalaisessa politiikassa, ja heidän näkemyksenä vaikkapa eurooppalaisen integraation tavoitteista tai Suomen turvallisuuspolitiikan tarpeista ovat usein kaukana toisistaan.

Edellä on luotu suhteellisen suoraviivainen katsaus suomalaisen ulkopolitiikan yleisiin muutoksiin EU-jäsenyyden aikaudella. Analyyttisemman tavan ajatella eurooppalaistumisen vivahteikkuutta tarjoaa Teemu Palo- 


\section{Henri Vogt}

saari tuoreessa Suomen ulkopolitiikkaa käsittelevässä väitöskirjassaan The Art of Adaptation (2011). Palosaaren ensisijaisena teoreettisena kehikkona on ajatus siitä, että yhtäältä ulkopolitiikka adaptoituu - mukautuu ja sopeutuu - eurooppalaisiin periaatteisiin ja käytäntöihin yhteensopivaksi; politiikka kulkee ylhäältä alas. Toisaalta jäsenmaat kuitenkin yrittävät projisoida omia arvojaan ylöspäin unioni-tasolle, muokata yhteistä ulkopolitiikkaa omien etujensa mukaiseksi. ${ }^{7}$ Lisäksi Palosaari tekee erottelun heikon ja vahvan (thin vs. thick) eurooppalaistumisen välillä. Vahva trendi merkitsee yhteiskunnan arvojen syvällistä sosiokulttuurista muutosta, jolloin voidaan jopa puhua kansallisen identiteetin muutoksesta. Heikko suunta taas viittaa lyhyen tähtäimen rationaalisiin ja instrumentaalisiin muutoksiin, jotka usein jäävät vaikutuksiltaan lopulta varsin pinnallisiksi. Periaatteessa eurooppalaistuminen voisi näin pitää sisällään neljä eri päämuotoa: heikon ja vahvan adaptaation sekä heikon ja vahvan projektion. Vahvassa projektiossa esimerkiksi ajatus koko eurooppalaisuudesta muuttuisi jonkin tietyn yhden jäsenmaan (tai jäsenmaaryhmän) toiminnan myötä. Viime aikojen vaikeudet eurooppalaisessa ulkopolitiikassa voidaan puolestaan nähdä kansallisvaltiollisten heikkojen projektioiden vahvistumisen näkökulmasta.

Näitä neljää ideaalityyppiä kehikkonaan käyttäen ja analyysinsa Eduskunnassa käytettyihin keskusteluihin perustaen Palosaari jakaa Suomen ulkopolitiikan eurooppalaistumisvaiheen kolmeen eri jaksoon. Ensimmäisessä vaiheessa eurooppalaistumisen alkutaipaleella 1990-luvulla pystyttiin perinteinen puolueettomuuspolitiikka määrittelemään uudelleen, niin että Euroopan unionin yhteisen ulko- ja turvallisuuspolitiikka, lyhyesti YUTP, ei näyttänytkään uhkaavan sen perinteitä, vaan se pikemminkin vain instrumentaalisesti täydensi Suomen omaa politiikkaa. ${ }^{8}$ Tätä voidaan siis pitää esimerkkinä heikosta ylhäältä alaspäin tapahtuvasta eurooppalaistumisesta.

Vuodesta 1997 alkaen Suomi yrittää myös yhä vahvemmin projisoida (heikko projisointi) omia näkemyksiään eurooppalaiselle tasolle. Vuosituhannen vaihteessa keskustelua käydään paljon muun muassa kansainvälisen kriisinhallinnan ja oman puolustuksen välisestä suhteesta - ja vakautetaan lopulta näkemys, jonka mukaan Suomella olisi paljon annettavaa tällä alalla. Myös edellä mainittu Pohjoisen ulottuvuuden aloite on tästä hyvä esimerkki. 
Kolmannessa vaiheessa, noin vuodesta 2003 alkaen, vakiintuu ajatukseksi, että pienelle maalle EU:n kautta saatavat turvallisuushyödyt ovat oleellisia, ja tämän takia hyvin vahvasti kansainvälisillä kentillä toimiva EU on myös Suomen kannalta etu. Tässä voidaan jo selkeästi puhua vahvasta, miltei identiteettien tasolle käyvästä adaptoituvasta eurooppalaistumisesta. Käsitys Suomen paikasta maailmassa olisi muuttumassa. Ehkäpä maan paikka Euroopassa olisi vakiintumassa.

\section{Varovaisuuden jatkumo}

Kaikki edellä kerrottu on pikemminkin tarinaa muutoksesta kuin jatkuvuudesta. Suomen ulkopolitiikassa voidaan kuitenkin myös nähdä tiettyä jatkuvuutta, joka nähdäkseni edelleenkin liittyy ennen kaikkea maan sodanjälkeiseen ulkopoliittiseen perinteeseen. Tuon perinteen mukaan Suomi on kansainvälisissä yhteyksissä halunnut pikemminkin näyttäytyä lääkärinä kuin tuomarina. Metafora oli aikanaan sikäli yksisuuntaisuudessaan osuva, että ulkopolitiikka oli pitkään niin vahvasti presidentin hallussa, että tällainen selväpiirteinen kuva oli mahdollista piirtää. Nykyisin tällainen tiivistys näyttää lähtökohtaisesti kyseenalaiselta, koska ulkopolitiikkaa tehdään niin montaa eri tietä, kuten edellä on todettu.

Käsityksiä jatkuvuudesta on viime vuosina esitelty eri tavoin. Vilho Harle (2008, HS 22.1.; vrt. esim. Kivinen HS 12.9.2008) on puhunut - enkä pysty hänen näkemystään kiistämään - siitä, kuinka realismin perintö edelleen on hallitseva filosofia suomalaisen ulkopoliittisen kannunvalannan taustalla; on erilaisia ulkopoliittisia näkemyksiä, mutta silti yksi linja vielä dominoisi. Suurvaltapolitiikan eturistiriitojen ja viime kädessä sotilaallisella voimalla uhkaamisen ajatellaan yhä vielä viime kädessä määrittävän sitä, miten maailma toimii ja mikä on pienen Suomen paikka tuossa maailmassa. Tarina ilmeisestikin jatkuu siten, että vain kansallinen yksituumaisuus ja varautuminen pahimpaan voivat meidät lopulta pelastaa.

Toisinaan yksituumaisuus näyttääkin edelleen löytyvän varsin vaivatta. Jos ajatellaan sitä, kuinka paljon Suomessa esimerkiksi vakavasti keskusteltiin keväällä 2011 siitä, pitäisikö maan osallistua Libyan vastaisiin sotilaallisiin pommituksiin, erilaisten näkemysten määrä oli häviävän 


\section{Henri Vogt}

pieni. Samoin kun tein sanomalehtianalyysia suomalaisesta ulkopoli keskustelusta tätä artikkelia varten ${ }^{9}$, silmiinpistävää oli edelleenkin ulkopoliittisten keskustelijoiden (ja todellisen keskustelun) vähäinen määrä - ja heidän tulemisensa vähintään keski-ikään ehtineistä miespiireistä; naisten osuus ulkopoliittisten keskustelijoiden joukossa on itse asiassa masentavan vähäinen. Ulkopolitiikkaan syvällisesti paneutuvien toimittajien määrä on myös erittäin rajallinen. Realismiin pohjautuvassa samanmielisyyden ilmapiirissä ulkopolitiikan sanastokin on helposti jo vanhentunutta, ei kompleksisen keskinäisriippuvuuden aikakauteen välttämättä sopivaa.

Mika Aaltolalle (2011) puolestaan on jatkumoa se, että Suomen kaltainen pieni maa pystyy jatkuvasti rekonstruoimaan ja leikittelemään identiteettinsä eri muodoilla, jopa kaikkein pysyvimmillä kansallisilla stereotyyppisillä kuvilla, joita hän kutsuu termillä "thick image”. Sellaiset kylmän sodan aikakaudella Suomeen liitetyt seikat kuin "silta idän ja lännen välillä" tai "pieni erikoistapaus" on nykyhetkessä pystytty muuttamaan niin, että ne sopivat "globaalin maailman" vaatimuksiin - nykyisessä kielenkäytössämme "maailma" ei ole enää pelkästään maailma vaan se on aina "globaali maailma". Jatkuvuutta olisi nimenomaan joustavuus jopa identiteettien tasolla.

Miten muuten voisimme analyyttisesti kuvata suomalaisen ulkopoliittisen ajattelun jatkumoa? Yksi mahdollinen tapa voisi olla lähteä liikkeelle moraalisen ja pragmaattisen ulkopolitiikan välisestä jaottelusta. Suomi on selkeä esimerkki jälkimmäisestä. Edelleenkin ulkopoliittisia lausumiamme leimaa varovaisuus, instrumentaalinen ajatus siitä, että meidän on jatkossa pystyttävä toimimaan kaikkien osapuolten kanssa ja solmimaan heihin kauppasuhteita sekä halu olla kiistan välissä pikemmin kuin jommankumman osapuolen kannalla. Ulkopoliittinen retoriikka sisältää näin varsin vähän vahvaa moraalista paatosta. Naapurimaa Ruotsi sen sijaan voidaan nähdä niin sanotusti moraali-vallan perikuvana. Maan kansallinen ulkopolitiikka on jo pitkään perustunut vahvaan näkemykseen ruotsalaisesta progressiivisuudesta, demokraattisuudesta ja yhteiskuntamallista, joka niin Euroopan kuin maailmankin tasolla on ainutlaatuisen hyvin toimiva. Tämäntyyppinen näkemys omasta maasta luo moraalisen oikeuden lausua kriisien suhteen yksiselitteisiä mielipiteitä (Trägårdh 
2002) ja vaikuttaa myös siihen, miten laajemminkin yhteiskunnassa ja mediassa keskustellaan ulkopoliittisista asioista. ${ }^{10}$

Kun verrataan Suomen ja Ruotsin suhtautumista viime vuosien merkittäviin kansainvälisiin konflikteihin, erot tässä suhteessa näyttäisivät olevan suhteellisen selkeästi näkyvissä - ulkopoliittisen johdon poliittisesta suuntautumisesta riippumatta. Esimerkiksi Irakin sodan (2003) ja Georgian ja Venäjän välisen konfliktin (2008) konteksteissa suomalaiset kannanotot näyttäytyivät selkeästi ruotsalaisia varovaisempina, vähemmän suoraan tuomitsevina, vielä vahvemmin kansainvälisen yhteisön roolia painottavina ja neuvottelutietä korostavina. ${ }^{11}$ Tässä meidän täytyy tyytyä vain yhteen esimerkkiin: kun Alexander Stubb 7.8.2008 kommentoi alkanutta kriisiä Georgian ja Venäjän välillä, hän valitsi sanansa tarkoin, siten, että ne näyttäisivät hyvin sopivan suomalaisen ulkopolitiikan jatkumoon:

Tilanne alueella on erittäin kireä ja vaaditaan pikaisia toimia jännityksen laukaisemiseksi. Olen tänään ollut yhteydessä sekä Tbilisiin että Tshkinvaliin ja kehottanut osapuolia lopettamaan kaiken sotilaallisen toiminnan ja pyrkimään takaisin suoraan neuvottelukosketukseen. Ilmaisin myös huoleni siitä, ettei konfliktin osapuolten tapaaminen tänään toteutunut, ja toistin heille kutsun saapua neuvottelemaan Helsinkiin mahdollisimman pian. Aion myös matkustaa Georgiaan lähiaikoina. (www.formin.fi, 6.9.2011)

Sen sijaan Ruotsin ulkoministeri Carl Bildt, joka tosin on muutenkin tunnettu vahvoista retorisista muotoiluista, oli kaksi päivää myöhemmin selvästi jyrkempi kannanotossaan, niin jyrkkä, että Ruotsin suhteet Venäjään ovat olleet jossain määrin ongelmalliset viime vuosina. Hänen sanansa kuitenkin sopivat hyvin siihen perinteeseen, joka Ruotsissa on ollut vallalla pitkään:

Vaadin Venäjän federaatiota, Georgiaa ja separatistisia Etelä-Ossetian ja Abhaasian hallintoja välittömästi ryhtymään tulitaukoon vihollisuuksien lopettamiseksi. [...] Pahoittelen [deplore; konnotaationa myös "tuomitsen"] syvästi Venäjän sotilastoimet Georgiaa kohtaan. Ne syyt, joita Venäjän viranomaiset ovat esittäneet, eivät oikeuta sotilaallisiin toimiin Georgian alueella, ei Etelä-Ossetiassa eikä muissakaan Georgian osissa. ${ }^{12}$ 


\section{Henri Vogt}

Meillä voisi olla myös toinen analyyttinen ulottuvuus käytettävissämme. Pertti Joenniemi (2002) on tehnyt jaottelun hegeliläiseen ja herderiläiseen ulkopoliittiseen ajatteluperinteeseen. Edellinen viittaa vahvasti valtiojohtoiseen ja näin usein valtapoliittiseen ajatteluun - valtio on itsessään hyvä ja eettinen idea. Herderiläinen perinne puolestaan korostaa kansallista kulttuuria ja sen voimistamista ja tunnetuksi tekemistä. Itse puhuisin näiden filosofisten käsitteiden sijaan pikemminkin "kulttuurisen vuorovaikutuksen" ja "valtiojohtoisen valtapolitiikan" välisestä jännitteestä.

Suomen kuva ei tässä suhteessa kuitenkaan ole erityisen selvä, kuten myös Joenniemi toteaa. Yhtäältä, kuten yllä on Vilho Harleen viitaten mainittu, Suomessa vaikuttaa vahva realistinen traditio, joka edelleenkin määrittää sitä, miten ulkopolitiikassa tulisi ajatella. Toisaalta - tässä taas on piirteitä Aaltolan argumentaatiosta - myös kansallisen kulttuurin erityislaatuisuuden painotus on jatkuvasti materialisoitunut ulkopoliittisissa käytännöissä. Kulttuurivienti ja maabrändäys nähdään ulkopolitiikan jatkeina; kansallinen, pikemminkin kuin valtiollinen, identiteetti heijastuu ulkopolitiikan kautta. Kaiken kaikkiaan ajattelisinkin, että Ruotsissa ja Tanskassa, vanhoissa eurooppalaisissa suurvalloissa, valtiollinen valtapoliittinen ajattelu on lopulta vahvempaa kuin Suomessa ja Norjassa, joissa kansa muodosti valtion historiallisesti suhteellisen myöhään (1904 ja 1917).

\section{Lopuksi}

Edellä on kuvattu suomalaisen ulkopolitiikan, ja ulkopoliittisen ajattelun, muutoksia erityisesti suhteessa eurooppalaistumiseen, joka sinänsä on jatkuvasti muuttuva käsite - eurooppalaistuminen kymmenen vuotta sitten oli aivan muuta kuin se on tänään. Perusväitteenä on ollut, että ulkopoliittinen eurooppalaistuminen on viime aikoina muuttunut yhä monisuuntaisemmaksi, mutta että Suomi ei tässä suhteessa millään lailla ole eurooppalainen erityistapaus. Toisaalta on korostettu sitä, että myös jatkuvuutta on ulkopolitiikassa kaikesta huolimatta nähtävissä: instrumentaalisen ja institutionaalisen varovaisuuden perinne ei ole kadonnut. 
Lopuksi on vielä syytä kysyä, millaista tulevaisuuskuvaa itsestään Suomi voi ulkopolitiikassaan tavoitella ja toteuttaa. Suomen ulkopolitiikkaa laajasti analysoinut Christopher Browning on hiljattain (2008) esittänyt Suomelle neljää kansainvälispoliittista perusvaihtoehtoa lähivuosille ja vuosikymmenille. Ensimmäisessä vaihtoehdossa Suomi haluttaisiin nähdä maailman johtajana ja globaalina kansalaisena. Suomen arviot maailmasta perustuisivat globaaleihin etuihin ja maa toimisi niiden puolesta aktiivisessa eturintamassa. Toisen vision mukaan Suomesta voisi tulla atlantistinen länsiliittoutunut, vähän samaan tapaan kuin Tanska, joka on ollut hyvin vahvasti angloamerikkalaisen turvallisuuspoliittisen ajattelun tukija viimeisen kymmenen vuoden aikana. Kolmas mahdollisuus puolestaan näkisi Suomen pienenä eurooppalaisena partnerina, joka keskittyisi lähinnä EU:n ja alueellisiin poliittisiin kysymyksiin. Neljännen mukaan taas Suomi jättäytyisi itäisen Euroopan syrjäiseksi vetäytyjäksi.

Ajattelisin, että päävaihtoehtoja tulevaisuudelle voisi vielä tiivistää, ehkäpä vain kahteen peruskategoriaan. Toisessa Suomi olisi aidosti avoin eurooppalainen ja globaali toimija, jonka politiikkaa ohjaisivat pitkän tähtäimen laajat intressit, vahva sitoutuminen koko kansainvälisen yhteisön demokraattisiin pelisääntöihin sekä ajatus siitä, että suhteellisen pienikin aktiivinen toimija voi hyvien argumenttien voimalla merkittävästi vaikuttaa kansainvälisen järjestyksen muotoutumiseen. Toisessa puolestaan suomalaiset lyhyen tähtäimen kansalliset edut määrittelisivät Suomen politiikkaa maailmalla globaalin ja eurooppalaisen näkökulman sijaan. Henkinen kiinnittyminen valtapoliittiseen realistiseen maailmankuvaan pysyisi vahvana. Eurooppalainenkin politiikka perustuisi ajatukseen suuralueiden välisestä kilpailusta ja pelosta sen suhteen, ettei tuossa kilpailussa pärjättäisi.

Kaikesta tämän hetken ristiriitaisuudesta huolimatta suomalainen ulkopolitiikan kehityskulut viittaavat - onneksi - siihen, että edellinen näistä vaihtoehdoista on jälkimmäistä todennäköisempi tulevaisuudessa. Tämä ei kuitenkaan ole itsestäänselvyys, vaan sikäli kuin avointa ja globaalia EU-Suomea halutaan, sen puolesta pitää koko suomalaisen yhteiskunnan, niin kansalaisyhteiskunnan kuin poliittisen eliitinkin, jatkuvasti argumentoida. 


\section{Henri Vogt}

\section{Lähteet}

Aaltola, Mika. 2011. Agile Small State Agency: heuristic plays and flexible national identity markers in Finnish foreign policy. Nationalities Papers, vol. 39 , no. 2.

Browning, Christopher S.. 2008. Constructivism, Narrative and Foreign Policy Analysis. A Case Study of Finland, Bern: Peter Lang Verlag.

Forsberg, Tuomas \& Henri Vogt. 2003. Suomen ulkopolitiikan eurooppalaistuminen. Teoksessa Pasi Saukkonen (toim.) Paikkana politiikka. Tietoa ja tulkintoja Suomen poliittisesta järjestelmästä. Acta Politica 27, valtio-opin laitos, Helsingin yliopisto.

Harle, Vilho. 2008. Turvallisuusrealismi jyrää Suomessa. Helsingin Sanomat 22.1.2009.

Joenniemi, Pertti. 2002. Finland in the New Europe: a Herderian or Hegelian project. Teoksessa Lene Hansen and Ole Wæver (toim.), European Integration and national Identity. The challenge of the Nordic states. London and New York: Routledge.

Joenniemi, Pertti. 2009. Suomen kannattaisi taas pyrkiä rauhanrakennuksen suurvallaksi', Helsingin Sanomat 27.7.2009.

Kivinen, Markku. 2008. Monet kylmän sodan uhat ovat edelleen olemassa. Helsingin Sanomat. 12.9.2009.

Marciacq, Florent . 2011. The Europeanisation of national foreign policy in nonEU Europe - analysing the ideational alignment of Western Balkan states in the United Nations and the OSCE. Paper presented at the 6th ECPR General Conference, 25th -27th August 2011, Reykjavik, Iceland.

Palosaari, Teemu. 2011. The Art of Adaptation. A Study on the Europeanization of Finland's Foreign and Security Policy. Tampere: Tampere Peace Research Institute.

Stoltenberg, Thorvald. 2009. Pohjoismaiden ulko- ja turvallisuuspoliittinen yhteistyö. Ehdotus Pohjoismaiden ulkoministereille ylimääräisessä pohjoismaisessa ulkoministerikokouksessa

Oslossa 9. helmikuuta 2009. (Epävirallinen suomennos; www.formin.fi, 6.9.2011).

Tiilikainen, Teija ja Kaisa Korhonen (toim.). 2011. Norden - Making a Difference? Possibilities for Enhanced Nordic Cooperation in International Affairs. Helsinki: Ulkopoliittinen instituutti. 
Trägårdh, Lars. 2002. Sweden and the EU: welfare state nationalism and the spectre of 'Europe. Teoksessa Lene Hansen and Ole Wæver (toim.), European Integration and national Identity. The challenge of the Nordic states. London and New York: Routledge.

Ulkoasiainministeriö. 2009. Pohjoinen ulottuvuus. Helsinki.

Vogt, Henri. 2009. Zwischen Pragmatismus und Moralismus: Überlegungen zum Finnischen und Skandinavischen Internationalismus. Internationale Politik und Gesellschaft, Heft 3, 2009.

Vogt, Henri (2010). Globalisation - Ten Years After. Teoksessa Pertti Ahonen, Sakari Hänninen \& Kari Palonen (toim.), Fortune rota volvitur. Studies on the writings and other work of Ilkka Heiskanen, Professor Emeritus of Political Science at the University of Helsinki, on the occasion of his 75th birthday 23 December 2010. Helsinki: Finnish Political Science Association, (pp. 251268).

\section{Viitteet}

1 Tuo artikkeli oli valtaosin Tuomas Forsbergin käsialaa. Jaottelu viiteen seikkaan eurooppalaistumisen kuvauksessa oli myös hänen.

2 Suurlähettiläspäivillä elokuussa 2008 pitämässään puheessa Alexander Stubb herätti kohua toteamalla Natosta, että "Jäsenyyttä on syytä harkita, päätöksen aika ei kuitenkaan vielä ole käsillä" (Helsingin Sanomat 6.9.2008). Se, että tällainen muotoilu pienimuotoisen kohun saa aikaan, osoittaa tietysti aiheen arkuutta ja ongelmallisuutta Suomen poliittisessa kentässä

3 Ympäristöpolitiikassa Pohjoisen ulottuvuuden toiminta on ollut kenties kaikkein onnistuneinta ja vahvinta. Vuonna 2002 perustettiin Pohjoisen ulottuvuuden ympäristökumppanuus (Northern Dimension Environmental Partnership) ja sen yhteyteen rahasto, josta oli vuoteen 2009 mennessä rahoitettu erilaisia pohjoisen ympäristöhankkeita noin 3,2 miljardilla eurolla, mukaan lukien Pietarin jätevedenpuhdistamot. (UM 2009, 7)

4 Artikkeli valmistui alkuvuodesta 2012 ennen Sauli Niinistön valintaa presidentiksi. On vielä liian aikaista arvioida ulkopoliittisen linjan muutoksia Niinistön kaudella. 


\section{Henri Vogt}

5 Helsinki-prosessin kenties konkreettisin, tosin epäsuora, seuraus on, että Suomen johdolla on Tansaniaan vuonna 2010 perustettu kestävän kehityksen instituutti.

6 Esim. Marciacq 2011. Tutkittua kuvaa siitä, miten uusi, vuoden 2011 toimintansa aloittanut ulkosuhdehallinto (European External Action Service) jatkossa muuttaa eurooppalaisen ulkopolitiikan kehikkoa, mutta ensimmäiset sisäpiiriläisarviot eivät yleensä ole olleet erityisen positiivisia.

7 EU-tutkimuksen terminologiassa puhutaan adaptaation ja projektion rinnalla myös usein downloading- ja uploading-mekanismeista.

8 Sivulla 87 Palosaari toteaa, että "the misfit between Finnish foreign and security policy and the requirements of EU accession was eliminated by a manouvre of national adaptation in which the meaning of neutrality was redefined."

9 Analyysiin sisällytettiin keskeiset ulkopoliittiset artikkelit Helsingin Sanomista, Turun Sanomista, Suomen Kuvalehdestä ja Kanavasta vuosilta 2008 - elokuu 2011. Kiitän Ville Sinkkosta tutkimusavusta.

10 Voi tosin pohtia, onko Ruotsin perinteinen globaaliagenda jossain määrin heikentynyt viime vuosina, ja maa alkanut keskittyä enemmän lähialueisiinsa. Kunnollinen analyysi tästä on kuitenkin tämän artikkelin tavoitteiden ulkopuolella.

11 Laajempi analyysi asiasta on luettavissa artikkelista Vogt 2009.

12 "I urge the Russian Federation, Georgia and the separatist South Ossetian and Abkhaz administrations to immediately enter into a cease-fire, in order to stop hostilities. [...] "I deeply deplore the military action taken by the Russian Federation towards Georgia. The reasons cited by the Russian authorities do not justify military action in the territory of Georgia, regardless of whether the action is taken in the province of South Ossetia or in other parts of Georgia." (www.regeringen.se, vierailtu 6.9.2011). 
Marjaana Jauhola

\section{Tasa-arvosta Suomen vientituote? Suomalainen tasa-arvopuhe erojen tuottajana ${ }^{1}$}

Kansainvälisenä naistenpäivänä, 8.3.2011², viikko ennen Suomen eduskuntavaalien varsinaista vaalipäivää, Suomen UN Women ${ }^{3}$ ja Väestöliitto julkaisivat tiedotteen otsikolla "Tasa-arvo Suomen vientituotteeksi" (Suomen UN Women 2011, Väestöliitto 2011). Tiedotteella nämä kaksi naisten oikeuksien ja sukupuolten välisen tasa-arvon edistämiseksi toimivaa järjestöä halusivat kiinnittää kansanedustajaehdokkaiden huomion kehitysmäärärahoista käytävään keskusteluun ja sen yhteyksiin naisten aseman ja sukupuolten välisen tasa-arvon yhteyksiin. Keskustelu kehitysyhteistyömäärärahojen suuruudesta nousi yhdeksi vaaliteemoista, erityisesti "jytkyn" saavuttaneiden perussuomalaisehdokkaiden vaalikampanjoinnissa, mutta keskustelu jatkui heti vaalien jälkeen, kun pankkiiri Björn Walhroosin totesi lakoonisesti, että "kehitysapu [on] syytä lopettaa" (Suomen Kuvalehti 2011).

Ajatus suomalaisesta tasa-arvosta vientituotteena ei ole suinkaan uusi. Samankaltaisia ajatuksia on herätelty jo aiemmin 2000-luvulla ${ }^{4}$. Uudet kauppatuoteideat näyttävät ajoittuvan suomalaisen talouden rakennemuutoksesta sekä globaalista talouskilpailusta käytyyn keskusteluun, jossa perinteisten vientituotteiden (metsä- ja metalliteollisuus) rinnalle on viime vuosina nostettu ainakin koulutusta ${ }^{5}$ (Opetusministeriö) sekä rauhanvälitystä (Ulkoasiainministeriö). Tiedotteen sävy myötäilee Ulkoasiainministeriön asettaman brändityöryhmän syksyllä 2010 tekemää eh- 


\section{Marjaana Jaubola}

dotusta Suomesta maailman ongelmanratkaisijaksi: "Tehtävä Suomelle! Miten Suomi ratkaisee maailman viheliäisimpiä ongelmia - consider it solved" (Maabrändiraportti 2011). Työryhmä pitää tasa-arvoa Suomen vahvuutena ja pitää Suomea "maailman toimivimpana yhteiskuntana" (Maabrändiraportti 2011, 63).

On varmasti liian aikaista arvioida kevään 2011 eduskuntavaalien tai vaalikampanjoinnin vaikutusta naisten oikeuksia ja sukupuolten tasa-arvoa edistävälle työlle tai suomalaiselle kehitysyhteistyölle. Sen sijaan lähestyn tässä artikkelissa suomalaista tasa-arvopuhetta tiedotteen "tasa-arvo Suomen vientituotteeksi" kautta. Teen artikkelissa kriittistä luentaa vaateesta "tasa-arvo Suomen vientituotteeksi" avaamalla sen ongelmallisuutta ja absurdiutta aiemmin tehdyn sukupuolentutkimuksen avulla sekä suomalaisesta tasa-arvopolitiikasta, että väittämistä "Suomi tasa-arvopolitiikan mallimaana" ja "jo saavutetusta tasa-arvosta" (ks. esim. Holli 2002; Julkunen 2010; Sulkunen 1987). Lähestymistapanani käytän otsikon outouttamista - feminististä strategiaa, jonka tavoitteena on suomalaisen tasa-arvopuheen, ja sitä myötä tasa-arvopolitiikan ja kehityspolitiikan, uudelleenpolitisoiminen.

Lähestyn tasa-arvopuhetta maailmanpoliittisesta näkökulmasta. Tämä tarkoittaa sitä, että tasa-arvoa ja sitä edistävää politiikkaa ei tarkastella yksinomaan Suomen sisäisenä politiikan lohkona jolloin tehtäisiin kategorinen ero kansallisten ja kansainvälisten ilmiöiden tai keskustelujen välillä (Aaltola 2007, 39-40). Sen sijaan tasa-arvoa ja tasa-arvopolitiikkaa käsitellään globaalien ja lokaalien politiikkojen kenttänä, jossa rajausta kansallisesta tasa-arvopuheesta kyseenalaistaa mm. vahva kansainvälisen ja valtioiden rajat ylittävän naisasia- ja feministisen liikkeen vaikutus. Tästä seuraa, että tässä artikkelissa esimerkiksi tasa-arvopuheen "suomalaisuus" ymmärretään normeja ja ideaaleja tuottavana, ei-neutraalina, poliittisena puheena, jonka tuottamia oletuksia normaalista, hierarkkisuutta ja suhdetta toiseuteen/toiseen artikkelissa tehdään näkyväksi.

Aluksi teen katsauksen tasa-arvo- ja tasa-arvopolitiikan käsitteisiin. Varsinaisessa analyysiosassa pohdin, miten edellä mainitun tiedotteen kaltainen puhe suomalaisesta tasa-arvosta tuottaa käsityksiä suomalaisuudesta ja tasa-arvosta. En pyri artikkelissa vastaamaan kysymykseen, mitä suomalainen tasa-arvo on tai arvioimaan tiedotteen laatineiden järjestöjen, Suomen UN Womenin ja Väestöliiton, varsinaista kehityspoliit- 
tista toimintaa. Sen sijaan pohdin, mitä tasa-arvon edistäminen vientituotteena merkitsee suomalaiskansallisena kertomuksena sekä erojen että toiseuden tuottajana.

\section{Tasa-arvon käsitteestä ja tutkimuksesta}

Suomessa tasa-arvon ja tasa-arvopolitiikan käsitteet ovat vakiintuneet 1980-1990-luvulta lähtien tarkoittamaan etupäässä sukupuolten välistä tasa-arvoa ja sen edistämistä (Borchorst 2001, 176). Näin määriteltynä tasa-arvopuheessa tehdään ns. hiljaista eroa esimerkiksi 1970-luvulla korostuneeseen taloudelliseen tai poliittiseen tasa-arvoon (mt.) tai vieläkin laajempaan tai "yleiseen" käsitykseen tasa-arvosta, joka pitää sisällään sukupuolen lisäksi esimerkiksi rotuun, sukupuoliseen tai seksuaaliseen suuntautumiseen liittyvän tasa-arvo-oletuksen (Holli 2002, 20). Tässä artikkelissa tasa-arvolla/tasa-arvopolitiikalla viittaan diskurssiin, jossa puhutaan sukupuolten tasa-arvosta ja sen edistämisestä. Tämä puhe on saanut erilaisia painotuksia ja sisältöjä ajankohdasta riippuen: sisältöjä on myös jatkuvasti kritisoitu erilaisista erotteluista ja rajojen vedosta (Holli 2002, Julkunen 2010, Kuusipalo 2002). Tällöin tasa-arvo ja siitä käyty yhteiskunnallinen keskustelu näyttäytyy jatkuvasti muuttuvana poliittisena kenttänä.

Feministisessä tutkimuksessa on puhuttu kolmesta tavasta käsittää sukupuoli: käsitys naisista ja miehistä perimmiltään samanlaisina (equality), käsitys naisista ja miehistä perimmiltään erilaisina (difference) ja sukupuolen kaksijakoisuuden sijaan epätasa-arvoisuuden ja erojen moninaisuuden korostaminen (diversity) (ks. esim. Kuusipalo 2002, 210220, Rossi 2010, 25-37). Tavoiteltava sukupuolten välinen ihannetila vaihtelee myöskin sen mukaan puhutaanko mahdollisuuksien, tulosten, tehtävien, velvollisuuksien tai ajankäytön tasa-arvosta. Esimerkkinä tästä jaottelu yhtäläisten mahdollisuuksien (de juro) ja yhtäläisten tulosten (de facto) tasa-arvoon: liberalistisen ajattelun mukaan yhteiskunnan tehtävä on luoda kummallekin sukupuolelle yhtäläiset mahdollisuudet toteuttaa samaa inhimillistä potentiaaliaan. Yhtäläisten tulosten tasa-arvo puolestaan kiinnittää huomiota niihin yhteiskunnan rakenteellisiin tekijöihin, jotka estävät erityisesti naisia toteuttamasta heille suotuja oikeuksia täy- 


\section{Marjaana Jaubola}

simääräisesti. Tasa-arvon toteutumiseksi ei riitä pelkkien mahdollisuuksien luominen, vaan tasa-arvopolitiikalla on oltava yhteiskuntaa ja sen rakenteita muuttava luonne (Holli 2002, 17).

Ymmärrän tässä artikkelissa tasa-arvopuheen "yhteiskunnallista todellisuutta tuottavaksi puheeksi" (Holli 2002, 14), jossa tarjoutuu mahdollisuuksia tietyntapaiselle toimijuudelle ja toimijalle (Rossi 2010, 30-31). Ymmärrän tasa-arvopuheen myös sellaiseksi puheeksi jossa sukupuolen lisäksi tuotetaan ymmärrystä suhteessa muihin risteäviin eroihin esimerkiksi seksuaalisuuteen, kansalaisuuteen, rotuun ja etnisyyteen (mt., 35-37). Tällöin analyysin keskiöön nousevat ideaalit, normit ja niiden sisäistäminen (esimerkiksi käsitteet kunnollinen nainen, kunnollinen mies, normiperhe - mitä on tasa-arvo ja ketä se koskee). Keskeistä tälle lähestymistavalle on ajatus vallasta tuottavana ja dynaamisena voimana vaikuttaen erilaisten toimijoiden asemiin ja suhteisiin: yksilöiden tai ilmiöiden asemaan erilaisten valtakäytäntöjen kehyksissä, kuten koulussa, työpaikalla, kuluttajana tai kansalaisena tasa-arvopuheen keskiössä (Kaisto \& Pyykkönen 2010, 9). Pyrkimyksenä on avata kysymisen tila, jossa kyseenalaistetaan luonnollisina ja pysyvinä ymmärrettyjä käsitteitä ja jossa hallintakäytännöissä vaikuttavat logiikat on mahdollista paljastaa (mt, 13-14). Ajatuksena on antaa mahdollisuus kyseenalaistamisen, toisinajattelun ja toisintoiminnan pohdinnalle.

Tässä artikkelissa analyysin apuna käytetään outouttamisen käsitettä. Sara Ahmed on $(2006,56)$ puhunut toiston merkityksestä normalisaation prosessissa: kuinka jostain asiasta tulee "normaali" tai niin itsestään selvästi totta oleva, että sitä ei enää kyseenalaisteta - normaaliksi tekemisen "työ" ja vaiva muuttuu näkymättömäksi. Outouttamisen menetelmällä tämä työ ja vaiva palautetaan näkyväksi, jolloin on mahdollista nähdä "normaalin" tai normaaliuden oletuksen absurdius.

Outouttamisen menetelmä on oman analyysini välineenä saanut vaikutteita useammalta yhteiskuntatieteellisen keskustelun kentältä: yhtäältä se kumpuaa niin sanotun mustan feminismin tuottamasta näkökulmasta valtavirtaan. Se on niin sanottu vastakatse, joka on muodostunut kolonialisoitujen mustien ihmisten vastarinnan alueeksi. Bell Hooksin (2003) mukaan vastakatse on kriittinen, oppositiossa oleva katse. Outouttamisen menetelmän taustalla on myös keskustelu, jossa englanninkielinen käsite queer/to queer on kääntynyt oudoksi, kummaksi, kum- 
masteluksi tai vikuroinniksi seksuaalisuuteen ja sukupuoleen liittyvien oletusten ja merkitysten kyseenalaistamisen menetelmänä (Vänskä 2007, 20 alaviite 28, myös Sorainen 2005, 35; queer ja pervo -termien käsitehistoriasta Kekki 2006a 3-18). Olennaisena metodina on katsojan/lukijan kyselevä ja kyseenalaistava asenne. Sara Ahmed $(1998,17)$ on viitannut tällä asenteella lukijaan, joka keskeyttää tekstin kysymyksillä ja pohtii miksi teksti toimii, miten ja kenelle. Outouttamisen menetelmään liittyy käsitteiden, kuten "nainen", tai "mies", kyseenalaistaminen ja ymmärtäminen ei-historiallisina, jopa rasistisina ja kolonialistisina kategoriana jossa on sisään rakennettuna oletus esimerkiksi naiseuden universaalista kokemuksesta (esim. Mohanty 1999).

Artikkelin loppuosa analysoi tiedotteen tuottamaa kuvaa Suomesta tasa-arvon mallimaana sekä pohtii tasa-arvopuhetta erojen ja toiseuden tuottajana peilaten tiedotteen tuottamia merkityksiä aiempaan suomalaista tasa-arvopolitiikkaa koskevaan tutkimukseen ja keskusteluun.

\section{Suomi - tasa-arvon mallimaa?}

Tiedotteen sävystä saa sen kuvan, että sukupuolten välistä tasa-arvoa pidetään Suomessa jo toteutuneena asiana, kun taas kehitysmaissa tasaarvotyötä riittää ("näin ei ole kaikkialla, eikä ole itsestäänselvyys, että naiset saavat ylipäätään osallistua politiikkaan tai edes äänestää”). Näin ollen ajatus tasa-arvosta suomalaisena vientituotteena esittäytyy varsin luontevana tapana, jolla Suomen hallitus, kansanedustajat ja kehitysyhteistyötä toteuttavat toimijat laajemmin voivat osallistua globaaliin oikeudenmukaisuuden kampanjaan: "Suomi voisi omaa esimerkkiään hyväksikäyttäen nostaa sukupuolten välisen tasa-arvon edistämisen kehityspolitiikkansa vientituotteeksi”.

Naisiin sijoittaminen näyttäytyykin yhtenä kustannustehokkaimpana tapana saavuttaa muut kehitystavoitteet: naisten koulutukseen sijoittamalla parannetaan "perheen elämää sekä koko yhteiskunnan sosiaalista ja taloudellista kehitystä, mikä puolestaan johtaa köyhyyden vähenemiseen". Tasa-arvoa perustellaan taloudellisen tehokkuuden keinoin. Naisten oikeuksien ja sukupuolten välisen tasa-arvon edistämisen perusteleminen kehityspolitiikan kustannustehokkuudella tai hyvinvoinnin, kehi- 


\section{Marjaana Jaubola}

tyksen ja köyhyyden vähenemisen välineenä näyttäytyy osana laajempaa kansainvälisten järjestöjen (esim. UN Women/Unifem, Maailmanpankki) tasa-arvostrategioiden uudelleenmäärittelyä olemassa olevan talousjärjestelmän, globaalin kapitalismin hengessä (Bedford 2009, 173). Se, että tasa-arvo esitetään kehityspolitiikassa suomalaisena vientituotteena, näyttääkin vahvistavan ajatusta, jossa tasa-arvo valjastetaan taloudellisten intressien palvelemiseen. Anne Maria Holli $(2003,15)$ on todennut, että tasa-arvopolitiikka on 1960-luvulta lähtien kytkeytynyt talouden ideologiaan ja naisten siirtyminen työmarkkinoille on katsottu merkiksi tasa-arvon toteutumisesta. Judith Squires ja Johanna Kantola (ilm.) ovat kutsuneet tasa-arvon edistämispolitiikan sulautumista vapaiden markkinoiden rationalismiin "markkinafeminismiksi".

Tiedotteessa esiintyvä oletus jo saavutetusta tasa-arvosta on Suomessa käytävän tasa-arvokeskustelun yksi myyteistä, jota tasa-arvopolitiikan- ja sukupuolentutkimus pyrkii murtamaan (Julkunen 2010, Holli 2002). Kevät Nousiaisen $(2005,1188)$ mukaan, mikäli naisten oikeudellisen tasa-arvon vahvistuminen ymmärretään evolutiivisena kehityskertomuksena, Suomi näyttäytyy tuossa kertomuksessa edelläkävijänä ja naisten oikeuksien puolustajana. Kansanvälisten vertailujen valossa kuva Suomesta ja yleisemmin Pohjoismaista "maailman parhaana kolkkana" (Julkunen 2010, 11-12) näyttäytyykin kiistattomana. Esimerkiksi maailman talousfoorumin sukupuolikuilun indeksi (global gender gap) ${ }^{6}$ sijoittaa Suomen vuoden 2010 raportissa sijalle 3 Islannin ja Norjan jälkeen ja vuoden 2010 YK:n inhimillisen kehityksen raportissa sukupuolten epätasaarvon indikaattorilla ${ }^{7}$ mitattuna Suomi on sijalla kahdeksan Hollannin, Tanskan, Ruotsin, Sveitsin, Norjan, Belgian ja Saksan jälkeen. Lars Trägårdhin mukaan käsitykset demokratiasta, hyvinvoinnista, modernisuudesta ja tasa-arvosta olleet olennainen osa pohjoismaista YK-politiikkaa (Lars Trägårdh 2002, 130-1), jossa korostuu käsitys Pohjoismaista maailman omatuntona (mt., 152).

Evolutiivista kehityskertomusta suomalaisesta tasa-arvosta ylläpidetään erilaisin tasa-arvon virstanpylväin: naisten äänioikeus valtiollisissa vaaleissa (1906) ja kunnallisvaaleissa (1917), naisten oikeus tulla valituksi valtion virkoihin (1926) sekä naimisissa olevista naisista täysivaltaisia kansalaisia (1930). Samoin sodanjälkeistä hyvinvointivaltiota on kutsuttu "tytön parhaaksi ystäväksi, timanttejakin paremmaksi", sen tarjoamien 
palveluiden ja sosiaaliturvan vuoksi (ks. esim. Anttonen 1994, Bergman 1998, 178-9; Bergqvist 2001, 17). Suomalainen hyvinvointivaltio on tarjonnut naisille työpaikkoja ja naisten osuus julkisen sektorin henkilökunnasta nousi vuosina 1960-90 40 \%:sta 65 \%:iin (Julkunen 2002, 32-34). 1980-luvulla myös suomalainen naistutkimus toisti kertomusta "vahvasta suomalaisesta naisesta", jossa tasa-arvo ja naisten yhteiskunnallisesti vahva asema liitettiin hyvinvointivaltioon ja laajaan julkiseen sektoriin. 80- ja 90-lukujen vaihteessa puhe hyvinvointivaltion hyveistä vaihtui kuitenkin hyvinvointivaltion alasajoa ja uusliberalismin käännettä korostavaan tutkimukseen. (Eräsaari 2010, 210)

Kertomus suomalaisesta tasa-arvosta kietoutuu kertomuksiin pohjoismaisesta hyvinvointivaltiosta, valtiofeminismistä ja sitä kautta muotoutuu kuva aktiivisen naiskansalaisuuden ideaalista: poliittisesti aktiiviset naiset työskentelemässä hyvinvoinnin ja tasa-arvon puolesta (Brunila 2009, 15). Hyvinvointivaltio onkin sekä mahdollistanut että rajannut naisille tarjolla olevia olemisen ja tekemisen tapoja: hyvinvointipalvelut ovat osallistuneet sukupuolijärjestyksen ylläpitämiseen tuottamalla naisille suunnattuja palveluja, sosiaaliturvaa ja työpaikkoja (Eräsaari 2010, 212-3). Raija Julkunen (2002, 34-7) arvioi kuitenkin, että näin on samalla tuotettu koulutukseen, ansiotyöhön, heteroseksuaaliseen parisuhteeseen ja heteroäitiyteen kiinnittynyttä naiseuden ihannetta. Edellisten lisäksi myös ikä ja yhteiskuntaluokka ovat säädelleet käsityksiä hyvästä äitiydestä. Irma Sulkunen (1987) onkin väittänyt, että demokraattinen molemmat sukupuolet huomioiva kansalaisuuskäsite on ollut Suomessa sukupuolenmukaisesti kaksijakoinen: feminiininen ja maskuliininen elämänpiiri toisistaan erotettuna. Feminiininen sijoittuu yksityisen ja hoivan puolelle, maskuliininen julkisen ja vallan (politiikka, talous, turvallisuus) puolelle.

\section{Äitikansalaisihanteen perintö}

Tiedotteen väite "naisten osallistuminen yhteiskunnalliseen päätöksentekoon on ratkaisevaa naisten asemaa parantavien toimenpiteiden aikaansaamiseksi” korostaa naistoimijuuden merkitystä tasa-arvon edistäjänä. Eduskuntavaalien yhteydessä todettuna tämä lause vahvistaa ajattelua 


\section{Marjaana Jaubola}

tasa-arvopolitiikasta valtiollisena toimintana jättäen ulkopuolelle valtion ulkopuolella tapahtuvan työn tasa-arvon edistämiseksi (Holli 2002, 21, valtiofeminismistä ks. esim. Bergman 1998, 179 ja Holli ja Kantola 2007). Sukupuolten välinen tasa-arvo määrittyy tiedotteessa naisten ja miesten yhtäläisinä mahdollisuuksina ("Suomessa naisilla on miesten kanssa yhtäläinen mahdollisuus osallistua poliittiseen toimintaan") sen sijaan, että painotettaisiin esimerkiksi toteutunutta tasa-arvoa tai kiinnitettäisiin huomiota naisten välisiin eroihin tasa-arvon saavuttamisessa.

Naistenpäivänä julkistettu tiedote näyttääkin heijastelevan sukupuolittunutta ideaa, jossa naisen ideaalimaailmassa toteutuu ansiotyön sekä uusia, tuottavia, kansalaisia kasvattavan äitiyden, niin sanotun äitikansalaisen (Anttonen 1994, 210-10), yhdistäminen: "koulutetun naisen yhteiskunnallinen asema on parempi, hän pystyy tekemään ansiotyötä, hankkii tutkitusti vähemmän lapsia, pystyy huolehtimaan heistä paremmin ja kouluttaa heidät varmemmin. Kaikki tämä parantaa perheen elämää sekä koko yhteiskunnan sosiaalista ja taloudellista kehitystä, mikä puolestaan johtaa köyhyyden vähenemiseen”. Ajattelu heijastelee suomalaisen naisliikkeen pitkää ns. maternalistisen feminismin, poliittisen äitiyden, (uudistusvaateiden kohdistuminen äitejä ja lapsia koskevaan politiikkaan) historiaa (Anttonen 1994, Kuusipalo 1994, Bergman 1998).

Naiskansalaisuuden lisäksi tiedote lataa kausaalisen yhteyden naisten koulutuksen, yhteiskunnallisen aseman sekä köyhyyden vähentämisen välille YK:n vuosituhattavoitteiden ${ }^{8}$ mukaisesti: sijoita tytön koulunkäyntiin - köyhyys vähenee - maailmasta tulee parempi paikka elää. Sara Ahmed (2000, 175-6) onkin muotoillut, että tyttöjen elämänkulusta muodostuu maailman kehityksen metafora ja tyttöjen mahdollisuuksien toteutuminen peilaa globaalin feminismin voittokulkua. Rosalind Eybenin (2009) kriittinen analyysi "investoinnista tyttöihin" kiinnittää huomiota tällaisen strategian yksinkertaiseen uskoon lineaarisesta ja kausaalisesta tapahtumaketjusta, jossa tarjolla oleva ratkaisu tekee näkymättömäksi epäoikeudenmukaisuuden ja epätasa-arvoisuuden historiallisia kehityskulkuja sekä tekee tarpeettomaksi kuulla yksittäisten ihmisten elämänkokemuksia tai haaveita omasta tulevaisuudestaan. 


\section{Suomalaisen tasa-arvopolitiikan kansainväliset kytkökset}

Tätä kautta herääkin kysymys: onko tasa-arvo suomalainen vienti- vai jopa mahdollisesti tuontituote? Tai, voidaanko tasa-arvoa ylipäänsä viedä tai tuoda? Lähestyn vientituote-ajattelua kahden esimerkin kautta: YK:n kaikkinaisen naisten syrjinnän poistamista koskevasta yleissopimuksesta sekä EU:n tasa-arvopolitiikasta käydyn tasa-arvopoliittisen keskustelun kautta osoittaen kuinka vienti/tuontituote-jaottelu häivyttää Suomessa käydyn tasa-arvopoliittisen keskustelun maailmanpoliittiset, kansalliset rajat ylittävät yhteydet, mutta samalla myös oletetaan tasa-arvon olevan valmis tuote, jota viedä muualle maailmaan.

YK:n kaikkinaisen naisten syrjinnän poistamista koskeva yleissopimus solmittiin vuonna 1979 ja Suomi ratifioi sen vuonna 1986. ' Suomen hallitus raportoi CEDAW-komitealle säännöllisin väliajoin; ensimmäinen raportti annettiin vuonna 1988, viimeisin kuudes raportti vuonna 2008 ja tuoreinta raporttia työstetään parhaillaan. Sopimuksen ratifiointiin liittyi merkittäviä tasa-arvopoliittisia muutoksia, joista merkittävimpänä pidetään tasa-arvolain hyväksymistä (1986). CEDAW-komitea on kiinnittänyt toistuvasti Suomen hallituksen raporteissa huomiota erityisesti naisiin kohdistuvaan väkivaltaan ${ }^{10}$, sukupuolikiintiöihin, ja palkkaeroihin. Komitean Suomen ensimmäisen raportin käsittelyssä kiinnitettiin huomiota naisiin kohdistuvan väkivallan kysymyksiin. Vaikka suomalaiset naisjärjestöt olivat nostaneet naisiin kohdistuvan väkivallan kysymyksiä jo 1970-luvulta alkaen mm. perustamalla turvakoteja, liitettiin naisiin kohdistunut väkivalta vasta vuonna 1997 valtakunnalliseen suunnitelmaan sosiaali- ja terveydenhuollon kehittämisestä ja vuonna 1999 käynnistettiin ensimmäinen naisiin kohdistuvan väkivallan ehkäisyyn keskittynyt valtakunnallinen sosiaalityön projekti (Ronkainen 2008, 390-1).

Onkin väitetty, että naisiin kohdistuva väkivalta tunnistettiin merkittäväksi tasa-arvopoliittiseksi ongelmaksi erityisesti kansainvälisen arvostelun kautta, joka nousi esiin CEDAW-sopimuksen lisäksi muun muassa YK:n taloudellisten, sosiaalisten ja sivistyksellisten oikeuksien sopimuksen täytäntöönpanoa valvova komitean toimesta (Pirjatanniemi 2011, 156 alaviite 13). Näin ollen oikeuden ja rikosoikeuden kansainvälistyminen on muokannut suomalaista kriminaalipolitiikkaa naisten oikeudet huomioivaan suuntaan. Aiemmin ihmisoikeuksia käytettiin 


\section{Marjaana Jaubola}

rikosoikeutta rajaavana argumentaation keinona, kun taas nyt uhrin asemasta käsin käydyssä keskustelussa ihmisoikeusargumentteja käytetään rikosoikeuden käyttöä perustelevina tekijöinä (Pirjatanniemi 2011, 155). Kansainvälisen lainsäädännön normistolla on ollut merkittävä vaikutus suomalaiseen tasa-arvopolitiikkaan, sekä lainsäädännölliseen työhön että tasa-arvotoimiin eikä viime vuosikymmenien suomalaista tasa-arvokeskustelua näin ollen voida pitää puhtaasti kansallisena politiikan muotona (ks. esim. Nousiainen 2005). Toisaalta, vaikka naisiin kohdistuvan väkivallan tutkiminen ja poistaminen tulivat osaksi tasa-arvopolitiikkaa 1990-luvulla sekä kansallisten turvallisuus- ja kriminaalipolitiikan ohjelmien asialistalle, suomalaista rikoslainsäädäntöä ei ole tarkasteltu tähän päivään mennessä tasa-arvopolitiikan tai syrjinnän näkökulmasta siitäkään huolimatta, että naisiin kohdistuvaa väkivaltaa on pidetty kansainvälisessä oikeudessa syrjintänä ja ihmisoikeusloukkauksena jo parin vuosikymmenen ajan (Nousiainen 2011,219).

Muita esimerkkejä CEDAW:in kautta käsittelyssä olleista naisiin kohdistuvan syrjinnän ja sen vastaisen työn kysymyksistä ovat olleet sukupuolikiintiöt, jotka liitettiin vuonna 1995 tasa-arvolakiin: niin sanottu kiintiösäädös määräsi 40-60 prosentin jakauman kumpaakin sukupuolta kunnallisiin toimielimiin valeilla valittuja valtuustoja lukuun ottamatta (Holli, Raevaara ja Luhtakallo 2007, 17). Toinen toistuva teema on ollut naisten ja miesten väliset palkkaerot, jonka tilanne ei ole juurikaan muuttunut eri raportointikertojen välillä (Tasa-arvovaltuutettu 2009). Kansalaisjärjestöjen varjoraportti vuodelta 2008 listaa seuraavat teemat keskeisinä ongelma-alueina Suomessa: tasa-arvolain ja yhdenvertaisuuslain suunniteltu yhdistäminen, vähemmistöryhmiin kuuluvien naisten oikeudet, naisiin kohdistuva väkivalta, naiskauppa ja prostituutio, tasaarvosuunnittelu oppilaitoksissa, epätasa-arvo työmarkkinoilla ja yhteiskunnallisessa elämässä ja sukupuolen huomioiva budjetointi (Naisjärjestöt yhteistyössä - Kvinno-organisationer i Samarbete NYTKIS ry 2008, 3-4).

Myös tuore tutkimus (Nousiainen 2005, Kantola ja Nousiainen ilm., Holli ja Kantola 2007) EU-jäsenyyden vaikutuksista suomessa tehtyyn tasa-arvopolitiikkaan osoittaa, että käsitys Suomesta puhtaasti tasa-arvon viejänä on vähintäänkin vääristynyt. Oikeudellisen tasa-arvon näkökulmasta katsottuna Euroopan jäsenyyden jälkeen Eurooppa-politiikasta 
on tullut olennainen suomalaisia tasa-arvonormeja muokkaava toimija YK:n sijaan (Nousiainen 2005, 1189). Hollin ja Kantolan (2007) haastattelemat valtiofeministit kokevat EU-jäsenyyden vaikuttaneen positiivisesti Suomessa tehtävään tasa-arvopolitiikkaan: työlle on saatu vahvistusta uusien työkalujen, rahoituksen ja erityisesti Euroopan unionissa määriteltyjen tasa-arvoindikaattoreiden kautta, joilla voidaan osoittaa, että sukupuolten välistä tasa-arvoa ei ole Suomessakaan vielä saavutettu (Holli ja Kantola 2007, 89-90).

Konkreettisesti EU-jäsenyys on merkinnyt tasa-arvolain uudistamista kahteen kertaan (2002 ja 2005), joiden kautta muutokset ovat koskettaneet syrjinnän vastaisen toiminnan vahvistamista suhteessa palkkaeroihin, raskaana oleviin naisiin, epäsuoraan syrjintään sekä seksuaaliseen häirintään liittyen (mt., 90). EU-jäsenyyden myötä vuonna 2004 Suomessa hyväksyttiin yhdenvertaisuuslaki, joka on rinnakkainen tasa-arvolaille kiinnittäen huomiota ikään, etniseen taustaan, kansalaisuuteen, kieleen, uskontoon, uskomukseen tai mielipiteeseen, terveyteen, vammaisuuteen ynnä seksuaaliseen suuntautumiseen liittyviin syrjintäkysymyksiin (Nousiainen 2005, Harjunen 2010). Euroopan unionin kautta suomalaiseen keskusteluun on tullut vahvemmin välillisen ja välittömän syrjinnän käsitteet ja toisaalta syrjintäkiellon tiukkuus ja laajuus ovat pakottaneet uudistamaan tasa-arvo- ja yhdenvertaisuuslakeja (Kantola \& Nousiainen ilm, 1). Toisaalta eroja on nähtävissä esimerkiksi äitiyslomissa ja vanhempainvapaan säätelyssä: EU käsittelee äitiyttä ja isyyttä erilaisina ilmiöinä ja pitää äidin suhdetta lapseen luonteeltaan ensisijaisempana kuin isän. Jäsenmaiden enemmistö näyttää hyväksyvän tämän ja Kantola ja Nousiainen olettavat, että sukupuolten eroa korostava käsitys EU:n vaikutuksista voi vahvistua myös Suomessa (Kantola ja Nousiainen ilm, 8).

Viimeaikoina on käyty keskustelua suomalaisen tasa-arvopolitiikan eurooppalaistumisesta, siirtymästä hyvinvointivaltiopolitiikasta syrjinnänvastaiseen politiikkaan, sekä tämän muutoksen tuomista mahdollisuuksista ja uhista. Mitä tapahtuu kun tasa-arvosta tulee syrjintäkysymys, jolloin tasa-arvoa lähestytään lähinnä oikeudellisena kysymyksenä? Syrjintälainsäädäntö pyrkii tavoitteisiin yhtäläisten mahdollisuuksien kautta, kun taas positiivisilla erityistoimilla tarkoitetaan hyvinvointivaltion ja sosiaalipolitiikan mahdollisuuksia ehkäistä tai kompensoida niitä 


\section{Marjaana Jaubola}

vinoutumia, joita syrjintä ja muu marginalisoituminen yhteiskunnassa aiheuttavat. Tutkijat pelkäävätkin, että muodollinen tasa-arvokohtelu voi vahvistaa epätasa-arvoisia rakenteita (Kantola ja Nousiainen ilm, 8).

\section{Tasa-arvo ja naisten väliset erot}

Sukupuolijakojen murros nähdään suurena modernisaatiokertomuksena, modernin kansalaisuuden syntymisenä (Julkunen 2010, 9). Sukupuolten tasa-arvon kertomus nivoutuukin siis kansalliseen tarinaan Suomesta ja suomalaisesta sukupuolittuneesta kansalaisuudesta, joiden kautta on syntynyt oletuksia myös toisista ja toiseudesta. Ruth Lister (2009, 243) on kutsunut pohjoismaiden ihannointia "pohjoismaiseksi nirvanaksi", minkä keskeisenä oletuksena normaalista on idea kahden heteron palkka- ja hoivasuhteesta. Lister kysyykin, onko nirvana kaikkien feministien utopia? Nostan seuraavaksi muutaman esimerkin siitä keskustelusta, jolla käsitystä suomalaisesta tasa-arvosta on kyseenalaistettu kiinnittämällä huomiota naisten ja miesten välisten erojen sijaan naisten välisiin eroihin esimerkiksi luokkaan ja seksuaalisuuteen liittyvissä kysymyksissä.

Suomalaisen naisasialiikkeen synty paikannetaan usein osaksi laajempaa kansalaisyhteiskuntamme syntyä 1800-luvun lopussa (Juvonen 2010, 258). Eräänä näyttämönä toimi helsinkiläinen salonki, jossa kokoontui fennomaanista liikettä lähellä olleen yläluokan ja nousevan keskiluokan naisten lukupiiri ${ }^{11}$. Samaan aikaan työväenliikkeen piirissä aktiiviset naiset järjestäytyivät perustamalla naisosastoja työväenyhdistysten alaisuuteen. Suomen Työläisnaisliitto (myöh. Suomen Sosiaalidemokraattinen naisliitto) perustettiin vuona 1900 (lisää historiasta ks. esim. Jallinoja 1983 ja Sulkunen 1987).

Kun muista Pohjoismaista on todettu, että 1800- ja 1900-lukujen vaihteessa naisasialiike yhdisti naiset, Suomen kohdalla sekä järjestäytymisessä että tärkeiksi koetuissa asioissa näkyi selkeä oikeisto-vasemmisto jaottelu. Onkin väitetty, että sukupuoli ei ollut se ensisijainen järjestäytymisen syy, vaan järjestäytymistä ohjasi vahva sitoutuminen luokkakysymykseen (Kuusipalo 1994, 57), mutta toisaalta naisten järjestäytymistä tapahtui myös uskonnollisissa herätys-, raittius-, nuorisoseura- ja osuusliikkeissä (Juvonen 2010, 258). Tutkija Katariina Järvinen Helsingin 
sanomien sunnuntaidebatissa herätteli syksyllä 2010 keskustelua tasaarvopolitiikan yhteyksistä yhteiskuntaluokkaan:

...hyvin ansaitsevien naisten joukko on erkaantunut suuresta keskituloisten naisten joukosta, köyhemmistä puhumattakaan...naisten keskinäiset suhteet ja valtataistelut jätetään liian vähälle huomiolle, kun puhutaan sukupuolijärjestelmän ongelmista...olisi myös tärkeää täsmentää, minkä sukupuolen ja yhteiskuntaluokan näkemyksiä tasa-arvokortilla ajetaan. (Järvinen 2010)

Järvinen palauttaakin puheenvuorollaan suomalaisen tasa-arvopoliittisen keskustelun feminismin keskeiseen kysymykseen sukupuolen suhteesta eriarvoisuuden ja erojen moninaisuuteen: sukupuolen ei ajatella riittävän valtasuhteiden ja epätasa-arvoisuuden analyysiperustaksi (Rossi 2010, 35).

Tasa-arvopolitiikkaa ja suomalaista hyvinvointiyhteiskuntaa on kritisoitu hetero-oletuksesta kiinnittämällä huomiota seksuaalisuuteen ja sukupuoli-identiteettiin esim. lainsäädännössä ja tasa-arvopolitiikassa (Juvonen 2002), koulumaailmassa (Lehtonen 2003) ja vanhemmuutta ohjaavissa instituutioissa (Vuori 2001 ja Kuosmanen 2007). Tästä kuvaava esimerkki keväältä 2011 on, että tasa-arvovaltuutetun toimisto järjesti ensimmäisen transihmisten tasa-arvoa ja ihmisoikeuksia käsittelevän seminaarin.

Naistenpäivän tiedotteen tapa määritellä tasa-arvo naisten ja miesten yhtäläisinä mahdollisuuksina ja tapa puhua naiskansalaisuudesta äitiyden, kasvattajuuden ja työmarkkinoille osallistumisen kautta uusintaa suomalaisen hyvinvointivaltion sukupuolittunutta ja naisten välisiä eroja häivyttävää käsitystä naiseuden mahdollisuuksista ja suhteesta valtioon. Kun katse käännetään sukupuolen lisäksi muihin tekijöihin, kuten luokkaan tai seksuaalisuuteen, näyttäytyy suomalainen tasa-arvopuhe aktiivisena erojen ja toiseuden tuottajana. Raija Julkunen $(2002,37)$ onkin todennut pohjoismaisen hyvinvointivaltion mallin palvelevan parhaiten koulutukseen, ansiotyöhön, heteroseksuaaliseen parisuhteeseen ja heteroäitiyteen kiinnittyvää naista. Sosiaalipolitiikka tai sosiaalityö ei ole tasa-arvopolitiikasta huolimatta pystynyt olemaan kovinkaan herkkä naisten keskinäisille eroille. 


\section{Marjaana Jaubola}

\section{Tasa-arvon suomalaiskansallinen kertomus ja rodulliset erot}

Seuraavassa pohdin vielä erikseen suomalaisen tasa-arvopuheen "suomalaisuutta" erityisesti rodullisten ja etnisten erojen tuottajana tiedotteen tekstin ja visuaalisen kuvaston kautta. Väitän, että tiedotteella tuotetaan ymmärrystä suomalaisesta tasa-arvosta sukupuolen, seksuaalisuuden ja luokan lisäksi myös rodullisena käsitteenä.

Tiedotteessa tuotetaan ero suomalaisen "jo saavutetun tasa-arvon" yhteiskunnan ja kehitysmaiden epätasa-arvoisten yhteiskuntien välillä toteamuksella "Suomessa naisilla on miesten kanssa yhtäläinen mahdollisuus osallistua poliittiseen toimintaan. Näin ei ole kaikkialla, eikä ole itsestäänselvyys, että naiset saavat ylipäätään osallistua politiikkaan tai edes äänestää”. Tällä näkemyksellä yhtäältä oikeutetaan tasa-arvopoliittinen ja naisten oikeuksia edistävä työ osana suomalaista kehityspolitiikkaa, mutta toisaalta myös tuotetaan rodullista eroa suomalaisten ja kehitysmaiden naisten välille. Salla Tuori $(2007,166)$ on todennut, että väite Suomesta tasa-arvon suhteen edistyneenä maana uusintaa sukupuolitettua rasismia, jota Lila Abu-Lugod $(1998,14)$ on kutsunut "vielä yhdeksi kertomukseksi, jossa valkoiset naiset pelastavat ruskeat naiset ruskeilta miehiltä".

Tällä tavoin tiedote toisintaa suomalaista niin sanottu maahanmuuttajayhteisölle suuntaamaansa tasa-arvopuhetta (katso Tuori 2007, Vuori 2007). Tässä puheessa maahanmuuttajanaiset esitetään epätasa-arvoisina ja uhkana nähdään "maahanmuuttajamiehet", ei suomalaisia miehiä, naisia tai suomalaista yhteiskuntaa (Tuori 2007, 166). Jaottelu "suomalaisiin" ja "ei-suomalaisiin" rakentaa oletusta suomalaisuudesta rodullisesti ja etnisesti yhtenäisenä kategoriana. Suomalaisessa keskustelussa esiintyvä ns. yhtenäiskulttuurin korostaminen pitää sisällään ajatuksen Suomen muuttumisesta monikulttuuriseksi maaksi vasta pakolaisten ja muun maahanmuuton myötä viimeisten parin vuosikymmenen aikana (Valovirta 2010,96). Tämä siitäkin huolimatta, että esimerkiksi perustuslaki vuodesta 1995 alkaen on tunnustanut vähemmistökansojen oikeuden kieleen ja kulttuuriin ja valtaväestön ja saamelaisten yhteentörmäystä on kutsuttu pohjoismaiseksi kolonialismiksi (mt.). ${ }^{12}$

Puhumalla "kehitysmaiden ihmisistä" sekä "maailman köyhistä" tiedote niputtaa kehitysmaiden naiset yhteen "kolmannen maailman naiset" - kategoriaan, joka näyttäytyy ristiriidattomana, yhtenäisenä ja muut- 
tumattomana (Mohanty 1999). Tiedotteen vahva kehitysyhteistyön ammattilais(nais)ten ääni uusintaa käsitystä ei-länsimaisista naisista hiljaisina ja kaikenkattavan patriarkaalisen vallan alistamina (ks. Tuori 2007, 156). Äänessä ovat suomalaiset kehitysyhteistyön ammattilaiset kehitysmaiden naisten puolesta (Spivak 1988). Epätasa-arvo sijoitetaan toisaalle (ks. myös Vuori 2007, 144).

Tiedotteen "tasa-arvosta Suomen vientituote" visuaalinen kuvasto vahvistaa kuvaa rodullisesti erotetuista toimijapositioista. Kehitysmaiden naiset näyttäytyvät kehityspolitiikan hyödynsaajina, eivät sen aktiivisina suunnittelijoina tai toteuttajina (ks. vastaavaa analyysiä maahanmuuttajanaistoiminnasta Tuori 2007, Vuori 2007). Väestöliiton kotisivuilla tiedote on sijoitettu otsakkeen "kansainvälisyys" alle ja kuvituksena on käytetty valokuvaa, jossa ilveilee ja hymyilee neljä lasta (kolme poikaa ja tyttö keskellä). Lapset seisovat päällystämättömällä tiellä pyykkien kuivuessa aidalla, betoniseinän tekstien perusteella etelä-aasialaisessa naapurustossa, naisen ja miehen kävellessä taustalla kohti kameraa ja katsojaa. Ikään kuin lähestyvät sitä tilaa, jossa katsoja, tai lahjoittaja elää.

Suomen UN Womenin kotisivuilla tiedote on sijoitettu otsikon "uutiset” alle. Tiedotteen kuvituksena on käytetty entisen YK:n pääsihteerin Kofi Annanin ja hänen vaimonsa Nane Marie Annanin lähikuvaa. Muutoin tiedotteen ympärille muodostuu Väestöliiton sivuihin verrattuna vahvempi järjestömaailman kuvitus. Kotisivuilla houkutellaan järjestön toiminnasta kiinnostuneita otsikoilla "lahjoita", "liity jäseneksi", "tilaa uutiskirje" ja "tue UN Womenia Sherwoodissa". Kuvitus tuottaa rodullisia ja toiminnallisia eroja: lahjoita-linkki on kuvitettu lähikuvalla hymyilevästä hampaattomasta aasialaisesta naisesta, "liity jäseneksi”-kehoitusta kuvittaa lähikuva kolmesta valkoisesta hymyilevästä nuoresta miehestä ja naisesta, kun taas musta nainen tuijottaa kaukaisuuteen piikkilankojen takaa "tilaa uutiskirje" - kehotuksen vieressä ja alimmassa kuvassa kolme eri väristä kättä päällekkäin otsakkeen "tue UN Womenian sharewoodissa” -linkin vieressä kuvastavat yhteisöllisyyttä ja yhteistyötä.

Molempien järjestöjen tiedotteessa käyttämä kuvitus, sekä laajempi kotisivujen kuvasto vahvistavat tiedotteen tekstin yhteyttä nuoriin ja heidän tulevaisuuteensa. Samalla tehdään eroa katsojan ja katsojan kohteen, kuvaajan, tiedotteen lukijan ja nimettömän kuvattavan, tasa-arvotoimenpiteiden ja vientiä harjoittavan ja vientituotteiden vastaanottajien välillä. 


\section{Marjaana Jaubola}

Tiedotteen tarkempi luenta tarjoaa mahdollisuuden pureutua suomalaisen tasa-arvopuheen, valkoisen feminismin ja naisliikkeen kipupisteisiin, sisäiseen rasismiin sekä niiden kautta muodostuviin valta-asemiin (Tuori 2007, 159-60; Ikävalko 2010, 96-7): minkälaista feminismiä ja naisten välisiä suhteita 'tasa-arvo vientituotteena' - ajatus edistää?

\section{Lopuksi}

Voidaanko suomalaista tasa-arvopolitiikkaa lainkaan edistää vientituotteena? Brittitutkija Judith Squiresin (2007) mukaan samanaikaisesti kun kansainvälisillä indikaattoreilla mitattuna sukupuolten välinen epätasaarvo on pienentynyt, niin luokkaperustainen sekä etelä-pohjoinen -akselilla mitattu epätasa-arvo on kasvanut. Hyvinvointi tai tuloerot eivät siis välttämättä selity pelkästään sukupuolittain eriteltyä tilastoa tuijottamalla.

Tämän artikkelin tarkoituksena on ollut purkaa "tasa-arvosta suomalainen vientituote" - ajattelun ongelma- ja kipupisteitä tarkastelemalla myyttiä jo saavutetusta tasa-arvosta sekä tarkastella tasa-arvopuhetta toiseutta tuottavana puheena. Kristiina Brunila (2010, 88-90) on todennut, että (suomalaisessa) tasa-arvotyössä on toimittu kulloinkin olemassa olevien mahdollisuuksien ja resurssien varassa. Näin siis myös kehityspolitiikkaan kytkeytyneen tasa-arvotyön merkeissä, jossa monenlaiset ehdot, kuten markkinoitumisen mukanaan tuomat tulostavoitteet, tasa-arvon brändäys ja tuotteistaminen ovat rajanneet tasa-arvotyötä. Brunilan $(2010,89)$ mukaan tasa-arvotyötä ja sen tavoitteita itsessään pidetään niin uhkaavana, että sitä piilotellaan ja valjastetaan muiden intressien palvelemiseen. Tämä niin sanottu diskurssitaituruus tarkoittaa, että tasa-arvotyön tekijät hyödyntävät niitä järjestelmiä, joiden varassa tasa-arvotyötä toteutetaan.

Feministisen toiminnan ja tasa-arvotyön kytkeytymisestä myyttiin jo toteutuneesta tasa-arvona, toiseutta synnyttävänä toimintana, tai yhdistyneenä talouden kilpailukykyisyyspuheeseen ei näytä aiemman tutkimuksen perusteella olevan mitään uutta. Kesällä 2011 julkaistu kehitysmaatutkimuksen asiantuntijoiden pamfletti "Kehitysapukeisarin vaatekaapilla" väitti, että 1980-luvulla vahvasti elänyt "developmen- 
talistinen"13 kehitysdoktriini, jossa kehitysyhteistyövaroissa käytetään runsaasti suomalaisia resursseja ja jotka sitten hyödyntävät suomalaista elinkeinoelämää, olisi vahvistunut uudelleen hallituskaudella 2007-11 hanketukena sellaisille sektoreille (metsä, tietotekniikka, energia, vesi), joilla suomalaisilla uskottiin olevan "kilpailukykyisiä resursseja" tarjottavanaan (Koponen \& Kontinen 2011, 11).

Brunila $(2010,90)$ toteaa optimistisesti, että hallinnan ja vallan näkyväksi tekeminen tarjoaa mahdollisuuden oppia tunnistamaan ne prosessit, joissa on opittu valitsemaan "niin sanotusti oikein". Tämän ajattelun mukaisesti outouttamisen menetelmän kautta tasa-arvopolitiikan alistavat vallan muodot tulevat paremmin näkyviin ja tätä myöten tarjoutuu mahdollisuus vastustaa niitä ja tehdä toisin. Kysymys kuuluukin, mitä vaihtoehtoisia feministisiä tapoja on puhua tasa-arvosta ja globaalista oikeudenmukaisuudesta kuin tuotteistaminen se vientituotteeksi? Tätä artikkelia kirjoittaessa, elokuussa 2011, käydään eurooppalaista keskustelua populistisen politiikan yhteyksistä rasismiin, islamofobiaan ja anti-feminismiin ja toisaalta todistetaan eurooppalaisen uusliberalistisen talouspolitiikan kriisiä. Nämä kysymykset vaativat yhä laajempaa keskustelua feminismin muodoista: minkälaista tasa-arvoa feministisen toiminnan kautta halutaan edistää ja kuinka pitkälle tasa-arvon edistämisen nimissä halutaan toimia valtaapitävien tai valtaa havittelevien virrassa.

\section{Lähteet}

Aaltola, Mika. 2010. Mitä maailmanpolitiikka on? Teoksessa Vilho Harle (toim.) Näkökulmia kansainvälisen politiikan tutkimukseen. Tampere: Tampereen yliopisto. Studia Politica Tamperensia 18, 39-78.

Abu-Lughod, Lila. 1998. Introduction: Feminist Longings and Postcolonial Conditions. Teoksessa Lila Abu-Lughod (ed.) In Remaking Women: Feminism and Modernity in the Middle East. Princeton: Princeton University Press, 3-32. 


\section{Marjaana Jaubola}

Ahmed, Sara. 2000. Strange Encounters: Embodied Others in Post-Coloniality. London: Routledge.

Anttonen, Anneli. 1994. Hyvinvointivaltion naisystävälliset kasvot. Teoksessa Anttonen, Anneli, Henriksson, Lea ja Nätkin Ritva (toim.) Naisten hyvinvointivaltio. Tampere: Vastapaino, 203-245.

Bedford, Kate. 2009. Doing Business with the Ladies: Gender, Legal Reform, and Entrepreneurship in the International Finance Corporation. Labour, Capital and Society 41:1\&2, 168-194.

Bergman, Solveig (1998) Naisliikehdinnän moninaisuus, uusi suomalainen naisliike yhteiskunnallisena liikkeenä. Teoksessa Ilmonen, Kaj. \& Siisiäinen, Martti. (toim.) Uudet ja vanhat liikkeet. Tampere : Vastapaino, 165-186.

Bergqvist, Christina (2001). Johdanto: Pohjoismaat - yksi vai useampia malleja? Teoksessa Bergqvist, Christina et al. (toim.) Tasa-arvoiset demokratiat? Sukupuoli ja politiikka Pohjoismaissa. Helsinki: Edita, 15-26.

Borchost, Anette. 2001. "Mitä on institutionalisoitu tasa-arvo?" Teoksessa Bergqvist, Christina et al. (toim.) Tasa-arvoiset demokratiat? Sukupuoli ja politiikka Pohjoismaissa. Helsinki: Edita, 175-180.

Brunila, Kristiina. 2009. Parasta ennen: Tasa-arvotyön projektitapaistuminen. Helsinki: Yliopistopaino. Kasvatustieteenlaitoksen tutkimuksia 22.

Brunila, Kristiina. 2010. Tasa-arvotyön projektitapaistuminen. Teoksessa Tuija Saresma, Leena-Maija Rossi ja Tuula Juvonen (toim.) Käsikirja sukupuoleen. Tampere: Vastapaino, 88-91.

Duffield, Mark. 1994. Complex Emergencies and the Crisis of Developmentalism. IDS Bulletin 25:4, 37-45.

Eräsaari, Leena. 2010. Miksi hyvinvointivaltio on tärkeä naisille? Teoksessa Tuija Saresma, Leena-Maija Rossi ja Tuula Juvonen (toim.) Käsikirja sukupuoleen. Tampere: Vastapaino, 210-222.

Eyben, Rosalind. 2009. What is happening to donor support for women's rights? Contestations: dialogues on women's empowerment, Issue 4. http://www. contestations.net/issues/issue-4/what-is-happening-to-donor-support-forwomen\%E2\%80\%99s-rights/. (22.8.2011).

Haavisto, Pekka. 2011. "Kokoaan suurempi Suomi” http://www.pekkahaavisto. net/?p=496 (17.8.2011).

Harjunen, Hannele. 2010. Intersektionaalisuus eurooppalaisen tasa-arvopolitiikan haasteena. Teoksessa Tuija Saresma, Leena-Maija Rossi ja Tuula Juvonen (toim.) Käsikirja sukupuoleen. Tampere: Vastapaino, 305-306. 
Hausmann, Ricardo, Tyson, Laura D. ja Zahidi Saadia. 2010. The Global Gender Gap Report 2010. Geneva: World Economic Forum.

Hentilä, Marjaliisa ja Lähteenmäki, Maria. 1990. Kansainvälinen naistenpäivä 1910-1990. Helsinki: Työväen arkisto. Työväen arkiston julkaisuja 2.

Holli, Anne-Maria. 2002. Suomalaisen tasa-arvopolitiikan haasteet. Teoksessa Holli, Anne-Maria, Saarikoski, Terhi ja Sana, Elina (toim.) Tasa-arvopolitiikan haasteet. Vantaa: WSOY, Tasa-arvoasiain neuvottelukunta/STM, 1230 .

Holli, Anne Maria ja Kantola, Johanna. 2007. State Feminism Finnish Style: Strong Policies clash with Implementation Problems. Teoksessa Outshoorn, Joyce ja Kantola, Johanna (eds.) Changing State Feminism. Hampshire: Palgrave Macmillan, 82-101.

Holli, Anne Maria, Raevaara, Eeva ja Luhtakallio, Eeva. 2007. Naiset, kunnallispolitiikka ja murros: johdatus tutkimuksen tematiikkaan. Teoksessa Holli, Anne-Maria, Luhtakallio, Eeva ja Raevaara, Eeva (toim.) Sukupuolten valtal kunta: Politiikka, muutos ja vastarinta suomalaisissa kunnissa. Tampere: Vastapaino,11-32.

Jallinoja, Riitta. 1983. Suomalaisen naisasialiikkeen taistelukaudet: Naisasialiike naisten elämäntilanteen muutoksen ja yhteiskunnallis-aatteellisen murroksen heijastajana. WSOY: Juva.

Julkunen, Raija. 2010. Sukupuolen järjestykset ja tasa-arvon paradoksit. Tampere: Vastapaino.

Julkunen, Raija. 2002. Timanttejakin parempi ystävä? Hyvinvointivaltion murroksen sukupuolittuneet seuraukset. Teoksessa Holli, Anne-Maria, Saarikoski, Terhi ja Sana, Elina (toim.) Tasa-arvopolitiikan haasteet. Vantaa: WSOY, Tasa-arvoasiain neuvottelukunta/STM, 32-49.

Juntti, Eira. 1998. 'Pohjolan naisten viemiset Eurooppaan': Suomalaisten naistenlehtien EU-keskustelu. Teoksessa Keränen, Marja (toim.) Kansallisvaltion kielioppi. Jyväskylä: Jyväskylän yliopisto, SoPhi 28, 64-89.

Kaisto, Jani ja Miikka Pyykkönen. 2010. Johdanto: Hallinnan analytiikan suuntaviivoja. Teoksessa Kaisto, Jani ja Pyykkönen, Miikka (toim.) Hallintavalta: Sosiaalisen, politiikan ja talouden kysymyksiä. Helsinki: Gaudeamus, 7-24.

Kantola, Johanna. 2002. "Rooman valtakunnan tuho": parisuhdelakikeskustelua eduskunnassa. Teoksessa Holli, Anne-Maria, Saarikoski, Terhi ja Sana, Elina (toim.) Tasa-arvopolitiikan haasteet. Vantaa: WSOY. Tasa-arvoasiain neuvottelukunta/STM, 287-304. 


\section{Marjaana Jaubola}

Kantola \& Nousiainen. Ilm. Euroopan unionin tasa-arvopolitiikka: velvoittavaa lainsäädäntöä ja pehmeää sääntelyä. Teoksessa Kantola, Johanna, Nousiainen, Kevät ja Saari, Milja (toim.) Tasa-arvo toisin luettuna.

Kantola, Johanna ja Squires, Judith. Ilm. From State Feminism to Market Feminism? International Political Science Review.

Kekki, Lasse. 2006. Pervon puolustus. Kulttuurintutkimus 23:3, 3-18.

Koponen, Juhani ja Kontinen, Tiina. 2011. Kehitysyhteistyön ristiriidat." Teoksessa Koponen, Juhani ja Kontinen, Tiina (toim.) Kehitysapukeisarin vaatekaapilla.. Helsinki: Into Kustannus, 5-13.

Kuosmanen, Paula. 2007. Mitäs ehkäsyy te käytitte?: asiakaskäytäntöjä ja ensimmäisten lesbojen taktiikoita äitiyshuollon tiloissa. Teoksessa Vuori, Jaana ja Nätkin, Ritva (toim.) Perhetyön tieto. Tampere: Vastapaino, 168-204.

Kuusipalo, Jaana. 2002. Mikä on se tasa-arvo, jota tasa-arvopolitiikka tavoittelee? Teoksessa Holli, Anne-Maria, Saarikoski, Terhi ja Sana, Elina (toim.) Tasa-arvopolitiikan haasteet. Vantaa: WSOY, Tasa-arvoasiain neuvottelukunta/STM, 208-220.

Kuusipalo, Jaana. 1994. "Emännät ja työläisnaiset 1930-1950-lukujen politiikassa - oppaina Tyyne Leivo-Larsson ja Vieno Simonen". Naisten hyvinvointivaltio. Toim.. Anneli Anttonen, Lea Henriksson, ja Ritva Nätkin. Tampere: Vastapaino. 157-78.

Lister, Ruth. 2009. A Nordic Nirvana? Gender, Citizenship, and Social Justice in the Nordic Welfare States. Social Politics 16:2, 242-278.

Maabrändiraportti. 2010. Tehtävä Suomelle! Maabrändiraportti 25.11.2010 http://www.maabrandi.fi/wp-content/uploads/2011/06/TS_koko_raportti_FIN.pdf (10.8.2011)

Mohanty, Chandra Talpade. 1999. Lännen silmien alla: Feministinen tutkimus ja kolonialistiset diskurssit." Teoksessa, Airaksinen, Jaana ja Ripatti, Tuula (toim.) Rotunaisia ja feminismejä: Nais- ja kehitystutkimuksen risteyskobtia. Tampere: Vastapaino, 229-273.

Naisjärjestöt yhteistyössä - Kvinnoorganisationer i Samarbete NYTKIS ry. 2008. Kansalaisjärjestöjen raportti YK:n kaikkinaisen naisten syrjinnän poistamista koskevan yleissopimuksen (CEDAW-sopimus) täytäntöönpanosta Suomessa, kesäkuu 2008 http://blogs.helsinki.fi/takurssi2010/files/2010/02/ CEDAW-Varjoraporttti-2008.pdf (10.8.2011).

Nousiainen, Kevät. 2011. Tasa-arvo- ja kriminaalipolitiikka: aina eri paria? Oikeus 40:2, 218-225. 
Pentikäinen, Merja. 2002. Naiset. Teoksessa Haapea,Arto (toim.) Ihmisoikeudet 2000-luvulla: Sopimuksia ja asiakirjoja. Helsinki: Edita, 544-557.

Pietilä, Hilkka. 2007. Naiset ja YK: Vuosikymmenien menestystarina. http://formin.finland.fi/public/download.aspx ?ID=15409\&GUID $=\{$ A62EFADA7E86-4302-8875-EF17B222CA5C\} (12.8.2011).

Pirjatanniemi, Elina. 2011. Haastavatko ihmisoikeudet Suomen kriminaalipolitiikan? Oikeus 40:2,154-174.

Rautalin, Jukka. 2008. Tasa-arvosta suomalaisen ay-liikkeen vientituote. http:// www.tasa-arvoklinikka.fi/tasa/index.php?option $=$ com_content\&view $=$ art icle\&id=191\&Itemid=100093 (17.8.2011).

Ronkainen, Suvi. 2008. Kenen ongelma väkivalta on? Suomalainen hyvinvointivaltio ja väkivallan toimijuus. Yhteiskuntapolitiikka 78:4, 388-401.

Rossi, Leena-Maija. 2010. Sukupuoli ja seksuaalisuus, erosta eroihin. Teoksessa Tuija Saresma, Leena-Maija Rossi ja Tuula Juvonen (toim.) Käsikirja sukupuoleen. Tampere: Vastapaino, 21-38.

Saarilahti, Jenni. 2000. Tasa-arvosta vientituote! http://plaza.fi/ellit/tyo-ja-yhteiskunta/ymparisto-yhteiskunta/tasa-arvosta-vientituote (17.8.2011).

Sorainen, Antu. 2005. Rikollisia sattumalta? Naisten keskinäistä haureutta koskevat oikeudenkäynnit 1950-luvun Itä-Suomessa. Helsinki: Yliopistopaino.

Spivak, Gayatri Charkavorty. 1988. Can Subaltern Speak? Teoksessa Nelson, Cary ja Grossberg, Lawrence (ed.) Marxism and the Interpretation of Culture. Illinois: Illini Books, 271-313.

Squires, Judith. 2005. Is Mainstreaming Transformative? Theorizing Mainstreaming in the Context of Diversity and Deliberation. Social Politics: International Studies in Gender, State and Society 12:3, 366-388.

Sulkunen, Irma. 1987. Naisten järjestäytyminen ja kaksijakoinen kansalaisuus. Teoksessa Alapuro, Risto, Liikanen, Ilkka, Smeds, Kerstin ja Stenius, Henrik (toim.) Kansa liikkeessä. Helsinki:Kirjayhtymä, 157-72.

Suomen Kuvalehti. 2011. Björn Wahlroos: Kehitysapu syytä lopettaa. <http:// suomenkuvalehti.fi/jutut/kotimaa/bjorn-wahlroos-kehitysapu-syyta-lopettaa> (4.8.2011).

Suomen UNIFEM. 2006. Kehitystä naisille - kehitystä kaikille: Suomen UNIFEM - Finlands UNIFEM 1981-2006. Helsinki: Suomen UNIFEM.

Suomen UN Women. 2011. Väestöliitto ja Suomen UN Women: Tasa-arvo Suomen vientituotteeksi. http://www.unwomen.fi/tasa-arvo-suomen-vientituotteeksi (8.3.2011). 


\section{Marjaana Jaubola}

Tasa-arvovaltuutettu. 2009. CEDAW-sopimus myös mahdollisuus tasa-arvon edistäjänä http://www.tasa-arvo.fi/nyt/puheita_kirjoituksia/cedaw2009 (10.8.2011).

Teräs, Leena. 2006. Resurssikeskuksilla on paikkansa naisten poliksina: Suomen naisresurssikeskukset tarvitsevat pysyvää rahoitusta. http://leenateras.net/ blogi/blogi2006.html (17.8.2011).

Trägårdh, Lars. 2002. Sweden and the EU: Welfare State Nationalism and the Spectre of 'Europe'. Teoksessa Hansen, Lene ja Wxver, Ole (ed.) European Integration and National Identity: The Challenge of the Nordic States. London: Routledge, 130-181.

Tuori, Salla. 2007. Erontekoja - Rodullistetun sukupuolen rakentuminen monikulttuurisessa naispolitiikassa." Teoksessa , Kuortti, Joel, Lehtonen, Mikko ja Löytty, Olli (toim.) Kolonialismin jäljet: keskustat, periferiat ja Suomi. Helsinki: Gaudeamus,156-174.

United Nations Development Programme. 2010. Human Development Report 2010. The Real Wealth of Nations: Pathways to Human Development. New York: United Nations Development Programme.

Valkonen, Kaija (toim.) 1999. Helvi Sipilä: Naisena ibmiskunnan asialla. Helsinki: WSOY.

Valovirta, Elina. 2010. Ylirajaisten erojen politiikkaa. Teoksessa Tuija Saresma, Leena-Maija Rossi ja Tuula Juvonen (toim.) Käsikirja sukupuoleen. Tampere: Vastapaino, 92-105.

Väestöliitto. 2011. Väestöliitto ja Suomen UN Women: Tasa-arvo Suomen vientituotteeksi. http://www.vaestoliitto.fi/kansainvalisyys/?x276765=959107 (8.3.2011).

Vänskä, Annamari. 2007. "Isona minusta tulee palomies!" - Kuinka lapsia heteroseksualisoidaan Vogue Bambinin muotikuvissa. Nuorisotutkimus 3/2007, $3-22$.

\section{Viitteet}

1 Tämä artikkeli pohjautuu kesällä 2011 Avoimessa yliopistossa pidetylle luennolle luentosarjassa "Miten suomalainen yhteiskunta ja politiikka ovat rakentuneet?". Kiitos Pirjo Jukaraiselle ja Johanna Kantolalle artikkelin luonnosvaiheessa tehdyistä ehdotuksista ja huomioista. 
2 Kansainvälinen naistenpäivän satavuotista perinnettä juhlittiin vuonna 2011. Ensimmäisen kerran kansainvälistä naistenpäivää vietettiin 19.3.1911 Itävallassa, Tanskassa, Saksassa ja Sveitsissä edellisvuonna kansainvälisen sosialistinaisten konferenssissa Kööpenhaminassa tehdyn päätöksen mukaisesti. Suomesta tähän konferenssiin osallistui viisi ensimmäisen kauden naiskansanedustajaa (Ida Aalle, Miina Sillanpää, Hilda Herrala, Aura Kiiskinen ja Hilja Pärssinen) ks. aiheesta lisää Hentilä ja Lähteenmäki 1990. Vuonna 1975 YK:n kansainvälisenä naisten vuonna, YK nimesi kansainväliseksi naistenpäiväksi päivämäärän 8.3., joka on vakiintunut naistenpäivän viettopäiväksi. Samana vuonna järjestettiin naistenvuoden maailmankonferenssi Meksikossa.

3 Suomen UN Women on heinäkuussa 2010 perustetun UN Womenin (United Nations Entity for Gender Equality and the Empowerment of Women) yksi 18:sta kansallisesta toimikunnasta. UN Womenin alaisunteen kunluvat YK:n naistenrahasto UNIFEM, YK:n naisten asemaa käsittelevä jaosto $D A W$, tasa-arvokysymysten ja naisten aseman erityisneuvonantajan toimisto OSAGI ja kansainvälinen tutkimus- ja koulutusinstituutti naisten aseman parantamiseksi, INSTRAW. Suomen UN Women jatkaa vuonna 1981 perustetun YK:n naisten kehitysrahaston Suomen yhdistyksen, sittemmin Suomen UNIFEMiksi (YK:n naistenrahasto) nimeänsä vaihtaneen järjestön toimintaa: tiedotustyötä ja varainhankintaa UNIFEMin ja nyttemmin UNWOMENin kehitysyhteistyöhankkeisiin (Suomen UNIFEM 2006). YK:n ensimmäisenä naisapulaispääsibteerinä toimineella (1972-1980) Helvi Sipilällä oli merkittävä rooli YK:n naistenrahaston perustamisessa sekä bän toimi Suomen yhdistykesen ensimmäisenä pubeenjobtajana. Lisää 1960- ja 1970-lukujen YK-politiikasta ks. Pietilä 2007 ja Valkonen 1999. Ensimmäinen Suomen UNIFEMin seminaari pidettiin kansainvälisenä naistenpäivänä vuonna 1982 Eduskunnan auditoriossa, yleisönään yhdistyksen jäsenet, naiskansanedustajat ja talouselämän naisjohtajat. Naistenpäivän luentotilaisuudesta on muotoutunut järjestön merkittävin tiedotustapahtuma (Suomen UNIFEM 2006, 12). Vuonna 1991 jublaluento nimettiin Helvi Sipilä-luennoksi Helvi Sipilän 75-vuotissyntymäpäivärahaston turvin. Vuoden 2011 juhla oli Helsingin yliopiston, Helsingin yliopiston alumnit ry:n, Naisjärjestöjen Keskusliitto ry:n ja Suomen UN Womenin yhteistyötä.

4 Tässä muutamia muita esimerkkejä: "Tietotekniikasta ylpeät suomalaiset ovat tehneet Suomesta oikean tekniikan mallimaan, kansainvälisen IT-veturin. Miksi emme markkinoi tasa-arvoa yhtä innokkaasti?" (Irina Krohnin haastattelu Saarilahti 2000), "Tasa-arvosta voitaisiin tehdä Suomelle vientituote. Suomella on yhä maine tasa-arvon mallimaana. Jos panostamme 


\section{Marjaana Jaubola}

tasa-arvoon, voimme markkinoida maatamme paikkana, jossa ihmisten on hyvä elää, kasvaa ja tehdä työtä. Näin voisimme houkutella uusia asukkaita ja toimijoita kylmään pohjoiseen.” (naisten resurssikeskuksista käytävää keskustelua Leena Teräksen blogissa Teräs 2006), "Tasa-arvosta suomalaisen ay-liikkeen vientituote" (Rautalin 2008),"Perustavanlaatuinen käsitys ihmisten ja sukupuolten tasa-arvosta on suomalainen vahvuus myös maailmalla. Se on vientituote." (Pekka Haavisto presidenttikampanjansa avauksessa 8.6.2011 Haavisto 2011).

5 Kansainvälisen naistenpäivän juhlassa 2011 Helsingin yliopiston 1. vararehtori Ulla-Maija Forsberg sekä professori Tuija Pulkkinen nostivat puheissaan esille koulutusmarkkinoiden kansainvälistymisen, koulutusviennin ja tasa-arvon edistämisen eettisiä kysymyksiä sukupuolittain eriytetyn koulutuksen ja naisten aseman parantamisen näkökulmasta viitaten Helsingin yhteistyöhön saudi-arabialaisten yliopistojen kanssa.

6 Indeksi mittaa taloudellista osallistumista (palkat, naisten osuus korkeasti koulutetuissa töissä), koulutusta, terveyttä, ja poliittista osallistumista (Hausmann, Tyson ja Zahidi 2010).

7 Indikaattori mittaa äitiyskuolleisuutta, hedelmällisyyslukua, naisten paikkoja parlamentissa, toisen asteen koulutusta, osuus työvoimassa ja ehkäisyn käyttö (United Nations Development Programme 2010).

8 YK:n vuosituhattavoitteet, ks. http://www.vuosituhattavoitteet.fi/ (10.8.2011).

9 Helvi Sipilän roolista sopimuksen neuvotteluprosessissa lisää Valkonen 1999.

10 Sopimukseen ei ole tehty muutoksia hyväksymisen jälkeen, mutta sopimusta ja sen täytäntöönpanoa valvova CEDAW-komitea on tehnyt vuosien varrella yleisohjeita ja suosituksia (Tasa-arvovaltuutettu 2009; Pentikäinen 2002). Näistä yhtenä esimerkkinä naisiin kohdistuva väkivalta, joka ei sellaisenaan kuulu sopimukseen, mutta CEDAW-komitea on vuonna 1992 hyväksynyt yleisen suosituksen, jonka mukaan sopimuksen 1. artiklaan kirjattu syrjinnän kielto kattaa myös naisiin kohdistuvan väkivallan (Pirjatanniemi 2011, 160).

11 Lukupiirissä luettiin mm. englantilaisen John Stuart Millin teosta Subjection of Women (suomennettu vuonna 1910 nimellä Naisen asema). Lukupiiriläiset perustivat vuonna 1884 Suomen naisyhdistyksen. Fennomaanisen liikkeen hajaannuttua vanha- ja nuorsuomalaisiin, tämä jako näkyi myös naisyhdistyksen jäsenistössä. Yhdistyksestä eronneet perustivat uuden järjestön, Unioni Naisasialiitto Suomessa vuonna 1892. 
12 Samantyyppinen jako jo saavutetun tasa-arvon Suomeen ja rodullisen ja etnisesti rakennetun jaon "meihin ja muihin" nähtiin Suomen EU-jäsenyysneuvottelujen aikana käydyssä naistenlehtien keskustelussa. Suomi ja Eurooppa esitettiin vastapooleina ja hierarkkisena, Suomen jäsenyyttä EU:ssa perustellaan sillä että ulkopuolelle jäädessä joudutaan samaan luokkaan Baltian maiden ja idän kanssa. Hierarkiaa rakennetaan Pohjois-Euroopan ja Etelä-Euroopan välillä, mutta myös suhteessa Itä-Eurooppaan - missä vielä tässä vaiheessa ollaan "auttamattomasti EUn ulkopuolella". EU:n uhkakuvat muuttuivat loppuvuodesta 1994 retoriikaksi "meillä on paljon annettavaa" ja "Eurooppa kuntoon voimalla kymmenen naisen". Pohjoismaista hyvinvointivaltiomallia oltiin viemässä Eurooppaan (Juntti 1998, 76-80). Myöskin Ei-EU:lle -liike käytti hyväkseen vahvoja mielikuvia EU-jäsenyyden vaikutuksista: jäsenyys merkitsee hyvinvointivaltion romauttamista ja roomalaiskatolilaisuus ja Paavi nimetään hyvinvointivaltion uhkina (Pietilä ja Söderlund 1994). Yhtymäkohtia löytyy muun muassa ruotsalaiseen EU-jäsenyyskeskusteluun, jossa Eurooppa esitettiin naisten loukkona ja yhdistettiin mielikuviin prostituutiosta ja seksismistä. EU nähtiin Ruotsin vastakohtana neljällä koolla: konservatismi, kolonialismi, kapitalismi ja katolilaisuus (Trägårdh 2002).

13 Mark Duffield käyttää termiä 'developmentalismi' puhuessaan normatiivisesta prosessista jonka lähtökohtana on moderniteetin idea ja usko, että köyhyyden ja haavoittuvuuden poistamiseksi tehty työ lisää ihmisten kokemusta turvallisuudesta ja hyvinvoinnista. Kehitys-paradigmaan kuuluu myös ajatus siitä, että jaettu kehitys (progressio) on normaali pitkäaikaisen yhteiskunnallisen muutoksen suunta (Duffield 1994, 38). 



\section{Omaperäinen parlamentarismi järjestyksen ja ulkoisten tehtävien puristuksessa}

\section{Pikkuvaltion parlamentarismin rajoitukset ja luovuus}

Akateemisessa keskustelussakin Suomen eduskunta usein nostetaan julkisen keskustelun ja lakipäätösten päälavaksi. Silloin kansaa erityisesti vaalien kautta edustavat suvereenit henkilöt käyttävät vakuutteluissaan ja lainsäädäntötoimissaan kansalta saamaansa valtaa. Tämä tasavaltalainen puhetapa tähdentää vielä vapaita ja kaikille täysivaltaisille kansalaisille avoimia vaaleja ja kansansuvereenisuusoppia: valta Suomessa kuuluu kansalle, jota edustaa valtiopäiville kokoontunut eduskunta. Parlamentarismin käsitettä tarvitaan useimmiten juuri tässä näkemyksessä. Nimenomaan eduskunnan enemmistön valta toteutuu myös suhteessa hallitukseen - hallituksen ja sen ministereiden on hankittava parlamentin enemmistön luottamus, minkä koettelevalla osallistumisella, passiivisella hyväksynnällä tai luottamuslauseäänestyksellä hallitusta valvotaan tai sitä kaadetaan opposition toimesta. Idealisoinneissa vastustajaryhmien on periaatteessa oltava valmiita muodostamaan uusi hallitus, ilman vaalejakin. Viime vuosina olemme oppineet puhumaan ja uskomaan myös käytännössä tällaiseen enemmistöparlamentarismiin.

Tätä brittiläisen parlamentarismin vastuumallia varjostivat Suomessa jo varhain perustuslaillisen vallanjaon seikat - valtionpäämiehen eli presidentin valtanormien itsenäisyys, niiden vahva käyttöönotto reaali- 
politiikan monissa suhdanteissa ja lakien säätämistä jarruttavat määräenemmistö- ja lepäämäänjättämissäännökset. Vaikka puolueilla ei ollut Suomessa laillista asemaa ennen 1960-lukua, ne loivat puoluepoliittisen asetelman parlamenttiin. (Parlamentaarisesta mallista ja poikkeuksista, von Sydow 1997; Nousiainen 2006, 183-184.) Toisaalta Suomea ei voinut verrata jäykän vallanjaon maihin kuten moniin monarkioihin, joissa väliin mittaa tosistaan ottavat parlamentti ja hallitus ovat etäällä toisistaan. Sen sijaan käsite puolittainen presidentinvalta (Duverger 1965, Jansson 1993) tai valtiosääntömme autoritaarista jatkuvuutta alleviivaama puoli-monarkia (Jyränki 1978) kuvasivat monimielisesti ja pitkään parlamentarismia koskeviä valta-ongelmia.

Monet tämän artikkelikoelman kirjoittajat (Herkman ja Sundberg, historiallisemmin Väyrynen ja Kettunen) tähdentävät lisäksi parlamentaariselle keskustelu- ja sopimiskulttuurille vieraita tai parlamentti-aktiviteettien ulkopuolelta määräytyviä tekijöitä. Näitä on luettu historiallisina eduskunnan ulkopuolella puitteistettuina tehtävinä ja välttämättömyyksinä - joiden kanssa parlamentaarikotkin ovat joutuneet kamppailemaan ja usein puolustamaan omaa valtaansa. Tällaisia ovat Ruotsin- ja Venäjänvallan aikaiset vallanjakojatkuvuudet, vuoden 1918 kapinan poljennot kansalaisyhteiskunnan poliittisen toiminnan tukahduttamisessa, aika lailla mielikuvituksettomassa voittajien epävirallisessa järjestyksessä - toisen maailmansodan jälkeisen idän- ja tulopolitiikan vallankeskityksessä ja eduskunnan hankala asema avoimen globaalin markkinakilpailun oloissa ja EU:n yhteisen ulko- ja finanssipolitiikan legitimoinnissa 2000-luvulla. (Kilpailu)talous on luettu meillä myös osaksi valtion toimintaa, kilpailuvaltiota ja hallitusohjelmia, myös poliittinen julkisuus on drastisesti muuttunut ja sen sääntely on nykyisin lähinnä markkinaohjausta.

Vaikka nämä välttämättömät tehtävät voikin nähdä eduskunnan (arvo)valtaa heikentävinä kehityskulkuina, on harvemmin mietitty, miten parlamentarismin periaatteelliset toimijat ja kansanedustajat ovat omintakeisilla tavoillaan ja pelikentillään kyenneet muokkaamaan kulloisistakin tehtävistä ja tosiasia-imperatiiveista oikeudenmukaisuusdebatteja ja lainsäädäntöä. Tai, miten ja missä näistä parlamentin puolustuskeskusteluista väiteltiin aikoinaan? Kun ulkoiset voimasuhteet ja korttitalot purkautuvat (1905 lakkoliike Venäjällä, 1945 toisen maailmansodan lopputulos ja 1991 Neuvostoliiton rauhanomainen romahtaminen), on vah- 
voilla parlamentaarikoilla tilaisuutensa - joita (jo Weberinkin mukaan) on hölmöä olla käyttämättä - poliittisen pelin ja myös parlamentaaristen toimintaperiaatteiden muutosten mielessä.

\section{Enemmistöparlamentarismista puheeseen, deliberaatioon ja kulttuuriin}

Parlamentaarisen politiikan vakavasti ottavat tutkijat pitävätkin parlamentaarista kulttuuria edelleen ohuena (Palonen 2012, 7-8) tai heikkona (Pulkkinen 2003, 251), jolloin selittyy sekin, että vuoden 1981 jälkeinen ja kansainvälisesti poikeuksellinen presidentinvallan vähentyminen ei ole saanut inspiroivia tulkintoja yliopistopiireissäkään. Ylipäänsä, parlamentaarikot ja tutkijat tyytyvät korostamaan politiikassa valmiiden osapuolten kompromissien ja sopimusten merkitystä kuten joukkopuolueiden sopimisia, puolueryhmätoiminnan edustajien autonomiaa kaventavaa ryhmäkurillisuutta, kansalaisten itsearvoista osallistumista tai ulko(maankauppa)politiikan tehtäviä yli ja ohi parlamentaarisen aktiivisuuden. Suomessa puolueosapuolet muokkaantuivat ruotuihinsa jo ennen yksikamarisia valtiopäiviä ja itsenäisyys- ja sosiaalista kysymyksiä ei kyetty debatoimaan parlamentaariselle puhujakunnalle ominaisilla retorisilla kulttuureilla, vastakkaisten näkemysten esiinnostamisen ja vastustajan käännyttämisen tai omienkin kantojen haastetuksi tulemisen keinoin. Edustettiin kansaa, ilman poliittisia mutkia tai kulttuuria. Sen sijaan parlamentin puhekulttuurissa - parhaimmillaan brittisalissa ilman paperia - nostetaan julkisuuteen erilaiset näkökannat ja kohdataan tässä puhetilojen rauhallisen järkevässä kokonaisuudessa myös vastustaja näin kehkeytyy näkökulmia koskevien kiistojen, dissensuksen ja debatin politiikka. (Palonen 2006, 74-75 ja 2012, 9-17.)

Deliberatiivisen demokratian - arviointiin perustuvian harkintojen, punninnan ja sovittelun - teoria on viime vuosina Suomessakin osoittautunut oivaksi tavaksi ymmärtää myös parlamentaarista yhteistyötä ja "rajoitettujen" konfliktien ratkomista. Lähtökohtana eivät siis ole etukäteiset konsensusvälttämättömyydet, suoraviivainen tahtopolitiikka tai tiukka kansalaisyhteiskunnan taustasta edustava tai liikkeistävä ryhmä- ja luokkapolitiikka. Vaikkemme uskoisikaan harmittomaan parhaan 
argumenttiin perustuvaan yksimielisyyteen, voimme Nadia Urbinatin (2008) mukaan yhdistää deliberaation - asioiden poliittisen punninnan, väittelyn ja valmiuden mielipiteiden sekä preferenssien muuttamiseen - demokratiaan, politiikkaan, osallistumiseen ja puheeseen. Konflikteihin voidaan puuttua vain silloin, kun osallisia on kuunneltu ja osapuolet voivat puhua itsensä esiin. Erimielisyyden läpinäkyvyys ja tasa-arvoinen analyysi edellyttävät keskusteluja ja deliberaatiota. Omien kannattajalojaliteettien lisäksi on ymmärrettävä vielä toisten toimijoiden pyrkimykset. Demokraattinen auktoriteetti ei voi myöskään olla mykkä tradition, kokemuksen tai valta-aseman varassa; se ei voi myöskään nojata yksinkertaiseen ääntenenemmistöön ilman todistelun ja vakuuttamisen taitovaatimuksia myös parlamentin ja sen valiokuntien enemmistöosapuolille. (Pekonen 2011, 48-49, 57-58, 63-65.)

Palonen (2012) onkin tarkastellut parlamentarismia erityisenä retorisena politiikan tyylinä. On yhdistettävä hallituksen vastuu parlamentille sekä toisaalta parlamentin toimintaproseduurien ja puhekulttuurin aktiiviset puolet. Virtuoosit parlamentaarikot politikoivat eduskunnan menettelytapoja ja puhekulttuureja hyödyntäen mielessään voimasuhteet ja arvioivat kokeneen senioriketun tai herkän oivaltajan tavoin poliittisen tilanteen avaamat ja sulkemat pelivarat, mahdollisuudet. (Pekonen 63-.) Palonen $(2012,86)$ jopa idealisoi Weberin hengessä eräänlaisen parlamentaarisen tietoteorian, missä retoriikan ja sofistiikan parhaat perinteet jouhevasti yhdistyvät: "...vaihtoehtoisten esitysten, tilanteen tulkintojen ja näkökulmien esittäminen ei ole vain asianmukaista vaan toiminta saa parlamentaarisen luonteensa juuri tästä vastakkaisten näkemysten esittämisestä ja kamppailusta niiden välillä.”

Parlamentaarista poliittista peliä on varsinkin yleisö- ja joukko-osallistumisen mukaisissa demokratiamalleissa usein juuri halveerattu tästä erityisestä pelillisyydestään. Parlamentaarinen matsi vielä poikkeaa porvarillisen normaalielämän kelvoista ja reiluista kriteereistä kuten aktiivisesta työnteosta. Nuorten sukupolvien populaareissa ja TV-paradigman (yleisödemokratian) mukaisissa media-kulttuureissa politiikan peli saa pejoratiivisen attribuutin toisin kuin muissa kiehtovissa pelikentissä - puhutaan sitten kasino-, koulu- tai työelämäkilpailun lajeista (Paakkunainen 1991 ja 2007). Palosen deliberatiivisen demokratia- ja parlamentti puhekuntana -teorian mukaisesti tämä ei ole sattumaa. Eduskunta vastakkais- 
ten näkemysten esittämisen taiteena tai tiedonpolitiikkana ei voi luopua elämälle vieraista ja tavallisesta arkimenosta poikkeavista periaatteistaan ja retoriikastaan ${ }^{1}$.

Vaikka parlamentaarisen demokratian ja retorisen kulttuurin fyysinen sijakin voidaan helposti osoittaa, se ei tarkoita, että sen toiminnalla olisi pysyvät muodot ja sisällöt. Kehityslaeista ja omasta varmasta roolistaan jumalallisesti tai historiallisesti tietoinen yksinvalta ja totalitarismi on korvattu modernilla demokratialla. Siellä valta kuuluu periaatteen mukaisesti kansalle. Abstraktista kansasta on kuitenkin muokattava poliittinen muoto ja sisältö. Tämä tapahtuu esittämisen ja edustamisen prosessissa. Kansanedustajat - jotka valtakirjallaan väliaikaisesti täyttävät tuon prosessin kansan esittäjän ja edustajan roolit - saavat toiminnan ja performanssin aktiiviset paikat. Positiot ovat epävarmoja, väliaikaisia ja perustuvat luottamuskilpailuun. Valta on peräisin kansalta, mutta se on aina jossain suhteessa ei-kenenkään-valtaa. Modernin demokratian epävarmuus ja häilyvyys näyttäytyvät myös siinä, että melkein kenestä tahansa voi tulla poliittisen vallan haltija; vain demokratian pelisäännöt ja institutionaaliset muodot - joilla konflikteja institutionalisoidaan - ovat varmoja suhteita. Edustamisen poliittinen järki onkin kilpailun, kamppailun ja (uudelleen)valinnan jatkuvassa muodossa - mikä on tarkoituksenmukainen yhteiskunnan muoto? (Pekonen 2011.)

Jatkuvassa kontingenssissa demokratia etsii aina perustojaan - Claude Lefortin $(1988,15)$ mukaan demokratian ytimeen liittyy epävarmuus, jota on syytä vaalia. Demokratian valta on oikeutettava. Se voi perustua vain toimijoihin, jotka onnistuvat väittämään edustavansa yhteiskunnan universaaleja etuja ja periaatteita. Tavoiteltavista asiantiloista ei kuitenkaan koskaan päästä yksimielisyyteen - erimielisyys, identiteettien, kokemusten ja kohtaloiden moninaisuus ja pluralismi implikoivat epävarmuutta, ja se on pikemminkin demokratian jatkuva ehto kuin sen este tai eroon päästävä ongelma. Normatiivisia tavoitteita tai abstrakteja kehittyviä käsitemaailmoja ei voi koskaan tavoittaa. Avoimen demokratian toimivuuden ydin löytyykin tästä - kuilusta toisaalta reaalisen yhteiskunnan ja toisaalta sitä ohjaavien periaatteiden välillä. Juuri tämä jännitteinen ja epävarman kiistalainen asioiden hoidon varjoalue on politiikan kenttä, ratkaisujen haaste - on argumentoitava ja toiminnallistettava ohjaavien periaatteiden ja lakien puutteet, edustajakin saa uutta voimaa 
ja legitimiteettiä muutoksenalaisista ei-valmiista agendoista. (Pekonen 2011,18-21.) Vanhojen ristiriitojen ratkominen oikeudenmukaisella tai legitiimillä tavalla ei johda politiikan ja ideologian kuolemaan, ne muokkaantuvat uusiksi, varjoalueelle nousee uusia kysymyksiä ja arvolatauksia. Edustajien ja edustettavien välille syntyy myös juopa, ensinmainittujen on jatkuvilla edustamisen periaatteilla vakuutettava jälkimmäiset. "Vallan haltijat eivät voi suoraan samastua periaatteisiin, joita he kuitenkin vain edustavat. Näyttelijän tapaan vallan haltija on juuttunut yleisön ja esittämänsä roolin väliin. Vallan haltijan toistaessa yhteiskuntaa ohjaavia kauniita periaatteita ja tavoitteita hänen on samalla osoitettava, etteivät nämä periaatteet ole täysin toteutuneet reaalimaailmassa.” (Emt., 21)

Parlamentti olisikin nostettava tarkastelujen keskiöön. Miten eri murroksissa ja historian vaiheissa hallituksen vastuu parlamentille on toteutunut? Miten parlamentin omat toimintatavat ja niiden asema poliittisen järjestelmän vallanjaossa ovat kehittyneet ja miten deliberatiivisen puhekulttuurin aktiiviset puolet on otettu käyttöön? Ideaalinen ja toimiva parlamentaarinen kulttuuri ei voi olla yhteiskunnan funktio tai palautua yhteiskunnallisiin konteksteihin, se ei ole (pienois)kuva kansasta tai reaalisen (talous)vallan lakeijojen turha joukko. Silti tulee koko ajan pohtia asioiden ja ratkaisujen ulkoista valmistelua ja edustamista, miten avoimesti ja vaihtoehtoisesti parlamentaarikot puhuvat ja muokkaavat asiakokonaisuuksiaan. Tässä pedagogisesti painotetussa esseessä turvaudutaan myös muihin tämän kirjan artikkeleihin; lisäksi parlamentarismin historiallinen analyysi seuraa ja pohtii nimenomaan alan modernien klassikkojen - Antero Jyrängin ja Jaakko Nousiaisen 2006 - tutkimusartikkeleita Suomen eduskunnan taipaleesta (ks. myös muut heidän kontribuutionsa esseen lähteissä).

Parlamentaarisen (puhe)kulttuurin kehittämisessä Suomessa on ollut suuria haasteita. Vaikka modernin parlamentarismin tuntijat valtio-opin ja Valtiotieteellisen yhdistyksen ensimmäisen sukupolven piirissä (19351950) tunnettiinkin värikkäsitä parlamentarismia koskevista väitöksistään ja monista sen idealisoinneista, on huomattava, kuinka heidänkin päähuomionsa oli parlamantaarisen demokratian historiallisessa, "ulkoparlamentaarisessa" ja järjestys-yhteiskunnallisessa taustassa (Paavo Kastari, Sven Lindman, Tuttu tarkiainen, Jussi Teljo ja K.R. Brotherus - vrt. erit. Palonen 1980 ja 2012, 247-60; Paakkunainen 1985, 78-109, 172- 
202). Keskustelurintamat kiihtyivät tiukkojen juristien, presidentinvallan puolustajien ja kansainvälisen politiikan sivistyspyrkimysten ja kansalaisyhteiskunnan mobilisaation vastustajien suunnissa. Itse eduskunta- ja parlamentaaristen mahdollisuuksien tutkimus oli harvinaisempaa, käsitteellinen parlamentarismin puolustus hallitsi.

\section{Kansalaisliikkeen hyppy eteenpäin, uudet instituutiot ja lupaukset parlamentarismista - ja sen kahlehtiminen vuosina 1905-1917}

Vuosien 1906 kansanedustusuudistus on oivallinen esimerkki useiden tekijöiden avaamasta poliittisesta murroksen pelitilasta. Yht'äkkiä kansalaisten joukkoliikkeelle tuli mahdolliseksi pakottaa autonominen Suomi osana Venäjä harppaukselliseen reformiin nelikamarisesta säätyedustuslaitoksesta yleisellä äänioikeudella valittavaan yksikamariseen eduskuntaan (vrt. Kettusen ja Suodenjoen artikkelit tässä kirjassa). Suomeenkin levisi Kanta-Venäjältä yleislakkoliike vuonna 1905 ja Nikolai I joutui painostuksen alla lupaamaan Venäjänmaalle länsimaisia tasavaltalais-henkisiä poliittisia oikeuksia.

Vielä 1900-luvun alkuvuosien säätykokoukset Suomessa olivat demokraattisen Euroopan periferian henkisiä, "ei-kenenkään-muun-kuinmonarkin" tuli hallita valtakuntaa. Kustaa III:n hallitusmuoto 1772 ynnä Yhdistys- ja vakuuskirja 1789 sekä säätyvaltiopäivien aktiviteettien palauttaminen 1886 olivat tiukka ja jatkuva perusta vallanjaolle. Edustuslaitos oli ollut pitkään keisarin autokratian ja ruotsalaishenkisen monarkkisen, kylläkin oikeusvaltiota korostavan, valtiosäännön pihdeissä. Vuoden 1906 yksikamarinen eduskunta oli taasen harvinainen lintu eurooppalaisten kaksikamaristen valtiopäivien joukossa; naisten vaalioikeudet, kansanedustajien koskemattomuuden normi, kolmen vuoden vaalikausi ja säädökset valtiopäivien kestosta ( 90 päivää) olivat radikaalisti parlamenttikeskeisiä ideaaleja. Esimerkiksi Ranskassa äänioikeusreformi oli toteutettu jo vuonna 1848 , mutta naiset pääsivät sen piiriin vasta toisen maailmansodan jälkeen (1946).

Edustuksellinen poliittinen kulttuuri ja kansalaiset yksilöinä löivät itsensä läpi vuoden 1906 reformissa. Samalla puolueruodut ja politisoituva 
joukkovalistus sekä sen leveä taisteluretoriikka muodostuivat hektisessä hengessä modernin edustuksellisen vaalidemokratian perushahmoksi ja sen uskomuksia ryydittäväksi ideaksi. Taustalla heijastui myös poliittisen mobilisaation, kansanliikkeiden ja ristiriitojen nopean politisoitumisen vaihe, jolloin valistuksellinen kansalaisyhteiskunta, sen liikkeet ja erityisesti työväenliike mobilisoituivat agraarilla, mutta kansainvälisesti ainutlaatuisen vahvalla tavalla. (Alapuro 1988, Alapuro-Stenius 1987.) Sosiaalisen kysymyksen lisäksi vuoden 1899 venäläistävä Helmikuun manifesti (yleisvaltakunnallinen lainsäädäntöjärjestys) loi poliittisen motivaation ja radikaalin sysäyksen ajaa parlamentin valtaa. Terävimmin sitä oli vaatinut huimasti voimistuva joukkoliike Suomen työväenpuolue (1899, myöh. SDP): "yleinen, yhtäläinen ja välitön äänioikeus kaikille 21 v. ikäiselle suomalaiselle sukupuoleen katsomatta kaikissa vaaleissa ja äänestyksissä."

Yhteiskunnalliset, sukupuoliperustaiset sekä oikeudettomaan työnjakoon palautuvat kansalaisten alistussuhteet problematisoitiin, ja se merkitsi myös auktoriteettisuhteiden avaamista - ja yhdessä ulkoisten voimasuhteiden ja radikaalien liikkeiden esimerkkien kanssa se merkitsi myös uusien sosiaalisten ryhmien ja sukupolvien poliittisen odotushorisontin ja mielikuvituksen laajenemista. Uudet epävarmuudet, tulevaisuuden ajattelu ja modernien liikkeiden (Koselleckin, 2006, 'satula-aika') ajatus tavallisten ihmisten liikkeelle-lähdön merkityksestä tulevaisuuden poliittisena tekemisenä oli suomalaista vapautumista. Se antoi myös mahdollisuuden sosiaalisesti ja poliittisesti entistä rikkaammalle poliittiselle spontanismille, kun Suomi rakensi itsenäisempää parlamenttiaan uusissa 'laittomuuden' tilanteissa venäjänvallan ja sen instituutioiden murentumisen vikkelään vaihtuvissa vaiheissa. Samalla Suomen työväenliikkeen historian vastakkaiset puolet tai kuvat - herravihainen luokkataistelu ja toisaalla fennomaaninen valistus- ja edustuksellisen itsekurillisen toiminnan projekti (vrt. Sami Suodenjoen tulkintasävyt kirjassa) - saivat kansallisesta projektista yhteisen kehyksen.

Kansainvälisestikin huikeaa - mutta "punaisen viivan" (Ilmari Kianto) vedon juhlalliset ja kansanvaltaiset odotukset pettänyttä ja deklamaatioksi jäänyttä - parlamenttiuudistusta on kuitenkin tarkasteltava myös normeja ja uudistuksia tyhjäksi tekevää auktoritatiivista autonomian ristiriitaista perinnettä, keisaria, vasten. Suomalaiset saivat tottumattomina 
ja odotusten hengessä soveltaa Ruotsin vallan aikaista oikeusjärjestystä ja käyttää hyväksi laajentuvaa tilaa osana Venäjää kehittääkseen kansalaisten organisoitunutta ja julkista toimintaa 'kansalaisyhteiskuntana', luoda omaa keskushallintoa ja edustuksellisen demokratian mallia.

Vaikka elimmekin Venäjän ja sen joidenkin venäläistämisprojektien varjossa, maailmanpolitiikan voimasuhteiden muutokset ja rajoja rikkovat politiikan 'hullut hetket' olivat 'luojan lykkyjä' myös suomalaisille parlamentarismipyrkimyksille ja siihen sitoutuville odotuksille 1905-07 ja 1917-1919. Venäjän heikentymiset ensin Japanin sodassa ja lopulta maailmansodassa loivat tilaa suomalaiselle poliittiselle kulttuurille ja itsenäisyydelle. 'Äiti-Venäjän' napanuora ensin löystyi ja lopulta muodollisesti katkesi (1917) ja antoi pelivaran suomalais-spesifille parlamentaarisen perustuslain muokkaantumiselle. Meille oli pitkälle lännestä omaksutut edustamisen uudistamista koskevat julkiset ideat ja käsitteet, joita realisoitiin Suomessa; nyt kansalliset liikkeet, passiivisen vastarinnan, suomalaisliikkeen ja työveänliikkeen ajatukset saivat spontaanin tilan toimia yhdessä. Eliitin ja aktiivisten kansalaisten välille oli nyt muodostettava poliittinen linkki - hektisessä tilanteessa oli kuunneltava säädyille ja snellmanilaiselle kansakunnan itsehallinto-ajattelulle vastakkaisia liikevoimia, ääniä eri puolelta maata. (Pohjantammi 2003, 369-371390-91.) Toisaalta pikkuvaltion rohkean realistiset ja kansainvälistä oikeutta realistisesti sohaisevat muodostamisideat (Rafael Erich) ja kansa-käsitteet erityisesti juuri kansalainen - eivät viitanneet vain taka-alalle siirtyvään ja autonomia-alamaisuuteen ja kokonaisyhteiskunnan nöyrään jäsenyyteen. Periferinen sivistyneistö saattoi luovasti tulkita jo koeteltuja eurooppalaisten keskusten käsitteitä ja normeja. (Vrt. Pauli Kettusen essee tässä kirjassa, Liikanen 2003, 300-302 ja Erichin suhteesta Hans Morgenthauhun, Korhonen 1983.)

Oikeustulkintataistelut Venäjän kanssa - ennen vuotta 1905 ja taas 1910-luvun integraatioaalloissa - vahvistivat legalististista ilmanalaa maassa. Totinen perustuslain lukeminen täydentyi varsinkin ei-tasavaltalaisen poliittisen leirin piirissä auktoriteeteilla - keisarin, monarkin tradition ja idean ja vahvan presidentin puskurilla liian hurjiksi koettuja kansanvaltaisia sovelluksia vastaan. Samalla esi- ja toimeenpanovallan hallintokulttuuri, mikä eli "normeissa, ohjesäännöissä ja virkamiehistössä" - esimerkiksi etabloituneiden ja legalististen keskusvirastojen itsenäisessä 
toiminnassa - tuki vanhan järjestyksen jatkuvuutta (Tiihosen, 1990, 24-25, 120-21, mukaan poliittisesti responsiivisempi ministerihallintoperiaate olikin vasta myöhemmän ajan pyrkimys). Valtiollinen ja yliopistollinen eliitti oli pitkään huolissaan uusien osallistumisoikeuksien kansalaisrahvaasta, sen "epäkypsästä" sivistymättömyydestä, potentiaalisesta rakenteellisesta anarkkis-radikaaleista vaaroista, joiden todiste oli lopulta hulluus kapinaan 1918.

Vuosisadan alku ennen lopullista venäläisen lain spontaania rikkomista Suomalaisessa itsenäisyysjulistuksessa oli ambivalentin poliittisen kulttuurin aikaa: Venäjällä ymmärrettiin vuoden 1906 'hyppy' enemmän yleisvaltakunnallisen lain kuin kansallisen edustuslaitoksen suostumuksen kautta - perustuslakimuutokset eivät tulleet voimaan ellei 'monarkki-auktoriteetti' niitä tue! Samanlainen poliittinen monimielisyys liittyi eduskuntauudistuksen perustaan: perustuslailliset ja vanhasuomalaiset puoluepiirit luopuivat säätyperustasta, mutta edustuslaitosuudistus jouduttiin toteuttamaan säätyvaltiopäivien foorumilla.

Uudella eduskunnalla (1905-07) ei ollut juurikaan reaali-valtaa: hallitsijan normatiivisestikin epämääräiset valtuudet olivat laajat - perustuslakimonarkismin tradition hengessä. Vuoteen 1917 mennessä jätettiin "Pietarin kortilla" eri tavoin vahvistamatta neljäkymmentä erilaista eduskuntalakia - ja kansalliset puolueryhmät jarrasivat yhdessä Pietarin pään kanssa monia uudistuksia vastaan. Ylipäänsä integraatio Venäjään tiukentui 1910-luvulla, valtiosääntönormeihin ei kysytty Suomen eduskunnan kantaa. "Kahlitusta eduskunnasta" vuosina 1906-17 kirjoittavan Jyrängin mukaan $(2006,14-31)$ keisarivallan luettelo yksinomaan valtakunnanhallinnon piiriin kuuluvista päätöksentekoasioista (keisari ja byrokratia) muistutti monessa Euroopan unionin 2000-luvun alun valtapiiriä (esimerkiksi tullit, rahajärjestelmä). Parlamentaarisen systeemin perusteet horjuivat muutoinkin: esimerkiksi edustajien keskustelu- ja aloiteoikeus jäi muodolliseksi, epäselvyydet suhteellisessa vaalitavassa, määräenemmistövaatimukset (esim. veroissa) ja lakien lepäämäänjättämismenettelyt, vaalikelpoisuuden sosiaaliset rajaamiset köyhäinhoidon piirissä olevilta (ja kapinan 1918 jälkeen kansalaisluottamuksensa menettäneiltä) sekä kaksijakoinen (vallanjako)suhde senaattiin. Sidokset osoittivat parlamentarismille relevanttien edustajien oikeuksien ja hallitukselta vaadittavan eduskunnan (valtiopäiville kokoontunut kansa) 
toteaman luottamussuhteen kankeutta ja ontumista, elämää tradition ja vallanjaon periaatteiden varassa.

Huolimatta vahvasta ja etäisestä keisarihenkilön auktoriteetista vuoteen 1917 saakka ja senkin jälkeen heijastuneissa autokraattisissa perinteistä meillä oli jo Venäjän varjossa omintakeinen poliittisen demokratian infrastruktuuri: paikalliset - niukasti kansanvaltaiset - itsehallintoyhteisöt, aluehallinto, eduskunta, vanhan senaatin hengessä itsenäinen hallitus, 'kollektiivisen byrokratian' henkiset virastot, tuomioistuimet ja politisoituvat joukko- ja vaalipuolueet ja kansalaisyhteiskunnan organisaatiot. Valtionjohtajan instituutio, henkilöauktoriteetti sekä oma itsenäinen väkivaltakoneisto - poliisi ja armeija - puuttuivat.

\section{Kaksoisvalta ja kapinan jälkeinen uusi järjestys}

Vasemmisto ja myös joukkopuolueen mitat rakentanut Maalaisliitto olivat avainvoimia kun Venäjän Marraskuun vallankumouksen jälkeen Suomen eduskunta päätti enemmistöllään, että se itsenäistyi ja 'otti' (!) perustuslakia säätävän kansalliskokouksen tehtävät - nekin funktiot, jotka olivat kuuluneet keisarille. Seurasi 'heittelehtivien' perustuslakitulkintojen vuodet (1917-19), jolloin perustavien poliittisten insituutioiden legimiteetti ja suhteet nopeasti muuttuivat - hämmennys vallitsi. (Jyränki 2006, 32-36.) Ennen ja jälkeen kapinan - talvi ja kevät 1918 - luotiin uusia säädöksiä, mm. parlamentaarinen hallitusta koskeva perusluottamusvaatimus, eduskunnan oma valta päättää kokoontumisestaan ja kansanedustajien kokonaisvaltainen aloiteoikeus lainsäädäntöön.

Neuvosto-Venäjän heikkouden hetki antoi itsenäisyysjulistukselle historiallisen tilaisuuden ja bolsevikkien hyväksynnän - taktisesta vähemmistökansallisuuspoliitisista syistä. Neuvosto-Pietarissa vierailleet sosialidemokraatit ja kuuluisa Svinhufvudin senaatin knallipäälähetystö saivat itsenäisyydelle myönteisen kannan. Mutta saatteekseen myös V.I. Leninin ja Lev Trotskin ironisia tokaisuja, joiden mukaan itsenäistynyt Suomi olisi pian sosialistivaltaisena maana kypsä omena maailmanvallankumoukselle. (Ketola 1987, 439-474.)

Miksi sitten Suomen itsenäistymistä (loppuvuosi 1917, itsenäisyyspäiväksi sovittiin 6.12.1917) seurasi epäselvä vallanjaon tilanne ja kapi- 
na heti miten vuonna 1918? Dynamiikka kiteytyy pitkälle Valtalakiin, jonka vahvasti esiin työntynyt eduskunta oli enemmistöllään hyväksynyt. Maaliskuun 1917 julistuskirjallaan Kerenskin Venäjän tasavaltalainen, ns. väliaikainen hallitus, kumosi vuoden 1899 julistuskirjan (ja vuoden 1910 normit Suomen säädösten antamisjärjestyksestä). Tämä ei riittänyt ratkaisemaan perusongelmaa Venäjän tasavallan ja Suomen epäselvistä päätöksentekosuhteista.

Laki korkeimman valtiovallan käyttämisestä (kuuluisa Valtalaki, 17.7.1917) hyväksyttiin hyvinkin yksimielisesti sosialistienemmistöisessä eduskunnassa Oskari Tokoin hallituksen aikana. Sillä eduskunta uskoi saavansa korkeimman vallan itselleen ulko- ja turvallisuuspolitiikkaa lukuun ottamatta. Sosialidemokraatit kuitenkin kokivat "traumaattisen" pettymyksen lain hyväksyntää ajaneen addressin saatua Kerenskiltä kielteisen vastauksen ja diktaatin uusien vaalien järjestämisestä ja eduskunnan hajottamisesta. "Porvarillisella puolella päätös otettiin vastaan huonosti salatun helpotuksen tuntein" (Jansson 1993, 37): mm. ministerivaltiosihteeri Carl Enckell kehui käyttäneensä Pietarin korttia. Demareiden menetettyä asemansa ja otteensa toimeenpanovaltaan, järjestöaktiivien itsekurillinen valistususkoinen reformitie murtui - kultivoituneen liikkeen muassa elänyt sosiaalinen osattomuus ja vihansekainen katkeruus artikuloituivat esiin pettymyksen myötä.

Talveen 1918 mennessä syntyi niin sanottu kaksoisvallan tilanne (Alapuro 1988; Alapuro-Stenius 1987): sekä porvarillinen enemmistö että demarit kokivat omaavansa legitiimin otteen vallasta, yhteistä demokraattista tai parlamentaarista harkintataitoa, traditiotulkintaa tai kansalaiskaartien ja suojeluskuntien yli nousevaa fyysisen "nyt-jäitä-hattuun" -sanktiovallan voimaa tai muuta auktoriteettia ei ollut olemassa. Kapina oli pettymyksen lisäksi kansainvälisten politiikan mahdollisuuksia koskevan murroksen - hulluuden hetkien ja valoilmiön - inspiroima. Maa ajautui sen myötä sisällissotaan, joka eskaloi militantit reaktiot ja vei vastakkainasettelun poliittisen ratkaisulogiikan tuolle puolen. Valkoiset vastasivat punaisten vallanottoon ja väkivaltaan - moninkertaisin ja väkivaltaisin voimin. Kesällä 1918 Suomi ja samalla myös vasemmisto (Suomen kommunistinen puolue, SKP, perustettiin elokuussa 1918 Pietarissa) oli halki ja näissä oloissa porvarillinen Suomi sai perustuslaillisen rakenteen ja sen (tasapainon) hegemonisen tulkitsijan aseman puoleksi vuosisadak- 
si - vasemmistolla ei ollut asiassa juurikaan puhevaltaa (Jyränki 2006, 3536). Vasta vasemmistolaisen Mauno Koiviston valinta presidentiksi 1982 poisti sisällissodan varjon perustuslakitulkinnasta (Jakobsson 1992, 254) ja enemmistöparlamentarismi alkoi kirkastua.

Maalaisliittokin tarkisti linjaansa tasavaltalaisista kannoista vallanjakojärjestelmän suuntaan. "Voittajien vapaaehtoisarmeija (ratkaisu fyysisen vallan sanktioijien puutteeseen ja kansalaissodan voiton tekijä, KP) oli poliittisen demokratian sisään rakennettu ehto" (Siltala 1985, 372). Sosialidemokraattien myöhemmin murentunut reformi-intentio ja vielä punaisten Helsingissä operoineen kansanvaltuuskunnan Otto-Ville Kuusisen inspiroima ehdotus Suomen valtiosäännöksi (kevät 1917) korostivat kansasta peräisin olevan ääni- ja reformivaltaa (vasemmiston kansansuvereniteetti), parlamentaarista ideaa ja sveitsiläishenkisiä kansanaloitteita (Rinta-Tassi 1988) jopa enemmän kuin toteutuneessa perustuslaissa (1919). Sisällissota muutti kaiken, vanhan työväenpuolueen aikomukset kääntyivät katkeraksi antautumiseksi, isommassa mittakaavassa alkoi bolsevismin vuosisata.

Porvarilliset piirit korostavatkin, kuinka yleinen ja yhtäläinen äänioikeus (1906-) oli ollut realistista, kun sillä oli ollut keisarivallan vastapaino. Tunnetusti maassa nousivatkin kapinan "vaarojen" jälkeen juristienkin tukemat monarkia- ja kaksikamarisen eduskunnan ajatukset. Hallituksen etabloitua asemaa määriteltiin toimeenpanon ylimmän johtajan kautta - oli hän sitten senaatin puheenjohtaja, valtionhoitaja, kuningas tai presidentti. (Tiihonen 1990, 120-121.) Ympärysvaltojen voitto maailmansaodassa kuitenkin heitti taas eteenpäin valtatasapainoilijoita: jo sovittu saksalainen prinssikuningas vetäytyikin, puolimonarkkinen presidentti-idea korvasi valtiosääntödebatissa kuningaskuntanormit; oli "kohotettava kasvoja" perustasavaltalaiselle uudelle Euroopalle. (Nousiainen 2006, 192-202, Jyränki 2006, 28-65.)

Vajaan eduskunnan (1918) jälkeen demarit pian palasivat valtapuolueeksi (1919) ja eduskuntaan tulikin tasavaltalainen enemmistö; vastakohtaisuus monarkistien ja tasavaltalaisten välillä heijastui kansallisen kokoomuspuolueen ja edistyspuolueen ohjelmissa ja kannatussuhteissa. Ulkosuhteiden muuttuneissa oloissa, valtionhoitaja Mannerheimin ylhäältä käsin rajoittamana keskustavoimat osana tasavaltalaisten enemmistöä kykenivät 'kiireellisiksi julistetuissa' lainsäätämisoloissa luomaan 
Ståhlbergin nimen saaneen kompromissiehdotuksen uudeksi vuoden 1919 hallitusmuodoksi. Demarit tekivät lukuisia eduskuntavaltaa puolustavia muutosehdotuksia, niiden hylkäämisestä huolimatta he tulivat mukaan historialliseen kompromissiin pienimmän pahan harkinnan hengessä. (Jyränki 2006, 39-42.)

\section{Kompromissin traditiot - arvoituksellisuus, improvisaatio ja kestävyys aina Koiviston aikaan?}

Kompromissi oli myös myönnytys järjestys-ideologiselle jatkuvuudelle, mihin keskusvaltanapanuorassa elävä eliitti oli monissa koetoksissa oppinut. Suomalaisten valtio-oppineiden pitkänä linjana onkin ollut selittää alamaisasenteet, valtionpäämiehen henkilökohtaisen vallankäytön siunauksellisuus ja parlamentarististen ihanteiden pelko aina "kustavilaisesta" jatkuvuudesta - Ruotsinvallan ajan valintojen, Ruotsin vapaudenajan turmiollisuuden ja Kustaa III:n vallankaappauksen ihannoinnista ja kuninkaan ja keisarin vaihdon helppoudesta saakka. Ei edes nationalismi, ulkomaailman liberaali parlamentaarinen kehitys, agraarin populistinen tai sosialistien radikaali kansanvalta horjuttaneet hallitsijakeskeisyyttä. (Teljo 1937, 348-50, Nousiainen 1985, 30-36.)

Vuoden 1919 HM-lakiteksti ja sitä täydentävä Valtiopäiväjärjestys (1928) ovat kuitenkin tasavaltalaisia ja demokraattisia asiakirjoja, osa eurooppalaista kansansuvereniteetin triumfia maailmansodan jälkeen. Hallitusmuodon 2.1 §:n muut momentit kuitenkin 'tasapainottavat' tätä valtaa vallanjaon muotoiluilla - presidentin vahvojen valtuuksien ja niiden laajan tulkinnan mukaisella parlamentarismin minimoinnilla. Vallan kolmijako toteutuu lainsäädännön, itsenäisen tuomiovallan ja toimeepanovallan piirissä Montesquieun hengessä: eliitit eroavat ja voivat vartioida tosiaan. Varottiin tuomiovallan asettumista lainsäätäjien yläpuolelle; presidentti saattoi pyytää korkeimmilta oikeuksilta lausuntoa lainsäädännön laillisuudesta. Eduskunta oli lainsäädännön ratkaiseva instanssi, vaikkakin sen piirin aloite- ja ohjausvalta reaalisesti koettiin parlamentaarisen hallitusvallan mukaisesti kuuluvan hallitusvallalle ja presidentille. Lakien lepäämäänjättämissäännöstö vaikutti kuitenkin poliittiseen harkintaan ja vei Suomea enemmistöparlamentarismista 2/3-parlamentarismin suun- 
taan. Hallitus kykeni vuoden 1919 perustuslain oloissa eduskunnan perustuslakikomiteaa paremmin myös määrittelemään sitä, milloin lait oli säädettävä perustuslain vaikeutetussa (määräenemmistö) tai tavallisessa säätämisjärjestelyssä. Eduskunnan budjettivalta laajeni periaatteessa koko finanssivaltaan (budjetin lisäksi, verot ja lainat) ja tarkentuvat mahdollisuudet vaikuttaa budjetin sisältöön laajenivat muun muassa edustajien raha-asia-aloitteen muodossa. Eduskunnan määräenemmistön edessä presidentilläkin oli vain lykkäävä mahdollisuus lakinormien suhteen: jos presidentti jätti eduskunnan hyväksymän lain allekirjoittamatta, sen ratkaiseva päätösvalta siirtyi uudelle eduskunnalle. (Nousiainen 2006, 197 202, Jyränki 2006, 28-65.)

Eduskunnan toimintatilaa rajattiin vuoden 1906 regiimin hengessä monin tavoin, parlamentarismin periaate vahvasta eduskunnasta ja hallituksen alistumisesta sen luottamukselle jäi sivuun ja vallanjako korostui. Samalla autonomian ajan henkinen 'kaksijakoinen eksekutiivi' - hallitusvallan jakaminen hallituksen ja erityisen vahvan, myös normaalioloissa aktiivisen, holhoavan presidentin kesken - nostettiin esiin. Presidentillä oli myös parlamentin hajotusvalta keisarihallitsijan tapaan. Puolimonarkin (Jyränki 1978) asema ja valintaprosessin poliittiset vaiheet ja harkintaelementit latautuivat ja vahvistuivat myös presidentin erillisillä ja välillisillä (valitsijamies)vaaleilla. Sotien välillä ulkopoliittinen valta säilyi pitkälle hallituksen ulko- ja pääministereillä, vaikka maan ulkosuhteista hallitusmuodon mukaan lopulta päättikin tasavallan presidentti. VPJ 1928 antoi eduskunnalle lisää sekaantumisvaltaa ulkoasioihin laajentamalla ponsi- ja hyväksyntävaltaa toimeenpanovallan ulko- ja turvallisuuspoliittisia tiedonannoilla eduskunnalle ja selonteoilla ulkoasianvaliokunnalle. (Nousiainen 2006, 197-202, Jyränki 2006, 28-65.)

Eduskunnalla ei ollut mahdollisuutta vetää pois luottamustaan presidentille, sen sijaan hallituksen se saattoi luottamusäänestyksessä kaataa. Suomalaisen erikoinen parlamentarismin muunnelma olikin kaksijakoinen. Hallituksen syntyminen oli riippuvainen sekä eduskunnan että useimmiten juuri presidentin tahdosta. Presidentin ratkaisutapa ”...taas tuli vain menettelyn mutta ei sisällön puolesta olemaan riippuvainen parlamentaarisesti vastuunalaisesta valtioneuvostosta " (Jyränki 2006, 46). Ståhlbergin kuulu muotoilu yritti kuvata suhdetta yksikäsitteisesti: "Presidentti on siis sidottu vastuunalaisten ministerien myötävaikutukseen, 
mutta ei heidän mielipiteeseensä.” Tämä suojasi käytännössä monen presidentin itsenäisyyttä - ratkaisuvaltaa hallitusasioissa eduskunnan luottamusta nauttivan valtioneuvoston kantaa vastaan.

Toisaalla presidentin ei-parlamentaarinen operointivara tulee esiin hallituksen muodostamisvaiheessa, kun hän kutsui valtioneuvoston jäseniksi henkilöitä, joiden tuli nauttia - tai ståhlbergilaisittain, joiden voitiin otaksua nauttineen - eduskunnan luottamusta (emt., 48). Doktriiniksi kiteytyi ajatus, että presidentin hallitus istui nauttien eduskunnan luottamusta kunnes vastakohta tälle osoitettiin. Eduskunnan myötävaikutuksen tapa oli osa eri historiallisten presidenttien tahto- ja pelivaraa, jonka hän selvitti eduskuntaryhmien presidentinkierroksella - mikä sekään ei ollut ehdoton normi, vaan oli mahdollista muodostaa vähemmistö- ja virkamieshallituksia jopa parlamentin enemmistöä vastaan. (Vrt. emt., 49-51.) Ennen Kekkosen presidenttiyttä (1956) eduskunta (välikysymys tai hallituksen luottamusäänestys) pääsi kymmenkunta kertaa erottamaan ministeristön, kun se oli ilmaissut epäluottamuksen koko hallitusta tai sen yksittäistä ministeriä kohtaan.

Erilaisen historiallisen epävarmuuden keskellä, kehittämistulkintojen muokkaantuessa 'laidasta laitaan' ja poikkeusolojen valtionhoitajien (Mannerheim, Svinhufvud) järjestyksenpito-otteiden vaihtuessa tasavaltalaisjulistuksiin suomalaisen demokratian luominen oli 'arvoituksellista': Venäjän väliaikaisen hallituksen lopullinen kaatuminen johti valtatyhjiöön, missä oli improvisoitava, pyrittävä jollain lailla pysyvään ratkaisuun ja taivuttava lopulta aika moiseen ja eriaineksiseen, monien motiivien kompromissin - millä kuitenkin oli hurja jatkuvuus. Angloamerikkalaiset analyytikot (Brycen 1933 teos suomennettiin Teljon toimesta ja Ståhlbergin aloitteesta, s. 22-36) epäilivät suomalaisen ja ylipäänsä balttilaisten kansallisvaltioiden selviytymistä ja kypsyyttä, Ståhlberg itse ihmetteli jälkiviisaasti 1920-luvun lopulla, kuinka suomalainen malli ihmeellisesti toimii, vaikka paljon on hiekkaa rattaissa. (Jansson 1993, 1926, Teljo 1937, 346-49; Paakkunainen 1985, 7-59 ja 1986, 1-45.)

Ensimmäisen tasavallan aikana korostui vallanjako, presidentinvalta ja parlamentarismi, kuitenkin vallanjakoa korostaen; presidentti oli vain harvoin riippuvainen ministerien mielipiteistä, vaikka luottamustavoite lausuttiinkin julki. Puoliparlamentaarisen vallanjaon oppi tai käänteisesti "puolittain presidentinvaltainen hallitsemistapa" (Maurice Duverger 
1980) - missä tasavaltalaisuuden vastapainona oli vahvan toimeenpanoja presidentinvallan ja sulkujen hakemisen periaate - eli pitkään. Ajatuksellisesti sitä vastaan argumentoitiin vahvasti modernin yhteiskunnan ja demokratian (uus)vasemmistolaisin tasa-arvoargumentein 1960- ja 1970-luvun vaihteessa (60-luvun lopun uusvasemmistolaisesta problematisoineista, ks. erit. Jyränki 1968, Valtiosääntökomitean välimietintö 1974, lausumat ja erit. Jyränki 2006, 74-80). Vasta Kekkosen vallan kirvottua, presidentti Mauno Koivisto mursi toimintatapojen tasolla esteet suomalaisen perustuslain parlamentaariselta tulkinnalta, josta oli puhistu jyrkän vallanjakokeskustelun pitkällä linjalla vuosikymmenien ajan. Hän viittasikin aikoinaan valtio-oppineiden parlamentarismi-ideaaleista inspiroituneeseen oikeustieteilijä Paavo Kastarin väitöskirjaan (1940) jota sodan ajan aikalaisjuristiikassa pidettiin oikeuden poliittisena puoskarointina (Paakkunainen 1985, 84-88). Vasemmiston ensimmäisen presidentti pystyi jo varapresidenttinä muuttamaan perustuslain tulkintaa uusissa voimasuhteissa - Kekkosen joutuessa sivuraiteelle ja Koivistoilmiön ollessa vahvimmillaan - ilman että kirjoitetut normit muuttuivat. (Koivisto 1988.)

\section{Ensimmäisen tasavallan pakot ja välttämättömyydet - sodan "pitkä parlamentti"}

Perustuslain teksti antoi siis tulkintavaran yhtä lailla sota- ja säännöstelytalouden 'totaalille' otteelle, presidentin hallitsemalle uudelle ulkopolitiikalle kuin 1960-luvun jälkeisille korporaatiohenkisille sosiaali- ja hyvinvointihallituksillekin. Pelivarat osoittautuivat aika pysyviksi. Jaakko Nousiaisen parlamentarismille varauksellinen retoriikka joustavasta dualismista on isällisen tuttua valtio-oppia harrastaneille (2006, 190-91): "Suomen hallitusmuotoon oli kirjoitettu rinnakkain kaksi periaatteessa ristiriitaista hallintamallia, parlamentarismi ja presidentinvalta. Näin valtiojärjestykseen yhdistettiin erisuuntaisia elementtejä: jäykkyys ja joustavuus, auktoriteetti ja kansanvalta, keskitys ja hajautus. Molemmat olivat pitkälle legitiimejä, hyväksyttyjä hallintamalleja, joiden välillä käytäntö saattoi valtioelämän sykleissä pitkin kaarin heilahdella. Tässä mielessä kirjoitettu valtiosääntö oli erinomaisen joustava ja jätti tilaa käytännön 
heilahtelulle yhdestä äärimuodosta toiseen parlamentaarisen asetelman vakaudesta, ratkaisua odottavaista ongelmista ja henkilösuhteista riippuen.” Nämä eri aikojen ja voimasuhdetilanteiden konteksteissa muhivat 'dualistisen vallan' pelivarat näyttäytyvät erilaisissa parlamentaarisissa toiminnoissa (ema, 191): ”... rekrytointi ja ylläpito (hallituksen muodostaminen ja ero, eduskunnan valitseminen ja toiminnan päättäminen kesken vaalikauden), kansallisen toimintapolitiikan muotoilu (aloite ja valmistelu, päätöksenteko, veto-oikeus) sekä valvontafunktiot.”

Nousiainen kuvaa vuosia 1919-1939 "parlamentarismin oppivuosina”, jolloin realistis-dualistisen parlamentarismi- ja demokratiatulkinnan lisäksi myös kansalaisyhteiskunnan puoluemuotoinen mobilisaatio hakivat muotoaan osana demokratiaa ja eduskuntaryhmiä. Vuosi 1937 nouseekin esiin jonkinlaisena myyttisenä murroksena (Cajanderin hallitus, demareiden ja maalaisliiton puna-multayhteistyön alku, talvisodan yksimielisyyden ideologinen ja osin myyttinen perusta). Torpparin ja duunarin yhteistyörintama kuitenkin alistui poikkeusolojen 'totalisoiville' elementeille. Tiihosen (1990, 21-22 ja 41-197) mukaan oikeusvaltio- ja markkinatalouden iskusanaperiaatteista poikettiin merkittävästi jo tasavaltalaisen alkuvaiheen sotatalouden oloissa. Ensimmäisen tasavallan kapinan kukistajien sanelemat poliittiset oikeudenkäynnit, puoluemuodostus, demokraattiset osallistumisoikeudet ja ammatillinen osallistumiskulttuuri olivat osaksi epävirallisella pakolla rajoitettuja. Voimakkaimmillaan Lapuanliike 1930-luvun taitteessa kyyditsi monia demokratian paikallisia ja valtiollisia luottamushenkilöitä ja presidenttiä. Vasemmistolaisten vaalilistojen ja demarikansanedustajia vangittiin, tasavallan suojelulaki rajoitti oikeusvaltion periaatteita - usein vasta jälkikäteen laeilla vahvistettiin hallinnon tiukat oikeustilat oli sitten kyse kansanedustajien toiminta- tai (poliittisten) yhdistysten vaali- tai julkaisuoikeuksista. Vuoden 1918 voittajien Suomi onnistui katkaisemaan vallanottoon liityvät autoritaariset oikeistopyrkimykset. Samalla se näytti työntävän osaa vasemmistoa syrjään omaan leiriinsä ja osaksi bolsevismin voimakomponentteja, joihin sitten myöhemmin voimasuhteiden muututtua jouduttiin taas uudestaan reagoimaan. (Vrt. myös Vares - Uola - Majander 2006.)

Kaikki arvioijat eivät kuitenkaan korosta yksipuolisen ja sisällissodan voittajien instansseihin nojaavan demokratian tai muodollisen 
oikeusvaltion ongelmia ja loukkauksia vaan pitävät 1930-lukuakin demokratian oppivuosina (Nousiainen 2006), missä sekä kansallisesti että ulkopoliittisesti uskallettiin käsitellä 1918 traumaa, sopeuduttiin välttämättömyyksiin - demokratian minimiehtoihin ja sen yhteisiin puolustustehtäviin. Näin Suomi kohtasi "kommunismin ongelman" tai viidennen kolonnan haasteen, jota oli käsiteltävän uudelleen toisen maailmansodan jälkeen. Samalla se kohtasi järjestyneesti suojeluskuntien Suomen. Skandinaavisessa katsannossa meillä käytettiin järeitä keinoja, toisaalta Baltian tie torjuttiin. Imperiumin kriisit ja hullut hetket kokeneiden seuraajavaltioiden joukossa Suomi oli omintakeinen puolustuksellisen välttämättömyyseetoksen ja demokratiasovelluksen maa. (Alapuro 1999 ja 2010.) Vareksen (2010, 222-225) mukaan eduskuntauudistuksen henki antoi Suomelle demokraattis-lailliset perusvalmiudet hallita itseään eikä hallitusvalta saanut eurooppalaisten autoritaaristen regiimien kaltaisia laajoja valtuuksia, demokratiavastaisten ryhtiliikkeiden meno pysähtyi 1930-luvun alussa (Lapuanliikkeen loppu, ja IKL:n paitsio) eikä perusoikeisto koskaan toiminut aristokraattisesti ylhäältä vaan eli fennomaanisessa perinteessä. Maalaisliitto tuki vahvaa eduskuntaa ja laillinen vasemmisto oli kompromissikykyinen.

Cajanderin "talonpojan ja duunarin" ensimmäinen yhteishallitus ("puna-multa” 1937-) näyttää monien mielestä muuttaneen monia asioita, osaltaan iskostaneen talvisodan henkeä - sosiaalipolitiikan infrastruktuurista parlamenttiyhteistyön sovitteluilmapiiriin ja demokraattisten oikeuksien suojaamiseen esimerkiksi VALPO:n toimia rajoittaen. (Soikkanen 1983.) Silti oli ahdasta, ulkoisten paineiden tulkittu yksimielisyysvaade ja sisäisen erimielisyyden (deliberatiivisen) väännön harvinaisuus - jonkinlainen demokratian itsepuolustus - heijastuivat myös parlamentissa (Pasi Saukkonen tässä kirjassa; vrt. Alapuro 1999, 103.) Parlamentaarinen keskustelujännite ja deliberaatio ei ollut poliittisen suunnanvalinnan torina (Poliksen Agora), jo ennen talvisotaa voidaan puhua sen henkisestä yksimielisyysvaatimuksesta, joka kehkeytyi eduskunnan seinien ulkopuolella sen seiniä kiristäen:”[Y]hteinen etu ei toteudu eri ryhmien etujen kompromissina, vaan se on ennalta annettu tehtävä, joka on jokaiselle kirkastettava. Niin paljon kuin olosuhteet [toisen maailman] sodan jälkeen muuttuivatkin, vaikuttaa siltä, että tällä näkemyksellä on ollut myöhempää kantavuutta ja että se on usein ohjannut toimintaa 
myös sodanjälkeisissä vähemmän kohtalokkaissa tilanteissa. Kompromissit on haluttu pukea ainoan mahdollisuuden asuun. Ne on esitetty pikemmin välttämättömänä pahana yhteisen hyvän pelastamiseksi kuin seurauksena monien vaihtoehtojen olemassaolosta. (Kettusen puhutteleva kontribuutio tässä kirjassa).

Hallitus johti tiukasti ulkopolitiikkaa jo Kallion presidenttikaudella vuodesta 1937 lähtien. Vallankin sodanajan eduskunta - "Pitkän parlamentin" muodollisesti toimintakykyistä kautta 1939-45 - voidaan pitää Nousiainen kirjoitushorisontissa (2006, 213-16) pelkästään "keskustelufoorumina" - vallattoman "pelkän retoriikan" kielikuvan mukaisena. Purettiin kansalaisten paineita, mutta vaalittiin militanttia yksimielisyyttä ja funktionaalinen puhe oli poliittisesta kiistelystä tyhjää. Foorumilta puuttui kokonaan parlamentaarisen tiedon, tyylin ja vastakkaisten ratkaisujen komponentit. Parlamentti ja eduskuntaryhmät olivat kaikkialle - myös kansalaisten klassisiin vapausoikeuksiin - tunkeutuvan yhteiskunnan ja talouden sotamobilisaation sekä strategisten ratkaisujen ulkopiirissä, usein ulkona, periaatteessa laajapohjaisten hallitusten sisäpiirien ratkaisupaikoista. Säännöstelyvaltuudet veivät Suomenkin valtionjohtoiseksi sotataloudeksi (Tiihonen 1990, 125-131), missä ratkaisujen logiikka ja legitimiteetti olivat kriisiratkaisujen luonnon kaltaisia ja siitä puuttui parlamentaarisen demokratian komponentti ja julkisuus. Puhekuntana parlamentti oli ikäänkuin kokonaan oppositiossa. Esimerkiksi, eduskunnan ulkoasianvaliokunta sai informaatiota ja keskusteli toimenpiteistä vasta molempien sotien loppuselvittelyjen yhteydessä.

\section{Vaaran ja toivon dialektiikka - sopeuttavat ehdot haetaan 1945-1961}

Politiikan näyttämö muuttui sodan lopputuloksen ja sen ennakoinnin vaiheissa, vaikka säännöstelyvaltion rakenteet säilyivät 1950-luvulle saakka - sotatilanormit purettiin 1947 ja säännöstelyvaltuudet vuonna 1955. Isänmaallisen jatkuvuuden puolustajat korostivat 1940 loppua "vaaran" ja monet paasikiviläiset realistit "uusien kasvojen" ja SKDL:llä vahvistuneen suunnan vasemmistolaiset päivänvaloon nousun ja "toivon" aikoina. Liiton keskeistä osaa, kommunisteja - pelättyä viidettä kolonnaa - ei 
enää voitu repression keinoin ohittaa. Oli tarjolla sama strategia - jolla 30-luvun sosialidemokraatit oli integroitu osaksi yhteiskuntaa; nyt kommunisteja suvaittiin ja hyväksyttiin kahden rintaman suunnassa - heitä integroitiin ja maan hegemonista politiikkaa sopeutettiin Välirauhan- ja YYA-sopimukseen ja Neuvostoliittoon, minkä aloitteellinen arkkitehti oli 1960-luvun loppuun mennessä monissa asia- ja valtatavoitteissaan onnistunut Kekkonen - joka sai Paasikiven luottoministerin position jo 1950-luvun alussa ja näin peruspositio kontrafinaaliselle presidenttikampailulle oli avattu. (Alapuro 1999 ja 2010.)

Sodanjälkeiset ristiriidat ja dialektiikka toivat eduskunnankin demokratiakeskusteluun vahvan sosiaalisen ulottuvuuden, YK-rauhanhakuisen suunnitelmajärjen ja joukko(liike)demokratian puheen parsia. Samalla vaalipuolueiden jäsenmäärät kasvoivat ja eduskuntavaalien äänestysprosentti nousi lähemmäs kahdeksaakymmentä prosenttia. Ulkopoliittista valtaa lukuun ottamatta valtiollinen järjestelmä monessa suhteissa parlamentarisoitui - missä hallituksen vastuulliset operatiiviset toimijat nousivat keskeisiksi. Kyse oli paljolti pääministerin ja hallituksen toimintamahdollisuuksista, presidentin ja peruskoalitiopuolueiden johtajien pelistä, jolla hallituksen avatuilla ja suljetuilla ovilla voitiin tasapainoilla. Toimeenpanon teoilla sekaannuttiin ja politikoitiin - sekaannuttiin uudella tavalla kansalaisyhteiskunnan järjestäytymisestä käytävään tiukkaan kamppailuun, minkä meteli kuului myös parlamenttin asti ja sen säröisellä puhujalavalla. Siinä uusilla parlamentaarisilla voimasuhteilla ja 'kasvoilla' oli strateginen merkitys. (Paasikivi 1986.)

Ilman laajaa parlamentaarisen puhekulttuurin tutkimusta on vaikeaa hahmottaa, miten kansanedustajien puhetilat ja -tavat rakentuivat eduskunnassa 1940-luvun lopulla - miten monipuolistunut ja värikäs sosiaalisen demokratian argumentti tunkeutui mukaan - olihan maan intellektuaalisessa polemiikissa heijastunut muun muassa Hans Kelsenin oikeusvaltioteorian sosiaalisen politiikan argumentit ja aktiivisuus, jonka kohteena oli parlamentin oikeudenmukaisuus ja laki. (Jansson 1952.) Tulee kysyä, miten monimielisesti sodan pölyjen laskeutuminen ja joukkodemokratian mahdollisuus hiljensivät tai vaaransivat edustajatyyppien puhelajeja tai miten parlamentaarikot itsessään olisivat taas mukana pikkuvaltion sisäisen ja ulkoisen jännitteiden samanaikeisessa pohdinnassa ja rajojen fundeeraamisessa. Sukupolvittainen 'uusien kasvojen' tarve ja 
Modus vivendin oikeistopolitiikka vihjaavat toisaalta aktiiviseen, toisaalta pysähtyneempään Kairos-politikointiin (ohimenevän epävarman suhdanteen hyväksikäyttöön). (Paakkunainen 1985, 155-57.)

Pääministerin tehtävät laajenivat ja hänen operationaaliset viiteryhmänsä tulivat entistä relevanteimmiksi talouspoliittisen koordinaatio- ja julkisen työmarkkinapolitiikan tasapainottajan (erit. Talousneuvosto) roolien rinnalla. Valtioneuvosto oli vahvana kollegiaalinen, ministerit eivät tiukkoina vuosina sooloilleet tai tehneet voimakasta sektoripolitiikkaa. Järjestysvaltio oli sodan aikana ottanut monia sosiaalis-taloudellisia tehtäviä hoitaakseen, niistä ei ollut paluuta sodan jälkeenkään. Valtion (johdon) suhteesta kamppailunalaisiin työmarkkinajärjestöihin muokkaantui keskeinen yhteiskuntakytkentä. Vaikka laajentuva etujärjestö- ja puoluetoiminta (puolue- ja etujärjestödemokratia) tunkeutuivat syvälle yhteiskuntaan ja valtioonkin, se ei muuttanut parlamentaarisia kirjoitettuja perusnormeja - mitä tuki vahva hallinnon jatkuvuus. (Nousiainen 2006, 217-240 ja Jyränki 2006, 37-67.) Silti jo vuonna 1960 ensimmäinen valtio-opin naisprofessori Lolo Krusius-Ahrenberg (1960, 36-37) varoitti painostuspolitiikan laajenemisesta parlamentarismin toiminnalle: yhtälössä valtion taloudellisten toimintojen laajuus ja etujärjestöjen voima ja keskitys eivät saaneet ylittää puoluelaitoksen vakavuutta ja julkisten viranomaisten komponenttia.

Uusi, jälleen erilaisin välttämättömyyksin, perusteltu ulkopolitiikka Neuvostoliiton suunnassa ja riippuvuus maassa aktiivisesta valvontakomissiosta merkitsivät sodan jälkeen haastetta myös parlamentarismille. Paasikivestä (1986) muodostui pääministeri- ja presidenttikausina omintakeinen karismaattinen hahmo, joka kykeni hallitsemaan ja suodattamaan uuden ulkopolitiikan - hankalasti täyteen parlamenttijulkisuuteen avautuvia paineita ja toimijasuhteita. Pikkuvaltiorealistina ja liikemaailman miehenä hänellä oli edelleen aika viileä suhde parlamentarismin periaatteisiin. Ulkopolitiikka oli luisunut ja eriytynyt presidentinlinnan suuntaan ja se perustui valtionpäämiehen henkilökohtaisiin ulkokontakteihin esimerkiksi Stalinin ja valvontakomission suunnissa. 'Valtionjärki' saneli tasapaino-otteet ja hän pystyi toimimaan 'pouvoir neutre' -periaatteen mukaisesti ja jäämään monissa mutkissa sisäpolitiikan voimasuhteiden kulisseihin. Ulkoisten paineiden ja ratkaisujen osalta presidentti luottohenkilöineen saattoi toimia hyvinkin itsenäisesti jopa hallituksen 
ulkoasianvaliokunnan tietämättä. Valtionpäämies kykeni nimittämän keskeisen uuden1940-luvun poliittisen ja hallinnollisen eliitin - johtavana julkiperiaatteena sotapolitiikan opposition rakentaminen. (Paakkunainen 1986; Tiihonen 1990, 170-203; Nousiainen 2006, 217-240; Jyränki 2006, 37 - 73).

Sodanjälkeisissä kansanrintama- ja enemmistöhallituksissa voikin puhua normaaliparlamentarismista 1930-luvun lopun Cajanderin hallituksen esimerkin mukaisesti. Huolimatta ulkoisista paineista ja hallitusten lyhytikäisyydestä varsinkin 1950-luvulla - "... hallituksia vaihdettiin kuin mustalainen hevosia" (Kekkonen) - ne nojasivat useimmiten vahvaan enemmistön eduskuntaluottamukseen, virkamieshallituksia ei juuri ollut ja ne kohtasivat ärhäkkään opposition ja kentän muhivat puoluejulkisuudet. Lainsäädäntötoimissa intensiiviset sodan jälkeiset parlamenttikaudet eivät vitalisoineet vain puhujalava-yleisistuntoa, vaan myös valiokuntatyöskentely virittyi uuden aallon aloitteiden ansiosta. Virallissäädösten tasolla presidentti ei puuttunut hallituksen toimiin, silti hallituksen ja varsinkin sen luotto-ulkoministerin ja toisaalta presidentin välillä oli vahva sidos. Monessa suhteessa kylmän sodan vuosina sosialidemokraatit keskustalaistuivat ja Maalaisliitto kasvoi taktiseen ja aloitevoimaiseen poliittiseen yhteistyökeskiöön - SKDL:n ristiriitainen, pelokaskin polku ja kylmän sodan kaltevat pinnat veivät sitä tilanteeseen, missä se oli mahdollista eristää pitkäaikaiseen oppositioon (1948-66). Mutta vasta 1960-luvun alussa modernin avautumisen ja Kekkosen presidentinotteen vahvistuessa voidaan katsoa "Sodanjälkeisen sopeutumiskauden" (Nousiainen 2006, 217) päättyneen - tuolloinhan käytiin aika lailla ratkaiseva kamppailu Paasikiven ja Kekkosen ulkopoliittisen linjan UKK-strategisesta tulkinnasta (Honkaliitto ja yöpakkaskaudet ennen sitä); presidentti onnistui irtautumaan parlamentaarisesta päätöksenteon, ajoituksen ja tiedon kehästä. (Nousiainen 2006, 217-240; Jyränki 2006, 37-73)

Puoluetoimintaa ja -koneita ei enää ensimmäisen tasavallan mielessä vieroksuttu ryhmäpelin kielteisin kielikuvin, ne säilyivät kuitenkin epävirallisina, valtiollisten normien ja asetusten ulkopuolella - järjestökansalaisuuksina ja kollektiivisten identiteettien opettajina; niiden joukkositeet ja eduskuntaryhmät muodostuivat tärkeiksi uusilla tavoilla. Maatalous-Suomen talouden yhteishyväpolitiikka, yhtenäiskulttuuri ja juristinen hallintovalta patosivat puoluedemokratian, talous- ja finanssipolitiikan 
sekä laajan työehtosopimuspolitiikan läpimurtoa. Talouspolitiikan liikkumavara ja korporaatiot nousivat puoluekytkyn kanssa - muttei ollut vielä parlamentaarista tai elinkeinojärjestöjen rakennetta käsitellä ja sopia näistä kehittämishaasteista tai stabilisoivista elementeistä osana suomalaista kasvutaloutta ja kauppaa. Koalitiovaihtoehtojen rajoittuneisuus, tunkkaisen korporaatio-taktikoinnin, ahtaiden etujen ja kabinettipolitiikan muodot esittäytyivät vahvasti 1950-luvun selviytymispolitiikassa. Sisä- ja ulkopolitiikan pienet piirit, kabinetit ja hallitusryhmien sisäiset voimatekijät ja fraktiot korostuivat. Ainakin jälkiviisas muistelu pitää 1950-luvun vuosia myös hektisen juoruilun ja ajanpeluun siivittämänä härskien juttujen, henkilö- ja fraktioleimojen aikana - jolloin eduskuntatalon (deliberatiivinen eteinen) kahvila saa uutta arvoa, mikä henki tietenkin heijastuu myös valiokuntiin. Perusoikeisto ja äärivasemmisto olivat pitkiä kausia poissa hallitusfoorumeilta - vähemmistöhallitukset eivät saaneet rakentavaa 'piiloluottamusta', vaikka pyrittiin enemmistöparlamentarismiin. (Nousiainen 2006, 217-240 ja Jyränki 2006, 37-67.)

Omalla tavallaan puolueiden etäisyydet ja staattiset kannatussuhteet olivat kompromissien ja parlamentaarisen (deliberatiivisen) luovuuden esteenä. Janssonin (1993, 191-198) mukaan ns. liittoutumakelpoisuus joka ratkottiin aika pienessä piirissä vaalien jälkeen ulko- ja sisäpoliittisen rajojen vetojen puitteissa - on suomalaisen hallituksenmuodostamisen ydin. Sen lisäksi presidentinvaalien tuloksella on ollut selvä yhteys hallituksen koostumukseen. Hallituksen kaatajan vastuu, vaalivoittajien ja valitsijoiden tahdon huomiointi voittavissa ja valtaan pääsevissä koalitioissa ei ole meillä itsestään selvää. Maalaisliitto-keskustalla ja Ruotsalaisella kansanpuolueella on sosialidemokraateja parempi historiallinen kelpoisuus poliittisiin hallituksiin, Kokoomus ja hännänhuippuna SKDL/ VL ovat eri tahtiin halunneet ja päässeet hallitusasemiin (ennen vuotta 1991). Silti voidaan tarkan sodanjälkeisen analyysin perusteella todeta, että varsinkin isojen puolueiden vaalivoitto vaikuttaa Suomessa selvemmin kuin muualla Euroopassa (erit. Italiassa) siihen, mitkä puolueet ovat hallituksessa ja mikä taho saa pääministeriyden. Tästä huolimatta kannatuksen ja hallituspohjan välinen heikko responsiivisuus on yksi parlamentaarisen demokratian keskeinen ongelma Euroopassa. (Mattila - Raunio 2002, 299-314). Valtiollisen toimijasuhteiden verkoston (Nousiaisen otsikkotermi; 2006, 180), sen eliitin ja parlamentaarisen 
harkinnan merkityksen kannalta tulos taas voi korostaa parlamentaarisen keskusteluvallan ja kompromissien mahdollisuuksia joissain poliittisissa tilanteissa tai jatkuvuksissa.

Puolueperustainen parlamentarismi ja sen kilpailusuhteet lämpenivät sopeutumiskaudella. Uusi ongelma puhdaslinjaisen edustuksellisen parlamentarismin ja sen mandaatin kannalta nousi esiin puolueiden ja eduskuntaryhmien valtasuhteen suunnassa. Puolueyhteisöön integroituminen kasvoi, kun puoluekoneen mobilisoiva, julkisuutta avittava ja rahallinen vaalituki kasvoivat. Eduskuntaryhmät (esim. Maalaisliiton piirissä) opponoivat puoluejohtoa, varsinkin porvarillisissa puolueissa tasapainotettiin puolue- ja parlamenttilinjan suhteita. Hallituksia muodostavat puolue- ja eduskuntaryhmien neuvotteluhenkilöt tulivat usein ML:sta ja SDP:sta, mutta jopa kuusi epäonnista kierrosta saattoi edeltää hallitusratkaisuyrityksiä. Itse valittu hallitus ei tarvinnut alkajaiksiksi minkäänlaista eduskunnan edessä esittäytymistä tai legitimiteetin testausta. Puoluelinjat, hallituspohjaneuvottelujen fraktiokonventiot sekä hektiset koalitio- ja aikapeluun muodot veivät aloitetta parlamentaarisimmilta tahoilta - olivathan henkilö- ja fraktioriidat syntyneet järjestömaailmassa tai ulko- ja sisäpolitiikan solmuisessa positiopelissä, esimerkiksi juuri hajanaisessa ay-liikkeessä eivätkä suinkaan parlamenttiargumenteissa. Toisaalta entistä enemmän - kaksi kolmasosaa - ministereistä oli kansanedustajia ja tavaksi tuli, että presidentin- ja eduskuntavaalien jälkeen pääministeri pyysi aina eron hallitukselleen. Hallituskoalitiot horjuivat sisältä käsin, vain harvoin eduskunnan epäluottamus kaatoi niitä. Parlamentaarisen työn intensiivisyyteen vaikuttivat myös valtionpäivien työvuorokausien kasvu - kaksi ja puolisataa päivää vuodessa vuosina 1945-1961 - sekä yksilöparlamentaarikkojen esiinnousu ainakin erilaisten aloitteiden aktiivisen kirjoittamisen ja jopa niiden läpimenon osalta. (Nousiainen 2006, 217-240 ja Jyränki 2006, 37-67.) 
"Suomettunut" hyvinvointikorporaatioiden maa nostaa elintasoa ja tasa-arvoa: ahtaan parlamentarismin ja voimakeskuksia heijaavan puheen vuodet 1962-81

Aikakausi Noottikriisin ratkaisusta (1961) Kekkosen dramaattiseen valtakauden loppumiseen (1981) sisältää selkeitä työnjaollisia ja valtamuutoksia poliittisessa järjestelmässä ja parlamentaarisissa käytännöissä. Uusi ulkopolitiikka liittyi myös maan selvitymiseen ja ajatukseen Neuvostoliiton ja sen liittolaisten vallan laajentumisesta kylmän sodan blokin lisäksi myös talouden ja teknologian aloilla. Jokainen sputnikkien valot taivaankaaressa viisikymmenluvun lopulla katsellut suomalainen - kuten tämän kirjoittaja lapsuuden hämärässä - pohti tätä voimaa; maailman vomasuhteiden heilahdellessa oli osoitettava suomalaisen kasvun ja modernin integraation oma (elin)voima (vrt. Kettusen tämän kirjan esseen imperatiivit). Ja tämähän onnistui huikean nopeasti 1960-luvun puolivälin jälkeen.

Kansainvälisessä katsannossa myöhäiset - mutta meillä harppaukselliset sosiaaliset reformit ja niiden läpiajajat - ryydittivät taloudellis-sosiaalisia ja poliittisia muutoksia, vaikka perustuslakinormien kirjaimet säilyivät lähes ennallaan (ks. Nurmisen, Väyrysen ja Puoskarin kontribuutiot tässä kirjassa). Modernin yhteiskunnan sosiaalinen draama - "suuri muutto" maalta kaupunkiin ja etupolitiikkaan ja arkeen työntyvä palkkatyöläismentaliteetti ja sen mukainen kulutus ja tasa-arvo - yhdistyi Suomen avautumiseen ja kansalaisten aktivoitumiseen uudessa TV-julkisuudessa. Nuoriso- ja kansalaisliikkeet politisoivat uusia asioita ja kysymyksiä kansalaisyhteiskunnassa - teinien lukujärjestyksistä sukupuolirooleihin ja mielenterveysongelmiin. Tämä modernin politisoitumisen ulospursunta ei kuitenkaan heijastunut parlamentaarisen politiikan ja eduskunnan valta-asemassa; silti puoluevaltaisella eduskuntatoiminnalla oli varsinkin 1970-luvulla paljon uusia kannattajia ja sen "edistyksellisissä" tyyleissä ja uusien asioiden ja sukupolven politisoinnin ja demokratisoinnin poljennoissa oli paljon uusia asioita (viimeistään vuoden 1970 vaalit). Ulkopolitiikan hovi ja toimeenpanovallan establishmentin kylkeen tarrautuneet korporaatiot ja puolueet veivät ratkaisuvallan, valmistelutiedon ja taloudellista kasvua luovat ja jakavat periaatevalinnat aika kauas eduskuntatalosta. 
Akateemisimmin aikalaistermein (Pekka Kuusi, Erik Allardt, Jaakko Nousiainen) erityinen parlamentaarinen legitimiteetti tai sen itsearvoisuuden puolustaminen demokratiana korvautuivat modernin yhteiskunnan integraation, kulutuksen, sosiaalipolitiikan, valitsijakunnan, puoluejärjestelmän, painostusryhmien ja joukkotiedotusvälineiden sosiaalista ja poliittista järjestelmää (system) sekä niiden ohjausjärjestelmiä koskevilla käsitteillä. Historiallis-poliittisesti nämä termit olivat Härmässä jopa radikaaleja ja avasivat sosiaalipoliittisen järjestelmän lisäksi akateemisen ja muun käsitekamppailun kansalaisyhteiskunnan tasapainosta, ongelmista ja mobilisaatiosta. Tällainen moderni systeemisyys oli epävirallista, minkä asemaa juristieliitti yritti jarruttaa jopa akateemisina tutkimusaiheina vielä 1950-luvun lopulla (Paakkunainen 1985).

Eduskunta joutui ulko- ja etupolitiikan uudessa kontekstissa - varsinkin uusien polvien (puolue)politisoituneeksi ajaksi usein kuvatulla 1970-luvulla - muualla tehtyjen päätösten, kasvu- ja intressisovittelujen sekä (parlamentin määräenemmistösäädöksistä ja ulkopolitiikasta juontuviin) hallitus-oppositio -sopimusten kirjaajaksi, "kumileimasimeksi” (Nousiainen 1977, 113-131). Aina kulmikas Matti Wiberg $(1995,219)$ kuvaa, kuinka pikemminkin eduskunnan enemmistön tuli nauttia toimeenpanovallan luottamusta kuin päinvastoin. Parlamentarismin (puhe)periaatteet olivat elossa ideaaleina, osana uusien asioiden politisointia ja jonkinlaisena sisäistettynä siunauspuheena: kansanedustajien vallan häivähdyksenä, periaatteellisena mutta voimattomana mahdollisuutena tulkita voimasuhteita ja ennakoida merkittäviä ratkaisuja, antaa kehityksen jatkua tai olla jatkumatta - käytännössä jatkuvuuden turvaamisena ja edustajan uskottavuudesta huolehtimisena. Linjapuheita lainsäädäntöprosessin lopulta varmistamassa instituutiossa, eduskunnassa ja vaalikentillä riitti.

Parlamentarismin ongelma sosiaalisen kierron ja tasa-arvoistuvan Hyvinvointi-Suomen oloissa on tietenkin osa poliittisen ja korporatiivisen vallan etabloitumisen historiaa ja aikauden superideologioita (esim. Saukkosen kirjoitus; Heiskanen 1977, 46). Myös kollektiivinen järjestösektori ja jopa markkinavoimat halusivat etabloitua osaksi vahvaa valtiollis-hallinnollista keskitystä, missä aikakauden oligopolistiset parlamentaariset peruspartnerit - keskusta ja demarit - oppivat elämään 
ja jakamaan valtaa yhdessä. Kekkosen otteiden kuvaaminen osana tätä hallintajärjestelmien blokkiutumista oli aikalaiskriitikoillekin vaikeaa, isolla realismin kynällä mahdotonta (Heiskanen 1983).1960-luvulta aina 1980-luvun loppuun taloudellinen kasvu ja tasa-arvon laajentaminen turvattiin (esim. Nurmisen essee tässä kirjassa) - parlamentaarinen demokratia ei ollut kuitenkaan sen keskeisin tahdittaja, vaikka lainsäätäjä-eduskunnan sosiaalisen politiikan huolehtijat tukivat vahvasti "edistystä". He osasivat myös puhua terveys- ja sosiaalipolitiikan siunauksellisista kehistä, tasa-arvosta pienen ihmisen kannalta ja toisaalta hallitsivat sen universaalit palvelut ja sektori- ja kattavuus"faktat" omien kannattajaryhmien etujen kannalta. Samalla he halusivat toimia aktiivisesti sovitellen osakysymyksissä aina kun eduskunnan valiokunnissa sille ilmestyi harvinainen tila. Vaali- ja kansanäänestysretoriikan erot sosiaali(vakuutus)politiikassa olivat sangen kulmikkaat aina 1980-luvulle, jolloin myös Kokoomus tuli mukaan hyvinvointivaltion (konsensuaaliseen) laajentamiseen omien kannattajiensa ehdoin.

Nopean modernisaation olosuhteissa käsitykset kansakunnasta moninaistuivat, poliittinen kannanottaminen ja ryhmääntyminen olivat legitiimejä ja liikauttivat varsinkin uusien sukupolvien avuin paljon myös maailmankuvaa ja puolueruotuja. Mutta tätä uuttakin moniarvoisuutta jäsennettiin kansallisesti välttämättömän taloudellisen kasvun, sovun ja sopeutumisen opeilla. Moderni tieto ja media maallistivat ja kiistanalaistivat asioita, rapauttivat työväen leirikulttuuria ja suomalainen kommunismikin maallistui - kaikki vedettiin mukaan koulutukseen ja kulutukseen. Rationaalisessa moniarvoisuudessakin oli pakkopluralismin makua, Heiskasen mukaan nyt kaikkien tuli olla vapaita, moniarvoisia ja ymmärtää toisiaan. (Alapuro 1999 ja 2010, Heiskanen 1997 ja 1982.)

Tässä oppikirjatekstissä onkin (turhan) helppo alkaa kirjoittaa tuon poliittisen ajan parlamentarismista UKK:n biografian ja valtasuhteiden termein. Kekkosen valta muuttui 50-luvun varovaisemmasta tasoittavasta ja ristiriitoja sovittelevasta voimasta yhteiskunnalliseksi mielipidejohtajaksi (Nousiainen 2006, 241-244), joka perustuslain tuntijana osasi työntyä kansalliseen toimeenpanovaltaan ja operoida parlamentaaristen periaatteiden ja vallanjaon oppien yli ja ali. Kekkonen tunsi parlamentarismin normit ja vipusimet - henkinen asiajohtajuus säilyi 
valtioneuvoston istunnoissa - presidentin veton mahdollisuus ja uhkaeleet olivat useimmiten esillä valmisteluissa ennen istuntoja.

Ulko- ja sisäpolitiikan kriisit aktualisoivat hänen kykynsä ja vallankäyttönsä. Sanotaan, että hän käytti niitä myös hyväkseen osoittaen niillä ainutlaatuisen tarpeellisuutensa. Alkukaudella hän ei puhunut presidentinvallan laajentamisen puolesta, vaan hänen luomassaan 'ison-riskin-hoitajan' roolissaan korostui pakko operoida kuin ei ongelmanratkaisu ja parlamentaarinen meno maassa muutoin sujuneet! (Nousiainen 2006, 241-273; Jyränki 2006, 68-73 ja 2009a) Ja operaatiot jäivät elämään jonkinlaisina varoituksina ja vallan varjoina. UKK:n aikeiden ennakointi oli relevantti osa reaalipolitiikkaa; voi puhua tällaisen UKK-toimien antisipaation ja toisaalta aikakauden valtatoimijoiden reaalipyrkimysten välisestä pelokkaasta epävarmuudesta. Tällainen kontingenssilla ahdistelu vaivasi monia eduskunnan toimijoiden mieliä ja jarrutti kielenkantoja 1960-luvun lopun ja 1970-luvun Suomessa. Kekkonen puuttui ongelmiin ja kirjoitti eri instituutioiden vaikeuksien voittamisesta - sekaantui rohkeasti yhteiskuntapolitiikkaan, suomalaisen historian uudelleen tulkintaan ja uskoi kirjoittamisen voimaan. Hänellä oli ehtymätön henkinen vitaliteetti ja dynaaminen avustajakunta- ja asiantuntijaintuitio - hän oli aktiivinen nimimerkkikirjoittajasta urheilupolitiikkaan ja kirkkoon, omiin työryhmiin ja myllykirjeisiin (henkilökohtaisesti ojentavat viestit). Aikalaisnimimerkkien mukaan hän alkoi olla läsnä kaikkialla. (Aikalaistulkinnasta, esimerkiksi Skyttä 1979.)

Kekkonen pystyi yhdistämään taloudellisia, kulttuurisia ja poliittisia voimia sekä sukupolvia omiin hegemonisiin projekteihinsa (vrt. Väyrysen essee tässä kirjassa) - 1960-luvun radikaalien lastenkutsuista, moderniin kirkkoon ja Neuvostokauppaan. Hänen toimissaan ulkopolitiikan realistinen viisaus sai myös suomettumisen piirteitä (keski-eurooppalainen 'Finlandisierung' -termi leimasi Suomen kehityksen kielteisenä vasallikehityksenä) - mistä tutkijoidenkin polemiikki jatkuu 2000-luvullakin. Tähän vaikutti myös Kekkosen taitavan "vehkeilevä" rohkeus ja nopeus esittää eleitä, yhteistyöpeliä, kauppoja ja esimerkiksi historiallisia tulkintoja silmämääränä neuvostojohdon, läntisten ja kotimaisten tahojen suostuttelu myöntämään Suomen puolueettomuus, autonomia ja mallimaa-asema lännen ja idän välillä. Ja kansa saattoi 
tavoitella läntistä elämäntapaa. (Kirby 2006.) Kylmän sodan maailmassa ja sen väleissä oli hankala esittää universaalille yleisölle uskottavia pikkuvaltioiden selviytymistarinoita ja 'kolmansia' ratkaisuja.

Vallankin Kekkosen vitaalin poliittisen sukupolven piirin ulkopuolella ja isännän ikääntyessä 70-lukulaisessa rituaalisessa ilmapiirissa suomettuminen sai myös ylilyöntien ja pakkoarjen piirteitä. Moskovan kortit, jopa Komsomol-viirit ja suurlähetystösaunat olivat ajan pääomaa, sisä- ja ulkopolitiikan eroa ei tunnistettu - kansallista ja omaa, taloudellista ja poliittista, etua koplattiin. Siinä, missä virallinen ja pääpuolueiden linja ja taustaoletukset eivät innostaneet, vaikeneminen ja sensuuri olivat osa tiedon ja julkisuuspolitiikkaa - myös parlamentaarisissa keskusteluissa, asiakirjoissa ja marginaalissa itsetietoisuudessa. (Vrt. Bäckmannin esseekavalkadi 2001, missä jälkisuomettuminenkin muhii; Suominen 1996; Paakkunainen 2012)

Parlamentaarisessa ja reagoivassa marginaalissa elänyt eduskunta omalta osaltaan luopui ulkoasianvallasta ja sen aktiivisesta muotoilusta. Itse eduskunnan toimintaan UKK:n ei tarvinnut puuttua ja hän kohtasikin henkilökohtaisesti eduskunnan lähinnä vain seremonioissa ja valtiopäivien avajaisissa: Urho Kaleva puhui aloitteellisesti ja eduskunta kuunteli. Silti ulko- ja sisäpolitiikan rajat ja asialistat olivat liukuvia, neuvostosuhteet olivat osa esimerkiksi talous- ja kulttuuripolitiikkaa. Ulkosuhteiden taustan ja tiedon hallinta oli ulkopoliittisen eliitin asia. Presidentillä oli mahdollisuus aktiivisen sopimisvallan hengessä tavata neuvostojohdon henkilöitä jopa kahden kesken. Samalla niin kutsutut puolue- ja KGB-linjat sekä kotiryssät ja läheiset puoluekontaktit ja -vierailut olivat neuvostosuhteiden luomisen kanavia presidentin näyttäessä tässä tietä. (Suominen 1996.) Usein kansanedustajien enemmistö ja eduskunta olivat ulkopoliittisessa jälkijunassa, ja se saikin ulkoasianvaliokuntansa kautta usein penättyä rapottitietoa presidentin ja ministereiden neuvotteluista ja ratkaisuista. (Nousiainen 2006, 26073.) Dynaamisillaan ja valveutuneimmillaan Kekkonen oli ulko- ja kauppapoliittisissa ratkaisuissaan, joilla hän pyrki takaamaan Suomen taloudellisen kasvun ja puolueettoman maan poliittisen legitimiteetin ja pelivaran osana Eurooppaa (ETYK 1975, bilateraalinen idänkauppa ja Efta- ja EU-vapaakauppasopimus 1960- ja 1970-luvuilla; Aunesluoma 2011). 
Varsinkin heikot hallitukset olivat presidentin huolen- ja toimintakohteina. Hallitusyhteistyön edellytysten ja toimivuuden kriittinen arvostelu tai hallituspohjan romuttaminen ja ennenaikaiset vaalit olivat parlamentaaristen instituutioiden välisessä pelissä oivia keinoja. Presidentin rooli hallituksen muodostamisessa oli luja, kuten edellä mainittu Koiviston tulkintamuutos 1981 dramatisoi. Useammin kuin kerran Kekkonen myös itse johti hallitusneuvotteluja eikä tyytynyt vain hallituspohjan selvitysmiehen ja kokoajan nimeämisiin (esimerkiksi vuosi 1972). Kekkosen valta oli yhdessä lakipisteessään, kun hänet valittiin jatkokaudelle poikkeuslailla (1973) ilman vaaleja ja menettelyn demokraatttisuuden hyväntahtoisetkin pohtijat - muun muassa prof. Göran von Bonsdorff valtio-oppineena ja neuvostoystävänä - joutuivat kärsimään. (Nousiainen 2006, 241-273; Jyränki 2006, 68-73.)

Poliittisia sosiaali- ja reformipaketteja määrittelevät tulopoliittiset kokonaisratkaisut mahdollistuivat palkkatyöväen määrän kasvaessa, keskiluokkastuessa ja ay-liikkeen yhtenäistymisen myötä. Korporatiivinen ja tulopoliittinen valtaryhmä kasvoi eduskunnan rinnalle ja monessa sen ohi. Se muodostui julkisen vallan, markkinoiden ja työelämäjärjestöjen (palkansaajat, maatalous ja työnantajat) tiiviistä yhteistyöstä, työehtoja paljon laajemmista sosiaalis-taloudellisista sopimuskokonaisuuksista sekä julkisen vallan valmistelu- ja komiteavallasta.

Järjestöedustukset laajenivat painavien kannanottojen lisäksi asiantuntija- ja päätöksenteon alueille, samalla (puoli)julkinen hallinto laajeni vahvasti ja rekrytoi uusia voimia vahvistuvasta ja osin koulutetusta järjestö- ja puoluekaaderista. Termi herrahissi käännettiin suomeksi. Tupon kentiksi muodostuivat ainakin sosiaaliturva, osa julkisista palveluista, työlainsäädäntö ja elvytys ja kokonaistalouspolitiikka. Laaja talouspoliittinen operointi ja ennustettavuuden lisäämisen politiikka sai perustelunsa myös teollisen ja palveluyhteiskunnan bkt-tulonjakokamppailusta, suhdanne- ja tulonsiirtopolitiikkaa perustelevasta Keynesin talouspolitiikasta (Pekka Kuusi) ja julkisten tehtävien laajenemisesta ja sektorien muokkausväittelystä. Muodostui uusi valtiollistunut eliitti - "kansi alkoi irrota kattilastaan" - joka pystyi määrittelemään eduskunnan päätösvallan asioita. (Nousianen 1985.)

Työelämän ja markkinoiden aktiiviset järjestövoimat hallitsivat agendaa - esimerkiksi kansaneläkeläisten kustannuksella. Presidentin 
huolet talouden ja tulopoliittisen vakauden takaamiseksi toivat hänet mukaan pelikentän muotoilijaksi. Kansanedustajille olikin hankalaa löytää paikkaa tupon (lakipakettien) ratkaisuvaiheissa, Paavo Haavikko laskikin leikkiä heikkojen parlamentaarikkojen pyrkimyksistä lyöttäytyä mukaan edes"tupon" tuloksia uutisoiviin mediakuviin. Vain harva parlamentaarikko tai ministeritoimija - poikkeuksena esimerkiksi Johannes Virolainen - halusi suojata eduskunnan lainsäädännöllistä ja budjettivaltaa ja näyttää tuolloisia tupo-lobbaajia pois edes kaikkein tärkeimmistä parlamentaaristisista kabineteista. (Erit. Haavikko 1992a ja b.) Tunnetusti presidentti vastusti aluksi puoluetukiuudistusta, mutta oli toisaalta aktiivinen ay-liikkeen vallan institutionalisoinnissa varmistamalla konkreettisesti tupo-neuvotteluprosesseja viimeistään 1970-luvulla (Bergholm 2007) ja tukemalla sen uutta tehokasta jäsenrekrytointikulttuuria. Toisaalla valtionpäämies vastusti perustuslain vallanjakonormien parlamentarisointia - ja puolueiden hajanaisuus antoi hänelle mahdollisuuden mitätöidä koko uudistushankkeen 1970-luvun alkupuolella. (Erit. Jyränki 2006, 74-80; ks. erimieliset lausumat, Valtiosääntökomitean välimietintö 1974.)

Varsinkin päähallituspuolueet keskusta, sosiaalidemokraatit ja ruotsalainen kansanpuolue saavuttivatkin uudenlaisia vallan asemia ja vallan verkkoja kunta- ja valtionhallinnossa, asiantuntija- sekä järjestömaailmassa. Mutta puolueiden asema vahvistui ja virallistui myös lainsäädännössä, valmistelukomiteoissa, vaaleissa ja puoluetukijärjestelyissä. Valtiollistuminen ja hallinnollistuminen rutinoivat myös keskeisten poliitikkojen dramaattsia välejä ja puheenpartta (myös eduskunnassa), virkamiehen ja poliitikon/parlamentaarikon roolit lähestyivät. Samalla puolueiden valtaverkot laajenivat moniin 'bulvaaneihin' - niitä lähellä oleviin nuoriso-, vanhus ja sivistysjärjestöihin. Tunnettua oli myös peruspuolueiden ankkuroituminen työmarkkinoiden lämpimien kumppanien, osuustoiminnan, rahoitusinstituutioiden ja säätiöiden resurssien bulvaanipiireihin. (Heiskanen 1977.)

Maan hallitus ja keskeiset ministerit muodostivatkin aikakauden eräänlaisen vaikutusvirtojen kabinettikeskuksen, heillä oli tasapainottava ohjausvalta laillisen eduskunnan ulkopuolella. Selonteot eduskunnalle ja eduskunnan lausunnot jäivät nekin marginaaliin - suunnittelu- ja tiedonhallinta olivat valtioneuvoston käsissä ja ministeriöiden 
suunnitteluration piirissä. Eduskunnan aloitteet olivat luonteeltaan keskusteluttavia - Eduskunnan ja hallituksen dualismi eli ilman responsiivista dialogia. Pääministerit eivät keskustelleet tai vastaväitelleet eduskunnan julkisilla foorumeilla, myös ministerit saattoivat olla mykkiä kyselyareenoilla ja tietoisesti poissa täysistunnoista. Deliberatiivisesta eduskunta- tai valiokuntajulkisuudesta, neuvottelu- ja sopimuskulttuurista ei voi puhua. Eduskunnan ulkoasianvaliokunta sai oman yhteistyöosapuolen kunnioitetun aseman osana presidentin ulkopolitiikkaa ja tiedottamista, samalla se tuli tietoiseksi presidentin toimista. (Nousiainen 2006, 241-273; Jyränki 2006, 68-73.)

Hallituksen oppositiolla eduskunnassa oli vaikeuksia. Sen puolueet olivat hajanaisia. Oppositio ei kyennyt juurikaan liittoutumaan eikä yhteisjulistuksiin - sen sijaan normien lepäämänjättämissäännöstö antoi oppositiolle oman valtasärmänsä; samaan aikaan kiireellisen säätämisjärjestyksen vaatimat perustuslailliset ratkaisut vaativat hallitusvallan etukäteisneuvotteluihin opposition kanssa. Huolimatta uuden sukupolven kokoomuslaisten monitasoisesta lojaliteetista Kekkoselle 1970-luvulla, ei puolue 'yleisistä' (Johannes Virolaisen kuulu muotoilu) eli ulkopoliittisista syistä päässyt Kekkosen valtakunnassa hallitusvastuuseen 1960-luvun alun jälkeen. SDP oli mukana UKK-takuumiehenä jo vuonna 1966. Myös SKDL oli sisäpolitiikankin tasolla yhteistyökykyinen - mutta fraktiokamppailussa sisäänpäin kääntynyt ja vaihtelevasti mukana Kekkosen hallituspohjissa.

Myös vuoden 1970 protestivaaleissa noussut Suomen maaseudun puolueen eduskuntaryhmä - joka tarrasi kiinni yhtä lailla Kekkosen kuin keskustapuolueenkin valtaan ja ylipäänsä jännitti uudella tavalla "suuressa muutossa" unohdetun kansanosan kokemukset ja valtiollisen eliittisen sopimisen pelikulttuurin - menetti "protestivaalien" (1970) voimaansa eduskuntaryhmän hajotessa. Vaikka parlamentaarinen keskiö ja akseli eivät toimineetkaan eduskunnassa, osa eduskunnasta oli meluinen ja aktiivinen: protestipuolue-Smp:n karismaattinen johtaja Veikko Vennamo käytti yhdellä kaudella viisi sataa täysistuntopuheenvuoroa ja joutui 1974 järjestyksen rikkomisesta lomauttamispäätöksen kohteeksi - kansanedustajan oikeuksiin vedoten hän jäi istuntosaliin ja vahtimestarit kantoivat hänet sieltä ulos. Eduskunnan luottamukselliset ja deliberatiiviset keskustelukulttuurit hallitusryhmien ja opposition 
edustajien välillä eivät jaksaneet hyvin. Opposition äänilajina - kansan, kentän ja joukkojen (liikkeiden) puolesta - olikin värikkäimmillään populistinen ja vasemmistolainen "kansanääniretoriikka" (Chambers 2009, 339), missä vennamolainen 'häiriöjulkisuus' tai esimerkiksi joukkopuoluefraktioiden - keskustasta vasemmistoryhmiin - kansanedustajien liittyminen eduskunnan ulkopuolella pohjoisen "karvalakkilähetystöjen" tai opiskelijamielenosoittajien huutoon olivat harkittuja performansseja.

\section{Enemmistöparlamentarismi ja taloudellisen ohjauksen muutokset 1980-luvulta lähtien...}

1980-luvun koivistolainen asennemuutos ja toimet parlamentarismin suuntaan toteutuivat asteittain ja ristiriitaisesti. Koivisto piti varovaisen tiukasti ja tarkasti kiinni ulkopoliittisesta ja osin taloudellisestakin "fundeerausvallastaan". Vaalien tuloksen kunnioittaminen ja hallitusneuvottelujen avaaminen koko puoluekentälle ja viimeistään Kokoomuksen Holkerin noustua "hallitun rakennemuutos" hallituksen pääministeriksi vuonna 1987 oli yksi murros tässä. Muutoslinjauksessa otettiin vakavasti kansainvälinen kilpailukyky, lännen integraatio ja julkisen vallan ja palveluiden laajentamisen ja kustannusten rajat. Parlamentaarisen avautumisen rinnalla presidentti osoitti valtaansa puolueiden suunnassa, presidentin tukema Holkeri nousi asemaansa vastoin porvarillisten puolueiden - joista osa oli pian hyvin katkerana - niin sanottua kassakaappisopimusta hallituspohjasta. Presidentin puheet luettiin laajemminkin edelleen hyvin vakavasti, muun muassa inkeriläisten paluumuuttoasetukset toteutuivat pian Koiviston periaatepuheenvuoron jälkeen. Yleislinjaksi presidentti oli iskostanut oman tukensa nimittämälleen ja eduskunnan tukemalle hallitukselle - mikä tietenkin säilytti hänen vaikutusvaltaansa politiikan sisältöön. (Nousiainen 2006, 275-; Jyränki 2006, 117-119.)

Presidentiltä odotettiin vahvaa idänpolitiikan silmää ja vastuuta - ja Koivisto keskittyikin valtionedun hengessä seuraamaan Neuvostoliiton ja sen liittolaismaiden kriisiä kunnes Baltian maiden huikeat itsenäistymisjulistukset saivat uskottavuutta ja Gorbatshovin vastainen vallankaappausmellakka epäonnistui ja Jeltsin nousi valtaan (1991). Tie YYA-sopimuksen avaamiseen ja Suomen taloudelliseen ja turval- 
lisuuspoliittiseen lännettymiseen (EU ja euroratkaisut) oli avautunut Neuvostojärjestelmän lähes rauhanomaisen historiallisen kaatumisen myötä. Unionisopimuksella (EU 1995) ja sitä pian täydentävällä liittymisellä Euroopan talous- ja rahaliittoon (EMU 1999 ja euroon siirtyminen 2002 alusta) oli käänteentekevä merkitys poliittiselle kulttuurille. Kylmän sodan logiikan väistyessä myös presidentin vallan perustelut tulivat entistä turhemmiksi ja eurooppalaistuminen on helppo tulkita myös valtasuhteiden parlamentarisoinnin ja markkinaketterän hallituspolitiikan luomisen vaatimuksena.

1990-luvun alku oli muutoinkin dramaattinen. Suomi avasi rahoitus- ja pääomamarkkinansa ja luopui kansallisen talouspolitiikan repertuaaristaan, pääomaliikkeet ja ulkomainen velanotto vapautetiin. Parlamentin ja parlamentaristististen instituutioiden perinteiset talous- ja finanssipolitiikan välineet annettiin pois asteittain integraatioja kirjavassa perustuslaillisessakin työskentelyssä 1980-luvun lopulta 2000-luvulle. Tämä vaikutti myös tulopolitiikan edellytyksiin. Aluksi tukeuduttiin suomalaiseen markkina-markkaan ja sen vahvuuteen: kiireisessä puhetavassa ja taloudellisissa toimissa - joissa myös presidentillä oli roolinsa - oli vauhtisokeutta, välttämättömyyden makua ja ajopuu-metaforia. (Kiander 2001; Kiander\&Vartia 1998.) Vapauden illuusion vauhdittama lama tapahtui kansallisena äkkirysäyksenä, aikalaistulkinnan mukaan oli 'kiivetty persusta edellä puuhun' - ja tulokset olivat ikäviä: pankkikriisi, konkurssit sekä työttömien ja toimentuloasiakkaiden määrän hurja nousu. 1990-luvun murroksessa omaksuttu tiukka julkisen sektorin "löysät pois" -säästöideologia oli taas yhteinen välttämätön ohjenuora ja se yhdistyi 1980-luvulla vauhdittuneeseen kilpailukykyvaltion ideaan ja hallinnossakin läpilyövään tulosvastuu- ja tehostamisajatteluun. Julkinen hallinto ja talous olivat monien mielestä paisuneet jo 1980-luvun puolivälissä hallitsemattoman isoksi ja menettänyt harkitun dynamiikkansa. Koko poliittinen järjestelmä ja parlamentaristinen kansallinen vallanjako joutui uuden ja monessa suhteessa kunnianhimoisen lännettyneen taloudellisen selviytymisohjelman ja turvallisuuspolitiikan rakentamisen ja toiminnan testiin. 1980-luvun tasaarvoretoriset 'superideologiat' (Saukkosen essee tässä kirjassa) jätettiin taakse yksissä tuumin, valtio alettiin monissa piireissä nähdä valtiokonsernin, globaalin talouden kilpailun ja sen peesaajan (vrt. Väyrysen essee 
tässä kirjassa) ja varsinkin EUn yhteisen ulko- ja rahapolitiikan muotoilijan rooleissa.

\section{...yhdistyvät julkisen konsernin tehokkuuteen ja kansalaisten sosiaalisiin oikeuksiin}

Parlamentin roolin selkeyttämisen lisäksi ja edustuksellisen puoluedemokratian rikastuttamiseksi (1987) sovittiin eduskunnan aloitteen varassa toimivasta ja neuvoa-antavasta kansanäänestysinstituutiosta; mielikuvitus sen käytössä on kuitenkin rajoittunut Suomen liittymiseen Euroopan unioniin. Tuoreen perustuslakimuokkauksen (2012) mukaan vähintään 50000 äänioikeutetulla Suomen kansalaisella on oikeus tehdä eduskunnalle aloite lain säätämiseksi. Integraatio, Euroopan ihmisoikeussopimus ja laman sosiaaliset reunaehdot heijastuivat myös monin tavoin perusoikeusjärjestelmän uudistamisessa (1995). Suomen oikeuden piiriin kuluvien henkilöiden kuten monien maahanmuuttajaryhmien perusoikeudet toteutuivat viimein myös meillä. (Jyränki 2006, 107-09; vrt. Saukkosen essee tässä kirjassa.) Kansalaisten tietosuoja ja julkisten asiakirjojen avoimuus olivat uusia perusoikeuksia. 1990-luvulla taattiin myös kansalaisten sosiaaliset oikeudet perusturvaan. Näillä hyvinvointinormeilla on vaikutusta erityisesti hallituksen valmisteluprosessiin, edelleen vahvasta perustuslaillisesta suojasta nauttivat perusoikeudet rajoittavat selvästi eduskunnankin poliittista harkintavaltaa. Hyvinvointioikeudet eivät ole olleet itsestään selvyyksiä - niiden sitovuudesta on värikkäästi keskusteltu perustoimeentulon leikkausten yhteydessä ja rajat on pohdittu (edelleen tiukan) omaisuudensuojapykälän kanssa.

Suomessa valitun tiukan säästöpolitiikan ja EMU-kriteereiden täyttämisvelvoitteen käytännön perspektiivissä perustuslain lepäämään jättämistä koskevat säännöstöt poistettiin kaksilla valtiopäivillä $(1992,1995)$. Lopultakin (iso perustuslakiremontti vuonna 2000) perustuslakimme on vapautunut kaikista vuoden 1906 eduskunnan "puolisivistynyttä enemmistöä" vastaan ankkuroiduista takeista (suuren valiokunnan kontrollitehtävät ja määräenemmistöt) lukuun ottamatta suhteellista vaalitapaa ja kahden kolmasosan määräenemmistöä peruslakien säätämisessä! (Jy- 
ränki 2006, 172-73, 176). Näin enemmistödemokratia ja normaaliparlamentarimi vahvistuivat olennaisesti.

Valtiontalouden ja eduskunnan budjettivallan normit muokattiin uusiksi (suurelta osin jo ennen vuotta 1991) ristiriitaisin tavoin. Merkittäviksi kasvaneet budjetin ulkopuoliset rahastot (pankkeja pelastanut vakuusrahasto, asuntorahasto, valtion eläkerahasto) saivat ensin perustamiskiellon, mutta tämä päätös peruttiin pian (1991). Tavallisten lakien valta kasvoi, verolakien erityinen säätämisjärjestys poistettiin, nettobudjetointi otettiin käyttöön, edustajien raha-asia-aloite laajeni koko (lisä) budjettiin. Kuntien talouden ja palveluiden ohjaamisesta ja korvamerkitystä tukijärjestelmästä luovuttiin jo 1980-luvulla (Jyränki 2006, 115172). Jo 1987 oli institutionalisoitu poikkeuslain turvin valtion liikelaitokset - jotka irrotettiin budjettitaloudesta ja joiden johtamiskäytännöt ovat monin askelin irronneet parlamentaaristen toimijoiden ja henkilöedustajien ohjauskeinoista tuon jälkeen; useat niistä muokattiin osakeyhtiöiksi ja yksityistettiin.

Toiminta- ja taloussuunnittelun (TTS) käytäntö oli ennakollisesti rajannut parlamentin budjettiharkinnan puitteita, mitä täydensivät hallintoyksiköiden johtajuutta tuulettavat tulosohjausnormit. Nämä säädökset olivat vain asetuksen tasoisia, mutta markkinataustaisten suoritus- ja vaikuttavuusperiaatteiden omaksuminen oli monessa suunnassa iso muutos. Toiminnan kohdentamisvapaudet ja määrärahojen käytöllä operoinnit mahdollistuivat kehysbudjetoinnissa ja tulossopimuskulttuurissa. Poliittinen taho ja virasto (hallinto, laitos tai puolijulkinen yhdistys) sopivat resurssista ja sen mahdollistavasta suorituksesta, palvelu(tuotteesta). Keskeinen tulosvastuun toimeenpanovalta muokkaantui valtioneuvoston ja ministeriöiden tasolle. 1990-luvun hallitusargumentaation mukaan uudistusrypäs merkitsi joustavan valtiontalouden kirjaamista perustuslakiin, mutta Jyränki summaa, että eduskunnan finanssivalta väheni ja päätösvalta etääntyi Arkadianmäeltä (ema).

Tehokkuus- ja tulosvastuuperiaatteet (sekä monessa suhteessa informaatio- ja ohjelmajohtaminen) tuulettivat legalistista hierarkiaa, ummehtunutta yhteistyötä, elinikäisten virkamiesten ja hallintojen tehokkuus- ja vastuukeskusteluita, mutta samalla monet julkisen talouden ja perusoikeus- ja tasa-arvoasiat sekä kansalaisyhteiskunnan kumppanuudet jäivät tehokkuusajattelussa sivummalle; eduskunta jäi tulosvastuun 


\section{Kari Paakkunainen}

myötämäärääjäksi toimintamäärärahojen yleisblokkien antajana ilman kestävää tavoitteenasettelun valtaa. Relevantti osa valtiontaloudesta on budjettiratkaisujen ulkopuolella, ja eduskunta lähinnä myötäilee tulosvastuuratkaisuja hallintojen ja virastojen sisällä ja valtioneuvostossa. Valtion tehtävät ovat rajusti eriytyneet ja hajautuneet viimeisen kahdenkymmenen vuoden aikana, jolloin normiohjauksesta on aika lailla täysivoimaisesti siirrytty tulos- ja markkinaohjaukseen.

Valtioyhteisö on nyt julkinen konserni, jonka ymmärtäminen ei palaudukaan aina parlamentarismin vallanjakoihin ja poliittisen valtion luottamustekijöihin vaan erilaisiin ja muodeiltaan muuttuviin johtamisstrategioihin, missä johtajavallan lisäksi taloudelliset vaikuttavuus- ja tilinpitokoodit, tuottavuusperiaatteet ja vastuullisuudet ovat keskeisiä. Näissä oloissa keskeinen ministeriöiden talousohjausvalta esikuntineen nousee fokukseen, jota parlamentaarinen julkisuus ja tila eivät hallitse. Samalla eduskuntaa lähellä oleva Valtiontalouden tarkastusvirasto on noussut poliittisestikin vastuullistavaksi instanssiksi ja julkisuusvaikuttajaksi. Erityisesti valtionvarainministeriön rooli on kasvanut, vuosikymmenien mittaan julkinen tavoitteenasettelu ja suunnitteluasiakirjat kirjoitetaankin usein retoriikalla, jonka yleisönä on tämän ministeriön virkamiehet. Markkinat on nyt monessa se valtioviisauden välttämätön tosi, jota kuunnellaan ja peesataan esimerkiksi kilpailukykypolitiikan ja kehysbudjettein kautta. Valtioyhteisö onkin julkinen konserni - joka rajaa ja haastaa virtuoosin parlamentaarisen politiikonkin operointivallan, tietämyksen ja aikataulut. (Vrt. erityisen Ahosen kontribuutio tässä kirjassa; Nousiainen 2006, 315-325, Jyränki 2006, 177 ja Palonen 2012, 97-113, 162-77.)

\section{Integraatio parlamentarisoi ristiriitaisesti vallanjakoa ja tuo uudet poliittiset instituutiot ja euron}

Eduskunnan parlamentaarinen asema koki drastisimman muutoksen sitten vuoden 1919 perusnormien asettamisen kun unionin toimivalta Maastrichtin hengessä laajentuneena (allekirjoitus1991) ulottui yhdistymisratkaisun jälkeen Suomeen. Vastapainona uusien eurooppalaisten yhdentymisoloille ja unioniasioiden käsittelylle politiikan dialektiikassa 
suuntauduttiin parlamentarismin ja eduskunnan aseman vahvistamisen suuntaan (varsinkin 2000 uudessa perustuslaissa). Jo Euroopan talousalueeseen liittyminen (Eta-sopimus 1992, voimaan 1994) oli integraation harjoituskierros, mikä merkitsi poliittisesti neuvotellun valtiosopimuksen ja sen osana satojen tavaroiden, pääoman, palveluiden ja työvoiman liikkumisvapautta koskevan normin voimaansaattamista Suomessa. Mutkikkaassa päätöksentekomenettelyssä turvauduttiin valtioneuvoston valmistelu- ja päätöksentekovallan lisäämiseen presidentinvallan kustannuksella - olihan kyse ensisijaisesti sisäpolitiikasta - ja toisaalta eduskunnan suuri valiokunta sai uuden arvovaltaisen tehtävän uudenlaisena integraatioelimenä: sen tuli sitoa eduskunta päätöksentekoon ja saada tämän edellytyksenä korrekti tieto ja asema neuvotteluargumenttien pohtijana ja ennakkolausuntojen antajana. (Jyränki 2006, 127-28; Nousiainen 2006, 315-325.)

Kylmän sodan jännitysten purkautuessa ja Eurooppa-yhteistyön muuttuessa sisä- ja ulkopolitiikan horisontiksi ja arjeksi, molemmissa politiikan lajeissa vahvasta presidentistä alkoi olla vastuullisen tehokkaalle asioiden ratkomiselle enemmän haittaa kuin hyötyä. Vuonna 1994 presidentiksi valittu Martti Ahtisaari ei Koiviston perusparlamentaarisen orientaation hengessä ollut valmis luovuttamaan Eurooppa-neuvoston osallistumisvaltaa (ns. kahden lautasen ongelma) kokonaan pääministerille ja ylipäänsä hän korosti presidentin ulko- ja turvallisuuspolitiikan johtajan valtaa myös Unionin ja sen valmistelufoorumien asioissa. Ahtisaaren tiukka ja erikoinen lausuma valtioneuvoston pöytäkirjaan (31.12.1994, jolloin vahvistettiin osittaismuutoksia v. 1928 valtiopäiväjärjestykseen) muokkasi eduskunnan kannan vastaisesti tilaa presidentin johtajuudelle ulkopolitiikassa myös EU-asioiden käsittelyssä ja hänen omalle harkinnalleen osallistua Eurooppa-neuvoston kokouksiin. Paavo Lipponen uuden hallituksen pääministerinä vahvisti tämän harkintavallan.

Itse EU-jäsenyysratkaisu vauhdittui ja mahdollistui monen eri tavalla julkisuudessa olevan tekijän muokkaamana - ennen eduskuntavaaleja 1991 ei juuri uskallettu tai haluttu keskustella unioniratkaisuista. Turvallisuuspolitiikka dominoi uuden integraatiosuunnan keskeisten toimijoiden joukossa (Koivisto 1995, 547) muttei julkisuudessa, keskustalainen pääministeri Esko Aho joutui toimimaan rohkein elein puolu- 
eensa perustukijoiden euro-skeptisimsiä vastaan ja Ruotsin myönteinen kanta unioniin vei perustaa Eta-ratkaisun merkitykseltä ja nosti tuolloisen integraatiojunan painoarvoa. Heikosti informoitu eduskunta saatiin tukemaan jäsenyyshakemusta tiedonantoäänestyksellä asiasta, josta oli kuitenkin tehty hallituksen luottamusäänestys. Talouden ja demokratian kysymykset - parlamentaarisen järjestelmän uudet perusnormit - jäivätkin EU-kansanäänestyksen julkisuudessa ja keskustelussa sivummalle kansallisten elinkeinoetujen ja taloudellisen integraation vastakkaisuudessa. Kansalaisten keskeiset ryhmät eivät tiedostaneet, miten myönteinen EU-kanta johtaa myös perustuslain ja parlamentaaristen ratkaisutapojen muutokseen. Hallitus katsoi kansanäänestyksen enemmistön myönteisen kannan legitiimiksi ehdoksi liittymiselle eikä suoraan sitonut kansanedustajien äänestysvapautta sopimuksen voimaansaattamisen poikkeuslaista ratkaistaessa, missä vaadittiin 2/3:n enemmistö päätöksen laillisuuden taakse. (Jyränki 2006, 129-135.) Kansanäänestys tuki EUratkaisua (71\% kansalaisista äänesti - 57\% heistä myönteisesti); kansanedustajien määräenemmistö (152 edustajaa) siunasi ratkaisun, keskustan ja vasemmistoliiton edustajat jakaantuivat selvästi kannaotoissaan.

Euroopan unioniin, talous- ja rahaliittoon (EMU) eli eurovaluuttaan liittyminen merkitsi kansallisten finanssipoliittisten keinojen luovuttamista Brysseliin ja Strassbourgiin. Tullipolitiikan integrointi, verotusvalta, sen yhtenäistäminen varsinkin välillisten verojen osalta, EU:n saamat rahasuoritukset ja kansallisten instituutioiden supistunut vapaus suunnitella julkisen talouden menoja ja tuloja rajautuivat ja vaativat suomalaisessa kurinalaisuudessa ja poliitisessa realismissa suuntautumista eurodemokratiaan ja hallintoon - vaikuttamaan ja lobbaamaan sen ytimiin, hallintoon ja instituutioihin. Myös laajemmin eduskunnan toimi- ja lainsäädäntövalta supistuivat. EMU ja euro merkitsivät Suomen pankin toiminnan siirtymistä Euroopan keskuspankkijärjestelmän osaksi (EKP) ja valuuttakurssipolitiikan kansalliset repertuaarit jäivät sivuun - samalla monet painostuskeinot julkiseen valuuttalinjaan heikentyivät, mutta kursseista saatiin näin vakaita. Tätä onkin pidetty rahaliiton keskeisenä ja siunaksellisena tekijänä, jopa viime vuosien euromaiden velka- ja talousvakauden suurten ongelmien keskellä. Samalla julkistalouksien ja hintojen vakautta pyrittiin ohjaamaan (viime vuosina surullisen kuuluisat budjettialijäämien katot) ja näin perinteiset talouspolicyn keinot har- 
venivat kansallisesti ja hintavakausoperaatioissa jouduttiin pohtimaan verojen harmonisoinnin keinoja. Kuten viime vuosina olemme saaneet tuta, vientikaupan kilpailun liberaali kärjistyminen ja verojen harmonisoinnin linja voivat molemmat olla ongelmallisia julkisen talouden rahoitusperustalle. (Jyränki 2006, 136-; vertaa erityisesti talouden ja politiikan asiantuntijoiden taustoitukset, Hulkko 2012.)

Parlamentaaristen toimijoiden täysvaltaisuus kapeni sekä eu-tavoitteiden mukaisten säädösten aktiivisten ja niistä pidättäytymiseen ohjaavien vaatimusten ja normien myötä. Jyrängin mukaan $(2006,136)$ voi puhua kolmesta tavasta tulla mukaan yhteisön lainsäädännön piiriin: valtion sisäisten normien koordinaatio (sosiaaliturvan toiminnan yhteensovittaminen); normistojen lähentäminen EY-direktiiveillä; välittömästi sitovat normit eli lähinnä EU-asetukset. Vaikka parlamentin valta unionissa on voimistunut sopimustenkin tasolla Euroopan neuvoston rooli hallitusten välisenä lainsäätäjänä on keskeinen. Tuomioistuin on autonominen ja pystyy puolustamaan unioninormien laillisuutta myös tilanteessa, jolloin kotivaltion lainsäädäntöä ei ole vielä muokattu integraation määräämien asetusten ja direktiivien mukaiseksi. Oikeuslaitoksen valta ja esimerkiksi ihmisoikeuslainsäädäntö ovat johtaneet siihen, että oikeustulkinnan merkitys korostuu kansallisen lainsäädännön kustannuksella. (Emt., 136-39.) Esimerkiksi Eurooppatason oikeusvalitukset ja julkinen politikointi lasten, naisten tasa-arvon tai vähemmistöjen kansainvälisten oikeuksien ja sopimusten universaalisuudella, kansallisella sitovuudella ja velvoitustulkinnoilla (ennakkopäätöksillä) on noussut merkitykselliseksi - esimerkiksi "uusien demokratioiden" ja jopa Suomen poliittisessa kulttuurissa (vrt. Jauholan essee tässä kirjassa). Lainsäädännön laatimis- ja järjestyssuhteiden sekä panopisteiden muuttuessa onkin vaikea yksikäsitteisesti laskea, kuinka suuri osa 2000-luvun lainsäädäntöasioista on siirtynyt unionille. Useat puhuvat kahdesta kolmasosasta normeista, joissa yhteisten säädösten normivaikutus todetaan tai se on tunnistettavissa. 


\section{Uusi vuoden 2000 parlamentti pyörii kansallisen ja eurooppalaisen vastuun piirissä}

Myös julkisuus ja media sekä kansalaisyhteiskunnan järjestymistavat kokivat liberaalit tuulet (esim. Herkman ja Väyrynen esseissään tässä kirjassa), ja aiemman ulkopoliittisen eliitin kylmän sodan tasapainoilun retoriikka korvautui pian uuden yhteisön viestikapuloilla ja arkisemmalla unionin ulko- ja sisäpolitiikan diskurssilla. Uudet ajatukset unionin kyvystä taata markkinakilpailukyky ja länsidemokratioiden normaaliparlamentarismin esimerkki ja käytännöt vahvistivat tietä parlamentarismia puolustaviin perustuslaillisiin ratkaisuihin. Eduskunnan asialista muokkaantui uusin ehdoin paljon juuri Brysselin hengessä ja parlamentarismin kansallisesti ja kansainvälisesti "pyörivä näyttämö" (Nousiainen 2006, 327-331) kiihdytti kaikkien vaalipuolueiden hallitusintoa ja -peliä - Suomi siirtyikin monessa suhteessa entistä reilumpaan normaaliparlamentarismin kulttuuriin. EU-ratkaisut liikuttivat vallanjakoa ja varsinkin vuoden 2000 perustuslakimuutosten myötä - joka kirjasi1990-luvun "uuden sukupolven" osamuutoksia ja käytäntöjä, mutta sisälsi uusia selkeitä normeja: maa on siirtynyt stabiilien neljän vuoden hallitusratkaisuihin ja niiden valinta-aloite on siirtynyt eduskunnalle. Jäätteenmäen hallituksen pikainen ero (2003) pääministerin käyttämien tietolähteistä nostetun poliittisen epäluottamuksen vuoksi parlamentaaristen kumppanien keskuudessa on ainoa poikkeus tästä sitten kekkoslaisen 1970-luvun.

Presidentiksi valittu Tarja Halonen joutuikin vuonna 2000 istumaan vallan perustuslain kokonaisuudistuksen keventämään vallan tuoliin ja hän puolustikin määrätietoisesti reviiriään. Konfliktit näyttäytyivät EU-lautasten lisäksi jopa sisäpolitiikassa: Suomen pankin johtajanimityksissä presidentti poikkesi pariin otteeseen eduskunnan pankkivaltuuston ja hallituksen henkilö(määrä)esityksistä. Eduskunnan parlamentaarista asemaa parannettiin - ei voi enää puhua Jyrängin hengessä puolimonarkkisesta vallanjaosta. Itse asiassa eduskunnan perustuslakivaliokunta (puheenjohtajana Ville Itälä) oli jo reformiesityksissään monissa kohdin irrottautunut istuvan hallituksen ohjauksesta. Nyt kirjoitettiin selkeästi esiin valtioneuvoston vastuuperiaate eduskunnalle. Hallituksen ja pääministerin valinta siirtyi ratkaisevalla periaatteellisella tavalla eduskunnalle. Eduskunta valitsee sekä pääministerin että hänen esittämänsä 
ministerilistan. Perustuslaissa todetaankin, "Ennen pääministerin valintaa eduskunnan eri ryhmät käyvät neuvotteluja valtioneuvoston kokoonpanosta ja ohjelmasta. [--] Näiden neuvottelujen perusteella sekä kuultuaan eduskunnan puhemiestä ja ryhmiä presidentti antaa eduskunnalle tiedon pääministeriehdokkaasta." Viime vuosien kirjoittamattomissa pelisäännöissä suurimman eduskuntaryhmän valitsema puoluejohtajahenkilö (SDP:n Lipponen, keskustan Vanhanen ja kokoomuksen Katainen) keskustelee muiden ryhmien kanssa, keskustelujen jälkeen kutsuu ryhmät koolle ja tuen saatuaan jatkaa hallituksen muodostamisprosessia. Poikkeustilannetta varten normeissa on kuitenkin säilytetty presidentinkierros ja hänen viimekätinen ehdotuksenteko-oikeutensa pääministeristä. (Jyränki 2006, 159.)

Ulkopolitiikassa presidentti ja hallitus toimivat yhteistyössä, ja heillä on yleensä intensiivinen neuvotteluyhteys. Parlamentarismin ja presidentinvallan potentiaalinen ristiriitatilanne jäi vielä vuoden 2000 perustuslakiuudistuksessa epämääräisen parlamentarismimuotoilun varaan, vaikka jälkimmäisen valtuuksia isolla kädellä supistettiin ja hänen toimensa on nyt selkeästi sidottu ministeriömyötävaikutukseen. Parlamentaarinen ministeristö muotoilee lainsäädäntöesitykset, joihin presidentin on "viime kädessä" mukauduttuva. Vuoden 2000 perustuslakia on edelleen muokattu "laustaskiistan" ratkettua pääministerin roolin suunnassa ja ministerimyötävaikutuksen vahvistuessa; ykkösministeri edustaa maata sen "ylimpänä johtona" Euroopan unionin toiminnassa ja valtioneuvosto hallitsee eurooppaintegraation kenttää. Silti presidentti säilyttää asemansa relevanttina valtiollisena instituutiona - "Suomen ulkopolitiikkaa johtaa tasavallan presidentti yhteistoiminnassa valtioneuvoston kanssa". Toinen selkiytys parlamentaariseen suuntaan oli se, että eduskunnan kanta ratkaisee eripuraisuuden presidentin ja valtioneuvoston välillä.(Perustuslainen muutokset 28.2.2012; Oikeusministeriö.) Suoran kansanvaalin (äänestäjien odotusten) legitimoima ja karismaattisen suosion tukema presidentti voi vahvoilla argumenteilla tai yleisödemokratian julkisuudessa vaikuttaa monenkirjaviin asioihin, monilla tasoilla² .

Koiviston jälkeen presidentit eivät ole juuri sekaantuneet parlamentaariselta ja kansalliselta määräysvaltaan kaventuneiden talous- ja finanssipolitiikan ratkaisuihin joitain tasa-arvo-, syrjääntymis- ja työttömyyskontribuutioita sekä globaalipolitiikan aloitteita lukuunottamatta. 
Eurooppalaistuminen ja globaali liberaali kilpailu ovat supistaneet myös tulopolitiikan keinoja ja alaa, silti niin sanotut työmarkkinoiden raamisopimukset ja korporaatioiden sananvalta perusturvauudistuksissa ovat osoittaneet, että hallituksella ja työmarkkinaosapuolilla on edelleen parlamentarismin periaatteille vierasta valtapotentiaalia. Joissain suhteissa tavallaan sekä presidentti että eduskunta jäävät sivummalle reaalivallan käytössä. Eduskunnalle annettiin ainakin "puolitehoiset" (Nousiainen 2006, 330-32) mahdollisuudet vaikuttaa maan edustajien linjoihin europäätöksenteossa, valmistelussa ja hallitusten välisissä yhteisissä ratkaisuissa. Myös presidentin päättäessä valtion sitoutumisesta uusiin kansainväisiin (laki)velvoitteisiin eduskunnan on tehtävä asiasta päätös. Europarlamentaarikot ovat edellä mainituista monista sisäpoliittisista sidoksistaan huolimatta periaatteessa itsenäisiä päättäjiä, joilla on myös omat eurooppalaiset ryhmänsä. Käytännössä meppivalinnatkin tapahtuvat usein kansallisen vaaliagendan puitteissa - osa ehdokkaista puhuu edelleen "siltarumpupolitiikan" termein, osan kyetessä eurooppalaisimpiin ohjelmiin. Eurooppalainen identiteetti ja toimivuus eivät ole meillä erityisen vahvoilla. (Hentilä 2008, Martikainen\&Pekonen 1999.) Perustuslain 96.- 97. \$:ien mukaan eduskunta Suuren valiokunnan (niin sanottu EU-valiokunta) ja muiden valiokuntien kautta osallistuu kansalliseen valmisteluun. Se antaa ohjeellisen kannan tai keskustelee esityksistään yleisistunnossa. Euroopan unionin poliittinen valmisteluprosessi ei enää jää vain ulko- ja sisäpolitiikan väliin vaan se usein muodostaa omalajisen valmisteluprosessinsa ja taitavan valtioneuvoston koordinoiman hallinnon valmistelu- ja eurokontaktit korostuvat.

Monien arvioiden mukaan parlamentaarinen käsittelyvalta ja vastuu toteutuvat - vaikkakin "suhteellisen rajallisesti" (vrt. esim. Vogtin essee tässä kirjassa) - näissä muodoissa. Jopa viime vuosien hankalissa eurotalouden ratkaisuissa Suomea edustanut pääministeri on ollut jo neuvottelujen aikana yhteydessä suuren valiokunnan puheenjohtajaan, suuren valiokunnan aikatauluilla ja käsittelyjärjestyksellä on pyritty takaamaan hallituksen ja eduskunnan välinen tiedonkulku, (neuvottelu)valtuudet ja viime kädessä parlamentaarinen legitimiteetti. Ministerit ovat aktiivisia valiokunta-aktiviteeteissa ja merkille pantavissa määrin kannanotot myös muuttuvat: teknisten muutosten lisäksi kasvavassa määrin myös sisällöt muokkaantuvat. Myös ulkoasianvaliokunnan rooli on nyt aktiivisempi 
kuin esimerkiksi 1960-luvun "kasvojen kohotusvuosina". Sillä on oikeus saada tarvitsemansa tiedot ulkosuhderatkaisuista ja sopimusvalmisteluista. Hallitus on myös velvollinen antamaan selontekoja merkittäväksi nousevista ulkopoliittisista muutoksista. (Nousiainen 2006, 321- ; Pekonen 2011.)

Eduskunnan uudistamisessa on kyetty pitämään yllä (puoli)tehokkaita vastuunalaisuuden ja läpinäkyviä parlamentaaristen puhekulttuurien ja yleistuntojen muotoja ja kohennettu välikymys- ja hallitusten ja pääministereiden tenttaamisen ja debatin sekä valiokuntakulttuurien ehtoja (Nousiainen 2006, 290-94; vrt. Palonen 2012, 92-94). Hallitus joutuu (valmistelu)toimissaankin monenlaisten eduskuntaryhmien ja -fraktioiden aloitteiden kohteeksi, (valiokuntien) asiantuntemuksella on merkitystä politiikan pelissä. Samaan aikaan parlamentin (yleisödemokratiassa menestyvien) karismaattisten ja luottamusta herättävien puurtajien ja argumentoijien on ollut mahdollista vaikuttaa myös parlamenttiasioiden käsittelyyn ja sisältöön (Pekonen 2011). Puoluevalta tai tiukka hallitusoppositio -jako eivät täysin madalla eduskuntaryhmien tai valiokuntaaktiivien alotteellisuutta ja ratkaisuja muokkaavaa deliberaatiota. Pekosenkin mukaan eduskunnan "diskursiivista edustamista" voidaankin nykyoloissa hyvin laajentaa, herkistyä koko kansakunnan mielialoille ja kipupisteille. Voitaisiin lisätä "...valiokuntien toimintamahdollisuuksia niiden aloiteoikeutta vahvistamalla sekä lisäämällä eduskunnan pääministerin ja muiden ministereiden alustamia poliittisia ajankohtaiskeskusteluja yleis- ja eurooppapoliittisista kysymyksistä sekä ajankohtaisista tärkeistä lakihankkeista” (Pekonen 2011, 223-24). Silti pääministerivaalien korostuminen ja enemmistöparlamentarismin vahvistuneet periaatteet ovat supistaneet deliberatiivisen parlamenttikulttuurin puolia. Euroopan integraation ja globalisaation voimavirrat saavat vahvat parlamentaarikot yhtä lailla hallituksessa kuin oppositiossakin myös valveille, eduskunnan on koko ajan myös kamppailtava asemastaan. (Seppo Kääriäinen ja Ilkka Kanerva Pekosen 2011, 86-87, tutkimusaineiston dokumentoiduissa kannanotoissa.)

Euroopan unionin talous- ja finanssipolitiikan sekä yhteisen turvallisuuspolitiikan parlamentaarista valmisteluproseduuria on arvostettu, siihen on käyty tutustumassa muualta Euroopasta. Mikään ei kuitenkaan muuta perustavaa valtainstanssien muutosta kansallisen parlamentaris- 
min kannalta: huolimatta Kekkosen ja Koiviston kausien jälkeisestä tähdellisestä ja läpinäkyvästä muutoksesta (enemmistö)parlamentarismin suuntaan, päätöksentekovaltaa on merkittävästi siirretty ja siirtynyt eduskunnan piiristä kansainvälisen politiikan (markkinaehtoisen) harkinnan ja instanssien suuntaan (erit. Väyrysen ja Kettusen artikkelit). Toisella tasolla Euroopan integraatio sopimuksineen, säädöksineen ja oikeudellisin päätöksin muokkaantuu koko ajan. Varsinkin viime vuosien finanssi- ja velkakriisi on muokannut liiton toimintaa markkinareaktiiviseen ja hallitsemattomaan suuntaan, mille unionin omat instituutiot ja talouspolitiikan liittorakenteet ja keinot eivät anna tukea - eurodemokratiasta ja vakiintuneista Euroopan vakausmekanismimenettelyistä (EVM) puhumattakaan.

Suomalaisilla europolitiikan eliitin jäsenillä on huomattavia vaikeuksia vakuuttaa kotimaan parlamentaarisia päättäjiä ja suurta valiokuntaa kriisiratkaisujen taakse, koska huippukokousten ratkaisut jäävät kovapintaisen suurten kansallisvaltioiden kovistelun ja monimielisten kompromissien varaan. Markkinat viime kädessä ratkaisevat poliittisten kompromissien arvon. Epävarmalla jahkaavalla reagointipolitiikalla ja (vahvojen) kansallisvaltioiden kompromissiliittona EU ei voi jatkaa pitkään, selviytyäkseen sen on avattava jämäkämpi demokraattinen tie kohti talous- ja rahaliittoa, jonka komissio olisi myös markkinoiden suunnasssa toimiva liiton hallitus ja se asettuisi vaalien ja eurooppalaisen kansalaisyhteiskunnan luottamuksen ja yhteisvastuun varaan (esim. Tiilikainen 2012). Tällainen "enempi Eurooppaa"-tie vaatisi myös kosmopoliittisempaa euroopalaista poliittista identiteettia ja tilaa (Beck\&Grande 2007), missä kansalliset edut tai tiukat parlamentaristiset rakenteet ja perinne eivät enää ratkaise politiikan valintoja. Kuten myös Kettunen, Väyrynen, Herkman, Jauhola ja Lindholm korostavat eri tavoin tämän kirjan esseissään, tulee nousta kilpailukyky-, hyvinvointi- ja muukalaispelkoisen nationalismin yläpuolelle ja luotava eurooppalaisen demokratian talouspolitiikan ja globaalien riskien sääntelyvälineitä ja eurooppalaista systeemistä julkisuutta. Näin uudenlaiset kansainvälisten markkinavoimien arvoketjut ja globaalit riskit voidaan kohdata eurooppalaisella ja globaalilla tasolla ja luoda uudelleen politiikan vaihtoehtoja markkinoille, korporaatioille ja globalisaatioille - niille luonnonvoimille, jotka ovat jäädyttäneet 
myös kansallisen parlamentarismin (hallituksen eduskuntaryhmien ja sen opposition) luovuutta meillä ja muualla (esim. Harle 2000, 145-48).

\section{Lähteet}

Alapuro, Risto. 1988. State and Revolution in Finland. Berkeley: University of California Press.

Alapuro, Risto. 1997. Suomen älymystö Venäjän varjossa. Helsinki: Tammi.

Alapuro, Risto. 1999. Kertomus suomalaisista idän ja lännen välissä. Teoksessa Markku Löytönen ja Laura Kolbe (toim.), Suomi - maa, kansa, kulttuurit. Helsinki: SKS, 98-112.

Alapuro, Risto, Liikanen, Ilkka, Smeds, Kerstin ja Stenius, Henrik (toim.). 1987. Kansa liikkeessä. Helsinki: Kirjayhtymä.

Alapuro, Risto ja Stenius, Henrik. 1987. Kansanliikkeet loivat kansakunnan. Teoksessa Risto Alapuro ym. (toim.), Kansa liikkeessä. Helsinki: Kirjayhtymä, 8-49.

Alasuutari, Pertti. 1996. Toinen tasavalta. Suomi 1946-1994. Tampere: Vastapaino.

Anckar, Dag. 2000. Jähyväiset semipresidentialismille. Politiikka 42:1, s. 9-14.

Anttila, Anu-Hanna, Kauranen, Ralf, Löytty, Olli, Pollari, Mikko, Rantanen, Pekka ja Ruuska, Petri. 2009. Kuriton kansa. Poliittinen mielikuvitus vuoden 1905 suurlakon ajan Suomessa. Tampere: Vastapaino.

Ankersmit, Frank R. 2002. Political representation. Stanford: Stanford University Press.

Aunesluoma, Juhani. 2011. Vapaakaupan tiellä. Suomen kauppa-ja integraatiopolitiikka maailmansodista EU-aikaan. Helsinki: SKS.

Beck, Ulrich, \& Edgar, Grande. 2007. Cosmopolitan Europe. Cambridge: Polity Press.

Bergholm, Tapio. 2007. Sopimusyhteiskunnan synty II. Hajaannuksesta tulopolitiikkaan. SAK 1956-1969. Otava.

Bryce, James. 1933. Nykyajan kansanvaltoja I - II. (Englannista kääntänyt Jussi Teljo). Porvoo : WSOY. 
Bäckman, Johan (toim.). 2001. Entäs kun tulee se yhdestoista? Suomettumisen uusi historia. Juva: WSOY.

Chambers, Simone. 2009. Rhetoric and the Public Sphere: Has deliberative Democracy Abandoned Mass Democracy? Political Theory 2009:37, s. 323-350.

Duverger Maurice. 1965. Poliittisetjärjestelmät. Porvoo: WSOY.

Eduskunta-aineistoja, mm. http://yle.fi/satavuottaeduskuntavaaleja/index. php?54 (15.5.2012)

Eduskunnan historia (kuvia, tekstiä, videoita): http://www.eduskunta.fi/histo$\mathrm{ria} /$ fin/index_6.htm (15.5.2012)

Haavikko, Paavo. 1992a. Suomen tauti: Sen diagnoosi ja hoito. Art House, 1992.

Haavikko, Paavo. 1992b. Jatkoaika presidentille: Kaaoksen arvoton järjestelmä. Art House, 1992

Harle, Vilho.2000.Suomalaisen parlamentarismin tila ja tulevaisuus: semiparlamentarismista kvasi-parlamentarismiin? (Pääkirjoitus) - Politiikka 4/2000, s. 145-48.

Heiskanen, Ilkka (1977) Julkinen, kollektiivinen ja markkinaperusteinen. Suomalaisen yhteiskunnan hallintajärjestelmien ja julkisen päätöksenteon ja hallinnon kehitys ja kehittäminen 1960-ja 1970-luvuilla. Deta 31. 1977, Helsinki.

Heiskanen, Ilkka (1982) Yhteiskuntatieteet, käytännön ybteiskuntateoria ja maamme älyllinen ilmasto. Helsingin yliopiston yleisen valtio-opin laitoksen tutkimuksia A 59. 1982, Helsinki.

Heiskanen, Ilkka. 1983. ”DETA-Projektin kokemuksista." Plenum-esitelmä Valtiotieteellisen yhdistyksen politiikan tutkimuksen päivillä. Kevät 1983.

Hentilä, Seppo. 2008. Euroopan unionin luottamuspula - suomalaisen kansanvallan haaste. Kirjassa "Suomen kansanvallan haasteet". Suomen eduskunta 100 vuotta 12/2008. Helsinki: Edita.

Hulkko, Kustaa. 2012. Markka vai euro? Suomen kuvalehden rahakomitean enemmistö arvioi, ettei Suomen pidä erota eurosta ensimmäisenä. Teoriassa markka sopisi byvin. - Suomen kuvalehti 27.7.2012. (30/2012).

Jakobsson, Max. 1992. Vallanvaibto: havaintoja ja muistiinpanoja vuosilta 1974-92. Helsinki: Otava.

Jansson, Jan-Magnus. 1952. Frihet och jämlikhet: en studie över den politiska demokratin. Helsingfors: Söderström. 
Jansson, Jan-Magnus. 1993. Hajaannuksesta yhteistoimintaan. Suomalaisen parlamentarismin vaibeita. Helsinki: Gaudeamus.

Jyränki, Antero.1968.Valtiosäännön säätäjän tarkoitukset ja noudatettu käytäntö. - Sosiologia 1968, 20-28.

Jyränki, Antero.1978. Presidentti: tutkimus valtionpäämiehen asemasta Suomessa 1917-76. Helsinki: Suomalaisen lakimiesyhdistyksen julkaisuja A-sarja; 123.

Jyränki, Antero - Nousiainen. Jaakko. 2006. Eduskunnan muuttuva asema. Suomen eduskunta 100 vuotta: 2 osa. Edita Prima Oy: Helsinki.

Jyränki, Antero.2009a. Punainen hattu. 1950-ja 1960-luku mielessäni. Helsinki: Edita.

Jyränki, Antero.2009b. Presidentti-instituutio meidän aikamme Euroopassa (Oikeusministeriön toimeksiannosta laadittu selvitys) http://www.om.fi/ Satellite blobtable $=$ MungoBlobs\&blobcol=urldata\&SSURIapptype $=$ BlobServer\&SSURIcontainer $=$ Default\&SSURIsession $=$ false\&blobke $\mathrm{y}=\mathrm{id} \&$ blobheadervalue $1=$ inline; $\% 20$ filename $=\mathrm{Jyr} \% \mathrm{C} 3 \% \mathrm{~A} 4 \mathrm{ngin} \% 20$ selvitys.pdf\&SSURIsscontext $=$ Satellite\%20Server\&blobw here $=1243790106552 \&$ blobheadername $1=$ Content - Dis position\&ssbinary $=$ true\&blobheader $=$ application $/$ pdf (15.5.2012.)

Kastari, Paavo.1940.Eduskunnan hajoitus Suomen oikeuden mukaan. Suomalainen lakimiesyhdistys. Helsinki.

Ketola, Eino. 1987. Kansalliseen kansanvaltaan: Suomen itsenäisyys, sosialidemokraatit ja Venäjän vallankumous 1917. Helsinki: Tammi.

Kiander, Jaakko.(Toim.) 2000. 1990-luvun talouskriisi. Helsinki : Valtion taloudellinen tutkimuskeskus : Suomen akatemia, 2000.

Kiander, Jaakko - Vartia, Pentti.1998. Suuri lama. Suomen 1990-luvun kriisi ja talouspoliittinen keskustelu. Elinkeinoielämän tutkimuslaitos (ETLA), julkaisuja B 143 (1998). (http://www.etla.fi/files/756_b143fin.pdf / 15.5.2012)

Kirby, David. 2006. A Concise History of Finland. Cambridge: Cambridge University Press.

Koivisto, Mauno.1988. Politiikkaa \& politikointia 1979-81. Helsinki: Kirjayhtymä.

Koivisto, Mauno. 1995. Kaksi kautta. 2. Historian tekijät. Helsinki: Kirjayhtymä.

Korhonen, Pekka. 1983. Hans Morgenthau : intellektuaalinen historia. - Jyväskylän yliopisto. Valtio-opin laitos. Julkaisuja ; no 46. 
Koselleck, Reinhart. 2006. Begriffseschichten. Studien zur Semantik und Pragmatik der politischen und sozialen Sprache. Frankfurt am Main: Sührkamp Verlag.

Liikanen, Ilkka (2003) Kansa. Artikkeli kirjassa Hyvärinen, M. - Kurunmäki, J. - Palonen, K. - Pulkkinen, T. - Stenius, H. (toim.) Käsitteet liikkeessä. Suomalaisen poliittisen kulttuurin käsitehistoria. Tampere: Vastapaino. 257308.

Lefort, Claude.1988. Democracy and Political Theory. Cambridge: Polity Press.

Martikainen, Tuomo \& Pekonen, Kyösti.1999. Eurovaalit Suomessa 1996: vaalihumusta päätöksenteon arkeen. Yleisen valtio-opin laitos. Helsingin yliopisto.

Mattila. Mikko - Raunio, Tapio (2002): Vaalimenestys ja hallituksen muodostaminen Länsi-Euroopassa 1945-1999. Politiikka 4/2002. 299-314.

Nousiainen, Jaakko.1977. Näkökohtia eduskunnan asemasta ja päätöksentekojärjestelmästä. Politiikka 2/1977. 113-131.

Nousiainen, Jaakko. 1983. Suomen poliittinen kulttuuri. Politiikka: 25: 1, 6-15.

Nousiainen, Jaakko. 1985. Suomen presidentit valtiollisina jobtajina K. J. Ståhlbergista Mauno Koivistoon. Porvoo: Werner Söderström.

Nousiainen, Jaakko. 1998. Suomen poliittinen järjestelmä. Helsinki: WSOY.

Nousiainen, Jaakko. 2000a. Suomalaisen parlamentarismin kolmas kehitysvaihe: konsensuaalinen enemmistöhallinta, vireytyvä eduskunta. Politiikka 42: 2, 83-96.

Nousiainen, Jaakko.2000b. Valtiosä̈̈nnön yhteiskunnallinen ja historiallinen tausta. Oikeusministeriön verkkosivut. http://www.om.fi/3318.htm (15.5.2012)

Nousiainen, Jaakko. 2006. Suomalainen parlamentarismi. Teoksessa Antero Jyränki - Jaakko Nousiainen: Eduskunnan muuttuva asema. Helsinki:Edita.

Nousiainen, Jaakko. 2008. Kolmenlaista parlamentarismia. Teoksessa Suomen ja kansanvallan haasteet. - Suomen eduskunta 100 vuotta. Helsinki: Edita Prima Oy.

Paakkunainen, Kari. 1991. Yhteisten asioiden hoidosta likaiseen peliin: empiirinen tulkinta nuorten politiikkakäsityksistä. Helsingin yliopiston yleisen valtio-opin laitoksen julkaisematon lisensiaattityö (2/2). 1991. Valtiotieteellisen tiedekunnan kirjasto. 
Paakkunainen, Kari.1985. Demokratia, tiede, kansanvalistus. Valtiotieteellisen yhdistyksen intellektuaalihistoriaa 1935 - 1985. Valtiotieteellinen yhdistys. Jyväskylä: Gummerus.

Paakkunainen, Kari. (Toim.)1986.Valtio-oppi tieteenä: Puheenvuoroja suomalaisen valtio-opin muotoutumisesta. Helsinki: Helsingin yliopisto, yleisen valtio-opin laitos: Julkaisuja 19/1986.

Paakkunainen, Kari. (Toim.) 2007. Sukupolvipolitiikka. Nuoret ja eduskuntavaalit 2007. Nuorisotutkimusverkosto/Nuorisotutkimusseura, julkaisuja 72. Helsinki: Yliopistopaino.

Paakkunainen, Kari. 2012. "Keppi-Saarelan" tie. Kirjassa Mikko Majander ja Kimmo Rentola (toim.). Ei ihan teorian mukaan. Kollegakirja Tauno Saarelalle 28. helmikuuta 2012. Työväen historian ja perinteen tutkimuksen seura. Helsinki: Unigrafia, s. 37-60.

Paasikivi, Juho Kusti. 1986. J. K. Paasikiven päiväkirjat 1944-1956. 1, 28.6.1944-24.4.1949 / (toim. Yrjö Blomstedt ja Matti Klinge). Porvoo: WSOY.

Palonen, Kari.1980. Politiikan ja valtion käsitteiden kriiseistä suomalaisen valtio-opin historiassa: tieteenalan perusteiden ja itseymmärryksen muuntumisen tulkintaa erityisesti subteessa Allgemeine Staatslehre-traditioon. Jyväskylän yliopisto. Valtio-opin laitos. Julkaisuja ; no 39.

Palonen, Kari.2012. Parlamentarismi retorisena politiikkana. Osuuskunta Vastapaino. Jyväskylä: Bookwell Oy.

Pekonen, Kyösti. 2011. Puhe eduskunnassa. Osuuskunta Vastapaino. Jyväskylä: Bookwell Oy.

Perustuslainen muutokset (tulevat voimaan maaliskuun alussa). 28.2.2012. Oikeusministeriön tiedote. http://www.om.fi/Etusivu/Ajankohtaista/Uutiset/1324022393587 (20.5.2012)

Pohjantammi, Ismo (2003) Edustus. Artikkeli kirjassa Hyvärinen, M. - Kurunmäki, J. - Palonen, K. - Pulkkinen, T. - Stenius, H. (toim.) Käsitteet liikkeessä. Suomalaisen poliittisen kulttuurin käsitehistoria. Tampere: Vastapaino, s. 363-412.

Rinta-Tassi, Osmo. 1986. Kansanvaltuuskunta punaisen Suomen hallituksena. Helsinki: Opetusministeriö.

Siltala, Juha.1985. Lapuanliike ja kyyditykset 1930. Helsinki: Otava.

Skyttä, Kyösti. 1979. Ison hoitajan maa vai inhimillisen kasvun ybteiskunta. Porvoo: WSOY. 
Soikkanen, Timo (1983) Kansallinen eheytyminen - myytti vai todellisuus. Ulko-ja sisäpoolitiikan vuorovaikutus ja linjat Suomessa vuosina 1933-39. Turun yliopiston julkaisuja, Sarja C. Scripta lingua Fennica edita; osa 37. Turku: Turun yliopisto.

Stenius, Henrik. 2003. Kansalainen. Teoksessa Matti Hyvärinen, Jussi Kurunmäki, Kari Palonen, Tuija Pulkkinen ja Henrik Stenius (toim.), Käsitteet liikkeessä. Suomen poliittisen kulttuurin käsitehistoria. Tampere: Vastapaino, 309-362.

Sundberg, Jan. 1996. Partier och partisystem i Finland. Helsingfors: Schildts.

Suominen, Ilkka.1996. Vierailuluento Helsingin yliopiston Avoimen yliopiston yleisen valtio-opin vierailulentosarjassa Helsingin Porthaniassa syksyllä 1996. (Kirjoittaja Kari Paakkunaisen muistiinpanot.)

Suomen työväenpuolueen ohjelma 1899. Http://www.fsd.uta.fi/pohtiva/ ohjelma?tunniste $=$ sdpohjelma1899 (31.7.2012)

Teljo, Jussi.1937. Kansaneduskunta ja valtion tulo- ja menoarvio. Jyväskylä: Gummerus.

Tiihonen, Seppo. 1990. Hallitusvalta: Valtioneuvosto itsenäisen Suomen toimeenpanovallan käyttäjänä. Hallintohistoriallisia tutkimuksia. Helsinki: VAPK-Kustannus.

Tiilikainen, Teija. 2012. Demokratia asetettava etusijalle EU:ssa. Vieraskynä -artikkeli Helsingin Sanomissa 31.7.2012, s. A2.

Valtiosä̈̈ntökomitean välimietintö. 1974. Komiteanmietintö 1974: 27.

Vares, Vesa - Mikko Uola - Mikko Majander.2006. Kansanvalta koetuksella. Suomen eduskunta 100 vuotta. Helsinki: Edita Proma Oy.

Von Sydow, Björn. 1997. Parlamentarismen i Sverige. Utveckling och utforming till 1945. Södertälje.

Wiberg, Matti (2003) Uuden perustuslain toimivuus. Politiikka 3/2003. 236244. 


\section{Viitteet}

1 Akatemiaprofessori Palonen $(2012,11-12)$ korostaakin seitsemän retorisen topoksen - tyypillisen paikan - merkitystä, kun haetaan anti-parlamentaarisia perusteita marginalisoida parlamentaarista politiikkaa. Samalla nämä topokset osuvasti kuvaavat puhekunnan kulttuuria. Ne ovat edustuksen (erotettuna kansalaistahdosta), kiistelyn (vs. yksimielisyys), puheen (vs. työ), muutoksen (vs. pysyvyys), ajanpeluun (vs. kiire), taktiikan (vs. asia) ja menettelytavan (vs. sisältö) topokset. $\mathrm{Ne}$ kaikki tarjoavat yksinkertaisia ratkaisuja - halutaan korvata likainen peli arkiterveellä ja tehokkaalla asioiden hoitamisen ja työstämisen tavalla.

2 Vrt. Vogtin artikkelin huomiot Martti Ahtisaaren ja Tarja Halosen aktiviteeteista; tätä myös presidentti Niinistön toiminta näyttäisi todentavan: vaalikampanjapuheet 2012, nuorten syrjääntymisen vastaisen ryhmän muodostaminen heti toimikauden alussa ja kannanotto Espanjan pankkitukipaketin ehtojen yksikäsitteisen ja seikkaperäisen selvityksen puolesta tilanteessa, kun hänen mukaan yleensä perusteellisesti asioita käsittelevä Suomen eduskunta kokousti kiistanalaisen informaation varassa Euroopan unionin vakausmekanismin mukaisesta Espanjan pankkien tukipaketista heinäkuussa 2012. (http://yle.fi/uutiset/niinisto_toivoo_selvitysta_espanjan_tukipaketin_ehdoista/6226865) (5.8.2012) 



\section{Kirjoittajat}

Pertti Ahonen on yleisen valtio-opin, erityisesti hallinnon tutkimuksen professori politiikan ja talouden tutkimuksen laitoksella Helsingin yliopistossa. Vuodet 1990-2010 hän oli julkishallinnon, erityisesti finanssihallinnon professori Tampereen yliopistossa. Hänen tuoreimmat artikkelinsa koskevat historiallisia organisaatioteorioita, hallinnontutkimuksen institutionalisoitumista Suomessa sekä maamme julkisen hallinnon ja julkisen sektorin institutionalisoitumista.

Juha Herkman on viestinnän dosentti sekä Helsingin että Tampereen yliopistoissa. Hän toimii viestinnän yliopistonlehtorina sosiaalitieteiden laitoksella Helsingin yliopistossa ja on viime vuosina julkaissut runsaasti tutkimuksia politiikan julkisuudesta, median poliittisesta taloudesta ja populaarikulttuurin ja median suhteesta.

Marjaana Jauhola on kehitysmaatutkimuksen tutkijatohtori politiikan ja talouden tutkimuksen laitoksella Helsingin yliopistossa. Hänen väitöskirjatutkimuksensa käsitteli sukupuolinäkökulman valtavirtaistamisen ja tasa-arvopolitiikan politiikkoja tsunamin ja konfliktinjälkeisessä Indonesiassa. Uudempi tutkimus pohtii jälleenrakennuspolitiikkojen sukupuolittuneita ja seksualisoituneita käytänteitä, brändättyä humanitarismia sekä kriittisen muistelutyön ja kumouksellisen feministisen politiikan mahdollisuuksia Etelä-Aasiassa.

Pauli Kettunen on poliittisen historian professori politiikan ja talouden tutkimuksen laitoksella Helsingin yliopistossa. Viime vuosina hän on tutkinut ja kirjoittanut lukuisia nationalismin ja globalisaation suhdetta, hyvinvointivaltion ja työn suhdetta Euroopassa sekä politiikan käsitehistoriaa koskevia artikkeleita ja kirjoja.

Arto Lindholm on valtiotieteen tohtori ja ympäristöpolitiikan tuntiopettaja Helsingin yliopiston sosiaalitieteiden laitoksella ja toimii $\mathrm{Hu}-$ manistisen ammattikorkeakoulun (HUMAK) lehtorina Kauniaisessa. Hän on julkaissut useita tutkimuksia globaali- ja ympäristöliikkeistä sekä ympäristöpolitiikasta. 
Rauli Mickelsson on dosentti ja toimii valtio-opin yliopistonlehtorina Tampereen yliopistossa. Perustavat tutkimus- ja julkaisuteemat liittyvät liike- ja puoluetutkimukseen, ideologioihin, puolueiden historiaan, tulevaisuuden tutkimukseen ja laadullisen tutkimuksen kehittämiseen.

Eija Nurminen on Avoimen yliopiston sosiaalipolitiikan yliopistonlehtori Helsingin yliopistossa. Hän on analysoinut viime vuosina suurten ikäluokkien elämäntarinoita, yhteiskunnallista eriarvoisuutta ja luokkatutkimusta.

Kari Paakkunainen on Avoimen yliopiston yliopisto-opettaja Helsingin yliopistossa. Hän on julkaissut lukuisia tutkimuksia valtio-opin historiasta, arviointitutkimuksesta sekä nuorten poliittisesta kulttuurista Euroopassa.

Pentti Puoskari on yleisen valtio-opin dosentti politiikan ja talouden tutkimuksen laitoksella Helsingin yliopistolla. Talouden ja politiikan aihepiirin lisäksi hän on tutkinut ja julkaissut viime aikoina muun muassa "Suuren muuton" hallituspolitiikan historiasta.

Pasi Saukkonen on valtio-opin dosentti ja toimii parhaillaan tutkijana Etnisten suhteiden ja nationalismin tutkimuskeskuksessa (CEREN) Helsingin yliopistossa. Hän on laajasti julkaissut nationalismia, kansallista identiteettiä ynnä integraation politiikkaa monikulttuurisessa yhteiskunnassa koskevia tutkimuksia ja kirjoja.

Jan Sundberg on yleisen valtio-opin ruotsinkielinen professori politiikan ja talouden tutkimuksen laitoksella Helsingin yliopistossa. Tutkimus- ja julkaisutoiminta on viime aikoina keskittynyt vähemmistöpolitiikkaan, poliittisiin puolueisiin, vaalijärjestelmiin, kunnallispolitiikkaan ja viimeksi eurooppalaisiin federalistisiin ratkaisuihin.

Sami Suodenjoki on Suomen Akatemian tutkijatohtori Tampereen yliopistossa, joka työskentelee Yhteiskunnan historian huippuyksikössä. Perustava tutkimuskohde on poliittinen osallistuminen ja kansalaisuus 1800-luvun ja 1900-luvun alun Suomessa.

Henri Vogt on yleisen valtio-opin, erityisesti kansainvälisen politiikan professori Turun yliopistossa. Hänen tutkimuksensa on keskittynyt de- 
mokratian ja globalisaation ongelmiin sekä Euroopan unionin kehitykseen

Raimo Väyrynen on valtio-opin professori emeritus, joka on toiminut professorina Helsingin ja Notre Damen yliopistoissa sekä Suomen Akatemian pääjohtajana. Hänen tutkimustoimintansa on kohdistunut kansainvälisten suhteiden historiaan ja teoriaan sekä poliittiseen taloustieteisiin sekä konflikteihin. 
